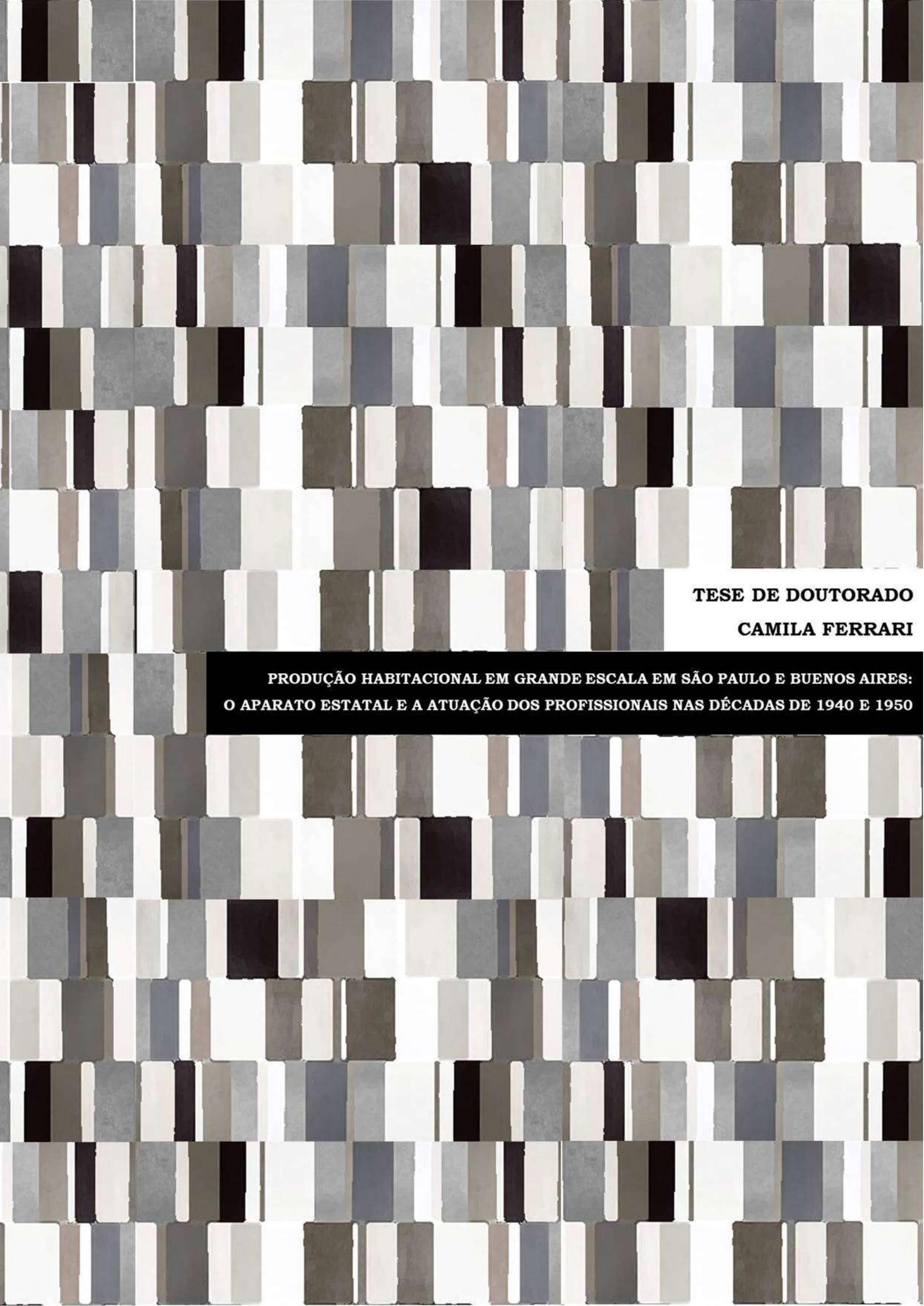



Produção habitacional em grande escala em São Paulo e Buenos Aires:

o aparato estatal e a atuação dos profissionais nas décadas de 1940 e 1950

\section{Camila Ferrari}

Tese apresentada ao Programa de Pós-Graduação em Arquitetura e Urbanismo do Instituto de Arquitetura e Urbanismo da Universidade de São Paulo para obtenção do título de Doutora em Arquitetura e Urbanismo

Orientadora

Prof.a Livre-Docente Sarah Feldman

Financiamento

Fundação de Amparo à Pesquisa do Estado de São Paulo

Área de Concentração

Teoria e História da Arquitetura e do Urbanismo

São Carlos, 

com os dados fornecidos pelo(a) autor(a)

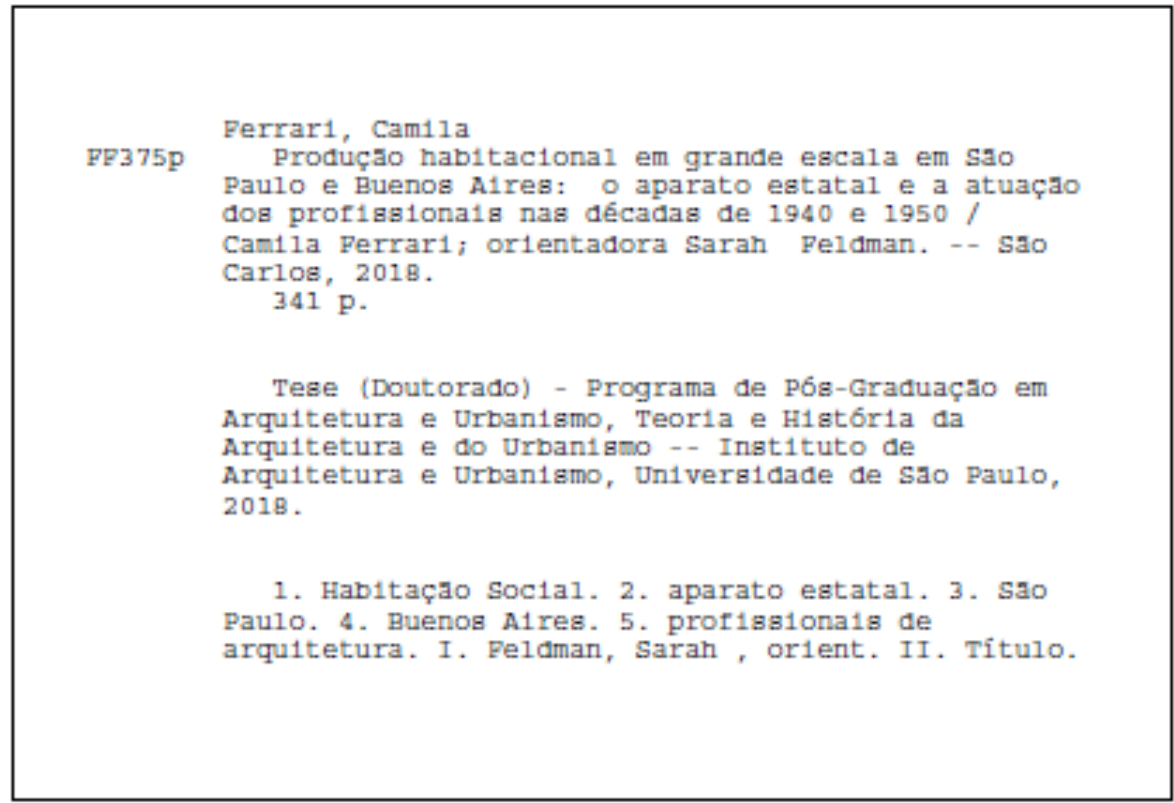

Bibliotecária responsável pela estrutura de catalogação da publicação de acordo com a AACR2:

Brianda de Oliveira Ordonho Sígolo - CRB - 8/8229

\section{Projeto Gráfico: Camila Ferrari}

Capa: Imagem confeccionada a partir do fragmento "Geometry", disponível em:

<https://www.onekingslane.com/p/4694490--geometry.do>

Fonte: Calibri 


\section{FOLHA DE JULGAMENTO}

Candidato(a): Camila Ferrari

Título da tese: "Produção habitacional em grande escala em São Paulo e Buenos Aires: o aparato estatal e a atuação dos profissionais nas décadas de 1940 e 1950".

Data da defesa: 07 de dezembro de 2018.

Orientador: Profa. Dra. Sarah Feldman

Comissão Julgadora:

$\underline{\text { Resultado: }}$

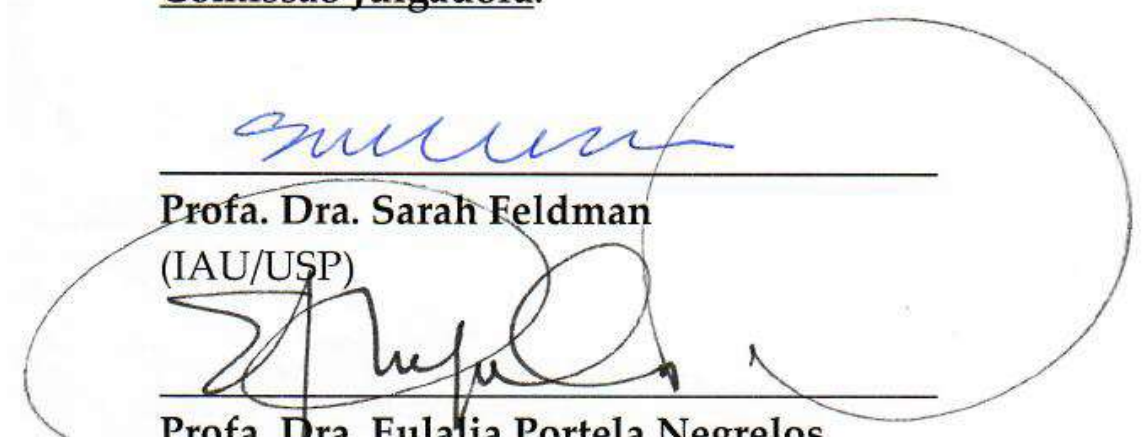

Profa. Dra. Eulalia Portela Negrelos

(IAU/U\$P)

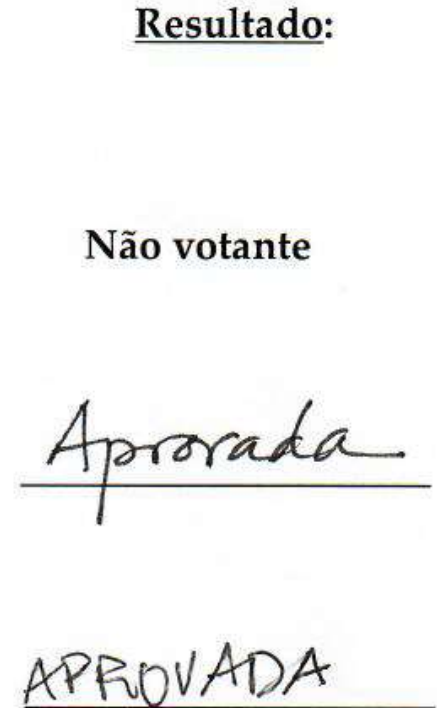

Profa. Dra. Nilce Cristina Aravecchia Botas

APROVADA (FAU/USP)

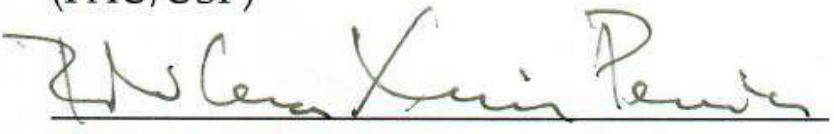

Prof. Dr. Paulo César Xavier Pereira

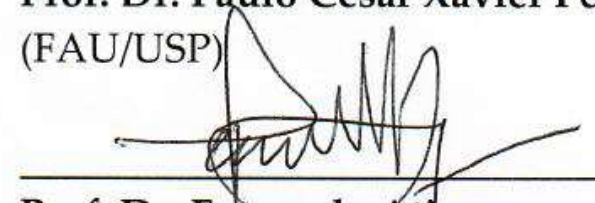

Prof. Dr. Fernando Atique

(UNIFESP)

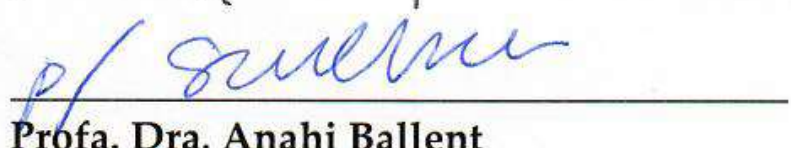

APROVA DA

Profa. Dra. Anahi Ballent

APROVADA

(Universidad de Quilmes)

Coordenador e Presidente da Comissão de Pós-Graduação do Programa de PósGraduação em Arquitetura e Urbanismo: Prof. Dr. Tomás Antonio Moreira. 

Agradecer àqueles que de alguma forma contribuíram para esta pesquisa e para a produção desta tese, amenizando as dificuldades da jornada e acrescentando a ela informação e conhecimento, é quase tão desafiador quanto o trabalho realizado ao longo destes quatro anos e meio.

Agradeço em primeiro lugar a Deus por chegar a este lugar e poder ter estas pessoas ao meu lado. Agradeço de forma especial ao meu companheiro e parceiro de vida. Tayguer, obrigada pelo amor e carinho de todos os dias, pelo nosso tempo juntos, pela compreensão pelo tempo em que não pudemos estar juntos e pelo tempo que temos pela frente, definitivamente juntos. Obrigada, meu amor, por acreditar em mim quando eu mesma não acreditava e por me fazer acreditar.

Agradeço especialmente aos meus pais. Obrigada por desde cedo me oferecerem a oportunidade de estudar nas melhores escolas possíveis e por acreditarem em mim. Obrigada por cuidarem de mim e por estarem sempre presentes e compreenderem que nem sempre eu podia estar presente.

Agradeço à minha família por todos os momentos e pelo imenso carinho. Obrigada meus queridos padrinhos, vocês são exemplos por todo amor que transborda de vocês. Obrigada Flá, por ser minha irmã e por tudo que compartilhamos. Obrigada vó Maria pelo interesse em meu trabalho e por sempre rezar por mim e vó Emília, por todo o amor e por agora olhar por mim lá de cima. Obrigada Maria, José Carlos e Nicole por serem também minha família.

Agradeço a Sarah pela trajetória de confiança e aprendizado que levo para a vida.

Agradeço aos professores da banca examinadora, que através de suas pesquisas e aulas contribuíram de forma contundente para o desenvolvimento da pesquisa. Agradeço especialmente Eulalia, parceira de pesquisas desde o mestrado.

Agradeço aos meus queridos amigos pelos momentos compartilhados, pelo apoio, por me tirarem de casa e tornarem o caminho mais divertido. Correndo o risco de não conseguir lembrar todos aqueles que deveriam estar aqui... Obrigada Regina pelo suporte e por me deixar usar seu espaço como centro de controle (e descontrole). Obrigada Equipe $\mathrm{AU}$ pela cumplicidade e alegria de cada momento (Arriba!). Obrigada Aline pelas conversas todas e por aquelas sobre Gramsci. Obrigada Nath por todas as conversas. Obrigada Naná, Dany e Lu por sempre estarem presentes, mesmo que à distância. Obrigada Carol, Layane, Julio, Arthur e Bárbara pela orientação compartilhada. Obrigada ao grupo CACAL pelos debates, pelas possibilidades, pelas trocas. Obrigada aos amigos que fiz pelo caminho da pesquisa, especialmente a Suzy que me fez sentir em casa em Buenos Aires.

Agradeço aos professores e funcionários do IAU.

Agradeço a Paulo Bruna, pelo interesse pela minha pesquisa e por me apresentar ao CEDODAL.

Agradeço aos bibliotecários e funcionários das Bibliotecas, dos Centros de Pesquisa e dos Arquivos visitados, pela assistência e suporte. Obrigada em especial às meninas da Biblioteca Central EESC. 
Obrigada a Marcos do Arquivo Geral de Processos de São Paulo. Obrigada a Alejandro e Gabi do CEDODAL. Obrigada à equipe da Biblioteca Peronista e da Dirección de Servicios Legislativos da Biblioteca del Congresso de la Nación. Obrigada à equipe da Predial de Luca por me receber e disponibilizar parte da história da construção civil em São Paulo.

Agradeço pelo apoio financeiro a esta pesquisa, conforme Processo n. 2014/ 14452-3, à Fundação de Amparo à Pesquisa do Estado de São Paulo (FAPESP). 


\section{Resumo}

FERRARI, Camila. Produção habitacional em grande escala em São Paulo e Buenos Aires: o aparato estatal e a atuação dos profissionais nas décadas de 1940 e 1950. Tese (Doutorado). IAU-USP, São Carlos, 2018.

Esta tese aborda a produção habitacional em São Paulo e Buenos Aires no quadro conformado em países da América Latina entre os anos 1930 e 1960, em que uma série de condições possibilitou que a habitação social fosse construída numa perspectiva de produção em grande escala. As décadas de 1940 e 1950 são definidas como recorte temporal a partir de aproximações entre São Paulo e Buenos Aires nos processos de configuração enquanto metrópoles. Busca-se compreender, por um lado, as especificidades da institucionalização da produção habitacional pelos Estados brasileiro e argentino e, por outro, o papel dos profissionais de arquitetura vinculados a esta produção. A pesquisa teve como suporte fontes bibliográficas, documentais e iconográficas e, enquanto abordagem, filia-se a trabalhos que trazem um esforço de reflexão sobre uma nova perspectiva latino-americana, compreendendo que a questão habitacional no período em tela e as soluções propostas para seu enfrentamento não se esgotam em âmbito nacional. Os contextos sócio-políticos no Brasil e na Argentina são estudados em relação ao processo de institucionalização da produção habitacional e à aproximação entre governos e população trabalhadora, a quem se dirigiam as políticas habitacionais. Os espaços de articulação entre profissionais de arquitetura na América Latina nas primeiras décadas do século XX são analisados de modo a desvendar o debate sobre a questão da habitação. Os processos de urbanização e desenvolvimento de São Paulo e Buenos Aires são relacionados à política e à produção habitacional dos respectivos países. Considerando-se este conjunto de aspectos, os projetos habitacionais são examinados a partir de aproximações e especificidades da produção em grande escala nas duas cidades. As diferenças na concepção da política habitacional e do aparato estatal, os diferentes vínculos entre profissionais de arquitetura e Estado, bem como as diferenças na ocupação urbana e nos processos de urbanização nas duas cidades, implicaram diferentes formas de concretização da perspectiva de produção em grande escala em São Paulo e Buenos Aires.

Palavras-chave: Habitação Social; São Paulo; Buenos Aires; aparato estatal; profissionais de arquitetura 



\begin{abstract}
FERRARI, Camila. Large-scale housing production in São Paulo and Buenos Aires: the state apparatus and the role of professionals in the 1940s and 1950s. Thesis (PhD). IAU-USP, São Carlos, 2018.
\end{abstract}

This thesis deals with the housing production in São Paulo and Buenos Aires within a context established in Latin American countries between the 1930s and 1960s, in which a series of conditions enabled social housing to be constructed in a perspective of large-scale production. The decades of the 1940s and 1950s are defined as periods of study based on approximations between São Paulo and Buenos Aires in the processes of configuration as metropolis. It is proposed to understand, on the one hand, the specificities of the institutionalization of housing production by the Brazilian and Argentine states and, on the other hand, the role of architecture professionals linked to this production. The research was supported by bibliographic, documentary and iconographic sources and, as an approach, is associated to works that bring an effort to reflect on a new Latin American perspective, understanding that the housing issue in the period in question and the solutions proposed for it are not exhausted at the national level. The socio-political contexts in Brazil and Argentina are studied in relation to the process of institutionalization of housing production and to the approach of governments and working population, to which housing policies were directed. The spaces of articulation between professionals of architecture in Latin America in the first decades of the twentieth century are analyzed in order to unveil the debate on the housing question. The processes of urbanization and development of São Paulo and Buenos Aires are related to the politics and the housing production of the respective countries. Considering this set of aspects, the housing projects are examined, by highlighting the approximations and specificities of large-scale or massive production in the two cities. Differences in the conception of housing policy and the state apparatus, the different links between architecture professionals and the State, as well as the differences in urban occupation and urbanization processes in the two cities, meant that the prospect of large-scale production were materialized in different ways in Sao Paulo and Buenos Aires.

Keywords: Social Housing; Sao Paulo; Buenos Aires; state apparatus; architecture professionals 



\section{Resumen}

FERRARI, Camila. Producción de viviendas a gran escala en São Paulo y Buenos Aires: el aparato estatal y la actuación de los profesionales en las décadas de 1940 y 1950. Tesis (Doctorado). IAUUSP, São Carlos, 2018.

Esta tesis aborda la producción de viviendas en São Paulo y Buenos Aires en el marco conformado en países de América Latina entre los años 1930 y 1960, en que una serie de condiciones posibilitó que la vivienda social fuera construida en una perspectiva de gran escala asociada al ideario moderno. Las décadas de 1940 y 1950 se definen como recorte temporal a partir de aproximaciones entre São Paulo y Buenos Aires en los procesos de configuración como metrópolis. Se busca comprender, por un lado, las especificidades de la institucionalización de la producción de viviendas por los Estados brasileño y argentino y, por otro, el papel de los profesionales de arquitectura vinculados a esta producción. La investigación tuvo como soporte fuentes bibliográficas, documentales e iconográficas $y$, como abordaje, se afilia a trabajos que traen un esfuerzo de reflexión sobre una nueva perspectiva latinoamericana, comprendiendo que la cuestión de la vivienda en el período en tela y las soluciones propuestas para su enfrentamiento no se agotan a nivel nacional. Los contextos socio-políticos en Brasil y en la Argentina son estudiados en relación al proceso de institucionalización de la producción de la vivienda y a la aproximación entre gobiernos y población trabajadora, a quienes se dirigían las políticas habitacionales. Los espacios de articulación entre profesionales de arquitectura en América Latina en las primeras décadas del siglo XX se analizan para desentrañar el debate sobre la cuestión de la vivienda. Los procesos de urbanización y desarrollo de São Paulo y Buenos Aires se relacionan con la política y la producción de viviendas de los respectivos países. Considerando este conjunto de aspectos, son examinados los proyectos habitacionales, destacándose aproximaciones y especificidades de la producción a gran escala o masiva en las dos ciudades. Las diferencias en la concepción de la política habitacional y del aparato estatal, los diferentes vínculos entre profesionales de arquitectura y el Estado, así como las diferencias en la ocupación urbana y en los procesos de urbanización en las dos ciudades, implicaron diferentes formas de concreción de la perspectiva de producción a gran escala en Sao Paulo y Buenos Aires.

Palabras clave: Vivienda Social; San Pablo; Buenos Aires; aparato estatal; profesionales de arquitectura 

1.1. Produção habitacional em grande escala em São Paulo: uma questão enfrentada pelos Institutos de Aposentadoria e Pensões

Capítulo 2. Varguismo, Peronismo e a habitação para o trabalhador 85

2.1. Nacionalismo, Industrialização e Trabalhismo no Brasil (1930-1964)

2.2. A institucionalização da produção habitacional pelo Estado brasileiro: a moradia como privilégio do trabalhador .96

2.3. A política previdenciária de habitação 103

2.4. O Peronismo e a Justiça Social na Argentina (1943-1955) 116

2.5. O processo de institucionalização da produção habitacional na Argentina 124

2.6. Produção habitacional na Argentina Peronista: a moradia como direito do trabalhador 129

Capítulo 3. A habitação como questão na América Latina: o debate e a atuação dos profissionais no Brasil e na Argentina

3.1. O debate sobre a habitação na América Latina: função social, ação estatal, planejamento e produção em grande escala 149

3.2. Arquitetos e engenheiros e o aparato estatal da habitação no Brasil 167

3.3. O protagonismo dos arquitetos na produção habitacional estatal na Argentina 180

Capítulo 4. Produção habitacional como política previdenciária em São Paulo nas décadas de 1940 e 1950. 191

4.1. A especificidade da produção previdenciária da habitação em São Paulo 193

4.2. A lógica de mercado na produção habitacional dos IAPs 200

4.3. Expansão urbana, industrialização e a política previdenciária de habitação em São Paulo 221 
Capítulo 5. Produção habitacional como política de Estado em Buenos Aires nas décadas

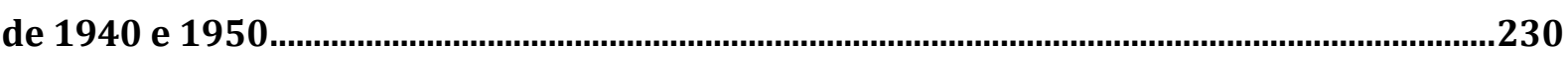

5.1. A Justiça Social através dos projetos de habitação .................................................................. 232

5.2. Os projetos habitacionais em Buenos Aires: acesso à cidade e urbanização............................... 240

5.3. Diferentes formas de morar em Buenos Aires no Peronismo ................................................. 252

5.4. Suburbanização e Metropolização: Moradias e Indústrias na Grande Buenos Aires.....................258

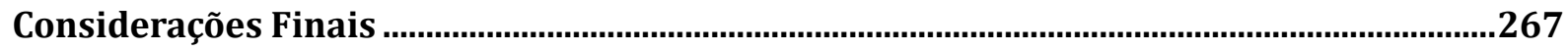

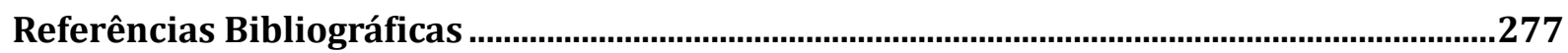

Apêndice A - Sistematização de elementos das formas de produção do espaço urbano

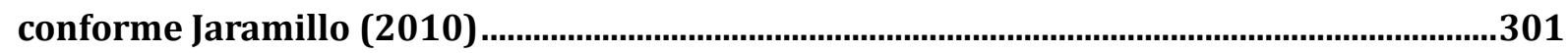

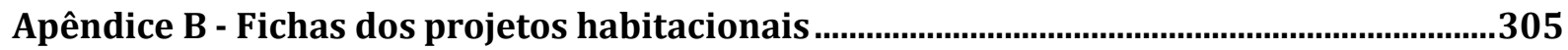


Introdução 
Esta Tese se conformou a partir do olhar para a habitação social produzida em diversos países da América Latina desde a década de 1930 até meados do século XX. Ao considerar a produção habitacional em países como Brasil, Argentina, México, Venezuela e Colômbia é possível perceber que o caminho para enfrentar a questão da habitação foi bastante similar. O estudo organizado por Sambricio em 2012, intitulado "Ciudad y vivienda en America Latina 1930-1960", aborda estas similaridades e mostra a importância de analisar esta produção como um conjunto, mesmo que se revele, em determinados pontos, específica às condições de cada país ou cidade. No conjunto, dois principais aspectos em comum se destacam. De um lado, o fato de este enfrentamento ser então assumido como questão estatal e, de outro, o aspecto formal desta habitação, em que se identifica uma perspectiva de produção em grande escala.

Partindo destas observações percebe-se que também condições econômicas, políticas e sociais específicas conformavam uma conjuntura peculiar entre as décadas de 1930 e 1960 em alguns países da América Latina, com a gradativa superação de Estados liberais e avanço de governos em que as classes trabalhadoras passaram a desempenhar um papel significativo como base de apoio de líderes que seriam lembrados pelo reconhecimento do papel e das necessidades destas mesmas classes. Entre estes governos destacam-se os de Getúlio Vargas no Brasil e de Juan Domingo Perón na Argentina. A promoção da moradia assume, nesses governos, importante papel não somente dentro de uma perspectiva de ascensão social da população, mas do próprio desenvolvimento nacional. 
No mesmo período se verifica na América Latina um grande intercâmbio de ideias entre arquitetos e urbanistas efetivado de forma ampliada a partir de 1930 através da realização de importantes encontros profissionais, onde a questão da habitação ocupa lugar de destaque. Dois pontos colocados em debate desde os primeiros encontros, ainda na década de 1920, se destacam: o vínculo entre o projeto da moradia e o planejamento urbano e o imperativo de se promover a habitação a partir da ação estatal. Ao mesmo tempo, chegava-se ao entendimento de que através do projeto da habitação se realizava a função social da arquitetura, isto é, a sua participação na melhoria das condições da sociedade.

Com o objetivo de melhor compreender as especificidades da produção habitacional realizada pela ação estatal entre as décadas de 1930 e 1960 na América Latina, propusemos olhar para uma parte deste universo: Brasil e Argentina e, especificamente, suas maiores cidades no período, São Paulo e Buenos Aires. Dois aspectos principais embasaram a escolha destes lugares sobre os quais a pesquisa se debruça: por um lado, o contexto político de valorização do trabalhador, que varguismo e peronismo parecem concretizar de modo mais complexo que outros governos no período e, por outro, as características dos processos de industrialização, urbanização e metropolização por que passam as duas cidades.

Nossa hipótese é que a produção da habitação social sob perspectiva de grande escala se concretiza de formas diferentes em São Paulo e Buenos Aires entre as décadas de 1940 e 1950 em função das diferenças na institucionalização da produção habitacional pelo Estado no Brasil e na Argentina e das diferentes formas de inserção de arquitetos e urbanistas no aparato estatal de cada país no período. Entendendo a produção habitacional como sistema que envolve fatores e componentes técnicos, políticos e institucionais e múltiplos atores para a realização de projetos de habitação e partindo dos casos de São Paulo e Buenos Aires entre as décadas de 1940 e 1950, a pesquisa ressalta o processo de institucionalização da produção habitacional pelo Estado no Brasil e na Argentina na conformação de órgãos e políticas de promoção da habitação social, com destaque para a ação estatal direta ${ }^{1}$. 0 processo de institucionalização se refere desde a formulações e debates sobre a questão da habitação até a organização formal da produção habitacional no aparato estatal, através de políticas claramente definidas e órgãos oficialmente constituídos, considerando os atores envolvidos em todo o percurso. O aparato estatal ou aparelho de Estado, é compreendido como os órgãos (e atores sociais neles inseridos) nos quais se realiza o arranjo político e administrativo do mesmo Estado. No período considerado, a produção habitacional assume em diversos países da América Latina uma perspectiva de produção em grande escala (SAMBRICIO, 2012; MORAIS, 2016). A produção em

\footnotetext{
${ }^{1}$ Compreendida como as intervenções em que o Estado, através de um organismo nacional, estadual ou municipal se constitui o comitente das obras [aquele que incumbe alguém de executar certos atos em seu nome e sob sua direção e responsabilidade]. Uma segunda linha de atuação estatal era ação indireta, baseada na promoção de empréstimos e no incentivo à autoconstrução, vinculada em ambos os países a um ideário conservador, que fazia do trabalhador um pequeno proprietário, livrando-o do encargo do aluguel. (BONDUKI, 1998; BALLENT, 2005)
} 
grande escala se identifica nos processos de padronização de elementos construtivos e tipologias habitacionais, na compreensão do projeto habitacional como projeto urbanístico, na utilização de novos materiais e métodos construtivos e na construção de edifícios verticais de moradia.

A institucionalização da promoção habitacional pelo Estado, nos moldes estabelecidos no Brasil e na Argentina no período em tela constituía, assim, um novo enquadramento do Estado frente ao desenvolvimento urbano e social e à industrialização. Através da produção habitacional colocava-se em perspectiva não somente a promoção de habitação, mas a criação de novo bairros, subúrbios e até mesmo cidades. Ao mesmo tempo, esperava-se através da produção habitacional garantir postos de trabalho, incentivar a construção e estimular a indústria como um todo.

Nesta conjuntura compreendemos a importância dos profissionais de arquitetura e urbanismo como atores sociais que buscaram naquele momento concretizar, através da produção habitacional, a função social da arquitetura, realizada justamente na habitação. Para tanto, esses profissionais se articularam ou se inseriram no aparato estatal dos dois países, onde se vincularam direta ou indiretamente - no setor técnico ou no setor administrativo - à produção da habitação estatal. Buscou-se assim entender como é orientada e organizada esta produção habitacional através do Estado e como os profissionais participam deste processo em cada país.

Em ambos os países a habitação é reconhecida como questão social, isto é, como questão a ser enfrentada pelo Estado em benefício das classes desfavorecidas. Este movimento ocorre na primeira década do século XX na Argentina e na década de 1930 no Brasil, mas é na década de 1940 que a produção habitacional ganha maior espaço e importância no discurso e na obra estatal dos dois países. A forma como ocorre a institucionalização da produção habitacional pelo Estado nos dois países neste momento, porém, é bastante diferente. Enquanto no Brasil se estabelece o que denominamos "política previdenciária de habitação", isto é, uma política de promoção habitacional baseada na aplicação dos fundos da Previdência Social, na Argentina se consolida uma política nacional de habitação estruturada a partir da atuação de órgãos especializados e da organização do sistema bancário. As realizações implementadas por estas políticas se estendem de forma efetiva até meados da década de 1950, quando no Brasil a forte inflação implica na redução da produção habitacional e na Argentina a chamada Revolução Libertadora põe fim ao governo peronista e às políticas habitacionais vigentes.

A reorganização econômica e política em ambos os países após a crise mundial de 1929 implica, nestas duas cidades em particular e de forma mais contundente na década de 1940, no processo de desenvolvimento e diversificação industrial, em ambas, associado a movimentos de expansão periférica ${ }^{2}$, ou suburbanização, termo utilizado na bibliografia argentina para se tratar deste

\footnotetext{
${ }^{2}$ o fenômeno, independentemente da denominação utilizada, é entendido como o processo de crescimento da cidade em direção à periferia, desenvolvendo-se inicialmente uma relação de dependência face à cidade "principal", em que a periferia ou os subúrbios oferecem essencialmente a função residencial. Uma forte característica do processo de suburbanização de
} 
fenômeno, e metropolização. Na década de 1940, as duas cidades e os municípios a ela adjacentes se destacam como núcleos de atração de expressiva população migrante desde outras partes dos respectivos países. São Paulo registra 2.198.096 habitantes em 1950, com 4.739.406 habitantes nos municípios vizinhos, já compreendidos como parte da "Grande São Paulo" (HISTÓRICO DEMOGRÁFICO...) . Buenos Aires, por sua vez, em 1947 registra 2.981 .043 habitantes no âmbito municipal e 4.722.381 nos partidos ${ }^{4}$ que compreenderiam a Grande Buenos Aires (BUENOS AIRES, $2003)^{5}$. É justamente a população migrante aquela que compõe o operariado das novas indústrias e que, desprovida de recursos, constitui, nomeadamente na Argentina, o público-alvo (ao menos nos discursos) das políticas de produção de moradia. No intervalo entre as décadas de 1930 e 1960, portanto, as décadas de 1940 e 1950 foram definidas como período em tela nesta Tese. (SINGER, 1968; AZEVEDO, 1958; GUTMAN; HARDOY, 1992; BELINI, 2005).

O estudo da produção da habitação social no Brasil e na Argentina, em São Paulo e Buenos Aires, se posiciona no sentido da compreender ações e fatos relacionados à questão nos dois países, bem como nas duas cidades, sem, contudo, partir do pressuposto de que estas ações e fatos fossem necessariamente identitárias. A pesquisa partiu de condições conjunturais de dois lugares e os enunciados se aproximaram em vários pontos, mas em outros não, resultado de uma construção metodológica formulada a partir da pesquisa bibliográfica e documental. Como exemplo, na análise da localização dos projetos habitacionais nas duas cidades foram preconizados os aspectos que mais implicaram a sua disposição no espaço urbano de acordo com a pesquisa realizada, a lógica de mercado em São Paulo e a urbanização e o acesso à cidade em Buenos Aires ${ }^{6}$, o que não quer dizer que o primeiro não existisse em Buenos Aires ou o segundo em São Paulo, mas apenas que, para a análise proposta, não se buscou equiparar a relevância de um e outro aspecto para as duas cidades.

Através da bibliografia e dos dados encontrados a pesquisa levantou as características da produção habitacional nestes espaços sem partir de um pressuposto, mas de um problema a investigar, a produção habitacional realizada pela ação direta do Estado nos dois países, nas suas principais cidades naquele momento, como parte do universo formado por grandes cidades da América Latina. Alguns dos mais recentes trabalhos a respeito da América Latina ou de assuntos conexos como a "cidade latino-americana" ou a "urbanização latino-americana" trazem em seu interior um esforço de

Buenos Aires, conforme se esclarecerá oportunamente, é que ele foi beneficiado desde muito cedo por uma ampla rede ferroviária.

${ }^{3}$ Conforme o primeiro recenseamento realizado no Brasil em 1872 a população de São Paulo era de 31.385 habitantes. Os censos seguintes revelam um crescimento demográfico sem precedentes, registrando-se 239.820 habitantes em 1900 e 579.033 em 1920. O Censo de 1940 é o primeiro a registrar população de mais de um milhão, com 1.326.261 habitantes em São Paulo e 1.568.045 nos municípios da "Grande São Paulo". (HISTÓRICO DEMOGRÁFICO...).

4 Os municípios são denominados constitucionalmente de "partidos".

${ }^{5} \mathrm{Na}$ década de 1880 a capital argentina passa a ser a cidade mais populosa da América Latina, com 433.375 habitantes, ultrapassando um milhão de habitantes na década de 1900. O Censo Nacional de 1914 registra 1.575 .814 habitantes em Buenos Aires e 2.034 .031 nos municípios adjacentes. (ARGENTINA: POBLACIÓN TOTAL..., s/d; BUENOS AIRES, 2003)

${ }^{6}$ Conforme se discute nos capítulos 4 e 5 , respectivamente. 
reflexão quanto à pertinência desses termos e a possibilidade de definir um modelo típico de "cidade latino-americana", ou mesmo de unificar nações e aspectos como arquitetura, Estado e processos sociais, econômicos ou culturais sob o título "latino-americano", questionando nesse sentido, a própria utilização do conceito de América Latina ${ }^{7}$. Em última instância, este conceito vem sendo apresentado como uma construção intelectual ou cultural que, no entanto, foi naturalizada, ou ainda reificada, na concepção de um recorte espacial dentro da subdivisão do mundo em continentes, à qual se recorre sem questionamentos. (GORELIK, 2005a; GORELIK, 2011; QUENTAL, 2012).

Gorelik (2005a) trabalha com a ideia da "cidade latino-americana" como construção cultural, ou seja, como proposição que foi tradicionalmente aplicada ou construída temporalmente no pensamento e planejamento dos centros urbanos do continente. Segundo o autor, a ideia de construção cultural tem por objetivo oferecer uma alternativa à noção de "invenção", em voga nos estudos históricos quando se trata de evidenciar processos de construção cultural opacos para seus próprios protagonistas e que a história naturalizou. Contudo, no contexto latino-americano, a noção de "invenção" corre o risco de não dar conta da extraordinária consciência com que as elites propuseram, vez por outra, a necessidade de invenção como processo inerente à baixa consistência que encontravam na realidade latino-americana. (GORELIK, 2005a, p. 112)

Para Gorelik (2005a) a "cidade latino-americana" existiu como objeto de estudos entre os profissionais do mundo ocidental no período desenvolvimentista (1945-1970), como local a ser projetado e planejado. Apostava-se que a modernização dos países latino-americanos ocorreria por meio de uma injeção de políticas de reforma e de uma planificação precisa, que poderiam evitar os problemas registrados nos países mais desenvolvidos, especialmente após a Segunda Guerra Mundial. "Sob o signo da planificação [...] se estruturou o principal núcleo do campo de estudos urbanos na região, que pensava cada cidade como 'caso' de uma 'urbanização latino-americana'" [...]. (GORELIK, 2011, p.5, tradução nossa)

O questionamento da ideia de "cidade latino-americana", da existência de um modelo específico de cidade no continente e da possibilidade mesma de comparação entre os núcleos urbanos dos distintos países, aparece como consequência de debates ocorridos na década de 1980 em torno do enfrentamento da "ideologia da planificação". A renovação nos estudos urbanos permitiu toda uma nova gama de abordagens que possibilitou a conformação ou a admissão de outros campos de pesquisa como a história cultural, a história da arte, a literatura, a filosofia, entre outros, que

\footnotetext{
${ }^{7}$ O termo América Latina passa a ser utilizado a partir da apropriação da expressão "latina" por intelectuais de origem hispânica no continente americano. O conceito de América Latina propriamente dito teria sido apresentado por José Maria Torres de Caicedo, jornalista e poeta colombiano, no poema "Las dos Américas" publicado no ano de 1856. A apropriação do termo se insere nos processos de independência das colônias espanholas no século XIX, que impuseram às elites criollas - espanhóis nascidos na América - a necessidade de inventarem-se a si mesmas. Nesse contexto, em que não mais a Espanha, mas a França constituía o ideal almejado de civilização - tal qual ocorrera no Brasil no final do século XIX -,as elites negavam o passado colonial, mas preocupavam-se ainda em pertencer à modernidade europeia, de modo que a "latinidade" se constituía como uma indicação de pertencimento.
} 
adotaram novas perspectivas urbanas. Estes novos estudos resultaram em uma série de pesquisas sobre cidades ou regiões específicas, associada a recortes nacionalistas, mas esta fase de estudos "monográficos" rapidamente insinuou a busca por uma nova perspectiva latino-americana, dado o reconhecimento por parte dos intelectuais locais de que, de fato, havia elementos comuns a se estudar (ALMANDOZ, 2003; 2004). Dentre os trabalhos mais recentes ressaltamos aqueles elaborados pela corrente teórica denominada Giro Decolonial, de autores como Arturo Escobar, Aníbal Quijano, Walter Mignolo, Santiago Castro-Gómez e Ramón Grosfoguel, e a vertente que se apoia na História Cultural Urbana, que estudamos a partir de Adrián Gorelik (2005a; 2005b; 2011) e Arturo Almandoz (2003; 2004; 2006). Ambas as correntes se destacam pela elaboração de questões a partir do próprio lócus de enunciação, a América Latina.

Gorelik (2011) observa que estas tentativas de conformar um olhar latino-americano para a América Latina estão se dando em dois campos principais no âmbito da história cultural: a construção de objetos de estudo supranacionais e o levantamento de contatos culturais específicos, da circulação de ideias, bens culturais e pessoas entre os países da região. No primeiro caso, se trata de delimitar questões cujo passado não é necessariamente nacional, ou não se esgota apenas nacionalmente. No segundo caso, são levantados episódios em que diferentes culturas entraram efetivamente em contato, produzindo novos circuitos culturais, que até então haviam sido pouco estudados, tais como, redes intelectuais transnacionais, periódicos de circulação continental, viagens e congressos.

Esta pesquisa procura se solidarizar a estes trabalhos, compreendendo o enfrentamento da questão habitacional entre as décadas de 1940 e 1950 a partir da produção de moradias em grande escala como objeto que não se esgota no contexto nacional, mas que está relacionado ao contexto mundial e, mais especificamente, regional, a que se dá enfoque nesta Tese. Ao mesmo tempo busca valorizar os espaços de interlocução entre os profissionais do continente onde circulavam pessoas e ideias importantes à produção da habitação social no período.

As décadas de 1940 e 1950, momento de maior produção previdenciária da habitação em São Paulo e período em que se efetiva a produção habitacional pelo Estado na Argentina (1943-1955), e especialmente em Buenos Aires como capital do país, se destacam como momento em que é possível distinguir características particulares em parte considerável dos projetos habitacionais propostos. Estas características evidenciavam uma perspectiva de produção em grande escala que se identifica em diversos pontos com o projeto de habitação proposto pela Arquitetura Moderna.

Retomá-las hoje é visitar a imaginação de um tempo em que a questão habitacional era pensada em termos da recriação da cidade como lócus da vida social. [...] Ou seja, uma cidade caracterizada pela emergência do que veio a ser designado pelo termo "massas". Um mercado de massas era o alvo da produção em série, da standartização, da difusão de novas tecnologias e de uma visível homogeneização, inclusive no campo da cultura, que marcam o período em termos mundiais. (GITAHY; PEREIRA, 2002, p.20) 
Essas características estão colocadas naquele momento como parte do enfrentamento da questão habitacional, tanto pelo setor privado quanto pelo Estado. No contexto de acirramento da precariedade das condições urbanas em São Paulo, assim como em Buenos Aires, o imperativo de se produzir em um curto espaço de tempo uma grande quantidade de edificações foi colocado. No Brasil, como enfatizam Gitahy e Pereira (2002, p.21), mas também na Argentina, como nossa pesquisa mostra, "ninguém deveria ficar sem habitação mínima. [...]. Vêm à luz novos conjuntos, zonas habitacionais de cidades novas, uma nova arquitetura, um novo urbanismo".

A pesquisa histórica do que se convencionou chamar a "questão da habitação" mostra que a compreensão e o debate sobre a moradia social como objeto do campo arquitetônico têm início por volta de década de 1920. Debates entre profissionais, técnicos e especialistas ocorreram tanto na Europa, com ênfase para a realização dos Congressos Internacionais de Arquitetura Moderna (CIAMs), quanto nas Américas, destacando-se a realização dos Congressos Pan-americanos de Arquitetos (CPAs). As soluções propostas em um e outro continente apresentaram grandes semelhanças, especialmente no que se refere às premissas de associação da arquitetura e do urbanismo no projeto da habitação e do imperativo da ação estatal no enfrentamento do problema. Conforme analisado por Kopp (1990), o movimento se relacionava a um contexto ampliado que se estabelece após a crise econômica de 1929 e que expõe mundialmente a questão da habitação - o segundo CIAM, realizado em 1929 tem como tema a habitação para o mínimo nível de vida. Em muitos países a solução para a carência de moradias é colocada a partir da indústria, que permitia alcançar novas escalas de produção, ao mesmo tempo em que exigia dos profissionais relacionados uma nova postura. Conforme colocado por Figueiredo (2002), o fato de a produção habitacional se transformar num processo em linha industrial, isto é, em grande escala, porém, ia além da adaptação da atividade de construir à tecnologia que já existia, mas exigia pensar em novas possibilidades. A produção em grande escala necessitava rigor técnico e padronização para se tornar exequível.

A Arquitetura Moderna aparece como uma expressão completamente fundamentada nesse contexto: se por um lado ela foi viabilizada pela evolução tecnológica e pelas próprias formas de produção, suas características também forçaram tais transformações. Isso é coerente às novas exigências da sociedade, num momento de outros programas e escalas. (FIGUEIREDO, 2002, p. 40)

Enquanto nas grandes cidades das Américas, e em especial da América Latina, a questão habitacional era no início do século XX um problema relativamente novo, conformado a partir do desenvolvimento e expansão urbana decorrentes dos processos de independência em meados do século XIX e inclusão no mercado internacional no final daquele século, na Europa a questão da habitação era objeto de estudos desde o início do século XIX, quando as cidades industriais tiveram grande aumento populacional. Longe de igualar os processos por que passaram os grandes núcleos urbanos em um e outro momento e espaço, cabe apontar em ambos a necessidade de enfrentar a falta de alojamentos 
para uma grande população que chegava às cidades desprovida de recursos e, mais ainda, as semelhanças no enfrentamento deste problema.

O conjunto de movimentos que conformam a arquitetura produzida entre finais do século XIX e o início do século XX foi designado genericamente como Movimento Moderno, enquanto o conjunto de características e princípios que o identificam foi designado ideário moderno. 0 ideário reflete a complexidade do Movimento que teve entre seus expoentes arquitetos de diferentes países, culturas e escolas como o franco-suíço Le Corbusier, o inglês Ebenezer Howard, os alemães Walter Gropius e Mies van der Rohe e o norte-americano Frank Lloyd Wright. Rompendo com a tradição cultural do século XIX estes profissionais conformavam o que se convencionou chamar de Vanguarda Arquitetônica que, de um modo geral, tinha como aspectos importantes a negação dos estilos históricos e a introdução da lógica industrial no pensamento arquitetônico.

No ideário moderno a habitação é compreendida como projeto que conecta arquitetura e urbanismo em um mesmo pensamento. Aymonino $(1972$, p.52) afirma que "se é que a cidade nova não pode ser prefigurada em seu conjunto, se formará mecanicamente no tempo, à medida que estejam resolvidas as necessidades de alojamento: a residência moderna condicionará até transformar a cidade moderna". O ideário moderno estava assim vinculado à ideia de um projeto de modernidade, referindo-se mais a uma causa que a uma estética unificada. Independentemente da estética ou linguagem formal, a modernização do habitar era uma resposta à necessidade de novas moradias ${ }^{8}$ para uma nova sociedade. $\mathrm{O}$ arquiteto é responsável pela construção socialmente justa do espaço habitado e cumpre este papel transformador na sociedade através do projeto habitacional. É na habitação, portanto, que a arquitetura cumpre sua função social. (KOPP, 1990)

$\mathrm{Na}$ América Latina todo um conjunto de postulados que define classicamente a Vanguarda Arquitetônica é questionado: a negatividade, o caráter destrutivo, o combate à instituição, a destruição da tradição, o internacionalismo. Gorelik (2005b) afirma que essa revisão da ideia de vanguarda a partir da arquitetura e sua construtividade dão sentido ao conceito na América Latina, sendo possível pensar nas vanguardas latino-americanas como membros da família das vanguardas históricas. Jorge Francisco Liernur (2010) critica o uso do termo "arquitetura nacional" que internacionalmente se conferiu a arquiteturas modernas como a brasileira, porque, ao mesmo tempo em que não podiam ser ignoradas, não podiam ser incorporadas ao movimento internacional, pois negavam premissas estruturantes daquele, colocando em risco sua identidade. A partir da revisão da noção de vanguarda sob uma perspectiva latino-americana torna-se possível observar sob novas chaves as arquiteturas desenvolvidas no continente dentro do conjunto da Arquitetura Moderna.

\footnotetext{
8 Aqui se distingue, conforme colocado por Marshal Berman em "Tudo que é solido desmancha no ar" (1986), modernização como o conceito referido aos processos estruturais e modernismo como as respostas culturais ou estéticas.
} 
Em um primeiro olhar para a habitação social produzida nas grandes cidades da América Latina desde a década de 1930 até meados da década de 1960 é possível identificar aspectos formais condizentes com projetos de habitação e cidade colocados pelo ideário moderno (FERRARI, 2013). As semelhanças ficam explícitas na construção de edifícios multifamiliares verticais e na reprodução de tipos construtivos em grande escala, na padronização e produção em série de elementos construtivos, na associação com o projeto urbanístico a partir de projetos de bairros ou unidades de vizinhança, que incluíam a construção de equipamentos comunitários e serviços.

Essa produção habitacional se destaca especialmente pela ideia do conjunto de moradias, ou seja, o agrupamento de unidades de habitação e equipamentos coletivos construídos como um sistema único. Até então, segundo Bonduki (1998, p.163), no Brasil "inexistia a própria ideia de conjunto habitacional" e, conforme se tem estudado, a afirmação é verdadeira também para outros países da América Latina (SAMBRICIO, 2012). O principal benefício do agrupamento das unidades de habitação era a possibilidade de maior eficiência na construção e no fornecimento de infraestrutura e serviços. Um ponto importante a ressaltar quando se analisa esses conjuntos habitacionais concebidos e/ou construídos entre as décadas de 1930 e 1960 é a associação dos espaços de morar a um conjunto de equipamentos coletivos e serviços. Eram previstos escolas, ginásios, ambulatórios, comércios e centros sociais, revelando-se uma preocupação em garantir certa autonomia aos conjuntos, suprindo as necessidades cotidianas junto ao espaço do morar. (FERRARI, 2013)

É possível perceber igualmente nos projetos, uma preocupação em conformar espaços livres que não somente garantissem aspectos técnicos como ventilação e insolação adequadas às unidades, mas que também permitissem a conformação de áreas verdes e espaços de sociabilização. Em diversos conjuntos a racionalidade do projeto urbanístico é perceptível também a partir a separação e hierarquia viária, propondo-se vias locais conectadas a vias da própria cidade e percursos dedicados exclusivamente a pedestres. A relação dos projetos com as cidades em que se inserem é estabelecida especialmente em função da preocupação com a circulação da população moradora, através da relação com redes viárias e ferroviárias, e da própria circulação de pessoas nos espaços livres dos conjuntos, frequentemente abertos às cidades como parques.

A possibilidade de inserção em áreas já consolidadas esteve associada a outro ponto de destaque da produção habitacional do período considerado, a verticalização dos edifícios de moradia. Os edifícios em altura destinados à habitação social constituem grande novidade no período em que mesmo as moradias destinadas a classes médias e altas apenas começavam a ser verticalizadas. Identifica-se ainda em muitos destes projetos de habitação a utilização de materiais e equipamentos que se associavam às novas técnicas e tecnologias desenvolvidas desde finais do século XIX. Nota-se a padronização de elementos, tanto estruturais quanto de vedação e acabamento e a repetição de tipos construtivos, admitindo-se a noção da produção em série. 
Um aspecto, porém, é fundamental para compreender a especificidade da produção habitacional na América Latina no período em tela. Essa habitação era promovida pelo Estado. Conforme sugere Ballent (2005, p.23, tradução nossa), é possível pensar, especificamente para o período estudado, em uma relação de tangência como um modo adequado de esboçar o vínculo entre técnica e política: imaginar a ideia de duas histórias - uma técnica ou disciplinaria e outra política - entendidas como duas linhas autônomas que se cruzam em um ponto, embora tenha começos e desenvolvimentos posteriores a tal cruzamento divergentes.

Destaca-se a partir dos anos 1930, e mais fortemente da década de 1940, "a centralidade da relação entre o Estado e a vanguarda arquitetônica", isto é, uma estreita ligação entre o plano técnico e o plano político ou decisório (GORELIK, 2005b, p.15). Na América Latina a vanguarda arquitetônica apresentará o agente fundamental para a atuação vanguardista: “o Estado [...]. Por meio da arquitetura, vanguarda e Estado confluem na necessidade de construir uma cultura, uma sociedade e uma economia nacionais". (GORELIK, 2005b, p.15-16)

Trata-se de uma vinculação mais ampla em que arquitetura (como instituição) e Estado (como agente estrutural da modernização) compartilham interesses e objetivos: os modernismos arquitetônicos foram postulados como instrumentos privilegiados da tarefa estatal por excelência, a representação da modernidade nacional. Isso é o que ofereceram ao Estado, ou isso foi o que o Estado encontrou ou convocou nelas; melhor, esse foi o território comum no qual se constituíram mutuamente. (GORELIK, 2005b, p.29)

Essa compreensão é fundamental para entender como temas pertinentes ao campo da arquitetura e do urbanismo, tais como o aspecto formal da produção habitacional, ao qual se vinculou uma perspectiva de produção em grande escala, "estiveram vinculados às dinâmicas de integração do país no sistema capitalista", através de sua associação ao desenvolvimento industrial, por exemplo. (ARAVECCHIA-BOTAS, 2016, p. 31)

Aos representantes vanguarda arquitetônica inseridos no aparato estatal varguista e peronista coube a tarefa de romper com a ideologia (cultural) das elites liberal-agrárias, que buscavam na matriz academicista europeia o referencial para a produção da obra pública, superando esta ideologia até então dominante e desenvolvendo uma nova (GORELIK, 2005b). A nova ideologia, apesar de não ser essencialmente contra-hegemônica posto que não viesse de uma classe dominada, garantiu, em associação com o projeto estatal, não somente a variação da linguagem arquitetônica adotada na obra pública, como a admissão da habitação como questão social, culminando na realização de projetos habitacionais em grande escala. (ARAVECCHIA-BOTAS, 2016; BALLENT, 2005)

Além do próprio aparato estatal e dos profissionais de arquitetura relacionados ao processo de institucionalização da produção habitacional pelo Estado considera-se também o papel social da classe trabalhadora, para quem essa habitação se destinava. Como mostram Gomes (2005) e Del Campo (1983), essa parcela da população não deve ser entendida como grupo passivo, que recebia os benefícios do Estado previdente e benfeitor, mas como classe que buscava, desde décadas 
anteriores, a obtenção de direitos profissionais e sociais que varguismo e peronismo integraram a suas propostas governamentais.

A compreensão dos profissionais de arquitetura e urbanismo e da classe trabalhadora como atores sociais participantes da conformação do quadro de institucionalização da produção habitacional pelo Estado e dos moldes como se processa a produção habitacional entre as décadas de 1940 e 1950 está diretamente relacionada à concepção de Estado adotada nesta Tese, que se baseia em um quadro teórico apoiado no materialismo histórico filiado à contribuição de Antonio Gramsci ${ }^{9}$.

Conforme analisado por Mendonça $(2007$, p.3), dos trabalhos dedicados à história política no Brasil não são poucos os que associam ao Estado "adjetivações como 'centralizador', 'cooptador' e 'coercitivo', o que pressupõe, enquanto seu reverso necessário, a fragilidade, 'dispersão' ou impotência da Sociedade [civil], incapaz de promover formas próprias de organização e representação política". De maneira similar, Ameztoy (1998) analisa o fenômeno do autoritarismo na constituição do Estado argentino desde o processo de independência, indicando momentos distinguidos pelo uso de dominação e repressão como forma de manutenção dos privilégios das classes dominantes sobre as classes médias e trabalhadoras. Tais visões obscurecem a noção do Estado enquanto uma relação social, logo, arena de conflitos entre sujeitos coletivos, organizados não somente na sociedade política, mas também a partir da sociedade civil.

Em Gramsci ${ }^{10}$ a "sociedade civil reúne o conjunto dos organismos vulgarmente ditos privados e corresponde à função de hegemonia ${ }^{11}$ que o grupo dominante exerce em toda a sociedade", agrupando as organizações e instrumentos de direção ideológica da sociedade (PORTELLI, 1977, p.20). A sociedade política corresponde a uma função de dominação direta que se refere à função de coerção, que é ampliada, referindo-se não ao simples domínio repressivo, mas à direção ideológica e cultural da sociedade, responsável pela imposição e difusão da hegemonia da classe dominante. Nesse sentido, a sociedade política se constitui como "prolongamento da sociedade civil" (PORTELLI, 1977, p.30).

A sociedade política em Gramsci se apoia no aparato estatal. Conforme Codato (2008), Nicos Poulantzas na década de 1970, sob o referencial teórico de Gramsci, compreende o Estado como conjunto de aparelhos. Interessa mencionar as definições do autor de "aparelho ideológico de Estado" e "aparelho repressivo de Estado", como forma de elucidar as definições de sociedade civil e política, ou as funções de consenso e coerção, respectivamente. Segundo Poulantzas (1969) os

\footnotetext{
${ }^{9}$ Como apoio e aporte às leituras de Gramsci, utilizaram-se as leituras de intérpretes como Hugues Portelli (1977), Carlos Nelson Coutinho (1989; 1992) e Sônia Regina Mendonça (2007).

${ }^{10} \mathrm{Na}$ noção marxista clássica a sociedade civil corresponde ao conjunto das relações econômicas da sociedade e a sociedade política equivale ao aparelho de Estado. (PORTELLI, 1977)

${ }^{11}$ A hegemonia significa o predomínio ideológico das classe dominante sobre a classe subalterna" (Carnoy, 1988, p.93) em virtude do qual os valores da primeira são aceitos pela maioria da população, ou seja, a classe dominante obtém o consenso dos dominados.
} 
aparelhos ideológicos do Estado são a escola, a Igreja, a imprensa, o cinema, os sindicatos, os partidos (ou seja, os órgãos privados de hegemonia), enquanto os aparelhos repressivos do Estado correspondem ao exército, à polícia, ao direito. $\mathrm{O}$ autor, porém, esclarece que a distinção entre um e outro aparelho é meramente didática e descritiva, pois na prática todas as instituições estão articuladas por uma mesma ideologia, que carregam e reproduzem nas suas ações e funções. (POULANTZAS, 1969)

"Ao recuperar, para a reflexão sobre o Estado, os conceitos de Sociedade Política e Sociedade Civil sobretudo este último - Gramsci opera uma redefinição do construto e, ao fazê-lo, recria um conceito de Estado que engloba, tanto a uma quanto a outra, em permanente interação e interconexão" (MENDONÇA, 2007, p.6). Essa estreita colaboração leva a uma "ampliação do conceito de Estado, entendido como o conjunto dos órgãos, qualquer que seja seu estatuto formal - organizações privadas ou aparelho de Estado -, através dos quais é exercida a influência do grupo dominante". (PORTELLI, 1977, p.34)

O Estado em sentido amplo [ou Estado ampliado], com novas determinações, comporta duas esferas principais: a sociedade política [...] que é formada pelo conjunto de mecanismos através dos quais a classe dominante detém o monopólio legal da repressão e da violência, e que se identifica com os aparelhos de coerção sob controle das burocracias executiva e policial-militar; e a sociedade civil formada precisamente pelo conjunto das organizações responsáveis pela elaboração e/ou difusão das ideologias, compreendendo o sistema escolar, as Igrejas, os partidos políticos, os sindicatos, as organizações profissionais, a organização material da cultura (revistas, jornais, editoras, meios de comunicação de massa) etc. (COUTINHO, 1989, p.76-77).

Conforme se vê em Mendonça (2007, p.6) pensar o Estado a partir de Gramsci leva a considerar, por um lado, como as frações de classe se organizam no contexto da sociedade civil e, por outro, como "as agências ou órgãos públicos contemplam projetos e/ou atores sociais, emanados dos aparelhos privados de hegemonia". Esse pensamento, portanto, leva a considerar como grupos ou sujeitos coletivos organizados na sociedade civil contam com representantes no interior ou junto da sociedade política, no aparato estatal, e quais aparelhos privados de hegemonia contam com representantes - ainda que não em posição hegemônica - junto ao aparato estatal. Assim sendo, as ações de grupos da sociedade civil - como associações profissionais e a própria classe trabalhadora como sujeito coletivo - repercutem na sociedade política e no aparato estatal em particular, e o Estado se confirma como uma relação social.

A noção de Estado Ampliado, portanto, oferece uma alternativa à compreensão dos estados varguista e peronista sob a noção do Populismo, fenômeno tipicamente associado à passagem da sociedade rural-agrária para a urbano-industrial, portanto, no contexto de desenvolvimento do modo de produção capitalista nestes países, "como política de massas, que buscava conduzir, manipulando 
suas aspirações" (WEFFORT, 1980, p. 49). O populismo no Brasil e na Argentina ${ }^{12}$ teve como característica, segundo lanni (1989, p.11), a adoção de "políticas econômicas destinadas a impulsionar o desenvolvimento econômico e particularmente a industrialização, ou substituição de importações," e as reformas implementadas em diferentes esferas do sistema político-econômico que parecem ter mudado a fisionomia do aparato estatal e, por consequência, o relacionamento do próprio Estado com a sociedade civil. A partir destes dois aspectos, Vargas e Perón teriam reconhecido nas classes trabalhadoras parte fundamental do processo de desenvolvimento nacional, incluindo-as entre as classes contempladas pelas políticas estatais, antecipando suas necessidades e garantindo a elas benefícios antes negados pelo Estado.

Procurou-se, com aporte de bibliografia recente (DEL CAMPO, 1983; GOMES, 2005), compreender a constituição da classe trabalhadora como ator coletivo cujas demandas foram incorporadas pela sociedade política, não através de simples manipulação ou cooptação, mas pela ação e escolha da própria classe por direitos sociais, antes que políticos.

Na América Latina, e não apenas no Brasil, o acesso à cidadania por parte dos setores populares não passou pelas lutas pela ampliação do direito de voto, segundo o modelo clássico de incorporação em regime de representação política liberal. Nestes casos o acesso à cidadania está relacionado a todo um processo de constituição da identidade da classe trabalhadora conduzido pelos próprios membros desta classe através de suas numerosas lutas políticas. [...]. Já no caso da América Latina, o acesso à cidadania combina-se com 'um processo de formação de atores políticos' - a classe trabalhadora em especial - onde é nítida a intervenção estatal e onde, em princípio, pode estar ausente o problema da extensão da participação político-eleitoral. (GOMES, 2005, p.23)

Em ambos os governos se constrói uma base institucional corporativista, particularmente a partir da inserção de representantes da burocracia estatal nos sindicatos e/ou da inserção de representantes das classes trabalhadoras, nomeadamente dos sindicatos, no aparato estatal ${ }^{13}$. Conforme colocado por Fortes (2007), o aparato estatal passava a permitir a expressão de lideranças atuantes no movimento operário ou que ao menos tinham como projeto canalizar as demandas sociais da classe trabalhadora. Lutas e reivindicações puderam ser articuladas de forma orgânica ao processo político e, nesse sentido, entendemos ser possível pensar na representação da classe trabalhadora no interior

\footnotetext{
12 Ianni (1989) considera também o cardenismo como caso típico do populismo na América Latina, porém, entendeu-se que, no período analisado, os Estados brasileiro e argentino, nas figuras do varguismo e do peronismo, parecem concretizar de forma mais ampliada os processos econômicos descritos pelo autor vinculando-os à produção da habitação social como forma de aproximação entre Estado e sociedade civil. A produção habitacional estatal no México será mais destacada no governo de Miguel Alemán em 1946 (ver Capítulo 03).

13 De acordo D'Araújo (1996) a postura benevolente e antecipadora das reivindicações do trabalhador adotada por Vargas abriu espaço para a ação do "pelego", liderança sindical formada na estrutura burocrática e corporativa, que defendia as orientações do Ministério do Trabalho entre a classe trabalhadora, cumprindo um papel de intermediário entre os sindicatos e o governo. Na Argentina o Ministério de Trabajo y Previsión é criado em 1949 por Perón, que indica como ministro o sindicalista José María Freire, que já ocupava desde 1946 o cargo de Secretário de Trabalho e Previdência antes ocupado pelo próprio Perón. Ligado ao Sindicato de Obreros de la Industria del Vidrio y Afines Freire exerceu o cargo de Ministro de Trabalho e Previdência desde 1949 até 1953. (GAMBINI, 2014)
} 
da sociedade política através da noção de Estado ampliado ${ }^{14}$. Contudo, conforme colocado por Gomes (2005), a incorporação da classe trabalhadora na sociedade política ocorreu, sobretudo, através de um viés social, e não necessariamente político.

Paralelamente, arrisca-se a compreensão de que o conceito de Estado Ampliado oferece também uma alternativa à noção do Estado como "cooptador" do profissional arquiteto, em especial a vanguarda arquitetônica latino-americana, como a historiografia por muito tempo apresentou tanto para o caso de Vargas no Brasil, quanto para o de Perón na Argentina (FAUSTO, 1999; CIRVINI, 2012). Embora não se compreenda a categoria como classe, é possível pensá-la como um dos vários atores em disputa no campo político, buscando também espaço para sua própria ideologia que, se não era contra-hegemônica, trouxe contribuições para a política estatal em especial quanto a seu posicionamento ante a questão habitacional.

A produção habitacional analisada nesta Tese foi realizada no Brasil a partir da conformação do que denominamos "política previdenciária de habitação", resultante da decisão de enfrentar a questão habitacional prioritariamente através da aplicação dos fundos previdenciários na construção da moradia para o trabalhador. Os projetos habitacionais produzidos pelos Institutos de Aposentadoria e Pensões (IAPs) foram analisados inicialmente por Martha Farah (1983) em sua dissertação de mestrado na FFLCH-USP, "Estado, Previdência Social e Habitação", que teve a importância de lançar o tema da intervenção estatal na produção habitacional. Em 1998 Nabil Bonduki (1998) e Paulo Bruna (1998) analisam esta produção do ponto de vista arquitetônico, ressaltando nomeadamente seu aspecto modernista e o pioneirismo dos profissionais a ela relacionados. Em 2014, retomando e ampliando o estudo do tema, Bonduki publica os volumes resultantes do estudo sobre os "Pioneiros da habitação social". O primeiro volume traz um panorama ampliado do papel do Estado e das políticas de produção habitacional do período 1930 a 1964; o segundo volume, organizado com Ana Paula Koury, traz um ampliado inventário dos projetos habitacionais realizados entre 1930 e 1964 pelos IAPs e CAPs, pela FCP e órgãos promotores regionais; no terceiro volume, também organizado com Ana Paula Koury, diferentes pesquisadoras vinculadas ao projeto de pesquisa como Flávia Brito do Nascimento, Nilce Aravecchia Botas, Elaine Pereira da Silva, Salua Kairuz Manoel Poleto e Maria Luiza de Freitas analisam onze projetos habitacionais realizados entre 1930 e 1964, selecionados por seu interesse do ponto de vista arquitetônico, urbanístico ou construtivo e profissional.

Destaca-se também no estudo da produção habitacional realizada pelos IAPs a tese de doutorado de Nilce Aravecchia Botas (2011), publicada em 2016, sobre a organização do escritório técnico do IAPI, considerando aspectos como as relações político-econômicas que condicionaram os projetos e obras, as conexões entre os campos intelectual e político e as possibilidades colocadas pelo

\footnotetext{
${ }^{14} \mathrm{O}$ conceito de Estado ampliado em Gramsci compreendia a sociedade política como extensão da sociedade civil, olhando particularmente para a atuação da própria classe burguesa, ou dos aparelhos privados de hegemonia da burguesia, ou seja, olhando para a inserção de representantes dessa classe ou desses órgãos no interior da sociedade política. (PORTELLI, 1977)
} 
desenvolvimento tecnológico, além da atuação dos profissionais envolvidos, com destaque para o papel de Carlos Frederico Ferreira na direção do escritório. Destacamos também a dissertação de Pessolato (2007), sobre o projeto do C. R. Vila Guiomar em Santo André, que reúne e analisa dados até então dispersos em fontes bibliográficas e documentais, abordando aspectos políticos, econômicos, sociais e técnicos presentes em cada momento da execução do projeto e da obra.

$\mathrm{Na}$ Argentina a produção habitacional aqui analisada se realizou a partir de importante planejamento, que garantiu a estruturação do aparato estatal e do sistema bancário para promover habitação aos trabalhadores, respondendo ao ideal de "Justiça Social" promovido pelo presidente Juan Perón. Os estudos iniciais referentes a esta produção realizada pela Administración Nacional de la Vivienda (ANV), posteriormente incorporada ao Banco Hipotecario Nacional (BHN) e pelo Ministério de Obras Públicas (MOP), no âmbito da estrutura estatal, e pela Dirección de Vivienda de la Municipalidad de Buenos Aires, no âmbito da estrutura municipal, são realizados na década de 1980 por Maria Isabel de Larrañaga e Alberto Petrina (1987), que destacam a dificuldade e a complexidade da tarefa de estudar um tema com quase nenhum trabalho antecedente e cujas fontes primárias foram substancialmente destruídas. Em 2000 Renée Dunowicz publica um inventário da "ação do Estado em matéria de moradia social na cidade de Buenos Aires, desde princípios do século até nossos dias, permitindo visualizar temporal e espacialmente a magnitude e as características mais salientes desta ação" (DUNOWICZ, 2000, p.20). A produção habitacional peronista é objeto de dois importantes trabalhos de 2005, a tese de doutorado de Anahí Ballent em que analisa especialmente a relação entre os campos técnico e político na produção da habitação estatal em Buenos Aires, e a dissertação de mestrado de Rosa Aboy em que aborda a questão do enfrentamento da falta de moradias pelo Estado e como se deu a utilização dos conjuntos habitacionais pelos usuários, analisando o caso do barrio Los Perales. Destacamos ainda, como análise ampliada da produção habitacional do período peronista, a publicação organizada por Ramón Gutierrez em 2011 no CEDODAL.

Nosso trabalho se articula a este grupo de estudos, aprofundando a análise dos projetos habitacionais produzidos entre 1940 e 1950 em São Paulo e Buenos Aires a partir de sua compreensão como produção em grande escala, ou massiva, como é referida na bibliografia argentina. No âmbito desta análise, o estudo da relação entre Estado e os profissionais de arquitetura relacionados à produção habitacional e de como estes se inserem no aparato estatal ganhou destaque, bem como o estudo das cidades como base material para a implantação dos projetos.

Além das já citadas referências bibliográficas que tratam da produção habitacional e das políticas de habitação do período em tela, constituíram importantes fontes de informação os Processos Administrativos e documentos correlatos dos projetos habitacionais armazenados no Arquivo Geral de Processos da Prefeitura de São Paulo (Divisão do Arquivo Municipal de Processos), e no Centro de Documentación e Investigación de la Arquitectura Pública (CeDIAP) de Buenos Aires. 
Realizamos também larga pesquisa e análise da legislação do período, em ambos os países e ambas as cidades, referente aos temas da habitação e da criação de órgãos e instituições relacionados à questão habitacional, normas construtivas e de urbanização, padrões de posturas e códigos sanitários, planos de governo e Constituições Nacionais. A legislação promulgada no período estudado é de suma importância para a compreensão do processo de institucionalização da ação estatal na produção da moradia, sendo fonte primária no estudo dos órgãos promotores de habitação e da própria política habitacional realizada.

Foram estudados também os anais e atas de congressos realizados no período - os Congresos Panamericanos de Arquitectos (1920-1960), o Primer Congreso Argentino de la Habitación (1920), o Primer Congreso Argentino de Urbanismo (1935), o Primer Congreso Panamericano de Vivienda Popular (1939), o Primeiro Congresso da Habitação (1931), o Primeiro Congresso de Urbanismo (1941), as Jornadas da Habitação Econômica (1941) - que constituem também fonte primária de informação sobre a circulação de ideias no período.

Destacamos ainda a pesquisa em periódicos especializados publicados nos dois países entre as décadas de 1930 e 1960, que constituem também importante fonte para a compreensão do debate e articulação profissional. Entre os periódicos argentinos destacam-se Nuestra Arquitectura ${ }^{15}$ e Revista de Arquitectura $^{16}$, publicados sistematicamente desde as primeiras décadas do século XX e, portanto, importantes para entender a evolução do debate profissional. Outras publicações referentes a assuntos específicos podem ser também destacadas tais como a revista El Arquitecto Constructor e o boletim oficial da Comisión Nacional de Casas Baratas, La Habitación Popular ${ }^{17}$.

São representativos entre os periódicos especializados brasileiros a revista Acrópole ${ }^{18}$ e a Revista de Arquitetura $^{19}$, ambas publicadas entre as décadas de 1930 e 1970 e, portanto, importantes ao estudo

\footnotetext{
${ }^{15}$ A revista Nuestra Arquitectura foi fundada pelo engenheiro estadunidense Walter Hylton Scott em 1929 e publicada mensalmente até 1986 (305 números). Conforme relatam Liernur e Aliata (2004) os primeiros números traziam temas e exemplares relacionados à arquitetura academicista de estilo Beaux-Arts, em voga no início do século XX, porém com o passar dos anos se perceberia cada vez mais a presença do ideário moderno nas matérias e projetos divulgados na revista. Segundo Liernur e Aliata (2004) Nuestra Arquitectura se dedicou mais à publicação de projetos e obras, majoritariamente localizados em Buenos Aires, que a aspectos críticos da própria arquitetura, salvo por contribuições específicas de arquitetos renomados.

${ }^{16}$ A Revista de Arquitectura apresenta algumas particularidades. O periódico foi publicado com este nome entre 1915 e 1956 (números 1 a 376), porém até março de 1917 era a publicação oficial do Centro de Estudantes de Arquitectura, sendo a partir de então a revista da Sociedad Central de Arquitectos (SCA). A SCA até 1917 publicara oficialmente outros periódicos: a revista "Arquitectura" entre abril de 1904 e dezembro de 1916 (números 1 a 109) e a "Revista de la Sociedad Central de Arquitectos" em janeiro, fevereiro e março de 1917 (números 110, 111, 112) e, a partir de 1955 até 1967, publicaria o "Boletín de la Sociedad Central de Arquitectos" (60 números), sendo estas quatro publicações consideradas como um conjunto.

17 "La Habitacion Popular" foi publicado entre 1934 e 1943. Além de textos referentes às atividades da própria CNCB, leemse também considerações sobre a moradia operária, o financiamento da moradia econômica, e as atividades do BHN e do Estado relativamente à produção habitacional.

${ }^{18}$ Entre 1938 e 1971 (390 números) a revista Acrópole publicou especialmente projetos arquitetônicos e urbanísticos recém-construídos, notando-se a partir da década de 1950 também ensaios e textos complementares aos projetos apresentados. A revista é dirigida por Roberto A. Corrêa de Brito até 1953, quando é vendida a Max M. Gruenwald, que a dirige até 1971. Segundo a apresentação da revista no site da FAU-USP, onde se encontra disponível on-line, sendo uma revista comercial direcionada não apenas ao público especializado, mas também para estudantes e demais interessados, a
} 
do debate profissional no período considerado, o Boletim do Instituto de Engenharia, publicado entre 1917 e 1941, seguido pela Revista Engenharia ${ }^{20}$, publicada a partir de 1942, e a revista Arquitetura e Urbanismo $^{21}$, órgão oficial do Instituto de Arquitetos do Brasil.

No Primeiro Capítulo, analisamos os projetos habitacionais realizados em São Paulo e Buenos Aires, bem como em cidades das respectivas regiões metropolitanas em que se identificam evidências de uma perspectiva de produção em grande escala. Procurou-se discriminar as especificidades de cada produção, ressaltando os aspectos mais relevantes em cada contexto, que aproximam os projetos desta perspectiva. Mais que propriamente identificar as características de cada projeto de habitação, a importância deste capítulo reside em evidenciar as particularidades da produção habitacional promovida pela ação direta do Estado em São Paulo e Buenos Aires e a relevância da investigação sobre as condições que implicaram nas semelhanças e diferenças encontradas. Para a análise realizada foram utilizadas fontes primárias, com ênfase em Processos Administrativos e Projetos Oficiais dos conjuntos nas duas cidades e trabalhos de autores como Bonduki (1998; 2014), Bruna (1998), Ballent (2005), Aboy (2005) e Gutierrez (2011).

$\mathrm{Na}$ sequência buscamos apresentar um quadro do que se considera terem sido condições fundamentais para a realização da produção habitacional nos moldes observados: os cenários socioeconômicos e políticos dos dois países e a articulação entre profissionais de arquitetura e urbanismo no continente.

O Capítulo 2 é dedicado à compreensão do cenário político, econômico e social conformado no Brasil e na Argentina, quando se inicia o processo de institucionalização da produção habitacional pelo Estado nos dois países, e das alterações deste cenário inicial enquanto as propostas e resultados se desenvolviam, nomeadamente nas décadas de 1940 e 1950. Não se buscou apresentar um resumo dos fatos históricos, mas as questões-chave para a compreensão do tema estudado, especialmente no que se refere a permanências e transformações na ação estatal diante da questão habitacional e à

Acrópole não apresentou uma ideologia clara ou uma única tendência na divulgação dos trabalhos, mas os muitos arquitetos colaboradores do periódico "delinearam as diversas personalidades da Acrópole ao longo de mais de três décadas, compondo um impressionante e surpreendente testemunho de época".

19 A Revista de Arquitetura foi criada como órgão oficial da Escola Nacional de Belas Artes, no Rio de Janeiro, sendo publicada mensalmente entre 1934 e 1978. A revista publica especialmente projetos arquitetônicos e textos sobre o tema da arquitetura, inclusive trabalhos acadêmicos, registrando-se opiniões e ideologias variadas, especialmente nos primeiros números, quando é notável o debate entre arquitetura tradicional e modernista. Outras publicações referem-se ao tema do urbanismo, também caro à própria instituição desde a década de 1930.

${ }^{20}$ O Boletim do Instituto de Engenharia começa a ser publicado em outubro de 1917, contado até 1929 com um Conselho Diretor e Técnico de profissionais do próprio Instituto. A partir desta data até 1941, quando a revista é extinta, seguiram-se na direção geral do Boletim Luiz de Mendonça Júnior, Ranulpho Pinheiro Lima, J. M. de Toledo e José Amadei. Os principais assuntos publicados referiam-se a temas da engenharia em geral, com predominância da engenharia civil e grande destaque para aspectos do urbanismo. Em 1942 foi criada a Revista Engenharia que daria continuidade à proposta do Boletim, tendo até 1950 um diretor-geral, Ranulpho Pinheiro Lima. A Revista Engenharia segue sendo o órgão do Instituto de Engenharia até os dias atuais.

${ }^{21}$ A Revista Arquitetura e Urbanismo foi publicada entre os anos de 1936 e 1942, com frequência bimestral. Sendo a publicação oficial do Instituto de Arquitetos do Brasil o órgão traz textos referentes ao exercício da profissão e às mudanças do papel do arquiteto na sociedade, mas também projetos arquitetônicos e urbanísticos e propagandas de escritórios de arquitetura e construção. 
relação entre Estado e população, especialmente a classe trabalhadora. Procuramos salientar como no interior destes Estados uma série de políticas e práticas estatais, entre as quais aquelas ligadas à produção habitacional destinada à classe trabalhadora, se apresentava como motor para uma transformação nacional.

A atuação estatal na produção da habitação destinada ao trabalhador é analisada na perspectiva colocada por Adrian Gorelik, que discute a noção de que na América Latina o trabalho dos profissionais ligados à produção da cidade pressupunha o Estado não apenas como viabilizador de projetos, mas como ator em um trabalho conjunto em prol do atendimento das necessidades sociais e da modernização.

No Capítulo 3, procuramos apresentar um quadro ampliado sobre a articulação entre profissionais de arquitetura e urbanismo em torno do tema da habitação no continente americano, com especial ênfase para a América Latina. Essa articulação se manifestava em congressos regionais e locais, na circulação de periódicos especializados, na formação e fortalecimento de associações profissionais e, ainda, na constituição e reorganização de instituições de ensino, que explicitam a importância do projeto habitacional na conformação do campo e, fundamentalmente, a sua compreensão como função social da arquitetura. Além de atas de congressos e periódicos brasileiros e argentinos selecionados para estudo, foram utilizados como referência os trabalhos de Martins (1987), Botas (2011), Ballent (2005) e Cirvini (2012), que tratam especialmente da relação entre Estado e profissionais, entre política e técnica. Alguns trabalhos se destacam ainda para a compreensão da recepção do ideário moderno na América Latina, e especificamente no Brasil e na Argentina, e sua adaptação às necessidades e condições locais entre as décadas de 1930 e 1960. Destacam-se entre as primeiras Gorelik (1999; 2005) e Liernur (2004) e, entre as segundas, Guerra (2010), Liernur (2001), Liernur e Pschepiurca (2008), Martins (1987; 1992; 1998) e Xavier (2003).

Considera-se que esta articulação contribuiu para que no Brasil, arquitetos e engenheiros ocupassem espaços importantes no aparato estatal reorganizado por Vargas, não apenas no setor técnico, como também no administrativo, relacionando-se a grandes planos de urbanização e industrialização (ARAVECCHIA-BOTAS, 2016). Na Argentina os arquitetos se sobressaem entre os profissionais atuantes no aparato estatal e na realização dos projetos de habitação nos espaços organizados pelo Estado peronista.

No Capítulo 4, a produção habitacional realizada em São Paulo foi estudada a partir de treze projetos promovidos pelos IAPs dentro de uma perspectiva de produção em grande escala. Conforme se verificou, os Institutos de Aposentadoria e Pensões mais atuantes na produção habitacional em São Paulo foram aqueles diretamente relacionados ao crescimento da importância econômica da cidade na década de 1940, bem como a seu processo de metropolização, o que se explora também neste capítulo. 
O Capítulo 5 apresenta as características da produção habitacional promovida pelo Estado na Argentina a partir dos projetos de habitação produzidos em Buenos Aires, sem perder de vista o fato de esta ser a capital do país, o que implicou algumas diferenças importantes com relação a outras cidades. Analisa-se a produção habitacional em Buenos Aires entre 1943 e 1955 com base em dez projetos em que se identificou a perspectiva de produção massiva. No estudo da inserção urbana destes projetos habitacionais verificamos que a sua localização esteve em grande parte relacionada a uma perspectiva de acesso à cidade consolidada, associada a um projeto de urbanização.

À guisa de Conclusão procurou-se ressaltar aspectos importantes à compreensão da produção da habitação social na América Latina como universo de estudo, mas de modo especial as similaridades e diferenças entre a produção habitacional realizada em São Paulo e Buenos Aires, enfatizando-se as condições para tais características. Consideramos que apesar de em ambas as produções haver uma perspectiva de grande escala, a sua materialização ocorreu de formas diferentes em cada cidade (e nas respectivas áreas metropolitanas) não apenas em função das cruciais diferenças nos processos de institucionalização da produção habitacional pelos Estados varguista e peronista e das diferentes formas de inserção ou vinculação dos arquitetos e urbanistas no aparato estatal em cada país, mas também em função dos respectivos processos de urbanização, expansão periférica e metropolização e de como as políticas de promoção habitacional se posicionaram com relação a estas cidades. 
Capítulo 1

Projetos habitacionais em grande escala em São Paulo e Buenos Aires 


\subsection{Produção habitacional em grande escala em São Paulo: uma questão enfrentada pelos Institutos de Aposentadoria e Pensões}

No início da década de 1940 a produção habitacional é institucionalizada pelo Estado brasileiro a partir da organização dos Institutos de Aposentadoria e Pensões (IAPs). Em 1937, através do Decreto no 1.749 o Estado regulamenta a atividade imobiliária dos IAPs, atribuindo-Ihes a possibilidade de aplicar até $50 \%$ de seus recursos na promoção da moradia aos trabalhadores (BRASIL, 1937). No entanto, a produção de habitações ocorreria de forma significativa a partir da década de 1940. Esta produção se destaca pela concepção de grandes projetos habitacionais que carregam na própria forma "conjunto" a ideia da produção em grande escala (BONDUKI, 1998; 2014; BRUNA, 1998). A proposição da construção de conjuntos de habitação onde se aplicasse a noção da produção em série é colocada por profissionais de engenharia, arquitetura e urbanismo inseridos no aparato estatal. O engenheiro-arquiteto Rubens Porto, que atua no MTIC como assessor técnico no Conselho Nacional do Trabalho, escreve em seu livro de 1938, "O Problema das Casas Operárias e os Institutos de Aposentadoria e Pensões", sobre a necessidade de "concentrar os programas de habitação barata sobre grandes planos de organização regional" (PORTO, 1938, p.61), verdadeiras células autárquicas de cidade, com vias próprias de tráfego exclusivamente local, ruas de pedestres e campos de esportes entre os edifícios, além de grandes áreas livres arborizadas que tornariam os lares mais aprazíveis e saudáveis. 
No interior da organização técnica dos Institutos também se colocava a necessidade de produção em grande escala, conforme fica explicitado na fala de Alim Pedro, presidente do Instituto de Aposentadoria e Pensões dos Industriários (IAPI) entre 1946 e 1951 no relatório "O Seguro Social, a Indústria brasileira e o Instituto dos Industriários", de 1950:

A construção em série, apresentando características de produção industrial, possibilita a obtenção de custos baixos, sem prejuízo de um padrão construtivo satisfatório. Por outro lado, a concentração em altura permite a diminuição do valor da cota-parte do terreno e da urbanização. (...) Edifícios coletivos elevados, convenientemente dispostos no interior de amplas áreas de utilização comum, representam, pois, a melhor solução do problema (PEDRO, 1950, pp.293, 294).

O mesmo tipo de indicação pode ser visto no conjunto de diretrizes colocadas para os projetos habitacionais do Instituto dos Comerciários (IAPC) de São Paulo, conforme o arquiteto Eduardo Kneese de Mello registra no "Il Anteprojeto do C.R. Cidade Jardim apresentado ao IAPC". Entre as diretrizes, indica-se que

a. o projeto deverá conduzir à realização de um conjunto residencial em moldes sociais modernos, articulados na disposição urbanística e composição arquitetônica, de acordo com os níveis de vida das categorias dos comerciários, compatíveis com aquele local; [...] e. as residências deverão ser padronizadas ao menor número de tipos, de acordo com as condições locais, sem reduzir a expressão arquitetônica do conjunto; f. os elementos construtivos ou acessórios, quer estruturais, quer de acabamento, ou mesmo os de ajardinamento, deverão ser concebidos em moldes a permitir a máxima pré-fabricação aconselhável; [...]. (KNEESE DE MELLO, 1945, s/p ${ }^{1}$ apud REGINO, 2006, p.156).

Propomos aqui analisar como se expressa nos projetos habitacionais realizados pelos IAPs em São Paulo esta perspectiva de produção em grande escala. Cada Instituto apresentou um padrão diferenciado de produção habitacional que se relacionava a fatores como as condições socioeconômicas dos associados e, por consequência, a arrecadação de cada Instituto, a atuação dos sindicatos de cada categoria e a consolidação de políticas próprias a cada escritório técnico. Implicava também a produção habitacional a questão do custo da terra, relevante quando se considera não apenas a localização dos projetos nas cidades e seus arredores, como também as tipologias utilizadas, conforme apresentaremos no Capítulo 4.

Foram utilizadas basicamente três tipologias nestes projetos habitacionais: a primeira, o conjunto de blocos multifamiliares implantados em grandes terrenos sem divisão de lotes, entendendo-se como bloco as lâminas com até quatro ou cinco pavimentos; a segunda, o conjunto horizontal de unidades unifamiliares em lotes individuais, mas de propriedade dos Institutos; e a terceira, o edifício vertical isolado (com dez ou mais pavimentos) inserido em terrenos pequenos se comparados aos anteriores, porém muito bem localizados, geralmente em áreas já consolidadas. Alguns projetos contam com

\footnotetext{
${ }^{1}$ KNEESE DE MELLO, Eduardo. IAPC. Delegacia de São Paulo. Conjunto Residencial Cidade Jardim. Anteprojeto II. Arquiteto Eduardo Kneese de Mello. São Paulo, [s.n.], 1945.
} 
duas tipologias: blocos multifamiliares e casas unifamiliares, blocos e edifícios multifamiliares e, em um único caso, casas unifamiliares e um edifício vertical.

Ocupando muitas vezes enormes glebas que se distinguiam do entorno pelo projeto urbanístico concebido, os conjuntos eram constantemente associados a equipamentos comunitários, serviços e espaços livres. Mesmo ocupando terrenos menores, também os edifícios isolados contavam com equipamentos coletivos e serviços disponibilizados aos moradores, mas também, em alguns casos, à população não moradora. A proposta de integração da moradia a equipamentos coletivos, espaços verdes e áreas de recreação possibilitava que atividades cotidianas pudessem ser realizadas sem que se saísse do conjunto ou edifício, sendo importante na concepção dos projetos porque se contrapunha à solução da moradia popular produzida sem qualquer infraestrura pelo mercado rentista.

Identificamos em São Paulo e em outros municípios da região metropolitana ${ }^{2}$ treze projetos habitacionais com mais de 300 unidades de moradia, número considerado nesta Tese como evidência de uma perspectiva de produção em grande escala nas décadas de 1940 e 1950. Os maiores projetos contam aproximadamente 4.000 unidades, embora não tenham sido construídos em sua totalidade. O grupo de projetos selecionados inclui os conjuntos residenciais da Várzea do Carmo, Japurá, Mooca, Vila Guiomar e Jardim Piratininga do IAPI; os conjuntos Cidade Jardim, Cidade Comerciária Presidente Vargas, Brasílio Machado Neto e o Edifício Santa Cecília do IAPC; os conjuntos Nove de Julho, Santo Antônio e Santa $\mathrm{Cruz}^{3}$ do Instituto dos Bancários (IAPB); além do Núcleo Residencial Francisco Morato do Instituto de Previdência do Estado de São Paulo (IPESP), que, portanto, atuou apenas neste estado 4 .

Estes projetos são concebidos e executados ${ }^{5}$ entre as décadas de 1940 e 1950 - exceto por um único conjunto da década de 1960 -, quando a grande escala de produção se distingue como importante característica da construção civil em São Paulo, especialmente em função do desenvolvimento da própria indústria da construção, mas também do processo de expansão urbana e metropolitana e do aumento populacional (GITAHY; PEREIRA, 2002; SINGER, 1968). A maioria dos conjuntos é constituída por cerca de 20 blocos idênticos ou, eventualmente, de dois ou mais tipos que se repetem. Dois conjuntos, o C.R. Santo Antonio e o Núcleo Francisco Morato, chegam a ter mais de 50 blocos. Os

\footnotetext{
2 Em 1973 São Paulo e mais 37 municípios vão compor a Região Metropolitana de São Paulo, não havendo ainda na década de 1940 uma nomenclatura que indicasse este conjunto. Assim, nos referiremos a "São Paulo e municípios vizinhos" para indicar onde estão localizados os projetos analisados nesta Tese.

3 O C.R. Santa Cruz foi incluído na seleção, embora com menos de 300 unidades (possui 282), por ser o primeiro conjunto de blocos do IAPB, sendo bastante representativo da "mudança de chave" da Divisão de Engenharia deste instituto, que, a partir de então, só produzirá projetos com blocos e edifícios multifamiliares.

${ }^{4}$ Ver Capítulo 02.

${ }^{5}$ Alguns projetos não foram executados, conforme indicamos quando necessário. Para algumas análises realizadas, porém, a construção ou não dos projetos é irrelevante, importando a sua concepção dentro de uma perspectiva de produção em grande escala.
} 
projetos constituídos por unidades unifamiliares apresentam, em geral, poucos tipos padronizados de unidades. Os edifícios verticais isolados possuem mais de 10 pavimentos e térreo liberado com pilotis ou constituído por salas de comércio e garagens.

O Quadro 1 apresenta os projetos relacionados em São Paulo e em municípios vizinhos. O quadro indica a área do terreno e número de unidades propostas e construídas em cada projeto, bem como a densidade habitacional proposta. As densidades, quando não encontradas nas fontes documentais e bibliográficas, foram calculadas com base na estimativa de grupos familiares de quatro pessoas por unidade projetada (estimativa em função de indicações de que a família operária se compunha em média por quatro pessoas, conforme artigos de periódicos da época). São apresentadas também as tipologias habitacionais de cada projeto e os equipamentos comunitários (entendidos como aqueles destinados aos moradores) e serviços e comércio (entendidos como aqueles destinados não apenas aos moradores, mas à população em geral). A partir do número de unidades projetadas, somamos o total de unidades propostas por cada IAP e, com estes dados, elaboramos também um gráfico (Gráfico 01) que evidencia a atuação de cada órgão. 
Quadro 1

Projetos habitacionais em São Paulo e municípios vizinhos nas décadas de 1940 e 1950

\begin{tabular}{|c|c|c|c|c|c|c|c|c|c|c|c|c|}
\hline \multirow[t]{2}{*}{ Órgão } & \multirow[t]{2}{*}{ Projeto } & \multirow[t]{2}{*}{$\begin{array}{c}\text { Área do } \\
\text { terreno e } \\
\text { densidade }\end{array}$} & \multicolumn{3}{|c|}{$\begin{array}{c}\text { Tipologias } \\
\text { multifamiliares: } \\
\text { Blocos (B)/ } \\
\text { Edifícios (E) }\end{array}$} & \multicolumn{3}{|c|}{$\begin{array}{c}\text { Tipologias } \\
\text { unifamiliares: } \\
\text { Casas Isoladas }(\mathrm{Ci}) / \\
\text { C. Geminadas }(\mathrm{Cg}) / \\
\text { C. Enfileiras }(\mathrm{Cf})\end{array}$} & \multirow[t]{2}{*}{$\begin{array}{l}\text { Equipamento } \\
\text { comunitário }\end{array}$} & \multirow[t]{2}{*}{$\begin{array}{l}\text { Serviços e } \\
\text { comércio }\end{array}$} & \multirow[t]{2}{*}{ Data } & \multirow[t]{2}{*}{$\begin{array}{c}\text { Núm. de } \\
\text { unidades } \\
\text { construídas } \\
\text { e } \\
\text { (propostas) }\end{array}$} \\
\hline & & & B & E & Pav. & $\mathrm{Ci}$ & $\mathrm{Cg}$ & Cf & & & & \\
\hline \multirow{5}{*}{ IAPI } & $\begin{array}{l}\text { C.R. da } \\
\text { Várzea do } \\
\text { Carmo }\end{array}$ & $\begin{array}{l}28 \text { ha } \\
D=1250 \\
\text { hab/ha }\end{array}$ & 43 & 12 & $\begin{array}{c}4[\mathrm{~B}] \\
\mathrm{T}+11[\mathrm{E}]\end{array}$ & - & 1942 & - & $\begin{array}{l}\text { (escola, clube, } \\
\text { restaurante, } \\
\text { creche) }\end{array}$ & $\begin{array}{l}\text { (cinema, } \\
\text { rodoviária, } \\
\text { edifício de } \\
\text { escritórios, } \\
\text { hotel, p. } \\
\text { combustível, s. } \\
\text { comerciais) }\end{array}$ & 1942 & $552(4038)$ \\
\hline & C.R. Japurá & $\begin{array}{c}\text { 0,8 ha } \\
\sim \mathrm{D}=1500 \\
\text { hab/ha }\end{array}$ & 1 & 1 & $\begin{array}{c}14[\mathrm{E}] \\
\mathrm{T}+1[\mathrm{~B}]\end{array}$ & & & & $\begin{array}{l}\text { cozinha, terraço, } \\
\text { playground, }\end{array}$ & $\begin{array}{c}\text { restaurante, } \\
\text { salas } \\
\text { comerciais } \\
\end{array}$ & 1942 & 310 \\
\hline & $\begin{array}{l}\text { C.R. Vila } \\
\text { Guiomar }\end{array}$ & $\begin{array}{l}50 \text { ha } \\
\sim D=240 \\
\text { hab/ha }\end{array}$ & $\begin{array}{c}26 \\
\text { (B1) } \\
36 \\
\text { (B2) }\end{array}$ & & $\begin{array}{c}4[\mathrm{~B} 1] \\
4+\mathrm{T} \\
{[\mathrm{B} 2]}\end{array}$ & 96 & 337 & & $\begin{array}{l}\text { escola, ginásio, } \\
\text { igreja, a. verdes }\end{array}$ & & 1942 & $\begin{array}{c}978+433 \\
(3000)\end{array}$ \\
\hline & $\begin{array}{l}\text { C.R. da } \\
\text { Mooca }\end{array}$ & $\begin{array}{l}5,30 \text { ha } \\
\sim D=430 \\
\text { hab/ha }\end{array}$ & $\begin{array}{c}12 \\
(\mathrm{~B} 1) \\
5 \\
\text { (B2) } \\
\end{array}$ & & $\begin{array}{l}4[\mathrm{~B} 1] \\
5[\mathrm{~B} 2]\end{array}$ & & & & $\begin{array}{l}\text { playground; } \\
\text { (ginásio, posto } \\
\text { médico) }\end{array}$ & (mercado) & 1946 & 576 \\
\hline & $\begin{array}{c}\text { C.R. } \\
\text { Piratininga }\end{array}$ & $\begin{array}{c}\text { 15,4 ha } \\
\sim D=1000 \\
\text { hab/ha }\end{array}$ & & & & 139 & 218 & & a. verdes & & 1946 & $\begin{array}{c}357 \\
(4000)\end{array}$ \\
\hline & & & & & & & & & & & & 11924 \\
\hline \multirow{4}{*}{ IAPC } & $\begin{array}{c}\text { Edifício de } \\
\text { Santa Cecília }\end{array}$ & $\begin{array}{l}0,7 \text { ha } \\
\sim D=2.000 \\
\text { hab/ha }\end{array}$ & & 2 & $\begin{array}{c}15+2 \mathrm{~T} \\
{[\mathrm{E} 1]} \\
7+2 \mathrm{~T} \\
{[\mathrm{E} 2]} \\
\end{array}$ & & & & & $\begin{array}{c}\text { salas } \\
\text { comerciais }\end{array}$ & 1947 & $\begin{array}{c}0 \\
(367)\end{array}$ \\
\hline & $\begin{array}{l}\text { C.R. Cidade } \\
\text { Jardim }\end{array}$ & $\begin{array}{c}24 \text { ha } \\
\text { D=130 } \\
\text { hab/ha }\end{array}$ & 2 & 1 & $\begin{array}{c}2+\mathrm{T}[\mathrm{B}] \\
10+\mathrm{T} \\
{[\mathrm{E}]}\end{array}$ & & & 518 & $\begin{array}{l}\text { (escola primária, } \\
\text { jardim de } \\
\text { infância, creche) }\end{array}$ & $\begin{array}{c}\text { centro } \\
\text { comercial, } \\
\text { ambulatório, } \\
\text { maternidade } \\
\end{array}$ & 1947 & $\begin{array}{c}0 \\
(600+518)\end{array}$ \\
\hline & $\begin{array}{l}\text { Comunidade } \\
\text { Brasílio } \\
\text { Machado } \\
\text { Neto }\end{array}$ & $\begin{array}{c}87,5 \text { ha } \\
\text { D=43 } \\
\text { hab/ha }\end{array}$ & 17 & & 2 & 580 & & (33) & $\begin{array}{l}\text { (escola, jardim de } \\
\text { infância, centro } \\
\text { comunal: igreja, } \\
\text { mercado, clube e } \\
\text { cinema, quadras) }\end{array}$ & $\begin{array}{l}\text { (rodoviária, } \\
\text { restaurante, } \\
\text { lojas) }\end{array}$ & 1958 & 782 (749) \\
\hline & $\begin{array}{c}\text { Cidade } \\
\text { Comerciária } \\
\text { Presidente } \\
\text { Vargas }\end{array}$ & $\begin{array}{c}29 \\
\sim D=72 \\
\text { hab/ha }\end{array}$ & & & & 523 & & & $\begin{array}{c}\text { escola, posto } \\
\text { abasteci/o, } \\
\text { clínica de saúde }\end{array}$ & & 1954 & 523 \\
\hline & & & & & & & & & & & & 2790 \\
\hline \multirow{3}{*}{ IAPB } & $\begin{array}{l}\text { C.R. Nove de } \\
\text { Julho }\end{array}$ & $\begin{array}{l}2,20 \text { ha } \\
\sim D=860 \\
\text { hab/ha }\end{array}$ & & 3 & $\mathrm{~T}+11$ & & & & $\begin{array}{l}\text { sala de estar, } \\
\text { depósito, centro } \\
\text { social: cursos, } \\
\text { ambulatório, } \\
\text { atend. médico e } \\
\text { odontológico }\end{array}$ & & 1948 & 473 \\
\hline & $\begin{array}{l}\text { C.R. Santa } \\
\text { Cruz }\end{array}$ & $\begin{array}{l}\text { 6,2 ha } \\
\sim \mathrm{D}=182 \\
\text { hab/ha }\end{array}$ & 23 & & 3 & & & & $\begin{array}{c}\text { clube, } \\
\text { ambulatório, } \\
\text { posto de } \\
\text { abasteci/o }\end{array}$ & & 1948 & 282 \\
\hline & $\begin{array}{l}\text { C.R. Santo } \\
\text { Antonio }\end{array}$ & $\begin{array}{l}12 \text { ha } \\
\sim \mathrm{D}=328 \\
\text { hab/ha }\end{array}$ & 53 & & 4 & & & & $\begin{array}{c}\text { Igreja, } \\
\text { (2 escolas, centro } \\
\text { social, esportivo, } \\
\text { abasteci/o, } \\
\text { ambulatório) }\end{array}$ & & 1962 & $\begin{array}{l}1272 \\
(984)\end{array}$ \\
\hline \multirow{3}{*}{ IPESP } & & & & & & & & & & & & 2027 \\
\hline & $\begin{array}{l}\text { Núcleo } \\
\text { Residencial } \\
\text { Francisco } \\
\text { Morato }\end{array}$ & $\begin{array}{l}15,3 \text { ha } \\
\sim D=220 \\
\text { hab/ha }\end{array}$ & 105 & & 4 & & & & a. verdes & & 1951 & 840 \\
\hline & & & & & & & & & & & & 840 \\
\hline $\begin{array}{l}\text { Fontes: } \\
\text { Corrêa } \\
\text { N.11.56 }\end{array}$ & $\begin{array}{l}\text { aboração da a } \\
\text { a (1942; } 1943 \\
46 ; \text { N.65.163/ }\end{array}$ & $\begin{array}{l}\text { ra com base } \\
\text { Mello (1947 } \\
\text { N.153.800/ }\end{array}$ & $\begin{array}{l}\text { m: B } \\
\text { Proce } \\
\text { 9. }\end{array}$ & 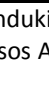 & $\begin{array}{l}\text { oury }(20 \\
\text { ninistrati }\end{array}$ & & $(199$ & & $\begin{array}{l}\text { 2005), Botas (2011 } \\
\text { /44; N.21.197/42; }\end{array}$ & $\begin{array}{l}\text { ssolato (2007 } \\
\text { L.964/48; N.1 }\end{array}$ & $\begin{array}{l}\text { gino; } \\
25 / 51\end{array}$ & $\begin{array}{l}\text { rone (2009), } \\
.188 .992 / 65 \text {; }\end{array}$ \\
\hline
\end{tabular}


Gráfico 01. Total de unidades previstas por IAP

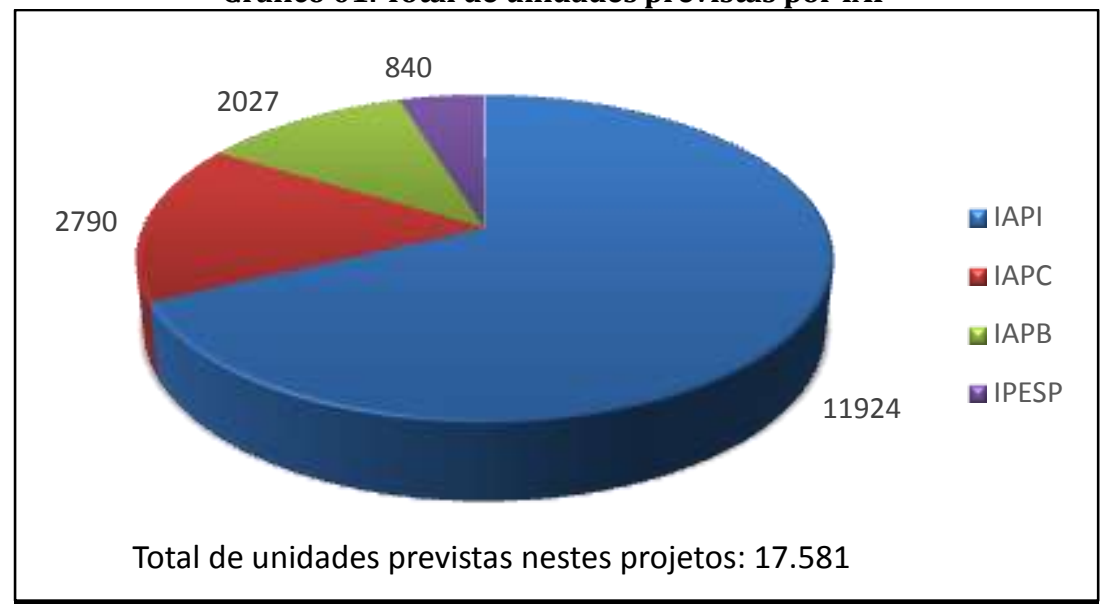

Elaboração da autora.

Vê-se que o IAPI foi o Instituto que produziu o maior número de projetos. Se construídos, ou construídos em sua totalidade, os cinco projetos do IAPI somariam 11.924 unidades. Os quatro projetos do IAPC somariam 2.790 unidades se construídos e os três projetos do IAPB, construídos, somam 2.027 unidades. O IPESP produziu um único conjunto em grande escala, com 840 unidades. No total, portanto, contam-se nestes projetos 17.581 unidades. Entre 1930 e 1964 os diferentes IAPs e o IPESP promoveram em São Paulo e em municípios vizinhos ao todo 39 projetos que somariam cerca de 21.400 unidades, conforme registramos a partir do Inventário realizado por Bonduki e Koury (2014). Assim, percebemos que mais de $80 \%$ do total de unidades projetadas estavam nestes projetos em grande escala produzidos entre as décadas de 1940 e 1950.

Este grupo de projetos nos ajuda na formulação e demonstração do argumento de que a produção em grande escala da moradia em São Paulo foi uma questão enfrentada pela atuação dos IAPs entre as décadas de 1940 e 1950. Conforme é possível perceber pelas indicações já feitas e como se procura demonstrar ao longo deste texto, a construção em grande escala se identificava ideologicamente - como questão social - e formalmente - como linguagem e técnica - com o ideário moderno. Assim sendo, a análise de determinados projetos foi privilegiada no sentido de reforçar a evidência de uma perspectiva de produção em grande escala - e de aspectos do ideário moderno na produção habitacional dos IAPs.

Olhando para este grupo de projetos destacamos os principais aspectos ou características que os identificam com a produção habitacional em grande escala e que são privilegiados em nossa análise. O primeiro aspecto que se sobressai é a linguagem formal, manifesta, sobretudo, nas tipologias multifamiliares verticais, que possibilitavam o adensamento populacional - reduzindo o fator "custo da terra" - e pressupunham a racionalização dos processos construtivos. Neste âmbito, a estandardização e pré-fabricação de materiais e a padronização de tipos construtivos, que possibilitavam a produção em série, são pontos importantes. Os conjuntos Japurá, Vila Guiomar, 
Francisco Morato e Santo Antonio (Figuras 01, 02, 03 e 04, respectivamente), todos com algum tipo de verticalização ${ }^{6}$, padronização de tipos construtivos e com número de unidades entre 310 e 3.000 , evidenciam estas características. O C.R. Vila Guiomar é constituído também de grande quantidade de unidades em tipologia unifamiliar produzidas de forma seriada. Sendo a verticalização um aspecto caro à proposta de produção em grande escala, explicitando a racionalização dos processos de projeto e construção, outros conjuntos que contam apenas com grande número de unidades unifamiliares, embora padronizadas, como os conjuntos Cidade Comerciária Presidente Vargas e Jardim Piratininga, respectivamente com 523 e 4.000 unidades, não serão objeto de análise / demonstração de nosso argumento.

O segundo aspecto a destacar é a concepção dos projetos habitacionais como projetos urbanísticos. Este aspecto é perceptível em praticamente todos os projetos, porém mais evidente em alguns, principalmente pela integração com a própria cidade e com equipamentos comunitários. Destacamse nesse sentido o C.R. da Mooca e o C.R. Nove de Julho (Figuras 05 e 06).

Alguns equipamentos, tais como clube, escola e creche, segundo Bonduki (2014), eram comumente previstos para os conjuntos dos IAPs, porém alguns dos projetos analisados apresentam uma gama de serviços que buscava não apenas atender as necessidades de seus moradores, mas também garantir a rentabilidade do empreendimento, conforme descreve o arquiteto Attílio Corrêa Lima (1942) na apresentação do C.R. da Várzea do Carmo publicada na Revista Municipal de Engenharia.

A renda a obter com a locação das habitações dos conjuntos residenciais, em que se procura realizar a finalidade social de habitação sadia, higiênica e confortável, dentro das possibilidades dos salários, implica simultaneamente na contingência de obtenção de um mínimo de percentagem sobre o capital aplicada, sem o qual não é possível ao Instituto o pagamento de benefícios. (Corrêa Lima, 1942, p.321)

Essa rentabilidade, segundo o arquiteto, podia ser atingida através do adensamento populacional garantido nomeadamente através da verticalização -, da racionalização dos processos construtivos e da associação do uso residencial popular a outros usos, características comuns a diversos projetos dos IAPs. A incorporação de serviços e comércios destinados não somente aos moradores, mas à população em geral é o terceiro aspecto a evidenciar nestes projetos, destacando-se os conjuntos Várzea do Carmo, Cidade Jardim e Comunidade Brasílio Machado Neto (Figuras 07, 08 e 09, respectivamente). Ao rentabilizar os conjuntos, este aspecto permitia maior retorno dos fundos investidos nos projetos, o que era fundamental à sua manutenção e à própria produção habitacional dos IAPs. A rentabilidade dos projetos habitacionais, segundo Corrêa Lima (1942), era tão importante como requisito de projeto, quanto a compatibilidade entre a condição econômica dos futuros moradores e o custo das habitações.

\footnotetext{
${ }^{6}$ É importante frisar que neste trabalho consideramos a presença de verticalização não apenas nos projetos formados por edifícios verticais (com mais de 10 pavimentos), mas também os projetos habitacionais compostos por blocos multifamiliares com pelo menos quatro pavimentos.
} 


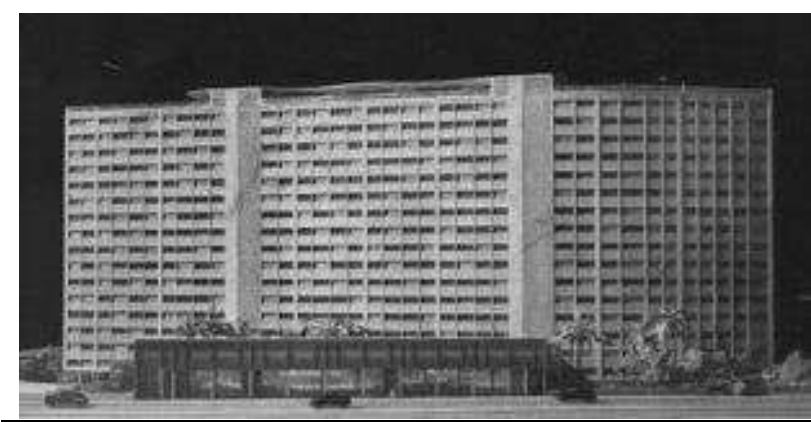

Figura 01. Maquete do C.R. Japurá. Fonte: Acrópole. Ano X, n.119, mar. 1948. p. 281.

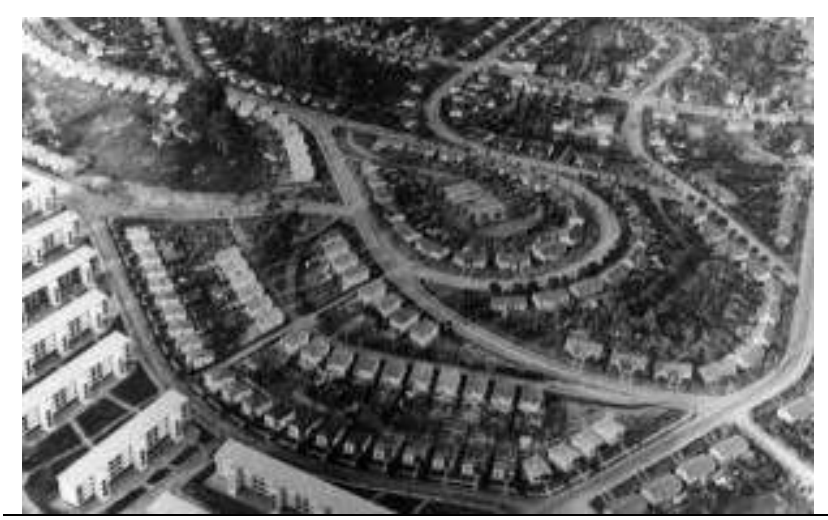

Figura 02: Vista Parcial do Conjunto Residencial Vila Guiomar. Fonte: PESSOLATO, Cintia. Conjunto IAPI Vila Guiomar - Santo André - SP: Projeto e História. Dissertação (Mestrado), FAU-USP, 2007, 1940. p.114.

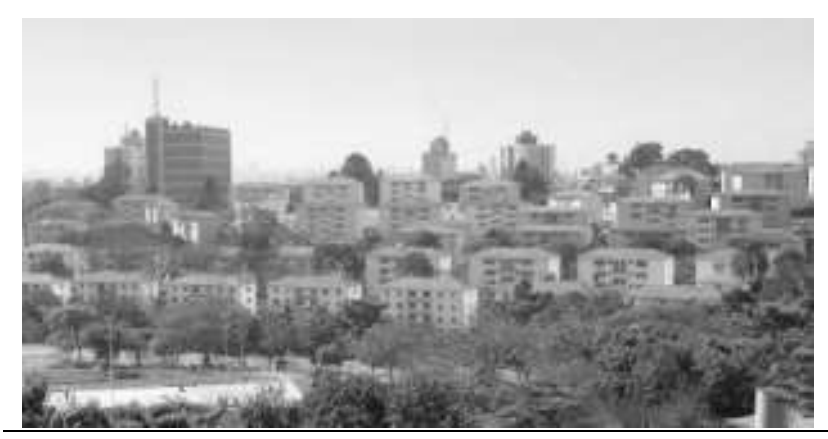

Figura 03. Vista do Núcleo Francisco Morato. Fonte: Panoramio - Google Maps.

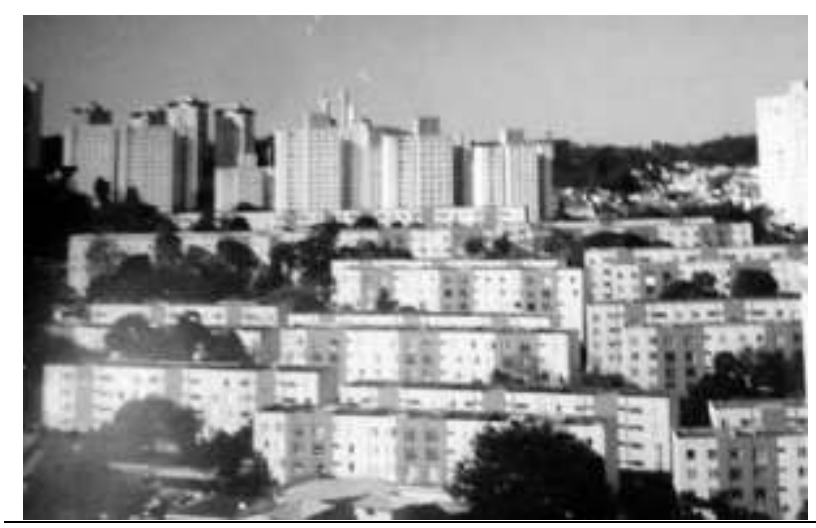

Figura 04: Foto aérea doada ao Condomínio Santo Antonio quando da reforma e pintura dos edifícios em julho de 2003 pela construtora Ankoflex, responsável pelas obras. Fonte: Acervo Condomínio Santo Antonio. 


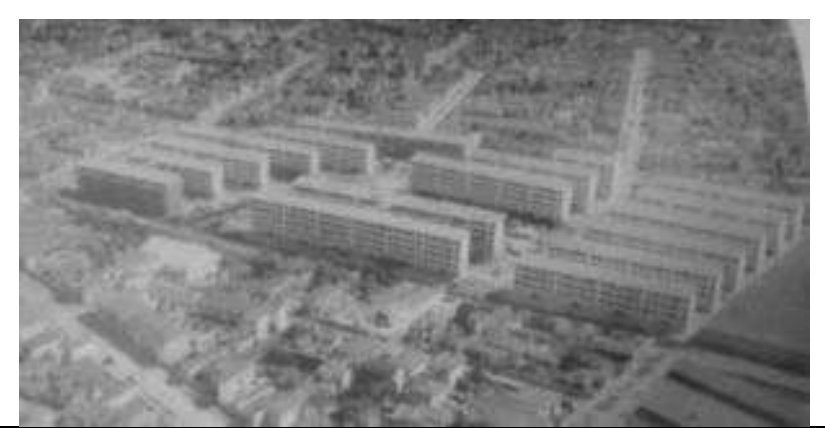

Figura 05: Conjunto do IAPI na Mooca. Fonte: Revista Industriários. n. 07, 1948-49. Contracapa.

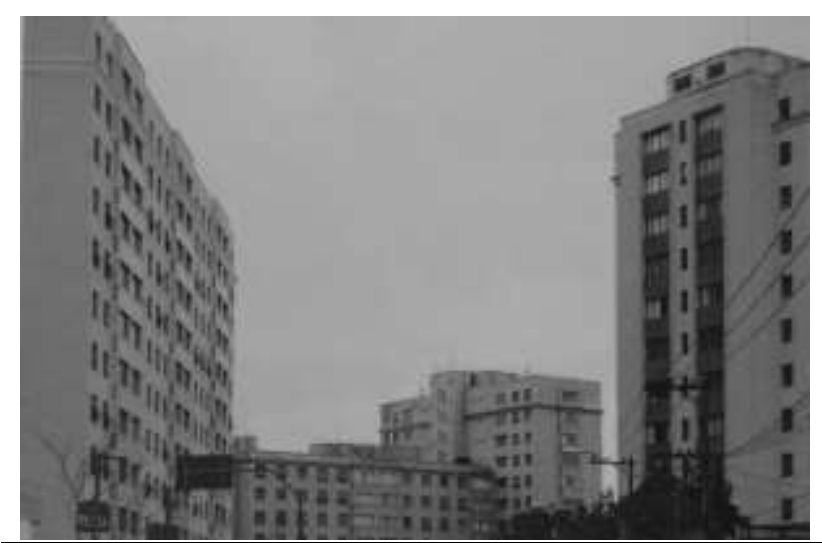

Figura 06. Vista do C.R. Nove de Julho a partir da Av. São Gabriel. Fonte: Bonduki, Nabil; Koury, Ana Paula. (orgs). Os pioneiros da habitação social no Brasil: inventário da produção pública no Brasil entre 1930 e 1964. São Paulo: UNESP: SESC, 2014. Volume 2. p.190.

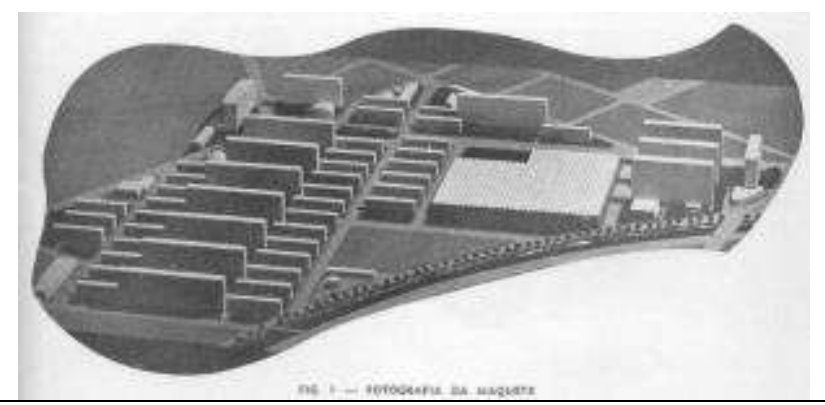

Figura 07: Fotografia da maquete do conjunto da Várzea do carmo. Fonte: Revista Municipal de Engenharia, n.6, vol. IX, Nov./1942, p. 321.

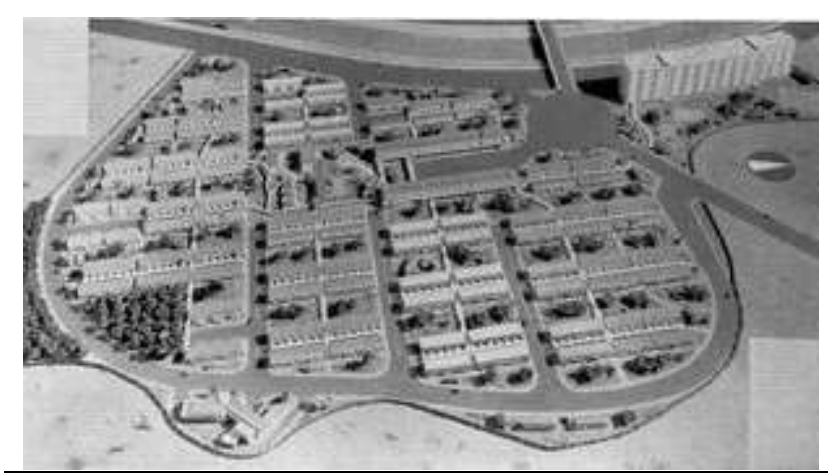

Figura 08: Vista geral do conjunto Cidade Jardim. Fonte: Acrópole, Ano 16, n. 184, ago. 1953, p. 183. 


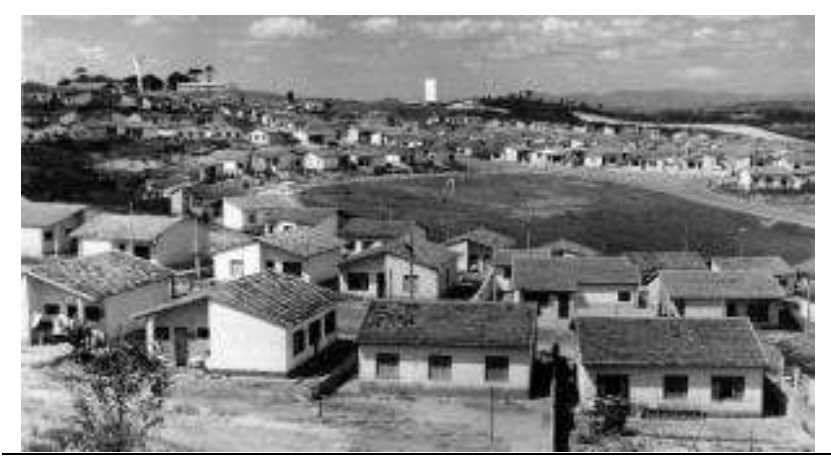

Figura 09. Fotografia do conjunto já construído. Fonte: Foto cedida pelo Portal SESC - Comunidade Brasílio Machado Neto Suzano - Recordações. Disponível em: <https://www.flickr.com/photos/sescsp/14067399434/in/photostream/> Acesso em 02 jul. 2017.

A adoção do ideário moderno no C.R. Japurá, projeto de Eduardo Kneese de Mello para o IAPI, é evidente, sendo possível verificar a utilização dos cinco pontos da arquitetura moderna difundidos por Le Corbusier: planta livre, fachada livre, terraço jardim, pilotis e janelas em fita, que destacam o projeto como exemplo da proposta de Unidade de Habitação, antes mesmo da construção da "Unité $d^{\prime}$ Habitation de Marseille" projetada por Le Corbusier em 19477. Segundo Bonduki e Koury (2014), o C.R. Japurá foi uma das primeiras propostas de um grande edifício residencial associado a equipamentos e serviços disponibilizados à população no térreo, o chamado "edifício-galeria", sendo precursor de um ciclo de empreendimentos privados de grande dimensão que adotaram essa proposta na década de 1950 em São Paulo.

Na publicação do projeto na revista Acrópole em 1948, Kneese de Mello faz uma espécie de memorial onde descreve o processo de projetação do conjunto. Buscando o máximo aproveitamento do terreno disponível sem comprometer as unidades de moradia, o arquiteto chegou à elaboração de um conjunto de dois edifícios, um mais baixo junto ao alinhamento e outro mais alto, recuado quase $18 \mathrm{~m}$, ambos elevados sobre pilotis. Na superfície liberada foram propostos equipamentos, serviços e garagens, conforme se observa na planta do subsolo (Figura 10). O edifício mais alto contava com terraço jardim com marquise, propondo-se aí uma área de convívio dos moradores, conforme se pode ver na maquete (Figura 11).

As 288 unidades residenciais da lâmina principal do Edifício Japurá foram projetadas como apartamentos duplex, sendo enumeradas por Kneese de Mello (1948) as vantagens deste tipo de apartamento:

1) Aumento de dois andares no edifício dentro do gabarito determinado pelo Código de Obras. 2) Redução de $50 \mathrm{~cm}$ de altura em cada dois pavimentos. [...] 6) não havendo corredor comum nos andares destinados a dormitórios o número de paradas dos elevadores fica reduzido à metade, tornando-os mais econômicos e

\footnotetext{
${ }^{7}$ A Unidade de Habitação, no original em francês Unité d'Habitation, é compreendida como um edifício residencial pensado em grande escala, para acomodar muitas pessoas. A ideia de Le Corbusier de uma "cidade jardim vertical" trazia a cidade para o volume do edifício, agregando, portanto, espaços privados, isto é, os apartamentos e, além destes, também espaços coletivos onde os moradores pudessem se abastecer, se alimentar e se reunir.
} 
mais eficientes. 7) Economia de mais de 12 mil metros cúbicos de construção em comparação com um edifício que fosse projetado com 16 andares de 3 metros de pé direito e com corredor em todos os pavimentos (KNEESE DE MELLO, 1948, p. 284)

A utilização de materiais pré-fabricados e a uniformização de elementos construtivos como painéis de vedação, esquadrias e a própria estrutura são pontos encontrados neste projeto. A estrutura do edifício Japurá foi executada em concreto armado, apresentando malha regular de pilares e vigas. Os elementos de vedação são independentes da estrutura, sendo utilizados painéis cimentícios e janelas horizontais em toda a fachada. A trama formada por estrutura e vedação nas fachadas é apenas interrompida pelas torres de circulação vertical, com parede contínua no prumo dos elevadores e com tijolos de vidro nas caixas de escadas. (KNEESE DE MELLO, 1948; BONDUKI; KOURY, 2014)

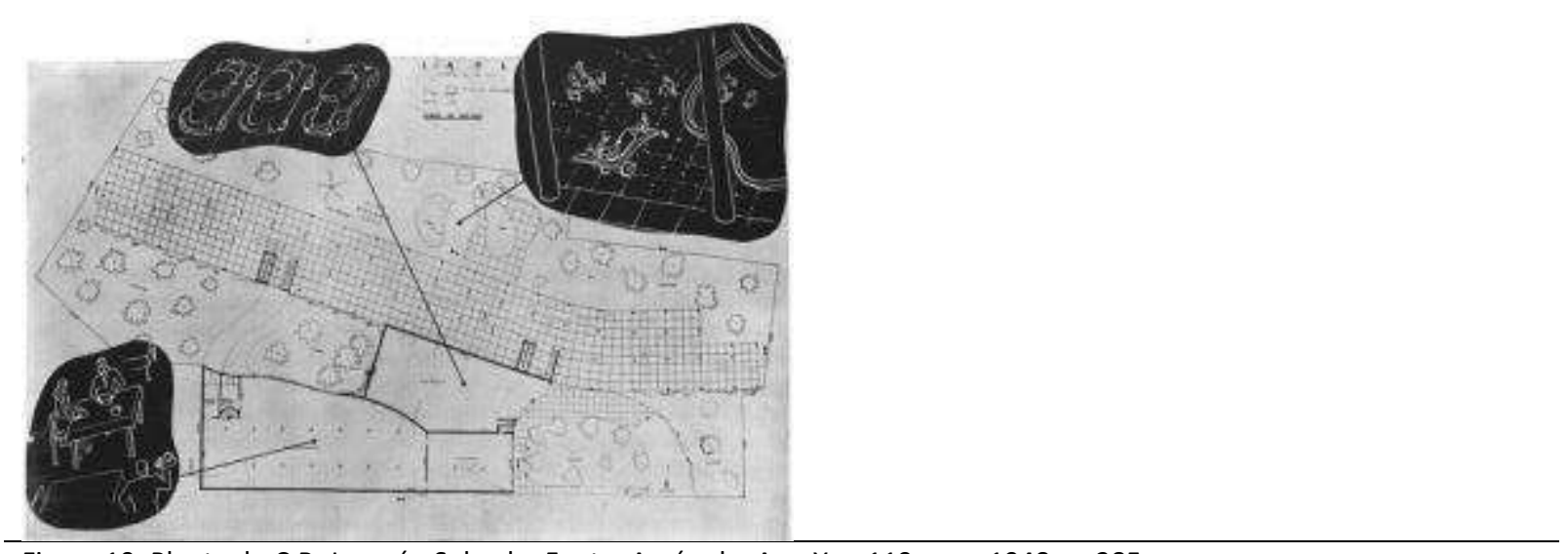

Figura 10: Planta do C.R. Japurá - Subsolo. Fonte: Acrópole. Ano X, n.119, mar. 1948. p. 285.

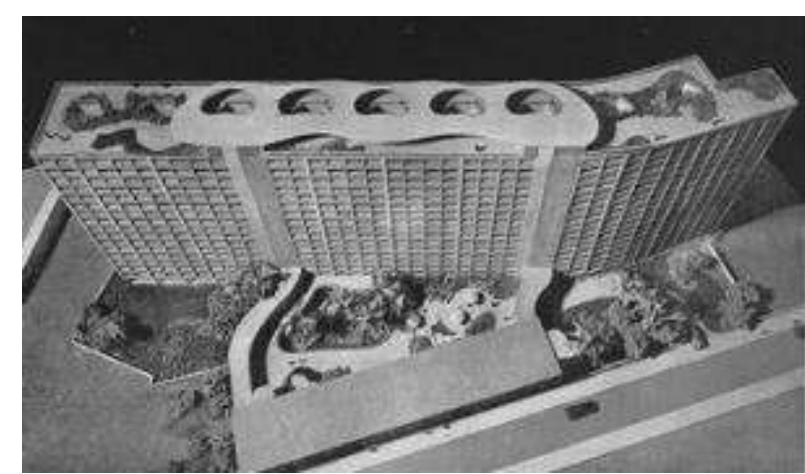

Figura 11: Maquete do C.R. Japurá. Fonte: Acrópole. Ano X, n.119, mar. 1948. p. 282.

Também se destaca no C.R. Japurá (assim como em outros projetos analisados) a utilização do elevador, cuja regulamentação ocorre São Paulo justamente na década de 1940. Sua utilização, conforme se verificou nos processos administrativos e apresentações de diversos projetos, se associava a esquemas e estudos de circulação que buscavam o melhor aproveitamento do equipamento, frequentemente associado à proposta do apartamento duplex ou a paradas intercaladas, que permitiam reduzir os custos de implantação e manutenção. As imagens a seguir trazem o esquema de paradas dos elevadores no Edifício vertical do C.R. Japurá, conforme apresentado por Kneese de Mello na revista Acrópole (1948) e o estudo da circulação de elevadores 
dos edifícios de 11 pavimentos do C.R. da Várzea do Carmo, constante do Memorial Descritivo anexado ao "Alvará de Construção" do projeto (PMSP, 1944b).

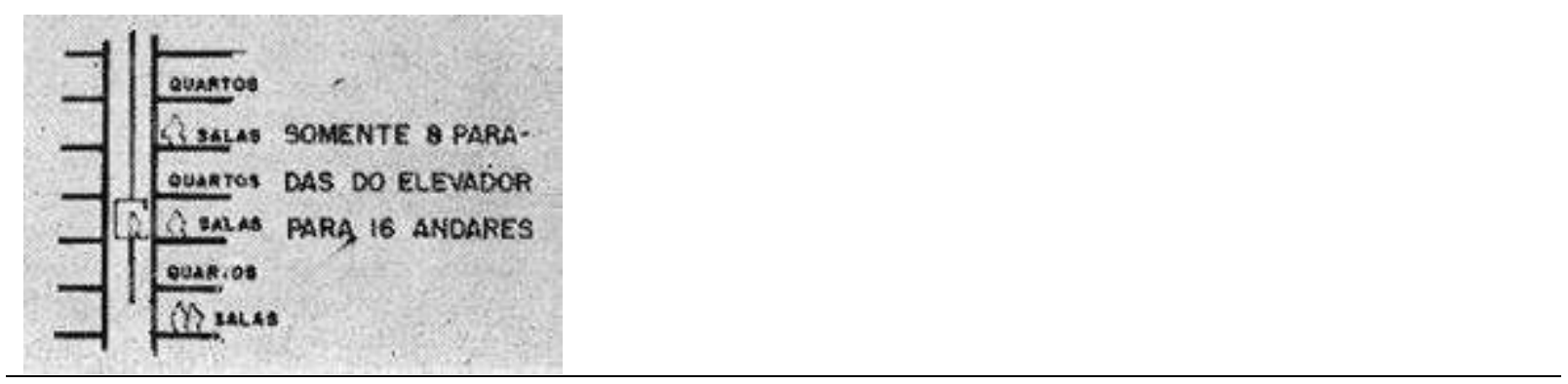

Figura12. Esquema da circulação de elevadores do Edifício Japurá. Fonte: Acrópole. Ano X, n.119, mar. 1948. p. 282

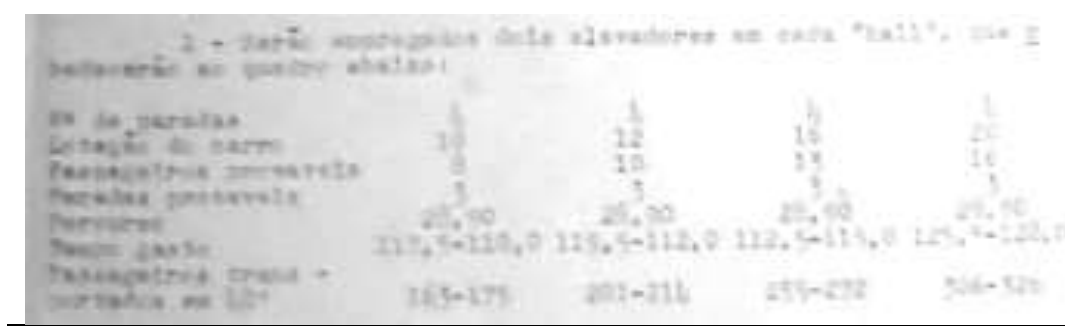

Figura 13. Exemplo de estudo da circulação de elevadores. Fonte: Processo 62.631/44: Alvará de Construção do C.R. da Várzea do Carmo - memorial descritivo.

A verticalização dos edifícios habitacionais era até então desconsiderada na produção da moradia ao trabalhador (BONDUKI, 2014). De acordo com Souza (1994, p.111) é na década de 1940 que o edifício vertical de apartamentos passa a ser considerado como possibilidade de moradia para as classes médias, "num programa que atendia às suas necessidades de dois ou três quartos, entrada social e de serviço separadas, banheiro, cozinha". Posteriormente, a tipologia foi adotada também para as classes mais abastadas. Nesse sentido, os Institutos são pioneiros em fazer uso do edifício de apartamentos na produção habitacional destinada ao trabalhador.

A linguagem formal associada ao ideário moderno não foi necessariamente associada à verticalização, conforme já afirmamos, e tampouco utilizada em todos os projetos analisados, porém em um ou outro projeto se verifica a aplicação de um dos "cinco pontos da arquitetura moderna". Destaca-se o uso dos pilotis e a cobertura plana, não necessariamente vinculada à ideia do terraço jardim. O terraço jardim na verdade foi proposto em poucos projetos dos IAPs além do Edifício Japurá, destacando-se o edifício vertical do C.R. Cidade Jardim (também projetado por Kneese de Mello), enquanto mais comumente os projetos constituem-se por lâminas com coberturas de duas águas, de uma água ou ainda telhados embutidos.

As plantas das unidades analisadas buscavam otimizar a utilização dos espaços, apesar de em poucos casos ter-se utilizado a solução da planta livre. Eram realizados estudos referentes às dimensões mínimas necessárias à habitação, propondo-se plantas que variavam em tamanho conforme o grupo 
familiar morador - evidência de uma relação entre Estado e Igreja que retomaremos posteriormente, em que o modelo de moradia moralmente aceito por esta, a casa da família trabalhadora, era a medida para os estudos da moradia mínima. Havia, por exemplo, unidades para casais sem filhos ou famílias com dois ou três filhos, havendo poucos conjuntos que incluíam unidades para solteiros apartadas daquelas destinadas a famílias -, como aquelas localizadas no edifício de menor altura no C.R. Japurá (BONDUKI, 2014). A racionalidade aparece também na localização de dutos de ventilação, prumadas de tubulação e aberturas das unidades, bem como na instalação de equipamentos como fogões e armários pré-fabricados.

A produção padronizada e em série pode ser identificada não apenas em elementos construtivos e nas próprias unidades unifamiliares, mas nos tipos de edifícios e casas. Particularmente em projetos que ocuparam grandes áreas, é possível observar a produção seriada de tipos construtivos, constituindo um exemplo o C.R. Vila Guiomar em Santo André. Neste conjunto o adensamento populacional foi preterido em função da idiossincrasia ${ }^{8}$ da população perante as unidades de habitação, priorizando-se uma concentração parcial, o que culminou a construção de edifícios associados a casas unifamiliares.

A área onde foi construído o C.R. Vila Guiomar possuía relevo acidentado e já se achava parcialmente urbanizada, com arruamento de desenho sinuoso que acompanhava o perfil do sítio (PESSOLATO, 2007). O projeto de Carlos Frederico Ferreira ocupou parte da gleba comprada pelo IAPI com a construção de 1.411 unidades (originalmente foram previstas 3.000). São 978 apartamentos em dois diferentes tipos de blocos, um dos quais já fora utilizado pelo IAPI no conjunto habitacional de Realengo no Rio de Janeiro, projetado pelo próprio Frederico Ferreira, e 433 unidades unifamiliares em casas isoladas ou geminadas. Como apoio ao C. R. Vila Guiomar foram previstos uma igreja e dois equipamentos apenas, uma escola e um ginásio, também projetados por Frederico Ferreira. (PESSOLATO, 2007; BOTAS, 2011; BONDUKI, 2014)

Como se pode observar na implantação do conjunto (Figura 14) as unidades unifamiliares foram em sua maioria localizadas na parte central do terreno. A fachada principal das casas era voltada para as vias de tráfego e os fundos voltados para uma ampla área verde comum no interior das quadras, remetendo aos projetos de bairros-jardins. As casas isoladas figuram majoritariamente na porção oeste da área central, enquanto o tipo geminado ocupou todo o restante do centro e ainda as margens de uma das principais avenidas que margeiam o conjunto.

\footnotetext{
${ }^{8}$ As fontes indicam que houve estranhamento e rejeição por parte da futura população moradora aos edifícios de apartamentos, havendo clara preferência pela conhecida casa térrea com quintal. (PESSOLATO, 2007; BOTAS, 2011; BONDUKI, 2014)
} 


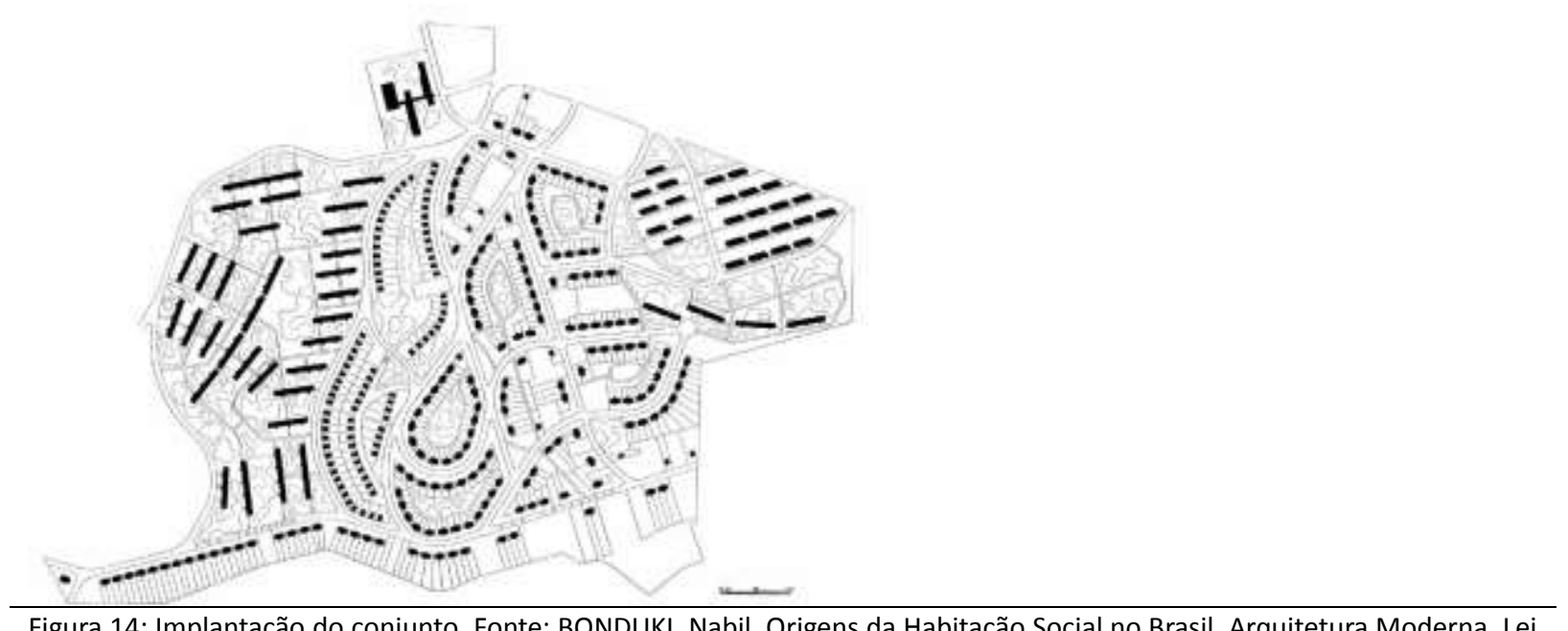

Figura 14: Implantação do conjunto. Fonte: BONDUKI, Nabil. Origens da Habitação Social no Brasil. Arquitetura Moderna, Lei do Inquilinato e Difusão da Casa Própria. São Paulo: Est. Liberdade/FAPESP, 1998, p.190.

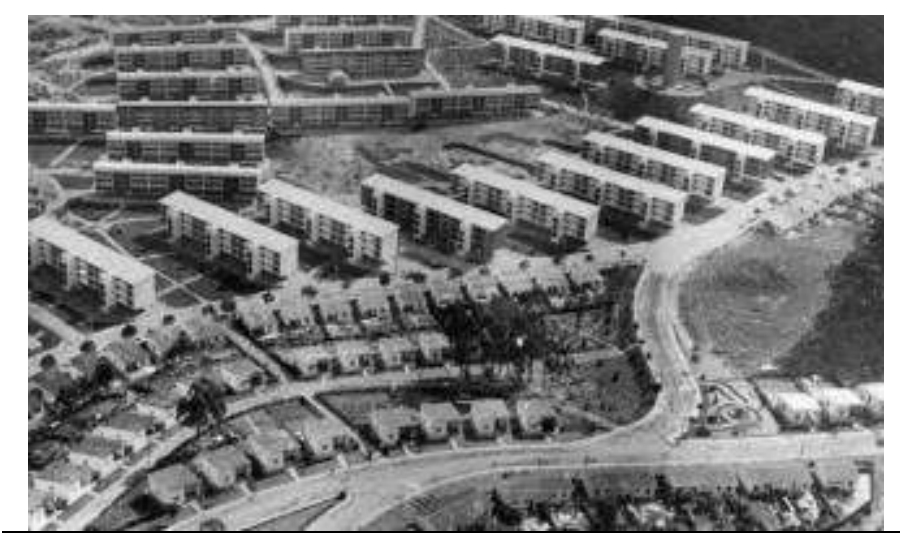

Figura 15. Vista Parcial do Conjunto Residencial Vila Guiomar. Fonte: PESSOLATO, Cintia. Conjunto IAPI Vila Guiomar - Santo André - SP: Projeto e História. Dissertação (Mestrado), FAU-USP, 2007, 1940. p.117.

Os dois tipos de blocos multifamiliares, ambos em formato laminar sobre pilotis, foram propostos nas extremidades do terreno e, embora os exemplares do primeiro tipo construído tenham uma implantação mais tradicional, junto ao alinhamento das ruas locais projetadas, os do segundo tipo parecem ter uma implantação mais livre. $\mathrm{O}$ traçado diferenciado das ruas, associado à extensão de áreas verdes mantidas para este conjunto, conferiram-lhe o aspecto de um gigantesco parque marcado por trajetos peatonais e espaços de sociabilização, estendidos ainda pela permeabilidade conferida pelos pilotis (Figuras 15 e 02 ).

Projetos de grandes proporções como o Vila Guiomar foram especialmente previstos para regiões mais afastadas do Centro, sendo a principal exceção o conjunto da Várzea do Carmo, em terreno bem próximo à área central ${ }^{9}$. Os bairros na Zona Norte de São Paulo eram, ainda na década de 1940, bem pouco ocupados, com poucos arruamentos abertos e edificados. A região contava, porém, com um importante acesso ferroviário desde o Centro - o Tramway da Cantareira - em função da existência de chácaras e locais de restabelecimento de saúde. Aí foram propostos dois projetos de grandes

\footnotetext{
${ }^{9}$ Ver no Capítulo 4 a Figura 71, "Área urbanizada de São Paulo e Municípios circunvizinhos em 1940 com localização dos projetos habitacionais promovidos entre 1930 e 1964".
} 
dimensões, o primeiro pelo IPESP em 1951, e o segundo pelo IAPB em 1962, que se destacam principalmente pela padronização e construção seriada de um mesmo tipo construtivo de bloco em grandes quantidades. O escritório de engenharia do IPESP realiza no bairro do Tucuruvi, próximo à Estação Villa Mazzei do Tramway da Cantareira, o projeto do Núcleo Residencial Francisco Morato, o maior empreendimento produzido pelo Instituto no período, com 840 unidades em 105 blocos residenciais idênticos, como se vê na planta (Figura 16) e fotografia do conjunto (Figura 03).

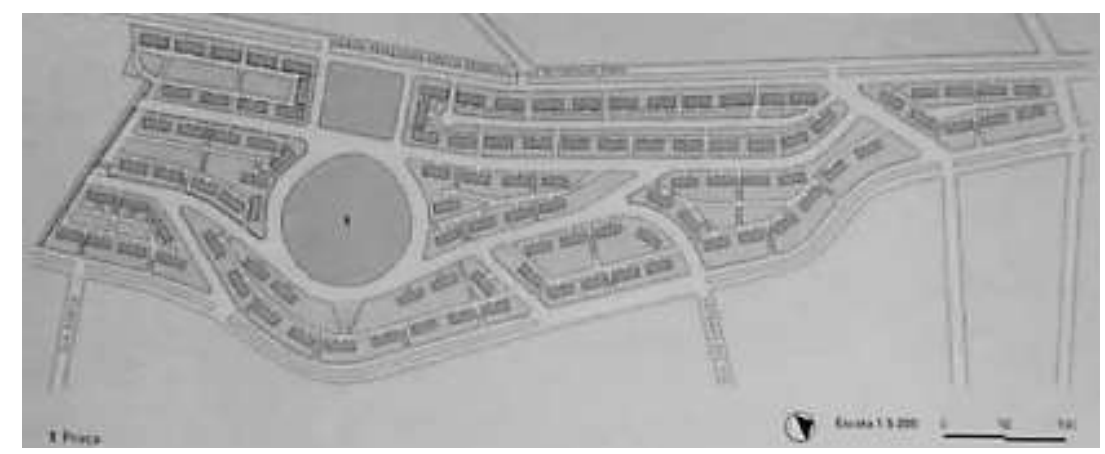

Figura 16. Implantação do Núcleo Francisco Morato. Fonte: BONDUKI, N.G.; KOURY, A.P. Os pioneiros da habitação social no Brasil: inventário da produção pública no Brasil entre 1930 e 1964. São Paulo: UNESP: SESC, 2014.Vol.2. p.407.

O projeto ocupou uma área de 15,3 hectares em declive com plano urbanístico que se ajusta à topografia e que conta com nítida hierarquia viária. Adentram o conjunto vias locais que contornam as quadras, porém o acesso aos blocos é feito pelo interior destas através de vias de circulação secundária, existindo, ainda, vielas de circulação de pedestres, como se pode observar na implantação do projeto (Figura 16) disponibilizada por Bonduki e Koury (2014). Não foram previstos equipamentos para este conjunto, exceto por duas grandes praças. Repetido em todo o plano, o bloco padronizado apresenta quatro pavimentos com duas unidades cada.

O segundo conjunto proposto para a Zona Norte, o C.R. Santo Antonio (IAPB), foi construído no Alto de Santana, junto à reserva que constitui o Horto Florestal. O projeto conta com um módulo-tipo de quatro pavimentos com duas unidades cada, uma com 60 e outra com $70 \mathrm{~m}^{2}$, servidas por uma caixa de escadas centralizada e embutida no corpo do prédio. Os módulos foram agrupados três a três, compondo lâminas com seis apartamentos por andar - a concepção de módulos compostos por duas ou mais unidades, que eram agregados quantas vezes fosse necessário para compor os blocos e edifícios é característica de diversos projetos analisados (é possível identificar o projeto de módulos e seu agrupamento nos blocos do C.R. da Mooca e do C.R. Santa Cruz, por exemplo, conforme análise dos Processos Administrativos n.45.127/1944 e n.104.125/1951, respectivamente). No conjunto, a implantação de duas ou mais lâminas no mesmo alinhamento, com apenas um pequeno espaço entre elas, confere a impressão de um único edifício longilíneo, como se pode observar na Figura 17. 


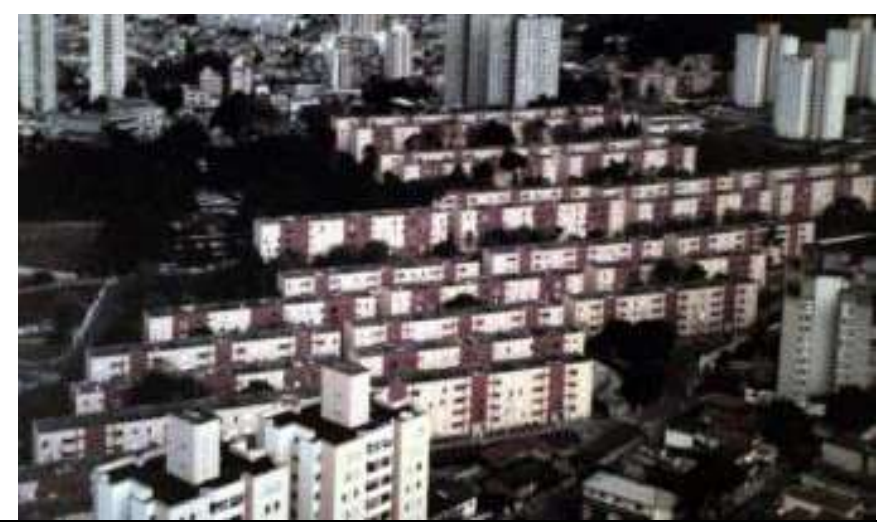

Figura 17: Foto aérea doada ao Condomínio Santo Antonio quando da reforma e pintura dos edifícios em julho de 2003 pela construtora Ankoflex, responsável pelas obras. As caixas de escadas evidenciadas por uma cor diferente de pintura na fachada possibilitam perceber a repetição do módulo. Fonte: Acervo Condomínio Santo Antonio.

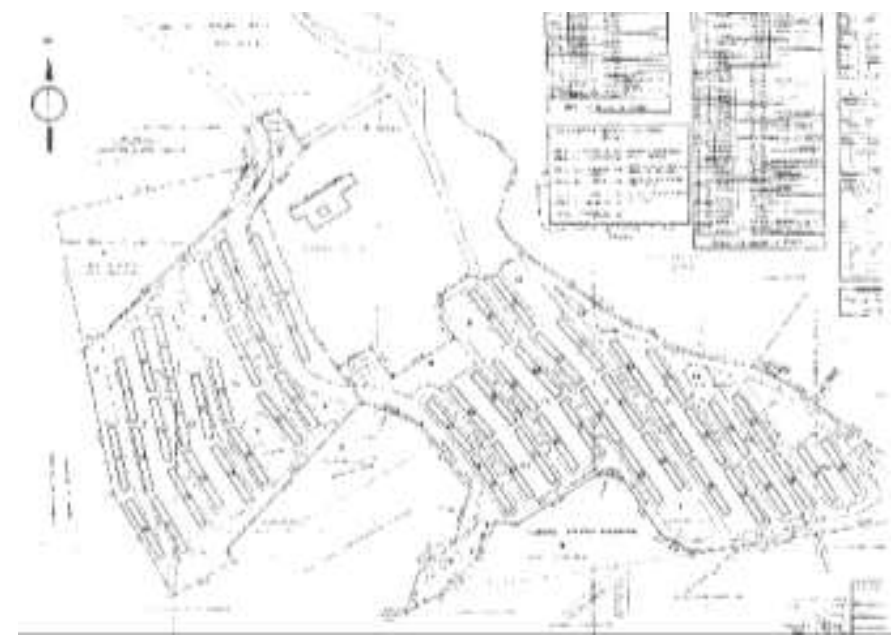

Figura 18: Planta do Conjunto Santo Antonio. Fonte: BRUNA, Paulo J. V. Os Primeiros Arquitetos Modernos: Habitação Social no Brasil 1930-1950. Tese de Livre-Docência, FAU-USP, São Paulo, 1998, p.179.

O local possuía relevo bastante acidentado e o terreno era dividido por um pequeno espigão, onde se projetou a principal via de acesso ao conjunto. Ruas locais foram implantadas perpendicularmente à via principal, contornando o conjunto enquanto as demais vias de acesso às unidades acompanhavam as curvas de nível. Os blocos foram implantados paralelamente às vias de acesso estendendo-se pelas encostas dos dois lados do espigão (Figura 18). O projeto previu originalmente 41 edifícios habitacionais, totalizando 984 unidades, sendo, porém, construído um número maior de blocos, 53 ao todo, resultando em 1.272 unidades.

Propondo formas racionalizadas de implantação, tanto de edifícios e blocos quanto de residências unifamiliares, estes projetos trabalhavam com a premissa de que não houvesse o parcelamento da gleba (mesmo que depois fossem construídas casas em lotes individuais). Desta decisão decorriam duas características importantes. A primeira, a quase sempre muito evidente diferenciação dos projetos com relação ao entorno com traçado tradicional; especialmente no caso dos conjuntos inseridos em vazios remanescentes essa distinção se faz ainda mais evidente. A segunda, a questão da propriedade, especialmente dos terrenos, que permanecendo com os IAPs, mas de uso comum, gerou questionamentos inclusive para a aprovação dos projetos junto ao poder público. 
O comentário do engenheiro Fernando Trapé, que analisa o processo de Aprovação do Conjunto Residencial da Mooca (IAPI) na Prefeitura de São Paulo, permite verificar esta questão, destacando-se o fato de que a implantação sobre o terreno livre e comum era grande novidade no período. 0 engenheiro questiona o fato de que o acesso aos blocos de moradia não ocorre diretamente através das vias de tráfego, mas pelo interior das quadras, que se apresentam ajardinadas e abertas. Sendo estas quadras de propriedade dos IAPs e não públicas, apesar do acesso público, o engenheiro sugere que sejam cercadas.

Casos como o presente não estão previstos no Código de Obras, porquanto os diferentes acessos dos blocos de apartamentos são feitos dentro do próprio lote e não diretamente pelas ruas a serem abertas. Nessas condições, por não ficarem de uso comum para o povo, as áreas ajardinadas entre os apartamentos, digo, os blocos de apartamentos, somos de parecer que taes áreas deveriam ser fechadas com grades no alinhamento das ruas, de modo a ficar garantido para a Prefeitura, que a conservação, limpeza, iluminação, etc. das mesmas fique a encargo do proprietário. (Processo Administrativo n.45.127/44, grifo nosso)

A solução do projeto, conforme se observa na planta (Figura 19) consistiu na implantação paralela de lâminas residenciais de aspecto similar (variando em comprimento e número de pavimentos, 4 ou 5) sobre uma grande área ajardinada e aberta, dividida em três grandes quadras sem distinção de lotes. Um grande espaço central (em verde) deveria abrigar um clube, salas de convívio e área de parque e recreação infantil, enquanto em uma área no vértice do terreno (em azul) deveria ser construído um mercado cuja localização permite supor que se destinava não somente aos moradores, mas à população em geral. (PMSP, 1944a; BONDUKI; KOURY, 2014)

A foto aérea do C.R. da Mooca (Figura 05), publicada na revista Industriários, confirma a distinção entre o traçado urbanístico do projeto e o traçado tradicional das quadras do bairro, bem como entre os blocos multifamiliares e as construções do entorno predominantemente ocupado por edificações industriais e moradias operárias. O conjunto foi construído em um terreno remanescente no bairro de pronunciada concentração fabril, já bastante consolidado na década de 1950.

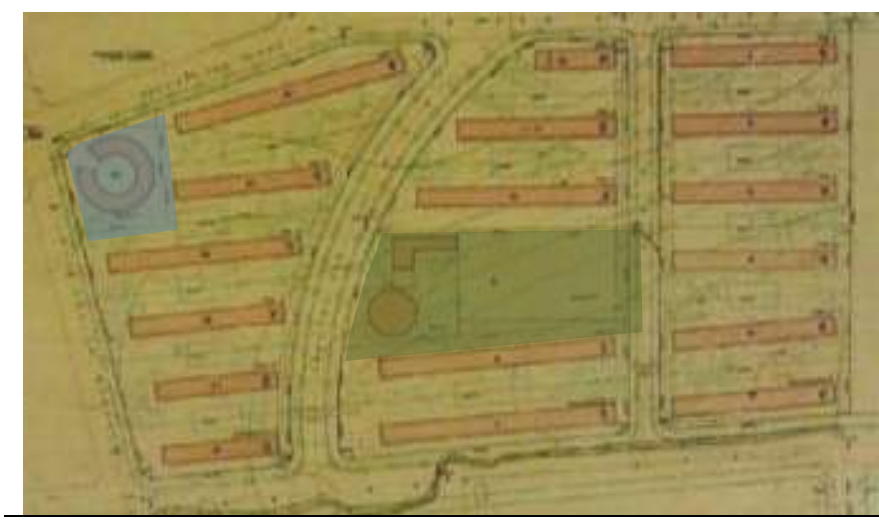

Figura 19: Planta do C.R. da Mooca. Fonte: BONDUKI, Nabil. Pioneiros da habitação social no Brasil. Tese de Livre-Docência. FAU-USP, 2011, vol.2, p. 47, com intervenção da autora. 
A ocupação racional dos terrenos e a relação entre os projetos arquitetônico e urbanístico são percebidas também nos projetos de edifícios verticais. Um único projeto em grande escala dos IAPs em São Paulo se trata de um conjunto de edifícios verticais, o C.R. Nove de Julho, construído a partir de 1945 a Sudoeste do Centro, entre os bairros Jardim Paulista, América e Europa. A divisão do terreno em três partes em função do cruzamento das avenidas Nove de Julho e São Gabriel sugeriu a implantação de edifícios verticais independentes, buscando-se o melhor aproveitamento possível (Figura 20). Foram assim propostos três edifícios de doze pavimentos com formatos diferentes, em I, em L e em T, este último em parte com dez pavimentos (Figura 21). Todos os edifícios contavam com garagem no subsolo, uma novidade nos projetos daquele período.

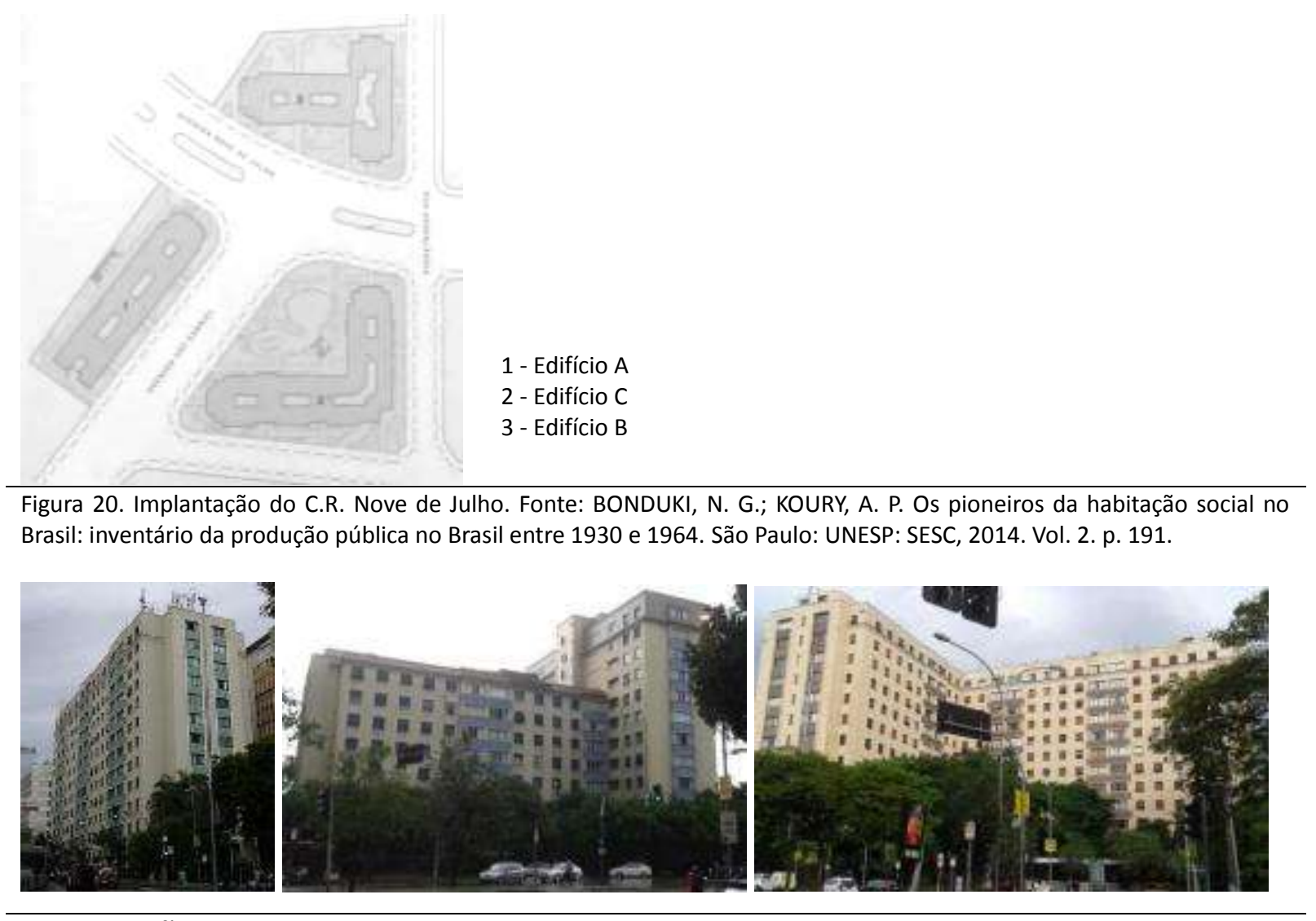

Figura 21: Edifícios A, B e C do C.R. Nove de Julho. Fonte: Acervo pessoal. Foto de Camila Ferrari. Abril, 2016.

Diversos equipamentos comunitários foram propostos para o C.R. Nove de Julho, a maioria dos quais inserida no próprio corpo dos edifícios. No térreo do edifício B foi previsto um centro social, com salas para oferecimento de cursos e atendimento médico e odontológico "de uso exclusivo para os moradores" (PMSP, 1956). O grande terreno do edifício C deveria contar com um centro comercial, associado aos jardins e espaços de recreação infantil. O conjunto contava ainda com salão de festas e lavanderia coletiva. O C.R. Nove de Julho é precursor da verticalização daquela região, à época parcialmente ocupada e predominantemente horizontal, característica dos bairros-jardim. (BONDUKI; KOURY, 2014) 
A linguagem formal associada à verticalização e padronização das tipologias e a concepção dos projetos habitacionais como projetos de urbanismo, bem como a incorporação de equipamentos coletivos, como já mencionamos, se expressam em praticamente todos os projetos analisados. Três conjuntos, porém, o C.R da Várzea do Carmo, a Comunidade Brasílio Machado Neto e o C.R. Cidade Jardim, se destacam não somente por apresentarem estas características de forma evidente, mas por contarem com uma gama ampliada de equipamentos para os moradores e de serviços destinados também à população não moradora.

O projeto do C.R. da Várzea do Carmo foi proposto para um terreno de aproximadamente 28 hectares remanescente no bairro do Cambuci, muito próximo ao Centro de São Paulo. Conforme se apreendeu da análise do Processo Administrativo n. 62.631 de 1944 (PMSP, 1944b) e da leitura de Corrêa Lima $(1942 ; 1943)$ o fato de o terreno permanecer desocupado decorria principalmente de sua localização. A área em questão, embora beneficiada pela proximidade com o Centro Tradicional, pela canalização do rio Tamanduateí e pela construção do Parque Dom Pedro II, entre outros fatores, ficava também muito próxima dos bairros operários que se estabeleceram a leste da área central e apresentava ainda pontos de alagamento.

O projeto propunha um tipo de ocupação totalmente diferenciado do entorno, com lâminas paralelas de dois tipos principais, o primeiro com quatro pavimentos e o segundo com onze e térreo liberado por pilotis, dispostas sobre um grande plano verde (Figura 22). A verticalização das unidades neste projeto permitia elevar a densidade habitacional, garantindo a concentração urbana sem, contudo, implicar em alto índice de ocupação. (CORRÊA LIMA, 1942)

No C.R. Várzea do Carmo estavam presentes a padronização de tipos e utilização de novos materiais e tecnologias, com destaque para o estudo do uso de elevadores (ver Figura 13). A relação entre os projetos arquitetônico e urbanístico é também bastante evidente, pronunciada pela própria implantação e pela hierarquia viária sugerida no desenho. Contudo, o que se destaca especialmente neste projeto é a gama ampliada de equipamentos e o grande número de serviços e comércios destinados não apenas aos moradores, mas à população em geral, buscando-se a conformação de uma centralidade urbana, que justamente atraísse pessoas para o local (FERRARI, 2013). A ideia, conforme Corrêa Lima $(1942 ; 1943)$ era garantir a rentabilidade do empreendimento associando a função residencial a outras funções urbanas.

A solução, que se aproxima da ideia de um parque, incluía percursos diferenciados para veículos e pedestres e conformava grandes espaços livres, pensados como jardins ou outros locais de recreio, como quadras esportivas. É possível ver na planta do conjunto (Figura 23) duas grandes áreas onde foram dispostos os equipamentos e serviços. Acreditamos que essa disposição foi feita de acordo com a possibilidade de uso e a capacidade de atração de pessoas para cada equipamento e serviço proposto. 


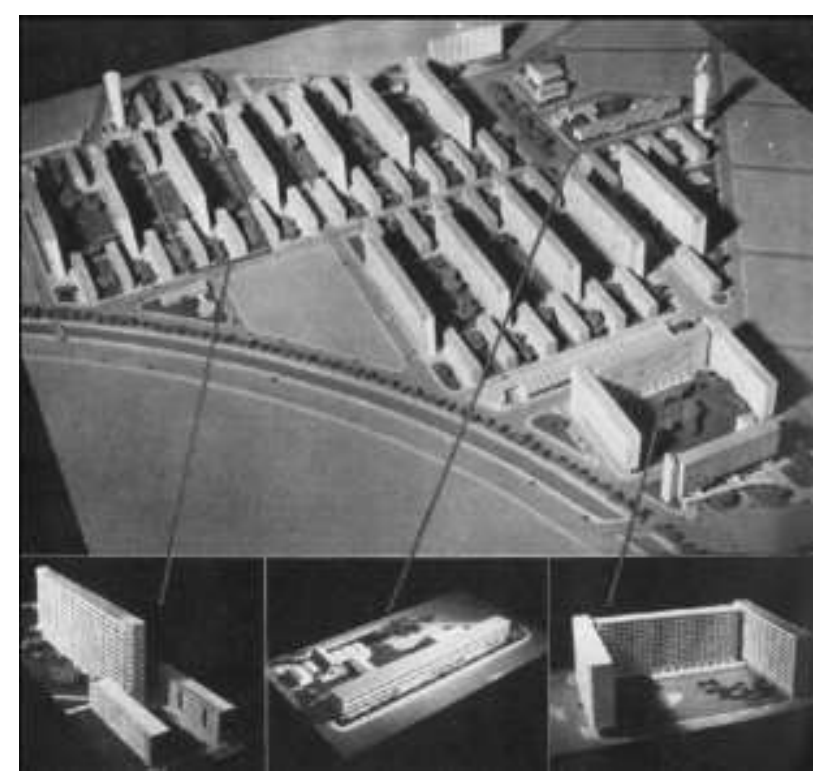

Figura 22. Vista aérea e detalhes do conjunto - maquete. Fonte: Revista Municipal de Engenharia, Vol. 9, n.6, out. 1943.

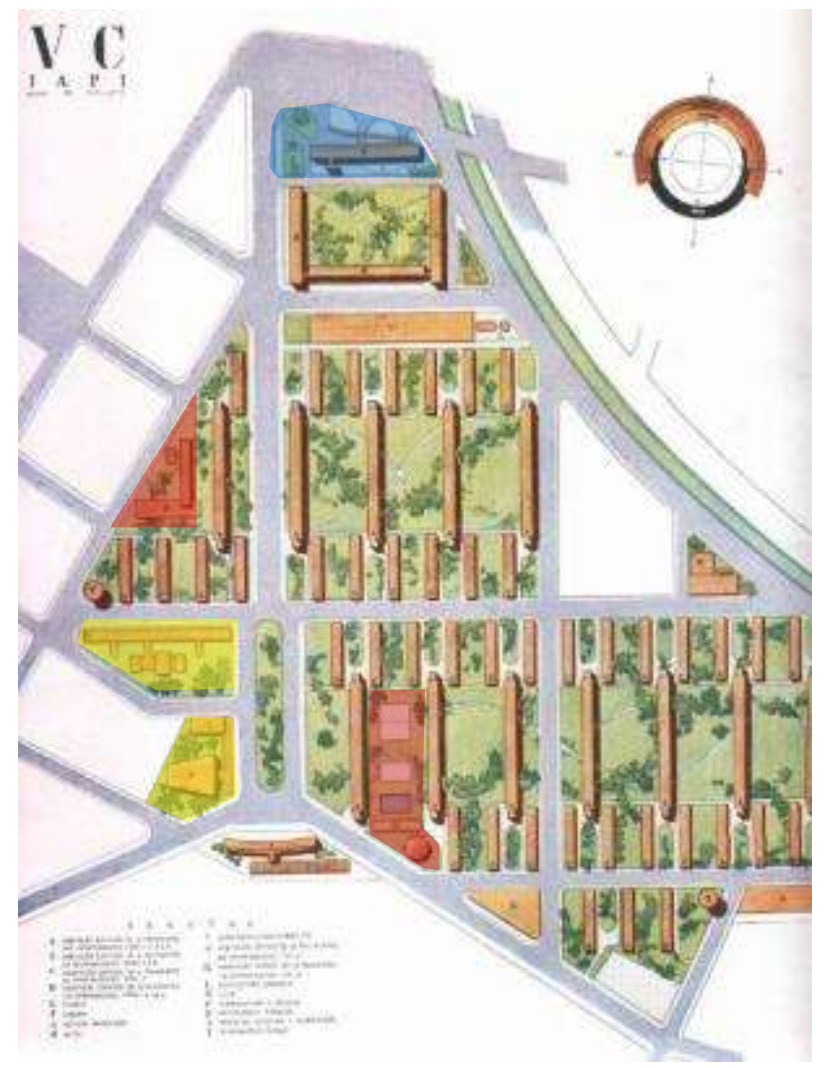

Figura 23: Planta do conjunto completo após as duas fases de implantação. Fonte: Revista Municipal de Engenharia, n.6, vol. IX, Nov./1942, p. 326. Com intervenções da autora.

Na Figura 23, vê-se na porção sudoeste do conjunto (em amarelo) duas praças, que abrigam escola, cinema e um edifício de consultórios e escritórios, enquanto nas quadras diretamente ao Norte e a Leste deste grupo (em vermelho) deveriam ser construídos, respectivamente uma creche e um clube. Este grupo de equipamentos comporta os serviços mais comumente integrados aos conjuntos residenciais e sua localização mais próxima ao bairro que da Avenida do Estado permite presumir 
uma intenção de utilização interna, pelos próprios moradores, mas também, eventualmente, pela comunidade do próprio bairro. Junto a estes equipamentos há ainda salas comerciais.

No extremo Norte do terreno (em azul na Figura 23) se localizam as grandes novidades em termos da proposição de serviços em um conjunto habitacional, um hotel e, em seu subsolo e térreo, uma estação rodoviária. Cabe lembrar que embora o transporte rodoviário ganhasse força na década de 1940, em 1942 não havia ainda uma rodoviária na cidade de São Paulo. As quadras ao norte do conjunto eram as mais valorizadas por estarem contíguas ao Parque D. Pedro II e à Av. do Estado, sendo também mais facilmente acessadas pelo público externo ao conjunto. A localização de uma rodoviária integrada a um hotel neste espaço pretendia criar aí um ponto de atração e desenvolvimento, agregando a noção de modernidade associada ao novo meio de transporte. Junto à Av. do Estado são previstos ainda salas comerciais, um posto de combustíveis e um restaurante popular. (CORRÊA LIMA, 1942; 1943)

É possível considerar que a proposta de conformação de uma centralidade urbana, através de grande quantidade de equipamentos comunitários e serviços, estava presente também em um projeto do IAPC proposto no município de Suzano, na área metropolitana a leste da capital. Projetado por uma equipe conduzida pelos arquitetos Oswaldo Corrêa Gonçalves e Heitor Ferreira de Souza o conjunto apresenta o padrão urbanístico da unidade de vizinhança, que se justificava para a conformação de um bairro (ou subúrbio) distante e relativamente autônomo com relação à capital, conforme apresentado em matéria sobre o projeto na revista Acrópole em 1958.

O projeto urbanístico da Comunidade Brasílio Machado Neto teve como elemento definidor o relevo da grande gleba de aproximadamente 87,5 hectares, conformando-se ruas de traçado sinuoso e amplas quadras irregulares (Figura 24). A hierarquia viária incluiu vias de acesso e ligação com o entorno, vias de trânsito local e vias exclusivas para pedestres localizadas nos miolos das quadras, junto às quais foram projetadas áreas de recreação infantil. Estas vias eram também utilizadas para passagem de redes de água e esgotos. (COMUNIDADE BRASILIO MACHADO..., 1958)

Foram previstas duas tipologias unifamiliares: três tipos de casas isoladas e um tipo de casa geminada e ainda a tipologia do bloco laminar de dois pavimentos, com quatro apartamentos cada. Neste projeto fica evidente a proposta de desconcentração (com baixa densidade populacional) e de conformação de um subúrbio, garantida pela expressiva quantidade de equipamentos e serviços propostos. Previa-se uma população moradora de cerca de 3.750 habitantes.

Destaca-se neste conjunto também a previsão de um terminal rodoviário, que possibilitaria a ligação do bairro em Suzano com a cidade de São Paulo, onde a maioria dos futuros moradores trabalhava. (BONDUKI; KOURY, 2014). O conceito de unidade de vizinhança foi utilizado para propor os equipamentos em proporção adequada à população prevista, assumindo-se que o conjunto era conformado por duas unidades e, a partir daí, indicando os equipamentos necessários (áreas 
pintadas por nós em laranja na planta - Figura 25). Integravam o conjunto um centro comunal e comercial, um centro esportivo e equipamento educacional.

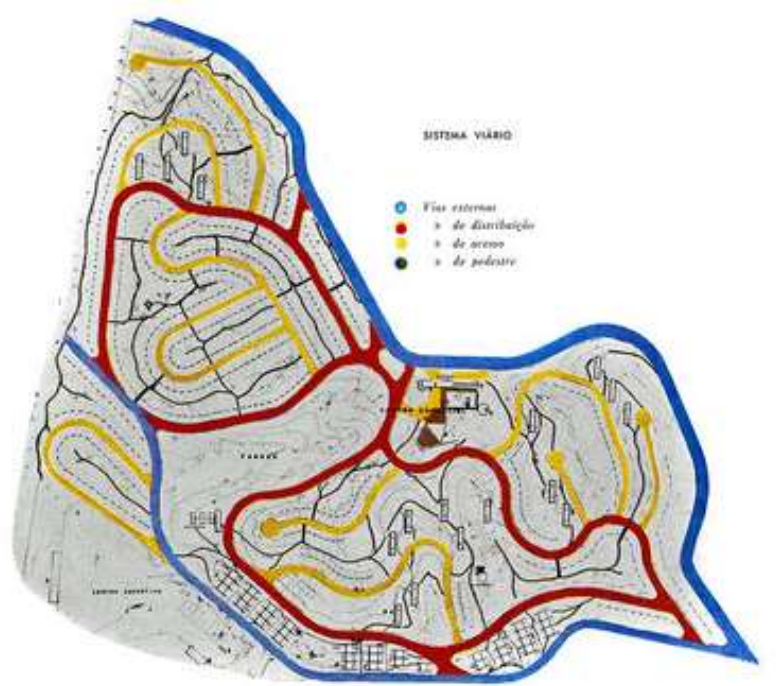

Figura 24: Sistema viário do conjunto. Fonte: Comunidade "Brasílio Machado Neto" In: Acrópole. São Paulo, Ano 20, N 238, ago. 1958. p.467.

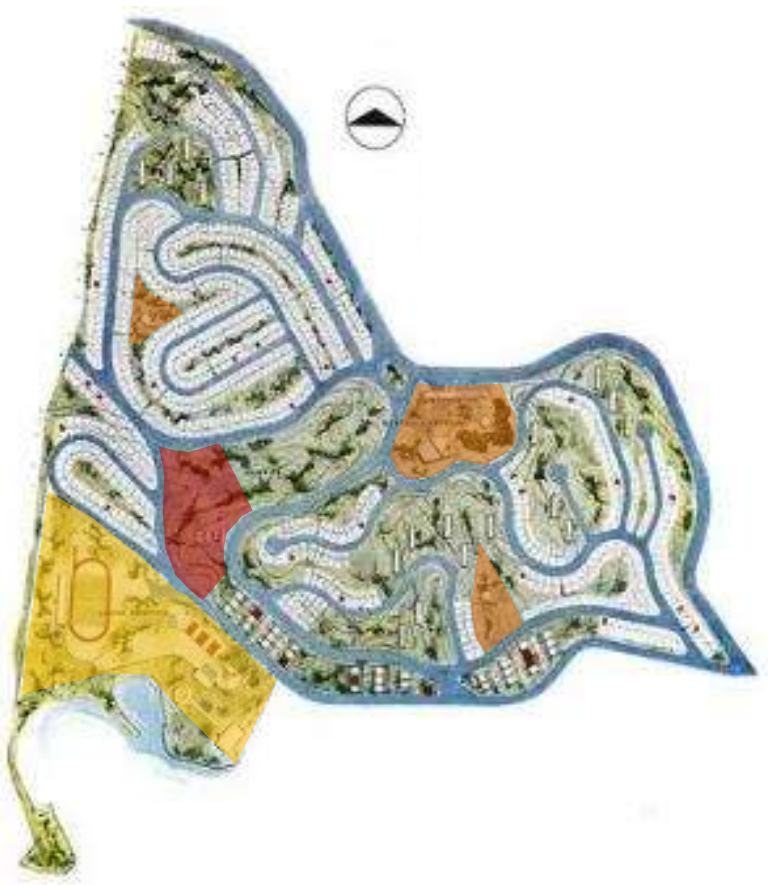

Figura 25: Implantação do conjunto. Fonte: Comunidade "Brasílio Machado Neto" In: Acrópole. São Paulo, Ano 20, N²38, ago. 1958. p.466. Com intervenções da autora.

O referencial da unidade de vizinhança é visível na previsão do equipamento educacional: uma escola primária, proposta no parque central do terreno, e dois jardins de infância, construídos cada um no centro das "duas unidades residenciais". O centro comunal contava com igreja, mercado, centro social, cinema, restaurante e estação rodoviária. Estes equipamentos e serviços foram dispostos ao redor de uma praça cívica aproximadamente ao centro do conjunto e junto à via que contorna o terreno (em vermelho na Figura 25), portanto, de fácil acesso também para a população externa à 
Comunidade. O centro esportivo compreendia piscina e vestiários, clube, campo de futebol e ginásio e foi proposto "fora" da via de contorno (em amarelo), sendo facilmente acessado tanto pelos moradores quanto eventualmente por público externo. (COMUNIDADE BRASILIO MACHADO..., 1958) O C.R. Cidade Jardim, projetado por Kneese de Mello, também é apresentado na revista Acrópole em matéria de 1947, com imagens da maquete e reprodução das pranchas de desenho apresentadas ao IAPC por Kneese de Mello. A proposta do projeto chama atenção por sua complexidade, agregando equipamentos variados que foram dispostos no conjunto em função das máximas distâncias a serem percorridas pelos moradores, evidenciando-se também a referência ao conceito de unidade de vizinhança. As construções foram implantadas sobre um grande pano verde, havendo poucas vias locais que convergiam para o interior do terreno, sem atravessá-lo. $O$ acesso até as unidades era feito através de vias peatonais. (Figura 26)

No centro do conjunto foi proposto como equipamento um núcleo educacional e social que incluía creche, jardim de infância, escola primária, playgrounds e centro social. Um "centro de abastecimento está junto à Avenida Cidade Jardim, com acesso direto para veículos que vem da cidade e, ao mesmo tempo, junto às residências" (NÚCLEO RESIDENCIAL DO INSTITUTO..., 1947, p.276). Em bolsões de terreno localizados do lado de fora da avenida que circunda as residências foram propostos um núcleo hospitalar que agregava ambulatório e maternidade e um grupo de oficinas. Por sua localização "exterior" às residências e próxima às vias de acesso ao conjunto é possível considerar que estes serviços se destinavam não somente ao uso dos moradores (NÚCLEO RESIDENCIAL DO INSTITUTO..., 1947). Na Figura 26 a área em que foram previstos os equipamentos comunitários está destacada em laranja e aquelas em que foram propostos comércios e serviços estão destacadas em vermelho.

Sobressaem-se como aspectos importantes deste projeto a verticalização, a padronização de unidades e da tipologia habitacional. No C.R. Cidade Jardim a maior parte do terreno disponível seria ocupada pela disposição de fileiras de seis casas assobradas, totalizando 466 unidades. Esta tipologia, havendo três tipos (A, B e C) com variação nas plantas das unidades, segundo Regino (2006; 2009) atendia a critérios econômicos em função da redução do custo de construção.

A verticalização neste projeto chama a atenção especialmente pelo fato de o conjunto localizar-se em uma área de expansão urbana, uma vez que a construção de edifícios em altura era naquele momento proposta especialmente junto à área central da cidade. 0 edifício vertical multifamiliar era uma lâmina curvilínea de 11 pavimentos com 572 unidades, elevado sobre pilotis. A liberação do solo permitia a utilização do térreo como passeio coberto, prolongando a área de parque em que está inserido o edifício. A cobertura foi concebida como terraço jardim, destinada ao lazer dos moradores, elemento já utilizado por Kneese de Mello no C.R. Japurá. (Figura 27) 


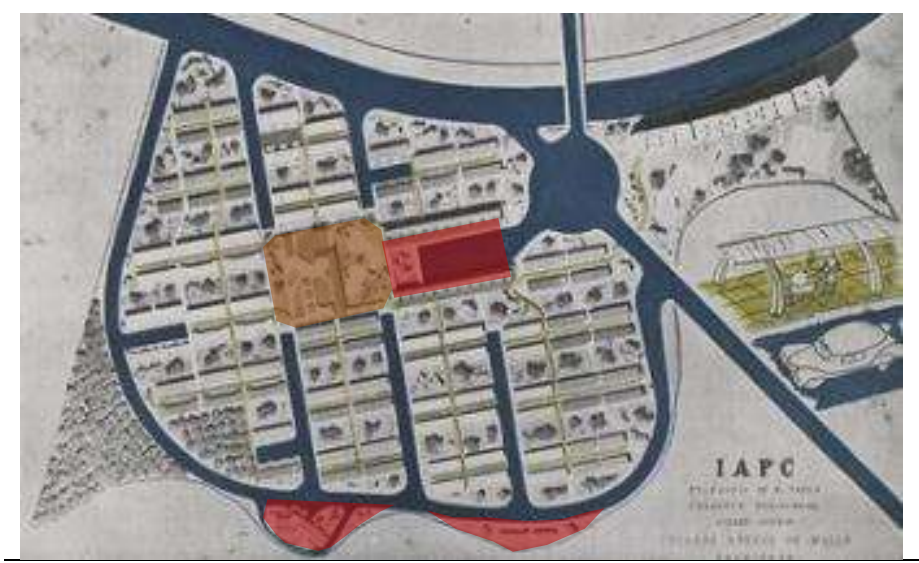

Figura 26: Planta do C.R. Cidade Jardim. Fonte: Acrópole, Ano 9, n. 107, março 1947, p. 275. Com intervenções da autora.

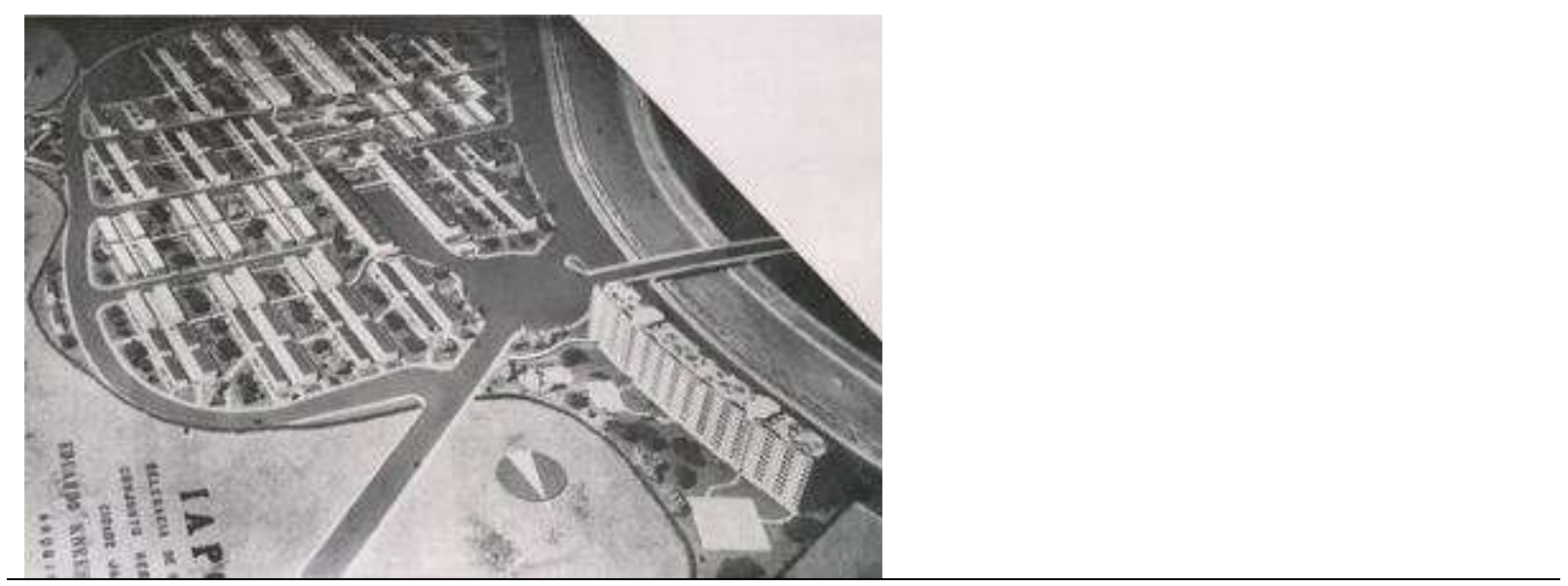

Figura 27: Vista geral do C.R. Cidade Jardim com edifício multifamiliar vertical em primeiro plano. Fonte: Acrópole, Ano 9, n. 107, março 1947, p. 274.

Embora, como se viu, seja possível reconhecer nos projetos habitacionais analisados uma perspectiva de produção em grande escala, não se encontra na legislação referente à atuação dos IAPs no setor imobiliário/habitacional indicações ou normativas sobre o número de unidades ou escala dos projetos a serem concebidos (BRASIL, 1933; BRASIL, 1934a; BRASIL, 1934b; BRASIL, 1936; BRASIL, 1937; BRASIL, 1938). É possível considerar, nesse sentido, a importância da atuação dos profissionais responsáveis por estes projetos. Acreditamos que a associação entre o cumprimento da função social da habitação e a necessidade de rentabilizar os projetos habitacionais, colocada como objetivo desses projetos conforme destacado nas falas de Rubens Porto, Alim Pedro, Kneese de Mello e Corrêa Lima apresentadas no início deste capítulo, foi fundamental à adoção das características da produção habitacional em grande escala nos projetos relacionados. 


\subsection{Produção massiva da habitação em Buenos Aires: a construção de "barrios peronistas"}

Em 1943 é institucionalizada de forma definitiva a produção habitacional pelo Estado na Argentina, embora desde 1915 o Estado já atuasse diretamente na produção de habitações. A forma "conjunto habitacional" era utilizada desde o final da década de 1930, contudo sem apresentar até então uma produção massiva. Em 1943 essa intenção é esboçada com a criação da Comisión Asesora para la Vivienda Popular e publicação de um Plano Orgânico para produção da habitação social. Contudo, é mais precisamente a partir de 1946 que o Estado Peronista assume como objetivo governamental produzir conjuntos massivos de habitação (HISTORIA ARGENTINA DE LA VIVIENDA..., s/d). Assim, embora o processo de institucionalização da produção habitacional pelo Estado na Argentina tivesse começado ainda no início do século XX, é na década de 1940, assim como no Brasil, que esse processo se efetiva, assumindo uma perspectiva de produção em grande escala.

A exposição de motivos que justificavam a intervenção estatal na provisão habitacional, conforme o Plano de Governo de 1946, indica que "o problema da moradia resiste nas grandes cidades, aspecto de extrema gravidade, motivado, em parte, pelo desequilíbrio que através de vários anos se produziu entre a oferta e a demanda. Por isso resulta indispensável tratar de restabelecer este equilíbrio" (PRESIDENCIA DE LA NACIÓN..., 1946, p.317). A ampliação da oferta de moradias ocorreria, por um lado, pela ação do capital privado, garantindo-se benefícios àqueles que edificassem moradias, e, por outro, pela produção massiva de habitações através da ação estatal, indireta, com oferecimento de empréstimos a juros baixos, e direta, através da construção de "bairros de casas baratas". (PRESIDENCIA DE LA NACIÓN..., 1946).

Três tipologias foram utilizadas na produção habitacional por ação direta do Estado em Buenos Aires e nos partidos da região metropolitana. A primeira tipologia foi o conjunto de casas unifamiliares vinculado ao padrão urbanístico cidade-jardim; a segunda foi o conjunto de "pabellones" ou "tiras", blocos laminares de pouca altura, implantados sobre grandes quadras livres propostas como parques integrados à cidade; e a terceira foi o conjunto de monobloques, edifícios verticais (com dez pavimentos ou mais), também implantados em grandes áreas verdes - vale lembrar que, exceto por um único projeto, não há no caso de São Paulo conjuntos formados exclusivamente por edifícios verticais, sendo essa uma importante peculiaridade da produção massiva da habitação em Buenos Aires. Há conjuntos habitacionais em que as três tipologias foram utilizadas concomitantemente, sendo expressivos os projetos de urbanização nos partidos vizinhos da capital. Poucos projetos constituem-se de edifícios verticais isolados.

De acordo com Aboy (2005), Buenos Aires, por ser a capital, foi onde se pôde experimentar mais em termos da produção habitacional, havendo aí maior variedade de projetos com relação a outros lugares do país. Deste modo, não é possível afirmar que existisse uma "arquitetura peronista" que obrigatoriamente devesse ser utilizada. No entanto, se não se distingue uma tipologia padrão para 
toda a produção habitacional argentina, se observa que cada órgão comitente apresentou uma produção habitacional específica, que refletia, por exemplo, as diferentes condições de produção, de financiamento e os atores envolvidos. Ou seja, cada órgão se caracteriza por um tipo de produção, que se não foi exclusivo, foi majoritário e bastante revelador das peculiaridades de cada instituição no interior do aparato estatal e de como este e a própria política habitacional se posicionavam com relação à cidade consolidada, conforme se discutirá posteriormente.

Dentre os projetos produzidos por distintos órgãos entre 1943 e 1955 foram identificados em Buenos Aires e nos demais partidos que compõem a área metropolitana, isto é, na Grande Buenos Aires ${ }^{10}$, onze em que se identifica uma perspectiva de produção massiva. Foram projetados pelo Ministério de Obras Públicas (MOP) o Barrio n ${ }^{\circ} 1$ - Justicialista, Ciudad Evita e o Barrio Juan Perón; pela Adminsitración Nacional de la Vivienda (ANV) foi construída a Villa Concepción e pelo Banco Hipotecário Nacional (BHN), atuando diretamente, foi construída a terceira etapa do Barrio Alvear e foram propostos os conjuntos Curapaligue e 17 de Octubre. A Municipalidad de la Ciudad de Buenos Aires propôs os conjuntos Los Perales e Grafa, a Urbanização de Bajo Belgrano e Casa Amarilla.

Estes projetos são constituídos por no mínimo 382 unidades em casas isoladas ou 600 unidades em edifícios coletivos ${ }^{11}$, chegando nos grandes projetos de urbanização, como Bajo Belgrano e Ciudad Evita, a números compatíveis com a formação de novos distritos, com 9.000 e 10.000 unidades, respectivamente. Tanto nos conjuntos de casas unifamiliares, quanto nos grandes projetos de urbanização se identifica a construção de tipos padronizados, que inclusive são utilizados em conjuntos diferentes, evidenciando uma perspectiva de produção em série tanto das unidades, quanto de elementos construtivos. Os grandes edifícios laminares que compõem os projetos possuem mais de 10 pavimentos e térreo com pilotis, apresentado forte referencial da linguagem moderna em seu desenho.

Foi proposta e construída uma gama ampla de equipamentos e serviços coletivos em praticamente todos os projetos analisados. A construção de equipamentos e serviços foi importante à política habitacional peronista, pois garantia à família trabalhadora, para quem estes projetos eram executados, a possibilidade de realizar as atividades cotidianas em local próximo à moradia, o que era considerado "digno" de sua importância para o país (LA NACIÓN ARGENTINA..., 1950). Além disso, o próprio Plano Quinquenal (1946) propunha a criação de bairros e a garantia do acesso a benefícios urbanos, de modo que a integração com equipamentos evidenciava a complexidade dos conjuntos, como parcelas de cidade.

\footnotetext{
${ }^{10}$ Em 1948 um decreto da Província de Buenos Aires (LA PLATA, 1948) adotou o termo "Gran Buenos Aires" para a área urbana e rural de 14 partidos que circundavam a capital, de modo que utilizaremos o termo Grande Buenos Aires para nos referirmos a estes municípios.

${ }^{11}$ A orientação metodológica pela identificação e seleção de projetos com mais de 300 unidades utilizada para o caso de São Paulo foi a mesma utilizada para o caso de Buenos Aires, onde, porém o número mínimo de unidades nos projetos em grande escala do período é maior.
} 
O Quadro 2 apresenta os projetos massivos identificados na Grande Buenos Aires entre aqueles produzidos de 1943 a 1955. No quadro informa-se para cada projeto o número de unidades propostas e construídas, a área do terreno e a densidade habitacional prevista. São apresentadas também as tipologias habitacionais e os equipamentos comunitários. O total de unidades proposto por cada órgão comitente foi somado e utilizado para a elaboração do Gráfico 02.

Quadro 2

Projetos habitacionais massivos propostos para Buenos Aires e partidos vizinhos entre 1943 e 1955 :

\begin{tabular}{|c|c|c|c|c|c|c|c|c|c|c|}
\hline \multirow[t]{2}{*}{ Órgão } & \multirow[t]{2}{*}{ Projeto } & \multirow[t]{2}{*}{$\begin{array}{c}\text { Área do } \\
\text { terreno } \\
\text { e densidade }\end{array}$} & \multicolumn{3}{|c|}{$\begin{array}{c}\text { Tipologia: } \\
\text { Pabellones (P) / } \\
\text { Monobloques (M) }\end{array}$} & \multicolumn{2}{|c|}{$\begin{array}{c}\text { Tipologia: } \\
\text { Casas Isoladas } \\
\text { (Ci) / Casas em } \\
\text { fileiras (Cf) } \\
\end{array}$} & \multirow[t]{2}{*}{$\begin{array}{l}\text { Equipamentos e serviços } \\
\text { comunitários }\end{array}$} & \multirow[t]{2}{*}{ Data } & \multirow[t]{2}{*}{$\begin{array}{l}\text { Núm. de } \\
\text { unidades } \\
\text { construídas e } \\
\text { (projetadas) }\end{array}$} \\
\hline & & & $\mathbf{P}$ & M & Pav. & $\mathrm{Ci}$ & Cf & & & \\
\hline \multirow[t]{2}{*}{ ANV } & $\begin{array}{c}\text { Villa } \\
\text { Concepción }\end{array}$ & $* *$ & & & & $x$ & $x$ & $\begin{array}{c}\text { centro comercial, igreja, } \\
\text { escola, piscina, quadra, } \\
\text { playground, teatro de } \\
\text { arena }\end{array}$ & $\begin{array}{c}1944- \\
49\end{array}$ & 530 \\
\hline & & & & & & & & & & 530 \\
\hline \multirow[b]{3}{*}{ BHN } & Curapaligüe & $\begin{array}{l}4,22 \text { ha. } \\
D=644 \\
\text { hab/ha }\end{array}$ & & 6 & $\begin{array}{c}\mathrm{T} \\
+10[\mathrm{M} 1] \\
\mathrm{T}+12[\mathrm{M} 2]\end{array}$ & & & praça, playground, correos & $\begin{array}{c}1948- \\
53\end{array}$ & 676 \\
\hline & $\begin{array}{c}\text { Barrio Alvear } \\
\text { III } \\
\text { (3a etapa) } \\
\end{array}$ & $\begin{array}{l}18 \text { ha. } \\
D=650 \\
\text { hab/ha }\end{array}$ & $\begin{array}{l}12 \\
{[\mathrm{P} 1] ;} \\
7[\mathrm{P} 2]\end{array}$ & 7 & $\begin{array}{c}5[\mathrm{P} 1] \\
3[\mathrm{P} 2] ; \\
7[\mathrm{M}] \\
\end{array}$ & & & 3 escolas, clube, igreja & $\begin{array}{c}1943- \\
54\end{array}$ & 1692 \\
\hline & $\begin{array}{c}17 \text { de } \\
\text { octubre - } \\
\text { Barrio } \\
\text { General Paz }\end{array}$ & $\begin{array}{l}235 \text { ha. } \\
D=133 \\
\text { hab/ha }\end{array}$ & 22 & 33 & $\begin{array}{l}10+t(M) \\
\quad 3(P)\end{array}$ & 1284 & & $\begin{array}{l}\text { escola primaria, escritórios, } \\
\text { cineteatro, salas } \\
\text { comerciais, clube, } \\
\text { mercado, correio, cartório, } \\
\text { igreja, hospital, } \\
\text { departamento de } \\
\text { bombeiros, escolas } \\
\text { secundárias, escola } \\
\text { técnica, centro desportivo }\end{array}$ & $\begin{array}{c}1948- \\
54\end{array}$ & 5536 \\
\hline & & & & & & & & & & 7.904 \\
\hline \multirow{3}{*}{ MOP } & $\begin{array}{l}\text { Barrio no. } 1 \text { - } \\
\text { Justicialista }\end{array}$ & $*$ & & & & $\mathrm{x}$ & $x$ & $\begin{array}{l}\text { centro cívico, teatro, igreja, } \\
\text { prédio adm. prédio de } \\
\text { comércios e lazer, escola, } \\
\text { hospital, abrigo de idosos }\end{array}$ & 1949 & 382 \\
\hline & Ciudad Evita & $\begin{array}{c}870 \text { ha. } \\
\text { D=89 } \\
\text { hab/ha } \\
(1960)\end{array}$ & & & & & & $\begin{array}{c}\text { escolas primárias, } \\
\text { comercio; } \\
\text { NC: igreja, biblioteca, } \\
\text { quadras }\end{array}$ & $\begin{array}{c}1947- \\
53\end{array}$ & $\begin{array}{l}5.000 \\
(10.000)\end{array}$ \\
\hline & $\begin{array}{l}\text { Barrio Juan } \\
\quad \text { Perón }\end{array}$ & $\begin{array}{c}29 \text { ha. } \\
\text { D=62 } \\
\text { hab/ha }\end{array}$ & & & & $x$ & & $\begin{array}{c}\text { centro cívico: igreja, escola, } \\
\text { cine-teatro, salas } \\
\text { comerciais, estação de } \\
\text { serviços, correios e } \\
\text { telecomunic. }\end{array}$ & $\begin{array}{c}1946- \\
49\end{array}$ & 428 \\
\hline & & & & & & & & & & 10810 \\
\hline \multirow{5}{*}{ MCBA } & Los Perales & $\begin{array}{l}20 \text { ha. } \\
D=230 \\
\text { hab/ha }\end{array}$ & 45 & & 3 & & & $\begin{array}{c}\text { playground, escola, piscina, } \\
\text { quadras, salas comerciais, } \\
\text { biblioteca, igreja }\end{array}$ & $\begin{array}{c}1946- \\
52\end{array}$ & 1068 \\
\hline & $\begin{array}{c}17 \text { de } \\
\text { Octubre } \\
\text { (Barrio Grafa) } \\
\end{array}$ & $\begin{array}{l}11 \text { ha. } \\
D=380 \\
\text { hab/ha }\end{array}$ & 34 & & 4 & & & $\begin{array}{l}\text { playground, ambulatório, } \\
\text { salas comerciais }\end{array}$ & $\begin{array}{c}1948- \\
50\end{array}$ & 959 \\
\hline & $\begin{array}{l}\text { Urbanización } \\
\text { de Bajo } \\
\text { Belgrano }\end{array}$ & $\begin{array}{l}170 \text { ha. } \\
\text { D=300-600 } \\
\text { hab/ha }\end{array}$ & 20 & & $\mathrm{~T}+18$ & & & $\begin{array}{l}\text { centro de artesãos, centro } \\
\text { comercial, esplanada } \\
\text { cívica, centro social e } \\
\text { esportivo, escolas, centros } \\
\text { de ensino secundário, } \\
\text { centro de saúde, igrejas }\end{array}$ & 1948 & $\begin{array}{c}0 \\
(9.000)\end{array}$ \\
\hline & Casa Amarilla & $*$ & & 41 & $*$ & & & $*$ & $*$ & $\begin{array}{c}0 \\
(6.200) \\
\end{array}$ \\
\hline & & & & & & & & & & 17.227 \\
\hline \multicolumn{11}{|c|}{$\begin{array}{l}\text { Fontes: Elaboração da autora com base em: La Nación Argentina... (1950); Ballent (1993; 2005); Dunowicz (2000); Gutierrez (2011); Aboy (2005); } \\
\text { Nuestra Arquitectura no 277, ago, 1952. Construcciones no 107, abril 1954. Revista de Arquitectura no 365, feb. 1952. pp. 23-30. Website La teja } \\
\text { <https://lateja2.wordpress.com>; Website Moderna Buenos Aires <https://www.modernabuenosaires.org> } \\
\text { Obs. * Dados não encontrados. }\end{array}$} \\
\hline
\end{tabular}


Gráfico 02. Total de unidades previstas por órgão comitente

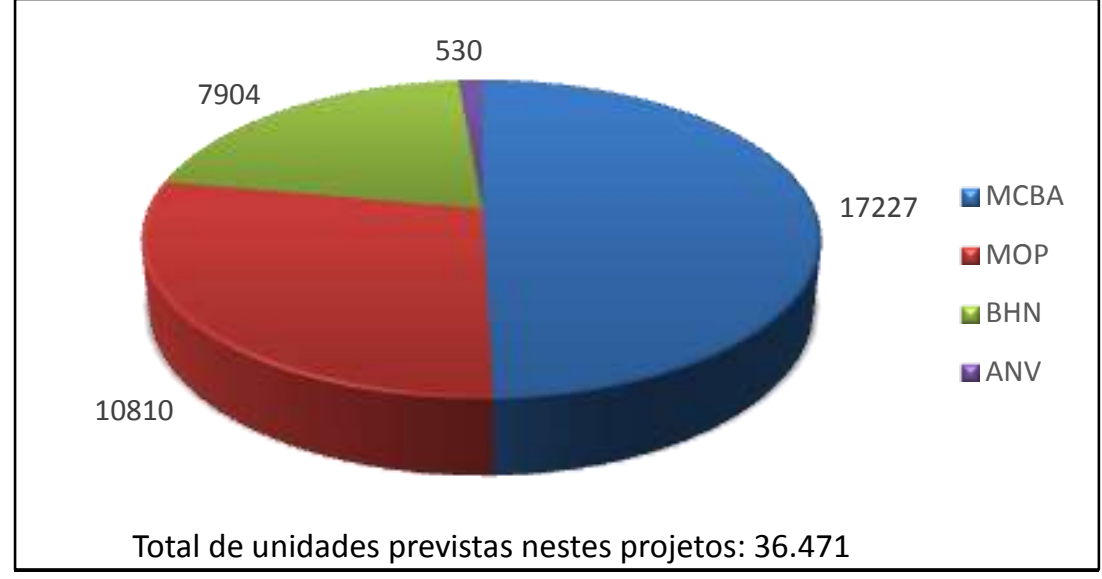

Elaboração da autora

A MCBA, através da Dirección Municipal de la Vivienda foi o órgão que produziu maior número de projetos massivos, mesmo atuando apenas no território da capital. Se todos os cinco projetos do órgão fossem concluídos, somariam aproximadamente 17.227 unidades ${ }^{12}$, tendo sido construídas apenas 2.027. O MOP produziu três projetos que juntos contam 10.810 unidades, das quais foram construídas cerca de 5.800. A ANV propôs um único projeto massivo, com 530 unidades, enquanto o BHN, por ação direta, produziu outros três conjuntos, que se construídos em sua totalidade somariam 7.904 unidades.

De acordo com as fontes pesquisadas, entre 1943 e 1955 foram propostos para Buenos Aires e alguns partidos vizinhos ao todo 28 projetos habitacionais que contavam 48.971 unidades (LA NACIÓN ARGENTINA..., 1950; DUNOWICZ, 2000; GUTIERREZ, 2011). Somando-se o número de unidades dos projetos selecionados chegamos a 36.471 , o que significa que aproximadamente $75 \%$ das unidades de moradia da capital e Grande Buenos Aires estavam nestes projetos. Essa proporção entre o total de unidades concebidas e o total daquelas pensadas sob perspectiva de produção massiva é bastante similar àquela encontrada em São Paulo (80\%). Em números, porém, a quantidade de unidades em Buenos Aires (36.471) é mais de duas vezes maior que aquela de São Paulo (17.581).

Assim como no caso de São Paulo, interessa-nos identificar e analisar como se expressa a produção massiva da habitação nos projetos selecionados em Buenos Aires. Entre os aspectos analisados, assim como em São Paulo, identifica-se a linguagem formal associada à verticalização, à padronização de materiais e unidades e à utilização de novas tecnologias construtivas e a concepção dos projetos habitacionais como projetos urbanísticos, associada a um amplo espectro de equipamentos comunitários. No entanto, o aspecto mais relevante a ressaltar, e que se diferencia do caso brasileiro,

\footnotetext{
12 Incluímos nesta somatória as unidades do conjunto previsto para a área conhecida como Casa Amarilla, por ser mencionado em diversas fontes pesquisadas, embora não o tenhamos incluído em outras análises realizadas devido à falta de dados sobre o projeto, não executado. Da publicação oficial "La Nación Argentina Justa Libre y Soberana" de 1950, consta apenas o número de unidades do Barrio Casa Amarilla - 6.200 -, e a informação de que estas se distribuiriam em 41 monobloques.
} 
é a própria escala dos projetos. Em Buenos Aires a compreensão do projeto habitacional como campo de estudos do urbanismo é ampliada e estruturada na escala do bairro. Os menores conjuntos têm entre 400 e 700 unidades e áreas entre 4 e 29 hectares, destacando-se os conjuntos Curapaligüe e Juan Perón (Figuras 28 e 29); os conjuntos "médios" têm em torno de 1000 unidades e áreas entre 11 e 20 hectares, sendo representativos deste grupo os conjuntos Grafa e Los Perales (Figuras 30 e 31). Os maiores projetos, que compreendemos como verdadeiros planos de urbanização, têm entre 5.500 e 10.000 unidades e áreas de 170 a 870 hectares. Três projetos demonstram esta proposta de estruturação de bairros: Bajo Belgrano, 17 de Octubre e Ciudad Evita (Figuras 32, 33 e 34, respectivamente). Para evidenciar a diferença de escala com relação aos projetos habitacionais do caso brasileiro, vale lembrar que em São Paulo dois projetos propuseram cerca de 1.000 unidades e apenas três projetos previram entre 3.000 e 4.000 unidades; quanto à área urbanizada, o maior terreno em que foi concebido um dos projetos relacionados em São Paulo possuía 87,5 hectares, sendo, portanto, quase dez vezes menor que o maior terreno dos projetos de Buenos Aires. No sentido desta abordagem, em que propomos analisar os projetos não apenas como produção em grande escala ou massiva, mas como projetos de urbanização, como "barrios peronistas", dois projetos - Villa Concepción e Barrio N. 1 - não puderam ser aprofundados devido à insuficiência de dados, particularmente com relação à área por eles ocupada. O caso de Casa Amarilla, embora constituísse propaganda oficial, inclusive com indicação do local a ser ocupado pelo projeto e do tipo de ocupação proposto, através da construção de monobloques, também não pôde ser analisado por falta de dados e documentação pertinente.

É importante ter em mente que a ocupação urbana de Buenos Aires já se achava, em 1943, bastante consolidada, havendo de fato poucos espaços disponíveis à produção habitacional. Contudo, foram disponibilizados pelo Estado terrenos de grandes dimensões na região periférica, tanto no espaço urbano, quanto no espaço suburbano. Especialmente nos municípios vizinhos de Buenos Aires os terrenos disponíveis e utilizados para a realização dos projetos tinham proporções de verdadeiros distritos, tanto pela área urbanizada quanto pelo número de unidades proposto. Também foram utilizados grandes terrenos em regiões desfavorecidas da capital e alguns terrenos menores ainda desocupados em meio ao espaço urbanizado ${ }^{13}$.

Buscando o melhor aproveitamento e ocupação dos terrenos disponíveis, os projetos analisados propuseram formas racionalizadas de implantação. Nas tipologias multifamiliares se trabalhava sem parcelamento da terra e predominantemente com a elevação dos edifícios sobre pilotis. Essas tipologias foram associadas à locação até que, em 1948, a Ley de Propriedad Horizontal possibilitou a aquisição de apartamentos. Nas casas unifamiliares partia-se do pressuposto de que cada terreno e

\footnotetext{
${ }^{13}$ Ver, no Capítulo 05, Figura 98, "Área urbanizada da Grande Buenos Aires em 1948 com localização dos conjuntos habitacionais projetados entre 1943 e 1955".
} 
unidade seriam vendidos a seu proprietário, fracionando-se as quadras em lotes particulares que, no entanto, não implicaram negativamente na integração entre o projeto arquitetônico e urbanístico. Ambas as tipologias conformaram núcleos bastante diferenciados de seu entorno especialmente pela distinção entre os projetos urbanísticos e o traçado tradicional da cidade em "damero" (ortogonal).

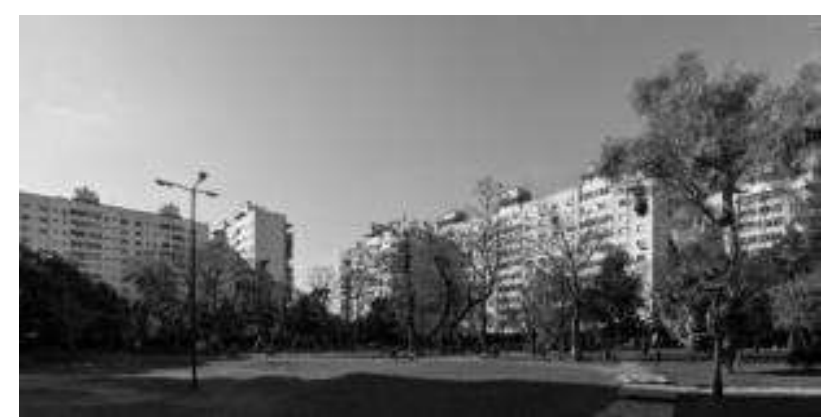

Figura 28. Curapaligue. Fonte: Barrio Simón Bolívar In: Moderna Buenos Aires (online). Foto de Albano Garcia. Disponível em: <https://www.modernabuenosaires.org/obras/20s-a-70s/barrio-simon-bolivar>. Acesso em 17 maio 2018.

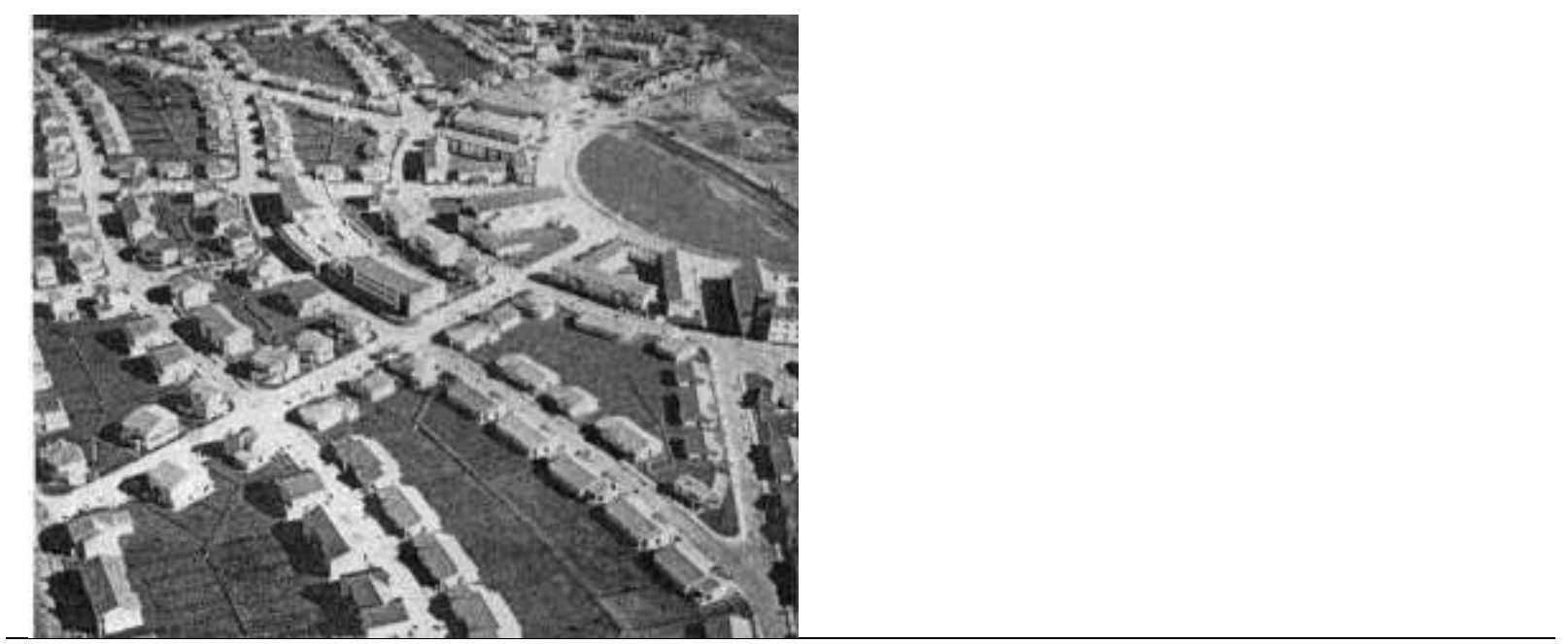

Figura 29. Vista aérea do Barrio Juan Perón. Fonte: Website La Teja.

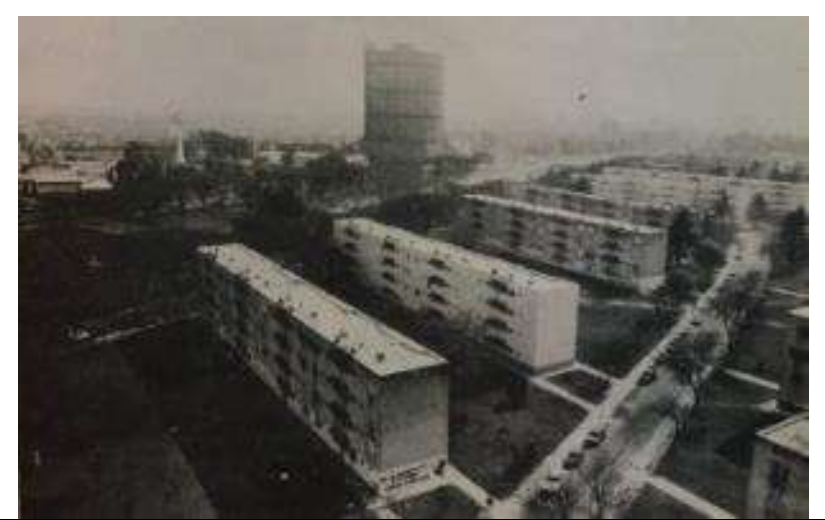

Figura 30. Barrio Grafa. Fonte: Historia argentina de la Viivenda de interés social - 2a parte: 1943-1955 In: Arquitectura y Comunidad Nacional. N.4, s/d. p. 59 


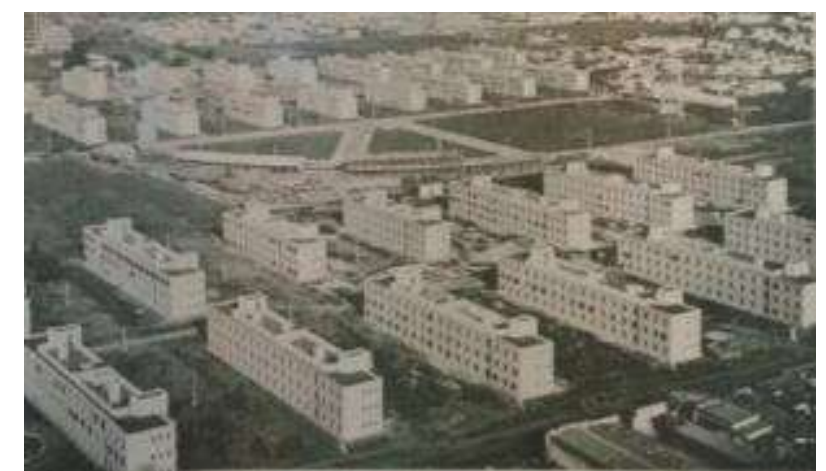

Figura 31. Barrio Los Perales. Fonte: Historia argentina de la Viivenda de interés social - 2a parte: 1943-1955 In: Arquitectura y Comunidad Nacional. N.4, s/d. p.60.

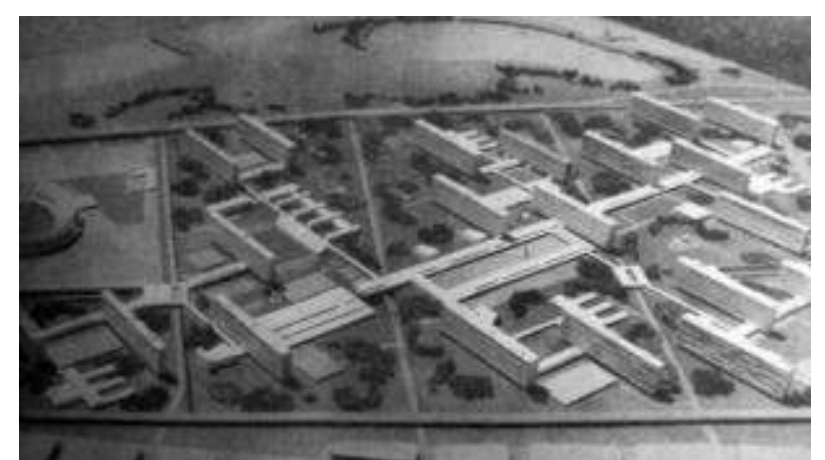

Figura 32. Maquete do conjunto. Fonte: “Urbanización de Bajo Belgrano" In: Revista de Arquitectura, n. 369, ene./feb. 1953. pp. 32.

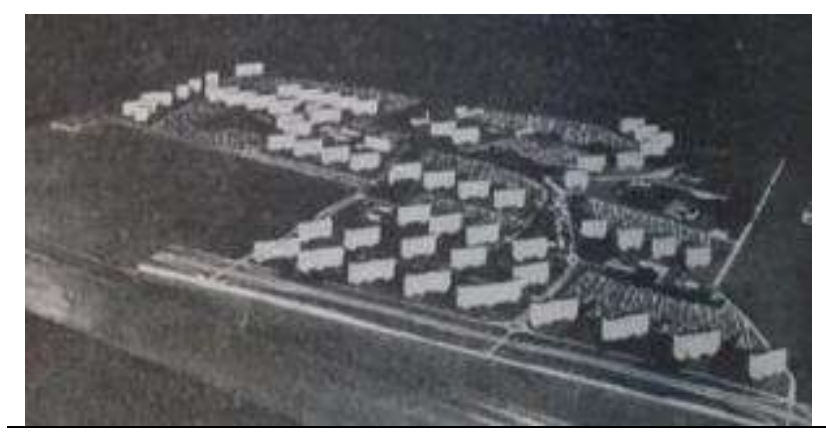

Figura 33. Maquete do conjunto. Fonte: RUBIO, S. "El barrio 17 de Octubre. Obra del Banco Hipotecario Nacional" In: Construcciones. $n$ 107, abril 1954. p.336

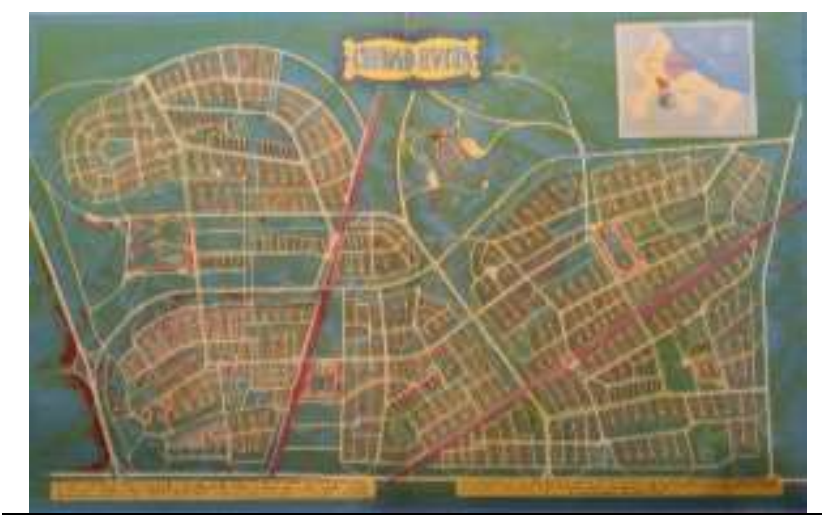

Figura 34. Panta de Ciudad Evita. Fonte: La Nación Argentina Justa Libre Soberana. Control de Estado de la Presidencia de la Nación (Ed.). Buenos Aires: Peuser, 1950. pp. 312-313. 
O menor projeto em termos da área ocupada aqui analisado é o Barrio Curapaligüe, implantado em um terreno de 4,22 hectares que, apesar de remanescente em meio a um bairro já bastante ocupado, não foi dividido para ajustar-se às quadras já existentes. Ao contrário, a área foi mantida em sua totalidade, sendo percorrida apenas por percursos peatonais através dos quais se acessa os edifícios e o miolo da superquadra.

O Curapaligüe se destaca pela na verticalização, pela utilização de materiais e tecnologias modernas e pelo projeto padronizado das unidades. Os edifícios foram dispostos de modo a conformar um grande espaço livre central, como se pode observar na planta (Figura 35). Molina e Vedia (1984), em matéria na revista Trama intitulada "O tecido misto na cidade real e o modelo teórico", analisam o projeto e sugerem uma aproximação com os Inmuebles-Villes projetados por Le Corbusier, o que nos parece razoável uma vez que os edifícios de fato parecem compor um único bloco ao redor da quadra, liberando o espaço central como área de sociabilização para os moradores - vale dizer que não há projeto similar a este em São Paulo. As 676 unidades de apartamentos se distribuem em seis edifícios de 10 e 12 pavimentos sobre térreo em pilotis (Figura 36). Esta característica confere destaque ao conjunto, inserido em um bairro constituído majoritariamente por residências térreas e de dois pavimentos.

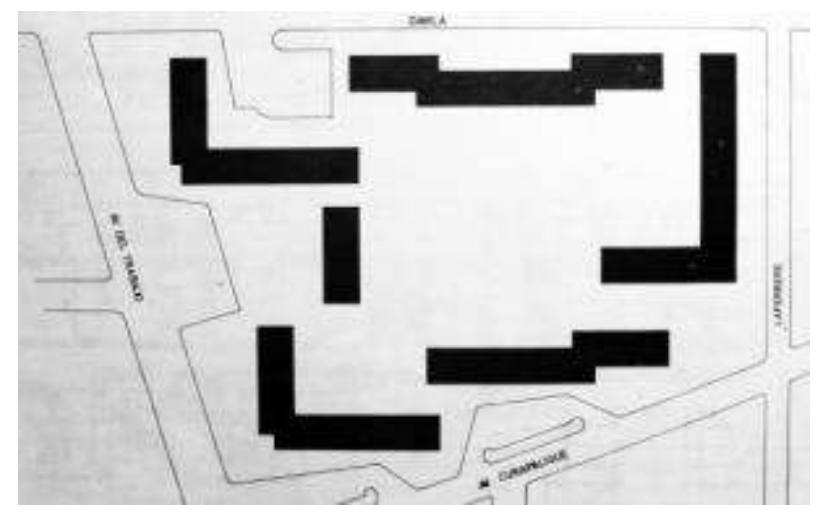

Figura 35. Planta do Conjunto Curapaligüe. Fonte: SORIA, Jaime. “La vivienda argentina en la decada del 50'” In: TRAMA. n. 17, año 1987. p.22.

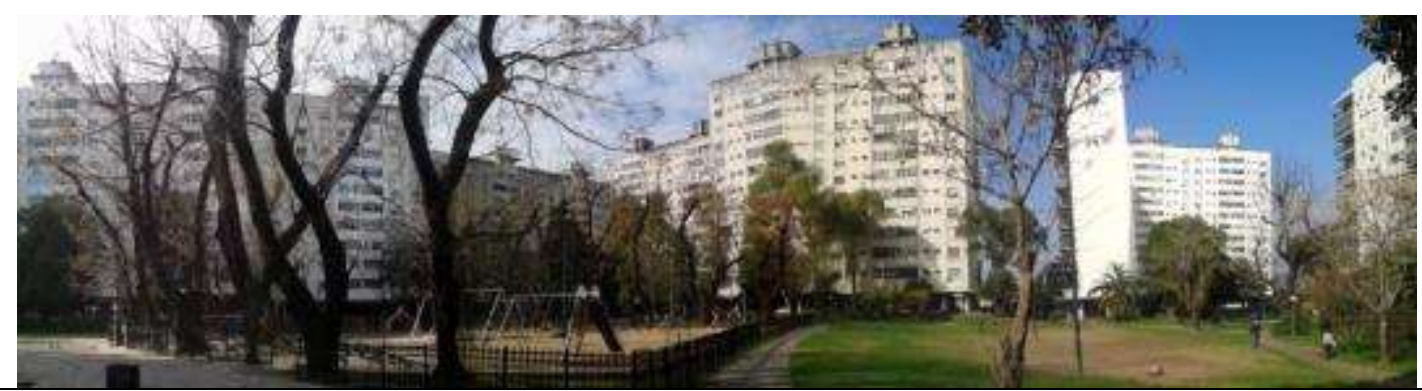

Figura 36. Conjunto Curapaligüe. Fonte: Acervo pessoal. Foto de Camila Ferrari, jul. 2014.

Conforme se observa na planta e na fotografia do conjunto, os edifícios foram pensados em formato laminar ou em "L", destacando-se o fato de os monoboques não serem propostos como lâminas 
contínuas, mas com volumes deslocados que conferem interesse às elevações marcadas por varandas e por caixas de escada com vedação em bloco de vidro. A variação nos formatos e volumetria dos blocos se deve ao "encaixe" dos módulos compostos por dois apartamentos de dois ou três dormitórios, realizado através da sobreposição das plantas. Para tanto, os módulos possuem varandas amplas nas extremidades, onde se dá a sobreposição, com deslocamento ou rotação dos módulos (Figura 37). Esse tipo construtivo é utilizado também no Barrio 17 de Octubre - General Paz.
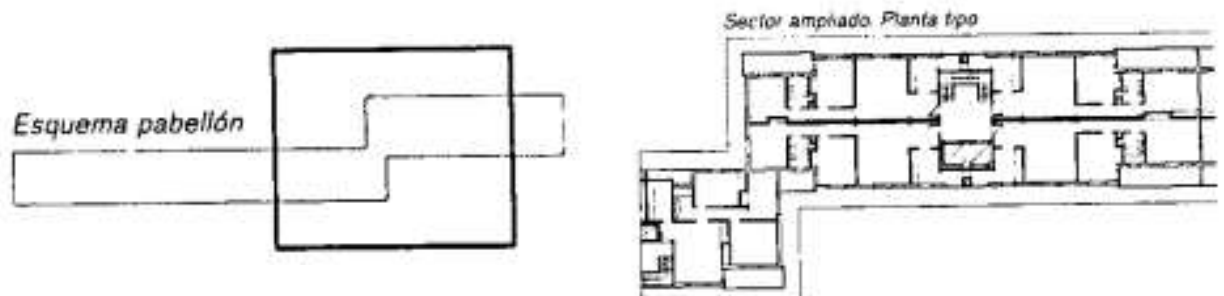

Figura 37. Esquema de sobreposição das plantas dos módulos que compõem os edifícios. Fonte: Dunowicz, Renée. 90 años de vivienda social en la ciudad de Buenos Aires. Buenos Aires: Programa de Mantenimiento Habitacional, 2000. p.79

A solução urbanística do Barrio Presidente Juan Perón, construído no limite noroeste da cidade, assume como referência o padrão urbanístico cidade-jardim e o que Ballent (2005) identifica como "desconcentração urbana", isto é, uma forma de morar mais campesina que urbana, mais dispersa e menos adensada. De fato, a área deste conjunto, de 29 hectares, é muito maior que a do Barrio Curapaligüe $(4,22 \mathrm{ha})$ e, no entanto, é proposto número muito menor de unidades. Deste modo, se apreende que as diferenças de escala dos projetos não dependiam apenas da área disponível, mas também da decisão pela desconcentração ou concentração urbana, que estava, por sua vez, bastante ligada, como explicaremos no Capítulo 05, a uma preocupação com a idiossincrasia da população migrante que se estabelecia na cidade e nos arredores e Buenos Aires.

A partir de um parque e um centro cívico foram projetadas vias radiais em direção aos limites do terreno e estas são atravessadas por outras com traçado orgânico (Figura 38). As quadras de formato irregular são divididas em lotes ocupados por casas térreas ou assobradadas junto ao alinhamento, liberando-se os interiores com áreas verdes. O centro cívico é formado por igreja, escola primária, centro comercial, cinema, associação de vizinhos e uma estação de serviços com garagem e mercado. Os equipamentos e serviços ocuparam edifícios destacados nas quadras adjacentes ao parque central (Figuras 39) e seguem funcionando até os dias atuais, exceto pelo cinema e pela estação de serviços, cujos espaços possuem hoje novas funções. Nas quadras adjacentes ao parque central foram propostas unidades coletivas enfileiradas com dois pavimentos, formando blocos em "L" acessados por entradas e escadas comuns a cada quatro unidades. Segundo se constatou no local, estes blocos eram formados por unidades pequenas destinadas à locação ${ }^{14}$.

\footnotetext{
${ }^{14}$ Segundo conversa informal com a Sra. Alicia, moradora original do Barrio Grafa em maio de 2017.
} 


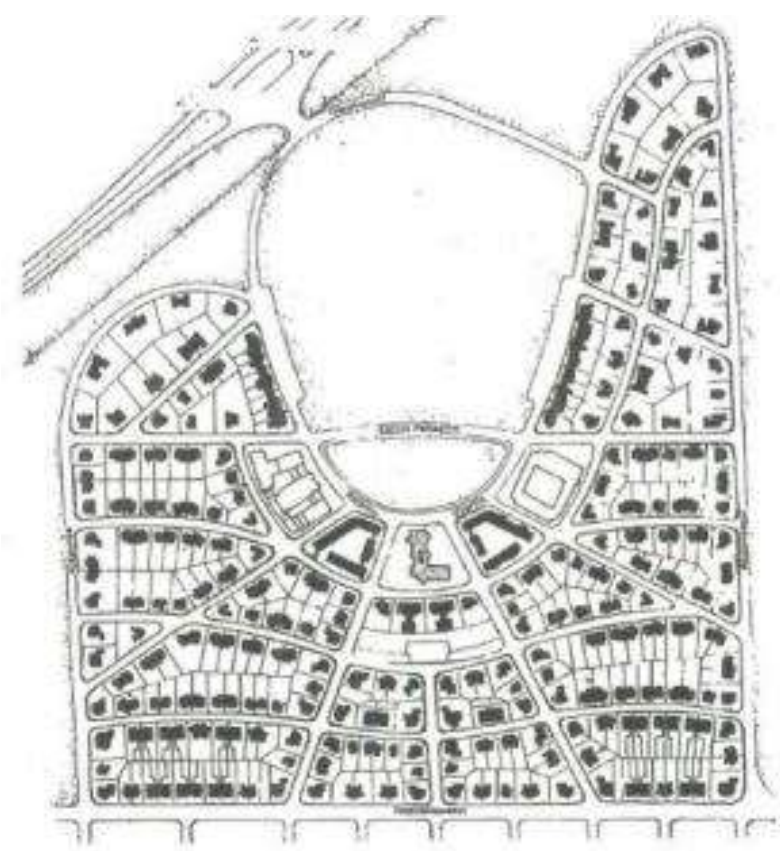

Figura 38: Barrio Juan Perón. Fonte: Historia argentina de la vivienda de interés social - 2a parte: 1943-1955 In: Arquitectura y Comunidad Nacional. n.4, s/d. p.41.

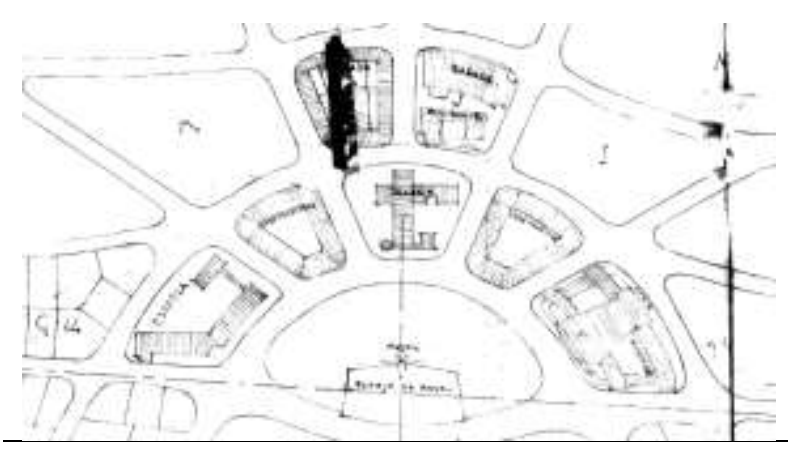

Figura 39. Recorte de estudo do conjunto Juan Domingo Peron mostrando os equipamentos comunitários. Fonte: Tipos de casas do Barrio Juan Perón. Plano codigo: 3745: barrio Cornelio Saavedra ex Presidente Peron, casa tipo en Cdad. de Bs.As. Ampliación de Loteo. Acervo Cediap.
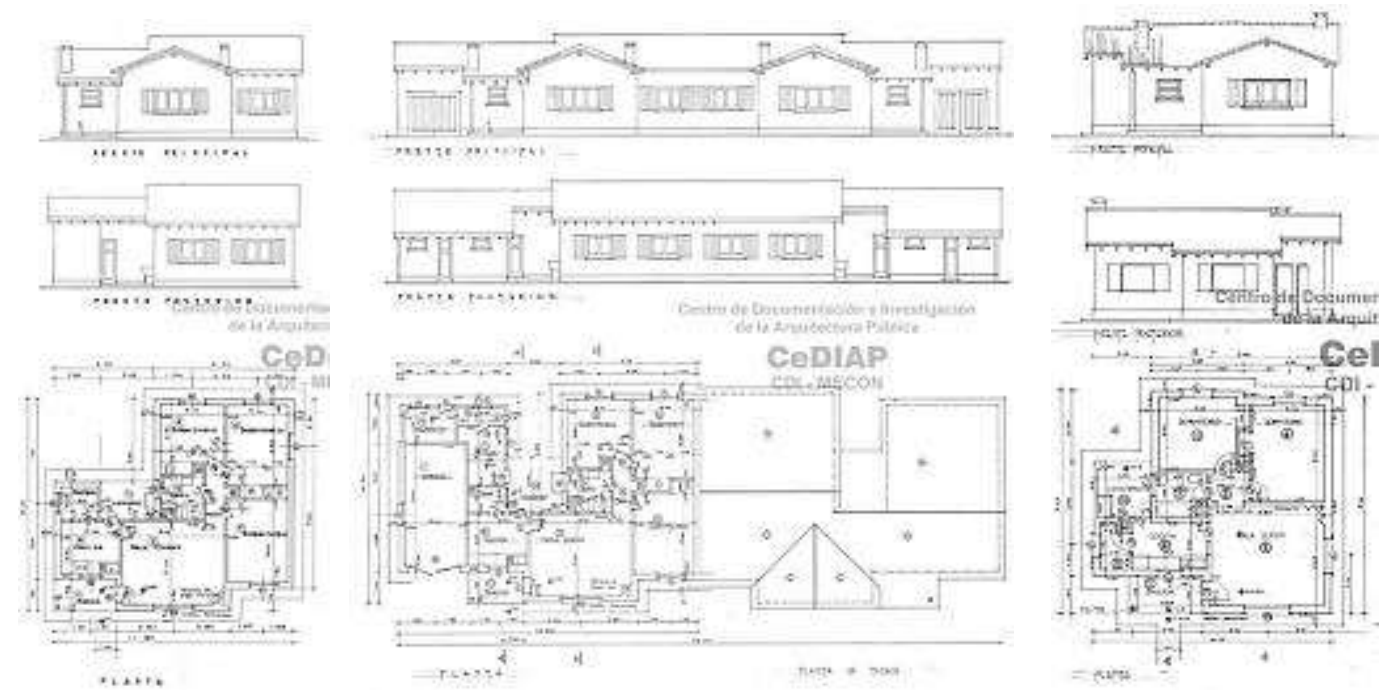

Figura 40. Tipos de casas do Barrio Juan Perón. Plano codigo: 3745: barrio Cornelio Saavedra ex Presidente Peron, casa tipo en Cdad. de Bs.As. Fondo: MOP. Pabellon B.P. 2; Pabellon B.P.1/2; Pabellon B.P.2/2. Acervo Cediap. 
As 428 unidades distribuíram-se em 27 tipos de casas isoladas, geminadas e em fileiras, térreas ou assobradadas, com 1, 2, 3 ou 4 dormitórios conforme exemplificamos a partir do material disponível no Processo Administrativo do conjunto (Figura 40). Cada tipo foi implantado conforme o lote disponível e de acordo com a ideia de conformar ruas de aspecto variado e com distintos grupos familiares e sociais. Eram realizados estudos referentes às dimensões mínimas necessárias às unidades em função das famílias moradoras, havendo em praticamente todos os conjuntos unidades com um até quatro dormitórios - também aqui, como no Brasil, a relação entre Estado e Igreja é evidenciada pela eleição da família nuclear como medida para o modelo de moradia mínima.

Muito próximo do Barrio Juan Perón foi construído o Barrio 17 de Octubre, desde o início da construção conhecido como "Barrio Grafa", devido à sua localização junto à fábrica têxtil GRAFA S.A. (Grandes Fábricas Argentinas S.A.). O projeto foi construído em um terreno de 11 hectares na Villa Pueyrredón e é considerado um barrio-parque (GUTIERRREZ, 2011), dada a implantação das tiras sobre um grande plano verde percorrido prioritariamente por vias peatonais. Os 34 blocos laminares implantados paralelamente possuem quatro pavimentos e são bastante similares, variando apenas no comprimento, como se observa na foto aérea do conjunto em "Umbrales de um Siglo", publicação do Ministerio de Planificación Federal, Inversión Pública y Servicio de 2010 (Figura 41). As tiras são acessadas através de caixas de escadas embutidas, havendo blocos com 2, 3, 4 ou 5 caixas de escadas que, na verdade, indicam o número de módulos que compõem cada tira.

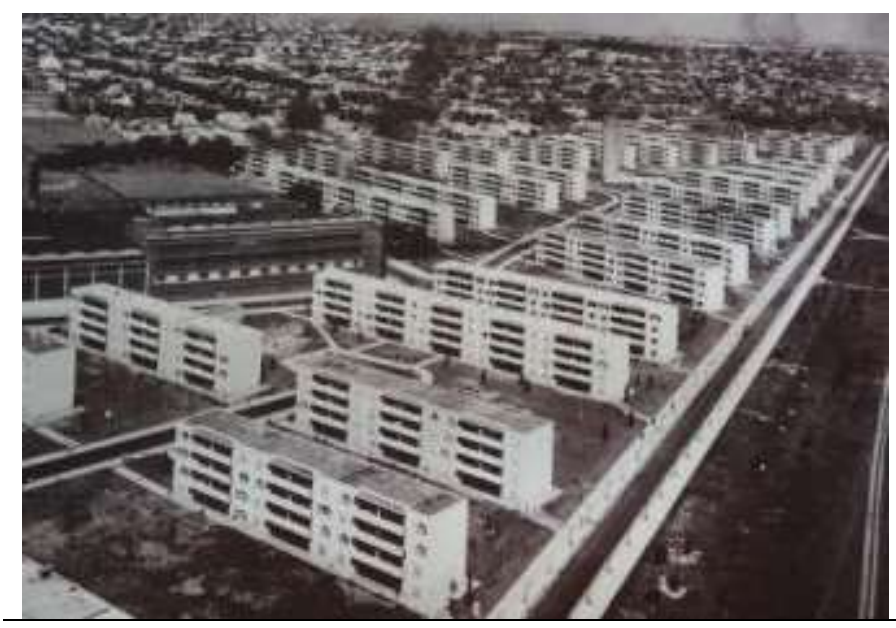

Figura 41. Vista aérea do Barrio Grafa. Fonte: BONTEMPO, Luis. Umbrales de un siglo: Una historia de la vivienda social en la Argentina. De los conventillos al Plan Federal. Buenos Aires: Ministerio de Planificación Federal, Inversión Pública y Servicio, 2010. p.134

Uma única avenida adentra o conjunto desde a Av. de los Constituyentes, via arterial do bairro, atravessando o grande terreno. Duas vias locais adentram o conjunto sem atravessá-lo, possibilitando o acesso de automóveis a áreas próximas aos blocos. O acesso a cada bloco é feito exclusivamente por vias peatonais, conforme se pode observar na foto aérea. (Figura 41) 
Uma grande área verde com equipamentos para atividades físicas, quadras e playground foi prevista para este conjunto (Figura 42, primeira planta). A ela estariam associados salas comerciais e um ambulatório, propostos no pavimento térreo de um dos blocos no limite da área (GUTIERREZ, 2011). Segundo relatos recolhidos no local ${ }^{15}$, uma escola deveria ser construída nesta área, porém, verificando-se que na Villa Pueyrredon, onde se situa o conjunto, o número de equipamentos educacionais era suficiente para atender à nova população moradora abandonou-se a ideia, sendo construídos novos blocos naquele espaço (Figura 43, segunda planta). Ainda assim, a área livre destinada à recreação e sociabilidade dos moradores tem grandes dimensões. (Figura 43)
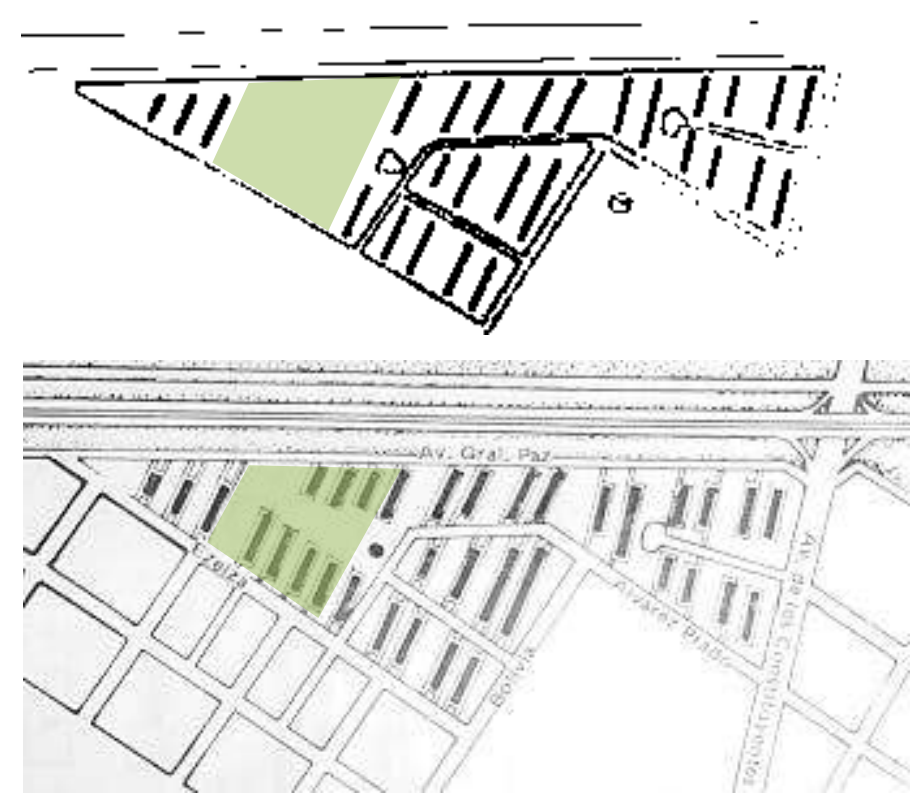

Figura 42. Planta do Barrio GRAFA - projeto original e executado. Fontes: ORTIZ, Federico; GUTIÉRREZ, Ramón. La Arquitectura en la Argentina 1930-1970. Buenos Aires. Separata del número 103 de la revista Hogar y architectura, 1972. p. 5; “Historia argentina de la vivienda de interés social - 2a parte: 1943-1955" In: Arquitectura y Comunidad Nacional. n.4, s/d. p.58.

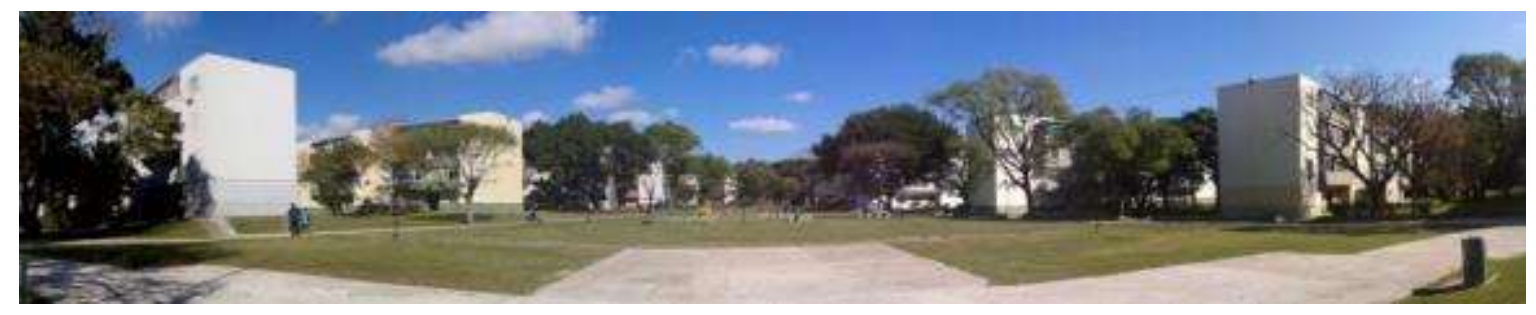

Figura 43. Barrio GRAFA. Fonte: Acervo pessoal. Foto de Camila Ferrari. Maio 2017.

O terreno conformado por ruas ortogonais existentes onde foi projetado o Barrio Los Perales possui 20 hectares e, de acordo com a proposta do projeto de Augusto Sergio Pieres, Dermot José Grehan e Bartolomé Repetto, também foi atravessado por uma única via de automóveis, sendo o acesso aos blocos feito exclusivamente através de vias peatonais. Quadras retangulares de pequena dimensão

\footnotetext{
${ }^{15}$ Segundo conversa informal com o Sr. Carlos, morador original do Barrio Grafa em maio de 2017.
} 
em comparação à grande área verde do conjunto podem ser observadas no entorno, que aparece na foto aérea (Figura 44). Além do próprio projeto urbanístico, o fato de Los Perales ser um conjunto de pabellones, o diferencia completamente do entorno no bairro de Mataderos, caracterizado fundamentalmente por grandes edificações fabris e casas térreas construídas em pequenos lotes.

O projeto previu a construção de 960 unidades, distribuídas em 39 edifícios laminares alinhados em paralelo nas porções laterais do terreno. $\mathrm{O}$ espaço entre cada lâmina corresponde aproximadamente a duas vezes a largura dos edifícios, favorecendo a iluminação e a ventilação das unidades e permitindo a existência de amplos espaços verdes.

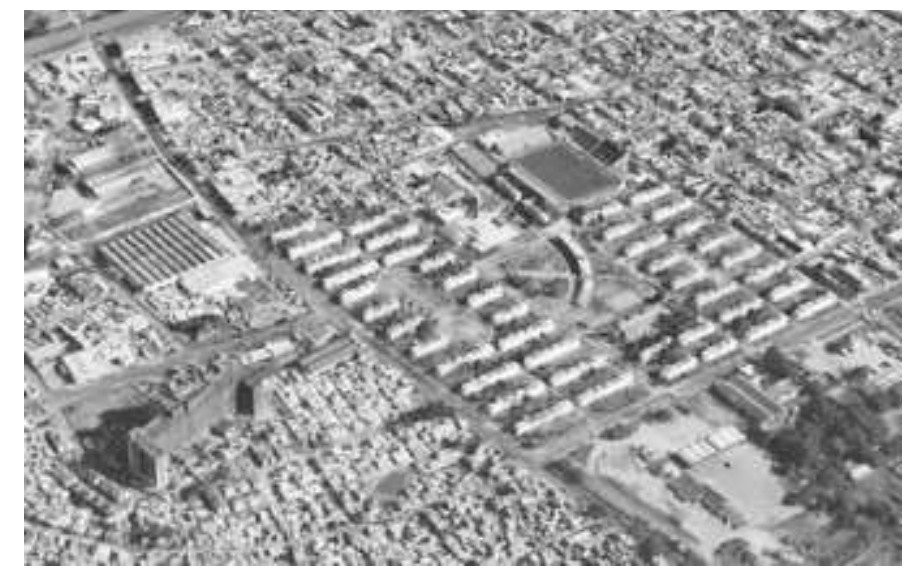

Figura 44: Foto aérea do Barrio Los Perales. No entorno se vêem pequenas casas operárias e edificações industriais características do bairro - vê-se também o Hospital conhecido como "Elefante Blanco", obra do governo peronista que até 2017 era ocupado por movimentos de moradia. Fonte: "Se demora la demolición del Elefante Blanco porque falta relocalizar a 40 familias" In: Clarín Ciudades (online) 20 sept. 2017. Disponível em: <https://www.clarin.com/ciudades/todavia-40-familias-demora-demolicion-elefante-blanco_0_ S1zfzS6cW.html> Acesso em: 20 jun. 2018.

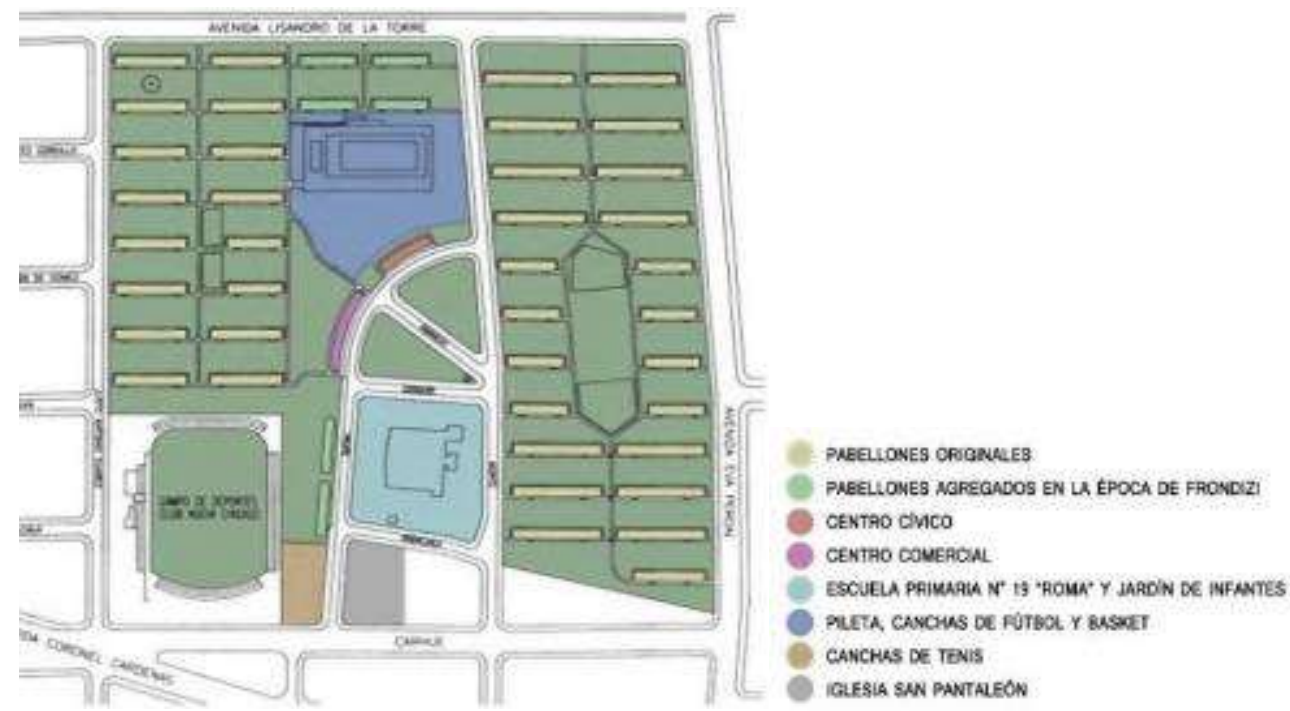

Figura 45. Planta do Conjunto Los Perales. Fonte: 1949: BARRIO LOS PERALES... (2009). 
Como se observa na planta do Barrio Los Perales (Figura 45) em toda a porção central do terreno foram localizados equipamentos e serviços comunitários. Entre eles está um centro cívico com biblioteca, salas de reuniões e cursos, um centro comercial com serviços como lavanderia, quitanda e sorveteria, um conjunto de equipamentos esportivos com quadras de futebol, tênis e poliesportivas e piscina semiolímpica, uma escola primária e um jardim de infância, somando-se ainda diversos espaços de recreação infantil localizados entre os blocos de habitação. (Figura 46)

As imagens permitem visualizar a construção seriada das tiras, que por sua vez eram conformadas pela junção de unidades padronizadas. A planta de uma tira do Barrio Los Perales (Figura 47), permite ver a reprodução de duas unidades típicas, a primeira com 3 dormitórios, sempre colocada nas extremidades dos edifícios e associada à caixa de escadas, e a segunda com 2 dormitórios que era sempre espelhada duas-a-duas, quantas vezes fossem desejadas. Além disso, se vê na planta a proposta de circulação através de ruas elevadas externas ao corpo do edifício e a utilização de dutos de descida de tubulação nas áreas molhadas, o que facilitava a execução e a futura manutenção das unidades.

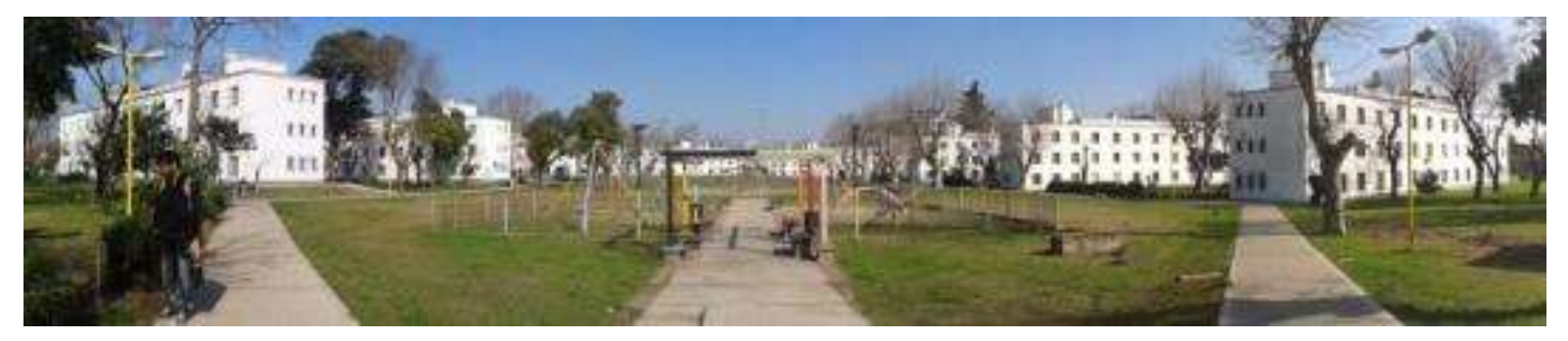

Figura 46. Conjunto Los Perales. Fonte: Acervo pessoal. Foto de Camila Ferrari, jul. 2014.

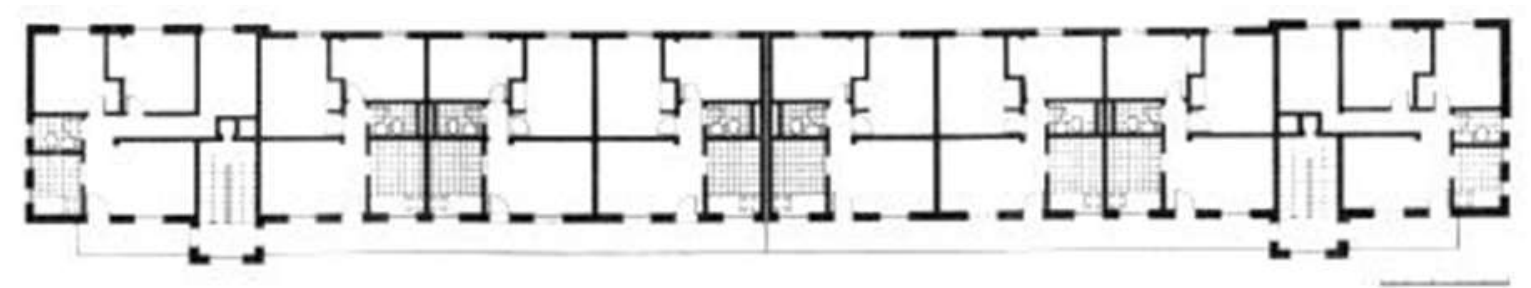

Figura 47. Planta do pavimento tipico dos pabellones do Barrio Los Perales. Fonte: DIAZ, Tony. Relevamientos. Buenos Aires: FAU-UBA, 1985. s/p.

Destacamos entre os projetos habitacionais propostos para Buenos Aires quatro conjuntos massivos que, por sua escala e complexidade, podem ser compreendidos como projetos de urbanização. Um projeto com 10.000 unidades foi idealizado para a Urbanización de Bajo Belgrano, devendo ocupar terrenos baixos e inundáveis de uma área de 170 hectares junto ao Rio de la Plata, no antigo município, e então bairro, de Belgrano, na zona norte da cidade. A solução era claramente referenciada pelo urbanismo corbusiano conforme fica evidente no próprio desenho do conjunto, mas também pela descrição e memorial do projeto apresentados na Revista de Arquitectura em 
1953. Segundo a apresentação, propunha-se "1. zoneamento de nova área residencial frente ao rio; 2. reorganização orgânica do corpo urbano com os princípios do bairro; 3. reorganização do tecido urbano com a manzana vertical e a diminuição do excessivo tamanho da cidade com o aumento de densidade" (URBANIZACIÓN DE BAJO BELGRANO..., 1953, p.21, tradução nossa).

A solução previa que a superfície ocupada por construções fosse igual a $15 \%$ da área do terreno, o que implicava diretamente na tipologia habitacional adotada, o edifício laminar em altura sobre pilotis. O programa incluía, além dos edifícios residenciais, uma vasta gama de equipamentos: centro de abastecimento diário, centro de artesãos, centro comercial e esplanada cívica, centro social e esportivo, 13 escolas, centros de ensino secundário (normal, técnico, profissionalizante), centro de saúde e igrejas, além do prolongamento do metrô até o bairro. O conjunto compreendia ainda grande quantidade de áreas verdes para convívio e recreação e uma grande área de lazer beneficiada pela vista do rio (importante elemento no planejamento adotado), o Parque Costaneiro, destinado ao uso da população em geral. (Figura 48)

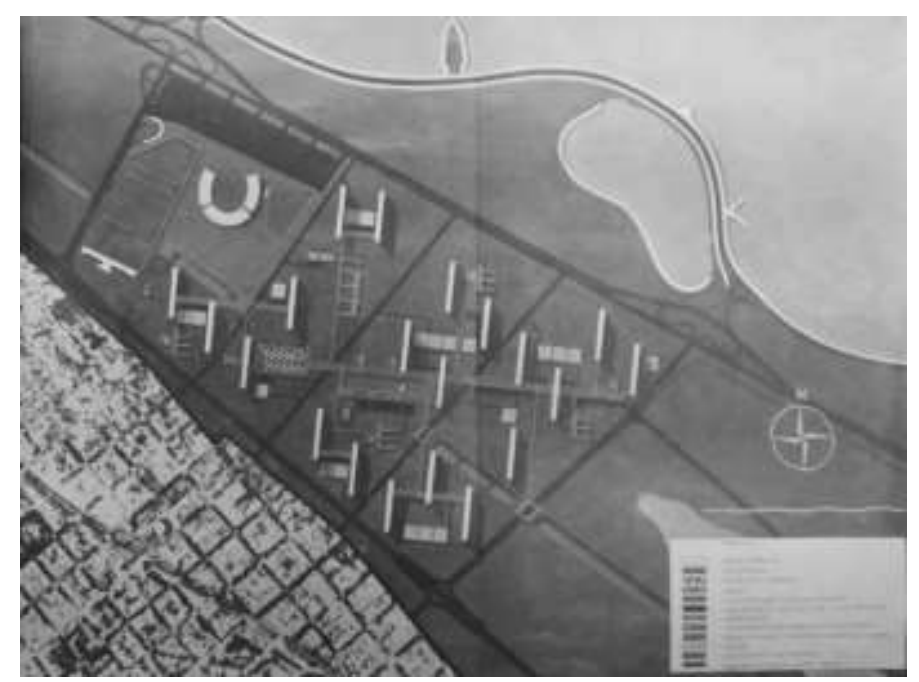

Figura 48. Planta do conjunto. Fonte: “Urbanización de Bajo Belgrano” In: Revista de Arquitectura, n. 369, ene./feb. 1953. pp. 33.

O ideário moderno estava claramente presente nos projetos executados pela equipe responsável por este projeto, de que faziam parte A. Bonet, J. Ferrari Hardoy e J. Vivanco, membros do extinto Grupo Austral $^{16}$, principal responsável pela difusão do modernismo na Argentina. A urbanização de Bajo Belgrano apresentava como premissa o "zoneamento funcional" amplamente divulgado a partir da Carta de Atenas, conforme apresentado na apresentação do projeto na Revista de Arquitectura (URBANIZACIÓN DE BAJO BELGRANO..., 1953). As imagens a seguir (Figura 49) mostram os estudos de zoneamento das funções contempladas pelo projeto de Bajo Belgrano.

\footnotetext{
${ }^{16}$ Ver Capítulo 03 para maiores informações sobre o Grupo Austral.
} 

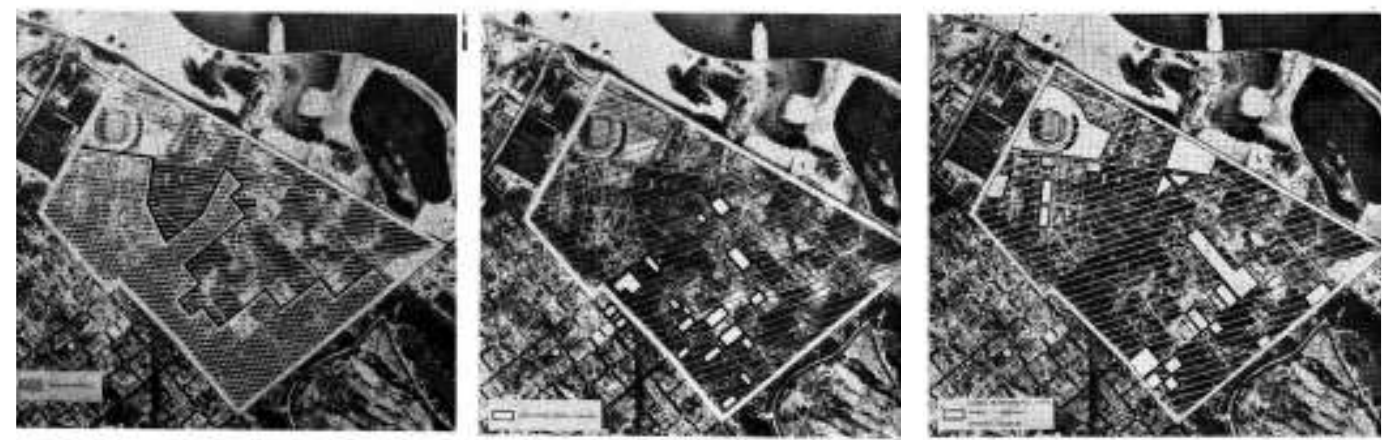

Mearracion

tearavo

ssancimento

Figura 49. Estudo de zoneamento das funções de habitação, trabalho e recreação. Fonte: "Urbanización de Bajo Belgrano" In: Revista de Arquitectura, n. 369, ene./feb. 1953. pp. 26 e 27.
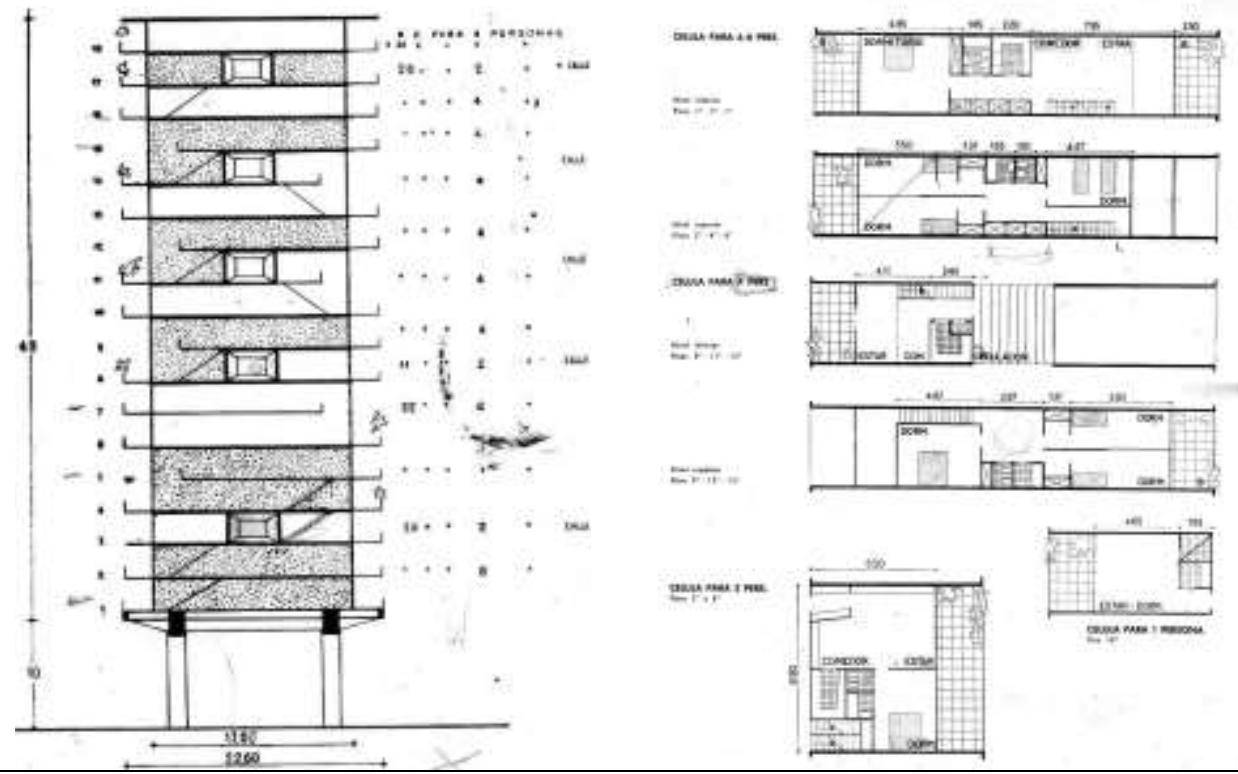

I.:-
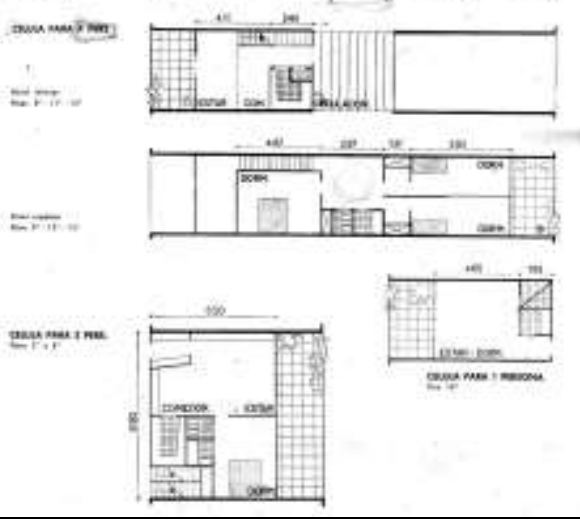

Figura 50. Corte esquemático e plantas das unidades para 6-8 pessoas, 4-6 pessoas e 2 pessoas. Fonte: “Urbanización de Bajo Belgrano" In: Revista de Arquitectura, n. 369, ene./feb. 1953. p.70, 71

A tipologia habitacional adotada se associava diretamente à proposta de alta densidade populacional (entre 300 e 600 hab./ha.) e baixa ocupação da área do terreno. Ao todo seriam "20 manzanas verticales de 2.500 habitantes cada uma, sobre colunas, com os seguintes serviços comuns: jardim de infância, sala comunal, solário, depósitos e lavanderia" (URBANIZACIÓN DE BAJO BELGRANO..., 1953, p.36, tradução nossa). A orientação das lâminas, cuidadosamente estudada, colocava os eixos "11 graus a Nordeste" a partir do que se garantia insolação adequada nas duas fachadas. Bajo Belgrano é o projeto em que as unidades mais se aproximam da linguagem formal moderna, com a utilização dos "cinco pontos da arquitetura". A apresentação do projeto na Revista de Arquitectura revela o percurso dos arquitetos ao estudar e comparar importantes casos de projetos habitacionais verticais em busca da melhor proposta. Nos desenhos do "bloco horizontal reto" como é denominado no projeto, é possível notar clara referência à "Unité d'Habitation de Marseille", especialmente devido à rua-corredor no interior do edifício associada a unidades duplex e estudos que permitiam menor número de paradas dos elevadores, fator importante de economia nestes projetos. (Figura 50) 
A verticalização estava bastante ligada à proposta de alta densidade populacional nos conjuntos habitacionais, mas também à localização dos projetos na cidade, em função da disponibilidade de terrenos, bastante escassa no espaço urbano portenho na década de 1940, como já mencionamos, especialmente nos locais próximos à área central. $\mathrm{O}$ uso dos pilotis foi comum nos projetos que propunham a moradia coletiva, sempre associados a edifícios verticalizados. Outro elemento comum a diversos projetos é a cobertura plana que foi proposta - e executada - em todos os edifícios laminares. Conforme se pode observar, a linguagem moderna dos edifícios e a linguagem pitoresca das casas unifamiliares, aqui chamada de californiana, conforme se explicará oportunamente, coexistiram nos projetos habitacionais propostos para Buenos Aires. Isso não significou, porém, que a produção em série não tenha sido implementada de maneira geral, associada a materiais construtivos e acessórios. Efetivamente, a pré-fabricação de elementos como painéis de vedação e elementos estruturais era facilitada pela linguagem menos provida de elementos decorativos, porém, tijolos, esquadrias e telhas utilizadas na tipologia californiana eram elementos também de simples produção seriada, sendo a utilização de materiais padronizados e, sempre que possível, préfabricados, uma condição colocada aos projetos pela Ley de Viviendas. (ARGENTINA, 1948)

Outros projetos de urbanização chamam a atenção pela associação de variadas tipologias e ampla gama de equipamentos. No conjunto 17 de Octubre, localizado no partido de La Matanza, a sudoeste da cidade de Buenos Aires, se fez uso ampliado da verticalização, com a construção de edifícios com dez pavimentos sobre pilotis, mas também de tiras e unidades unifamiliares. O projeto, realizado por uma equipe coordenada pelo arquiteto italiano Luigi Piccinato, pode ser considerado como um plano de urbanização de bairro, que, se construído em sua totalidade, ocuparia aproximadamente 235 hectares. A planta original do projeto é apresentada na Figura 51, em que se pode distinguir áreas ocupadas por edifícios laminares e áreas loteadas, destinadas à implantação de unidades unifamiliares. O projeto da equipe liderada por Piccinato baseou-se na referência da unidade de vizinhança, chegando-se à proposta do conjunto conformado por cinco unidades ou setores, conforme consta da descrição do projeto no Arquivo Luigi Piccinato (BARRIO 17 DE OCTUBRE..., s/d). Cada unidade contava com edifícios laminares e casas unifamiliares, sendo realizados estudos de localização de cada tipologia, dos equipamentos necessários, do esquema viário e da população, conforme apresentado na Figura 52. 


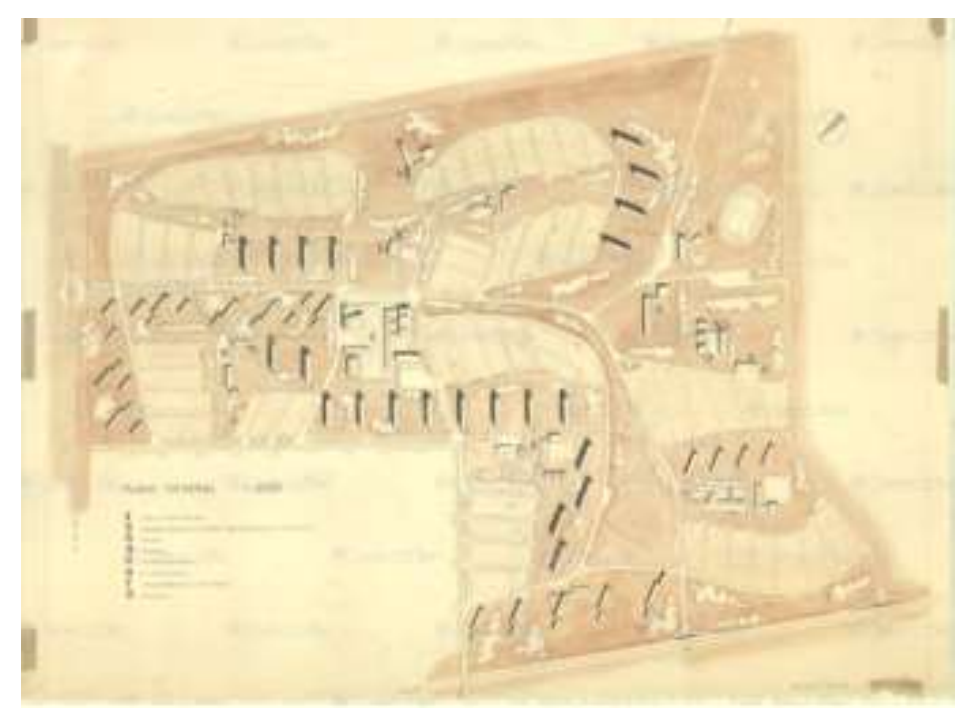

Figura 51. Barrio 17 de Octubre - Plano Geral. Esta é uma primeira versão do Plano, posteriormente todos os edifícios laminares seriam dispostos no eixo Norte-Sul. Fonte: Barrio 17 de Octubre a Buenos Aires. Disponível em: <http://www.archivioluigipiccinato.it/?s=17+de+octubre> Acesso em 28 abril 2017.

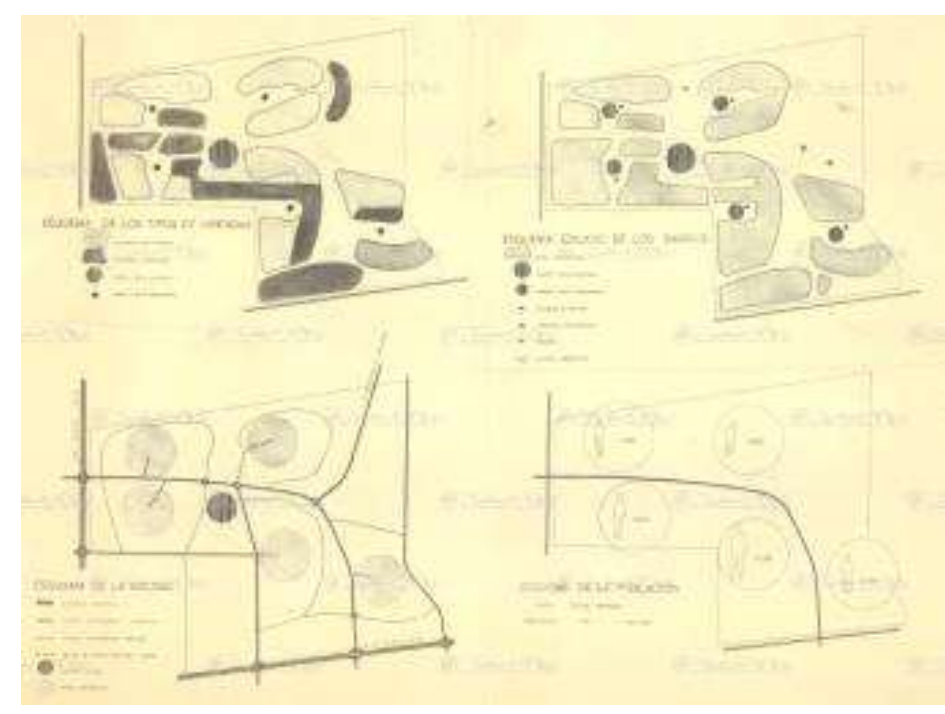

Figura 52. Barrio 17 de Octubre - Esquemas de tipologias, equipamentos, circulação e população. Fonte: Barrio 17 de Octubre a Buenos Aires. Disponível em: <http://www.archivioluigipiccinato.it/?s=17+de+octubre> Acesso em 28 abril 2017.

Conforme se apreende da leitura do projeto e das análises estudadas, destacando-se matéria na revista Construcciones de 1954, a maior parte dos edifícios possuía dez pavimentos com térreo livre, havendo também a tira com três pavimentos sem pilotis em pontos determinados em função dos estudos realizados. 0 projeto previa 33 monobloques de 10 pavimentos e 22 tiras de três pavimentos, estando estes mais próximos do bairro enquanto os primeiros estão mais próximos às grandes avenidas no entorno, o que é representativo de uma proposta de aproximação gradativa com o gabarito local (Figura 53). As casas foram propostas em lotes privados sobre ruas locais de pequena extensão, não havendo na bibliografia consultada maiores informações sobre seu projeto arquitetônico. Contavam-se 4.252 apartamentos que se somariam a 1.284 casas unifamiliares totalizando, portanto, 5.536 unidades de habitação. 


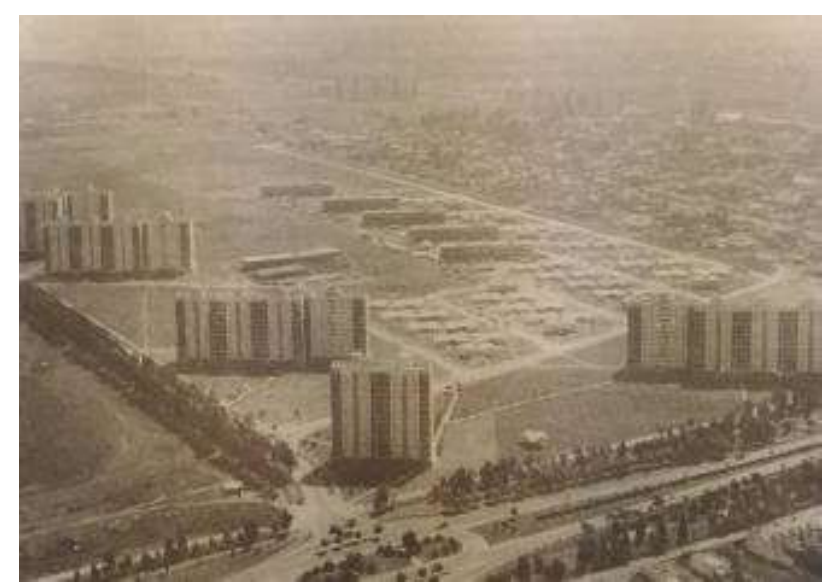

Figura 53. Barrio 17 de Octubre. Fonte: GUTIÉRREZ, Ramón; GUTMAN, Margarita (comp.). Vivienda: Ideas y contradicciones (1916 - 1956). Buenos :Instituto argentino de investigaciones de historia de la arquitectura y del urbanismo, 1988. p.130.

Os edifícios propostos são similares aos do conjunto Curapaligüe, dado importante para a verificação de uma padronização na produção habitacional do período. Os módulos de apartamentos conformaram edifícios laminares com volumes deslocados, formados, como se viu, pelo "encaixe" das varandas, não havendo edifícios em "L" neste projeto.

Quanto aos equipamentos, foram propostos subcentros em cada setor, com uma escola primária e edifícios comerciais, e um Centro Cívico para o conjunto como um todo, com cineteatro, salas comerciais, escritório, mercado, correio, cartório e subprefeitura. O Barrio 17 de Octubre possuía ainda igreja, hospital, departamento de bombeiros, duas escolas secundárias, uma escola técnica um centro desportivo e clube social. A Figura 54 mostra a planta de duas das unidades de vizinhança em detalhe (Setor Sul), em que se pode observar a área destinada ao Centro Cívico e os dois subcentros.

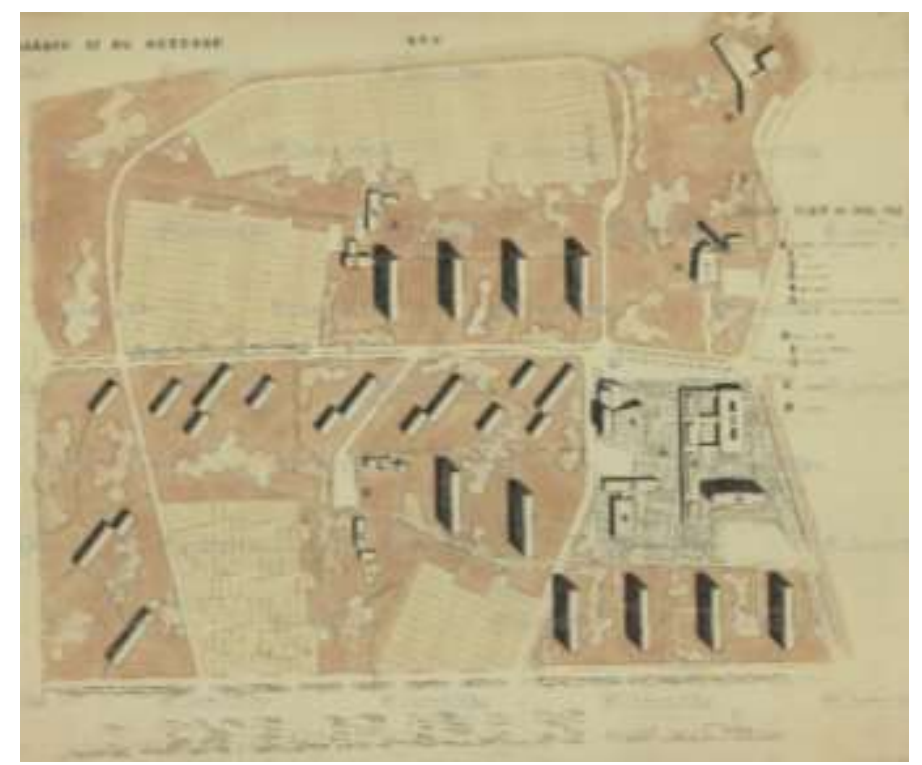

Figura 54. Barrio 17 de Octubre - Planta do Setor "Sur". Fonte: Barrio 17 de Octubre a Buenos Aires. Disponível em: <http://www.archivioluigipiccinato.it/?s=17+de+octubre> Acesso em 28 abril 2017. 
A hierarquia viária proposta era complexa, incluindo uma via arterial que atravessa o conjunto, ligando as duas avenidas intermunicipais que margeiam a área, e uma que liga o conjunto até a estação de trens mais próxima (La Salada); vias secundárias que adentram as diferentes unidades de habitação; vias locais de acesso às áreas residenciais unifamiliares e, por fim, vias peatonais que permitem o acesso a todos os espaços do conjunto (BARRIO 17 DE OCTUBRE..., s/d).

Próxima à área do Barrio 17 de Octubre outra gleba com aproximadamente 870 hectares no município de La Matanza foi destinada ao projeto de Ciudad Evita, também realizado por equipe coordenada por Piccinato. Assim como o primeiro projeto, por suas dimensões e programa, Ciudad Evita pode ser considerado um projeto de urbanização, neste caso efetivamente uma pequena cidade ou subúrbio autônomo, estimando-se sua população em aproximadamente 50.000 habitantes. Sua solução urbanística também tem referência no padrão da unidade de vizinhança e o plano foi assim dividido em cinco unidades, atualmente chamadas de circunscrições (circunscripciones) (MAPA DE LA CIUDAD..., s/d). Um dos aspectos mais evidenciados do traçado de Ciudad Evita é o seu contorno, que reproduziria o perfil de Evita Perón (BALLENT, 2005; GUTIERREZ, 2011), como se pode observar na Figura 55.

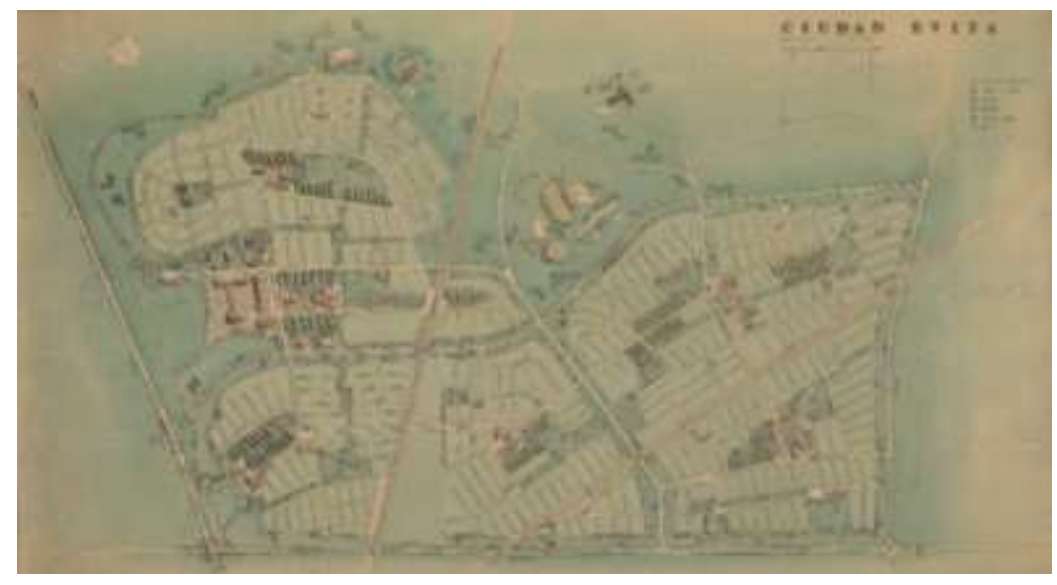

Figura 55. Planta do bairro Ciudad Evita. Fonte: Ciudad Evita a Buenos Aires. Disponível em: <http://www.archivioluigipiccinato.it/?s=ciudad+evita> Acesso em 28 abril 2017.

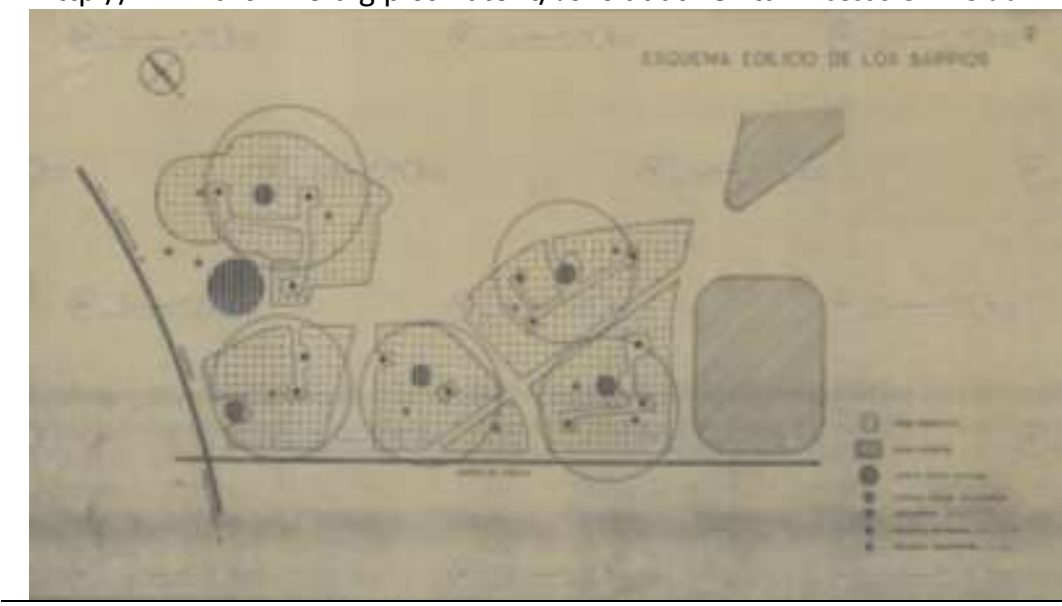

Figura 56. Esquema edilício das unidades de Ciudad Evita. Fonte: Ciudad Evita a Buenos Aires. Disponível em: <http://www.archivioluigipiccinato.it/?s=ciudad+evita> Acesso em 28 abril 2017. 
Assim como no Barrio 17 de Octubre, os estudos para a realização de Ciudad Evita foram bastante complexos, incluindo esquemas edilícios, estudos populacionais e viários, inclusive correlacionados à capital Buenos Aires, além de esquemas referentes aos equipamentos e serviços necessários a cada unidade de habitação e ao plano geral. A Figura 56 mostra os estudos referentes ao esquema edilício de Ciudad Evita disponíveis no Arquivo Luigi Piccinato. (CIUDAD EVITA..., s/d)

Além das escolas primárias e secundárias em número adequado, cada unidade de vizinhança proposta contava com jardins de infância, quadras esportivas e um centro social, ou subcentro, com espaços para recreação, clube, igreja e um posto de provisões a ser administrado por cooperativas de moradores. Outros equipamentos coletivos foram incorporados a uma ou outra unidade, tais como ambulatórios, cartório, hotéis e oficinas. As plantas de duas unidades são apresentadas na Figura 57. O plano como um todo incluía ainda um hospital, um centro esportivo e um centro cívico com centro comercial, cinema, biblioteca, agências bancárias e outros serviços comunitários destinados a garantir ao novo bairro todas as atividades cotidianas. Duas estações de trens vinculadas aos ramais da linha Roca foram instaladas em pontos estratégicos do conjunto.
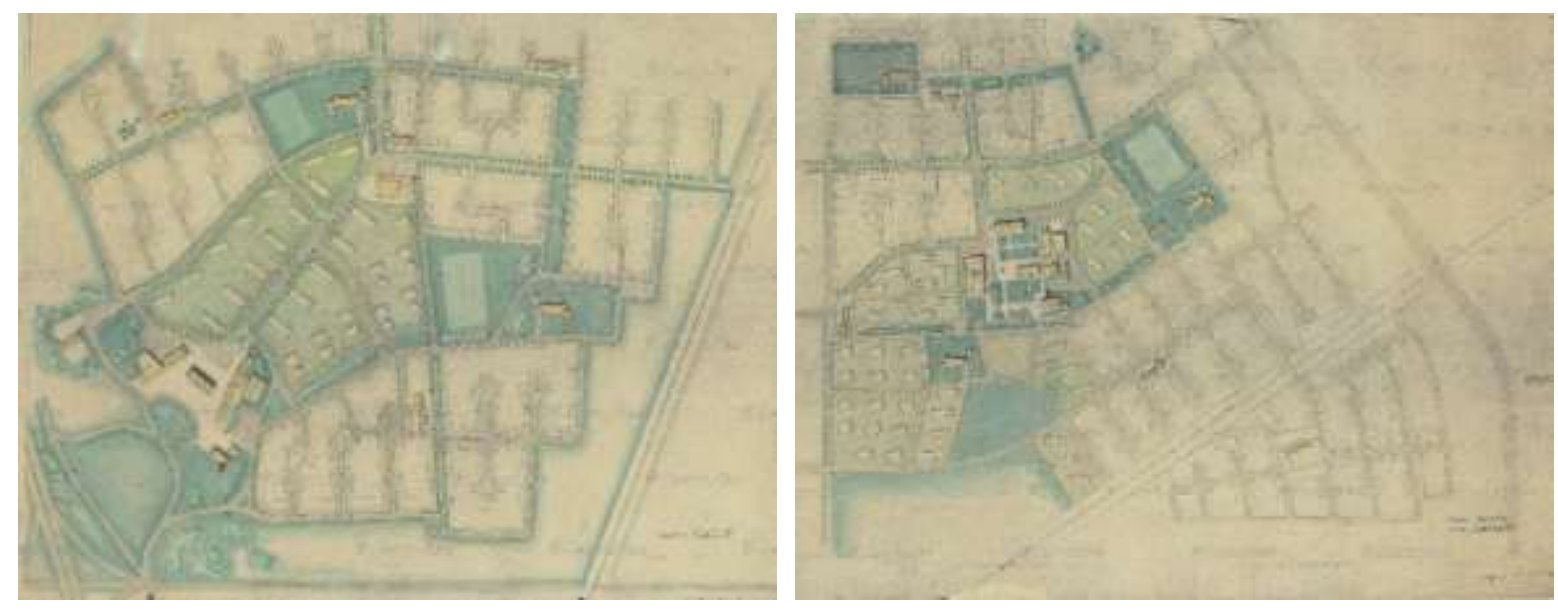

Figura 57. Plantas de duas unidades / circunscrições de Ciudad Evita. Fonte: Ciudad Evita a Buenos Aires. Disponível em: <http://www.archivioluigipiccinato.it/?s=ciudad+evita> Acesso em 28 abril 2017.

Em Ciudad Evita foi proposta uma grande variedade de tipos habitacionais entre edifícios coletivos e unidades unifamiliares, que buscavam atender a diferentes grupos familiares e setores sociais (BALLENT, 2005). Além dos monobloques e pabellones, propostos em todo o conjunto, os edifícios foram propostos em outros diferentes formatos e alturas, que conforme se pode observar nas plantas da Figura 57, parecem ser específicos a cada unidade, criando uma identidade a cada uma delas. Assim como no Barrio Juan Perón, havendo tipos bastante similares, se não iguais, nos dois projetos, as unidades unifamiliares foram divididas em casas isoladas e em fileiras, térreas ou assobradadas, com 1, 2, 3 ou 4 dormitórios, conforme ilustram as imagens retiradas da publicação de Ortiz e Gutierrez (1973) (Figuras 58 e 59). 


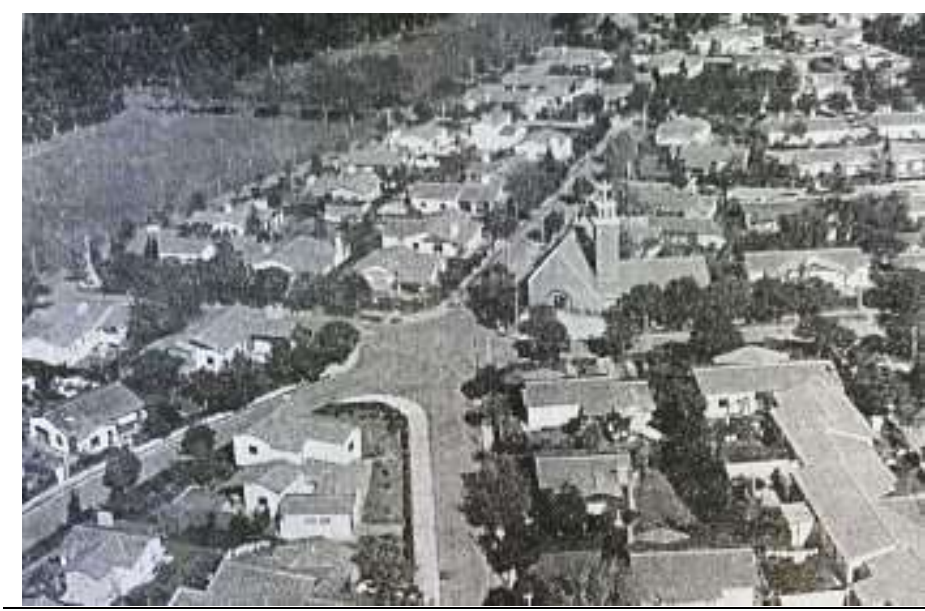

Figura 58. Vista aérea parcial de Ciudad Evita. Fonte ORTIZ, Federico; GUTIÉRREZ, Ramón. La Arquitectura en la Argentina 1930-1970. Buenos Aires: Unión Internacionale des Architetes. Separata del número 103 de la revista Hogar y Architectura, 1972.
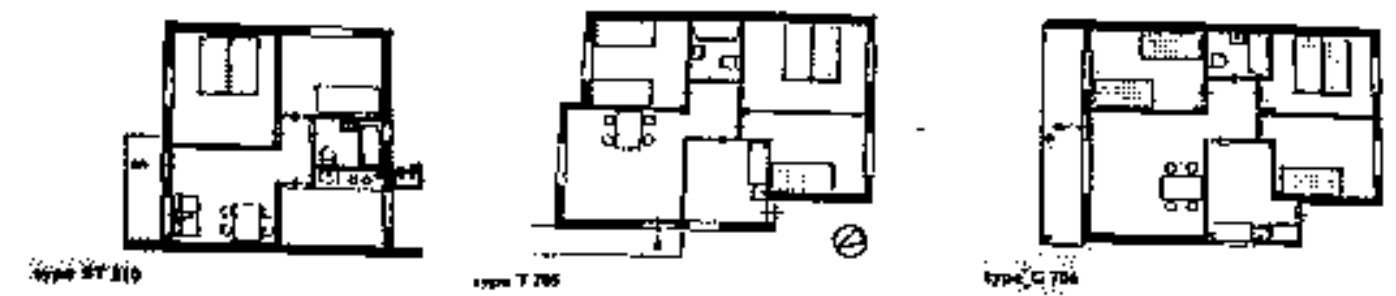

Figura 59. Tipos de unidades unifamiliares de Ciudad Evita. Fonte ORTIZ, Federico; GUTIÉRREZ, Ramón. La Arquitectura en la Argentina 1930-1970. Buenos Aires: Unión Internacionale des Architetes. Separata del número 103 de la revista Hogar y Architectura, 1972.

Em Buenos Aires a produção habitacional massiva foi priorizada pelo próprio Estado, que se empenha na solução da questão da moradia compreendendo-a e promovendo-a como ajuda social e obra pública. De tal forma, os terrenos (grandes terrenos) pertencentes ao Estado foram utilizados para a realização de projetos habitacionais em que se evidencia a perspectiva de produção em grande escala no número de unidades, na repetição de tipologias e nos equipamentos que garantiam autossuficiência aos projetos, compreendidos como bairros. Embora fosse proposta a construção de "bairros de casas operárias", a incorporação de gama ampliada de equipamentos, como se vê nestes projetos, não estava prevista oficialmente até 1951 , como se explicará adiante. Este fato indica a intensa participação de profissionais de arquitetura na elaboração dos projetos e planos, trazendo para a prática proposições teóricas colocadas nos diversos espaços de articulação profissional que se conformam em âmbito continental na primeira metade do século XX, como apresentamos no Capítulo 03. 
Capítulo 2

Varguismo, Peronismo e a habitação para o trabalhador 


\subsection{Nacionalismo, Industrialização e Trabalhismo no Brasil (1930-1964)}

O cenário político-social e econômico que antecede o início do processo de institucionalização da produção habitacional estatal no Brasil explica algumas das condições sob as quais se desenrola a promoção da habitação a partir da década de 1930. O cenário conformado na República Velha é amplamente descrito por autores como Faoro (2001), Fausto (1988) e Weffort (1980), de modo que ressaltamos aqui apenas algumas características da chamada "Política do Café com Leite" em relação aos campos político e social. Reside justamente no liberalismo ou laissez-faire da oligarquia agrária uma das razões determinantes para a ausência de atuação estatal direta no campo habitacional.

O crescimento da economia baseada na produção e exportação do café marcou a constituição de uma nova classe dominante, que logo percebeu a importância de ter "o governo como instrumento de ação econômica" (FURTADO, 2003, p.122). Esta condição teve seu ápice nas primeiras décadas da República com o crescimento do poder político dos cafeicultores e outros grupos associados à agroexportação, quando estes se tornam também o grupo dirigente, estabelecendo o que se convencionou chamar "Política do Café com Leite". Essa classe se manteria no poder desde 1898 até 1930 revezando na presidência da república representantes da elite agrária dos estados de São Paulo (mais poderoso economicamente, principalmente devido à produção de café) e Minas Gerais (maior contingente eleitoral do país à época e produtor de leite), até que em finais da década de 1920 esse ciclo fosse interrompido, tendo como consequência o fim do esquema. 
Ao longo da década de 1920, se reconhece a constituição de pelo menos outros dois grupos no interior da estrutura social brasileira e, nomeadamente, em suas maiores cidades, Rio de Janeiro e São Paulo: uma elite ligada ao desenvolvimento da atividade industrial, que já se manifestava no sentido de participar da política, porém ainda sem muita expressividade, e as classes médias urbanas, principal grupo a pressionar pela derrubada da oligarquia agroexportadora, porém sem condições econômicas e políticas hegemônicas para enfrentar sozinho o grupo dominante. (WEFFORT, 1980)

Ocupa lugar na estrutura social brasileira no momento que antecede o fim do governo oligárquico ainda outro grupo constituído pelas classes trabalhadoras urbanas. O processo de formação deste grupo tem como fatores cruciais a abolição do trabalho escravo e o advento da República: é a partir de então que se torna necessário e possível conformar um modelo de trabalhador livre. Desde este momento se constituíam entre os trabalhadores lideranças e propostas divergentes quanto ao caminho - político, social ou trabalhista - para conformar uma identidade coletiva e alcançar direitos até então negados à classe.

Ao mesmo tempo em que se conformavam novos grupos sociais, no final da década de 1920 se revelaram disputas internas à própria oligarquia que afetaram a manutenção da "Política do Café com Leite" $^{1}$ e implicaram na estruturação de um grupo de oposição, a "Aliança Liberal", formado por expoentes de Minas Gerais e Rio Grande do Sul, com apoio de grupos dos demais estados do país. Em julho de 1929, a aliança lança as candidaturas de Getúlio Vargas (presidente do Rio Grande do Sul) e João Pessoa (presidente da Paraíba) à presidência e à vice-presidência da República, respectivamente, mas apesar da forte campanha e do apoio popular manifestado a Vargas, as eleições deram vitória ao candidato situacionista. O assassinato de João Pessoa em julho de 1930 seria estopim para novas manifestações, com grande comoção popular, levando setores do Exército a apoiar a causa. O movimento político-militar levou Getúlio Vargas à presidência em novembro de 1930, colocando fim à República oligárquica liberal.

Para regularizar a situação de crise econômica do Brasil, tanto internamente quanto no cenário internacional, algumas das primeiras atitudes de Getúlio Vargas foram dirigidas à atividade cafeeira. Uma vez que o café ainda fosse a base da economia, o Estado varguista não poderia prescindir do setor. Contudo, como uma de suas primeiras medidas, Vargas incentivou a diversificação da produção agrícola, atendendo às reivindicações dos agricultores desvinculados do empreendimento cafeeiro, e deu início a um processo de despolarização da economia em torno do café, passando a incentivar os investimentos na indústria, elemento-chave para sua proposta de desenvolvimento nacional.

\footnotetext{
${ }^{1}$ Visando dar continuidade à sua política econômico-financeira o presidente Washington Luís, proveniente de São Paulo, indica como seu sucessor o também paulista Júlio Prestes, rompendo o esquema de revezamento segundo o qual o próximo candidato oficial deveria ser de Minas Gerais. O candidato mineiro, Antônio Carlos de Andrada busca então apoio no Rio Grande do Sul, terceiro estado em importância eleitoral, para se opor à candidatura paulista. (Fausto, 2001)
} 
A atividade industrial foi incentivada, entre outras formas, através da destinação do excedente de lucro gerado pelas produções agrícolas para o incremento industrial e através da implantação de indústrias de base pelo próprio Estado como suporte ao desenvolvimento (FURTADO, 2003). À proposta de desenvolvimento industrial se aliou um forte sentimento nacionalista relacionado à busca por independência política, econômica e cultural com relação aos países mais desenvolvidos (MARTINS, 1987). A articulação entre industrialização e nacionalismo se denominou NacionalDesenvolvimentismo.

O novo governo, conformado a partir de uma aliança, apesar de conseguir deslocar do poder a oligarquia agrária, não contava com um grupo com a mesma representatividade que pudesse estabelecer hegemonicamente as bases do novo governo. Em suma, o novo grupo dirigente já não era a expressão política imediata dos valores e interesses particulares do grupo dominante, tal qual ocorrera durante a República Velha, e tampouco representava ideologicamente outro grupo dominante (WEFFORT, 1980). A partir daí a legitimação do poder de Getúlio Vargas não implicou no afastamento de grupos da sociedade política, mas na ampliação do acesso a grupos antes excluídos. Entre estes grupos estava a classe trabalhadora, que, sendo fundamental à industrialização, passa a representar papel importante à imagem da nação desenvolvida que se buscava forjar. (MALLOY, 1986) É a partir de 1930 que o trabalhador recebe do Estado uma atenção inexistente nos governos anteriores quanto a seus direitos sociais e trabalhistas. Assim mesmo, dois momentos particulares, no que se refere a ações estatais destinadas a beneficiar os trabalhadores antes de $1930^{2}$, devem ser lembrados: o primeiro, a criação do Conselho Nacional do Trabalho (CNT), destinado a assessorar o executivo em assuntos relacionados à classe operária e à organização do trabalho e da previdência social, conforme Decreto no 16.027 de 1923, e, o segundo, no mesmo ano, a promulgação da Lei Elói Chaves (Decreto no 4.682/1923), considerada ponto de partida do sistema previdenciário brasileiro.

A Lei Elói Chaves estabeleceu em cada companhia de estradas de ferro a criação de uma Caixa de Aposentadoria e Pensões (CAP) para os respectivos empregados. As CAPs proporcionavam quatro benefícios: socorros médicos, descontos em medicamentos, aposentadoria compulsória ou por invalidez e pensão em caso de falecimento do associado (BRASIL, 1923). Os recursos para garantir estes benefícios eram conformados por uma contribuição mensal dos empregados, uma contribuição anual da empresa e uma contribuição do governo. Não por acaso, os benefícios garantidos eram praticamente os mesmos oferecidos por associações de trabalhadores já estabelecidas como as sociedades de ajuda mútua e os sindicatos cooperativistas.

Em 1926 a lei se estendeu aos estivadores e marítimos e, a partir de então, a outras categorias profissionais. Em 1930 havia 47 Caixas, contando com cerca de 140 mil associados. Para Malloy

\footnotetext{
${ }^{2}$ É possível considerar que, assim como em outros países da América Latina, a apresentação de projetos oficiais de reforma em prol da "questão social" acontece na década de 1920 especialmente como forma de enfrentar a difusão do comunismo, dada a Revolução Russa (1917) e a constituição do Partido Comunista em 1922. (GOMES, 2005)
} 
(1986) não era uma coincidência o fato de a lei e sua ampliação em 1926 trazerem proteção social às três categorias mais bem organizadas entre os trabalhadores - ferroviários, estivadores e marítimos e, sim, uma forma de garantir a aproximação entre o Estado e esses grupos-chave para a economia agroexportadora.

Em 1930 é criado o Ministério do Trabalho, Indústria e Comércio (MTIC) e, em 1931, vinculado a este, é criado o Departamento Nacional do Trabalho (DNT), sendo transferidas para ambos as funções do antigo CNT (Decreto no 19.433/1930; Decreto no 19.667/1931). O Estado determina ainda as organizações que representavam os trabalhadores através de uma estrutura legalmente formalizada, baseada em três subestruturas fundamentais: os Sindicatos, os Tribunais Trabalhistas e o Sistema de Previdência Social, reorganizado pela concepção dos Institutos de Aposentadoria e Pensões (IAPs).

O trabalho é a partir de então compreendido como meio de ascensão social e a identidade política e social do homem-cidadão brasileiro é definida pelo seu status de trabalhador. "O trabalho organizado foi entendido como força política concreta que não podia mais ser excluída da vida nacional. A tarefa era, no entanto, incorporar o trabalho de tal modo que reforçaria o projeto de desenvolvimento e modernização" (MALLOY, 1986, p.64). Para tanto, ao lado da política de desenvolvimento nacional atrelada à industrialização, a política trabalhista - baseada nos sindicatos e na Justiça do Trabalho - e a política social - sobretudo a previdência social, os IAPs - empreendidas pelo novo Estado, personificado na figura do presidente Vargas, preencheram vazios organizacionais, promovendo a comunicação entre governo e sociedade civil.

As primeiras propostas em benefício do trabalhador são consolidadas na Constituição Nacional de 1934, promulgada num contexto de reivindicações por uma nova constituinte, especialmente por parte da elite agrária de São Paulo ${ }^{3}$. Destacam-se no documento a instauração da Justiça do Trabalho, a sanção de leis trabalhistas e a concessão para a conformação de sindicatos. A carta instituía ainda a proibição do trabalho infantil e o estabelecimento da jornada de trabalho de oito horas com repouso semanal obrigatório, além de férias remuneradas. Contudo, a Constituição de 1934 teve vida curta, correspondente ao período conhecido como Governo Constitucional (1934-1937).

Em 1937 é promulgada nova Constituição, dando início ao Estado Novo. A justificativa para o golpe que dava início ao Estado de cunho autoritário consistia no enfrentamento de uma iminente (e questionável) nova intentona comunista (a primeira, real, ocorrera em 1935). A principal característica da nova carta era a concentração de poderes nas mãos do chefe do Executivo. Foram criados órgãos técnicos com ampla participação das classes produtoras, responsáveis por assessorar a orientação política e econômica nacional atribuída ao presidente. Os meios de comunicação em

\footnotetext{
${ }^{3}$ Primeiro grande levante contra a administração de Getúlio Vargas, a Revolução ou Movimento Constitucionalista de 1932 tinha um caráter conservador. A elite agrária paulista buscava retomar o comando político perdido desde 1930, exigindo do então Governo Provisório a elaboração de uma nova Constituição e a convocação de eleições para presidente. (FGV/CPDOC. Anos de Incerteza)
} 
massa foram obrigados a transmitir comunicados do governo ${ }^{4}$ e à Polícia Especial foi conferida total liberdade de ação. No setor trabalhista destacam-se o estímulo à organização sindical em moldes corporativos, como fomento do espírito associativo (modelo vigente até a década de 1970) e a proibição às greves. (FGV/CPDOC. Verbete: Constituição de 1937.)

A partir de 1937 os sindicatos das diferentes categorias deveriam ser legalmente reconhecidos para poderem participar do sistema trabalhista e dele se beneficiar, sendo oficialmente reconhecido apenas um sindicato para cada categoria profissional. D'Araújo (1996) registra depoimentos de Segadas Viana ${ }^{5}$ em que este afirma que "o mal para o trabalhismo brasileiro e sobretudo para o sindicalismo é que Getúlio antecipava as reivindicações dos trabalhadores. Como não havia nada para reivindicar, não havia líderes. Líderes se formam com a luta." As lideranças sindicais eram então escolhidas pelo próprio governo, tornando-se comum a imagem do "pelego", líder que defendia as orientações do MTIC entre os trabalhadores. "O governo burocratizou os sindicatos de tal maneira que eles se tornaram extensões do aparelho estatal" (MALLOY, 1986, p.67).

Os sindicatos eram encarregados de promover a solidariedade geral, fornecendo importantes serviços sociais e assistência legal aos seus membros. Uma parte significativa dos fundos sindicais era destinada para estes fins e há evidências de que, através dos anos, cada vez mais tempo, energia e recursos dos sindicatos eram destinados a serviços sociais [...]. Além disso, há razão para crer que muitos trabalhadores ingressaram nos sindicatos não como meio de articular seus interesses de grupo, mas para tirar proveito dos serviços sociais que eles ofereciam na forma de escolas, serviços médicos, colônias de férias, etc. ${ }^{6}$. (MALLOY, 1986, p.68)

Havia ainda forte conexão entre sindicatos e Justiça do Trabalho, sendo uma das principais funções daqueles representar seus membros individual ou coletivamente, controlando, através dos tribunais do trabalho, a implementação dos contratos e o respeito às leis trabalhistas. A Justiça do Trabalho é organizada em 1939 pelo Decreto-Lei № 1.237, tendo como função principal regular os conflitos oriundos das relações entre empregados e empregadores.

Desde 1933 o governo atua sobre a previdência social constituindo os IAPs, sendo o primeiro deles o Instituto de Aposentadoria e Pensões dos Marítimos (IAPM) (BRASIL, 1933). A base da constituição definida em 1923 para as CAPs é mantida, sofrendo algumas alterações estruturais que ampliavam as relações entre Estado e população. A inovação mais importante neste sentido indicava que cada

\footnotetext{
${ }^{4}$ Em 1939 seria criado o Departamento de Imprensa e Propaganda (DIP), cujo objetivo era difundir a ideologia estadonovista e promover pessoal e politicamente o presidente, bem como as realizações governamentais, buscando especialmente o apoio e a adesão das classes trabalhadoras, às quais se referia como "Trabalhadores do Brasil", ao regime. Esta associação entre a figura do chefe de governo e as obras realizadas garantiria a formação da imagem de Vargas como o "pai dos pobres".

${ }^{5}$ José de Segadas Viana se tornou em 1942 assistente técnico do ministro do Trabalho e pouco depois assumiu o cargo de diretor-geral do DNT, passando em 1943 a chefiar a Divisão de Organização e Assistência Sindical. Ainda em 1943, participou da elaboração da Consolidação das Leis do Trabalho. Em 1945, foi um dos fundadores do Centro Trabalhista de Estudos Políticos e Sociais, que teve destacado papel na organização do Partido Trabalhista Brasileiro (PTB). (FGV/CPDOC. Verbete: José de Sagadas Viana)

${ }^{6}$ Note-se que o componente assistencialista estava fortemente presente nestes sindicatos.
} 
Instituto atendesse uma categoria profissional como um todo, independentemente das empresas contratantes.

Após sua constituição legal pelo Estado os Institutos eram organizados pelos próprios associados, mas o controle de sua gestão era feito através do Ministério do Trabalho, cujas atribuições incluíam orientar e supervisionar a previdência social, inclusive pela nomeação do presidente de cada IAP. Os presidentes eram assessorados por um conselho, com igual representação de empregadores e empregados da categoria, cujos membros eram sempre relacionados por representantes dos sindicatos. Os IAPs podem, assim, ser compreendidos como extensões do aparato estatal junto à sociedade civil.

A extensão do atendimento previdenciário se fez aos poucos, grupo a grupo de trabalhadores, cujas profissões fossem oficialmente reconhecidas pelo MTIC. Foram criados em 1934 o IAPB (Bancários) e o IAPC (Comerciários) e em 1936 o IAPI (Industriários), embora sua atuação comece apenas em 1938 (BRASIL, 1934a; 1934b; 1936). Em 1938 são criados o IPASE (Instituto de Pensões e Assistência dos Servidores do Estado) e o IAPETC (Empregados em Transportes e Cargas) (BRASIL 1938a; 1938b), e em 1939 é criado o IAPE (Estivadores), incorporado ao IAPETC em 1945 (BRASIL 1939; 1945b). Em 1939 existiam, portanto seis IAPs e ainda 98 CAPs, com população total segurada de 1.838 .885 ativos e 81.142 não ativos. Em 1953 todas as CAPs remanescentes seriam unificadas sob o título de Caixa de Aposentadoria e Pensões dos Ferroviários e Empregados em Serviços Públicos (CAPFESP), cuja organização é semelhante a dos Institutos (BRASIL, 1953). Todos funcionavam basicamente sob a mesma organização, com as mesmas fontes de receita e com relativa variação quanto ao oferecimento de benefícios e às possibilidades de aplicação dos recursos, entre as quais a promoção de moradias aos associados.

Ao serem eleitos por Vargas como provedores não apenas de direitos trabalhistas, mas também de direitos sociais como assistência médica e habitação, os Institutos de Aposentadoria e Pensões se convertem em instrumentos de uma "cidadania regulada", isto é,

o conceito de cidadania cujas raízes encontram-se, não em um código de valores políticos, mas em um sistema de estratificação ocupacional, e que, ademais, tal sistema de estratificação ocupacional é definido por norma legal. Em outras palavras são cidadãos todos aqueles membros da comunidade que se encontram localizados em qualquer uma das ocupações reconhecidas e definidas em lei. [...] A extensão da cidadania se fazia via regulamentação de novas profissões e/ou ocupações, em primeiro lugar, e mediante ampliação do escopo dos direitos associados a estas profissões, antes que por expansão dos valores inerentes ao conceito de membro da comunidade. (SANTOS 1979, p.75)

Aqui cabe destacar um ponto fundamental identificado por Santos (1979) e Mendonça (2007): a cidadania regulada pela inserção no mundo do trabalho não se definiu pelo gozo de direitos políticos ou civis, mas sim, de direitos sociais e trabalhistas. Contudo, uma série de brasileiros ficava à margem 
dos direitos garantidos pelo sistema previdenciário ${ }^{7}$ e, portanto, pelo Estado. 0 instrumento jurídico que comprovava o acordo entre Estado e cidadãos era a carteira profissional, criada em 1932 (BRASIL, 1932), "que se torna em realidade, mais do que uma evidência trabalhista, uma certidão de nascimento cívico" (SANTOS 1979, p.76). A cidadania atestada pela carteira de trabalho confirma o pacto entre Estado e classe trabalhadora, que, ao mesmo em que é construído, constitui também o projeto político estatal.

Em 1945, numa tentativa de reforma da política previdenciária, o governo promulga a Lei Orgânica dos Serviços Sociais do Brasil (BRASIL, 1945a), que trazia inúmeras inovações, tais como o atendimento aos trabalhadores autônomos e informais, bem como aos estrangeiros legalmente domiciliados no país. O decreto-lei propunha ainda a criação do Instituto de Serviços Sociais do Brasil (ISSB), que unificaria os distintos IAPs. A melhoria das condições sociais do trabalhador, garantindo suas necessidades mínimas no que concernia à sua alimentação, habitação, vestuário e saúde, aparecia na Lei Orgânica como forma de aplicação das reservas de todos os Institutos, unificadas no ISSB. Entretanto, divergências no interior do governo impediram a implementação do ISSB e da

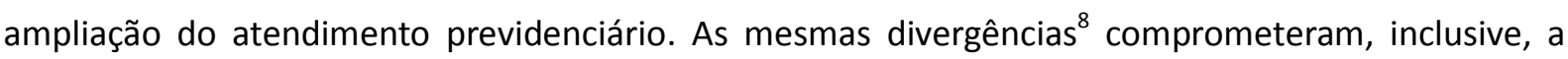
continuidade do Estado varguista.

Após a deposição de Vargas, nos governos consecutivos, com retorno do próprio Vargas entre 1951 e 1954, foram mantidos o sistema de controle dos sindicatos pelo Estado, as leis trabalhistas e a política previdenciária, sem que se implementassem grandes alterações em benefício da população de baixos recursos. Vale destacar, porém, a constituição da Fundação da Casa Popular (1946) destinada a promover a moradia à população de poucos recursos não atendida pelos IAPs, que retomaremos na sequência, e o "Regulamento Geral dos Institutos de Aposentadoria e Pensões" (Decreto no 35.448, de 1 o de maio de 1954), nova tentativa de Lei Orgânica para reforma e unificação do Sistema Previdenciário, revogada no mesmo ano após a morte de Vargas.

O processo de conformação da classe trabalhadora como ator político, ou de sua identidade política, na década de 1930, é amplamente compreendido como um projeto articulado pelo próprio Estado (MALLOY, 1986; FAORO, 2001; WEFFORT, 1980). Predomina na historiografia a perspectiva de que os trabalhadores teriam sido subjugados pelo projeto varguista-populista em troca dos benefícios por

\footnotetext{
${ }^{7}$ O sistema "não estendeu a cobertura ao setor rural, aos autônomos, profissionais liberais, domésticos, lojistas e vendedores por conta própria ou àqueles que não tinham emprego certo ou trabalhavam sem vínculo empregatício". (MALLOY, 1986, p.69)

${ }^{8}$ Segundo Malloy $(1986$, p.83,84) o regime varguista buscou promover a integração nacional por meio da expansão do aparato estatal e de sua inserção na sociedade, o que se confirma de forma mais concreta na constituição deste aparato a partir de dois princípios contraditórios: a meritocracia e o patronato. Em 1936 foi estabelecido que o ingresso nos cargos públicos seria regulamentado por um sistema de concursos, constituindo-se um sistema baseado no mérito pessoal. Paradoxalmente, o regime mantinha um sistema de patronato, que se utilizava de cargos públicos para constituir uma clientela política, preenchendo cargos através de recrutamento. A bifurcação do serviço público gerou uma divisão importante entre uma ala mais tecnocrata, associada ao conceito de um executivo forte, e outra ala associada a estruturas mais clientelistas, ligada a interesses particulares regionais e de grupo.
} 
ele concedidos, que antecipavam as suas reivindicações. Vinculados a lideranças externas à classe e interesses que não eram os seus, os trabalhadores teriam sido travestidos de uma identidade e uma ação política distante daquela que se vinha construindo na Primeira República.

Esta linha de interpretação - que destitui de qualquer autonomia a classe trabalhadora - é questionada por Ângela de Castro Gomes (2005) que constrói, como alternativa ao Populismo, o conceito de "Trabalhismo". Sua importância reside no resgate do processo de construção da identidade coletiva da classe trabalhadora no Brasil anterior a 1930, de forma a compreender os motivos pelos quais o projeto político estatal do pós-1930 foi implantado com tanto sucesso. De acordo com Gomes (2005), este sucesso se explica pelo fato de ter tomado elementos-chave do discurso dos próprios trabalhadores elaborado durante a Primeira República e os ter investido de novo significado, articulando uma lógica material, baseada nos benefícios garantidos pela legislação social, e uma lógica simbólica, que deixava vislumbrar estes benefícios como doações do Estado, personificado na figura do presidente Vargas. Nesse sentido se verificaria a atuação da própria classe trabalhadora na conformação de sua identidade política, ao contrário da passividade normalmente relatada na historiografia. Esta compreensão é fundamental no âmbito da noção gramsciana de "Estado Ampliado" que adotamos neste Tese, no sentido de entender o papel dos trabalhadores enquanto parte da sociedade civil que constitui este Estado.

Gomes (2005) entende que o processo de constituição da identidade política da classe trabalhadora acontece em dois momentos principais. O primeiro ocorre ainda na Primeira República a partir de uma diversidade de propostas e lutas coordenadas por lideranças vinculadas aos próprios trabalhadores. São diferentes lideranças com propostas políticas também diferentes que se esforçam desde finais do século XIX até a década de 1920, ora se sucedendo, ora se sobrepondo temporalmente, para construir a identidade deste trabalhador como ator coletivo. 0 segundo momento se inicia em 1930, quando a constituição da identidade do trabalhador já não mais ocorre a partir de propostas variadas formuladas no interior da própria classe trabalhadora, mas de uma proposta articulada a um projeto político estatal, capaz de silenciar discursos divergentes.

O esforço inicial vem, segundo Gomes (2005), daqueles que se autonomeavam socialistas, que procuravam garantir inicialmente um lugar de destaque para o trabalhador no mercado e posteriormente na política. Sua proposta organizacional se baseava na formação de um partido político operário. No início do século XX desenvolve-se também entre os trabalhadores o associativismo, através da formação voluntária de Sociedades de Ajuda Mútua, que a partir de contribuições ofereciam aos membros benefícios médicos, aposentadoria e auxílio-funerário. Estas associações, porém, eram malvistas por "líderes radicais como forma de organização regressiva, que tolhia a consciência de classe e desenvolvia uma mentalidade assistencialista passiva entre os trabalhadores" (MALLOY, 1986, p.44). 
Entre estes líderes radicais se sobressaiam os anarquistas e seriam eles os principais responsáveis entre 1906 e 1920 por um novo tom de atuação dos movimentos operários, bem como pelo novo tom de enfrentamento destes por parte do poder público. Atribui-se, por exemplo, aos anarquistas a organização da Greve Geral de 1917 em São Paulo, importante momento do movimento operário brasileiro em busca de melhores condições de trabalho. A organização do trabalhador segundo a orientação anarquista se dava nos sindicatos de ofício, ou "sindicatos de resistência", cujo objetivo era lutar contra o patronato e o Estado.

Havia ainda a proposta cooperativista, cujo modelo de organização se baseava em sindicatos que operavam por meio de cooperativas, "cuja finalidade era realizar acordos entre a classe trabalhadora e o patronato" (GOMES, 2005, p.30). Estes sindicatos, porém, se distanciavam do modelo anarquista, estando mais próximos do modelo mutualista, visando benefícios aos associados. Ao longo da década de 1920 o projeto cooperativista passa por mudanças, especialmente em função da organização da proposta comunista no país. O Partido Comunista do Brasil foi fundado em 1922 e renovou a proposta organizacional dos trabalhadores em um partido operário e a construção de sua ação política por meio do voto. A principal alteração no âmbito do cooperativismo foi a combinação do modelo de organização por sindicatos cooperativistas com as ações partidária e eleitoral, explicada por uma atuação, em maior grau dos comunistas e, em menor grau também dos socialistas, contra a proposta anarquista. A nova forma de organização sindical sugerida cresceu a partir de então e "veio a combinar legitimamente ações políticas reivindicatórias com práticas assistencialistas no interior dos sindicatos". (GOMES, 2005)

O segundo momento de constituição política da classe trabalhadora, segundo a autora, é viabilizado por duas características importantes. O Estado, por um lado, omite e até mesmo suprime os discursos elaborados pela classe trabalhadora até então e, por outro lado, constrói o discurso estatal com os mesmos elementos presentes naqueles discursos dos trabalhadores. $\mathrm{O}$ discurso proclamado por Vargas em 10 de maio de 1940 aos "Trabalhadores do Brasil" - vocativo utilizado pelo presidente desde novembro de $1938^{9}$ - demonstra como o Estado se coloca como um doador de benefícios aos trabalhadores, capaz mesmo de antever as suas necessidades.

A ação tutelar e previdente do Estado patenteia-se, de modo constante, na solicitude com que cria os serviços de proteção ao lar operário, de assistência à infância, de alimentação saudável e barata, de postos de saúde, de creches e maternidades, instituindo o ensino profissional junto às fábricas e, ultimamente, voltando as suas vistas para a construção de vilas operárias e casas populares. (VARGAS, 1940, grifo nosso)

\footnotetext{
9 Discurso proferido pelo presidente Vargas no Rio de Janeiro, a 10 de novembro de 1938. Discurso dirigido aos trabalhadores na inauguração do edifício-sede do Ministério do Trabalho, Indústria e Comércio. Vargas afirma que sua popularidade é fruto do exercício de suas funções de governante e da atenção que sempre deu às classes trabalhadoras. (D’ARAÚJO, 2011)
} 
A fala de Vargas evidencia aquilo que D’Araújo (1996) destaca na fala de Segadas Viana sobre a ação "previdente" do Estado, que supostamente antecipava as necessidades da classe trabalhadora, o que tornava pouco necessária a ação de líderes sindicais combativos. Greves eram consideradas ilegais e atividades político partidárias eram proibidas no interior dos sindicatos, podendo implicar na demissão de seus líderes, caso se comprovasse sua participação em tais atividades. À parte alguns movimentos isolados, apenas em 1946 se percebe uma maior articulação operária com a criação da Confederação dos Trabalhadores do Brasil (CTB).

Desde o início de 1946, vários congressos sindicais de nível estadual vinham sendo realizados em todo o país sob o patrocínio do Movimento Unificador dos Trabalhadores (MUT). Esse movimento, criado em abril de 1945, subsistia a despeito da repressão anticomunista, pretendendo unir todos os trabalhadores em sindicatos, e posteriormente numa confederação geral, sob o princípio da unidade da classe operária. (FGV/CPDOC - verbete: CTB)

Dada a permanência das leis sindicais do Estado Novo, porém, a CTB não é reconhecida pelo MTIC. "Ao advertir os sindicatos de que sua filiação à nova entidade os tornava igualmente ilegais, o Ministério do Trabalho dificultou bastante o recrutamento de membros por parte da nova confederação" (FGV/CPDOC. Verbete: CTB). Apesar disso, registra-se uma expansão do sindicalismo até 1947, quando as repercussões da Guerra Fria atingem os trabalhadores no Brasil, com fechamento da CTB e intervenções nos sindicatos. No início da década de 1950, com o retorno de Vargas, ocorre novo aumento da mobilização popular e, apesar de algumas conquistas, como o Estatuto do Trabalhador Rural (1962), o movimento sindical se manteria sob as mesmas bases até 1964, quando o regime militar intervém novamente nos sindicatos e coloca várias organizações trabalhistas na ilegalidade. (FGV/CPDOC. Verbete: CTB; GOMES, 2005)

\subsection{A institucionalização da produção habitacional pelo Estado brasileiro: a moradia como privilégio do trabalhador}

Desde o início do período republicano até 1964, é possível definir dois grandes períodos da atuação estatal no campo da habitação social no Brasil. O primeiro período vai desde finais do século XIX, quando se intensificam as atividades urbanas, principalmente na capital federal e na capital paulista, com forte aumento populacional, até 1933 , quando se decreta a formação do primeiro IAP, já possibilitado de promover habitações. A questão da moradia adequada à população de poucos recursos era entendida como problema desde o final do século XIX, mas o Estado liberal se concentrava em ações como a promulgação de leis e códigos sanitários, sem atuar diretamente na promoção de moradias ou mesmo na concessão de recursos ou subsídios. O segundo período, em que se insere esta pesquisa, se inicia em 1933 e vai até 1964, quando o regime militar institui nova política de promoção habitacional, extinguindo as políticas e órgãos anteriormente vigentes. Entre 
1933 e 1964 é possível dizer que se consolida a institucionalização da produção habitacional com a ação direta do Estado na provisão de habitação para o trabalhador promovendo a produção de milhares de unidades habitacionais no país.

Desde finais do século XIX, segundo Correia (2004), a falta ou a precariedade de habitações para os trabalhadores eram conhecidas. Eram os engenheiros e médicos sanitaristas que, em função da preocupação com a saúde pública, visitavam as moradias dos trabalhadores e faziam relatórios a respeito de suas condições, revelando muito sobre as habitações populares do período. Seus relatórios indicavam que em grande parte estas habitações ocupavam os locais menos favorecidos das cidades, como regiões de várzeas e áreas periféricas, e apresentavam problemas de iluminação, umidade e ventilação. Associada à questão higienista, conformou-se a noção de que casas precárias e insalubres propiciavam a promiscuidade, o vício e doenças e que não ofereciam condições apropriadas ao descanso, fazendo de seus moradores trabalhadores ineficientes.

Entretanto, é o setor privado que assume o papel de construir moradias econômicas voltadas a esta população, disponibilizando-as através do mercado rentista. O Estado atua apenas na promulgação de leis e normas sanitárias, construtivas e urbanísticas. É importante lembrar que na década de 1920 o sistema previdenciário organizado nas Caixas de Aposentadoria e Pensões previa a possibilidade de aplicação dos fundos na promoção de habitações aos associados, porém essa ação não era considerada oficial, resultando em número bastante reduzido de unidades oferecidas.

Segundo Bonduki (1998) e Blay (1985), no final do século XIX os trabalhadores abrigavam-se em vários tipos de alojamentos precários tais como os "hotéis-cortiços", onde viviam operários sem família em aposentos bastante reduzidos; as moradias improvisadas em "cômodos de fundo de lote", que eram alugados pelas famílias operárias e considerados o pior tipo de acomodação por ficarem próximos a estábulos e depósitos insalubres; as "casas de cômodos", antigas casas e sobrados transformados em cortiços. Havia também moradias construídas por empresários e destinadas ao mercado rentista como o "cortiço-pátio", que se localizava no interior de quadras, onde se dispunha de um pátio de três ou quatro metros de largura para o qual se abriam as portas e janelas das casas enfileiradas, e uma espécie de mercearia para abastecer os moradores, sendo este tipo altamente rentável "em virtude do intenso aproveitamento do terreno e da economia de material possibilitada por sua organização espacial" (BONDUKI, 1998, p.25). Havia ainda as "casinhas", que, embora voltadas para a rua, às vezes fechavam quarteirões inteiros com construções e, abrigando um número de pessoas incompatível com seu tamanho, não atendiam a questões de higiene e iluminação.

Além das formas improvisadas de alojamento, destaca-se a construção das vilas operárias, aquelas destinadas à população empregada nas fábricas e ferrovias, e que muitas vezes serviam como intermediação no vínculo entre trabalhador e fábrica. Incentivados pelo poder público através de privilégios como a redução ou isenção de impostos, indústrias, companhias ferroviárias, empresas e 
investidores particulares produziram conjuntos de casas econômicas para trabalhadores desde a década de 1890 (CORREIA, 2004). A produção de habitações operárias era uma fonte de rendimentos, uma mercadoria aos olhos de investidores capitalistas. A busca incessante por lucros, porém, originava construções muitas vezes tão precárias quanto os cortiços.

Uma terceira solução encontrada no período foi a compra de terreno e a autoprovisão da moradia. Como os aluguéis absorviam grande parte do salário, alguns operários preferiam adquirir seus próprios terrenos nas periferias, onde havia lotes com valores mais baixos, porém ainda sem qualquer infraestrutura, onde construíam suas próprias casas. Muitas vezes estas habitações resultavam tão precárias que o Estado viria a interditá-las ou destruí-las nas buscas por focos de doenças. (CORREIA, 2004; BONDUKI, 1998)

Em meio à proposta de reorganização política, econômica e social colocada a partir de 1930, a habitação aparece como caminho para modificar as condições da classe trabalhadora. A moradia passa a ser vista pelo Estado como item básico da reprodução da força de trabalho e, portanto, como fator fundamental ao plano de industrialização do país, o que implicou, diretamente, no reconhecimento de que cabia ao próprio Estado, e não ao setor privado, o enfrentamento da questão habitacional. Esta noção fica especialmente clara a partir de 1937 quando são propostas duas linhas principais de ação. Por um lado, o Estado regulamenta o loteamento de terras e sua venda/ aquisição através de prestações, facilitando nesse sentido a posse da propriedade ao trabalhador, onde este construiria a própria casa. Por outro lado, é estabelecida a produção de habitações aos trabalhadores através da regulamentação da atividade das carteiras prediais dos Institutos de Aposentadoria e Pensões (IAPs). Sendo a moradia uma das principais reivindicações das massas e sindicatos mais combativos, sobretudo o Sindicato dos Bancários, a promoção habitacional, portanto, se encaixa no projeto do Trabalhismo, como meio de aproximação entre Estado e trabalhador.

Duas questões em especial ajudam a esclarecer por que o Estado atuou sobre a legislação de loteamentos, facilitando a compra de terrenos - e consequentemente a autoconstrução da casa pelo trabalhador, que de outro modo, dadas as baixas remunerações, não conseguiria fazê-lo. Em primeiro lugar a ideologia da casa própria era importante para o Estado Novo na medida em que representava uma base material à família operária, como um símbolo do crescimento econômico e valorização do trabalhador. Era interessante ainda porque de certo modo rompia com a identidade entre propriedade e elite, repassada desde o período colonial latifundiário, fazendo da classe média e do operariado também proprietários. Assim boa parte dos discursos e debates estimulava a propriedade da moradia, a legislação privilegiava aspectos jurídicos sem exigir padrões de qualidade urbanística e os Institutos de Aposentadoria e Pensões (IAPs) garantiam empréstimos àqueles que desejassem comprar ou construir sua residência. (BONDUKI, 1998; 2014) 
As facilidades jurídicas e urbanísticas promovidas pelo governo para abertura de novos loteamentos e aquisição de terrenos para autoconstrução associavam-se ainda a uma visão conservadora presente em grande parcela da sociedade política ${ }^{10}$, que, associada a setores da Igreja Católica, compreendia a propriedade da casa unifamiliar como garantia de estabilidade social. Sustentava-se que a construção de unidades isoladas em lotes preservava a família cristã e que a propriedade da moradia era a solução mais consoante com a encíclica papal de 1891, em que o Papa Leão XIII escreve "sobre a condição dos operários", definindo uma doutrina social para a Igreja Católica ${ }^{11}$. (MELO, 1990)

A compreensão do papel da Igreja e da ação de membros católicos no interior do aparato estatal, segundo Melo (1990, p.41,42), "é essencial para o entendimento da política de habitação e, por extensão, da política social adotada na década de quarenta". A Igreja buscava naquele momento se reaproximar do Estado, ao mesmo tempo em que buscava "incorporar as massas urbanas em um projeto corporativo a partir de uma perspectiva definida pela doutrina social da Igreja"12.

Em segundo lugar, destaca-se como questão o fato de que os órgãos designados para a produção habitacional estatal, os IAPs, não supriam a demanda por moradias destinadas à população de poucos recursos. Embora fosse possível comprovar a relação entre a promoção da habitação social e - Trabalhismo, sobretudo a partir da ação direta do Estado através da construção de conjuntos habitacionais pelos IAPs, estes se destinavam apenas aos associados, isto é, a moradia era um privilégio dos trabalhadores sindicalizados.

Além disso, a conjuntura que se estabelece no campo da habitação econômica após o início da segunda guerra mundial implicou em clara redução do número de unidades disponibilizadas no mercado, o que exigiu a ação do Estado, que se posicionou de diferentes formas. As dificuldades de importação, com ênfase para os materiais de construção, durante a Segunda Guerra, associadas a um aumento geral de preços e, paralelamente, a um desenvolvimento de determinados setores da economia, estiveram relacionados desde 1939 a um aumento inflacionário sem precedentes, retroalimentado pelo próprio crescimento econômico e pelas pressões originárias da guerra. Em consequência ocorreu o aumento das transações imobiliárias, assim como dos valores dos imóveis, o que fez da inversão predial um foco de investimentos por parte do setor privado. Tal movimento se associava à "ânsia de se protegerem [os investidores capitalistas] da contínua depreciação

\footnotetext{
10 Profissionais e especialistas vinculados aos grupos de Ação Social da Igreja Católica assumiram posições importantes no MTIC, onde participaram do processo de institucionalização da produção habitacional pelo Estado brasileiro, conforme explicamos no Capítulo 3. Entre eles é possível mencionar Rubens Porto e Paulo Accioly de Sá, que, inclusive, integraram a equipe que representou o Brasil no I Congresso Pan-americano de Vivienda Popular em Buenos Aires em 1939. (MELO, 1990)

11 Carta Encíclica Rerum Novarum: Sobre a condição dos operários. 15 maio 1891, Papa Leão XIII. Disponível em: <https://w2.vatican.va/content/leo-xiii/pt/encyclicals/documents/hf_l-xiii_enc_15051891_rerum-novarum.html> Acesso em 19 jun. 2017.

12 São criados na década de 1930 grupos de Ação Social com especial atuação nas favelas, com destaque para o Rio de Janeiro, onde se constitui em 1936 a Associação Lar Proletário, e o Recife, onde se inicia em 1939 a Cruzada Social Contra os Mocambos, promovendo-se os primeiros levantamentos sobre as condições de vida e de habitação nas favelas.
} 
inflacionária da moeda, através de investimentos considerados seguros e capazes de uma revalorização altista automática em função da alta de preços", conforme apresentado no Relatório da Comissão Mista Brasil-Estados Unidos de 1955 (2008, p. 346). Além da manutenção de terrenos urbanos à espera de capitalização, destaca-se nas grandes cidades do país neste momento a construção de edifícios de apartamentos para aluguel e venda, com consolidação da verticalização residencial rentista apenas esboçada até então (SOMECK, 1987). Devido à especulação imobiliária, pouco seria revertido em vilas operárias, sendo os novos imóveis nesse momento destinados majoritariamente às classes de mais alta renda. (BONDUKI, 1998)

O Estado, empenhado em fazer crescer a indústria brasileira, considerou baixo o investimento de particulares no setor industrial, uma vez que destinavam capital ao setor predial, e passou, através de uma série de medidas, a dificultar o crédito imobiliário. Os resultados mais uma vez atingiram a população de menores rendimentos: a falta de opções, entre as unidades já existentes e as poucas unidades novas, propiciou o aumento dos valores dos aluguéis.

Como a elevação dos custos de locação podia prejudicar os trabalhadores e, consequentemente, as intenções do Estado de favorecê-los em seu projeto trabalhista-desenvolvimentista, em 1942 foi promulgada a Lei do Inquilinato (Decreto-Lei no 4.598). A Lei estabelecia o congelamento dos aluguéis nos valores estipulados em dezembro de 1941 pelo prazo de dois anos (BRASIL, 1942) e seria consecutivamente renovada e aperfeiçoada até 1964. Segundo Bonduki (2014, p.43), a Lei tinha três objetivos claros: ampliar as bases do apoio popular ao projeto de governo, "reduzir o custo de reprodução da força de trabalho e desestimular o investimento em casas de aluguel de modo a concentrar a aplicação de capitais nos setores considerados mais estratégicos para o projeto desenvolvimentista, em especial a indústria".

Em um primeiro momento, a população operária se beneficiou amplamente, pois se tornou possível guardar parte de seus rendimentos, que antes eram logo absorvidos pelos aumentos dos aluguéis. No momento seguinte, porém, com grande aumento da população urbana do país, estando os valores de aluguéis estagnados e já não existindo as isenções fiscais disponíveis antes do período Vargas, se viu mais uma vez o desinteresse do capital privado em investir no setor, posto que já não fosse mais tão rentável. Como consequência, em meados da década de 1940, se via a precarização de unidades já existentes, a elevação da demanda por habitações populares e a ampliação da autopromoção ou produção doméstica da moradia. É nesse cenário que Vargas anuncia em 1944 a remodelação do sistema previdenciário, com destaque para as mudanças na aplicação de recursos para a produção da habitação social.

Terminada a fase de experiência e solidificação dos Institutos e Caixas, cujas reservas vinham sendo aplicadas sob o critério de imediata segurança e rendimento certo, é tempo de iniciarmos uma política de mais largo alcance relativamente ao emprego dos fundos acumulados. Emprestar os depósitos das organizações de seguro social para construções suntuárias ou fazê-los circular a 
juros bancários é afastá-los da finalidade superior que ditou a legislação trabalhista. Ao contrário disso, nas suas linhas mestras, a nova lei orgânica de previdência em elaboração igualará os benefícios de todos os grupos profissionais, [...]. Com a colaboração das administrações municipais, que entrosarão os respectivos projetos nos seus planos de urbanização, construiremos cidadesmodelos nas proximidades dos grandes centros industriais, com instalações de tratamento de saúde, de educação profissional e física. (VARGAS, 1944, grifo nosso) Com o fim do Estado Novo, a proposta de unificação dos recursos dos diversos IAPs em torno de um único órgão, o já mencionado ISSB, que realizasse a produção habitacional com o objetivo de um atendimento social mais amplo, toma forma no governo de Eurico Gaspar Dutra. Segundo Melo (1990), o tema da habitação foi constantemente abordado nas campanhas presidenciais de 1945. Em um de seus discursos, apresentado no jornal O Estado de São Paulo, Dutra afirmou que o problema era "grave" e que precisava "ser resolvido com toda a urgência para o bem-estar de nossas classes trabalhadoras", para tanto, se eleito, apoiaria a "criação de um órgão específico para todo o serviço de habitação popular [...] que deverá denominar-se Caixa Nacional de Habitação e permitirá a mobilização de recursos para o financiamento e construção inicial de 100.000 habitações de tipo popular" (O PROBLEMA DA HABITAÇÃO..., 1945, p.4). Em 1946, através do Decreto-Lei no 9.218 é criada a Fundação da Casa Popular (FCP).

A FCP se destinava a proporcionar a aquisição ou a construção da casa própria em âmbito nacional, em zona urbana ou rural, sendo, portanto, o primeiro órgão nacional voltado exclusivamente à provisão de moradia para as populações de menor poder aquisitivo, e que, ao contrário dos IAPs, previa um atendimento à população pobre em geral, incluindo os trabalhadores informais, que ficavam de fora do âmbito de benefícios oferecidos pelos diversos Institutos. (AZEVEDO; ANDRADE, 1982)

A Fundação tinha o objetivo de "favorecer aos mais necessitados, sendo vedadas obras que não pudessem ser qualificadas como de tipo genuinamente popular" (BRASIL, 1946). Novo decreto do mesmo ano possibilitou também à FCP articular moradia e desenvolvimento urbano, prevendo a execução de infraestrutura junto às áreas residenciais, além de incentivos à indústria da construção civil e à pesquisa de novas técnicas construtivas que barateassem as obras. (BRASIL, 1946)

Segundo Melo (1990, p.44) "o decreto que estabeleceu as bases da Fundação da Casa Popular, na verdade, constitui um resíduo do anteprojeto divulgado que sofreu fortes críticas e ensejou um projeto de negociação de interesses entre diversos grupos". Um dos principais pontos de críticas e questionamentos era a unificação e administração dos recursos previdenciários, bem como das operações imobiliárias e carteiras prediais dos IAPs pela FCP. A separação dos fundos de previdência por categorias interessava aos respectivos IAPs, especialmente aqueles com maior número de associados e, logo, maiores recursos, no sentido de manutenção de seus próprios rendimentos. Além disso, para o próprio Estado interessava que os fundos previdenciários pudessem ser utilizados para 
outros propósitos além da habitação, pois estes constituíam, de acordo com Melo (1990), a mais significativa fonte de recursos estatais, sendo inclusive utilizados para os primeiros grandes projetos de industrialização, como Volta Redonda, por exemplo. Nesse sentido, a proposta de unificação das carteiras prediais prevista no anteprojeto da FCP foi abandonada no projeto aprovado.

Sem fonte garantida de recursos e alvo de constantes críticas, a FCP nunca atuou da maneira esperada, produzindo ao longo de sua existência menos unidades habitacionais que os IAPs, algo em torno de 20 mil moradias distribuídas em 202 conjuntos, sendo apenas um na área metropolitana de São Paulo, no município de Santo André (1948-1949, 400 unidades). A produção da FCP caracterizouse principalmente pela construção de pequenos núcleos habitacionais (com cerca de cinquenta unidades) em parceria com as prefeituras que se responsabilizavam pela doação de terrenos e pela solicitação para a implantação dos conjuntos. (BONDUKI, 2014)

Ao contrário da proposta que previa o desenvolvimento urbano, a maior parte dos conjuntos foi entregue com infraestrutura precária ou inexistente. Além disso, o orçamento limitado implicou também na opção por soluções construtivas mais tradicionais, com técnicas e materiais convencionais e pouco ou nenhum incremento arquitetônico, com a maior parte das unidades em casas térreas isoladas ou geminadas. Os projetos das habitações eram sempre desenvolvidos pela própria Fundação, que chegou a instituir alguns "tipos" em função de determinadas condições locais, conformando em geral conjuntos com unidades homogêneas e metragem entre $40 \mathrm{~m}^{2}$ e $70 \mathrm{~m}^{2}$. (AZEVEDO; ANDRADE, 1982)

As maiores exceções localizam-se na então capital Rio de Janeiro, com utilização de novas técnicas e projetos diferenciados, dentre os quais se destaca o Conjunto Residencial Presidente Getúlio Vargas, o Conjunto Deodoro, projetado pelo arquiteto Flávio Marinho Rego. São característicos do projeto dois blocos sinuosos de sete pavimentos projetados no centro da grande gleba destinada ao conjunto, adaptando-se às curvas de nível com a utilização de pilotis, passarelas e ruas elevadas. Os demais edifícios eram lâminas de três pavimentos sobre pilotis dispostas paralelamente umas às outras em partes mais planas da gleba. O projeto contava ainda com equipamentos como mercado, escola, ginásio e quadras esportivas. (BONDUKI, 2014)

As ações empreendidas ao longo da primeira metade do século $X X$, considerando-se especialmente aquelas realizadas pelos IAPs e pela FCP, embora não tenham de fato conseguido solucionar completamente o problema da habitação, tiveram o mérito de introduzir no país a noção de que a questão habitacional era um problema social a ser resolvido pelo poder público. Contudo, em consequência da inexistência de políticas eficazes de promoção habitacional voltadas às pessoas de poucos recursos, o déficit de moradias passa a ser um problema de ordem maior e chega a configurar uma crise. No início da década de 1960 estimou-se um déficit habitacional entre cinco e sete milhões de unidades (INSTITUTO DE ARQUITETOS DO BRASIL, 1963; 1964). 
Em 1961, sob a vigência do governo de Jânio Quadros, é proposta a criação do Instituto Brasileiro de Habitação (IBH), cujo objetivo final era o de produzir cem mil moradias. A proposta, embora transformada em Projeto de Lei, não se concretiza após a renúncia do presidente em agosto do mesmo ano. (BONDUKI; KOURY, 2010)

O ano de 1964 marca a nova organização institucional, jurídica e programática da política habitacional estatal, com a criação, pela Lei 4.380 (BRASIL, 1964), do Sistema Financeiro da Habitação (SFH), do Banco Nacional da Habitação (BNH) e do Serviço Federal de Habitação e Urbanismo (SERFHAU). A legislação da FCP foi revogada e seu patrimônio absorvido pelo SERFHAU. O Art. 65 da Lei 4.380 de 1964 estabeleceu que as Carteiras Imobiliárias dos IAPs não poderiam iniciar novas operações imobiliárias e seus segurados passariam a ser atendidos pela nova política habitacional. Os Institutos deveriam vender seus conjuntos e unidades residenciais e os recursos obtidos deveriam ser aplicados em Letras Imobiliárias emitidas pelo BNH. Em 1966 o Decreto-Lei $n^{\circ} 72$ reuniu os seis IAPs no Instituto Nacional de Previdência Social (INPS) ligado ao Ministério do Trabalho e Previdência Social e em 1968 a Lei no 5.455 possibilitou a aplicação dos recursos adquiridos pelas vendas das unidades habitacionais dos IAPs na aquisição ou construção de imóveis destinados às instalações do INPS, como os edifícios-sede (muitos construídos junto a conjuntos habitacionais). Com o fim dos IAPs, findava também a promoção habitacional pelo sistema previdenciário.

\subsection{A política previdenciária de habitação}

Nos primeiros anos da década de 1940 a maior parte dos IAPs passa a construir conjuntos de habitações para os trabalhadores associados das categorias profissionais atendidas pelo sistema previdenciário. Os conjuntos produzidos eram constantemente mencionados nos discursos do presidente como doação do Estado e parte do projeto de ascensão social do trabalhador. Ao estabelecer que a promoção habitacional fosse realizada pelos órgãos de previdência o Estado constituía o que denominamos "política previdenciária de habitação", baseada em fundamentos que a diferenciavam de uma política pública habitacional em sentido literal.

Embora desde 1930 fosse possível e legal (Decreto $n^{\circ}$ 19.496) a aplicação de recursos previdenciários em habitação, é somente em 1937 que se busca criar condições para uma atuação mais vigorosa dos IAPs no setor imobiliário. No Decreto $\mathrm{n}^{\circ} 1.749 / 1937$ "fica aprovado novo regulamento para a aquisição de prédios destinados à moradia dos associados dos Institutos e Caixas de Aposentadoria e Pensões" (BRASIL, 1937), que permitia o "financiamento para aquisição de prédio destinado a moradia [...] mediante":

a) compra de prédio e respectivo terreno; b) compra de terreno e construção do prédio, ou construção de prédio em terreno já de propriedade do associado; c) compra de terrenos e construção de casas, ou de prédios de apartamentos, por iniciativa direta dos Institutos ou Caixas, para venda aos seus associados; d) 
concessão de empréstimo garantido com hipoteca até $2 / 3$ (dois terços) do valor do prédio gravado de propriedade do associado. [...] Poderão os Institutos ou Caixas alugar, a terceiros, casas ou apartamentos construídos [...] enquanto não vendidos, dando, porém, preferência aos respectivos associados. (BRASIL, 1937, grifos nossos).

A atuação dos IAPs no setor da habitação dividiu-se inicialmente em três modalidades: Planos A, B e C, que variavam de acordo com o público a que se destinava e o tipo de serviço concedido. Uma publicação da "Folha Bancária", órgão oficial do sindicato da categoria, traz explicações aos leitores quanto ao funcionamento da carteira predial e de operações imobiliárias do IAPB (bem como demais Institutos), já então modificada pela Portaria SCM366 de 27 de maio de 1940 do então Ministro do Trabalho Waldemar Falcão:

Plano A - arrendamentos ou venda de habitações, em conjuntos residenciais adquiridos ou construídos por iniciativa do Instituto; Plano B - financiamento para aquisição ou construção de habitações por iniciativa dos associados; Plano C operações imobiliárias diversas. Nos casos de locação, o assegurado pagará, além do aluguel, juros de 1,5\% ao mês sobre o valor estipulado para o imóvel; prêmio de seguro mixto; prêmio de seguro contra o risco de fogo; quota referente aos impostos e taxas que incidam ou venham a incidir sobre o imóvel locado e as despesas gerais de administração e conservação. [...] 0 financiamento para construção ou aquisição de habitações por iniciativa dos associados, consistirão em: compra de terreno e construção de casa; construção de casa em terreno de associado; compra de casa; compra ou construção de conjunto residencial; encampação de dívida hipotecária para aquisição ou construção de moradia [...]. A realização de uma dessas operações obriga o associado ao pagamento de uma prestação mensal compreendendo quota de amortização e juros de 7,5\% ao mês e demais seguros e impostos semelhantes aos casos de locação. [...]. O plano $C$ compreende as operações que o Instituto julgue conveniente realizar, objetivando uma constante e mais elevada remuneração de suas reservas, e consistirá em aquisição de terrenos e construção de edifícios, por iniciativa direta do Instituto, para instalação dos seus serviços ou locação a terceiros. (O PROBLEMA DA AQUISIÇÃO..., 1940, p.8, grifo nosso)

O Decreto $\mathrm{n}^{\circ}$ 34.828, de 17 de dezembro de 1953 "dispõe sobre as operações imobiliárias das Instituições de Previdência Social" e traz como principal alteração ao Decreto n 1.749/37 que as operações imobiliárias dos Institutos se fariam sob cinco planos:

As operações do Plano A objetivarão proporcionar aos segurados a locação da casa para moradia; As operações do Plano B compreenderão os financiamentos a segurados, com finalidade de proporcionar-Ihe, mediante condições especiais, a aquisição, construção, conservação, reforma e ampliação de imóveis para moradia própria; As operações do Plano C compreenderão as inversões em imóveis para uso ou venda das Instituições, tendo em vista, ainda, manter a estabilidade do seu patrimônio; As operações de Plano D compreenderão os empréstimos hipotecários a qualquer pessoa física ou jurídica realizados pelas Instituições com o propósito de obter constante e mais elevada remuneração de sua reserva; As operações do Plano E compreenderão os empréstimos destinados ao custeio da construção ou aquisição de escolas, hospitais, creches, ambulatórios, sanatórios ou colônia de 
férias, construção ou aquisição de refeitórios e restaurantes, construção ou aquisição de sede para associações sindicais. (BRASIL, 1953, grifo nosso)

Fica assim bastante clara a atividade rentista dos Institutos no setor imobiliário, cuja capitalização de recursos era prevista nos diferentes planos (exceto pelo Plano E): "Plano A - de finalidade preponderantemente social e de renda; Plano B - de finalidade social e de renda; Plano C - de finalidade administrativa, patrimonial, social e de renda; Plano D - de finalidade essencialmente econômica - financeira para as Instituições; Plano E - de finalidade social e interesse coletivo" (Brasil, 1953). Pode-se afirmar que os Planos A e B, embora baseados na aplicação de reservas, representavam objetivos sociais e ideológicos, pois pressupunham a adesão política do trabalhador para que esse desfrutasse dos benefícios garantidos pelos IAPs, garantindo o vínculo ideológico entre os associados aos diversos Institutos e o governo. Nos planos C e D, porém é possível notar mais nitidamente a atuação dos Institutos como operadores financeiros.

Um dado importante que a Portaria SCM366 e o Decreto $n^{\circ} 34.828 / 53$ revelam é a inclusão da locação como possibilidade garantida pelo Plano A, o que não estava estipulado no decreto de 1937, que relegava ao aluguel um caráter temporário, enquanto não se dava a venda das unidades. Esse movimento pode estar relacionado à ampliação do debate em torno da propriedade da moradia que ocorre naquele momento: entendia-se que os gastos com a reprodução da força de trabalho na locação da moradia eram mais compatíveis com os baixos salários dos trabalhadores, muito menores que aqueles necessários para sua aquisição e, embora a habitação fosse reconhecida como questão de utilidade pública, se compreendia que o Estado era incapaz de enfrentar o problema habitacional provendo uma casa própria a cada família, mas seria possível a opção da locação. $\mathrm{O}$ aluguel permitia ainda aos IAPs a manutenção da propriedade imobiliária, implicando uma grande reserva de valor.

Dentro das burocracias atuariais dos IAPs, conforme afirma Bonduki (2014), havia quem considerasse a inversão dos recursos em moradias uma forma pouco proveitosa de aplicação, uma vez que, se por um lado o retorno financeiro era garantido, por outro era necessário despender recursos com as construções. No entanto, a inversão imobiliária era considerada uma atividade segura de capitalização ${ }^{13}$ e a locação dos imóveis, conforme disposto na Portaria Ministerial, garantia também bom retorno aos fundos (através dos próprios aluguéis, mas também de taxas, juros e seguros), ao mesmo tempo em que garantia o alojamento de grande número de trabalhadores das diversas categorias profissionais. Essa ambiguidade - entre questão social e financeira - persistiria durante toda a vigência da política previdenciária de habitação.

\footnotetext{
${ }^{13}$ Desde o início do século XX "o trabalho da construção produzia cada vez mais um valor excedente, que se constituía, de um lado, pela terra capitalizada [proveniente dos aumentos de preços dos imóveis resultante do desenvolvimento das condições gerais, quer por alterações na estrutura urbana da cidade, quer pelo seu significado como reserva de valor], e de outro, pela exploração do trabalho de construção [cada vez mais um fator barato, abundante e enfraquecido]". Em consequência, "tornava-se questão fundamental na produção imobiliária a propriedade privada da terra. Com o avanço da industrialização, crescia o domínio sobre as condições naturais - geológica, pedológica e topográfica - e mudava-se o aspecto da propriedade da terra - de elemento de produção para o de base - na determinação da renda da terra, que, de fundiária, passava a imobiliária". (PEREIRA, 1988, p.153,154)
} 
Jaramillo (2010), ao analisar o espaço urbano de Bogotá, parte do princípio que há distintas "formas de produção"14 $^{14}$ deste bem - cuja categoria mais importante é a habitação - operando simultaneamente, com dinâmicas internas particulares e entrelaçadas entre si. A produção capitalista exclui, segundo o autor, setores populares numericamente importantes, que não representam uma demanda efetiva, de modo que a produção de mercado convive com outras formas de produção que atendem a esta população: produção doméstica, por encomenda e estatal. Concluindo que a forma de produção do espaço construído a partir dos conjuntos habitacionais dos IAPs não se acomoda a nenhuma das categorias elencadas por Jaramillo (2010), esquematizamos um quadro (Quadro 3) com as características desta forma de produção urbana que chamamos de "previdenciária" ${ }^{15}$. A análise da "forma de produção do espaço construído" dos projetos habitacionais dos IAPs permite enfatizar a especificidade da política previdenciária de habitação com relação a uma política habitacional estatal no sentido literal.

Cabe relembrar ou esclarecer alguns pontos: a) a conformação dos fundos dos IAPs se dá de forma tripartida entre empregado, empregador e Estado; b) a produção habitacional era prevista como modalidade de aplicação de recursos (não era um benefício previsto entre os fins da previdência social) e se destinava aos trabalhadores associados aos diferentes Institutos; c) os IAPs dispunham de setores de Engenharia próprios, porém boa parte de sua produção, especialmente aquela localizada fora da capital Rio de Janeiro, era realizada por promotores terceiros, desde a concepção do projeto até a implantação e execução das obras; d) embora parte dos projetos residenciais fosse construída sob processos manufatureiros, a padronização foi rapidamente incorporada nos Institutos com maiores recursos, visando maior produtividade e redução de custos; e) uma porcentagem das unidades residenciais seria vendida aos futuros proprietários, mas a grande maioria - quase totalidade - permaneceria como propriedade dos IAPs, sendo alugada aos associados.

\section{Quadro 3}

Forma de Produção urbana previdenciária

\begin{tabular}{|c|c|c|c|c|c|c|c|}
\hline $\begin{array}{c}\text { Forma de } \\
\text { Produção Urbana }\end{array}$ & $\begin{array}{l}\text { Controle } \\
\text { técnico }\end{array}$ & $\begin{array}{c}\text { Controle } \\
\text { econômico }\end{array}$ & Motor da produção & $\begin{array}{l}\text { Forma de } \\
\text { circulação }\end{array}$ & $\begin{array}{c}\text { Processo de } \\
\text { trabalho }\end{array}$ & $\begin{array}{l}\text { Propriedade } \\
\text { do espaço } \\
\text { construído }\end{array}$ & $\begin{array}{c}\text { Produção } \\
\text { de valor }\end{array}$ \\
\hline PREVIDENCIÁRIA & $\begin{array}{c}\text { IAPs / } \\
\text { construtor }\end{array}$ & IAPs & $\begin{array}{c}\text { autoprovisão de valor } \\
\text { de uso / acumulação } \\
\text { de capital }\end{array}$ & $\begin{array}{l}\text { demanda } \\
\text { efetiva }\end{array}$ & $\begin{array}{c}\text { manufatureiro/ } \\
\text { racional }\end{array}$ & IAPs & $\operatorname{sim}$ \\
\hline
\end{tabular}

No controle econômico e no que diz respeito à propriedade do espaço construído está uma particularidade desta produção, uma vez que os fundos previdenciários, bem como as terras que permitiam comprar, segundo os moldes dos IAPs, podem ser entendidos como pertencentes

\footnotetext{
14 "Formas de produção": se tratam de sistemas que relacionam os homens entre si e estes com os meios de produção para produzir um bem ou uma série de bens. (JARAMILO, 2010, p.175, tradução nossa)

${ }^{15}$ No Apêndice A apresentamos uma tabela semelhante, com as distintas formas de produção urbana tratadas em Jaramillo (2010).
} 
simultaneamente aos usuários finais (os empregados associados), a capitalistas (as empresas das diversas categorias e os próprios Institutos) e ao Estado.

O motor da produção e a forma de circulação ${ }^{16}$ são intimamente relacionados entre si e também ao controle econômico e consistem, a nosso ver, nas principais características desta produção. Uma vez que esta era direcionada a uma demanda efetiva, os trabalhadores associados aos Institutos, um dos motores da produção é a autoprovisão de valor de uso da moradia, já que parte dos fundos vem dos salários dos empregados. Contudo há ainda outro motor, a acumulação do capital, que interessava diretamente aos próprios Institutos como forma de ampliação de seus recursos, o que se dava tanto pela capitalização da renda das terras que adquiriam, quanto a partir dos aluguéis pagos pelos moradores dos conjuntos. A noção de que esta produção se destinava a uma demanda efetiva é um dado importante que teria reflexos na concepção de outras políticas de promoção habitacional no período, como a atuação estatal que facilitava a compra de terrenos e a autoconstrução da moradia e a concepção da Fundação da Casa Popular, como forma de atender à população não contemplada pela ação dos IAPs. Dada a finalidade de acumulação de capital, interessava a produção de valor e a racionalização dos processos construtivos contribuía para isso, reduzindo os custos de produção e garantindo maior reprodutibilidade dos projetos, o que poderia também reduzir os preços cobrados aos inquilinos e compradores.

É possível ressaltar duas questões que mostram como a ambiguidade entre a questão social e a questão financeira se traduziram na concepção dos projetos e na forma de produção do espaço construído dos conjuntos habitacionais dos IAPs. Por um lado, revela-se uma preocupação com a racionalidade dos planos urbanísticos e espaços de morar, tanto a casa isolada no lote quanto o apartamento no edifício em altura. Essa racionalidade se relacionava a certa autonomia proposta tanto aos conjuntos de blocos e casas, quanto aos edifícios isolados, como unidades de habitação, associando as moradias a serviços, equipamentos comunitários e áreas verdes. Por outro lado, através da habitação projetava-se uma nova dimensão social aos seus moradores, dada pela qualidade arquitetônica, urbanística e construtiva.

Estas características revelavam, conforme enfatizaremos no capítulo seguinte, uma aproximação bastante efetiva com as discussões realizadas por profissionais de arquitetura em âmbito continental, nomeadamente latino-americano, com relação à questão habitacional. Destas discussões destacamse aspectos como a participação direta do Estado no enfrentamento do problema, a associação entre projeto habitacional e urbano e a perspectiva de produção da moradia em grande escala. A moradia em grande escala era assumida pelos profissionais como possibilidade de a arquitetura ser usufruída por grande parcela da população e, assim, cumprir sua função social.

\footnotetext{
${ }^{16}$ Forma de circulação: "o processo que encadeia os produtos e os distribui desde a produção até seu momento de consumo", ou seja, as condições de sua reprodução. (JARAMILO, 2010, p.176, tradução nossa)
} 
Contudo, determinadas características da produção em grande escala eram também interessantes à capitalização da renda da terra. As tipologias arquitetônicas se baseavam na padronização e verticalização, fatores de redução dos custos de produção. A racionalização dos projetos arquitetônicos e urbanísticos, bem como a associação das moradias a equipamentos e serviços, garantiam determinada ascensão social aos moradores, ao mesmo tempo em que agregavam valor aos projetos e, portanto, aos imóveis. A localização próxima ao centro da cidade ou outros locais privilegiados garantiam vantagens aos moradores no sentido de sua proximidade a serviços, infraestrutura e locais de trabalho, mas também aos proprietários desses terrenos, valorizados tanto pela própria construção da "mercadoria-habitação" (PEREIRA, 1988), quanto pela sua localização.

Lembramos a fala de Corrêa Lima $(1942)^{17}$ ao esclarecer os principais objetivos do projeto para o conjunto da Várzea do Carmo em São Paulo, em que destaca, por um lado, a função social da habitação através da compatibilidade entre a condição econômica dos futuros moradores e o custo das habitações e, por outro, a rentabilidade dos projetos habitacionais, garantindo-se retorno aos recursos aplicados pelo IAPI. É possível afirmar que estes objetivos norteavam os projetos habitacionais dos IAPs de um modo geral, buscando-se atingir ao mesmo tempo os objetivos sociais e financeiros da produção habitacional realizada através dos fundos de previdência.

De acordo com a legislação correspondente à criação dos IAPs, a construção de moradias não era prevista como um dos benefícios garantidos pela Previdência Social, ou seja, uma de suas finalidades, mas uma das possíveis modalidades de aplicação de seu patrimônio, garantindo um serviço aos associados com reconhecido retorno do capital investido. Assim, esse duplo sentido, social e financeiro, permeia todo o processo de institucionalização da produção habitacional por estes órgãos. Uma especificidade da política previdenciária de habitação, portanto, reside no fato de a função social estar ao lado da capitalização dos recursos investidos como finalidade desta forma de produção habitacional. A inversão de fundos no setor imobiliário e a produção de habitações, ao mesmo tempo em que garantiam o direito à moradia do trabalhador, garantiam aos Institutos o retorno financeiro de seus investimentos.

Sem a pretensão de destrinchar todas as características da produção habitacional realizada pelos IAPs em São Paulo, entende-se como fundamental, porém, indicar aspectos marcantes da produção dos Institutos que mais atuaram em São Paulo, IAPI, IAPB e IAPC, assim como particularidades das respectivas práticas de promoção habitacional. Nesta análise incluímos também a pesquisa sobre a política e a produção habitacional do IPESP em São Paulo.

\footnotetext{
${ }^{17}$ Ver Capítulo 01.
} 


\section{IAPI}

O Instituto de Aposentadoria e Pensões dos Industriários (IAPI) se destaca no sistema previdenciário brasileiro por sua concepção. Diferentemente de outros Institutos, conformados em função da atuação de sindicatos atuantes e combativos, o suposto ${ }^{18}$ baixo coeficiente de organização autônoma dos industriários e, possivelmente, a necessidade de uma maior aproximação entre o Estado e este setor-chave para a economia, implicaram na organização do IAPI a partir do próprio governo. Em 1936 foi composta uma comissão de especialistas em diversos campos, liderada pelo engenheiro João Carlos Vidal, destinada a planejar a criação do IAPI. Esta comissão providenciou para que, pela primeira vez, o pessoal do Instituto fosse relacionado por mérito pessoal e não por interesses ou conveniências, organizando um concurso em âmbito nacional para a seleção do quadro de funcionários. O concurso para o IAPI foi considerado um modelo, sendo precursor para concursos posteriores do sistema através dos quais Vargas e os governos seguintes relacionavam os servidores públicos em geral. (ARAVECCHIA-BOTAS, 2016)

É interessante observar que o IAPI, órgão através do qual foi construída a maioria das habitações entre a totalidade dos IAPs e a maior parte das unidades de São Paulo, não apresentasse em sua concepção a construção de casas para os associados nem como benefício, nem como forma de aplicação de reservas - embora previsse empréstimos para financiamento de casas para moradia - e, ainda em 1939, não houvesse incorporado este serviço, conforme se lê em "A criação e a organização do Instituto de Aposentadoria e Pensões dos Industriários", publicação do próprio Instituto (IAPI, 1939). Em 1950, porém, o IAPI já contava com uma produção de vinte casas por dia, tendo produzido quatorze mil casas ao final daquele ano, "doze mil construídas de 1946 a 1950", conforme matéria daquele ano na revista Industriários, órgão oficial do IAPI (CASAS PARA OS INDUSTRIÁRIOS, 1950).

Botas (2011) destaca que no IAPI se conformou uma importante Divisão de Engenharia em que se desenvolveu uma política de projetos consistente e atualizada com os novos métodos de construção e fortemente imbuída do ideário moderno, sendo fundamental ao processo o papel do arquiteto Carlos Frederico Ferreira, diretor da Divisão durante toda a existência do Instituto. Durante o Estado Novo (1937-1945), que Botas (2011) identifica como a primeira fase da produção habitacional do IAPI, os projetos são pensados com a pretensão de serem objetos de destaque e representatividade do governo no espaço urbano, sendo projetados por profissionais renomados e, sempre que possível, alocados em regiões centrais ou nos bairros operários. Após o período estadonovista, em 1946 o governo Dutra aponta uma perspectiva de construção massiva de moradias e a produção "assume um

\footnotetext{
18 A suposta falta de organização dos trabalhadores da indústria não parece se confirmar. O sindicato da indústria, conformado na década de 1920, rompeu a noção de organização sindical por ofício e abrangeu todos os ofícios de um ramo industrial e, além disso, recuperou a tradição mutualista, garantindo pensões e aposentadoria a determinados trabalhadores e atividades de recreação e lazer através da organização de uma biblioteca, festas e campeonatos esportivos (GOMES, 2005). Nesse sentido, é possível supor que dada esta organização pioneira, a necessidade do Instituto fosse a princípio pouco sentida.
} 
grau maior de reprodutibilidade", com a adaptação de tipologias utilizadas nos primeiros conjuntos e localização majoritariamente periférica.

Na Divisão de Engenharia do IAPI foi desenvolvida uma gama de tipologias arquitetônicas, como casas térreas isoladas, geminadas, em renque e sobrepostas, sobrados, blocos ou lâminas com múltiplos pavimentos, a serem utilizados nos diversos conjuntos habitacionais produzidos. Foram ainda estipulados critérios para a definição de tipos e densidades utilizadas nos projetos, de acordo com as características dos locais e das cidades em que fossem implantados.

Conforme os critérios de definição de projetos, nos grandes centros urbanos deveriam ser construídos conjuntos de blocos multifamiliares, como o C.R. da Várzea do Carmo e o C.R. da Mooca, bem como edifícios verticais isolados, como o C.R. Japurá. Nas grandes glebas em que fossem implantadas mais de mil unidades, seriam utilizadas tipologias diversificadas entre blocos e casas. É o caso do C. R. Vila Guiomar construído em Santo André, em que são utilizadas duas tipologias de residências, isoladas e geminadas, e dois tipos de blocos, que inclusive haviam sido desenvolvidos para o projeto de Realengo, primeiro conjunto construído pelo IAPI e projetado pelo próprio Carlos Frederico Ferreira, o que é demonstrativo da lógica de padronização de projetos incorporada à produção habitacional do IAPI. (PESSOLATO, 2007)

A habitação era compreendida como serviço social oferecido aos associados e a função da moradia deveria ser complementada pelo próprio Instituto com a implantação de equipamentos e espaços coletivos, como escolas, unidades de saúde, postos de abastecimento e equipamentos de esporte e lazer, embora na prática nem sempre estes tenham sido construídos.

\section{IAPB}

Uma questão importante para a administração do IAPB se refere à construção de casas para residência dos seus associados, "seguindo, aliás, o programa traçado pelo presidente Getúlio Vargas e pelo ministro Valdemar Falcão", conforme descrito em matéria na Folha Bancária daquele ano (MAIS DE CEM CASAS..., 1939, p.6). Nesse mesmo ano são construídos três pequenos conjuntos de residências unifamiliares em bairros importantes de São Paulo, Vila Mariana e Pinheiros. A categoria dos bancários possuía bons salários em comparação às demais categorias profissionais, o que implicava em maiores rendimentos ao IAPB e, possivelmente, em maior flexibilidade na aplicação dos recursos o que permitiu ao Instituto aplicar seus fundos em terrenos com boa localização. (BONDUKI, 2014)

A referida matéria sobre a produção habitacional do Instituto destaca que as moradias feitas pelo IAPB eram de duas naturezas, "por iniciativa do associado e por iniciativa do Instituto", estando entre as últimas "as construções em série, em um mínimo de 20, de casas e apartamentos" (grifo nosso). No caso de a construção ser realizada pelo associado eram fornecidos gratuitamente projetos de diversos "tipos de casas apropriadas às diversas regiões do país, modernos, confortáveis e elegantes" 
(MAIS DE CEM CASAS..., 1939, p.6, grifos nossos). Os projetos de "tipos de casas" eram fornecidos pelo próprio Serviço de Engenharia do IAPB.

O IAPB inicia sua produção habitacional utilizando uma arquitetura tradicional, embora seriada, baseada em unidades unifamiliares isoladas em conjuntos horizontais que eram vendidas aos associados, caso, por exemplo, dos Conjuntos Ibirapuera I e II, construídos na Vila Mariana. Gradativamente seu Serviço de Engenharia desenvolve uma política de projeto particular e já em meados da década de 1940 o órgão passa a adotar duas alternativas: os edifícios multifamiliares verticais isolados, inseridos na malha urbana em áreas muito bem localizadas e o conjunto de blocos multifamiliares de quatro pavimentos implantado em terrenos remanescentes, como o C.R. Nove de Julho, ou em áreas de expansão urbana, como os conjuntos Santa Cruz e Santo Antonio em São Paulo. A nova política se consolida nos anos 1950 quando o Serviço foi dirigido pelos arquitetos Carlos Leão e Aldary Toledo, destacando-se neste momento a produção de edifícios verticais isolados. Situados em regiões próximas ao Centro de diversas cidades, os "Edifícios dos Bancários" representaram o pioneirismo dos IAPs na adoção da verticalização residencial e na difusão de novos modos de morar.

Do "Alvará de Licença para Construir" do C.R. Nove de Julho consta o "Caderno de Encargos" da Carteira Imobiliária do IAPB (Processo n.31.964, 9 de março de 1948). O Caderno traz as "Disposições Gerais e Obrigações Técnicas" a serem respeitadas na execução de projetos e obras para o Instituto, interessando neste momento ressaltar as prescrições quanto aos materiais a serem utilizados. Destaca-se a recomendação para que materiais de acabamento como azulejos, ladrilhos, ferragens e esquadrias fossem "de primeira qualidade", nota importante quando se observa o padrão construtivo - notadamente elevado - das construções do IAPB, mais um indício de sua arrecadação potencialmente superior à de outros IAPs.

Destaca-se também no Caderno a indicação de "especificar preferencialmente produtos fabricados nacionalmente", dentre os quais, cimento Portland, gesso e azulejos cerâmicos. Esta informação revela uma compreensão da relação entre a produção habitacional e a indústria da construção como parte do projeto de desenvolvimento nacional.

\section{IAPC}

A política de projeto da Divisão de Engenharia do IAPC, segundo Bonduki (2014), procurou adaptar sua produção habitacional à baixa capacidade de pagamento dos empregados e assim a maior parte dos projetos são conjuntos horizontais de unidades unifamiliares. Os maiores conjuntos, porém, são mistos, compostos de unidades unifamiliares e blocos multifamiliares e, apesar das restrições orçamentárias, grande parte dos projetos apresentava equipamentos comunitários, como escolas, áreas de lazer, centros comerciais e equipamentos de saúde. 
O engenheiro Ulysses Hellmeister, diretor da Divisão de Engenharia do Instituto dos Comerciários no início da década de 1940, "buscou aliar os princípios de higiene e salubridade à economia" e suas propostas foram utilizadas em alguns conjuntos do IAPC que ficaram conhecidos como "Cidades Jardim dos Comerciários" (BONDUKI; KOURY, 2014, p.107). Estes projetos eram na verdade bastante diferentes da proposta urbanística da Cidade-Jardim inglesa de Ebenezer Howard, combinando relativo adensamento a partir da utilização de casas sobrepostas e escalonadas e grandes áreas verdes. Um exemplo desta tipologia em São Paulo é o C.R. de Perdizes, projeto do próprio Hellmeister e do engenheiro Gregório de Freitas Machado. No Rio de Janeiro o conjunto residencial conhecido como Olaria (1938), com 484 unidades em blocos assobradados distribuídos sobre um grande plano ajardinado é referência desta tipologia.

Na década de 1940, percebe-se a necessidade de aumento da produção que, associada à perspectiva de maior produção habitacional buscada pelo governo Dutra, leva ao abandono da tipologia da cidade jardim de Hellmeister, em função de projetos marcados por maior adensamento e racionalização construtiva. Dois projetos habitacionais propostos a partir deste movimento se destacam em São Paulo, o C.R. Cidade Jardim (não construído) de Eduardo Kneese de Mello e a Comunidade Brasílio Machado Neto, projeto de Osvaldo Corrêa Gonçalves e Heitor Ferreira de Souza bastante próximo do ideário do subúrbio-jardim inglês, parcialmente implantado em Suzano.

Neste momento dirigia a seção de Engenharia da Delegacia de São Paulo do IAPC o arquiteto Francisco J. E. Kosuta ${ }^{19}$ que traça um conjunto de diretrizes a serem seguidas na elaboração de projetos habitacionais. Conforme já mencionamos, estas diretrizes são apontadas por Kneese de Mello em anteprojeto do C.R. Cidade Jardim e incluíam a) a articulação entre a "disposição urbanística e composição arquitetônica, de acordo com os níveis de vida das categorias dos comerciários"; b) a obediência a preceitos gerais de salubridade através da organização interna e externa da unidade, bem como da melhor orientação solar; c) a "consistência econômica, tanto para os segurados locatários como para o Instituto financiador"; d) a padronização das residências ao "menor número de tipos de acordo com as condições locais, sem reduzir a expressão arquitetônica do conjunto"; e) a pré-fabricação de "elementos construtivos ou acessórios, quer estruturais, quer de acabamento". (MELLO, 1945, s/p apud REGINO, 2006, p. 156) ${ }^{20}$.

\section{IPESP}

O IPESP foi criado em 1939 pelo então governador de São Paulo Ademar de Barros para assegurar os benefícios de aposentadoria e pensões aos funcionários estaduais, municipais e de institutos

\footnotetext{
${ }^{19}$ Francisco Kosuta comporia em 1948 e 1953 a Comissão Orientadora do Plano da Cidade de São Paulo. (FELDMAN, 2005)

${ }^{20}$ MELLO, Eduardo Kneese de. IAPC. Delegacia de São Paulo. Conjunto Residencial Cidade Jardim. Anteprojeto II. Arquiteto Eduardo Kneese de Mello. São Paulo: 1945. Acervo particular RALMF.
} 
autônomos, e reforma aos militares estaduais e municipais ${ }^{21}$. Os fundos do IPESP, salvo aqueles destinados a despesas administrativas e ao pagamento dos benefícios, deveriam ser aplicados na aquisição ou construção de residências para os contribuintes, além da aquisição de títulos da dívida pública estadual. Também neste Instituto, portanto, a promoção habitacional aparecia como modalidade de investimento dos fundos de previdência.

Não é possível afirmar que houvesse uma política de projeto estabelecida no IPESP, dado que os conjuntos têm características bastante diversas entre si, apesar de projetados pelo próprio escritório técnico do Instituto. O Núcleo Residencial do Caxingui no Butantã é composto por casas isoladas e geminadas e sobrados isolados, com grande quantidade de áreas verdes entre as unidades; o Núcleo Residencial do Catumbi, no bairro do Belém, é formado por três blocos de três pavimentos com formatos diferentes que compõem entre si pátios internos destinados ao recreio dos moradores; e o Núcleo Residencial Francisco Morato, no Tucuruvi, se constitui de blocos de quatro pavimentos implantados sobre uma grande área verde.

Apesar das diferenças se percebe nos conjuntos uma preocupação com a composição urbanística. Nos três casos os conjuntos são implantados de forma a integrarem-se à paisagem existente, o N.R. do Catumbi, por exemplo, conta com salas comerciais no térreo dos blocos implantados junto ao alinhamento da rua, confundindo-se com outras edificações do bairro do Belém, apesar da criativa composição no interior da quadra. Os dois maiores conjuntos se destacam pela ocupação de extensas áreas em declive com planos urbanísticos que se ajustam à topografia, o que confere grande qualidade ao ambiente construído. Nestes projetos são propostas ainda vias secundárias de acesso às unidades pelo interior das quadras, evidente referência ao padrão Cidade-Jardim.

A produção habitacional do IPESP se inicia na década de 1950 e é parte de um programa habitacional estadual estabelecido por Ademar de Barros. O programa, denominado "Casa Própria - Plano Popular Governador Ademar de Barros" é organizado, segundo Bonduki e Koury (2014), em função da recusa do governador em transferir para a Fundação da Casa Popular os recursos arrecadados do Estado, conforme estipulava a lei referente àquele órgão, tendo solicitado inclusive o fechamento do escritório da FCP em São Paulo. Tal fato ajuda a explicar a inexistência de conjuntos da FCP na cidade. Um único conjunto, o Núcleo Residencial Santo André (1948-49, 400 unidades) foi construído pela FCP na cidade de Santo André, região metropolitana de São Paulo, de modo que, dada a preponderância da produção previdenciária em São Paulo optou-se por não o incluir na análise realizada nesta Tese.

\footnotetext{
${ }^{21}$ A receita do Instituto era formada por: a) uma contribuição do Estado; b) igual contribuição dos municípios interessados e dos institutos autônomos, relativamente aos seus servidores; c) a renda do selo de previdência, de sobre todos os requerimentos e documentos que transitassem nas repartições estaduais, nas entidades interessadas e no próprio Instituto. Constituíam outras fontes: impostos, juros, taxas de serviços, rendas patrimoniais e doações filantrópicas. (SÃO PAULO, 1939)
} 


\section{A indústria da construção e a produção previdenciária da habitação}

O contexto político desenvolvimentista levado a cabo a partir de 1946 com Dutra (1946-50), mas especialmente com o segundo governo Vargas (1951-54) e nomeadamente com o governo JK (195661), criou condições para o crescimento da indústria brasileira. A proposta de desenvolvimento a partir de setores de infraestruturas, como transportes e energia, e o incentivo à indústria de base e automobilística marca definitivamente o território paulista, sendo especialmente estes ramos os que vão se instalar na Grande São Paulo naquele momento. Contudo, o desenvolvimento da indústria de materiais para construção e da própria indústria da construção civil também se vinculam ao projeto desenvolvimentista e são importantes para a análise da produção habitacional realizada entre as décadas de 1940 e 1950.

De acordo com Campos (2012), até 1930 a indústria da construção no Brasil se restringe ao estabelecimento de uma tímida infraestrutura urbano-industrial, com predomínio da atuação de empresas estrangeiras. Entre 1930 e 1955 promoveram-se mudanças estruturais tanto na sociedade quanto no Estado associadas à promoção da industrialização, que incluíram um "reposicionamento da indústria da construção na economia". Este processo se relacionou a

uma demanda de obras públicas no país, com a construção de cidades, infraestrutura urbana, aeroportos, estádios, obras de saneamento, de transporte (em especial rodovias) e de energia (com destaque para as hidrelétricas). Tendo o Estado como indutor do novo padrão de acumulação, centrado no setor industrial, foram criadas agências para a contratação desses empreendimentos de engenharia. (CAMPOS, 2012, p. 38)

Quando se toca especificamente no tema da indústria da construção é possível registrar que as dificuldades de importação pós-1929 implicaram na fabricação de bens de produção necessários ao processo produtivo da construção. A Companhia Brasileira de Cimento Portland, instalada em São Roque (SP) em 1926, atinge a autossuficiência na produção nacional no final da década de 1930 e "entre 1943 e 1952 o consumo aparente de cimento cresceu a taxas médias de 13\% ao ano" (CAMPOS, 2012, p.23). A política favorável à industrialização favoreceu diretamente o setor através da criação da Comissão Siderúrgica Nacional em 1930, que levou à implantação da Usina da Companhia Siderúrgica Nacional em Volta Redonda; durante o governo JK é instalada em Cubatão a usina da Companhia Siderúrgica Paulista (Cosipa).

Associada ao desenvolvimento da indústria de materiais de construção, desde a década de 1930 é possível verificar uma diversificação das empresas vinculadas ao processo produtivo da construção civil (PEREIRA, 1988; GITAHY, 2002; GITAHY; PEREIRA, 2002). "Estas se integram e se consolidam pela organização de diversos subsetores: produção de materiais de construção e equipamentos, construtoras, escritórios de arquitetura e engenharia e serviços imobiliários" (GITAHY; PEREIRA, 2002, p.16). O novo momento registra também regulamentação de associações técnicas, entre as quais 
destacamos a formação do Instituto de Arquitetos do Brasil (IAB) e do Instituto de Pesquisas Tecnológicas (IPT) em 1934.

Outro marco para a construção civil é a própria institucionalização da produção habitacional pelo Estado em 1937 através dos Institutos de Aposentadoria e Pensões e a criação da Fundação da Casa Popular, que carregava um projeto - não implementado - de produção habitacional massiva. Os escritórios técnicos dos IAPs buscavam utilizar materiais de construção nacionais em suas obras, proposta evidenciada no "Caderno de Encargos" do IAPB (PMSP, 1948a). A implementação de ambas as políticas favorece a indústria da construção. A produção habitacional, por um lado, demanda materiais de construção que o Estado produzia ou intentava produzir internamente, como o cimento e o aço, por exemplo, além de materiais de acabamento e, por outro lado, favorecia a atuação de empresas construtoras ou empresas de engenharia que foram as responsáveis pela construção de boa parte dos projetos habitacionais produzidos entre as décadas de 1940 e 1960, ao mesmo tempo em que se criavam inúmeras vagas de emprego no setor da construção.

A produção habitacional se configura, assim, como importante nicho de atuação das construtoras e demais empresas ligadas ao ramo da construção civil, consolidando-se como campo fundamental à indústria da construção (CAMPOS, 2012). Uma perspectiva de produção em massa, distinguida através da racionalização na distribuição dos espaços, uso de novos materiais e tecnologias e da padronização de unidades e elementos construtivos foi fundamental para a competitividade da indústria da construção civil naqueles anos. (GITAHY; PEREIRA, 2002)

É durante governo JK, com a implementação do Plano de Metas, que o setor da construção é alavancado, com nacionalização das atividades e fortalecimento das empresas brasileiras. Desde a década de 1940 foram propostos planos econômicos para o desenvolvimento nacional, entre os quais os Planos Salte e Lafer (FERRARI; NEGRELOS, 2016) e planos estaduais como o do governo Carvalho Pinto em São Paulo, porém, é com o Plano de Metas que se articulam as condições necessárias para o desenvolvimento de setores variados como transporte, energia e indústrias de base, além da construção da nova capital.

Para a realização dos projetos e das obras de Brasília foi criada em 1956 a Companhia Urbanizadora da Nova Capital (Novacap), que representava claramente o novo tipo de relação estabelecida entre o aparato estatal e as empresas de engenharia. Suas funções incluíam a contratação de projetos e de empresas que realizariam as obras, posteriormente coordenando a sua execução, sem atuação direta. Segundo Campos (2012), a construção da nova capital deu oportunidade especialmente para empresas construtoras mineiras, paulistas e cariocas, favorecendo ainda uma aproximação entre empresários que atuavam isoladamente até então, a partir do que se verificou a organização de associações de âmbito nacional, tais como a Câmara Brasileira da Indústria da Construção (CBIC) fundada em 1957. 
Ainda nesse momento, porém, mantinham-se componentes estruturais do projeto inaugurado em 1930. Nesse contexto o quadro institucional de promoção habitacional baseado nos IAPs implicou uma atuação conjunta com o setor da construção envolvido na produção de moradias, registrada em diversos projetos a partir da década de 1950 e, por extensão, na construção de Brasília. Também em Brasília os IAPs foram responsáveis pela promoção de áreas residenciais, as superquadras, cuja construção foi majoritariamente efetuada por empresas construtoras. Vale registrar como exemplo as superquadras SQS 107, 108, 307, 308, promovidas por IAPB e IAPETC, em conjunto com o Banco do Brasil, projetada por Oscar Niemeyer (contratado da Novacap), Marcelo Campello e Sérgio Rocha e construída pela Empresa de Construções Gerais Planalto entre 1958 e 1961, e a SQS 109, promovida pelo IAPB, projetada por Aldary Toledo, José Filgueiras Lima (Lelé) e Luigi Patresi e construída pela Ribeiro Franco S/A, que, inclusive, atua em um dos conjuntos analisados em São Paulo, entre 1960 e 1965. (BONDUKI; KOURY, 2014; FERRARI; NEGRELOS, 2018)

\subsection{O Peronismo e a Justiça social na Argentina (1943-1955)}

Assim como no Brasil, o cenário que antecede o início do processo de institucionalização da habitação pelo Estado argentino elucida o modo como o enfrentamento da questão habitacional se estabeleceu ainda na década de 1910, confirmando-se de maneira mais contundente a partir de 1943. Em 1880 assume a presidência o General Julio A. Roca, dando início à chamada República Conservadora, período de estabilidade política e fortalecimento da economia baseada na agroexportação, com importantes consequências sobre o campo social.

Fortemente marcada pela atuação de seus líderes, cujo grupo ficaria conhecido como Generación del '80, a República Conservadora de características profundamente liberais representava os interesses da elite agrária, promovendo forte impulso à atividade agropecuária. Deste modo, no final do século XIX a Argentina se integra ao mercado internacional como país agroexportador, destacando-se na exportação de grãos e produtos derivados da carne, que em última instância implicariam, inclusive, no desenvolvimento de certa produção industrial vinculada a esta atividade, especialmente na cidade de Buenos Aires. (ROMERO, 2016; GUTIERREZ, 2014)

No entanto, a cidade a partir de então atrai também um grupo economicamente desfavorecido e marginalizado da vida política. Desde 1880 o governo recém-instituído incentivava a imigração com a finalidade de povoar o campo, porém, grande parte dos imigrantes se dirigiu especialmente a Buenos Aires em busca de trabalho na incipiente indústria. É neste momento de amadurecimento do modo de produção capitalista que, particularmente na capital, se aprofunda a estratificação social e se conforma este novo grupo social, o operariado, inicialmente com grande porcentagem de imigrantes. Entre os imigrantes estavam ativistas de orientação socialista e anarquista, de modo que ainda na década de 1890 se formam as primeiras associações de trabalhadores em busca de melhores 
condições de trabalho. A questão social foi lentamente introduzida na pauta de problemas a serem enfrentados pelo setor dirigente, destacando-se um projeto de lei ainda de 1904 que se ocupava da "questão operária" sob o ponto de vista das condições de trabalho.

O projeto da "Ley Nacional del Trabajo" (1904) estabelecia jornada de oito horas e descanso semanal, regulamentava o trabalho infantil, de mulheres e povos indígenas e trazia disposições sobre acidentes de trabalho, condições de higiene e segurança, criação de sindicatos, associações profissionais e tribunais de conciliação e arbitragem, entre outras questões pertinentes ao tema. O projeto não foi aprovado, porém é preciso reconhecer o pioneirismo da proposta, até porque algumas de suas disposições, por exemplo, quanto ao trabalho dominical, foram transformadas em lei (PALLERO, 2014). Em março de 1907 o então presidente José Figueroa Alcorta cria o Departamento Nacional del Trabajo, com a missão de "coletar, coordenar e publicar todos os dados relativos ao trabalho na República, especialmente quanto às relações entre trabalho e capital e às reformas legislativas e administrativas capazes de melhorar a situação material, social, intelectual e moral dos trabalhadores". (HISTORIA DEL MINISTERIO..., tradução nossa)

Os fenômenos do crescimento econômico, do processo de urbanização e da imigração alteraram substancialmente a sociedade portenha, tanto quanto à sua organização e estruturação, quanto à possibilidade de mobilidade social, constituindo-se e ampliando-se nesse começo do século XX os estratos médios. A classe média urbana era na realidade um grupo vasto e heterogêneo, formada por pequenos industriais, prestadores de serviços e comerciantes, pessoas ligadas à imprensa, com forte destaque para a presença de imigrantes que, portanto, não se restringiam à classe operária. (HORA; LOSADA, 2011)

Em 1916, nas primeiras eleições em que se permitiu o acesso ao sistema eleitoral por outros grupos sociais além da elite oligárquica ${ }^{22}$, é eleito um representante da União Cívica Radical (UCR), partido de cunho socialdemocrata e formado predominantemente por membros da classe média argentina, tendo início o que se chamou de Governo Radical. (ROMERO, 2016)

A eleição do candidato antissistema e líder da UCR, Hipólito Yrigoyen, produziu uma separação entre o poder político e o poder econômico, isto é, entre a nova elite dirigente e a elite agrária responsável por gerar o capital que promovia a modernização do país. Yrigoyen buscou promover um diálogo entre Estado e classe operária e embora esta postura não caracterizasse uma política estatal de fato, era importante como forma de demonstrar à oligarquia anteriormente no poder sua capacidade de manter a ordem.

Contudo, o vínculo entre a classe trabalhadora e o governo radical "não chegou a ser estável nem permanente" (DEL CAMPO, 1983, p. 23). Após a Primeira Guerra Mundial ocorre uma intensificação

\footnotetext{
22 Em 1912, é aprovada a Lei Geral de Eleições, conhecida como Ley Sáenz Peña (ARGENTINA, 1912), que estipulava o voto obrigatório e universal, acabando com a democracia restritiva vigente até então. Essa decisão, segundo Torre (2012) uma tentativa de legitimar o regime político oligárquico, acabou não apresentando o resultado esperado.
} 
de lutas sociais por direitos trabalhistas que culminou no episódio conhecido como "Semana Trágica" (entre 7 e 14 de janeiro de 1919). A permanência do governo radical passa a depender a partir de então de uma atitude de repressão aos movimentos populares. Apesar disso algumas medidas foram adotadas em prol da questão social durante o governo de Torcuato de Alvear, sucessor de Yrigoyen, com destaque para um conjunto de leis trabalhistas.

O radicalismo seguiu com relativa estabilidade no poder até a deflagração da crise de 1929 , que implicou um retrocesso da atividade agrícola-pecuária, a diminuição do valor da moeda nacional e o prejuízo às atividades industriais, especialmente àquelas que dependiam de matéria prima importada. Em setembro de 1930 o poder é retomado pela classe dominante ligada à agroexportação. Para manter as finanças o novo governo limita seus gastos, aumenta os impostos e implementa um novo modelo econômico calcado em medidas de cunho protecionista, que rapidamente promoveram a recuperação da economia. As novas condições do mercado internacional tornam fundamental o desenvolvimento da indústria, que cresce ao longo da década de 1930, devido especialmente a um aumento populacional urbano, com forte componente migratório.

Em 1943 os ânimos políticos se agitavam pela descontinuação do governo liberal-oligárquico e o Grupo de Oficiales Unidos (GOU) organiza o golpe conhecido como Revolución del 43 que dá início a um regime militar que dura três anos. O General Juan Domingo Peron assume o Ministério da Guerra em junho de 1943, sendo esta já uma primeira experiência que o coloca em contato com as agremiações e lideranças sindicais, em que demonstra habilidade política em um campo até então inexplorado pelos militares. Paralelamente, Perón assume o Departamento Nacional do Trabalho ${ }^{23}$.

A promoção de políticas de benefício à classe trabalhadora por parte de Perón tem início praticamente no mesmo dia em que assume o Departamento Nacional do Trabalho em 1943, a partir da indicação de novos objetivos e da revitalização do órgão. Perón procurou destacar a importância de uma ação sobre o corpo social como forma de consolidar o novo governo e logo promove este departamento a Secretaria de Trabajo y Prevision Social (Decreto-Ley n. 15.074/43). É nesta posição que Perón inicia uma política de aproximação com as classes trabalhadoras, que, em última instância, o levará à presidência em 1946. À frente da Secretaria, conforme descreve Gambini (2014), Perón iniciou uma tarefa de instrução política e social dos trabalhadores complementada com realizações concretas no campo social, procurando garantir direitos à classe trabalhadora ${ }^{24}$.

A proposta de Perón, ainda à frente da Secretaria, era estabelecer as condições para alcançar a "Justiça Social", entendida como a elevação do nível de vida da maior parte da população, "a partir da

${ }^{23}$ O então diretor do Departamento Nacional do Trabalho, o Coronel Carlos Gianni, iniciava também uma política de aproximação das massas, mantendo literalmente as portas abertas para que o povo pudesse fazer suas reivindicações. 0 coronel buscava tornar esta ação pública, convidando oficiais, professores e lideranças sindicais para conferências sobre as obras do Departamento, atraindo a atenção de Perón, que reivindica o cargo.

24 Entre as realizações da Secretaria pode-se mencionar a Criação dos tribunais de trabalho, a regulamentação de associações profissionais, a garantia de férias remuneradas, a prevenção de acidentes de trabalho, o "13으 salário" (aguinaldo), a extensão do regime de aposentadorias, os convênios coletivos de trabalho. (HISTORIA DE LA VIVIENDA.,s/d) 
redistribuição equitativa da renda, fundamentando a Independência econômica e consequentemente a soberania política" (HISTORIA DE LA VIVIENDA..., s/d, p.8, tradução nossa). Seu projeto considerava a expansão da indústria de bens de consumo e o aumento dos salários, de modo que o operário pudesse consumir mais, o que, se supunha, levaria a um aumento da produção.

Em outubro de 1945, devido à postura de aproximação com os trabalhadores que desagradava às elites, Perón é convocado a abandonar seus cargos. Após grande manifestação com ameaça de greve generalizada no país no dia 17 de outubro de 1945, o então presidente Farrel renuncia e Perón, que se achava preso, é libertado. Eleições são convocadas em fevereiro de 1946, com vitória do Partido Laborista (Peron-Quijano).

Um grupo da população em especial seria responsável pela vitória de Perón: os trabalhadores migrantes que chegam a Buenos Aires entre as décadas de 1930 e 1940 em busca das oportunidades de emprego oferecidas pela industrialização, que compunham um novo operariado sem tradição sindical. Esta população permanece alheia às organizações e reivindicações trabalhistas, gozando de poucos ou nenhum dos privilégios por elas adquiridos. Estando excluída física, política e socialmente esta população recebe a atenção de Perón, e, em troca, dedica a ele seu apoio. O vocativo "Mis queridos descamisados", em referência aos trabalhadores "companheiros" para os quais se dirigia o Justicialismo, é utilizado a partir de 17 de outubro de 1946 no discurso de Perón, quando da comemoração do "Día de la Lealtad" (Dia da Lealdade).

O desenvolvimento da indústria é ponto focal do governo peronista, a partir do que não apenas se alcançaria a soberania nacional e a independência dos capitais estrangeiros, como se possibilitaria a criação de postos de emprego para a população, visando-se uma economia de pleno emprego. Uma das primeiras medidas de Perón como presidente consistiu na regulação da economia, transferindo recursos do setor agrícola para o industrial. Esta medida, se por um lado fazia crescer a atividade industrial, por outro enfraquecia o poder econômico da elite agrária. Entretanto, assim como no Brasil, a elite agrária continuava a ser o grupo de fato responsável por gerar o capital necessário ao processo de modernização e industrialização, não podendo ser prescindido pelo governo. A solução encontrada pelo Estado peronista foi estabelecer o controle governamental sobre as instituições financeiras, nacionalizando o sistema bancário e convertendo a política creditícia e monetária em uma alavanca para o desenvolvimento industrial, garantindo a aplicação de recursos onde fosse necessário. (LA NACIÓN ARGENTINA..., 1950)

Tal esquema se inicia com a nacionalização do Banco Central da República Argentina, que se converte em instrumento de ação do governo. Tornam-se atribuições do Banco e, logo, do Estado, a emissão da moeda, a regulação dos créditos bancários e a fixação das taxas de câmbio. $O$ passo seguinte foi a nacionalização dos depósitos, isto é, todos os demais estabelecimentos bancários deveriam registrar 
os depósitos em nome do Banco Central. Esta medida colocava à disposição do governo, "ao serviço do bem-estar da sociedade", toda moeda e crédito. (SETTIMI; AUDINO, 2012)

O Estado assumiu sob seu controle direto a criação de todo o dinheiro, não apenas dos ingressos. A quantia de dinheiro [disponível] deixava de estar ligada às reservas internacionais ou aos depósitos do público. Importavam as autorizações que o Banco Central outorgava às instituições financeiras para que estas injetassem dinheiro na economia, através da concessão de empréstimos, convertendo-se em meros intermediários que trabalhavam em comissão. Eles não tinham capacidade para decidir quem beneficiar com os créditos ou quais taxas cobrar, estas eram competências exclusivas do Banco Central que refletiam as prioridades oficiais. (SETTIMI; AUDINO, 2012, p.242, tradução nossa)

Outra de suas primeiras medidas foi a criação do Instituto Argentino para la Promoción del Intercambio (IAPI), responsável por controlar as transações econômicas e os preços de mercado, reunindo recursos para financiar a industrialização. A transferência de capitais do setor agrário (ou de quaisquer setores) para o industrial não era apenas uma tentativa de enfraquecimento da elite agroexportadora, mas um projeto de redistribuição da renda, tendo um beneficiário bastante específico: a classe trabalhadora, conforme é explicitado na publicação oficial do governo "La Nación Argentina Justa Libre Soberana" (1950). A aplicação do capital em novos empreendimentos produtivos e não especulativos garantiria o desenvolvimento industrial, capaz de gerar emprego e justa compensação para a população. Nos três primeiros anos do governo peronista (1946-1949) os salários dos funcionários públicos tiveram aumento de $35 \%$, enquanto os salários dos trabalhadores industriais aumentaram em média 50\%, o que favoreceu diretamente o mercado interno, com aumento de consumo de aproximadamente $20 \%$ no período. (LA NACIÓN ARGENTINA..., 1950)

A Doutrina Justicialista, concretizada no Poder Executivo a partir de 1946 através de uma coerente planificação estatal e regulamentada posteriormente através de nova Constituição Nacional, buscou materializar uma comunidade organizada sob as bandeiras "soberania política, independência econômica e justiça social" (LARRAÑAGA; PETRINA, 1987). Pela primeira vez se aplicava uma rigorosa planificação de governo: cada estrutura do Estado tinha um objetivo particular que se articulava em um objetivo comum expresso no Plano de Governo, posteriormente conhecido como "Primer Plan Quinquenal", a ser implementado entre 1947 e 1951.

O Primeiro Plano Quinquenal buscou no plano econômico desenvolver o mercado interno e fazer crescer a indústria argentina de bens de consumo e no plano social promover justiça para a maioria, ampliando as aspirações de progresso da população. Entre as "obras sociais" previstas no Plano Quinquenal estavam "o Trabalho", "a Previdência" e "a Habitação", convertidas não apenas em propostas de ação, como em projetos de lei. (PERÓN, 1946)

A primeira-dama Eva Perón teve importante papel simbólico no processo de implementação do Primeiro Plano Quinquenal, nomeadamente no seu viés social. Grande quantidade de obras voltadas ao povo seria desenvolvida através da Fundación Ayuda Social Maria Eva Duarte Perón, ou 
simplesmente Fundación Eva Perón, símbolo da profunda transformação que fazia o peronismo na vida social do país (HISTORIA DE LA VIVIENDA.... s/d). A Fundação Eva Perón é constituída em 1948 pelo Decreto n. 20.564 e abordava o tema da ajuda social a partir do pressuposto de que no atendimento das necessidades essenciais para proporcionar uma vida digna às classes menos favorecidas o conceito de caridade deveria ser substituído pelo de Justiça Social. O papel da Fundação era estabelecer um nível mínimo de existência e garantir que a ajuda alcançasse todo o povo, ao mesmo tempo almejando o pleno emprego da população. A frase "Perón cumple, Evita dignifica" era repetida entre as famílias atendidas e é fato que "uma percentagem considerável do pressuposto nacional foi dedicada a atender as necessidades sociais básicas das classes trabalhadora e média, nunca antes contempladas pelas administrações liberais." ${ }^{25}$ (LARRAÑAGA; PETRINA, 1987, p.109, tradução nossa)

Em 1949 é promulgada a Nova Constituição Argentina, a ferramenta jurídica que transformava em lei a Doutrina Justicialista. Entre os muitos temas abordados pela nova constituição é preciso destacar a declaração dos direitos especiais do trabalhador e o tratamento do caráter social da propriedade privada, do capital e da atividade econômica. O Artigo no 37 trazia a Declaração dos Direitos dos Trabalhadores, proclamada pelo Presidente Perón em fevereiro de 1947, transformada no Decreto № 4865 , e então incorporada à Constituição. A declaração resumia dez direitos básicos do trabalhador ${ }^{26}$ entre os quais o direito ao bem-estar, que incluía moradia, indumentária e alimentação adequadas.

Outra medida importante implementada por Perón foi a criação de empresas estatais e a nacionalização de empresas estrangeiras de diversos setores. Em 1947 é criada a Dirección Nacional de Industrias del Estado (D.I.N.I.E.), que administrou a partir de então diversas empresas relacionadas a setores estratégicos para o desenvolvimento industrial, tais como, mecânicas, têxteis, químicas e de materiais de construção, a maioria de origem alemã, estatizadas desde quando a Argentina se opôs ao Eixo em 1945. Mais do que representar a institucionalização da prestação destes serviços por parte do Estado, estas empresas criaram junto aos trabalhadores a elas vinculados uma noção de pertencimento ou ligação direta entre o modelo econômico peronista e as demandas da classe trabalhadora. Essa noção foi fundamental para a conformação de um sentimento de nacionalismo econômico e social, com um importante contexto de classe. (GUTMAN; HARDOY, 1992; TORRE, 2012)

\footnotetext{
${ }^{25}$ Não existe um número oficial das obras realizadas pela Fundação Eva Perón em todo o país, mas dentre elas é possível citar: três albergues (hogares de tránsito) na Capital Federal e outros em distintos pontos do país; 13 hospitais-gerais, os chamados "policlínicos", em todo país; cinco hospitais-modelo no interior e na Grande Buenos Aires; 21 lares para empregadas, anciãos, etc; escolas de distintos graus; jardins de infância; conjuntos esportivos; 150 centros de abastecimento (proveedurías) na Capital Federal (HISTORIA DE LA VIVIENDA..., s/d).

${ }^{26}$ Os demais direitos do trabalhador incluíam o direito ao trabalho, à retribuição justa, à capacitação, a condições dignas de trabalho, à saúde, à segurança social, à proteção familiar, à melhoria econômica e à defesa dos interesses profissionais. (ARGENTINA, 1949)
} 
Se no Brasil a historiografia compreendeu que a conformação da identidade política do trabalhador se deu a partir do Estado varguista, na Argentina se compreendeu o Estado peronista como uma ruptura na história da conformação da identidade política da classe trabalhadora. Os primeiros estudos sobre o peronismo, ainda na década de 1950, o consideraram como um momento de anormalidade política, determinado por circunstâncias que uma vez desaparecidas implicariam na sua extinção. Contudo, hoje é possível afirmar que o peronismo como ideologia se incorporou à realidade argentina, especialmente entre a classe trabalhadora, o que nos últimos anos fez surgir estudos que o compreendem não mais como ruptura, mas como etapa da história do movimento operário argentino. (DEL CAMPO, 1983; TORRE, 2012)

Hugo del Campo (1983) procura enfrentar o que chama de "versão apocalíptica" que divide a história do movimento operário em dois momentos díspares e sem conexão, "separados por uma espécie de catástrofe", após a qual desaparecem os anos anteriores e surge um novo tipo de trabalhador totalmente novo. A importância de seu trabalho para a história do movimento operário na Argentina é a de procurar demonstrar que no Estado Peronista houve a persistência de características do modo de organização dos trabalhadores em períodos anteriores, portanto, admitindo não apenas o pertencimento do peronismo como momento de constituição da identidade coletiva do trabalhador, como também a postura ativa do trabalhador nesse processo.

O estudo da organização política da classe trabalhadora na Argentina até o Peronismo, segundo Del Campo (1983) pode ser dividido em três períodos. O primeiro se inicia na década de 1890 , quando ocorre grande aumento da população operária, especialmente em função da imigração, e segue até 1916, quando se inicia o Governo Radical de Yrigoyen e se caracteriza por propostas variadas de organização, com destaque para o socialismo e o anarquismo.

Os imigrantes alemães foram os principais responsáveis pela divulgação do socialismo na Argentina ainda nos primeiros anos da década de 1890. Em 1896 é fundado o Partido Socialista argentino, considerado a primeira forma de organização política do proletariado no país. Do programa do partido constavam reivindicações que mais tarde se confirmaram como leis trabalhistas, como a jornada de 8 horas, o descanso obrigatório, a igualdade de condições de trabalho e remuneração entre homens e mulheres, além de questões referentes à higiene e segurança no ambiente de trabalho (DEL CAMPO, 1983). Vale ainda mencionar que os socialistas seriam, ao lado da Igreja Católica, o principal grupo a se organizar em função da produção de moradias para os trabalhadores. Apesar da forte organização socialista a corrente anarquista foi predominante entre os trabalhadores argentinos naqueles primeiros anos do movimento operário. Segundo Aiziczon (2016) o anarquismo teve grande aceitação entre os trabalhadores porque no âmbito desta corrente se desenvolveu uma intensa atividade assistencialista, com a criação de bibliotecas e teatros populares e a realização de palestras e atividades para crianças, além disso, com a publicação de livros e periódicos em várias 
línguas. A corrente anarquista foi hegemônica no movimento operário argentino até a década de 1910, quando se propagam entre os trabalhadores outras correntes de esquerda, como o comunismo e o próprio socialismo, que traziam em seu bojo aspirações políticas e partidárias, justamente em um momento de mudança do sistema eleitoral argentino que tornaria possível a sua participação nas eleições, enquanto o anarquismo se mantinha fora deste esquema.

O segundo período de conformação da identidade política da classe operária se inicia em 1916, no governo de Hipólito Yrigoyen e se estende até 1930, com o fim dos Governos Radicais. A interpretação tradicional, segundo Torre (2012, p.13), via nos governos radicais exercidos entre 1916 e 1930 fator fundamental para a "falta de correspondência entre condição operária e identificação política de classe", atrapalhando o processo de conformação da classe operária como ator político de duas formas principais. Por um lado, à medida que se abria às demandas dos trabalhadores, o Estado conseguira retardar o enfrentamento entre classe operária e a classe dominante e, com isso, frear a influência socialista. Por outro lado, a aprovação de medidas de proteção social (leis de aluguéis, leis de aposentadorias, entre outras) e o aumento de salários durante esses governos garantiram o apoio de lideranças sindicais, inclusive nas urnas, determinando certo tipo de clientelismo político. Essa visão, como se percebe, retira da classe trabalhadora sua autonomia, extinguindo a possibilidade de arbítrio na relação/negociação com o Estado como parte do processo de conformação da sua identidade política.

A comunicação entre governo radical e classe trabalhadora ocorre fundamentalmente através de uma nova corrente de organização trabalhista, o Sindicalismo, e essa ligação, bem como o predomínio da corrente sindicalista durante os governos radicais, não ocorrem por acaso. Por um lado, as visões socialista e anarquista, cujas armas eram, respectivamente, a ação partidária e a greve geral, são gradativamente superadas por uma visão mais orientada a buscas por reformas no interior da própria fábrica com objetivos concretos para atender às necessidades de uma classe bastante heterogênea. As lideranças sindicalistas conduziam as associações de trabalhadores cuja atividade era chave para a economia: ferroviários e marítimos, daí o forte interesse do governo em estabelecer com elas um bom relacionamento. (TORRE, 2012)

Por outro lado, enquanto os socialistas se posicionavam contra o governo radical, especialmente em função da inserção do tema da ajuda social no horizonte estatal, e os anarquistas se opunham ao próprio sistema político, os sindicalistas percebem a conveniência da negociação com o Estado como possibilidade de atingir os objetivos da classe trabalhadora e estabelecem um diálogo direto com o presidente Yrigoyen, buscando obter através do Estado aquilo que não conseguiam na esfera do mercado. (DEL CAMPO, 1983; TORRE, 2012) 
Em 1930 se constitui a partir de um acordo entre socialistas e sindicalistas a Confederación General del Trabajo $(\mathrm{CGT})^{27}$, que fundia as duas centrais sindicais mais antigas do país, a Unión Sindical Argentina e a Confederación Obrera Argentina. Em função do desenvolvimento da atividade industrial a CGT se converteria em uma ampla organização e ao longo da década se tornaria a única central sindical do país, com a adesão dos comunistas e a diminuição da influência anarquista.

Desde 1930 até 1943, quando Perón dá início ao projeto justicialista, o Sindicalismo se mantém forte entre os trabalhadores através da CGT, porém sem contar com a relação direta com o Estado estabelecida durante os Governos Radicais. Em 1943 se inicia o terceiro período de organização política dos trabalhadores e a partir de 1946 o movimento operário, especialmente em sua vertente sindicalista, atuou ativamente em conjunto com política estatal de Perón, assim permanecendo até 1955, quando termina sua segunda presidência.

A integração entre Estado e sindicatos se deu por duas vias principais. De um lado, através da conquista de demandas históricas e, de outro, através da participação de líderes sindicais no interior do aparato estatal, cuja indicação ocorria por via direta, pelo próprio Perón. Favorecidos também por uma política de crédito muitos sindicatos construíram seus próprios hospitais e colônias de férias. No entanto, desde 1946, a classe trabalhadora buscou definir os termos pelos quais participava da política peronista, garantindo o cumprimento das medidas trabalhistas e sociais pelas quais elegera Perón. Não deixam de ocorrer manifestações e greves, registrando-se, ao contrário, o maior número de episódios nos três primeiros anos do governo, basicamente com o objetivo de se fazer cumprir as deliberações estabelecidas pela nova legislação justicialista. (DEL CAMPO, 1983)

Neste sentido, assim como no caso brasileiro, vale questionar a noção amplamente difundida de que os benefícios econômicos e sociais promovidos aos trabalhadores foram uma doação ou dádiva do Estado. Conforme afirma del Campo (1983), o fato mesmo de o peronismo persistir como ideologia entre os trabalhadores após o governo de Perón faz cair por terra as interpretações de "manipulação desde o alto".

\subsection{0 processo de institucionalização da produção habitacional na Argentina}

A construção estatal de moradias para os setores de menores recursos foi um feito comum a outros países no mesmo período, porém este processo conheceu na Argentina características próprias, ligadas à qualidade particular da relação entre Perón e seus seguidores. [...] O peronismo manteve um sistema de vasos comunicantes com os setores do trabalho. (ABOY, 2005, p.12, tradução nossa)

\footnotetext{
${ }^{27}$ Em 1935, socialistas e sindicalistas entram em choque, causando a divisão da central em CGT-Independencia (socialistas e comunistas) e CGT-Catamarca (sindicalistas). Esta última se converteria na base de sustentação do movimento peronista.
} 
Entre 1946 e 1955 o Estado se propõe a construir 500.000 unidades de habitação econômica ${ }^{28}$, das quais foi construído um número menor, em torno de 300.000 , embora a precisão dos números seja dificultada pela destruição de arquivos desde 1955 (LARRAÑAGA; PETRINA, 1987). A maior parte dos projetos foi concebida e executada entre 1948 e 1949, logo após a promulgação do Primeiro Plano de governo. O número de famílias atendidas é ainda maior se considerarmos os 300.000 créditos destinados à compra ou construção de casas outorgados pelo Banco Hipotecário durante toda a chamada década peronista (1946-1955) - enquanto desde 1886, quando é criado, até 1946 são outorgados 20.000 créditos. (LARRAÑAGA; PETRINA, 1987; ABOY, 2005)

Contudo, é possível definir uma periodização do processo de institucionalização da produção habitacional, com base especialmente nas características das ações diretas e indiretas do Estado desde o final do século XIX, quando das primeiras reivindicações sociais por melhores condições de moradia. O primeiro período, entre 1887, ano da construção do primeiro conjunto habitacional estatal, e 1943, ano do golpe militar, compreende o início do debate sobre a moradia econômica e do próprio processo de institucionalização da produção habitacional pelo Estado. O segundo período vai de 1943, quando Juan Domingo Perón assume a Secretaria de Trabajo y Previsión, a 1955, quando termina a presidência de Perón, abrangendo os anos em que a produção habitacional é encarada como parte de um programa de desenvolvimento econômico e social.

Entre 1887 e 1943 são aprovadas as primeiras leis relacionadas à questão habitacional, enquanto é criado o primeiro órgão estatal destinado à provisão da habitação, a Comisión Nacional de Casas Baratas. Paralelamente, e de forma mais contundente, o período é marcado também pela ação privada, que, influenciada principalmente por ideais socialistas, se organizaria em função da produção de moradias para os trabalhadores.

A solução do alojamento se dava de formas variadas e assumiu versões coletivas e unifamiliares que até a década de 1940 foram mais ou menos utilizadas em função especialmente das possibilidades financeiras das famílias ocupantes e do desenvolvimento de meios de transporte coletivo, que possibilitaram o progressivo afastamento desta população do Centro. A casa de inquilinato ou conventillo, principal alternativa dos imigrantes, se origina da subdivisão da típica casa colonial ainda em meados do século XIX ${ }^{29}$. Denominava-se assim também construções novas ou improvisadas por particulares, que consistiam em uma série de quartos ao redor de um pátio, cuja finalidade era abrigar muitas famílias, o que implicava em grandes problemas de ordem higiênica e social e, ao

\footnotetext{
${ }^{28}$ A cifra corresponde, segundo os autores, a unidades habitacionais que preenchiam os requisitos exigidos pelas operatórias da época, como a existência de serviços de infraestrutura básica (pavimentação, água potável, esgoto, eletricidade, gás, etc.), a utilização de materiais não perecíveis (concreto armado, alvenaria, etc.) e técnicas de construção que resolvessem adequadamente os aspectos de isolamento ambiental, o atendimento às normas acerca das áreas mínimas totais e por cômodo, bem como o cumprimento da relação entre o número de habitantes e a quantidade de quartos e a proximidade com equipamento comunitário. (LARRAÑAGA; PETRINA, 1987)

${ }^{29}$ Após as epidemias de cólera e febre amarela na década de 1870, quando muitas famílias se mudaram para o Norte da cidade de Buenos Aires, famílias imigrantes se alojaram nos casarões abandonados ao Sul da área central.
} 
mesmo tempo, conformava um espaço de alta sociabilidade, onde se desenvolveram expressões artísticas como o próprio tango ${ }^{30}$.

As soluções unifamiliares apresentavam-se como uma superação das más condições do conventillo e a busca pela casa própria era associada a uma "ética de esforço e superação" (ABOY, 2005, p.26). As moradias se concretizavam pela compra do lote à prestação e geralmente através da autoconstrução, distinguindo-se: a) a "casa chorizo", símbolo do fracionamento especulativo da terra tanto em áreas já urbanizadas quanto de áreas de expansão urbana, uma construção estreita e de grande comprimento, que partia desde a rua em direção ao fundo do lote agregando cômodos contíguos (não raro construídos em tempos diferentes, à medida que os recursos permitissem) ao longo de um corredor lateral, sendo predominante em Buenos Aires entre as décadas de 1910 e 1940; b) a casilla, unidade exígua em peça única construída em madeira e chapas de zinco, geralmente de caráter transitório; c) a "casa cajón" que consistia em um retângulo repartido em quatro peças com funções específicas: cozinha, estar, dormitório e banheiro, mais difundida já na década de 1930; e d) os "ranchos", construções simples com materiais locais, geralmente construídos em áreas pouco urbanizadas, especialmente terrenos baixos e inundáveis, sendo a opção inicial de migrantes vindos do interior do país. (ABOY, 2005; CRAVINO,2009; HISTÓRIA ARGENTINA DE LA VIVIENDA..., s/d) Segundo Cravino (2009) a alta concentração urbana associada a formas precárias de morar é considerada um problema de saúde pública desde os últimos anos do século XIX e, assim como no Brasil, os médicos higienistas foram os primeiros profissionais a se preocupar com a questão da moradia na Argentina, ocupando-se especialmente da casa operária. Inicialmente os discursos abordavam a salubridade do habitat e gradualmente se preocupariam com temas morais e sociais, como a promiscuidade, o alcoolismo, o papel da mulher e o abandono infantil ${ }^{31}$, conforme registrado pelo médico Juan Dassen em "Algunas consideraciones sobre la vivienda obrera en la Argentina", matéria publicada em "Habitación Popular" (publicação oficial da Comisión Nacional de Casas Baratas) em 1942.

Em julho de 1904 o deputado Ignacio Yrigoyen apresenta à Câmara dos Deputados o primeiro projeto de lei de "Casas para Obreros". O projeto autorizava a Municipalidade de Buenos Aires a emitir títulos para compra de terrenos adequados à construção de grupos de casas isoladas unifamiliares, destinadas às famílias operárias (RIGOTTI, 1991). Em outubro de 1905 é promulgada a Ley de Casas para Obreros, ou Ley Yrigoyen, a primeira lei referente à moradia na Argentina (Ley n. 4.824/1905). Por seu caráter precursor, é possível considerar, segundo Rigotti (1991), que assenta as bases da compreensão da moradia operária como necessidade social. A lei autorizava a Municipalidade de

\footnotetext{
${ }^{30}$ São bastante característicos do bairro de La Boca em Buenos Aires os conventillos construídos com madeira e chapas de zinco, onde teria se desenvolvido o tango.

${ }^{31}$ É possível mencionar os escritos de Samuel Gache, "Les logements ouvriers a Buenos-Ayres". Paris: G. Steinheil, 1900; e Guillermo Rawson, “Estudio sobre las casas de inquilinato de Buenos Aires”. [Buenos Aires]: Imprenta La Vanguardia, 1883.
} 
Buenos Aires $^{32}$ a emitir títulos destinados a um fundo para a construção de casas operárias em terrenos fiscais e ainda possibilitava que o Estado transferisse terrenos seus ao município para este fim. Foram construídos a partir da Ley Yrigoyen o Barrio Butteler (1907, 64 unidades) e o Barrio Patrícios (1910, 116 unidades), ambos constituídos por casas isoladas. A aprovação da lei pode ser compreendida também como uma tentativa de enfrentamento do socialismo, que naquele mesmo ano se organizava para produzir moradias aos trabalhadores.

Em julho de 1905, por iniciativa de um grupo ligado ao movimento socialista, é criada a cooperativa "El Hogar Obrero" (EHO). A cooperativa nasce com o objetivo de contribuir para a solução do problema da moradia operária e, ao longo do tempo, desenvolve também seções de crédito e uma importante atividade educativa e cultural. Além de empréstimos hipotecários aos associados que desejassem construir sua moradia, a EHO construiu também unidades isoladas e "barrios obreros" (vilas operárias), atuando em seus primeiros anos especialmente na capital federal. O primeiro Barrio Obrero da EHO foi construído em Buenos Aires em 1911 com 21 unidades do tipo chalé, mas, a partir de então, se iniciaria a construção de conjuntos formados por "moradias coletivas", blocos multifamiliares, que logo incorporariam equipamentos e salas comerciais. (HISTÓRIA...)

Dentro de uma postura religiosa que se convencionou chamar "Doutrina Social da Igreja", setores ligados ao catolicismo começaram também a enfrentar a "questão social", conformando em Buenos Aires a Liga Democrática Cristiana, em resposta à encíclica papal de 1891, sobre os direitos dos trabalhadores. Entre 1907 e 1908 a Liga promove conferências onde diversas figuras ligadas ao movimento discursam sobre projetos sociais. Entre estas figuras está o médico e deputado Juan Félix Cafferata, cujo discurso realizado em 1907 reivindicava melhoramentos na moradia operária. Anos depois Cafferata teria papel fundamental nos primeiros passos para a institucionalização da produção habitacional na Argentina.

Com o propósito de estabelecer um órgão de estudo e ação social e inspirado pelo "Musée Social de Paris", em junho de 1911, o engenheiro agrônomo Tomás Amadeo funda o Museo Social Argentino (MSA). Reconhecendo a necessidade de cooperação intelectual, sob disciplina científica, o objetivo do MSA era, por um lado, conhecer e estudar os problemas sociais, a fim de propor soluções que atendessem às necessidades do país e, por outro lado, reunir e sistematizar as informações obtidas para que fossem de fácil acesso a estudiosos, legisladores e promotores de ações sociais. Segundo Zanzottera (2013) o MSA pode ser entendido como um espaço associativo que propunha a mediação entre o Estado e a sociedade, buscando vincular o desenvolvimento científico, os novos profissionais e as burocracias estatais. Compunham o grupo fundador do MSA profissionais e especialistas de diferentes organizações sociais, culturais e econômicas. Muitos membros ligavam-se ao aparato estatal (deputados, senadores, ministros), embora pertencentes a diferentes correntes políticas, e a

\footnotetext{
${ }^{32}$ Vale lembrar que naquele momento a capital Buenos Aires não possuía autonomia administrativa.
} 
diversas instituições nacionais e internacionais, o que foi fundamental para a consolidação institucional do MSA. (ZANZOTTERA, 2013)

Questões relacionadas à habitação urbana e rural foram tratadas esporadicamente no Boletín del Museo Social Argentino até 1920. Considerando vantajosa a discussão pública e partindo da análise das conclusões de outros eventos sobre a questão da habitação, o MSA dedica número integral do Boletín de 1920 ao problema da moradia e propõe no mesmo ano a realização de um congresso sobre o tema, o Primer Congreso Argentino de Habitación, sobre o qual se tratará oportunamente.

Em 1915 o deputado Juan Cafferata propõe uma nova lei referente à moradia, a partir da qual se institui o primeiro órgão estatal responsável pela promoção da moradia argentina, a Comisión Nacional de Casas Baratas (CNCB). A Lei n. 9677, a "Ley Nacional de Casas Baratas", buscava dotar a família trabalhadora de moradia cômoda e higiênica, financiando um aluguel barato ou mesmo a aquisição da moradia. As linhas de ação previstas incluíam, por um lado, a ação direta através da inversão de fundos próprios da CNCB na construção de moradias a serem vendidas ou alugadas a "operários, jornaleiros e empregados de pequenos rendimentos" e, por outro, a ação indireta com o estímulo à iniciativa privada através de créditos e liberações de impostos. Seriam consideradas casas baratas as moradias individuais ou as casas coletivas

situadas em locais próximos ou de fácil acesso a locais de concentração operária; que sejam destinadas, por aluguel ou venda, a pessoas estabelecidas pela lei; que o preço de venda ou aluguel esteja dentro do limite que fixa a Comissão e, finalmente, que se enquadrem dentro das prescrições gerais quanto a sua construção e exploração. (Ley 9677/1915, Art. 9o, tradução nossa)

Para Yujnovsky (1974, p.15, tradução nossa) a CNCB "nunca foi dotada de fundos suficientes para que sua atuação fosse significativa". Até 1943, quando é incorporada à política habitacional proposta pelo regime recém-instituído, a Comissão construiria aproximadamente mil unidades na cidade de Buenos Aires $^{33}$ e apesar de nacional, não atuaria fora da capital. Contudo, de acordo com Cravino (2009, s/p., tradução nossa), é preciso ressaltar que a Comissão, neste momento inicial da produção habitacional estatal argentina, foi o espaço ideal para a realização de experimentações em torno da moradia, "confrontando não apenas os modos individuais ou coletivos de morar, mas também diferentes tipologias construtivas de uma ou outra alternativa".

A industrialização no país era ainda incipiente, de modo que eram importados materiais como aço, cerâmicas e chapas metálicas, o que era incompatível com as propostas de produção de moradia barata e em grande escala que já circulavam entre os profissionais nos periódicos especializados e congressos e que a própria CNCB tentava empreender, o que resultou em projetos que utilizavam prioritariamente o sistema construtivo tradicional. Ainda predominava como ponto de partida para a

\footnotetext{
33 Segundo Pastor (1944) foram construídas 1095 unidades; segundo Schteingart e Torres (1974) foram 1012; segundo Yujnovsky (1974) foram 977 unidades e segundo Liernur e Aliata (2004) foram construídas 972 unidades. Em matéria publicada em "La habitación Popular" órgão oficial da CNCB, Juan Justo Dassen, encarregado do Escritório de Informações e da Biblioteca da CNCB, afirma terem sido construídas 1095 unidades até 1942.
} 
elaboração destes projetos a preocupação com questões sanitárias e morais relativas à família operária que se refletiam diretamente nas plantas e na ocupação urbana. Os critérios de composição eram acadêmicos, de referência clássica baseada em tipologias pré-determinadas e apenas nas últimas obras do período se percebem referências ao Racionalismo nas fachadas, porém ainda sem implicações nas plantas.

"É possível estabelecer elementos comuns quanto à resolução dos conjuntos no âmbito da cidade" em pelo menos duas formas de relação com o meio (HISTORIA ARGENTINA DE LA VIVIENDA..., s/d, tradução nossa). De um lado, se viam edifícios inseridos no lote, com volumetria que tendia a recompor virtual ou concretamente a quadra tradicional, reforçando a situação de esquina. De outro lado, se viam conjuntos de edifícios ocupando uma ou mais quadras, integrando-se à trama viária existente e sugerindo espaços livres como pátios e percursos internos, que se diferenciavam da simples área remanescente do espaço construído, evidenciando uma intenção de desenho.

Após a conformação da CNCB as únicas novidades referentes ao tema da moradia na Argentina até 1943 são as Leis de Emergência no 11.156 e 11.157, aprovadas em 1921, durante o governo de Hipólito Yrigoyen. A partir destas leis se institui por um período de dois anos o impedimento de despejo por falta de pagamento de aluguel e a prorrogação dos valores de locação de casas, cômodos e apartamentos (com base nos valores aferidos em 10 de janeiro de 1920). Os proprietários, portanto, ficavam por este tempo impedidos de desalojar seus inquilinos e de aumentar os preços cobrados pela locação. Na prática, as leis não resolveram o problema da moradia, por um lado, porque a população continuava a crescer e, por outro, porque implicaram não apenas em uma profunda falta de interesse e quase total paralisação da atividade construtiva voltada ao mercado rentista popular, como também na falta de manutenção e deterioro das unidades existentes. Progressivamente houve uma retirada dos capitais do setor e sua reorientação para indústrias, negócios agropecuários ou outros setores que oferecessem rendimentos mais elevados. (MINISTERIO DE TRABAJO..., 1953)

\subsection{Produção habitacional na Argentina Peronista: a moradia como direito do trabalhador}

\section{Comisión Asesora para la Vivienda Popular}

As primeiras medidas do governo estabelecido em junho de 1943 voltam a versar sobre o controle dos aluguéis, com destaque para o Decreto-Ley no 1580 de 29 de junho de $1943^{34}$, que rebaixa os preços de aluguéis a valores praticados em dezembro de 1942 e cria um organismo denominado "Cámara de Alquileres", responsável por controlar a execução da mesma lei. Ainda em julho do mesmo ano, porém, é constituída a Comisión Asesora para la Vivienda Popular (Decreto n.

\footnotetext{
${ }^{34}$ Não se pode deixar de atentar para a proximidade temporal, ou coincidência, entre a promulgação deste decreto e a promulgação da Lei do Inquilinato, no Brasil, em agosto de 1942. Embora ainda em 1921 as Leis de Emergência tivessem tratado do congelamento de aluguéis, é apenas em 1943 que este tema - e a promulgação de leis correspondentes - é retomado.
} 
2746/1943). Composta por representantes do aparato estatal e de órgãos exteriores ao governo, a Comissão foi encarregada da elaboração de um plano nacional para a construção de moradias. Para tanto, é realizado um estudo sobre a condição habitacional do qual resulta um "Informe Preliminar" que informava que "as moradias econômicas ou populares necessárias no país alcançam a importante cifra de 650.000 unidades" (SECRETARIA DE TRABAJO..., 1943a, p.5, tradução nossa). No Informe a Comissão ainda determina as áreas onde preferencialmente seriam construídas as novas moradias, localizando os estabelecimentos industriais e o respectivo número de operários e zonas desocupadas nos arredores da Capital Federal.

Em dezembro de 1943 a Comissão publica o "Plan orgánico para la construcción de viviendas destinadas al sector de población de renta reducida que, imprescindiblemente, requere el aporte del Estado". No próprio título, portanto, se indicavam vários pontos do plano: tratava-se de um projeto de intervenção direta do Estado na construção de moradias a uma população que sem a ajuda estatal não conseguiria obtê-la, ou seja, uma demanda não efetiva para os investidores privados. Não se pretendia competir com a ação privada, pois se entendia que esta era também fundamental à solução da questão habitacional.

Para sua execução, o plano previa a criação de um órgão dedicado ao sistema, sendo possível presumir, embora não esteja assim descrito, que este órgão viria a ser a Administración Nacional de la Vivienda, criada em 1945. A ser executado em 20 anos, o plano deveria "dotar o país de moradias na proporção adequada a suas necessidades", estimando-se a princípio serem necessárias 300.000 unidades. São indicados os padrões construtivos das moradias e é conferida prioridade à moradia individual, devendo-se

criar bairros jardim, com vida própria, onde as casas rodeiem um grande parque comum, com o qual se comuniquem através de vias de serviço, isoladas das circulações externas. No parque deverá haver espaços reservados para os diversos centros de atração e concentração: escolas, clube de esportes, jardim de infância, teatro ao ar livre e capela. (SECRETARIA DE TRABAJO..., 1943b, p.3, tradução nossa).

Demonstrando que o financiamento da habitação era também uma preocupação, em janeiro de 1944

a Comissão Assessora lança, em complementação ao Plano, um projeto para criação do Banco Nacional de la Vivienda, "um organismo financeiro oficial, especializado nas operações bancárias vinculadas a esta matéria, cuja função básica seria estruturar um 'Sistema oficial de poupança e empréstimos para a moradia'". (SECRETARIA DE TRABAJO..., 1944, p.5, tradução nossa)

É possível conjeturar que os estudos e propostas feitas pela Comissão Assessora tenham sido recuperados na produção habitacional posterior a 1946, por exemplo, quanto à localização dos conjuntos em áreas desocupadas nos arredores de Buenos Aires junto às indústrias e ao modelo urbano-arquitetônico baseado no padrão cidade-jardim associado a unidades individuais de moradia. Embora o Banco Nacional de la Vivienda não tenha se constituído, outros bancos nacionais, em 
especial o Banco Hipotecário, depois de 1946 teriam suas organizações modificadas para que servissem ao propósito de enfrentamento da questão habitacional pelo Estado.

\section{Administración Nacional de la Vivienda}

Ainda em 1945, através do Decreto n. 11.157, é constituída a Administración Nacional de la Vivienda (ANV), que "[...] com o fim do bem-estar geral, tem por objeto o melhoramento das condições higiênicas, técnicas, econômicas e sociais da moradia urbana e rural em todo o território da Nação e a redução progressiva da moradia inadequada, insalubre ou perigosa" (ARGENTINA, 1945, tradução nossa, grifo nosso) - destacamos o preceito de bem-estar geral, que conforme já mencionamos, era fundamental à política de Justiça Social implementada pelo Estado peronista. Conforme o Decreto, a ANV se constituía como repartição autárquica com pessoal próprio e mantinha contato com o Poder Executivo através da Secretaria de Trabajo y Previsión. As principais atribuições da ANV, conforme disposto no Artigo 8, compreendiam:

a) construir moradias econômicas, individuais ou coletivas, quer se trate de planos de conjunto ou obras isoladas, ou adquirir através da inversão de seus bens e recursos próprios [...]; alugar ou vender tais moradias e intervir na construção, compra, locação e venda [...]; b) proporcionar recursos às autoridades locais, entidades públicas, sociedades cooperativas, associações mutualistas, sociedades mistas, empresas privadas e pessoas responsáveis para a construção de moradias econômicas [...]; c) proporcionar recursos [...] com fins de recondicionamento de moradias econômicas; d) fazer convênios com as administrações locais e demais entidades públicas e privadas [...] com o fim de prestar assistência técnica que se faça necessária; [...] k) recomendar o desenvolvimento racional das cidades [...], propondo normas e projetos de legislação para regulação de seu crescimento, colaborando com outras repartições, participando da formação de pessoal especializado em planejamento urbano e rural, organizando concursos, exposições e conferências e efetuando estudos e publicações; I) estimular o aperfeiçoamento da indústria da construção [...]. (ARGENTINA, 1945, tradução nossa, grifos nossos).

A ANV, portanto, podia atuar direta e indiretamente, ela própria construindo as habitações ou fornecendo recursos para que outras entidades o fizessem. Fica subtendido que o órgão possuía poderes para atuar junto ao planejamento urbano, sendo esta uma das primeiras tentativas estatais em âmbito nacional de atrelar planejamento e moradia (LIERNUR; ALIATA, 2004). Declaravam-se de utilidade pública os terrenos e materiais destinados às construções, podendo a ANV celebrar acordos diretamente com os proprietários para estabelecer expropriações e ainda adquirir terras por licitação pública ou privada. O órgão era responsável pelas licitações para construções, contratação de serviços, realização dos convênios necessários e pela compra de materiais de construção, dando-se preferência àqueles de produção nacional e local, dado relacionado à indicação de estímulo à indústria da construção e relevante quando se considera a política de industrialização nacional.

Uma informação importante para nossa pesquisa diz respeito ao preenchimento dos cargos técnicos da ANV. O Artigo 17 do Decreto determina que "ao Conselho Diretor corresponde nomear, promover 
e deslocar o pessoal administrativo, técnico, operário e de serviços da Administración Nacional de la Vivienda [...] preenchendo as vagas por concurso nos casos em que julgue conveniente" (ARGENTINA, 1945, tradução nossa, grifo nosso).

Em 1947 tem início a implementação do Primer Plan Quinquenal, que propôs o desenvolvimento da política habitacional por ação direta (através da construção de unidades de moradia pelos órgãos estatais) e indireta (através da outorga de créditos). A ação direta foi naquele primeiro momento promovida unicamente pela ANV, posteriormente incorporando-se à política habitacional outros órgãos estatais, provinciais e municipais. A ANV, porém, é vinculada em 1947 ao Banco Hipotecário Nacional, que soma então ao seu tradicional papel creditício o papel de promotor técnico, tornandose, é possível dizer, o principal agente da produção habitacional peronista.

Entre os projetos promovidos pela ANV ainda antes de sua vinculação ao BHN pode-se mencionar a finalização da Casa Colectiva Martin Rodriguez (141 unidades, 1943-45), em La Boca, cujas características arquitetônicas e urbanísticas ainda remetem aos projetos da CNCB (GUTIERREZ, 2011). Já entre os projetos elaborados após 1947, em que se identifica a ação direta do BHN, destacam-se os conjuntos Curapaligue (676 unidades, 1948-53) e 17 de Octubre - General Paz em La Matanza (5.536 unidades, 1948-54), utilizando-se em ambos o mesmo tipo de edifícios em altura, no segundo concomitantemente a casas individuais.

\section{Plan de Gobierno 1947-1951 - Primer Plan Quinquenal}

Não apenas a capacidade de alojamento das grandes cidades é notoriamente ineficiente, o que repercute no elevado custo dos aluguéis, como também a população vive de forma absolutamente inadmissível. [...]. Naturalmente que a solução não pode recair integralmente sobre o Estado, como requere outra série de colaborações [...]. (PRESIDENCIA DE LA NACIÓN, 1946, p.315, tradução nossa)

Este pequeno trecho do discurso de Perón na apresentação do item "Vivienda" (Capítulo III - Obra Social) do Plan de Gobierno para os anos de 1947 a 1951, posteriormente denominado Primer Plan Quinquenal, dá indícios das soluções para o problema da moradia a serem executadas pelo Estado a partir daquele momento. As soluções incluíam a institucionalização da produção da moradia pelo Estado e o incentivo à ação privada na promoção habitacional, o enfrentamento do custo elevado das locações através de leis e o fomento à manutenção e melhoramento das unidades existentes. As ações previstas compreendiam:

fomentar a edificação de moradias de todas as classes; [...] coordenar a atuação da Administración Nacional de la Vivienda com o Banco Hipotecario Nacional e as diversas caixas de aposentadoria integrantes do Instituto Nacional de Previsión Social, a fim de que como meio de inversão de reservas tracem planos de empréstimos para a construção de conjuntos de casas baratas ${ }^{35} ;[\ldots]$ fomentar

\footnotetext{
35 Nota-se neste item a semelhança com a política previdenciária de habitação implementada no Brasil, com a diferença que na Argentina os órgãos de promoção habitacional atuariam em conjunto com o sistema previdenciário, enquanto no Brasil os próprios órgãos previdenciários realizariam a promoção da moradia. Além dessa diferença estrutural, vale dizer que
} 
dentro das normas legais e ordenanças municipais, a construção direta e pessoal da moradia operária [...] colocando gratuitamente à disposição dos interessados planos e orientação técnica para torná-las higiênica e esteticamente adequadas". (PRESIDENCIA DE LA NACIÓN, 1946, p.316, tradução nossa)

O plano considera também indispensável ao enfrentamento da questão habitacional o fomento à propriedade horizontal. A sua regulamentação é prevista não apenas como "meio de aumentar a capacidade habitacional, como também para canalizar uma corrente que claramente se desenha", a construção de moradias coletivas (PRESIDENCIA DE LA NACIÓN, 1946, p.318, tradução nossa). A Lei n. 13.512, conhecida como "Ley de Propiedad Horizontal", seria promulgada em 1948, permitindo a subdivisão e venda em separado de distintas unidades de um imóvel multifamiliar. A sanção da Lei 13512/1948 buscava facilitar o acesso à propriedade privada e constituía peça fundamental da legislação sobre o tema, possibilitando o surgimento de um novo modelo de moradia coletiva urbana, o apartamento em propriedade horizontal ${ }^{36}$.

Até 1948, os pequenos proprietários só podiam viver em suas propriedades se fossem casas individuais, o que trazia como consequência o afastamento do centro; em contrapartida, para habitar um edifício de apartamentos em altura - luxuoso ou econômico - era necessário ser um inquilino. (TORRES, 2006, p.16, tradução nossa)

Previa-se também no Primeiro Plano Quinquenal o incentivo à edificação de moradias para todas as classes por parte do setor privado, incluindo a obrigação dos proprietários industriais e agrícolas cujas instalações estivessem fora dos núcleos urbanos em proporcionar moradias a seus empregados. No entanto, o governo identifica aí uma dificuldade: a propriedade imobiliária era considerada a forma mais segura de inversão de capitais e muitas ficavam anos à espera de capitalização. A partir desta constatação o Plano indica que "para o fomento às atividades privadas para construção de moradias deve-se tomar como ponto de partida a repercussão econômica favorável para quem edifique e desfavorável para quem mantenha a propriedade sobre terrenos baldios" (PRESIDENCIA DE LA NACIÓN, 1946, p.316, tradução nossa).

Esta decisão é convertida no Projeto de Ley de Bases, anexado ao Plano. O Projeto de Lei previa que "todo proprietário de terreno baldio que em um ano edificasse ele mesmo casas destinadas à moradia, ou a moradia e comércio, ficava isento do pagamento de contribuição territorial por um período de cinco anos" (PRESIDENCIA DE LA NACIÓN, 1946, p.319, tradução nossa), contanto que se

esta era apenas uma das frentes de ação da política habitacional argentina, enquanto no Brasil foi a principal responsável pelos projetos habitacionais do período considerado. O Instituto Nacional de Previsión Social (INPS) foi criado em 1944 com a finalidade de unificar e expandir os sistemas de seguro social existentes e seus fundos foram, assim como no Brasil, como se nota pelo trecho citado, utilizados pelo Estado não apenas para cumprir as funções de promover aposentadorias e pensões, mas para impulsionar políticas de cunho social e econômico. (LLOYD-SHERLOCK, 1992)

${ }^{36}$ O mercado de apartamentos em "propriedade horizontal" teve seu crescimento nas décadas de 1950 e 1960 . Os proprietários destes edifícios, geralmente profissionais da construção (arquitetos, engenheiros), realizavam todas as atividades necessárias para a construção e venda das unidades, constituindo o que no Brasil se convencionou chamar de uma classe de incorporadores imobiliários. Os apartamentos em propriedade horizontal, beneficiados pela localização em áreas consolidadas, foram ocupados especialmente pela classe média de Buenos Aires. 
construísse "casas econômicas" para no mínimo quatro famílias, cujas condições de higiene, capacidade, espaços livres e, inclusive, os possíveis beneficiários das casas construídas fossem determinadas pelo Poder Executivo.

O plano para construção de moradias previsto no Plano Quinquenal é instituído em 1948 na "Ley General de la Vivienda" (Lei 5.396). O principal ponto da lei determinava que se somaria à atuação da ANV, já vinculada ao BHN, a ação de outro órgão nacional. A existente Dirección de la Vivienda Económica, do Ministério das Obras Públicas (MOP), seria então denominada "Dirección de la Vivienda" e teria "o objetivo de promover a construção, aquisição, venda e locação da habitação urbana ou rural no território da Província, com destino às famílias de empleados y obreros, imigrantes ou de famílias desamparadas" (ARGENTINA, 1948, tradução nossa). A Dirección de la Vivienda tinha as seguintes funções:

a) construir moradias econômicas, individuais ou coletivas, quer se trate de planos de conjunto ou obras isoladas, ou adquirir através da inversão de seus bens e recursos próprios [...]; alugar ou vender tais moradias e intervir na construção, compra, locação e venda $[\ldots]^{37}$; b) assinar acordos de coparticipação e financiamento de obras com entidades nacionais e provinciais, com os municípios, empresas industriais, comerciais, sociedades mutuárias e sindicatos; [...] d) determinar, com a aprovação do Executivo, as normas de uso das moradias vendidas ou alugadas, e inspecioná-las, a fim de garantir a manutenção adequada; e) adquirir por compra, troca, expropriação, doação ou herança, as propriedades necessárias para os fins que propõe a lei; f) estimular o aperfeiçoamento da indústria da construção em relação à produção e comercialização de materiais e métodos construtivos, baseados em esquemas de racionalização, [...] e promover a formação de operariado, e de pessoas de gestão de obras, mediante capacitação. [...]. (ARGENTINA, 1948, tradução nossa)

Os fundos da Dirección de la Vivienda foram constituídos principalmente por cotas do erário nacional destinadas aos planos de obras públicas e pelos valores recebidos por vendas ou locações das habitações, sendo administrados pelo Banco de la Provincia de Buenos Aires. A Lei previa a distribuição das casas através de sorteio entre os solicitantes, sendo estes empregados, operários e demais trabalhadores com família e bons antecedentes. As unidades eram prioritariamente vendidas, podendo a Dirección de la Vivienda inclusive adquirir uma extensão de terras, fracioná-la e vendê-la previamente, utilizando os recursos obtidos para o financiamento das construções. A opção pela locação existia, mas ficava sujeita a determinações do órgão para cada caso (ARGENTINA, 1948). Assim se fixava entre as competências do MOP a construção de moradias ${ }^{38}$.

Entre os projetos habitacionais realizados pelo MOP em Buenos Aires está o Barrio General Juan Domingo Perón (atual Saavedra, 1947-1949) que apresenta, como era típico às obras do MOP, o

\footnotetext{
${ }^{37}$ Atentar para o fato de esta primeira função ser redigida exatamente como a primeira função da Administración Nacional de la Vivienda.

38 Desde 1943 o MOP era conduzido por Juan Pistarini, figura ligada ao militarismo católico, que considerado aliado de Perón é mantido à frente do ministério após 1946. Desde 1943 Pistarini propôs a construção de moradias para o próprio pessoal do MOP, valendo mencionar como exemplo um conjunto em San Isidro, com 90 unidades. (BALLENT, 2005)
} 
chamado "estilo californiano" e a tipologia do chalé unifamiliar associado ao lote individual e um desenho urbano com referência no modelo cidade-jardim, predominando a noção de individualidade e a ideologia da casa como refúgio da família operária, revelando-se forte vinculação com o catolicismo social. Na Grande Buenos Aires o MOP é responsável por um amplo projeto habitacional, o Ciudad Evita (1948), verdadeiro plano de urbanização para uma área de aproximadamente 870 hectares, em que se identifica o mesmo modelo urbano-arquitetônico, porém também a referência ao padrão urbanístico da unidade de vizinhança, especialmente no que se refere à distribuição dos equipamentos propostos.

Segundo Ballent (2005), a figura de Eva Perón foi estreitamente vinculada ao imaginário da habitação popular, seja porque os conjuntos habitacionais produzidos pelo MOP fossem sempre associados à Fundación Ayuda Social Eva Duarte Perón, mesmo antes desta assumir a distribuição das unidades por ele produzidas (conforme revisão da Lei n. 5.396 em 1951), seja porque os discursos do próprio Perón e a imprensa oficial relacionassem Evita à provisão habitacional, destacando o trabalho social desempenhado pela primeira-dama. Desde 1947, segundo Ballent (2005), havia um projeto da Fundação para a construção de 40 mil moradias no interior do país através do MOP, porém o número de unidades de fato executadas no âmbito deste projeto é impreciso, devido especialmente à dificuldade de diferenciação entre as obras do próprio MOP e da Fundação. Sobre as obras da Fundação, Eva Perón escreve em "La razon de mi vida":

Os arquitetos e engenheiros da Fundação projetam sobre meus grandes planos, e depois eu coloco em cada obra tudo o que eles não viram. Sobretudo, a princípio me custava fazê-los entender que os lares da Fundação não eram asilos... que os hospitais da Fundação não eram antessalas de morte, mas antessalas de vida... que as moradias não deviam ser lugares para dormir, mas lugares para viver alegremente... não era culpa deles que não me compreendiam na primeira intenção. Durante cem anos a alma estreita dos ricos, para calar a voz da consciência, não concebeu nada melhor que tratar os pobres com migalhas e esmolas. [...] A mim me tocou a honra de destruir com minha obra alguns desses velhos conceitos. (PERÓN, 1951, p.154, tradução nossa, grifo nosso)

Conforme se apreende do trecho citado, Evita colocava seu saber acima do conhecimento de engenheiros e arquitetos que, supostamente, por realizarem também projetos para as elites, não compreendiam as reais intenções do trabalho da Fundação. É importante destacar que a Fundação Eva Perón ampliava a ação estatal aos setores não contemplados por outros órgãos estatais tais como a ANV e o BHN, mais limitados aos trabalhadores assalariados.

\section{O Banco Hipotecário Nacional e o Plan Eva Perón}

O peronismo "imprimiu ao BHN o caráter social que se associou à entidade até sua privatização nos anos 1990" (BALLENT, 2005, p.84, tradução nossa). Fundado em 1886, o Banco Hipotecário Nacional (BHN) tinha o propósito inicial de estimular o desenvolvimento da riqueza agropecuária, ajudando os proprietários de terra para que tivessem o capital necessário para explorá-la ou fazer novas inversões. 
De fato, 90\% das hipotecas outorgadas pelo BHN entre 1903 e 1908 foram a propriedade rurais (SCOBIE, 1974), mas uma análise realizada por Cortés Conde (2011), com base nas Memórias do BHN sobre sua atuação desde 1887 (até 1944), mostra que ao longo dos anos na realidade suas operações favoreceram mais os proprietários de terras urbanas que rurais e que não concretizaram a função social segundo a qual fora criado. A partir de 1911 uma revisão da Lei Orgânica do BHN possibilitou a outorga de créditos para a construção de moradias, proposta que se revelou frustrada pelas próprias características de atuação do Banco, que não sustentavam ações de caráter social. (REPETTO, 1954) Embora os dispositivos legais para o crédito à construção de moradias existissem desde 1911, os empréstimos de caráter social para construção habitacional praticamente se iniciam em 1946, quando se decidiu canalizar todo o esforço econômico em prol da habitação a partir de um único instrumento, o Banco Hipotecário Nacional, tornando-o independente da capitalização de fundos no mercado de capitais (ARGENTINA, 1946a). Para tanto se resgatou a totalidade das cédulas hipotecárias ainda em circulação, despendendo-se quase 1.500 milhões de pesos do erário nacional. A nova modificação da carta orgânica do BHN em 1946 é feita a partir de uma "reforma bancária com orientação social que indicou especialmente ao BHN a missão de direcionar a política em favor da edificação de moradias mediante operações de crédito real" (REPETTO, 1954, p.77, tradução nossa). Perón propõe em 1946 a reorganização de todo o sistema bancário, cujo objetivo principal era a nacionalização, ou "argentinização", dos capitais em circulação no país. Conforme registrado em La Nación Argentina Justa Libre Soberana "a nacionalização do Banco Central foi ponto de partida para levar a cabo todas as coisas que se estão comemorando, porque quando o dinheiro se fez argentino se pôde ir comprando tudo o mais que não era argentino" (LA NACIÓN ARGENTINA..., 1950, p.55, tradução nossa). A reforma bancária determinava que o Banco Central de la República Argentina, recém estatizado, fosse o ente financiador e agente responsável pela inspeção e controle de todos os bancos do país, alguns dos quais, como o Banco de la Província de Buenos Aires e o Banco de la Nación Argentina, também seriam incorporados ao esquema governamental de provisão habitacional, sendo o primeiro responsável pela administração financeira dos fundos destinados à moradia promovida pelo MOP e o segundo pelo financiamento da construção de moradias rurais. (ARGENTINA, 1946b).

A partir da reforma bancária o BHN se tornou acessível à população de poucos recursos e teve a sua estrutura descentralizada em quatro gerências regionais de modo a garantir uma atuação nacional (LA NACIÓN ARGENTINA..., 1950). Desde 1946 até 1955 o BHN financiaria a construção de milhares de casas que, no âmbito da política justicialista, implicavam na existência de milhares de pequenos proprietários. Havia diferentes linhas de crédito: duas se destinavam à aquisição ou construção da casa própria, sendo uma para o público geral e outra dirigida aos associados das caixas de previdência social, e outras duas linhas se destinavam ao fomento à construção de casas para aluguel - menos 
atrativas em um mercado de aluguéis congelados. No primeiro ano completo (1948) após a reforma bancária foram escriturados 23.123 empréstimos. (REPETTO, 1954)

Em 1946 o BHN convoca um "concurso para construção de casas pré-fabricadas" (Decreto n. 18.376/ 1946) $)^{39}$. As justificativas para a convocatória do concurso consideravam que a questão da moradia era encarada com especial interesse pelo Estado por seu conteúdo sanitário e social,

sendo necessária sua solução na forma mais rápida e eficiente com utilização dos meios que a moderna técnica tem estabelecido para a formação de cidades jardins e bairros próprios para as famílias humildes, cujas construções reúnam as condições de higiene, conforto e estética necessárias e cuja implantação seja dotada de vias fáceis de comunicação; [...] e que para eleger os tipos de moradia mais conveniente para a grande construção em série, é necessário conhecer e comparar os modelos dos distintos sistemas que reiteradamente se oferecem ao governo; observar a rapidez da montagem e construção, solidez, comodidade, condições de higiene que reúnam essas moradias e o custo das mesmas [...]. (ARGENTINA, 1946c, tradução nossa, grifo nosso)

É em 1947 que o BHN começa a atuar por ação direta, como já mencionamos, a partir da vinculação da ANV, o que nos leva a crer que esta convocatória se relacionava à prática que se estabelece no BHN de fornecer aos interessados não apenas o crédito para a aquisição dos terrenos, mas também o projeto de unidades habitacionais. A partir de 1952 o BHN implementaria o "Plan Eva Peron" que consistia no financiamento integral da moradia individual destinada a "obreros e empleados" compreendidos pelas leis de previdência social. Através do Plano Eva Perón os créditos para construção ou aquisição da moradia social eram outorgados mais rapidamente e projetos completos de unidades-modelo eram disponibilizados aos eventuais interessados em construir (REPETTO, 1954). Conforme nossa pesquisa em arquivos do Ministério de Finanzas de la Nación, eram fornecidas "Carpetas Técnicas" com os planos, cálculos e cômputos completos, elaborados pela Dirección Técnica Plan Eva Perón. Além de facilitar o crédito para a casa própria, pode-se considerar que o Plano Eva Perón pretendia que essa casa fosse construída mediante planejamento, prevendo-se redução de tempo e custos, simplicidade e adaptabilidade a necessidades diversas, além do controle das características tipológicas e construtivas.

As casas do Plano Eva Perón (Figura 60), apesar de guardarem uma linguagem arquitetônica tradicional - tipos variados de chalés -, propunham a utilização de materiais padronizados e projetos funcionais que procuravam adaptar-se às necessidades das famílias de diferentes regiões do país. Para tanto eram propostos tipos variados em função do tamanho das famílias e dos custos, esquematizados de modo a atender aos requisitos para aprovação de crédito. "Em um primeiro momento, buscando-se o atendimento da demanda, foram projetadas casas baratas, sem revestimentos e outros utensílios que seriam colocados pelo morador depois, conforme suas possibilidades" (REPETTO, 1954, p.81, tradução nossa).

\footnotetext{
${ }^{39}$ Não temos informações sobre os resultados deste concurso.
} 


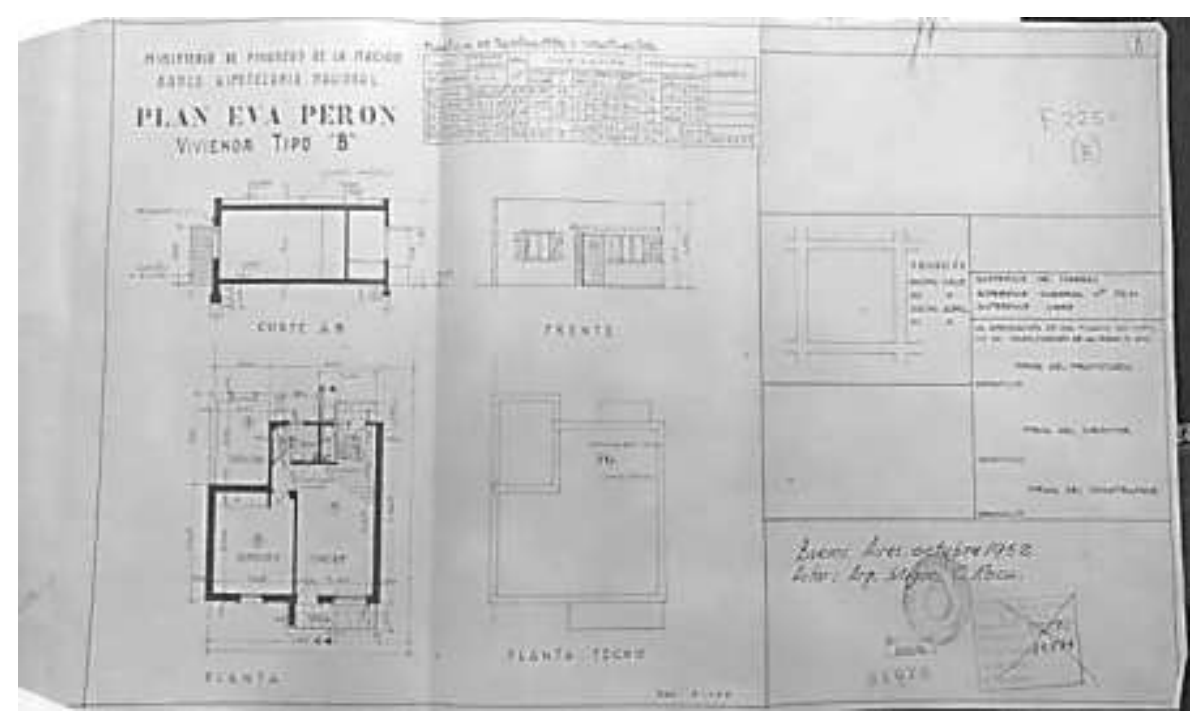

Figura 60: Vivienda tipo "B". Fonte: Carpeta Técnica del Plan Eva Perón. Ministério de Finanzas de la Nación. Banco Hipotecario Nacional. Buenos Aires, 1952.

A construção de conjuntos massivos era colocada em primeiro plano como forma de solução ao problema da habitação, mas, ao assumir a unidade individual como chave das operações o Plano Eva Perón instituía uma nova forma de encarar a moradia em grande escala, através do incentivo a autoconstrução. Este dado é indicativo de um problema que em poucos anos se faria notar na Grande Buenos Aires: a autoconstrução da moradia em pequenos lotes individuais se associava a uma falta de controle sobre o crescimento urbano. Contradizendo a própria postura intervencionista do peronismo, "este hiato entre planejamento da moradia e planejamento urbano se produzia em um momento em que o Estado incorporava de forma explícita a necessidade de elaboração de planos urbanos, [expressa inclusive] no capítulo 'Moradia' do Segundo Plano Quinquenal”. (BALLENT, 2005, p.90, tradução nossa)

Apesar da grande quantidade de unidades produzidas com fundos provenientes do BHN e de créditos outorgados por ele para o setor habitacional, Esteban Guaia, Secretário do Estado de Vivenda no início dos anos 1960, aponta dois fatos que atenuaram a ação do Banco. Em primeiro lugar, a forma de financiamento adotada foi a emissão de moeda, o que contribuiu para um processo inflacionário de difícil controle e, muito embora a atividade do BHN não fosse a única causa da inflação, esta foi alvo fácil de acusações. Em segundo lugar, apesar dos concursos para construção de casas préfabricadas, "não houve orientação para a tecnificação, a racionalização de processos, a inversão em equipamento moderno ou na maximização da eficiência" (GUAIA, 2012, p.26, tradução nossa). Segundo Guaia (2012) se perdeu a oportunidade de instalar no país uma indústria de construção sólida e moderna, orientada à moradia econômica, porém, é possível afirmar que o setor cresceu e se consolidou durante o peronismo a partir da obra pública, nomeadamente a produção habitacional, em que centenas de pequenas empresas e milhares de operários foram mobilizados, o que foi benéfico numa política que buscava o pleno emprego. 


\section{Segundo Plan Quinquenal (1953-1957)}

A recessão de 1949 obriga o Estado a modificar não apenas a política econômica, como também a política habitacional. As únicas obras públicas que não param nesse momento são aquelas vinculadas à moradia, porém se percebe nitidamente uma diminuição da ação direta, enquanto aumenta o incentivo à ação indireta, com estímulo à atuação de associações intermediárias como cooperativas, consórcios e associações profissionais. Embora em 1952 já se notassem melhoras na economia, a ação estatal indireta é privilegiada no Segundo Plano Quinquenal (Lei n. 14184). Com menos ambiguidades e maior clareza de objetivos e meios que o primeiro plano de governo, o plano trazia em sua primeira parte a planificação da "Ação Social" do governo para os seguintes cinco anos (19531957), incluindo o tema da habitação ${ }^{40}$.

A partir da declaração de que "a habitação desempenha, para felicidade do povo e grandeza do país objetivos fundamentais da doutrina peronista -, uma eminente função social uma vez que contribui para a dignidade do homem e a manutenção da saúde física e moral da população" (2o PLAN QUINQUENAL..., 1954, p.506, tradução nossa) o Plano defende a progressiva urbanização de todos os povoados com base em planos reguladores, que desde sua concepção deveriam contar com o cadastro e a reavaliação da propriedade, que deveria cumprir sua função social.

Assim são previstas pelo Plano taxas progressivas aos proprietários de terrenos vazios, a repressão à especulação imobiliária e a adoção de medidas legais que, "fundamentadas na função social da propriedade, permitam a adequada disposição das terras necessárias para a construção de moradias e a realização dos planos reguladores" (20 PLAN QUINQUENAL..., 1954, p. 507, tradução nossa). 0 Estado promoveu a formulação de planos reguladores e de urbanização a serem desenvolvidos entre 1953 e 1957 pelas municipalidades de todo país, responsáveis por realizar estudos em matéria de habitação nas respectivas jurisdições. (BALLENT, 2005)

O regime de crédito bancário destinado à produção habitacional é descrito de forma detalhada no Segundo Plano Quinquenal, sendo esta a forma prioritária da ação estatal nesse momento. Sua outorga se dava da seguinte maneira:

a) $O$ crédito para construção de residência em propriedade individual destinado a famílias de trabalhadores terá prioridade sobre todo outro tipo de crédito para habitação. Terão preferência os créditos para associações profissionais, cooperativas e entidades civis sem fins lucrativos que tenham por objetivo a construção de moradias para seus afiliados; b) 0 crédito para habitação será distribuído geograficamente, tendo em conta as necessidades e características regionais e os planos de promoção econômica; c) A condução do regime creditício

\footnotetext{
40 A primeira parte incluía os seguintes temas: I. Organização do povo - população; II. Trabalho; III. Previdência; IV. Educação; V. Cultura; VI. Pesquisas científicas e técnicas; VII. Saúde Pública; VIII. Habitação; IX. Turismo. A segunda parte compreendia a "Ação Econômica", a terceira, "Comércio e Finanças", a quarta, "Serviços e Trabalhos Públicos" e a quinta tratava de racionalização administrativa, legislação, inversões estatais e planos militares, constituindo o que se pode chamar de "Ação Política".
} 
para moradia rural será realizada pelo Banco de la Nación Argentina [...]; d) 0 crédito para a moradia dos trabalhadores será outorgado de acordo com os custos reais de edificação, situação patrimonial e ingressos familiares dos beneficiários. A taxa de juros será reduzida e os prazos de amortização serão estendidos nos casos justificáveis; e) Os projetos que se utilizarem de materiais padronizados oficialmente terão prioridade na outorga de crédito. (2 PLAN QUINQUENAL..., 1954, p.508, tradução nossa)

As indústrias dedicadas à extração e produção de materiais de construção, pré-fabricação de moradias, fabricação de equipamentos e ferramentas destinados à construção contariam com a ajuda técnica e financeira do Estado a fim de racionalizar sua produção e elevar sua capacidade técnica e financeira. O Estado patrocinaria o estabelecimento de novas indústrias, uma vez que utilizassem matérias primas de origem nacional e/ou incorporassem novos processos técnicos e/ou econômicos de produção. A normatização dos elementos construtivos e a estandardização dos materiais, assim como a modulação dos projetos de moradias seriam realizadas pelo próprio Estado.

O Plano se propõe ainda a incentivar a ação de cooperativas e consórcios civis para construção habitacional e, em particular, a ação de associações profissionais para a produção habitacional a seus associados, mediante assessoramento técnico que compreendia inclusive aspectos de financiamento. Conforme o Plano, o Estado proporcionaria gratuitamente "assessoramento técnico, econômico e legal em tudo que se relacione à produção habitacional, em particular aquela realizada com a colaboração financeira do sistema bancário ou de previdência" (2 PLAN QUINQUENAL..., 1954, p.508). O assessoramento deveria ser efetuado pelas instituições públicas competentes, pelas entidades privadas e pelas universidades, compreendendo projetos, cômputos e detalhes construtivos, determinação e especificação dos materiais mais adequados a cada caso e consultas de ordem jurídica.

Previa-se o ensino especializado na formação de pessoal técnico e na capacitação de mão de obra e a atuação do Estado junto a entidades privadas na realização de pesquisas e estudos para o progresso nacional em matéria de habitação. Os principais pontos a desenvolver eram, de um lado, a estatística especializada em habitação que informasse adequadamente o Estado sobre a situação da moradia em todo país, e de outro,

urbanismo, zoneamento, racionalização, técnica moderna de fabricação de materiais e da construção de moradias, mecanização do processo construtivo etc., e em geral sobre todos aqueles aspectos que possibilitem a construção de casas econômicas, higiênicas, confortáveis e em escala industrial". (2으 PLAN QUINQUENAL..., 1954, p.509, tradução nossa)

É possível afirmar que o Segundo Plano Quinquenal apresenta, na acepção exata do termo, o primeiro "Plano Nacional de Habitação Argentino", compreendendo a complexidade da questão e expondo objetivos e ações necessárias para seu cumprimento (Figura 61). O "objetivo especial" do plano, a ser cumprido até 1957, era aumentar a oferta de habitação disponível no país em 150\%. 
O objetivo fundamental da Nação, em matéria de habitação, será assegurar a todos os habitantes do país a posse de uma moradia adequada, higiênica, confortável e econômica. A moradia, em sua condição de propriedade individual, tem uma função social a cumprir e por isso há de ser considerada bem familiar, garantindo o Estado sua condição como tal. (2 PLAN QUINQUENAL..., 1954, p.505, tradução nossa, grifos nossos)

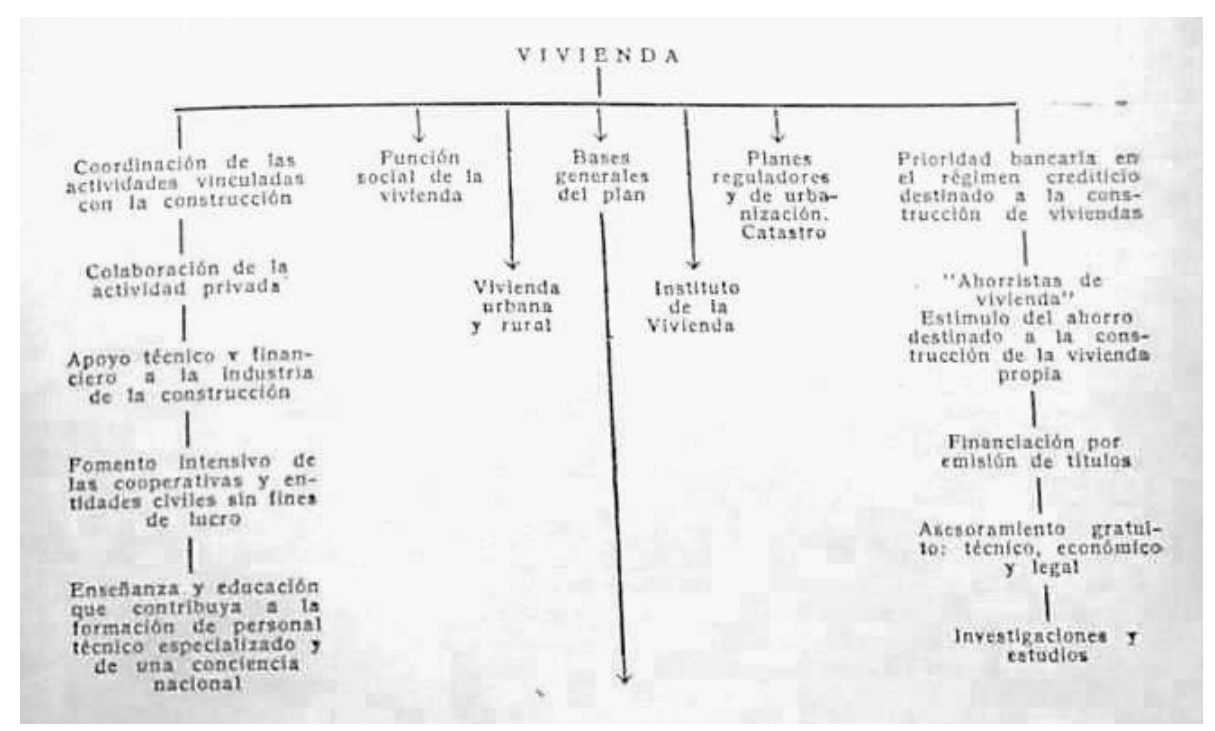

Figura 61. Esquema do Plano de Habitação do Segundo Plano Quinquenal. Fonte: 2o Plan Quinquenal de la Nacion Argentina: texto completo del 2ㅇ Plan Quinquenal (Ley 14.184). Buenos Aires: Ediciones Hechos e Ideas, 1954. p.505.

É importante perceber que os dois objetivos, especial e fundamental, não eram equivalentes, mas complementares. Aumentar o número de unidades de habitação disponíveis significava aumentar a ação estatal direta na produção da moradia, disponibilizando-a à população por meio de venda ou locação, enquanto assegurar a "posse de uma moradia" implicava em garantir o acesso à casa na propriedade, situação concretizada especialmente pela ação estatal indireta na outorga de créditos para a autoprovisão da moradia.

As "bases gerais do plano de habitação" trazem a ação do Estado para a concretização destes objetivos: a) estimulando a construção de moradias rurais e assegurando, ao mesmo tempo, a fixação da população agrária; b) promovendo o planejamento urbano regulador e regulamentando a construção de novas unidades unifamiliares e coletivas; c) eliminando gradualmente, até seu desaparecimento, a moradia insalubre e a superlotação; d) contribuindo técnica e economicamente com os planos habitacionais de associações profissionais. (2 PLAN QUINQUENAL..., 1954)

A execução de moradias cuja construção seja promovida pelo Estado, no âmbito dos objetivos do plano, será confiada primordialmente à atividade privada. As construções em grande escala correspondentes ao progressivo desenvolvimento de planos reguladores poderiam ser realizadas por empresas ou grupos de empresas. (2ㅇ PLAN QUINQUENAL..., 1954, p.507, tradução nossa, grifos nossos) 
Este parágrafo retirado do Segundo Plano Quinquenal traz um dado fundamental à nossa pesquisa no que se refere à indústria da construção e à atuação de empresas construtoras na produção habitacional. As empresas construtoras de moradias contavam com o apoio do Estado para elevar sua capacidade técnica e financeira e, não havendo indicação semelhante à supracitada no Primeiro Plano Quinquenal, seria possível considerar que apenas a partir de então, já na década de 1950, o Estado preconizava a participação das empresas privadas de construção no âmbito da política estatal de habitação. Entretanto, conforme as fontes pesquisadas, toda a obra pública era executada a partir da contratação de empresas construtoras por meio de licitações, o que permite considerar que o Segundo Plano Quinquenal apenas formalizava na produção habitacional, assim como a respeito dos equipamentos coletivos, o que na prática já ocorria; apesar disso foram localizadas apenas as empresas construtoras responsáveis por três projetos massivos construídos entre 1948 e 1954. (LA NACIÓN ARGENTINA..., 1950; BALLENT, 1993; DUNOWICZ, 2000; GUTIERREZ, 2011)

\section{A indústria da construção no projeto peronista ${ }^{41}$}

Segundo Yujnovsky (1984), a política habitacional era coerente com a política peronista de industrialização, de modo que se esperava que a demanda por insumos, em função da produção massiva, chegasse até a indústria da construção propiciando sua ampliação. Assim, a perspectiva de construção massiva foi fundamental para a produção habitacional estatal, por um lado porque era a chave para o atendimento ampliado da população e, por outro, porque se associava ao objetivo de industrialização nacional.

Em 1895 o setor da construção era um dos mais desenvolvidos da indústria nacional argentina, juntamente com os setores alimentício, têxtil e gráfico (IRIGOIN, 1984). O ambiente de desenvolvimento econômico e crescimento populacional entre o final do século XIX e o início do século XX favoreceu a modernização urbana, tanto através das novas construções, quanto de infraestruturas, com a instalação de redes elétricas e, nomeadamente, com a construção da primeira linha de trens subterrâneos. O grande programa de construção de infraestruturas organizado pelo Estado favoreceu diretamente a organização do Centro Nacional de Ingenieros em 1895, instituição privada que buscava garantir o espaço de atuação profissional, compreendendo os novos problemas urbanos como pertencentes ao campo da engenharia, antes que ao da política. Neste momento, segundo Freitas (2010) se estabelecem no país as primeiras empresas construtoras de origem estrangeira, com destaque para as de origem alemã.

Esse quadro, porém, seria modificado já a partir da década de 1910. A primeira guerra mundial e a crise econômica a ela associada desde 1914 afetaram profundamente a economia argentina com forte impacto no setor construtivo devido à dificuldade de importações e à diminuição da entrada de

\footnotetext{
${ }^{41}$ Registramos que este estudo é bastante incipiente, devido principalmente à dificuldade no levantamento de material relacionado ao tema.
} 
capitais que promoviam a implantação de infraestrutura (IRIGOIN, 1984). Diante das dificuldades se instala em 1916 a primeira fábrica de cimento Portland do país, a Compañía Argentina de Cemento Portland "Cementos San Martín". Instalada em Sierras Bayas, no município de Olaravarría, na província de Buenos Aires, a fábrica em pouco tempo foi capaz de suprir um terço da necessidade de cimento do país (INDUSTRIAS DE LA CONSTRUCCIÓN..., 1922).

Neste momento o cimento já era utilizado em obras públicas e particulares, mas é na década de 1930, de acordo com Freitas (2010), que esta indústria se desenvolve e possibilita a disseminação do uso do concreto armado em substituição às estruturas metálicas, devido especialmente à sua autonomia em relação à necessidade de importação. Segundo Ballent (2016), os programas estatais incentivavam a utilização do concreto armado e na década de 1930 a produção nacional de cimento pela primeira vez superou a importação. Um passo importante para a utilização do concreto armado e a modernização das técnicas construtivas foi a organização do Instituto de Racionalización Argentino de Materiales em 1935, responsável pela normatização e certificação de materiais.

Gradativamente, o setor da construção voltava a crescer, dada a ênfase na obra pública e os incentivos à industrialização colocados pelo Estado a partir de então. Era o primeiro período de substituição de importações, que se apoiava na industrialização anterior dinamizando as indústrias de bens de consumo, maquinários, metalurgia e a indústria da construção, especialmente a partir das indústrias de base (cimento e aço), porém, ainda sem alcançar a importância que possuía no final do século XIX e início do XX. (IRIGOIN, 1984).

No final de 1937, a construção estava localizada no quarto lugar industrial por sua produção e em primeiro lugar pelo número de trabalhadores empregados e operários. Referimo-nos centralmente aos seguintes aspectos: 1) produção de materiais de construção - onde houve aumento de volume e substituição de insumos ou bens importados; 2) aumento de pessoal ocupado pelo setor; 3 ) crescimento e diversificação de empresas de construção e 4) ampliação, em alcance e pessoal, de numerosos órgãos técnicos estaduais. (BALLENT, 2016, s/p)

No entanto, a citação a seguir, retirada de matéria de 1939 da revista Nuestra Arquitectura, manifesta uma preocupação diante da falta de materiais construtivos nacionais adequados à produção racionalizada ou industrializada da moradia operária, ao mesmo tempo em que revela a existência de uma articulação ou diálogo que permitia aos profissionais argentinos ter conhecimento sobre a indústria da construção no Brasil.

Essa nossa preocupação é já uma realidade no Brasil, que não apenas conseguiu extrair de seu solo todos os materiais que necessita para industrializar a construção da moradia operária, como hoje exporta para a Argentina grande quantidade de madeiras, azulejos, telhas, cerâmicas em geral, perfis de ferro, e está por instalar em Buenos Aires uma filial da fábrica de elevadores que hoje é responsável por quase $60 \%$ das máquinas colocadas no Brasil. (LA VIVIENDA POPULAR..., 1939, p.403, tradução nossa) 
Esta mesma matéria, transcrição do discurso do engenheiro Luis Migone ${ }^{42}$ no Centro Argentino de Ingenieros em outubro de 1939, ressalta o desenvolvimento da indústria construtiva no Brasil, onde afirma não ter ocorrido um simples crescimento industrial, mas uma resposta à supervisão constante do Estado, exercida por meio de organismos técnicos especializados. O IRAM, não era exclusivamente destinado à indústria da construção, mas a diversos setores da economia, de modo que apesar da sua existência, Migone defende em seu discurso a criação de um órgão argentino similar ao Instituto de Pesquisas Tecnológicas (IPT) do Brasil, voltado ao desenvolvimento da indústria da construção e à normatização de materiais e métodos construtivos.

A década de 1930, de acordo com Ballent (2006), pode ser compreendida como momento particular em que se estreitaram os vínculos organizacionais e políticos entre Estado, engenheiros e indústria da construção, institucionalmente representados no Ministério de Obras Públicas (MOP), no Centro Nacional de Ingenieros, renomeado em 1930 como Centro Argentino de Ingenieros (CAI) e na Câmara Argentina de la Construcción (CAC). A Câmara Argentina de la Construcción é fundada em 1936 e seu nome original, "Cámara de la Construcción, de Socios del Centro Argentino de Ingenieros", indicava a estreita relação com a agremiação formada pelos responsáveis por dezesseis empresas construtoras nacionais, várias delas ligadas à execução de obras públicas.

Esses vínculos registram o importante papel dos engenheiros na construção do país e, especificamente, da cidade de Buenos Aires naquele momento. Ressalta-se que havia assim "grande contraste com os arquitetos, cujas ligações institucionais com o Estado e com a indústria da construção foram muito mais frágeis e mutáveis e, especialmente no caso da relação com o Estado, tardias em relação às ações dos engenheiros no mesmo sentido" (BALLENT, 2016, s/p), conforme analisamos posteriormente.

Contudo, de acordo como Ballent (2016), era sintomático de que um novo contexto se conformava, ainda em 1936, o fato de a presidência do CAI deixar de estar entre engenheiros vinculados à obra pública e passar a ser ocupada por figuras ligadas à atividade privada da construção. $O$ fato indicava transformações na maneira de entender o exercício da profissão e o setor da construção como um todo, bem como o vínculo entre estes e o Estado. O vínculo direto entre a Câmara Argentina de la Construcción e o Centro Argentino de Ingenieros deixaria de existir em 1942, quando já contando com cerca de sessenta empresas associadas, a CAC assume o nome abreviado e passa atuar sem o controle direto do CAI.

Ao final da década de 1930 circunstâncias externas contribuíram para as mudanças que se estabeleceriam a partir de então. A Segunda Guerra Mundial dificultava e encarecia a importação de materiais de construção, de modo que os empresários do setor passaram a tratar diretamente com o

\footnotetext{
42 Luis Vicente Migone foi organizador e membro fundador do CAC e um dos diretores do CAl originários da atuação no setor privado. De acordo com Ballent (2016), Migone manteve conexões internacionais relevantes (especialmente latinoamericanas) com entidades de engenharia profissional e científica.
} 
Estado sobre as possibilidades de atuação disponíveis, para que não prejudicassem o setor e tampouco a execução da obra pública. Para Ballent (2016), essa nova relação entre indústria da construção e Estado, sem a mediação do CAl, demarcava um novo momento para o setor, que seria fortalecido após 1943 pelos grandes planos de obras públicas do peronismo, aos quais se associou o incentivo à indústria.

A partir de 1946, no âmbito do objetivo peronista de desenvolvimento industrial, segundo Bellini (2005), uma das maiores ambições era implantar uma indústria siderúrgica integrada e complexa, capaz de suprimir a necessidade de importação de aço no país, tão necessário ao plano de obras públicas, quanto à própria empresa industrial e ainda às Forças Armadas. Este anseio, porém, não pôde ser alcançado. As causas remetiam à própria política econômica que privilegiava a inversão de capitais públicos no projeto, embora desde o início, em função de outros investimentos e obras, a indústria siderúrgica nunca tenha recebido os recursos necessários. O projeto de desenvolvimento da indústria de materiais de construção através de ajuda técnica e financeira do Estado é descrito no Segundo Plano Quinquenal, porém, para Cirvini (2012, p.127)

o Estado peronista desconsidera os debates disciplinares e não busca a melhor solução técnica para o problema, mas adota aquilo que o projeto político exige: em suas soluções há uma vontade e intenção de reparação simbólica, de demanda social, de apropriação daqueles elementos de alto valor simbólico dentro da imaginação coletiva.

Um ponto fundamental a destacar, nesse sentido, é que a questão das técnicas construtivas e dos materiais a serem utilizados para a realização da política habitacional era importante para o Estado no âmbito de seu projeto social. Materiais e técnicas deveriam responder ao panorama tecnológico local, "permitindo a absorção de uma enorme quantidade de mão de obra não especializada, que os sistemas de construção mais sofisticados não poderiam admitir", fato relevante dentro de uma política que buscava o pleno emprego. Tecnologias mais complexas e os postulados teóricos da arquitetura moderna foram utilizados nos locais em que havia disponibilidade de materiais e mão de obra qualificada, sendo progressivamente incorporados em outros locais. (LARRAÑAGA; PETRINA, 1987, p.110, tradução nossa) 
Capítulo 3.

A habitação como questão na América Latina:

o debate e a atuação dos profissionais no Brasil e na Argentina 
3.1. O debate sobre a habitação na América Latina: função social, ação estatal, planejamento e produção em grande escala

O diálogo entre profissionais na América Latina nas primeiras décadas do século XX se sobressai como aspecto crucial para o desenvolvimento de projetos habitacionais nos moldes propostos e produzidos nomeadamente a partir da década de 1940, em São Paulo e Buenos Aires. Nosso trabalho se solidariza a Gorelik (1999; 2005b), Martins (1998), Ballent (2005), Aboy (2005) e Botas (2011) na compreensão de que estes projetos foram, naquele momento particular (que trouxe outras condições específicas), o resultado de um encontro entre política e arquitetura.

Gorelik (1999) destaca nos países latino-americanos um momento iniciado ainda nos anos 1920, que se fortalece e toma corpo na década de 1930 e tem por característica a construção de Estados nacionalistas que dão condições à atuação da vanguarda arquitetônica. Esta vanguarda, entretanto, não assume a posição destrutiva historicamente atribuída à vanguarda, mas ao contrário, tem a tarefa de construir em cada país, junto com o Estado, o futuro da sociedade, economia e cultura nacionais.

Martins (1987) analisa a relação que se estabelece entre o Estado brasileiro pós-1930 e a vanguarda arquitetônica e revela um esforço de superação da divisão tradicional entre arte e técnica, que leva a arquitetura a integrar-se ao processo de transformação social. A cidade se torna o objeto de trabalho a ser reorganizado em favor da coletividade, onde a produção habitacional figura como função social da arquitetura e onde, de acordo com Botas (2011, p.19), a vanguarda alinha "seus interesses específicos ao projeto de modernização empreendido pelo Estado". 
Ballent (2005) trabalha a noção de que durante o governo peronista houve um encontro entre técnica e política, cujas propostas naquele momento convergem para a realização da produção habitacional social através de projetos massivos. De maneira análoga, Aboy (2005) compreende que nesta convergência os interesses de ambos os campos se validavam mutuamente, materializando-se nas distintas linguagens formais utilizadas na obra pública, nomeadamente nos conjuntos habitacionais. Embora as condições técnicas, políticas e culturais de cada país fossem distintas, é possível considerar que o fenômeno social correspondente à questão da habitação e sua percepção e enfrentamento por Estado e arquitetos atravessasse as fronteiras nacionais. Acreditamos assim, que os debates e a articulação profissional em torno da habitação deram aporte ao processo de institucionalização da produção habitacional pelo Estado, consolidado a partir da década de 1940 no Brasil e na Argentina.

Neste encontro, os dois mundos, o político e o arquitetônico, falaram sobre o mesmo problema, mas com linguagens distintas, e ambos, o projeto político e a proposta espacial, uniram interesses para transformar os modos de habitar do povo. Tanto os governos, que deram importância à modernização de seus países, como o arquiteto, que foi consciente do papel protagonista que devia assumir no crescimento da cidade e melhoramento da moradia do homem moderno, estiveram marcados por um consciente objetivo pedagógico realizado através dos conjuntos habitacionais, como instrumentos modernizadores [...]. (PINO, 2011, p.117, tradução nossa)

As primeiras décadas do século XX são marcadas de um modo geral por debates acerca das novas possibilidades, assim como das novas necessidades das cidades e do homem que nelas habita. A industrialização e suas consequências na sociedade sugeriam reflexões na busca de soluções para os problemas da arquitetura e do urbanismo da época. O urbanismo e a arquitetura de que tratavam os profissionais de diversos países tinham suas referências na racionalização industrial, como forma de superar os modelos tradicionais de cidade e moradia, entendidos a partir de então como obsoletos e inadequados a receber as novas tecnologias.

No campo da arquitetura essa preocupação se revelou no continente através da realização de congressos pan-americanos ${ }^{1}$ e nacionais, do trânsito de profissionais, da circulação de periódicos, da formação e fortalecimento de associações profissionais e, ainda, da constituição e reorganização de instituições de ensino. Entre os primeiros temas abordados destacam-se, pelo alcance dos debates e das realizações deles resultantes, a noção da habitação como função social do arquiteto e como questão social a ser enfrentada pelo Estado. A perspectiva de produção habitacional em grande escala e a incorporação da questão habitacional ao campo do urbanismo ou do planejamento urbano ganham força na década de 1940 em função especialmente do aumento populacional de grandes cidades latino-americanas ao longo da década de 1930. Os espaços de discussão, os temas abordados

\footnotetext{
${ }^{1}$ Cunhado nos EUA em finais do século XIX, o termo "pan-americanismo" referia-se, resumidamente, a uma ideia de integração continental, havendo, porém variadas interpretações sobre o próprio termo e as propostas dele derivadas. Ver: ATIQUE, Fernando. Arquitetando a "Boa-Vizinhança": a sociedade urbana do Brasil e a recepção do mundo norte-americano, 1876-1945. Tese (Doutorado) FAU-USP, São Paulo, 2007.
} 
e as eventuais consequências deles decorrentes, em especial no Brasil e na Argentina, são estudados por Atique (2005; 2007), Gutiérrez, Tartarini e Stagno (2007), Feldman (2010; 2014a; 2014b) e Collado (2011).

Em 1920 um grupo de arquitetos uruguaios organiza em Montevidéu o primeiro espaço de discussão para os profissionais da América Latina, os "Congresos Panamericanos de Arquitectos" (CPAs). Estes, segundo Atique (2007, p.48), foram "os principais fóruns de debates dos arquitetos no continente americano, antecipando, em certo sentido, e encontrando muitas vezes mais prestígio do que os contemporâneos Congressos Internacionais de Arquitetura Moderna" (CIAMs).

É interessante notar que o primeiro CPA é realizado antes do primeiro CIAM, que ocorre em 1928, e, mais importante, que alguns temas foram discutidos em ambos os congressos, com destaque para o debate sobre a própria profissão e sobre a questão habitacional. É possível afirmar que boa parte das questões colocadas em torno do tema da habitação nos CPAs, tais como a racionalização e a padronização dos elementos e processos construtivos, a verticalização e a associação entre o projeto da moradia e o planejamento urbano, relacionavam-se ao ideário do movimento moderno, que trazia em seu interior a noção do alojamento como função social da arquitetura.

A partir da década de 1940 a América Latina e a "cidade latino-americana" aparecem no centro dos debates profissionais do Ocidente como lócus de análises de questões urbanas e regionais e da possibilidade de modernização e desenvolvimento através da planificação (Gorelik, 2005a). Segundo Feldman (2014b, p.134)

ao longo dos anos 1940 e 1950 a associação entre planejamento e habitação é institucionalizada no âmbito dos programas de cooperação interamericana. Nesse processo, a mobilização de experts ligados às universidades e à prática no campo do planejamento e de profissionais dos países da América Latina e Central impulsionou a reflexão sobre a realidade latino-americana.

Órgãos internacionais como a Organização das Nações Unidas (ONU), criada em 1945, e a Organização dos Estados Americanos (OEA), criada em 1948, garantem o "suporte institucional para envolver profissionais de diferentes disciplinas e de diferentes países em programas de cooperação e assistência técnica para as regiões subdesenvolvidas" (FELDMAN, 2014b, p.134). Uma agenda desenvolvimentista comum a diversos países latino-americanos foi respaldada por órgãos cujo objetivo específico era estimular o desenvolvimento no continente, destacando-se a Comisión Económica para América Latina y el Caribe (CEPAL), organizada pela ONU em 1948.

Acompanhar as discussões realizadas nos congressos latino-americanos ou pan-americanos desde a década de 1920 até a década de 1960 possibilita destacar os principais temas debatidos em cada momento para o enfrentamento das questões colocadas, com especial interesse na questão habitacional e, principalmente, a evolução destas preocupações concomitantemente à evolução urbana e técnica ao longo dos anos, considerando-se as particularidades de cada país em relação a aspectos como os processos de urbanização e planejamento urbano, o desenvolvimento da indústria 
da construção, entre outros. Este estudo ajuda ainda a compreender a multiplicidade de questões atribuídas à atuação do arquiteto, bem como o desenvolvimento da própria profissão e de sua atuação no cenário regional, especificamente no Brasil e na Argentina.

São também de grande relevância para a compreensão do debate e articulação profissional no período e, em especial na Argentina e no Brasil, os artigos publicados em periódicos especializados que circularam nos dois países nas primeiras décadas do século XX com os temas da arquitetura, do urbanismo e da construção civil ${ }^{2}$. Esses periódicos especializados destinavam-se especialmente aos profissionais que atuavam no setor, mas também a estudantes de arquitetura e engenharia e ao público em geral, sendo publicados por órgãos ou associações profissionais, ou editoras particulares. É interessante mencionar que nos textos encontrados nos periódicos argentinos os termos "vivienda popular", "vivienda económica", "vivienda urbana", "casas baratas" e ainda, de forma um pouco mais específica, "vivienda obrera" são utilizados para tratar a questão. Alguns poucos textos utilizam o termo "habitación popular", que aparece, por exemplo, como título da publicação oficial da Comisión Nacional de Casas Baratas. Nos periódicos brasileiros também é grande a variação dos termos utilizados para aludir à questão, entre os quais, "casa popular", "casa econômica", "habitação popular" e "habitação operária", o termo "casas baratas", comumente utilizado na Argentina, aparece em um único artigo.

Como já esboçado anteriormente, é possível distinguir dois momentos particulares desta articulação entre os profissionais americanos em torno da questão habitacional, especialmente em função dos temas abordados. O primeiro momento vai de 1920, ano em que se realiza o primeiro Congreso Panamericano de Arquitectos (CPA) e termina em 1939, ano do Primer Congreso Panamericano de Vivienda Popular e é marcado especialmente pela distinção da questão habitacional como questão social. O segundo momento se inicia em 1940, quando são retomados os CPAs, e segue até 1965, ano do XI CPA, o primeiro realizado em solo não latino-americano, atestando as mudanças que se seguiriam no campo da habitação. Este segundo período é marcado principalmente pelo tema do planejamento e sua relação com a produção habitacional.

\section{Articulação de profissionais entre 1920 e 1939: a habitação como questão social}

Entre os encontros e congressos de profissionais ligados à arquitetura, ao urbanismo e à habitação os Congresos Panamericanos de Arquitectos se destacam. Assim como em Atique (2007), em Gutiérrez, Tartarini e Stagno (2007, s/p, tradução nossa) encontramos os CPAs como o mais importante espaço de reunião dos arquitetos americanos durante o século XX: "eles testemunham as preocupações, debates e reflexões dos arquitetos da América integrados profissionalmente em seus respectivos países e ratificam a vontade de pensar desde a profissão as problemáticas globais e regionais".

\footnotetext{
2 Dos periódicos selecionados - ver Introdução -, foram analisados os números compreendidos entre as décadas de 1930 e 1950.
} 
A principal razão para a realização dos CPAs, conforme descrito em publicação da Revista de Arquitectura de 1927, ano do terceiro congresso, era a aproximação entre os profissionais da América, com as "vantagens derivadas de uma obra comum". O momento colocava a "necessidade de intercâmbio de ideias", de discussão dos distintos métodos de ensino, de problemas comuns aos diferentes países e a "oportunidade de lutar pela dignidade profissional" (LOS CONGRESOS PANAMERICANOS..., 1927a, p.305, tradução nossa).

O contexto denota a época de mudanças em que os valores culturais europeus e o ensino academicista da arquitetura passam a ser questionados, principalmente em função da Primeira Guerra Mundial, ao mesmo tempo em que profissionais locais se expressavam em favor de arquiteturas nacionais e do estudo da história da arquitetura e das cidades americanas. Arturo Almandoz (2003) observa que naquele início do século XX, circularam obras referenciais para a conformação do campo da historiografia urbana na América Latina. Além disso, desde o final do século XIX a utilização do termo "pan-americano" era reforçada pela constante ação da União Panamericana, constituída durante a Conferência Internacional Americana celebrada em Washington em 1890 como espaço em que se buscava melhorar a comunicação e o intercâmbio comercial entre os países do continente (NOSSA HISTORIA, s/d).

A partir da realização do primeiro CPA em Montevidéu em 1920 - sendo o grupo organizador inicialmente formado por arquitetos uruguaios sob a direção de Horacio Acosta y Lara - é interessante notar, como observam Gutiérrez, Tartarini e Stagno (2007), que a realização dos CPAs foi se construindo "ao andar", uma vez que os cinco primeiros congressos têm como sede o que hoje chamamos de países do Cone Sul, até que em 1947 o Congresso é realizado em Lima, em 1950 em Havana, em 1952 no México e em 1965 em Washington.

Inicialmente centrados na questão profissional, os temários incluíram, porém, uma série de outras questões enfrentadas pelos arquitetos americanos, entre as quais figura desde a primeira reunião a questão da habitação, como destaca Atique (2007). Feldman (2014b) afirma que os congressos eram espaços onde o ideário arquitetônico e urbanístico pan-americano e, precisamente, latino-americano era firmado, repercutindo-se na atuação dos profissionais em cada país.

Quatro CPAs são realizados entre 1920 e 1930, havendo um hiato de dez anos até o quinto congresso em função das dificuldades geradas pela crise econômica de 1929 e do advento da segunda guerra mundial. Nestes primeiros encontros, é interessante notar que apesar da motivação inicial das reuniões - discutir o papel e a atuação do profissional arquiteto - o tema da habitação ganha espaço importante. A relevância da questão habitacional veio de seu reconhecimento como questão social resultante dos processos de modernização e expansão urbana por que passavam as grandes cidades da região no início do século XX, o que exigia proposições por parte dos arquitetos e urbanistas. 
A Argentina se sobressai na América Latina como ponto nevrálgico da discussão sobre a produção habitacional desde os primeiros anos do século XX. Reconhecendo o problema da habitação no país como questão social o Museo Social Argentino (MSA) organiza em 1920 - antes do primeiro CPA - o Primer Congreso Argentino de la Habitación. Esse reconhecimento tinha como pano de fundo os últimos acontecimentos no cenário internacional, a Revolução Russa e o término da Primeira Guerra Mundial e, no cenário nacional, o aumento do custo de vida que em 1920 alcançava o nível mais alto do período. É neste momento que os profissionais de arquitetura se deparam com a necessidade mundial e local de produzir habitações econômicas e em grande quantidade que pudessem reduzir o custo de reprodução social do trabalhador, em que o aluguel reconhecidamente representava um fator importante. (ZANZOTERA 2013)

A importância do Primer Congreso Argentino de la Habitación reside não apenas em seu pioneirismo como espaço de discussão, mas no fato de que o tratamento da questão da habitação foi já neste momento extrapolado e compreendido como uma questão urbanística. Era a primeira vez que estas duas questões chaves para o desenvolvimento urbano, a moradia e o planejamento urbano, eram articuladas, de modo que é possível entender este congresso como marco divisório na história do urbanismo argentino (COLLADO,2011). Ao mesmo tempo, foram também colocados em pauta pontos que seriam alvo de debate entre os profissionais em âmbito pan-americano especialmente depois de 1940, como as condições necessárias à moradia mínima, o emprego de novos materiais e a construção massiva de habitações como forma de baratear custos. Foram discutidas também medidas financeiras necessárias para facilitar a aquisição da casa pelos trabalhadores, superando-se a condição do aluguel, e colocados argumentos pela construção de casas individuais ou coletivas. As conclusões apontaram para um compromisso do Estado para com a construção de casas econômicas, prevendo-se a expropriação de terrenos vazios para a construção de moradias, o incentivo à iniciativa privada e ao desenvolvimento de cooperativas de construção. (GENEAU, 1920; ZANZOTERA 2013)

No Primeiro CPA a questão da atuação da iniciativa privada também seria abordada. Os arquitetos participantes concluem que a solução para a falta de moradias nas grandes cidades da América Latina viria de um trabalho conjunto entre o setor privado e o Estado. O setor privado foi reconhecido como principal responsável até então pela produção de "casas baratas", constatando-se o imperativo da atuação estatal tanto em termos legais, quanto operacionais e financeiros. Com o passar dos encontros, cada vez mais relevância foi dada ao papel do Estado na solução da questão habitacional, havendo uma concordância de que a iniciativa privada sozinha não poderia resolver a questão, posto que seu interesse na atividade imobiliária estivesse no retorno proporcionado pela inversão e no caso da habitação econômica este retorno era reduzido.

$\mathrm{O}$ incentivo à ação privada, porém, seria recorrentemente abordado pelos profissionais como possibilidade de ampliação da oferta de moradias. Em artigo intitulado "La vivienda urbana", 
publicado na Revista de Arquitectura em 1944 o arquiteto e urbanista José Pastor escreve sobre a necessidade da atuação do setor privado. Segundo o autor, o incentivo a esta atuação poderia consistir na colaboração estatal através de: (1) ajuda para adquirir ou arrendar a terra necessária para o desenvolvimento de bairros inteiros, propondo-se que expropriações fossem realizadas pelas Municipalidades, que então as venderiam ou arrendariam aos interessados; (2) organização de um sistema de empréstimos em longo prazo e com juros baixos por meio de bancos oficiais. Cabe aqui lembrar que as duas propostas colocadas pelo arquiteto fariam parte da política habitacional do Estado peronista, conforme descrito nos Planos Quinquenais. (PASTOR, 1944b)

Outro ponto a se destacar no primeiro encontro é a indicação para a construção de moradias coletivas nos centros urbanos mais povoados, registrando-se a pertinência do debate ao Movimento Moderno em um momento em que o edifício multifamiliar era ainda uma novidade mesmo para as famílias abastadas. (ATIQUE, 2007; GUTIÉRREZ; TARTARINI; STAGNO, 2007)

Interessa-nos pontuar entre as conclusões do segundo CPA, realizado em Santiago do Chile em 1923, o entendimento do Estado como responsável também por "fomentar e ajudar a criação de indústrias de materiais e elementos de construção, que se submetam a determinados tipos, classes e dimensões, buscando a produção em série de tipos estandardizados" (II CONGRESO PANAMERICANO..., 1923, p.81, tradução nossa, grifo nosso). A adoção da padronização e da produção em série na construção de habitações colocada neste momento encontrava ainda dificuldades de implementação nos países pouco industrializados, mas seria importante à solução da questão habitacional numa perspectiva de produção massiva na década de 1940 . Destacamos ainda neste congresso uma das conclusões da sessão sobre "casas baratas":

a fim de estimular a edificação e fomentar a previdência social [...] recomenda-se em todo continente a instituição do Seguro-Habitação mediante a formação de Cajas Patronales [Caixas de Empregadores] constituídas com aporte direto das empresas, do Estado e dos operários e empregados que resultem beneficiados. (II CONGRESO PANAMERICANO..., 1923, p.81, tradução nossa, grifo nosso).

Em janeiro daquele ano havia sido promulgada no Brasil a Lei Elói Chaves, que estabeleceu a criação das primeiras "Caixas de Aposentadoria e Pensões", ficando evidente a afinidade entre os debates brasileiro e regional quanto às questões social e habitacional, pois a partir da década de 1930 os fundos previdenciários seriam usados para construir moradias destinadas aos trabalhadores.

Nas conclusões do terceiro CPA, que ocorreu em 1927 em Buenos Aires, fica também evidente a relação entre o contexto argentino em termos das realizações no campo da produção habitacional e o debate realizado no congresso. Entre as conclusões se propôs para cada país "a criação de comissões oficiais de casas baratas" e a aprovação de leis que regulassem a ação de cooperativas, mutualidades e sociedades edificadoras tanto urbanas quanto rurais, que se propusessem a facilitar a construção de casas econômicas (III CONGRESO PANAMERICANO..., 1927b, p.315, tradução nossa). Lembramos que desde 1915 a produção estatal de moradias econômicas era realizada na Argentina pela Comision 
Nacional de Casas Baratas e que desde antes disso atuavam no país algumas cooperativas de construção de moradias, a mais importante, a Cooperativa "El Hogar Obrero". No III CPA foi proposta ainda a "fundação em todos os países americanos de Museus Sociais organizados com o fim de estudar e buscar a solução dos problemas jurídicos, econômicos, técnicos e sociais relacionados com a habitação" (III CONGRESO PANAMERICANO..., 1927(b), p.315, tradução nossa). Desde 1911 o Museo Social Argentino atuava no país, estabelecendo um instituto de estudo e ação social.

Vale lembrar que em 1929 o segundo CIAM é realizado em Frankfurt e traz como tema a Existenzminimum, a habitação para o mínimo nível de vida. Mais do que abordar a questão a partir da relação do seu ponto de vista físico, isto é, o simples dimensionamento mínimo, o encontro tratou das mínimas condições sociais estabelecidas na e pela habitação, compreendendo-se que no alojamento se realizava a função social da arquitetura (FOLZ, 2005). Se desde o primeiro CIAM se considerou que o urbanismo era a "organização das funções da vida coletiva", no segundo se compreende que a partir da moradia, a existência mínima social se estende para o ambiente em que está inserida, envolvendo espaços livres e equipamentos coletivos necessários à vida cotidiana. Além disso, "a verticalização e o adensamento são entendidos como elementos estruturais de organização do espaço da cidade". Desde então, as relações entre unidade habitacional e cidade vão progressivamente adquirindo maior complexidade. (FELDMAN, 2005, p.74-75),

Segundo Huapaya (2015) a proposta de execução de planos reguladores para os grandes centros urbanos ganha força a partir deste momento, evidenciando a noção de que se ampliavam as funções do arquiteto à escala do projeto urbano. No CPA seguinte, que aconteceu no Rio de Janeiro em 1930, destacou-se a indicação de que o estudo do problema das casas econômicas fosse realizado em relação a planos reguladores de transformação e desenvolvimento das cidades, buscando-se os locais mais apropriados para a construção de bairros residenciais. A partir de então a integração entre projeto habitacional e planejamento urbano seria amplamente discutida nos CPAs, registrando-se como as ideias perpassavam os debates profissionais realizados no continente e fora dele.

A sessão sobre "urbanismo" no IV CPA concluiu que este, "por sua importância, constituísse tema obrigatório dos futuros congressos" (LAS CONCLUSIONES..., 1930c, p.544, tradução nossa) e recomendava a realização de encontros nacionais de urbanismo e de Conferências Pan-americanas de Urbanismo entre os CPAs. Além disso, foi proposta a criação de Institutos de Urbanismo e Urbanística em todos os países americanos "com a finalidade de levar a cabo uma ação coordenada de investigação, docência e divulgação dos problemas urbanos e rurais, tendo a visão conjunta de país, região e lugar" (CONCLUSIONES APROBADAS..., 1940a, p.196, tradução nossa).

Embora não houvesse outro CPA até 1940, os debates continuariam através de periódicos e encontros nacionais, dentre os quais destacamos o Primer Congreso Argentino de Urbanismo, que tem lugar em Buenos Aires em 1935. Na verdade, nos anos de hiato dos CPAs realizaram-se nos 
países americanos diversos encontros nacionais e internacionais ligados ao tema do urbanismo e habitação, entre os quais podemos mencionar também o Congresso Internacional de Americanistas (Lima, 1937), o Congresso Internacional de Planificação e Habitação (México, 1938 e o Congresso Internacional de Arquitetos (Washington, 1939) (GUTIÉRREZ; TARTARINI; STAGNO, 2007, p.64).

No Brasil, embora ainda sob um viés conservador sobre o tema, em 1931 foi promovido pela Divisão de Arquitetura do Instituto de Engenharia de São Paulo o Primeiro Congresso da Habitação. Convém destacar a participação do arquiteto argentino Raul Pasman, que apresenta a tese "Casas Baratas", a respeito da solução para o problema da moradia na Argentina $^{3}$. Outras teses que merecem menção são "Casas Populares - Cidades Jardins" do engenheiro Marcelo C. de Mendonça, "Sugestões para a solução do problema das casas operárias" do engenheiro Henrique Dória e "Habitações Econômicas" de Bruno Simões Magno. Nas teses de Pasman, Doria e Magno é possível perceber uma orientação semelhante, focada na função social do problema habitacional. Identificou-se no congresso a necessidade de promover ações que garantissem o aumento da provisão habitacional através de novas tecnologias e métodos organizados de produção. A moradia coletiva, no entanto, não era ainda uma opção.

O estigma dos cortiços e conventillos ainda afastava a ideia do edifício multifamiliar como local adequado à moradia naqueles anos, especialmente em função de aspectos sanitários, devido à concentração urbana, e sociais, devido ao temor pela disseminação do comunismo nos espaços comuns. Contudo, na década de 1930 a questão econômica associada à produção de um maior número de unidades e à diminuição do custo da unidade em função do preço da terra vinculado à verticalização e, logo, à moradia coletiva, começava a ganhar força.

Nas últimas décadas, o crescimento rápido da população das cidades, a veloz evolução das ciências e atividades industriais, com toda a complexidade de fatores que colocam em jogo, deram um impulso extraordinário a algumas cidades, cujo desenvolvimento, escapando a todas as provisões normais, coloca problemas de tal magnitude que faz necessário sair da inércia e apatia para buscar soluções ainda factíveis que evitem males irremediáveis. (INFORMACIONES DEL PRIMER..., 1935, p.217, tradução nossa)

Já em 1935, o ponto alto do Primer Congreso Argentino de Urbanismo foi a exposição de um conjunto de habitações para operários construído na cidade de Mendoza. O conjunto era constituído por blocos laminares com três pavimentos, totalizando 576 apartamentos associados a equipamentos comunitários (COLLADO, 2011). Ficava explícita a vinculação do projeto habitacional ao urbanismo, ganhando destaque o tema da organização funcional da cidade, e da realização de planos reguladores que localizassem os bairros de moradia nos locais mais apropriados. (FIGURA 62)

\footnotetext{
${ }^{3}$ A exposição de Pasman trata fundamentalmente da Comisión Nacional de Casas Baratas (CNCB), sua organização, regulamentação e funcionamento, sendo relevante mencionar o fato de que, segundo o arquiteto, quando das inscrições para interesse nas unidades pôde-se verificar que havia uma preferência pela unidade individual, que recebe 1800 inscrições (contra 600 para moradias coletivas). (PRIMEIRO CONGRESSO DE HABITAÇÃO, 1931)
} 
Destaca-se o fato de este congresso ter reunido um grupo heterogêneo de profissionais de distintas disciplinas formado por membros do governo, de entidades públicas e privadas, universidades e instituições vinculadas ao desenvolvimento urbano, estudantes e todos os demais cidadãos interessados, conforme descrito em matéria sobre o congresso na Revista de Arquitectura. (INFORMACIONES DEL PRIMER..., 1935)

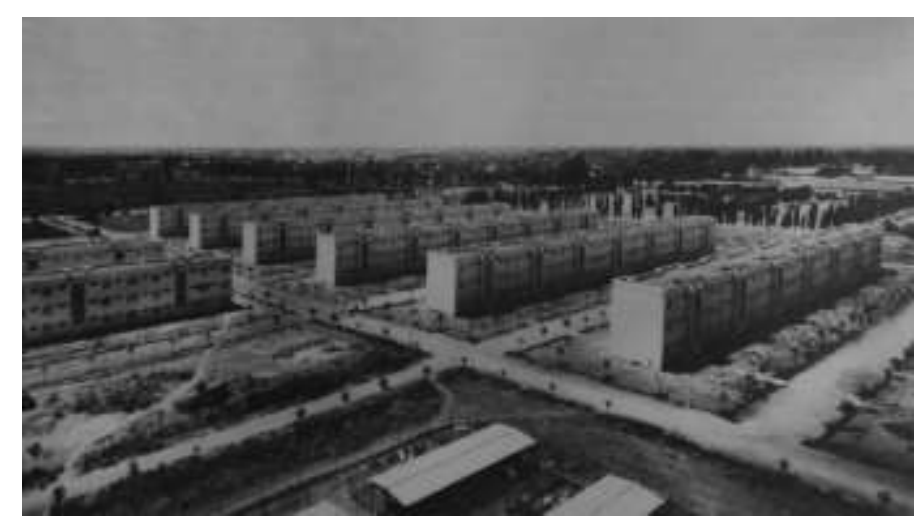

Figura 62. "Barrio Gobernador Guillermo Cano" em Mendoza (1935). Fonte: GUTIERREZ, Ramón; GUTMAN, Margarita (comp.). Vivienda: Ideas y cosntradicciones (1916-1956): de las Casas Baratas a la erradicación de Villas de Emergencia. Buenos Aires: Instituto Argentino de Investigaciones de Historia de la Arquitectura y el Urbanismo, 1988. p. 70.

A contundência com que era colocada a questão da habitação social nos espaços de discussão latinoamericanos, destacada pelos profissionais e por diversos governos ao longo da década de 1930, culminaria na formação de um espaço específico de discussão do tema em 1939 na realização do Primer Congreso Panamericano de Vivienda Popular em Buenos Aires. Segundo o então vicepresidente argentino Ramón Castillo "era esperado [...] que se designasse Buenos Aires como sede deste congresso, não apenas porque a resolução teve origem em uma iniciativa argentina, mas também porque nessa República se realizaram notáveis feitos na luta contra estes males". (CASTILLO, 1939, p.9, tradução nossa)

O discurso realizado por Ramón Castillo em $1939^{4}$, intitulado "La vivienda y la ación del Estado" é fundamental para entender como o Estado argentino compreendia a questão habitacional naquele momento. Para Castillo (1939) as leis sobre a moradia eram, juntamente com a legislação de assistência social, um complemento às leis trabalhistas. O vice-presidente destaca a existência de leis argentinas sobre o tema da moradia e as obras realizadas tanto pelo Estado como pela iniciativa privada, mas se ressente da falta de uma "Ley de la vivienda popular" e de um Plano Orgânico detalhado para solução do problema, que submetesse toda iniciativa, pública ou privada, de

\footnotetext{
${ }^{4}$ Nos meses que antecederam o Primer Congreso Panamericano de Vivienda Popular, entre janeiro e agosto de 1939, através das estações de rádio argentinas del Estado, Splendid e Cultura, foi realizada como parte das atividades preparadas pela Comissão Organizadora do congresso uma série de conferências cujo conteúdo traz algumas considerações de interesse.
} 
construção de moradias. No enfrentamento da questão da moradia popular, não apenas o tema da higiene deveria ser perseguido, mas a realização do ideal da casa própria. A construção de "blocos de numerosas habitações" em bairros exclusivos é vista como problema por Castillo (1939), que indica a supressão desse tipo de produção, já então realizada, ainda que modestamente, pela CNCB e pela Cooperativa El Hogar Obrero, substituindo-a pela construção de moradias individuais.

Outro discurso importante foi pronunciado naquele momento que precede o encontro pelo então ministro de Relações Exteriores, José Maria Cantilo. O ministro ressalta que a moradia social é uma questão governamental, mas que sua solução necessita de colaboração multidisciplinar: dos sistemas financeiro e econômico, da arquitetura e do urbanismo, da higiene, do direito, da educação e da assistência social e afirma ainda:

É lógico, pois, que os governos tenham um interesse positivo, antes de iniciar ou prosseguir seus esforços no plano nacional, em conhecer a fundo as gestões que se realizam no mesmo sentido em outros países, aproveitando como possível a experiência alheia; e que tratem de entrar em contato, por meio de seus experts na matéria, para elucidar em comum as fórmulas gerais mais adequadas para uma boa política nacional de casas baratas. E ambos os propósitos são alcançados mediante reuniões internacionais. (CANTILO, 1939, p. 13, tradução nossa)

Cantillo (1939) alega que razões geográficas, sociais e econômicas indicavam que o tema da moradia, embora universal, apresentava nos países americanos características comuns que tornavam "particularmente proveitosa" uma reunião entre os países do continente com o propósito específico de discutir a questão habitacional. Assim, todos os governos americanos foram convidados a participar do Primer Congreso Panamericano de la Vivienda Popular através de delegações que poderiam apresentar projetos e conferências. Paralelamente, foi solicitado à União Panamericana, à Sociedad de las Naciones, à Oficina Internacional del Trabajo, à Federação Internacional de Habitação e Urbanismo de Bruxelas e ao CIAM realizado em Zurich, que enviassem ao Congresso profissionais para apresentar as experiências internacionais.

A delegação brasileira foi formada por profissionais brasileiros vinculados a instituições-chave não apenas para a produção da habitação popular, mas ligados à indústria da construção e ao planejamento urbano: Rubens Porto, vinculado ao Ministério do Trabalho; Francisco Baptista de Oliveira ${ }^{5}$, representante do Clube de Engenharia e do Sindicato Nacional de Engenheiros; Plínio Cantanhede, presidente do IAPI; e Paulo Accioly de Sá, diretor da Divisão de Indústria da Construção no Instituto Nacional de Tecnologia (FELDMAN, 2014b). É relevante o fato de esta delegação, conforme Portaria SCsm-138, de 30 de agosto de 1939 assinada pelo então Ministro do Trabalho, Valdemar Falcão, ter sido "financiada pelos seis IAPs subordinados a este Ministério, aos quais

\footnotetext{
${ }^{5}$ Em 1940 Oliveira apresenta no Instituto de Engenharia de São Paulo a palestra "A casa proletária brasileira", baseada em sua tese e apreciação do Congresso de 1939, em que se destacam as conclusões da "Comissão de Urbanismo" do Congresso para a solução do problema da casa popular.
} 
interessam grandemente os resultados que é lícito esperar daquele certame". (DOU, Seção 1, 01 set. 1939, p. 44)

A delegação Argentina teve forte presença da Corporação de Arquitetos Católicos e apresentou como conclusão do congresso que "o problema da moradia popular deveria ser resolvido preferencialmente através da construção de casas individuais cuja propriedade pudesse ser adquirida pelos trabalhadores como patrimônio familiar", postura totalmente diferente daquela sustentada no próprio congresso e também pela $\mathrm{CNCB}$, que naquele momento já produzia conjuntos de moradias coletivas. Similar à indicação do vice-presidente Castillo, a solução colocada pela comissão argentina trazia fortemente, portanto, a postura adotada pelo catolicismo, que ainda vinculava a moradia coletiva aos cortiços e às más condições de higiene e moralidade a eles associadas. (BALLENT, 2005; CRAVINO, 2015)

Entre os temas discutidos no congresso se sobressai, porém, a construção de moradias coletivas e conjuntos habitacionais, além da moradia mínima adequada à família operária. Outras discussões trataram da estandardização de tipos e elementos construtivos e da utilização de matérias primas e produtos regionais com vistas a baratear a produção habitacional, prevendo-se um intercâmbio panamericano de materiais de construção. (PRIMER CONGRESO PANAMERICANO..., 1939)

Vale mencionar as recomendações da Comissão de Aspectos Sociais de "que todo bairro operário, todo conjunto de casas baratas, composto por casas individuais ou coletivas, próprias ou alugadas, fosse complementado com instalações de assistência médica e social, cultural e esportiva" e, da Comissão de Urbanismo, cujo presidente era o brasileiro Francisco Baptista de Oliveira, de que "todo plano de habitação popular deveria ser encarado como um plano urbanístico e, portanto, como parte integrante de um plano regulador e regional". (PRIMER CONGRESO PANAMERICANO..., 1939, p.381,382, tradução nossa)

Dois anos depois Francisco Baptista de Oliveira preside a Comissão Organizadora do Primeiro Congresso Brasileiro de Urbanismo organizado pelo Departamento de Engenharia do Centro Carioca. Apesar de realizar-se em 1941, por sua temática este congresso pode ser incluído no primeiro momento de articulação de profissionais. As suas conclusões foram as mesmas da Comissão de Urbanismo do Congreso Panamericano de Vivienda Popular, coincidência que pode ser atribuída à própria atuação de Francisco de Oliveira nos dois encontros.

Na sessão temática "Urbanismo e Habitação" fica evidente a complexidade que se atribui à questão habitacional e se confirma sua incorporação ao escopo do urbanismo. "A habitação é abordada em seus aspectos sociais, técnicos, financeiros e urbanísticos, e em suas especificidades no contexto urbano e rural. [...]. Emerge uma concepção de habitação imbricada com os vários elementos constitutivos do espaço urbano." (FELDMAN, 2008, p.92) 
Ao final do Congresso o projeto da habitação foi assumido como questão urbanística, ganhando relevância e amplitude no âmbito da política trabalhista implementada por Vargas e sendo abordado por distintas disciplinas (FELDMAN, 2008; BONDUKI, 1998). Além disso, é relevante que ao final do encontro os participantes tenham sido recebidos por Getúlio Vargas, em um gesto de demonstração de que o governo estava disposto a colaborar para a implementação de conclusões e decisões tomadas pelos congressistas.

É possível afirmar que na América Latina o Congreso Panamericano de la Vivienda de 1939 marcava o fim de um período de amadurecimento do debate sobre a moradia. A habitação era reconhecida como questão a ser enfrentada pelo Estado, com participação de outros setores da sociedade e o projeto habitacional era definitivamente integrado ao campo do planejamento urbano, tema que deu a tônica aos encontros realizados a partir de 1940.

\section{Articulação de profissionais entre 1940 e 1965: planejamento e produção habitacional}

Segundo Atique (2005, p.1), se até então os CPAs mostravam "uma pluralidade de pensamento e opções ideológicas, políticas, estéticas e construtivas entre os arquitetos", a adesão ao Movimento Moderno - tendo como forte componente a associação entre planejamento urbano e habitação garantiu certa homogeneidade às discussões posteriores a 1940. Para Feldman (2014a) desde 1940 é possível verificar uma correspondência direta entre as decisões tomadas nos Congressos Panamericanos de Arquitetos e nas Conferências Interamericanas ${ }^{6}$ promovidas ao longo das décadas de 1940 e 1950 pela OEA, atestando também essa homogeneidade do debate. Em 1940 no V CPA, que aconteceu novamente em Montevidéư ${ }^{7}$ o urbanismo foi o principal tema em discussão, com conclusões similares às do Congresso de Moradia de 1939.

É relevante ao longo da década de 1940 o debate virtual, em matérias de periódicos, e real, nas associações profissionais e instituições, referente à questão da melhor forma de acesso à moradia. Uma ala dos profissionais entendia a aquisição da casa própria como meio de resolver não apenas a questão habitacional, mas também outras questões sociais, enquanto outra defendia a locação das unidades como forma de facilitar o acesso à moradia.

A solução para o problema habitacional unicamente através da aquisição ou construção da casa individual se associava especialmente à visão da Igreja, mas era analisada também com relação às possibilidades oferecidas pelas grandes cidades. Para Pastor (1945), a casa própria unifamiliar era

\footnotetext{
6 “Ao longo das décadas de 1940 e 1950 as Conferências Interamericanas como órgão supremo da OEA são os fóruns onde planejamento e habitação na perspectiva da metrópole da América Latina toma forma - em conteúdo e em estrutura institucional". (FELDMAN, 2014, p. 136)

${ }^{7}$ As dificuldades econômicas e a crise política por que passam diversos países do continente empurram a realização do $\mathrm{V}$ CPA, que deveria realizar-se em 1933, para 1940. No congresso anterior se havia decidido que a cidade sede seria Havana, porém o contexto de crise associado ao advento da Segunda Guerra Mundial inviabiliza a realização da reunião em Cuba, de modo que esta se realiza novamente no Uruguai, que contava com uma conjuntura mais favorável: naquele momento eram arquitetos o presidente do Uruguai (Alfredo Baldomir) e o intendente de Montevidéu, o arquiteto Horacio Acosta y Lara, um dos idealizadores dos 1으.
} 
possível especialmente nas áreas suburbanas (periféricas) onde o preço da terra permitia a compra do lote a e a ocupação através de densidades menores, enquanto nas áreas urbanas consolidadas, onde o preço da terra era maior, era possível a propriedade horizontal em edifícios coletivos.

O médico Juan Dassen, ao escrever para "La Habitación Popular", órgão da CNCB, em 1942 defende a produção de unidades de habitação que pudessem ser alugadas por um valor modesto, dado que a aquisição de uma unidade teria um custo elevado para o futuro proprietário com relação aos seus ganhos (DASSEN, 1942). A locação da unidade era quase sempre associada à moradia coletiva, em que o custo da terra era reduzido em comparação à propriedade individual isolada. Ao longo da década de 1940, quando a necessidade de aumento da produção habitacional é compreendida em diversas cidades do continente, se percebe nos debates uma evolução da concepção da moradia coletiva como possibilidade de solução para a questão habitacional.

Após a Segunda Guerra é possível constatar que se opera uma profunda tomada de consciência sobre a dimensão social do elevado déficit de moradias no continente e a urgente necessidade de enfrentálo. Chama a atenção no VI CPA, que acontece em 1947 em Lima, justamente a "discussão sobre a função social da arquitetura e a responsabilidade do arquiteto", entendendo-se que o enfrentamento da questão habitacional através de aspectos técnicos, econômicos e sociais era o papel a ser desempenhado pelo arquiteto naquele momento (HUAPAYA, 2015, p.68).

O conceito de Planificação, mais ampliado que o de Planejamento, é incorporado aos discursos a partir deste momento ${ }^{8}$. A planificação é associada ao projeto desenvolvimentista proposto aos países latino-americanos no pós-guerra, indicativo da presença estadunidense no encontro. Uma das conclusões do VI CPA prevê a "formação de Organismos Nacionais e Pan-americanos de Planificação". (CONGRESO PANAMERICANO DE ARQUITECTOS..., 1947, p.435, tradução nossa)

Em 1951 a Organização dos Estados Americanos (OEA) estabelece em Bogotá o International Housing and Planning Center, conhecido pela sigla em espanhol CINVA (Centro Interamericano de Vivienda y Planeamiento Urbano). Fundamental do ponto de vista da institucionalização da questão habitacional em âmbito continental, o CINVA atua em ensino, pesquisa, intercâmbio e assistência em habitação, arquitetura e urbanismo (ARAVECCHIA-BOTAS, 2012). Em 1956, durante um seminário sobre ensino da planificação, realizado em Porto Rico sob os auspícios das Nações Unidas e da OEA, é criada a Sociedad Interamericana de Planificación (SIAP), cujo principal objetivo seria coordenar o esforço de estimular o desenvolvimento, o conhecimento e a aplicação da planificação integral.

\footnotetext{
${ }^{8}$ Conforme definições do Diccionario de la Real Academia Española (DRAE): planejamento (designado planeación, planteamiento ou planeamiento conforme o país na América Latina), a ação ou efeito de planejar, traçar um plano, tendo um ou vários objetivos a cumprir, abrangendo as ações requeridas para que este objetivo possa ser alcançado, e planificação (planificación), a ação ou efeito de planificar, traçar um plano de grande amplitude com determinado objetivo, implicando mais em um processo de tomada de decisões, de previsão (antecipação), visualização (representação do futuro desejado) e predeterminação (tomada de medidas para alcançar o futuro desejado), tais como o desenvolvimento harmonioso de uma cidade, o desenvolvimento econômico, a pesquisa científica, a operação de uma indústria, etc.
} 
Desde o VII CPA em 1950, que finalmente aconteceu em Havana, o tema da planificação é debatido e compreendido como meio mais adequado para o desenvolvimento das cidades americanas e se reforça a associação entre habitação e planejamento como forma de cumprir a função social da arquitetura. A "planificação integral dos espaços de habitação" é compreendida como a resposta aos problemas sociais que enfrentavam as cidades americanas e, em especial, as grandes cidades latinoamericanas naquele momento (GUTIÉRREZ; TARTARINI; STAGNO, 2007). O oitavo e o nono Congressos Pan-americanos de Arquitetos, realizados respectivamente na cidade do México em 1952 e em Caracas em 1955, têm em comum o enfoque na planificação e na função social da arquitetura, sendo seus títulos respectivamente "A planificação e a arquitetura nos problemas sociais da América" e "A função social do arquiteto: o arquiteto e a planificação".

Vale a pena apresentar como referências da produção habitacional social realizada nas décadas de 1940 e 1950 dois exemplos mexicanos. O México é, assim como o Brasil e a Argentina, um dos países em que a relação entre o Estado e a classe trabalhadora é representada na figura do presidente que "concede" benefícios às classes, entre os quais a habitação. Conforme apontado por De Anda Alanis (2008, p.195, tradução nossa) no início da década de 1930 é possível reconhecer diversas ações estatais quanto ao planejamento urbano de modo a beneficiar a população trabalhadora. Contudo, é a partir de 1946, no governo de Miguel Alemán, que tem início um programa nacional de provisão de moradias. $\mathrm{O}$ arquiteto Mario Pani foi um dos principais responsáveis pela apropriação do conceito de moradia coletiva no México, sendo pioneiro no desenvolvimento de edifícios verticais de habitação e tendo executado "aproximadamente 136 projetos, 66 arquitetônicos e 70 de planejamento e urbanismo" para o governo mexicano entre 1946 e 1963 (REZA, 2006). Pani é responsável por estes dois projetos habitacionais, um anterior e outro posterior ao CPA realizado no país em 1952.

o Centro Urbano Presidente Alemán (CUPA) foi projetado por Mario Pani e Salvador Ortega Flores ao sul da Cidade do México, em meio à área urbana consolidada, entre 1946 e 1949. Como uma superquadra, o CUPA não é atravessado por ruas de tráfego de veículos, apresentando apenas vias peatonais de acesso aos edifícios (Figura 63). A elevação dos edifícios sobre pilotis e a "multiporosidade dos contornos propicia o livre intercâmbio de ambientes: da cidade ao novo conjunto e vice-versa" (DE ANDA ALANIS, 2008, p.246, tradução nossa). Uma série de equipamentos comunitários e serviços foi prevista no conjunto, propondo-se sua utilização tanto pelos moradores quanto pela população do entorno. 


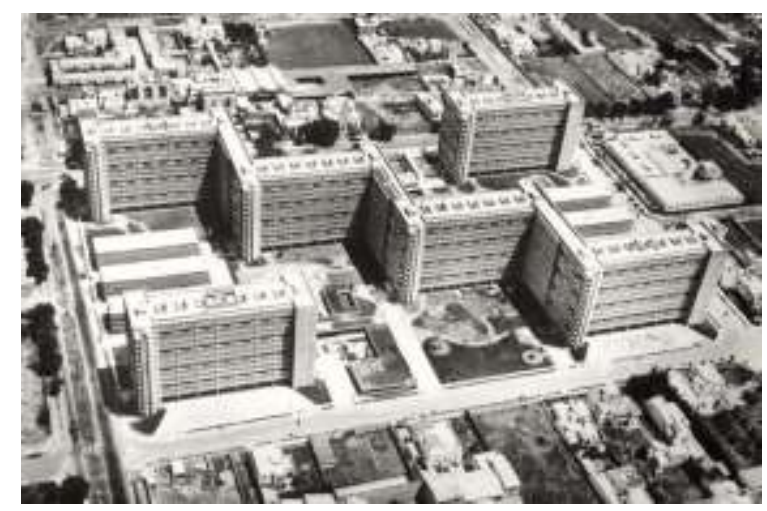

Figura 63: Centro Urbano Presidente Alemán (1946-49). Fonte: "65 años del CUPA" In: Arquine, 18 oct. 2012. Disponível em: <http://www.arquine.com/blog/65-anos-del-cupa/> Acesso em 05/11/2014.

O Conjunto Urbano Presidente Lopez Mateos também conhecido como "Unidade Habitacional Nonoalco-Tlatelolco", foi projetado em 1958 por Mario Pani e Luis Ramos Cunningham para uma grande área ao norte da Cidade do México. A área comportava antigas instalações de empresas ferroviárias e encontrava-se ocupada por moradias irregulares, de modo que o projeto tinha forte caráter de remodelação e incluiu unidades destinadas a classes populares, média e alta, com densidade estimada em 1000 hab./ha,, para tanto fazendo uso de edifício verticais, que se destacam na região ocupada por construções baixas. (Figura 64)

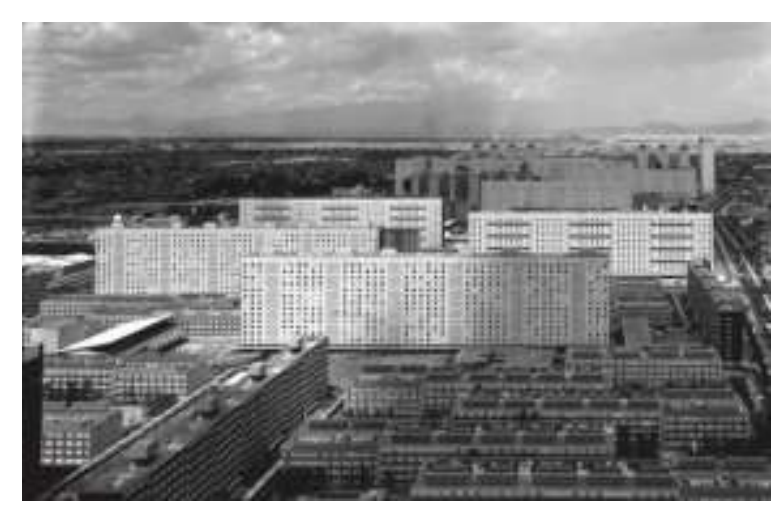

Figura 64. Unidad Habitacional Nonoalco Tlatelolco (1958). Fonte: Museo Amparo - Exposiciones pasadas: Arquitectura en México, 1900-2010. La construcción de la modernidad. Obras, diseño, arte y pensamiento. Disponível em: <http://museoamparo.com/exposiciones/pieza/823/conjunto-habitacional-nonoalco-tlatelolco> Acesso em 25 fev. 2018.

Destaca-se entre as conclusões do IX CPA (Caracas, 1955) a indicação pela a criação do Banco Privado Interamericano de Fomento à Moradia de Interesse Social. É a primeira vez que aparece o termo "moradia de interesse social" - vivenda de interés social - nos CPAs. A proposta de criação do Banco considerava que a ação isolada de cada país da América Latina - também pela primeira vez as conclusões referem-se exclusivamente aos países latino-americanos - era incapaz de atenuar o elevado déficit de moradias. Vele lembrar que em 1959 seria criado o Banco Interamericano de Desenvolvimento (BID), que além proporcionar empréstimos tinha também o propósito de apoiar iniciativas de redução da pobreza, garantir assistência técnica e promover a integração regional. 
Outras duas conclusões do IX CPA são significativas para nossa pesquisa. A primeira recomenda a garantia de intercâmbio de informes entre as Associações de Arquitetos dos países americanos através da Federação Pan-americana de Associações de Arquitetos (FPAA), buscando facilitar a troca de experiências e o conhecimento dos resultados obtidos sobre a questão habitacional. A segunda propõe solucionar a questão da moradia através da redução do preço final, não a custo do espaço habitável, mas mediante a simplificação de métodos e a aplicação de processos como a préfabricação, a industrialização e a produção em massa para abastecer mercados comuns. (GUTIÉRREZ; TARTARINI; STAGNO, 2007). Ainda das conclusões consta a previsão de elaborar a "Carta de Caracas", em que constariam os princípios sobre a planificação e sobre a função social do arquiteto aprovados no IX CPA, porém não foi encontrada qualquer outra menção a este documento.

Em 1958 é realizado em Bogotá o Seminario de Técnicos y Funcionarios en Planeamiento Urbano, que resultou num conjunto de propostas para o tratamento da questão habitacional associada ao planejamento urbano compiladas na "Carta de Los Andes". "A 'Carta de los Andes', documento com as conclusões e recomendações do Seminário expressa o processo que ocorre nos programas de cooperação interamericanas a partir do final da década de 1930 até o final da década de 1950". (FELDMAN, 2014b, p.137). Dirigida ao povo latino-americano, a carta confirma a planificação como a ferramenta mais adequada para enfrentar os problemas regionais decorridos do baixo nível de desenvolvimento econômico, social e cultural.

A "Carta de los Andes", segundo Feldman (2014b), teve uma difusão significativa entre os urbanistas, sendo traduzida e publicada no Brasil em 1960. A publicação traz um prefácio escrito por Anhaia Mello que a descreve como "um dos três documentos que orientam o planejamento territorial", ao lado da Carta de Atenas (1943), resultante do IV CIAM e da Charte d'Aménagement (1952), resultante da semana de estudos sobre ordenamento do território promovida pelo grupo Economie et Humanisme, em La Tourrete, na França.

No mesmo bojo de propostas de cooperação interamericana ${ }^{9}$ em agosto de 1961 o presidente John Kennedy lançava oficialmente durante a conferência da OEA em Punta del Este, Uruguai, a "Aliança para o Progresso". O programa reconhecia a necessidade de integração e crescimento sustentável

\footnotetext{
${ }^{9}$ O presidente brasileiro Juscelino Kubitschek propusera em 1958 a Operação Pan-Americana (OPA), um programa de cooperação e assistência ao desenvolvimento econômico dos países latino-americanos. De acordo com a exposição de Kubitschek a política externa estadunidense frustrava as aspirações de desenvolvimento dos países latino-americanos, devido à prioridade conferida à luta contra o Comunismo, que para ele representava menor problema que a miséria da população e a estagnação econômica. O programa buscava basicamente melhorar os preços das matérias-primas vendidas aos EUA e garantir financiamentos em apoio ao processo de industrialização da América Latina. Em agosto daquele mesmo ano os EUA reconheceram formalmente a proposta da OPA, propondo a criação de um mecanismo financeiro multilateral que viria a ser o Banco Interamericano de Desenvolvimento (BID) - e a concepção de um mercado comum latinoamericano - futuramente a Associação Latino-Americana de Livre Comércio (ALALC). Contudo, enquanto a OPA reivindicava um plano de desenvolvimento global, os EUA limitaram-se a aprovar a criação do BID, frustrando os países membros e confirmando a existência de um abismo entre as expectativas da América Latina e os interesses dos EUA. A OPA se encerrava em dezembro do mesmo ano, porém muitas de suas propostas seriam incorporadas à Aliança para o Progresso. (FGV/CPDOC. Verbete: Aliança para o Progresso)
} 
para todo o continente e foi oficializado através da "Carta de Punta del Este", documento assinado naquele momento por 22 países latino-americanos e Estados Unidos.

Em suma, de acordo com a Carta, os países latino-americanos deveriam traçar planos de desenvolvimento, cuja implementação contaria com a ajuda financeira dos EUA. Os planos deveriam incluir entre outras medidas de aceleração do desenvolvimento econômico e social, planos habitacionais urbanos e rurais (FGV/CPDOC). À parte a clara tentativa estadunidense de impedir o avanço do comunismo pelo continente desde Cuba, de fato o programa proporcionou a incorporação de novas tecnologias construtivas aos projetos de habitação, embora outras perspectivas começassem a organizar a produção habitacional. Em diversos países latino-americanos bairros residenciais extensivos conhecidos como Ciudad Kennedy, ou Vila Kennedy no caso brasileiro, foram edificados com recursos do programa Aliança para o Progresso.

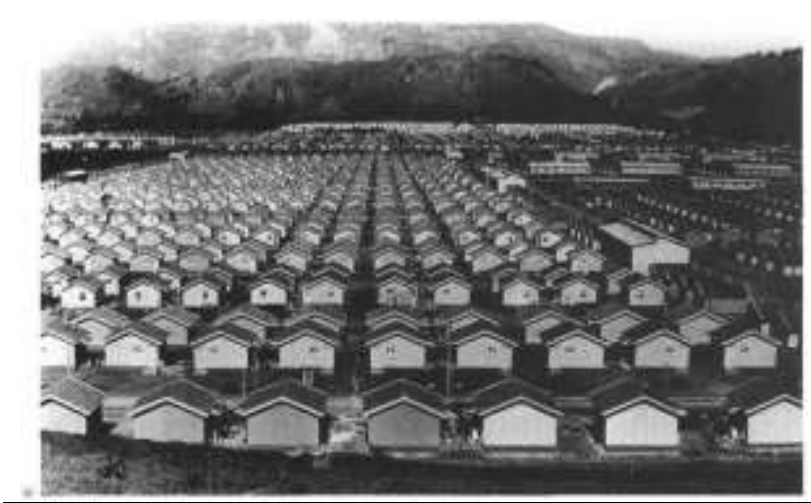

Figura 65. Vila Kennedy, 1965. Fonte: FREIRE, Américo; OLIVEIRA, Lúcia Lippi (orgs.). Capítulos da Memória do Urbanismo Carioca: depoimentos ao CPDOC/FGV, Rio de Janeiro: Folha Seca, 2002. p.87.

Em 1965, após 45 anos desde o primeiro CPA, o XI encontro é realizado nos Estados Unidos, confirmando a preponderância estadunidense naquele momento. Registrava-se a manutenção do pensamento que associava habitação e planificação e, concomitantemente, a mudança de chave do pensamento formado pelo ideário moderno. O desenvolvimento da produção habitacional era colocado em outro plano em função da conformação de um novo quadro político e socioeconômico, em que muitos países latino-americanos eram dominados por ditaduras e o sistema cultural do pósguerra começava a ser substituído por outro que questionava as bases do Movimento Moderno. 


\subsection{Arquitetos e engenheiros e o aparato estatal da habitação no Brasil}

É possível afirmar que no Brasil, a preocupação com a habitação dita popular até os primeiros anos do século XX restringiu-se particularmente ao tema do Higienismo, sendo os engenheiros e médicos sanitaristas os principais responsáveis pela sua investigação e enfrentamento. O reconhecimento da questão habitacional como problema social no início do século XX vinculou-se especialmente à localização das moradias populares nas cidades, implicando em leis e normas que refletiam ainda a preocupação com a higiene e então também com o custo da terra urbana. Vilas operárias foram produzidas por industriais, empresas ferroviárias e investidores e destinadas ao mercado rentista.

A institucionalização da produção habitacional pelo Estado, como sabemos, ocorre apenas na década de 1930, contando com grande participação de arquitetos, urbanistas e engenheiros que atuaram no âmbito da política previdenciária de habitação. A organização e articulação de profissionais ante a questão habitacional, porém, é anterior e não se restringe ao aparato estatal. Desde a década de 1920 constituem-se no Brasil associações profissionais como o Instituto Brasileiro de Architectura (1921), formação inicial do Instituto de Arquitetos do Brasil (renomeado em 1934), e a Divisão de Arquitetura (1929) do Instituto de Engenharia, que, fundado em 1916, se confirmava como importante espaço de debate.

Um dos pioneiros na abordagem da questão habitacional no país - atuando fora do aparato estatal foi o industrial Roberto Simonsen, que ainda em 1912 fundou a Companhia Santista de Habitações Econômicas, cujo objetivo era edificar um bairro operário modelo com casas econômicas produzidas em série. A experiência não teve sucesso em função da "impossibilidade de remuneração dos capitais nela investidos pela angustiante precariedade dos recursos financeiros da massa trabalhadora" (SAMPAIO, 2002, p.1), mas a questão da qualidade de vida do trabalhador e a possibilidade de ampliar a tecnologia aplicada à produção habitacional não são abandonadas por Simonsen.

Em 1931 o empresário participaria da formação do Instituto de Organização Racional do Trabalho (IDORT), que entre outros objetivos tinha o intuito de difundir métodos organizados de construção, promovendo o taylorismo, pois "produzir mais e melhor em um menor tempo era o objetivo básico da racionalização do trabalho" (CORREIA, 2004, p.81). Em 1941 o IDORT realizaria, simultaneamente em São Paulo e no Rio de Janeiro, as Jornadas da Habitação Econômica, cujas discussões se aproximaram daquelas abordadas no Primeiro Congresso de Urbanismo realizado no mesmo ano, confirmando-se o vínculo entre urbanismo e habitação e a preocupação diante da questão habitacional em função do crescimento das grandes cidades.

Encontros profissionais em torno do tema da habitação são realizados no Brasil a partir de 1930, reunindo áreas afins como arquitetura, direito e economia. O "Primeiro Congresso Brasileiro de Urbanismo" (1941) se destaca por incorporar uma nova visão sobre a moradia, tratando de sua relação com o planejamento urbano. A articulação com o projeto político de desenvolvimento 
nacional proposto pelo Estado varguista é colocada nos debates como possibilidade de realização da função social da arquitetura.

Os debates formulados no âmbito dos congressos continentais e locais e nas associações profissionais, circulados em forma de artigos e periódicos, conformam um conjunto particular de soluções que em menor ou maior proporção foram utilizadas no enfrentamento da questão habitacional no Brasil. Nesse sentido, procuramos compreender como se deu a atuação dos arquitetos, engenheiros e urbanistas no contexto da produção da habitação social iniciada na década de 1930, seja no aparato estatal ou fora dele, em escritórios particulares e enquanto corporação, posicionando-se diante da questão habitacional. Compreendemos este momento da produção habitacional estatal a partir da noção de que as questões colocadas em debate pelos profissionais que buscavam cumprir a função social da arquitetura se articulavam à preocupação estatal de estruturação de uma gama de direitos sociais, dentre os quais a habitação.

Prevaleceu por algum tempo a interpretação lançada por Fausto (1999) de que a vanguarda arquitetônica no Brasil teria sido cooptada pelo regime estado-novista:

Comparado com o nazismo, o Estado Novo tem uma política no campo estético que nada tem a ver com aquele. Enquanto o nazismo acaba com a chamada arte degenerada, o regime estado-novista convoca - tratando de cooptar, por certo a vanguarda modernista, que representa um ponto alto e muitas vezes irreverente da cultura do país. (FAUSTO, 1999, p.20, grifo nosso)

Martins (1998, p.70) sugere uma noção inversa àquela perpetuada pela historiografia: a aposta modernista em fazer do Estado seu "agente fundamental de institucionalização". Botas (2011, p.19) compreende que aquela noção "desconsidera os objetivos da própria vanguarda local e a expressão política que ela alcançou ao empenhar-se na tarefa de alinhar seus interesses específicos ao projeto de modernização empreendido pelo Estado." Nesta tese, procuramos olhar para a relação estabelecida entre Estado e vanguarda arquitetônica a partir da perspectiva partilhada por estes autores.

O nacional-desenvolvimentismo é ponto fundamental para o sucesso da implementação da arquitetura e do urbanismo modernos no Brasil: o novo governo, ao buscar uma identidade nacional representada por um país moderno e desenvolvido, portanto uma identidade a ser projetada e não recuperada do passado, criava as bases para o sentido do modernismo no Brasil. Ao mesmo tempo, uma arquitetura nova e adaptada aos tempos industriais dava ao Estado um caráter modernizante e atualizado com o contexto internacional. Tal situação explica a possibilidade de construção de obras públicas vinculadas ao ideário moderno - ainda que não fosse a única linguagem utilizada - a partir do Estado varguista, tais como o Edifício do Ministério da Educação e Saúde Pública, largamente 
apresentado pela historiografia $^{10}$. Os conjuntos habitacionais dos IAPs, apesar de aqui considerados não como simples obra pública, mas como forma de produção urbana previdenciária, podem ser compreendidos também no interior desta produção identificada com o ideário moderno. Desde estas instituições os profissionais de arquitetura tiveram a oportunidade de concretizar a produção da habitação social.

Até então a presença de arquitetos no aparato estatal era reduzida. Segundo Campos (2012), as grandes obras públicas, como as ferrovias, por exemplo, eram muitas vezes demandadas por empresas particulares, havendo pouca atuação governamental que indicasse a conformação de uma burocracia técnica ampliada. As grandes obras de urbanismo nas primeiras décadas do século XX foram quase sempre encomendadas a urbanistas estrangeiros, o que gerava grande indignação entre os representantes nacionais da categoria. As transformações urbanas na cidade do Rio de Janeiro no início do século XX teriam incitado um movimento inicial entre os arquitetos em torno dos interesses da categoria, existindo documentos que mencionam a criação de um Centro de Arquitetos e Construtores do Rio de Janeiro, em 1903. (HISTÓRIA..., s/d)

Em termos da conformação do campo profissional cabe resgatar a constituição do Instituto Brasileiro de Arquitetura em 1921, cujos primeiros anos foram dedicados à preocupação com o exercício profissional e à divulgação da profissão, através da realização de concursos de arquitetura. Ainda naquele momento inicial, divergências de interesses levariam a uma divisão do grupo original, a partir do que seria constituída uma segunda associação denominada Sociedade Central de Arquitetos. Contudo, logo se percebeu que a existência de duas entidades representava um enfraquecimento para as pretensões de afirmação da profissão e, em 1924, as duas se unem no Instituto Central de Arquitetos.

No final daquela década o Instituto organiza o IV CPA que acontece em 1930 no Rio de Janeiro, em que foram definidas diretrizes importantes e definitivas para o estudo e a prática da profissão de arquiteto. Em 1931, sob a direção de Lucio Costa, a Escola Nacional de Belas Artes assume uma aproximação com ideário do Movimento Moderno colocada naquele congresso, revolucionando o ensino e a prática profissional, com introdução do urbanismo como componente indissociável do projeto de arquitetura. A corrente modernista foi oficialmente assumida pelo Instituto Central de Arquitetos a partir de então, anunciando um novo momento da profissão. Em 1934 é então constituído o Instituto de Arquitetos do Brasil (IAB).

Durante o Estado Novo, superada a luta pela regulamentação profissional, buscou-se manter a autonomia com relação ao poder central. O governo procurava controlar as entidades profissionais e

\footnotetext{
${ }^{10}$ GOODWIN, Philiph L.; SMITH, Kidder. Brazil Builds: architecture new and old 1652-1942. The Museum of Modern Art: Nova York, 1943; BRUAND, Yves; Arquitetura contemporânea no Brasil; São Paulo: Editora Perspectiva, 1981; MINDLIN, Henrique Ephim. Arquitetura moderna no Brasil. Rio de Janeiro: Aeroplano Editora, 2000; SEGRE, Roberto. Ministério da Educação e Saúde - Ícone Urbano da Modernidade Brasileira. São Paulo: Romano Guerra, 2013; XAVIER, Alberto. Arquitetura Moderna no Rio de Janeiro. São Paulo: Pini: Fundação Vilanova Artigas, 1991.
} 
em 1939 promulga o Decreto-Lei no 1.402, que regula as associações profissionais, a partir do que foi preciso decidir se o IAB seria ou não transformado em sindicato, optando-se pela permanência como associação profissional. A criação de um sindicato para a categoria só viria a ocorrer vinte e cinco anos depois (HISTÓRIA..., s/d). Em 1944 o IAB se manifestava abertamente pelo fim do governo Vargas, embora os arquitetos se mantivessem nos espaços a eles garantidos no aparato estatal, inclusive no interior dos IAPs.

De acordo com Fausto (1998, p. 213), "o Estado Novo procurou reformular a administração pública, transformando-a em um agente de modernização". À parte a concepção de que esta burocracia seria cooptada e imbuída dos "princípios do regime", a partir de 1930"11, conforme analisa Feldman (2008), a ampliação do aparelho estatal incluiu a inserção de urbanistas, não apenas em cargos técnicos, mas também administrativos - diversos prefeitos e interventores indicados por Vargas depois de 1937 são urbanistas. A partir do pressuposto da separação entre administração e política, garantiu-se uma atuação que introduziu critérios de eficiência, economia e racionalidade.

A institucionalização do urbanismo no interior do aparato do Estado foi acompanhada pela regulação do exercício das profissões de arquiteto e engenheiro. O Decreto № 23.569 promulgado em 11 de dezembro de 1933 reconhecia e regulamentava as profissões técnicas e criava o Conselho Federal de Engenharia e Arquitetura e os primeiros oito Conselhos Regionais a ele subordinados, constituindo-se a partir de então o sistema CONFEA/CREAs. O decreto dispunha que "a União, os Estados e os Municípios, em todos os cargos, serviços e trabalhos de engenharia, arquitetura e agrimensura, somente empregarão profissionais diplomados pelas escolas oficiais ou equiparadas" (Art. 9ㅇ, Decreto no 23.569), o que foi considerado uma vitória para as categorias. (HISTÓRIA..., s/d).

Com base nesta disposição é possível compreender não apenas a integração de urbanistas no aparato estatal, como também a conformação dos escritórios técnicos no interior dos IAPs, garantindo-se que os trabalhos fossem executados por profissionais das respectivas áreas. $\mathrm{O}$ avanço do debate em torno da associação entre habitação e urbanismo desde 1937, segundo Melo (1990), se relacionou especialmente ao processo de reflexão e prática de um grupo particular de profissionais, que, no interior do aparato estatal, defendia a ação estatal direta na produção da habitação social. Estes profissionais discutiram questões associadas ao debate continental, às propostas dos CIAMs e às realizações da socialdemocracia europeia no entre-guerras e se inseriram em órgãos que desde a década de 1930 estiveram relacionados à produção da habitação. Além dos próprios IAPs, órgãos promotores desta produção, estes profissionais estavam também no interior do MTIC, destacando-se as figuras de Rubens Porto, Paulo Accioly de Sá e Moacir Velloso Cardoso de Oliveira.

\footnotetext{
${ }^{11}$ Para garantir a reforma administrativa o governo cria em 1938 o Departamento Administrativo do Serviço Público (DASP), cuja função principal era capacitar os funcionários para os novos cargos públicos.
} 
Conforme apresentado no Capítulo 01, a produção habitacional dos IAPs foi bastante heterogênea, basicamente em função das particularidades das categorias atendidas e das políticas dos escritórios técnicos de cada Instituto. Acreditamos que estes espaços foram fundamentais à própria confirmação da profissão de arquiteto e, conforme colocado por Martins (1998), à institucionalização da arquitetura e da produção habitacional. Ao mesmo tempo nos pareceu importante eventualmente esclarecer a atuação destes profissionais na sociedade com relação à questão habitacional, independentemente de sua inserção nos escritórios dos IAPs.

Os IAPs dispunham de setores técnicos cuja função específica era cuidar das realizações das Carteiras Prediais, dentre as quais se destacava a produção habitacional. Desses escritórios faziam parte arquitetos e engenheiros incumbidos da realização de projetos e fiscalização das obras promovidas pelos Institutos. Alguns nomes se destacam na presidência dos setores técnicos pelo direcionamento e promoção de políticas e práticas particulares, que distinguem a produção habitacional de cada IAP. O arquiteto Carlos Frederico Ferreira foi chefe da Divisão de Engenharia do IAPI durante toda a existência do Instituto. Segundo Botas (2011, p.132), nas publicações do IAPI ficava evidente "a preocupação da direção do órgão [geralmente na figura de um engenheiro] em pautar-se nas discussões técnicas em curso nas esferas especializadas" referentes à questão da moradia. Nesse contexto, o engenheiro Plínio Cantanhede, presidente do IAPI, integrou a comissão brasileira em 1939 no Primer Congreso Panamericano de la Vivienda Popular e Frederico Ferreira representou o IAPI em 1949 no VII Congresso Pan-Americano de Arquitetos em Havana e, em 1954, no IV Congresso Brasileiro de Arquitetos. Conforme depoimento de Frederico Ferreira a Bonduki (1998) a iniciativa do IAPI de construir moradias para atender seus associados através de grandes conjuntos habitacionais dava aos profissionais uma possibilidade concreta de efetivação de suas proposições sociais sobre habitação e cidade.

Sim porque eu não queria fazer só habitações. Habitação, na época, para eles, era fazer uma casa 'dois quartos e sala', e está acabado. Pronto, o resto vem depois! Mas eu não, eu queria fazer habitação mesmo, habitação como eu achava, com escola, edifícios de apartamento com comércio, equipamentos. Eu previ até um circo. (depoimento de FREDERICO FERREIRA a BONDUKI, 1998, p.157).

A economia na construção da moradia estava entre as maiores preocupações do arquiteto e nesse contexto buscou racionalizar os projetos, trabalhando dentro da lógica da produção em série, utilizando novas técnicas e materiais - destacando-se a produção in loco de blocos de concreto - e, além disso, sugerindo a adoção de tipos que seriam reproduzidos em diversos projetos. Entre 1940 e 1942 Frederico Ferreira assinou uma seção na "Revista Inapiários", na qual entre outros tópicos discutiu projetos de residências mínimas e indicou soluções construtivas. Estas matérias, que incluíam projetos padronizados de elementos estruturais e construtivos, indicam seu posicionamento quanto à habitação e, mais que isso, "sua preocupação com economia, industrialização e racionalização da construção para além de seu trabalho no IAPI" (BOTAS, 2011, p.132). 
O engenheiro Ulysses Hellmeister foi diretor da Divisão de Engenharia do Instituto dos Comerciários no início da década de 1940. Sob sua direção foram promovidas as "Cidades Jardim dos Comerciários" (BONDUKI; KOURY, 2014), que aliavam relativo adensamento a partir da utilização de casas sobrepostas e escalonadas e grandes áreas verdes. Uma de suas principais preocupações refere-se à possibilidade de reprodução em grande escala aliada ao baixo custo dos projetos, de modo que buscou empregar materiais econômicos e técnicas baseadas na racionalidade e préfabricação, utilizando, por exemplo, o bloco de solo-cimento. Ao mesmo tempo, Hellmeister enfatizava a função social da arquitetura ao compreender a moradia não como necessidade isolada, mas parte de uma questão maior que incluía elementos como saúde, educação e alimentação. Nesse sentido, suas propostas se aliavam, portanto, aos objetivos dos próprios institutos, incorporando aspectos sociais e financeiros.

Estes profissionais lideravam equipes cuja responsabilidade, portanto, ia além da execução de projetos específicos, incluindo o estudo de tipologias habitacionais e novas tecnologias e materiais a serem utilizados. Além disso, faziam parte das equipes dos Serviços de Engenharia de cada IAP engenheiros responsáveis pela administração e fiscalização das obras. O recorte do Caderno de Encargos do IAPB (FIGURA 66) indica que a fiscalização das obras era da competência de técnicos do Serviço de Engenharia da Carteira Imobiliária do IAPB ou de técnicos designados pelo próprio Instituto.

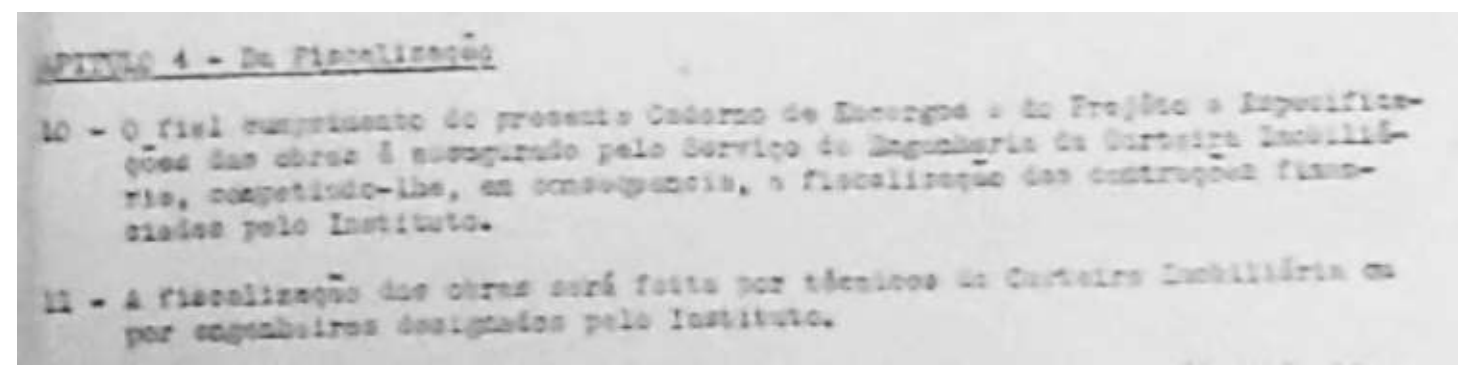

Figura 66. “Da Fiscalização”"12. Fonte: Caderno de Encargos. Processo Administrativo 13964/1948 - “Alvará de Licença do Conjunto Residencial Nove de Julho".

Entre estes profissionais destacamos Sylvio Jaguaribe Ekman, engenheiro fiscal do IAPB. Formado na Escola de Engenharia Mackenzie na década de 1920, Ekman atua como engenheiro fiscal do IAPB a partir da segunda metade da década de 1940 (BONDUKI, 2014). Além da atividade de fiscalização, o engenheiro foi também responsável pelo projeto e construção de edifícios e conjuntos residenciais e edifícios-sede do IAPB em diversas cidades. Possuindo escritório técnico próprio, Ekman constrói também diversos edifícios para o setor privado em São Paulo, tais como os Edifícios Clipper e

\footnotetext{
12 “O fiel cumprimento do presente Caderno de Encargos e do projeto e especificações das obras é assegurado pelo Serviço de Engenharia da Carteira Imobiliária, competindo-Ihe em consequência a fiscalização das construções financiadas pelo Instituto. A fiscalização das obras será feita por técnicos da Carteira imobiliária ou por engenheiros designados pelo Instituto."
} 
Roosevelt, conforme se vê em diversos números da revista Acrópole (EDIFÍCIO CLIPPER, 1944; EDIFÍCIO ROOSEVELT, 1947; EDIFÍCIO ROOSEVELT, 1949).

Conforme se lê no "Caderno de encargos" (1948), aos engenheiros competia gerenciar a obra e averiguar se os projetos e especificações eram seguidos corretamente, se o andamento das obras estava de acordo com a previsão dos prazos de entrega, avaliar a qualidade dos materiais empregados, podendo rejeitar o que fosse considerado inadequado. Além dos engenheiros pertencentes aos quadros técnicos, os Institutos podiam também designar profissionais externos para efetuar a fiscalização de obras.

É importante aqui descrever como se montava o quadro de funcionários dos IAPs, entre os quais aqueles pertencentes aos serviços e divisões de engenharia. Desde a criação do IAPI e da realização do enorme concurso público para preenchimento de seus cargos, referencial para concursos posteriores, consolida-se no setor público de modo geral o sistema de admissão baseado no mérito. Contudo, o sistema baseado na indicação não é abandonado e ambos os sistemas conviveram, como característica do funcionalismo público brasileiro.

Aravecchia-Botas (2016) indica que não é explícita, por exemplo, a forma de emprego do pessoal responsável por projetos e administração das obras do IAPI. Neste Instituto foi implementado de maneira expressiva o sistema de concursos, porém a autora acredita ser "provável que entre os arquitetos e engenheiros que trabalharam nas obras do IAPI também houvesse distinção entre efetivos e indicados" (ARAVECCHIA-BOTAS, 2016, p.82). O próprio Carlos Frederico Ferreira teria sido indicado para o cargo de chefe da Divisão de Engenharia do IAPI pelo presidente do Instituto, Plinio Cantanhede. Nos demais Institutos, não se encontrando documentação específica quanto à forma de admissão dos profissionais, é possível supor que depois de 1937 também se realizassem concursos, porém é mais provável que os cargos mais destacados, como de Chefe da Divisão de Engenharia, fossem preenchidos por indicação.

Além dos profissionais do próprio Serviço de Engenharia, conforme ressaltado pelo arquiteto João Filgueiras Lima, o Lelé, em entrevista a Bonduki sobre o IAPB, também arquitetos das cidades onde eram promovidas habitações, eram contratados temporariamente para realizar os projetos para o Instituto (BONDUKI, 2014). A contratação de profissionais para projetos específicos ocorria igualmente em outros Institutos, distinguindo-se inclusive o pessoal empregado do pessoal contratado, este último grupo justamente de caráter temporário (ARAVECCHIA-BOTAS, 2016). Dos projetos selecionados em São Paulo muitos foram realizados por profissionais contratados, conforme registrado no Quadro 4. 


\section{Quadro 4}

Projetos habitacionais em São Paulo e municípios vizinhos (1940-1950): Profissionais de projeto e construção

\begin{tabular}{|c|c|c|c|c|c|c|c|}
\hline \multirow{2}{*}{ Órgão } & \multirow{2}{*}{ Projeto } & \multicolumn{3}{|c|}{ Realização do projeto } & \multicolumn{2}{|c|}{ Construção } & \multirow[b]{2}{*}{ Data } \\
\hline & & $\begin{array}{c}\text { Arquiteto / Engenheiro- } \\
\text { Arquiteto }\end{array}$ & Engenheiro & Órgão & Empresa & Órgão & \\
\hline \multirow{5}{*}{ IAPI } & $\begin{array}{l}\text { C.R. da Várzea } \\
\text { do Carmo }\end{array}$ & $\begin{array}{c}\text { Attilio Correa Lima; } \\
\text { Hélio Lage Uchôa } \\
\text { Cavalcanti; } \\
\text { José Teodulo da Silva; } \\
\text { Alberto de Mello Flores } \\
\end{array}$ & $\begin{array}{l}\text { Vicente Campos } \\
\text { Paes Barreto } \\
\text { (Resp. Técnica) }\end{array}$ & & - & $\begin{array}{l}\text { Serviço de Eng. } \\
\text { do IAPI }\end{array}$ & 1942 \\
\hline & C.R. Japurá & $\begin{array}{l}\text { Eduardo Kneese de } \\
\text { Mello }\end{array}$ & $\begin{array}{l}\text { Vicente Campos } \\
\text { Paes Barreto } \\
\text { (Resp. Técnica) }\end{array}$ & & - & $\begin{array}{l}\text { Serviço de } \\
\text { Eng. do IAPI }\end{array}$ & 1942 \\
\hline & Vila Guiomar & $\begin{array}{c}\text { Carlos Frederico } \\
\text { Ferreira }\end{array}$ & & $\begin{array}{l}\text { Serviço de } \\
\text { Eng. do IAPI }\end{array}$ & - & $\begin{array}{l}\text { Serviço de } \\
\text { Eng. do IAPI }\end{array}$ & 1942 \\
\hline & C.R. da Mooca & Paulo Antunes Ribeiro & $\begin{array}{c}\text { Vicente Campos } \\
\text { Paes Barreto } \\
\text { (Resp. Técnica) }\end{array}$ & & - & $\begin{array}{l}\text { Serviço de } \\
\text { Eng. do IAPI }\end{array}$ & 1946 \\
\hline & $\begin{array}{c}\text { C.R. } \\
\text { Piratininga } \\
\end{array}$ & $\begin{array}{c}\text { Carlos Frederico } \\
\text { Ferreira } \\
\end{array}$ & & $\begin{array}{l}\text { Serviço de } \\
\text { Eng. do IAPI }\end{array}$ & & $\begin{array}{l}\text { Serviço de } \\
\text { Eng. do IAPI }\end{array}$ & 1946 \\
\hline \multirow{4}{*}{ IAPC } & $\begin{array}{c}\text { Edifício de } \\
\text { Santa Cecília }\end{array}$ & $\begin{array}{l}\text { Eng. Arq. Armando } \\
\text { Ciampolini }\end{array}$ & & & - & - & 1947 \\
\hline & $\begin{array}{l}\text { C.R. Cidade } \\
\text { Jardim }\end{array}$ & $\begin{array}{c}\text { Eduardo Kneese de } \\
\text { Mello; } \\
\text { Hélio Duarte; } \\
\text { Luís Carlos Berrini; } \\
\text { Roberto Burle Marx; } \\
\text { José Zanine Caldas } \\
\end{array}$ & & & - & - & 1947 \\
\hline & $\begin{array}{l}\text { Comunidade } \\
\text { Basílio } \\
\text { Machado Neto }\end{array}$ & $\begin{array}{c}\text { Osvaldo Correa } \\
\text { Gonçalves; } \\
\text { Heitor Ferreira de } \\
\text { Souza; } \\
\text { Araken de Martinho; } \\
\text { Mário Reginato; } \\
\text { Ubirajara Giglioti } \\
\end{array}$ & & & & $\begin{array}{l}\text { Divisão de } \\
\text { Eng. do IAPC }\end{array}$ & 1958 \\
\hline & $\begin{array}{c}\text { Cidade } \\
\text { Comerciária } \\
\text { Presidente } \\
\text { Vargas } \\
\end{array}$ & & & $\begin{array}{l}\text { Divisão de } \\
\text { Eng. do IAPC }\end{array}$ & & $\begin{array}{l}\text { Divisão de } \\
\text { Eng. do IAPC }\end{array}$ & 1954 \\
\hline \multirow{3}{*}{ IAPB } & $\begin{array}{l}\text { C.R. Nove de } \\
\text { Julho }\end{array}$ & - & $\begin{array}{c}\text { Alceu Sant'Anna de } \\
\text { Almeida (E1; E3) } \\
\text { Sylvio Jaguaribe } \\
\text { Ekman (E2) }\end{array}$ & $\begin{array}{l}\text { Serviço de } \\
\text { Eng. do IAPB }\end{array}$ & $\begin{array}{c}\text { Alceu Sant'Anna } \\
\text { de Almeida } \\
\text { Sylvio Jaguaribe } \\
\text { Eckman }\end{array}$ & - & 1948 \\
\hline & C.R. Santa Cruz & $\begin{array}{l}\text { Marcial Fleury de } \\
\text { Oliveira; } \\
\text { Roberto J. G. Tibau }\end{array}$ & - & - & $\begin{array}{l}\text { Marcial Fleury de } \\
\text { Oliveira }\end{array}$ & - & 1948 \\
\hline & $\begin{array}{l}\text { C.R. Santo } \\
\text { Antonio }\end{array}$ & - & $\begin{array}{l}\text { Nicolau Barbieri } \\
\text { (Resp. Técnica) } \\
\text { Rubens Betelman } \\
\text { (Resp. Técnica) }\end{array}$ & - & $\begin{array}{l}\text { Companhia } \\
\text { Construtora } \\
\text { Centenário } \\
\text { Carvalho Hosken } \\
\text { S/A Engenharia e } \\
\text { Construção }\end{array}$ & - & 1962 \\
\hline IPESP & $\begin{array}{l}\text { Núcleo } \\
\text { Residencial } \\
\text { Francisco } \\
\text { Morato } \\
\end{array}$ & & & $\begin{array}{l}\text { Escritório } \\
\text { técnico do } \\
\text { IPESP }\end{array}$ & $\begin{array}{c}\text { Ribeiro Franco } \\
\text { S/A } \\
\text { (parcial) }\end{array}$ & - & 1951 \\
\hline $\begin{array}{l}\text { Fontes: } \\
\text { (2009), } \\
\text { n.104.12 }\end{array}$ & $\begin{array}{l}\text { ração da auto } \\
\text { et. al (1942; } \\
51 ; \text { n.188.992 }\end{array}$ & $\begin{array}{l}\text { com base em: Bonduki; } \\
43) \text {, Mello (1947), Proc } \\
65 ; \text { n.11.569/1946; n.65. }\end{array}$ & $\begin{array}{l}\text { Iry (2014), Bruna (19 } \\
\text { sos Administrativos } \\
3 / 1948 ; \text { n.153.800/1 }\end{array}$ & $\begin{array}{l}\text {, Ficher (2005 } \\
62.631 / 1944 \\
9 .\end{array}$ & $\begin{array}{l}\text { Botas (2011), Pessc } \\
\text { n.45.127/1944; n.2 }\end{array}$ & $\begin{array}{l}\text { to (2007), Regir } \\
\text { 197/1942; n.31 }\end{array}$ & $\begin{array}{l}\text { Perrone } \\
4 / 1948\end{array}$ \\
\hline
\end{tabular}


Como se pode observar, uma parte dos projetos do IAPI foi realizada por seu próprio Serviço de Engenharia na figura de Carlos Frederico Ferreira, enquanto outra parte foi realizada por arquitetos contratados, entre os quais se destacam Attílio Correa Lima, Eduardo Kneese de Mello e Paulo Antunes Ribeiro. Nos projetos do IAPC a realização dos projetos coube majoritariamente a profissionais contratados, entre os quais Oswaldo Correa Gonçalves e, novamente, Eduardo Kneese de Mello, excetuando-se a Cidade Comerciária Presidente Vargas, cujo projeto é realizado pela Divisão de Engenharia do Instituto. Na realização dos projetos do IAPB se vê a atuação de um profissional do próprio Serviço de Engenharia (Sylvio Ekman) e de profissionais contratados como Marcial Fleury de Oliveira e Alceu Sant'Anna de Almeida, que seriam inclusive responsáveis pela execução dos mesmos projetos. Ao mesmo tempo se vê também a atuação de engenheiros das próprias construtoras responsáveis pela execução. O Escritório técnico do IPESP é o responsável pela realização do projeto do Instituto.

Formado na ENBA e com especialização no Institut d'Urbanisme de L'Université de Paris, Attilio Corrêa Lima se destaca por seu trabalho como urbanista, mais pronunciado que sua atuação no campo arquitetônico. Na década de 1930 Corrêa Lima elabora o Plano Diretor da Cidade de Goiânia e o Plano de extensão e embelezamento do Recife e, nos primeiros anos da década de 1940, elabora o Plano Urbanístico de Volta Redonda e o Plano Regional para o município de Barra Mansa. Ainda nestes anos elabora o Parecer sobre o plano da Cidade Operária da F. N. M. (1943), onde esclarece as vantagens da moradia coletiva em detrimento da casa isolada, como a possibilidade de ampliar o atendimento à população e, ainda, criar áreas livres e otimizar a infraestrutura. É a partir do plano de Barra Mansa e do projeto de um conjunto de residências para os operários da CSN em Volta Redonda a ser promovido pelo IAPI, que Corrêa Lima toma contato com Plínio Cantanhede, presidente do Instituto, e é convidado a elaborar aquele que seria - se implantado em sua totalidade - o maior conjunto habitacional do IAPI em São Paulo, o C.R. Várzea do Carmo ${ }^{13}$, que deveria atender 22 mil pessoas.

Eduardo Kneese de Mello, formado na Escola de Engenharia Mackenzie, foi um dos arquitetos que mais se dedicaram à produção de habitação popular em São Paulo. Ao lado de Rino Levi, Kneese de Mello trabalhou pela constituição da divisão paulista do IAB, tornando-se o primeiro Presidente do IAB-SP, função que exerce entre 1943 e 1949. O tema da habitação destinada às populações econômica e socialmente desfavorecidas é constantemente explorado por Kneese de Melo, sendo muito relevante seu estudo intitulado "Evolução da Habitação no Brasil" (KNEESE DE MELLO, 1964), em que aborda a moradia brasileira ao longo da história e dos ciclos econômicos desde o período colonial. A partir da década de 1940 se dedica ao estudo da moradia coletiva e ressalta a relevância

\footnotetext{
${ }^{13}$ Corrêa Lima menciona no "Parecer para o plano de Cidade Operária da F.N.M." que projetaria também para o IAPI a Vila Heliópolis, outro conjunto de grandes proporções, destinado a abrigar 16 mil habitantes, não havendo, porém, maiores informações sobre este projeto.
} 
da racionalização do projeto e da pré-fabricação para a solução do problema habitacional. 0 planejamento de "unidades de habitação completas" era concebido pelo arquiteto como única forma de a arquitetura se tornar realmente social e democrática, atendendo a todos os homens e não apenas a alguns privilegiados. A habitação, para atender à sua real função, pressupunha aspectos de cidadania, que extrapolavam a simples moradia.

O complexo da habitação deixou de ser só a casa. A casa é um dos seus elementos, o elemento central da habitação, mas ela tem que ser servida por escolas de diversos graus, ela tem que ter o 'playground' para a criança pequena, tem que ter assistência médica, assistência social, assistência de todo tipo. Tem o contato com o trabalho, com o divertimento, com a cultura. Então a Arquitetura deixou de ser a casa, passou a ser um complexo. E a Arquitetura de hoje tem que ser feita com essa ideia. (SANTOS 1985, p.102,103).

Kneese de Mello preconizava que os IAPs, além de prestarem assistência médica e social, conferissem também assistência à habitação e elabora dois projetos para os Institutos, um para o IAPI, o Conjunto Residencial Japurá (1942) e outro para o IAPC, o Conjunto Residencial Cidade Jardim (1947). Em ambos os projetos é possível perceber a intenção social da arquitetura projetada pelo arquiteto.

Paulo Antunes Ribeiro, assim como Correa Lima, se forma na ENBA e se especializa no Institut d'Urbanisme de L'Université de Paris. Sua produção para o setor privado inclui edifícios residenciais e de escritórios, hospitais e clubes, maiormente localizados no Rio de Janeiro, com destaque na historiografia para o Edifício para Exposições e Venda de Automóveis para a empresa de tratores alemã Hanomag, conhecido como Oficinas Gastal, projetado em 1952 e demolido em 2004 (SEGRE, 2004). São perceptíveis em sua obra referências à Escola Carioca de arquitetura moderna, com destaque para a utilização do piloti, com recuo do alinhamento e projeção junto ao passeio público, conformando uma espécie de galeria. Antunes Ribeiro também é autor de diversos projetos urbanos, tendo participado da equipe de Corrêa Lima na concepção no plano para a cidade de Goiânia. Entre 1953 e 1956 preside o Instituto dos Arquitetos do Brasil e, como tal, compõe o júri do concurso público de Brasília.

Oswaldo Correa Gonçalves forma-se engenheiro-arquiteto em 1941 e engenheiro civil em 1944 na Escola Politécnica de São Paulo, participando ainda recém-graduado da criação da divisão paulista do (IAB) e tornando-se membro da primeira direção, sendo posteriormente presidente (1961-1963) e anos mais tarde vice-presidente da direção nacional do IAB (1973-1974). Apesar de sua formação, é possível identificar em suas primeiras obras uma identidade com a escola carioca de arquitetura, e apenas em um segundo momento a aproximação com a escola paulista (OSWALDO CORREA..., 2018) O quadro técnico dos profissionais ligados aos projetos habitacionais dos IAPs se complementa pelos profissionais que construíam estas habitações. A atividade construtiva poderia ser realizada sob os auspícios dos próprios Setores de Engenharia a partir da contratação de pessoal técnico para obras específicas, neste caso sendo sua a responsabilidade pela obra. Em outros casos poderiam ser 
contratados construtores ou empresas construtoras, sendo estes então os responsáveis pelas obras, embora sob a fiscalização do Setor de Engenharia do IAP contratante. O Decreto no 1.749 de 1937, em seu Art. 13ำ institui que as construções das casas e edifícios se realizariam "após concorrência, aberta a construtores de reconhecida idoneidade técnica e financeira" (BRASIL, 1937). O Capítulo 3 do "Caderno de Encargos" do IAPB (1948), intitulado "Das Concorrências", indica que as construções financiadas pelo Instituto deveriam realizar-se por meio de "concorrência pública ou administrativa", sendo que as concorrências administrativas deveriam ocorrer entre no mínimo três construtores, do que compreendemos ser esta modalidade, na verdade, o que hoje conhecemos como "Convite" (FIGURA 67). É possível supor que nos demais Institutos uma política similar fosse seguida, do que se pode aferir que, assim como no caso da realização dos projetos, também a execução das obras poderia realizar-se através do sistema de indicação, por Convite, ou do sistema de meritocracia, através das concorrências.

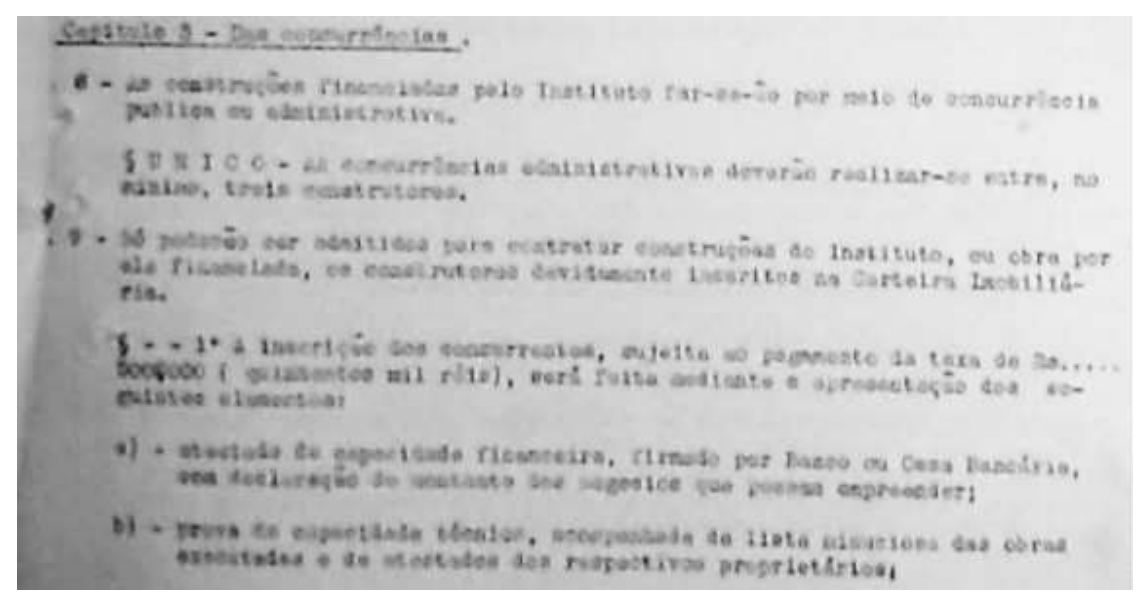

Figura 67. "Das Concorrências". Processo Administrativo 13964/48 - "Alvará de Licença do Conjunto Residencial Nove de Julho", Caderno de Encargos.

O novo quadro no setor da construção registrado nomeadamente na década de 1950, em que, segundo Gitahy e Pereira (2002, p.16), é possível "verificar a importância da diversificação industrial das empresas vinculadas à construção", coloca em relevo a atuação de empresas construtoras, sendo importante compreender como se articulam junto ao aparato estatal, integrando-se à política de promoção da habitação, fenômeno ainda inicial que seria ampliado e fortalecido no mecanismo SFHBHN a partir de 1964. A partir da atuação destas empresas e profissionais é possível ampliar o estudo da organização do setor na construção em São Paulo, inclusive pelo fato de que algumas destas empresas seguiriam atuando na produção habitacional promovida pelo Estado após a mudança da política habitacional em 1964, como se vê em Campos (2012).

Conforme apresentado no Quadro 4, uma parte dos projetos dos IAPs foi construída em São Paulo pelos próprios escritórios técnicos. Todos os projetos (construídos) em grande escala do IAPI e do IAPC foram executados, respectivamente, pelo Serviço de Engenharia do IAPI e pela Divisão de 
Engenharia do IAPC. Paralelamente, todos os projetos em grande escala do IAPB e ao menos uma parte do projeto do IPESP foram executados por empresas construtoras ou construtores. São contratados pelo IAPB as empresas Companhia Construtora Centenário e Carvalho Hosken Engenharia e Construção S/A que atuaram nas duas distintas fases de construção do C.R. Santo Antonio e profissionais que atuavam como construtores, entre os quais Marcial Fleury de Oliveira e Alceu Sant'Anna de Almeida, além do já mencionado Sylvio Jaguaribe Ekman. O IPESP contrata para executar uma parte do conjunto Francisco Morato a construtora Ribeiro Franco S/A. É importante dizer que estes projetos foram construídos a partir de 1948, portanto, já na perspectiva do novo quadro do setor da construção indicado por Gitahy e Pereira (2002) para a década de 1950.

A Companhia Construtora Centenário é responsável pela construção de parte do C.R. Santo Antônio (PMSP, 1965). A empresa paulista tem início em novembro de 1952 sob a denominação Cia. Imobiliária Centenário, possuindo como objeto a construção de prédios em geral, o comércio de materiais de construção e a execução de toda e qualquer outra operação relacionada a negócios imobiliários. Em março de 1956 a Cia. Imobiliária Centenário é renomeada Cia. Construtora Centenário e o objeto da empresa passa a tratar apenas de serviços de engenharia civil e arquitetura. Entre os gerentes da empresa está o engenheiro Nicolau Henrique Barbieri, responsável pela construção do C.R. Santo Antonio em 1962. (Ficha de Breve Relato)

Em 1969 a Cia. Construtora Centenário é incorporada à Cetenco S/A, braço do grupo que assumira o ramo imobiliário em 1954, tornando-se uma das maiores empresas construtoras a atuarem no Brasil a partir da década de 1970 (CAMPOS, 2012). A Cetenco seria responsável pelas obras de diversas Usinas Hidrelétricas no Brasil, atuando ainda no túnel Rebouças no Rio de Janeiro e em obras do metrô em São Paulo. A empresa atuou também na Venezuela, em conjunto com a Camargo Corrêa, na construção do metropolitano de Caracas e da hidrelétrica de Guri. Segundo Campos (2012) parte do sucesso da Cetenco naquele momento se deve ao bom relacionamento de seu presidente, Eduardo Celestino Rodrigues, com figuras como Ademar de Barros, Delfim Netto e Lucas Garcez, mas também à sua presença institucional, como professor da Escola Politécnica da USP e presidente do Instituto de Engenharia de São Paulo entre 1969 e 1970.

A Carvalho Hosken Engenharia e Construção S/A, responsável pela construção de parte do C.R. Santo Antonio (BONDUKI; KOURY, 2014), foi fundada no Rio de Janeiro em 1951 sob a denominação Construtora Carvalho Hosken Ltda. e inicia suas atividades através da construção de imóveis residenciais e comerciais e da participação em licitações e concorrências, construindo obras públicas especialmente nas cidades do Rio de Janeiro e São Paulo (CAMPOS, 2012). Em setembro de 1966 é constituída a Carvalho Hosken S/A Engenharia e Construções, que participa ativamente da construção de Brasília, principalmente após a criação do BNH, construindo núcleos habitacionais nas cidadessatélites do Distrito Federal. É possível supor que sua participação na construção da segunda fase do 
C.R. Santo Antonio, finalizado em 1967, esteja associada ao vínculo entre a empresa e o $\mathrm{BNH}^{14}$, uma vez que naquele momento o conjunto já não pertencesse mais ao IAPB.

Marcial Fleury de Oliveira formou-se engenheiro-arquiteto pela Escola Politécnica de São Paulo em 1926 e trabalhou na Divisão de Urbanismo da Prefeitura da cidade entre 1931 e 1935. Em 1934 começou a atuar no setor imobiliário, na construção e venda de residências prontas e loteamentos, construindo cerca de uma centena de residências unifamiliares (FICHER, 2005). Mais tarde passou a trabalhar em parceria com seu filho, o arquiteto José Luiz Fleury de Oliveira, no projeto e construção residências e edifícios de apartamentos. Na década de 1940 é contratado pelo IAPB para a construção em São Paulo de 47 casas à Rua Abílio Soares e posteriormente para o projeto e execução do C.R. Santa Cruz. (FICHER, 2005)

Sua atividade profissional, porém, não se restringiu à prática construtiva. Fleury participou ativamente dos órgãos profissionais, sendo atuante na política profissional do Instituto de Engenharia, vice-presidente do IAB-SP em meados da década de 1950 e conselheiro do CREA-SP por várias gestões entre 1934 e 1955. Em 1931 participou do I Congresso de Habitação e em 1954 do IV Congresso Brasileiro de Arquitetos.

Apesar da participação ativa na produção habitacional realizada no pós-1930, para Bonduki e Koury (2010) o posicionamento decisivo dos arquitetos para a promoção de uma política habitacional articulada ao planejamento urbano ocorreria na década de 1960. Durante o governo de João Goulart (1961-1964) os arquitetos contribuíram intensamente para o debate sobre uma nova política habitacional articulada à questão urbana e vinculada à perspectiva de transformação estrutural da sociedade brasileira, através das "Reformas de Base". Neste quadro, os arquitetos colocaram pela primeira vez em pauta a reforma urbana como um elemento indispensável para enfrentar a grave crise de moradia que afetava as cidades brasileiras no início dos anos 1960. (BONDUKI; KOURY, 2010)

Neste contexto, onde os principais problemas nacionais - como a questão agrária, a educação e o desenvolvimento nacional - foram debatidos sob uma intensa politização das iniciativas públicas, os arquitetos capitanearam o processo de discussão sobre a questão urbana e habitacional. Introduziram temas, abordagens e propostas novas, de tendência claramente progressista, que colocaram pela primeira vez em pauta a reforma urbana como um elemento indispensável para enfrentar a grave crise de moradia que afetava as cidades brasileiras no início dos anos 1960. (BONDUKI; KOURY, 2010, s/p).

\footnotetext{
${ }^{14}$ Cabe mencionar a ligação existente entre a Carvalho Hosken e Sandra Cavalcanti, mentora do Plano Nacional de Habitação que origina o BNH. De acordo com Melo $(1988$, p.2) entre 1964 e 1965 teria se formado uma coalizão entre políticos conservadores (em especial da UDN carioca) e a indústria da construção (de diversas organizações civis) que teria implicado em notáveis alterações no esboço do plano habitacional apresentado ao presidente Castello Branco, com base justamente nas demandas do empresariado da construção civil. Sandra Cavalcanti, a quem coube a concepção geral do Plano, contou com assessoria técnica de elementos associados com a UDN, entre os quais Renato do Amaro Machado da Construtora Carvalho Hosken Ltda que "opinou sobre os assuntos legais".
} 
Em 1963 o IAB promove a realização do "Seminário de Habitação e Reforma Urbana", ponto alto do processo que repensava a produção da moradia popular no espaço urbano, contando com o apoio governamental através do Instituto de Pensões e Aposentadoria dos Servidores do Estado (IPASE). Durante o encontro foram discutidos diferentes aspectos relativos aos temas da habitação e do planejamento urbano no Brasil e, ao final do seminário, foi produzido um documento onde constavam considerações e propostas, incluindo a criação de uma "Política Nacional de Habitação e Reforma Urbana".

Entendeu-se como urgente naquele momento a formação de um órgão central - substituto da FCP que respondesse à demanda por habitações e realizasse uma reforma urbana, premissa para a resolução da questão habitacional. Retomaram-se os temas do enfrentamento do custo da terra e da propriedade privada do solo urbano, através do planejamento e da disponibilização de áreas de interesse social destinadas à produção massiva de moradias populares, e da participação da iniciativa privada no oferecimento da habitação social, considerando-se também a participação popular em programas de desenvolvimento.

Entre as propostas do Seminário estava a idealização de Planos Nacionais que orientassem a coordenação e assessoria de entidades locais, centralizando os recursos federais. Estes mesmos planos deveriam indicar as medidas necessárias para o crescimento da indústria da construção civil e o desenvolvimento de processos construtivos, de modo a favorecer a padronização dos materiais e a pré-fabricação. Idealizava-se um Plano Nacional de Habitação (PNH) que buscasse suprir o déficit de moradias e oferecer serviços e equipamentos urbanos.

Em 1964 a inércia da política previdenciária de habitação estabelecida por Vargas é interrompida com o golpe militar, que organiza nova política habitacional e, com ela, nova relação com o campo profissional. A partir de então as competências de promoção e execução de projetos habitacionais foram atribuídas a agentes privados, incorporadoras e construtoras. A perspectiva da produção habitacional em grande escala se concretiza, porém no caráter extensivo dos conjuntos, desprezandose a integração entre projeto arquitetônico e urbanístico e a racionalização da produção, com clara redução do ideário moderno e afastamento dos profissionais da conquista da função social da arquitetura durante o período anterior. (FERRARI; NEGRELOS, 2018)

\subsection{0 protagonismo dos arquitetos na produção habitacional estatal na Argentina}

Assim como no Brasil, no final do século XIX a preocupação quanto à habitação econômica na Argentina se relacionava ao Higienismo e ao elevado custo da terra, que inviabilizava a casa própria operária. Unidades econômicas destinadas ao mercado de locação eram construídas por industriais e investidores particulares. Já nos primeiros anos do século XX, porém, o debate é ampliado em função da compreensão da falta de moradias como problema social e são estruturados órgãos estatais e 
privados (cooperativas e mutualidades) dedicados a enfrentar o problema sem, contudo, representar grandes avanços em termos práticos. Naquele momento, o entendimento da questão habitacional como questão social era ressaltado sobretudo nos setores vinculados ao Movimento Socialista e à Igreja Católica. É especialmente após a Primeira Guerra Mundial que a questão habitacional ganha relevância e passa a ser discutida em âmbitos variados, com destaque para periódicos especializados, associações profissionais e congressos promovidos no próprio país. Segundo Collado (2011) as proposições resultantes dessas discussões culminaram na conformação de um conjunto de ideias, que no contexto político apropriado representaram aportes concretos para o enfrentamento do déficit habitacional argentino.

Destaca-se como espaço de debate neste momento inicial da articulação profissional o "Primer Congreso Argentino de la Habitación" (1920), que reúne ainda profissionais de distintas áreas em torno do enfrentamento da questão. Embora as associações profissionais de arquitetos e engenheiros tenham sido conformadas na Argentina ainda no final do século $X^{15}{ }^{15}$, a regulamentação destas profissões e a criação do Consejo Profesional de Arquitectura y Urbanismo (CPAU) e do Consejo Profesional de Ingeniería Civil (CPIC) ocorreriam apenas em 1944.

Desde o Congreso Panamericano de Vivienda Popular em 1939 a constatação da necessidade de um grande número de unidades habitacionais para abrigar a população de poucos recursos nas grandes cidades - particularmente Buenos Aires - e a insatisfação com os resultados obtidos pela escassa ação estatal até então realizada ${ }^{16}$ direcionam o debate dos arquitetos argentinos para uma perspectiva de produção massiva como forma de solucionar a questão da habitação.

O estudo sobre a produção habitacional realizada entre 1943 e 1955 revelou a predominância dos profissionais de arquitetura na realização dos projetos. Esta é uma informação importante referente à atuação profissional e sua relação com o aparato estatal no país naquele momento. De acordo com Cirvini (2012), desde o início do século XX, quando começam a se expandir os quadros técnicos do Estado, se questionava a ausência de arquitetos nos cargos de direção dos órgãos responsáveis pela obra pública. Nesse sentido, parece possível afirmar que este protagonismo dos arquitetos na produção habitacional estatal pós-1943 pode estar relacionado a uma proposta de reparação ou aproximação com a categoria. Como se viu, a premissa de intervenção estatal na produção da habitação estava colocada pelos arquitetos argentinos desde muito antes do período peronista, de modo que o Estado, ao assumir a produção habitacional, parecia incorporar um ideário do próprio campo da arquitetura.

Ballent (2005) descarta tanto a ideia de autonomizar o campo técnico ou estético, quanto perspectivas que o consideram reflexo da política: não seria possível pensar um profissional alheio

\footnotetext{
${ }^{15}$ A Sociedad Central de Arquitectos, com sede em Buenos Aires, foi fundada em 1886; o Centro Argentino de Ingenieros é fundado em 1895 pelos primeiros engenheiros diplomados no país.

${ }^{16}$ Conforme se apresentou no Capítulo 2.
} 
aos fatos sociais e políticos e tampouco é válida a ideia de uma arquitetura peronista, o que se verifica pela diversidade da produção no período. É fato que não houve um arquiteto ou grupo permanentemente vinculado ao governo. Jorge Sabaté ${ }^{17}$ foi a figura mais próxima disso, sendo conhecido como o "arquiteto do Justicialismo", e mesmo ele não chega a produzir sob um único estilo (GUTIERREZ et all, 2009). Para Aboy (2005, p. 72, tradução nossa) "as distintas equipes técnicas, representantes de outras tantas linhas de pensamento social, viram no novo governo o veículo para cristalizar em suas obras seus programas teóricos. Por sua parte, o governo encontrou neles os instrumentos para materializar sua política social". Assim, de modo paralelo e similar ao que acreditamos ter ocorrido no Brasil, também na Argentina parece ter havido uma associação de interesses entre Estado e arquitetos na produção da habitação social.

Assim como no Brasil, até as primeiras décadas do século XX havia grande predomínio da presença de profissionais estrangeiros na realização da obra pública na Argentina. Este dado possivelmente se relaciona à visão negativa do trabalho na administração pública que vigorava no interior da Sociedade Central de Arquitetos (SCA), que como porta-voz da categoria sustentava que o que definia o trabalho do arquiteto, o que o diferenciava, por exemplo, de um construtor, era o exercício liberal da profissão, isto é, o fato de ser remunerado exclusivamente através de honorários.

Conforme leitura de Cirvini (2012), a Sociedade Central de Arquitetos foi constituída no estágio fundacional da prática arquitetônica no país, em 1886. A criação da associação atendia aos anseios de engenheiros-arquitetos formados na Universidad de Buenos Aires (UBA) e de profissionais formados na Europa, cujos diplomas já eram validados no país, estabelecendo os limites entre os que estavam dentro e fora do campo profissional. Em 1903 fica determinado no estatuto da SCA que eram aceitos como sócios apenas os profissionais que trabalhassem de forma independente. Desse modo, embora - Estado lançasse concursos e concorrências para a execução da obra pública, esta era realizada majoritariamente por profissionais estrangeiros. O trabalho na administração pública, na visão conservadora - da associação, comprometia os direitos de propriedade artística do arquiteto, além de implicar em uma arquitetura de baixa qualidade em função das restrições orçamentárias e dos interesses próprios do Estado. Contudo, nas primeiras décadas do século XX alguns fatos relevantes no âmbito profissional começaram a indicar a necessidade de revisão dos critérios de admissão de novos associados e de reavaliação da atividade profissional dentro da administração pública.

Ainda na década de 1910 a SCA se viu diante de uma progressiva incorporação dos graduados "arquitetos" na Escola de Arquitetura da UBA, que começa a funcionar em 1901 - até então se formavam "engenheiros-arquitetos". Na década de 1920 a grande mudança vem com o crescimento

\footnotetext{
17 Apesar de não ser peronista, o bom relacionamento de Jorge Sabaté com o governo permitiu-lhe participar em programas únicos, como exposições nacionais, além de trabalhar como assessor do governo nacional e conselheiro da Fundação Eva Perón. Entre 1952 e 1954 foi intendente da cidade de Buenos Aires, onde realizou uma vasta obra pública, concluindo também projetos anteriores, um importante trabalho de promoção da arquitetura moderna.
} 
de uma perspectiva de função social da profissão diante dos problemas advindos dos processos de modernização e urbanização, em especial na capital Buenos Aires. A imprensa especializada começou a considerar que o trabalho do arquiteto cumpria uma função social quando tratava de questões como a produção habitacional, o que era percebido também como uma contradição da prática liberal defendida pela SCA.

Apesar de as mudanças mais notáveis no aparato estatal ocorrerem a partir de 1946 com Perón, desde a década de 1930 houve mudanças na organização da estrutura técnica (BALLENT, 2005). Estas mudanças não implicaram na alteração estrutural do aparato, sendo mantida aquela do começo do século, mas a presidência de Agustín P. Justo (1932-1938) introduziu reformas importantes que afetaram especificamente a Dirección General de Arquitectura do MOP.

As modificações tenderam a adaptar a estrutura da administração pública à crescente complexidade das funções e atividades do Estado, que desde sua origem liberal burguesa evoluiu para um Estado fortemente intervencionista, antecessor do estado de bem-estar que se cristalizará com o justicialismo. As reformas na Direção Geral de Arquitetura contaram com o apoio da SCA, que viu nesta mudança a possibilidade de hierarquizar a profissão. (CIRVINI, 2012, p.118, tradução nossa)

Em 1944 foi promulgado o Decreto-Ley n. 17.946 que regulamentava o exercício das profissões de Arquiteto, Agrimensor e Engenheiro no país. O Artigo 13으 criava os respectivos conselhos profissionais, entre eles o Consejo Profesional de Arquitectura y Urbanismo (CPAU). Também em 1944 finalmente um arquiteto é nomeado chefe da Direção Geral de Arquitetura, cargo até então ocupado por engenheiros, o que era criticado havia tempos pela SCA. De acordo com Rigotti (2005) desde o início da década de 1940 houve gradual substituição de engenheiros por arquitetos em posiçõeschave no interior do aparato estatal, o que foi acompanhado de uma progressiva valorização do exercício da profissão na função pública.

Contudo, segundo Cirvini (2012), apesar da possibilidade de aproximação entre Estado e profissionais, nos primeiros anos do Justicialismo, com Perón ainda na Secretaria de Previsión y Trabajo, o que une a grande maioria dos arquitetos é a oposição ao governo, principalmente quanto à produção habitacional. A SCA, apesar de nada propor de concreto para solucionar a questão habitacional, sustentou uma franca postura crítica à ação do governo entre 1944 e 1946. O grupo de profissionais mais conservadores dentro da instituição via como ameaça ao trabalho liberal na produção de casas de renta não apenas a produção estatal, como também a extensão das leis de congelamento de aluguéis, enquanto a fração mais progressista se opunha ao governo por questões técnicas e ideológicas, especialmente em função da proposta da Comisión Asesora para la Vivienda de que a desconcentração urbana - com unidades individuais e urbanismo do tipo cidade jardim era a melhor forma de enfrentar a questão da habitação. 
A Administración Nacional de la Vivivenda foi alvo em um artigo anônimo na Revista de Arquitectura, órgão oficial da Sociedade, na véspera das eleições que levariam Perón à presidência. $O$ artigo denominado "Qué hay del plan de vivienda popular?", publicado em janeiro de 1946 critica o fato de a ANV existir já havia mais de dois anos e não ter proposto ainda um plano orgânico para solução da questão habitacional. Segundo o artigo, os arquitetos do escritório técnico da ANV trabalhavam nas obras "herdadas" da CNCB (Barrios Concepción e Alvear, por exemplo) e produziam apenas estudos esquemáticos, sem valor prático. O problema identificado no artigo era a inaptidão das autoridades encarregadas pela questão habitacional que, desconsiderando o respeito e o reconhecimento que o governo vinha nutrindo pelos "profissionais técnicos", eram despreparadas para resolver o problema, sendo imperativo consentir que arquitetos assumissem o controle da tarefa (QUÉ HAY DEL PLAN..., 1946). Este posicionamento mostra que a presença de um arquiteto à frente da Direção Geral de Arquitetura não abrandou os ânimos da SCA por maior participação de arquitetos nos cargos de liderança de órgãos vinculados à obra pública.

Em 1946 é divulgado o primeiro Plano Quinquenal que incluía um Plano de Obras Públicas e a reorganização integral do aparato estatal para a produção urbano-arquitetônica, que passa a articular as instâncias nacional, provincial e municipal em órgãos comitentes e promotores financeiros. (PRESIDÊNCIA DE LA NACION..., 1946). Com base na Dirección General de Arquitectura, é criada a Dirección Nacional de Arquitectura, que passa a centralizar planejamento, projeto e execução das principais obras públicas, concentrando fundamentalmente sob os auspícios do MOP os escritórios técnicos antes dispersos em ministérios variados. Em cada província a estrutura administrativa é reorganizada e seu funcionamento é articulado ao aparato estatal central, enquanto entidades autárquicas como a ANV e órgãos estatais têm seus próprios escritórios técnicos vinculados à administração central. Além disso, a integração entre política e técnica também foi estabelecida a partir da relação com profissionais "liberais" através da contratação de projetos realizados por escritórios particulares.

A realização dos projetos habitacionais estatais em Buenos Aires coube na instância nacional à ANV, depois absorvida pelo BHN, e à Dirección Nacional de Arquitectura do MOP e na instância municipal à Dirección de Vivienda de la Municipalidad de la Ciudad de Buenos Aires. A capital, vale lembrar, não possuía autonomia administrativa, de modo que, embora contasse com órgãos municipais, era administrada pelo Estado Nacional, o que neste momento rendeu importantes recursos para a promoção habitacional realizada através da Municipalidad de la Ciudad de Buenos Aires (MCBA). O Quadro 5 elenca os profissionais responsáveis pelos projetos habitacionais massivos produzidos para Buenos Aires. 
Quadro 5

Projetos habitacionais em grande escala na Grande Buenos Aires (1943- 1955): Profissionais de projeto e construção

\begin{tabular}{|c|c|c|c|c|c|c|c|}
\hline \multirow{2}{*}{ Órgão } & \multirow{2}{*}{ Projeto } & \multicolumn{3}{|c|}{ Realização do Projeto } & \multicolumn{2}{|c|}{ Construção } & \multirow{2}{*}{ Data } \\
\hline & & Arquiteto & Eng. & Órgão & Empresa & Órgão & \\
\hline ANV & $\begin{array}{c}\text { Villa } \\
\text { Concepción }\end{array}$ & $\begin{array}{l}\text { Carlos Alberto } \\
\text { Chapeaurouge; } \\
\text { Augusto Pieres; } \\
\text { Carlos Juan Muzio; } \\
\text { A. Fragueiro Olivera; } \\
\text { J. Burone Risso; } \\
\text { L. Nolasco Ferreira }\end{array}$ & & & \multicolumn{2}{|r|}{$\begin{array}{c}\text { BHN } \\
\text { (pós-1947) }\end{array}$} & $\begin{array}{c}1944- \\
1949\end{array}$ \\
\hline \multirow[b]{3}{*}{ BHN } & Curapaligüe & Héctor Fariña Rice & - & & & $\begin{array}{c}\text { BHN } \\
\text { (ação direta) }\end{array}$ & $\begin{array}{c}1948- \\
1953\end{array}$ \\
\hline & $\begin{array}{c}\text { Barrio Alvear } \\
\text { III } \\
\text { (3a etapa) }\end{array}$ & - & - & $\mathrm{BHN}$ & $(*)$ & $(*)$ & $\begin{array}{c}1943- \\
1954\end{array}$ \\
\hline & $\begin{array}{c}17 \text { de octubre } \\
\text { - Barrio } \\
\text { General Paz }\end{array}$ & $\begin{array}{c}\text { Luigi Piccinato } \\
\text { Oscar J. Stortini } \\
\text { Francisco Dighero } \\
\text { Ernesto Gomez } \\
\text { Ricardo J. Morelli (colab. }\end{array}$ & & & $\begin{array}{c}\text { Edifa, Sociedad } \\
\text { Responsabilidad } \\
\text { Limitada; } \\
\text { Barraseta y Hartz } \\
\text { Inmobiliaria; } \\
\text { Joaquín de Gamboa } \\
\text { Construcciones, S.A.; } \\
\text { Sebastián Maronese } \\
\text { e Hijos, Sociedad de } \\
\text { Responsabilidad } \\
\text { Limitada } \\
\end{array}$ & & $\begin{array}{l}1948- \\
1954\end{array}$ \\
\hline \multirow{3}{*}{ MOP } & $\begin{array}{l}\text { Barrio no. } 1 \text { - } \\
\text { Justicialista }\end{array}$ & Fernando L. F. Capilla & & MOP & & $\begin{array}{c}\text { BHN } \\
\text { (ação direta) }\end{array}$ & $\begin{array}{c}1948- \\
1949\end{array}$ \\
\hline & Ciudad Evita & Luigi Piccinato & & & & $\begin{array}{c}\text { BHN } \\
\text { (ação direta) }\end{array}$ & $\begin{array}{l}1947- \\
1953\end{array}$ \\
\hline & $\begin{array}{l}\text { Presidente } \\
\text { Juan Perón }\end{array}$ & $\begin{array}{l}\text { Fernando L. F. Capilla; } \\
\text { Roberto Quiroz }\end{array}$ & & MOP & & $\begin{array}{c}\text { BHN } \\
\text { (ação direta) }\end{array}$ & $\begin{array}{c}1946- \\
1949\end{array}$ \\
\hline \multirow{3}{*}{ MCBA } & Los Perales & $\begin{array}{l}\text { Augusto Pieres; } \\
\text { Dermot José Grehan; } \\
\text { Bartolomé Repetto }\end{array}$ & - & $\begin{array}{l}\text { Dirección } \\
\text { Municipal de } \\
\text { la Vivienda }\end{array}$ & Várias $\left({ }^{*}\right)$ & - & $\begin{array}{l}1946- \\
1952\end{array}$ \\
\hline & $\begin{array}{l}17 \text { de Octubre } \\
\text { (Barrio Grafa) }\end{array}$ & $\begin{array}{l}\text { Carlos Coire; } \\
\text { Carlos Giannoni; } \\
\text { M. C. Bianchi }\end{array}$ & - & & $\begin{array}{c}\text { Fernando Vanelli y } \\
\text { Hijos }\end{array}$ & - & $\begin{array}{c}1948- \\
1950\end{array}$ \\
\hline & $\begin{array}{l}\text { Urbanización } \\
\text { de Bajo } \\
\text { Belgrano }\end{array}$ & $\begin{array}{c}\text { Jorge Ferrari Hardoy; } \\
\text { Antonio Bonet; } \\
\text { Jorge Vivanco } \\
\text { Miguel C. Roca }\end{array}$ & & & - & - & 1948 \\
\hline \multicolumn{8}{|c|}{$\begin{array}{l}\text { Fontes: Elaboração da autora com base em: La Nación Argentina... (1950); Ballent (1993; 2005); Dunowicz (2000); Gutierrez (2011); } \\
\text { Aboy (2005); Nuestra Arquitectura no 277, ago, 1952. Construcciones no 107, abril 1954. Revista de Arquitectura no 365, feb. 1952. pp. } \\
\text { 23-30. Website La teja <https://lateja2.wordpress.com>; Website Moderna Buenos Aires <https://www.modernabuenosaires.org> } \\
\text { * Informações não localizadas. }\end{array}$} \\
\hline
\end{tabular}

Na realização do projeto da ANV vê-se a participação de um grande grupo de arquitetos entre os quais destacamos Augusto Pieres. O BHN dispunha de uma Gerencia de Construcciones, mas contou também com arquitetos externos para a realização de seus projetos, contratados principalmente através de concursos. Destaca-se a participação do arquiteto italiano Luigi Piccinato em dois projetos executados em La Matanza, município vizinho de Buenos Aires, um promovido pelo BHN e outro pelo MOP. Exceto por este arquiteto, se observa que os grandes projetos habitacionais do MOP foram realizados por membros de sua própria estrutura técnica, entre os quais Fernando L. F. Capilla e 
Roberto Quiroz. Também Bartolomé Repetto é personagem importante no quadro técnico do MOP, embora atuasse também em outros espaços institucionais como a MCBA. (GUTIERREZ, 2011)

Na construção dos projetos habitacionais massivos se percebe um predomínio da ação direta do BHN, através de sua Gerencia de Construcciones, muito embora, conforme as fontes pesquisadas, é provável que empresas construtoras tenham atuado na construção de todos os projetos, eventualmente sob a responsabilidade dos escritórios técnicos dos órgãos comitentes. Apesar disso, apenas os documentos referentes a três projetos pesquisados fazem menção à participação de empresas construtoras na execução das obras. Um destes projetos é do próprio BHN e é onde se vê a atuação de distintas empresas: Edifa Sociedad Responsabilidad Limitada, Barraseta y Hartz Inmobiliaria, Joaquín de Gamboa Construcciones S.A., Sebastián Maronese e Hijos Sociedad de Responsabilidad Limitada, o que se explica por tratar-se de um projeto de urbanização, em que houve grande quantidade de obras e diferentes momentos de implantação do projeto (RUBIO, 1954). Em dois projetos da MCBA também houve atuação de construtoras, no Barrio Los Perales e no Barrio Grafa. Do primeiro encontramos apenas a informação de que foi executado por "várias" empresas e do segundo que foi executado por Fernando Vanelli y Hijos. (DUNOWICZ, 2000)

Entre os órgãos promotores de habitação em Buenos Aires aquele que mais realizou projetos calcados no ideário moderno foi a Dirección de Vivienda da MCBA, o que é atribuído ao fato de aí estarem reunidos importantes personagens do "Grupo Austral”, principal responsável pela divulgação dos preceitos propostos pelo modernismo dos CIAMs na Argentina. Atuam na MCBA os membros do núcleo fundador do grupo Antonio Bonet, Juan Kurchan e Jorge Ferrari Hardoy, que além de projetos habitacionais realizaram verdadeiros projetos de urbanização, com grande destaque para o Estudo para o Plano de Buenos Aires (EPBA) em 1947 e também outros arquitetos que se incorporaram ao grupo como Jorge Vivanco e Carlos Coire.

O Grupo Austral foi fundamental ao desenvolvimento da arquitetura moderna no país, atuando entre 1938 e 1941 principalmente em Buenos Aires. O arquiteto catalão Antonio Bonet e os argentinos Juan Kurchan e Jorge Ferrari Hardoy se conhecem enquanto trabalhavam no escritório de Le Corbusier em Paris em meados da década de 1930. A bonança econômica na Argentina e o conflito iminente na Europa levaram o grupo a se mudar para Buenos Aires em 1938, onde fundaram o Grupo Austral juntamente com jovens arquitetos locais. Os membros se reuniam em diferentes configurações e trabalhavam em vários níveis, projetando desde mobiliário até planos urbanísticos, e mesmo depois da dissolução do grupo continuariam atuando sozinhos ou associados, dentro e fora do aparato estatal. (BONET, ANTONIO, s/d)

Antonio Bonet é formado na Escuela Superior de Arquitectura de Barcelona em 1936, mas desde 1932 trabalhava no escritório de Josep Lluis Sert e Josep Torres Clavé, tornando-se, como estes, um membro do GATCPAC (Grupo de Artistas y Técnicos Catalanes para el Progreso de la Arquitectura 
Contemporánea). Seu trabalho, porém, foi especialmente influenciado por sua participação no IV CIAM em 1933 e, por conseguinte, pela Carta de Atenas, resultante daquele congresso. Naquela ocasião faz contato com Le Corbusier, passando a trabalhar em seu escritório em seu Paris, onde conhece Kurchan e Ferrari Hardoy. (KATZENSTEIN; NATANSON; SCHVARTZMAN, 1978).

A produção de Bonet é marcada por estas três experiências, denotando-se nela a referência ao moderno, a finalidade social e o estudo sistêmico do planejamento urbano. Bonet ocupou um lugar de importância na vanguarda moderna argentina entre as décadas de 1940 e 1950, realizando uma série de projetos com membros do Grupo Austral até 1941, quando o grupo se dissolve, trabalhando a partir de então sozinho ou em eventuais parcerias. Seu projeto para a área conhecida como Casa Amarilla (1943) em parceria com Horacio Caminos e Eduardo Sacriste para a Organización de la Vivienda Integral de la Republica Argentina (OVRA), embora não construído, é considerado um marco no projeto de conjuntos habitacionais pelo pioneirismo da proposta calcada na preocupação social e nos conceitos modernos de arquitetura e urbanismo. Entre os projetos habitacionais promovidos pelo governo peronista - embora também não executado - a Urbanización de Bajo Belgrano (1949), planejada em parceria com J. Ferrari Hardoy, J. Vivanco e Miguel C. Roca se destaca pelos mesmos critérios. (BENDER, 2014)

Jorge Ferrari Hardoy se formou em 1937 na Escola de Arquitetura da UBA, após o que viajou a Paris em companhia do colega Juan Kurchan com o objetivo de trabalhar e complementar seus estudos. Após o fim do Grupo Austral em 1941 os dois montam um escritório de projetos, sendo responsáveis por obras importantes ao modernismo na Argentina como o edifício na Calle O’Higgins 2319, que serve de ensaio para "Los eucaliptos", moradia coletiva na Calle Virrey del Pino 2446, e para outros conjuntos de moradias unifamiliares em Buenos Aires. (FERRARI HARDOY, s/d)

Jorge Vivanco cursava economia e trabalhava no Banco de Boston quando assistiu à conferência de Le Corbusier em 1929 em Buenos Aires. Sem qualquer conhecimento arquitetônico prévio, Vivanco fica admirado com o arquiteto francês e a disciplina de arquitetura e ingressa na Escola de Arquitetura da UBA. Graduado em 1938 se junta ao Grupo Austral e participa de concursos variados com colegas do grupo, merecendo referência o concurso para protótipos de moradia organizado pelo Banco de la Nación em 1939. Em 1946 integra o Departamento de Obras Públicas da Provincia de Tucumán, onde ao lado dos arquitetos Horacio Caminos e Eduardo Sacriste, desenvolveu o primeiro plano de obras públicas da província. (VIVANCO, JORGE, s/d)

Utilizando-se de preceitos do urbanismo moderno dos CIAMs, Vivanco se destacou por sua atuação em projetos urbanos, sendo na década de 1950 o autor de um dos mais importantes planos reguladores desenvolvidos no país, o Plan Regulador Jujuy - Palpalá, que, no entanto, não pôde ser implementado em função de questões econômicas, tendo aspectos pontuais recuperados em ações posteriores. 
Graduado na Escuela Superior de Bellas Artes de Buenos Aires, Carlos Coire recebeu posteriormente o título de arquiteto pela Escola de Arquitetura da UBA em 1940. Entre 1958 e 1962 foi decano da Faculdade de Arquitetura da UBA e durante este período, coordenou o projeto e a execução da Cidade Universitária, destacando-se como arquiteto e construtor. Coire trabalhou em parceria com Antonio Bonet, Juan Kurchan, Jorge Vivanco, Marcel Bauer, Eduardo Catalano, Horacio Caminos, entre outros arquitetos ligados à arquitetura modernista, destacando-se no projeto de moradias coletivas e unifamiliares, tanto estatais, quanto privadas para o mercado rentista (COIRE, CARLOS, s/d). O projeto do Barrio Grafa tem grande destaque em sua obra e apesar de ter sido realizado em parceria com Carlos Giannoni e Mário C. Bianchi é atribuído - não oficialmente ${ }^{18}$ - apenas a Coire.

Apesar do cunho moderno das obras da MCBA, nem todos os arquitetos de seu quadro técnico possuíam formação no ideário moderno. Em 1949 Augusto Pieres foi designado arquiteto da Dirección Municipal de La Vivienda da MCBA, finalizando o Barrio 1을 de Marzo e projetando os Pabellones Acoyte e Ambrosetti, em associação com outros profissionais. Pieres participa também de vários concursos para a construção de importantes edifícios públicos, tendo recebido o primeiro prêmio em alguns deles. Entre outras atividades, Pieres realizou o projeto de extensão da Linha D do metrô bonaerense. Fora do aparato estatal, apesar da formação academicista, Pieres pouco a pouco se aproximou de uma arquitetura racionalista, projetando para vários edifícios de apartamentos em propriedad horizontal. (GUTIÉRREZ, 2011)

O desenvolvimento e impulso aos conjuntos de moradias coletivas na Argentina no final da década de 1940, sugerindo outra escala à proposta de produção massiva da habitação associada à utilização de menores porções de terras, esteve vinculada a pelo menos duas circunstâncias. Por um lado, a aprovação da lei de propriedade horizontal em 1948 garantiu a possibilidade da propriedade em edifícios habitacionais multifamiliares, não apenas às unidades produzidas pelo setor privado e destinadas a classes mais abastadas, mas também às unidades construídas pelo próprio Estado e destinadas aos trabalhadores. Por outro lado, a consolidação do movimento modernista a partir da década de 1930, mas fundamentalmente na década de 1940 entre membros do quadro técnico do aparato estatal possibilitou, especialmente nos primeiros anos do peronismo, a experimentação e o desenvolvimento de novas formas de morar.

Desde a década de 1930 a tradição acadêmico-eclética perde hegemonia na Argentina, enquanto, especialmente a partir da visita de Le Corbusier em 1929, as vanguardas do Movimento Moderno conseguem consolidar posições entre os profissionais mais jovens. Em 1928 a Universidade de Buenos Aires foi local de uma oficina de urbanismo e de um ciclo de palestras sobre diferentes temas da profissão, promovido pelo Centro de Estudiantes de Arquitectura. A formação acadêmica é

\footnotetext{
${ }^{18}$ Esta informação nos foi dada pelo Sr. Carlos, morador original do conjunto 17 de Octubre em conversa informal, e consta também de websites localizados na Internet.
} 
questionada, procurando-se diversificar o campo de atuação do arquiteto, incorporando o campo do urbanismo. Muito em breve, em 1935 como se viu, se promoveria a realização do Primeiro Congresso de Urbanismo, porém as bases da disciplina se estabelecem anos antes com a criação da cátedra de urbanismo na Universidad del Litoral, em Rosario ainda em 1929. O responsável por tal feito é o engenheiro argentino Carlos Della Paolera formado pelo Instituto de Urbanismo parisiense, que ocupa a partir de 1933 a mesma cátedra na Universidade de Buenos Aires. (ALMANDOZ, 2007)

Apesar de a Escola de Arquitetura da Universidad de Buenos Aires (UBA) existir desde 1901 é em 1947 que ocorre a criação da Facultad de Arquitectura, Diseño y Urbanismo, finalmente tornando o curso independente da Faculdade de Ciências Exatas. O projeto de transformação da Escola de Arquitetura em Faculdade fora elaborado em 1944 pelo arquiteto Carlos Mendioroz, delegado interventor da Faculdade de Ciências Exatas da UBA. Contudo, apenas a partir da ação conjunta de diversos atores e instituições, entre as quais a SCA, foi possível a aprovação da lei que criou a Faculdade (Ley n. 13045/47), não sem amplo debate entre conservadores e radicais, mesmo no interior das próprias instituições que apoiavam o projeto. No quadro do programa Justicialista para a Universidade de Buenos Aires se promoveu a incorporação de preceitos e práticas modernas de projeto, "com uma adaptação programática e funcional a uma sociedade de massas" (CIRVINI, 2012, p.123, tradução nossa). A transição para uma hegemonia do modernismo no ensino seria promovida pela criação de Faculdades de Arquitetura e Urbanismo em todo o país ${ }^{19}$.

Apesar disso, conforme se esclarecerá oportunamente, diversas linguagens foram amplamente utilizadas na obra estatal vinculada ao peronismo. A obra pública, produzida fundamentalmente pelo MOP, assumiu uma linguagem eclética, próxima do neoclássico nas obras mais representativas, como edifícios oficiais, e próxima do neocolonial nas construções populares, instituindo o que se convencionaria chamar de "chalé peronista". (BALLENT, 2005)

Entre os arquitetos que atuaram no MOP Bartolomé Repetto foi figura fundamental junto a Perón para o projeto de criação da Facultad de Arquitectura, Diseño y Urbanismo da UBA. No interior do aparato estatal Repetto foi avaliador técnico do BHN e entre 1955 e 1957 foi chefe da Dirección de Arquitectura do MOP, atuando ainda na MCBA, quando participa do projeto do Barrio Los Perales junto a Augusto Pieres e Dermot J. Grehan. Além disso, o arquiteto foi presidente da Comisión Directiva da Sociedad Central de Arquitectos (1941-43; 1946-47), membro do Colégio de Jurados e delegado dos Congressos Pan-americanos de Arquitetura de Montevidéu (1920) e Lima (1947) e presidente da delegação argentina no CPA de Havana (1950). (GUTIERREZ, 2011)

\footnotetext{
19 O peronismo articulou a política universitária e o funcionamento institucional e científico das universidades, com os objetivos e interesses de seu projeto político. Nesta reorganização do sistema universitário novas faculdades foram criadas de acordo com o que foi considerado necessário ao país. Este programa de ampliação da oferta educacional universitária teve uma grande quota de reparação histórica em direção aos setores populares, permitindo a entrada de filhos dos setores médios e operários na universidade. (CIRVINI, 2012, p.125, tradução nossa; em itálico no original)
} 
Roberto Quiroz se formou na Escola de Aequitetura da UBA em 1938 e entre 1943 e 1952 trabalhou na Dirección de Arquitectura do MOP, estando vinculado a conjuntos habitacionais promovidos pelo Ministério entre os quais se destaca o Barrio Juan Perón, que projetou em 1949 em parceria com Francisco Capilla, diretor técnico do MOP naquele momento. (QUIROZ, ROBERTO, s/d)

Desde 1946, porém, segundo Cirvini (2012), é possível identificar certa "apatia política" por parte dos membros da SCA, que, se não apoiavam o peronismo, tampouco o criticavam. Tal postura seria um indicativo de um equilíbrio de forças em que encontravam vantagens tanto os arquitetos quanto o governo justicialista, que justamente se destaca pela execução da obra pública. Para Cirvini (2012, p.122, tradução nossa) a estratégia estatal de "absorver as reivindicações da SCA" - admitindo arquitetos nos cargos institucionais responsáveis pela obra pública, por exemplo - demonstrava "disposição para negociar e consideração pela opinião da corporação". Contudo, discordamos da autora quando vê associada a esta estratégia uma perda da autonomia profissional, com "clara subordinação do papel dos técnicos ao projeto político e a uma permanente sinalização de que é o poder político que tem o poder de decidir sobre a obra pública". Esta visão de "subordinação" não apenas retira dos profissionais sua autonomia, como também desconsidera a importância da concretização dos objetivos da classe.

Concordamos com Ballent (2005) e Aboy (2005) que destacam a heterogeneidade da obra pública do Estado peronista. Independentemente da centralização do aparato estatal pelo Executivo, cada órgão responsável pela produção habitacional promoveu distintas tipologias urbano-arquitetônicas de projetos habitacionais e, logo, distintas formas de morar, conforme se apresentará oportunamente. Cada um destes órgãos estava submetido a diferentes condições e possibilidades de produção de acordo com as áreas institucionais a que estavam diretamente vinculados, os atores envolvidos, o público e o local a que se destinavam.

A obra pública se modifica inclusive ao longo da década peronista em função de questões políticoeconômicas, fato notado pelas profundas alterações propostas pelo Segundo Plano Quinquenal que implicaram em modificações na política habitacional e no aspecto físico da obra construída a partir de então. Nos anos conseguintes ao Primeiro Plano Quinquenal, segundo Aboy (2005), a bonança econômica permitiu aos arquitetos maior liberdade de experimentação, particularmente no campo da habitação e em Buenos Aires, como capital, sendo construídos neste momento massivos conjuntos habitacionais de distintas tipologias. 
Capítulo 4.

Produção habitacional como política previdenciária em São Paulo nas décadas de 1940 e 1950 


\subsection{A especificidade da produção previdenciária da habitação em São Paulo}

Em São Paulo e nos municípios vizinhos da capital foram previstos por diferentes institutos de previdência - IAPI, IAPB, IAPC, IPASE, IAPETC e CAPFESP - 36 projetos habitacionais entre 1933 e 1964. Deste total, foram construídos 32 projetos, totalizando aproximadamente 9.000 unidades distribuídas entre o território da capital e alguns municípios vizinhos. No âmbito da política previdenciária de habitação é possível considerar para a análise aqui realizada ainda outros três projetos construídos em São Paulo pelo Instituto de Previdência do Estado de São Paulo (IPESP), somando mais 1.133 unidades construídas. O mapa (Figura 68) mostra a localização dos projetos habitacionais propostos para São Paulo e municípios vizinhos entre 1930 e 1964 sobre a área urbanizada de 1940, momento a partir do qual se dá a produção efetiva dos conjuntos habitacionais pelos IAPs.

Nota-se especial concentração em um raio de cerca de $5 \mathrm{Km}$ ao redor do marco zero, na Catedral da Sé, estando aí 19 dos projetos propostos. Conforme apresentado na sequência, em que se buscou compreender o processo de urbanização de São Paulo, estas eram áreas já bastante ocupadas e adensadas, o que nos leva a considerar que estes projetos foram propostos para terrenos remanescentes ou, eventualmente, remodelados em função do próprio processo de desenvolvimento urbano e reestruturação por que passou a área central de São Paulo (PEREIRA, 1988). Os demais projetos dividem-se nas regiões Leste, com mais quatro projetos fora deste raio central; Norte, com 
mais dois projetos; Oeste, com quatro projetos; e Sul, com grande privilégio desta última, onde se contam onze projetos fora do raio central de $5 \mathrm{Km}$.

Conforme se observa no mapa, a mancha urbanizada - baseada na "Planta da Cidade de São Paulo e Municípios Circunvizinhos de 1943" - era também maior no vetor Sul no início da década de 1940. No entanto, como se verá na planta de São Paulo de 1951 (Figura 71), as demais regiões da cidade e também municípios vizinhos passarão por expressivo processo de ocupação ao longo desta década. Uma parte dos projetos foi proposta em vazios remanescentes em bairros já urbanizados que, contudo, não estavam totalmente ocupados. É preciso dizer que embora muitas vezes apresentassem obstáculos à construção, como baixa altitude e alagamentos, estes terrenos eram estimados por sua localização com relação a pontos de interesse e infraestrutura previamente implantada, conforme se apreendeu, por exemplo, no "Memorial descritivo para o anteprojeto de aproveitamento dos terrenos do Instituto de Aposentadoria e Pensões dos Bancários, à Rua Santa Cruz" (MEMORIAL DESCRITIVO PARA O ANTEPROJETO..., 1948).

A outros projetos habitacionais couberam ocupações quase que pioneiras, determinantes para o desenvolvimento suburbano posterior (LANGENBUCH, 1970; BONDUKI, 1998), sendo casos expressivos os conjuntos construídos no setor Norte, junto à Serra da Cantareira. Em termos da localização periférica, destacamos a construção de conjuntos de grande escala nos municípios de Suzano, Osasco e Santo André. Conforme se vê no mapa, exceto por Santo André, praticamente não havia urbanização expressiva nestes locais e tampouco, um indicativo de conurbação com o município de São Paulo, o que, contudo, ocorreria já na década de 1950.

O Quadro 6 reúne os projetos habitacionais promovidos pelos IAPs e CAPs para São Paulo e municípios vizinhos da capital entre 1930 e 1964, destacando-se em cinza os projetos com mais de 300 unidades e indicando (com sublinhado) aqueles localizados em um raio de $5 \mathrm{Km}$ desde o marco zero. Além do local e ano em que foram produzidos os projetos e os respectivos órgãos promotores, o quadro traz também as tipologias utilizadas, importantes dentro da lógica da política previdenciária de habitação, conforme se explica a seguir. 
Grande Såo Paulo
O. Habiacionas
C. Hebracionas
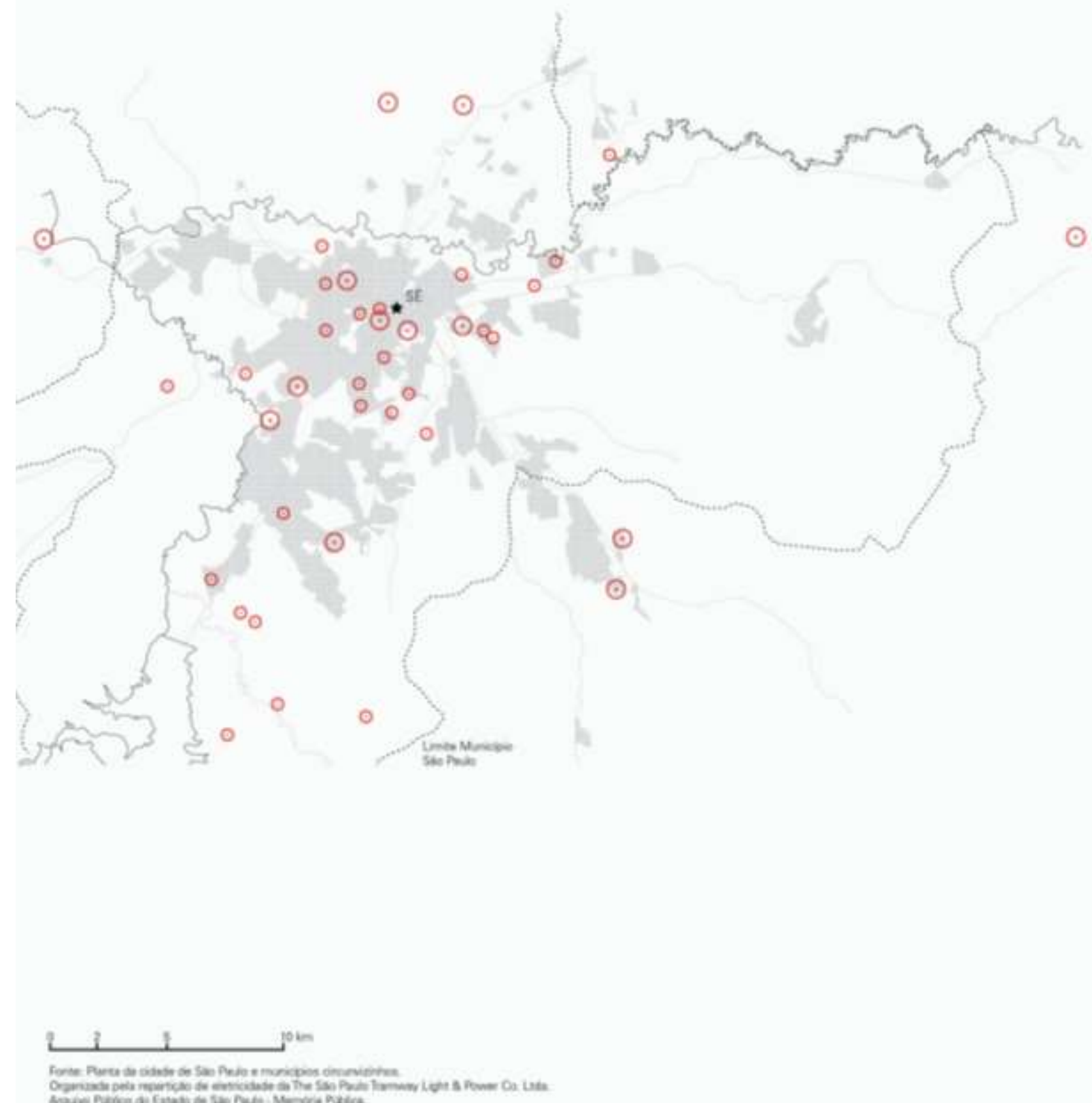

Figura 68. Área urbanizada de São Paulo e Municípios circunvizinhos em 1940 com localização dos projetos habitacionais promovidos entre 1930 e 1964. Elaboração da autora. Execução de Carolina Passos.

* Foi localizado neste mapeamento também o Núcleo Residencial de Santo André, projetado pela FCP. 
Quadro 6

Projetos habitacionais propostos pelos IAPs e CAPs para São Paulo e municípios vizinhos

\begin{tabular}{|c|c|c|c|c|c|c|c|}
\hline \multirow[b]{2}{*}{ Projeto } & \multirow[b]{2}{*}{ Órgão } & \multirow[b]{2}{*}{ Localização } & \multirow[b]{2}{*}{ N. Unidades ${ }^{1}$} & \multicolumn{3}{|c|}{ Tipologia } & \multirow[b]{2}{*}{ Ano } \\
\hline & & & & $\begin{array}{l}\text { Edifício } \\
\text { vertical }\end{array}$ & $\begin{array}{c}\text { Conjunto } \\
\text { de } \\
\text { blocos }\end{array}$ & $\begin{array}{l}\text { Conjunto } \\
\text { de casas }\end{array}$ & \\
\hline Parque São Jorge & CAP STLFG* & $\begin{array}{l}\text { Tatuapé } \\
\text { São Paulo }\end{array}$ & 100 & & & $x$ & 1936 \\
\hline Edifício Xavier & IPASE & $\begin{array}{l}\text { Liberdade } \\
\text { São Paulo }\end{array}$ & 28 & $x$ & & & 1938 \\
\hline$\frac{\text { C.R. da Barra }}{\text { Funda }}$ & $\begin{array}{l}\text { CAP Ferrov. } \\
\text { Sorocabana }\end{array}$ & $\begin{array}{c}\text { Barra Funda } \\
\text { São Paulo }\end{array}$ & 137 & & & $x$ & 1939 \\
\hline C.R. Ibirapuera I & IAPB & $\begin{array}{l}\text { Vila Mariana } \\
\text { São Paulo }\end{array}$ & 54 & & & $x$ & 1939 \\
\hline C.R. Ibirapuera II & IAPB & $\begin{array}{l}\text { Vila Mariana } \\
\text { São Paulo }\end{array}$ & 69 & & & $x$ & 1939 \\
\hline C.R. Manduri & IAPB & $\begin{array}{l}\text { Pinheiros } \\
\text { São Paulo }\end{array}$ & 26 & & & $x$ & 1939 \\
\hline Edifício Anchieta & IAPI & $\begin{array}{l}\text { Consolação } \\
\text { São Paulo }\end{array}$ & 80 & $x$ & & & 1941 \\
\hline$\frac{\text { C.R. da Várzea do }}{\underline{\text { Carmo }}}$ & IAPI & $\begin{array}{l}\text { Cambuci } \\
\text { São Paulo }\end{array}$ & $552(4028)$ & $x$ & $x$ & & 1942 \\
\hline C.R. Japurá & IAPI & $\begin{array}{l}\text { Bela Vista } \\
\text { São Paulo }\end{array}$ & 310 & $x$ & & & 1942 \\
\hline$\frac{\text { C.R. de Vila }}{\text { Mariana }}$ & IAPI & $\begin{array}{l}\text { Vila Mariana } \\
\text { São Paulo }\end{array}$ & $97(131)$ & & & $x$ & 1942 \\
\hline Vila Guiomar & IAPI & $\begin{array}{l}\text { R. da Catequese, } \\
\text { Santo André }\end{array}$ & $1411(3000)$ & & $x$ & $x$ & 1942 \\
\hline C.R. do Tatuapé & CAP STLFG & $\begin{array}{c}\text { Tatuapé } \\
\text { São Paulo }\end{array}$ & 6 & & & $x$ & 1944 \\
\hline C.R. Anhanguera & IAPC & $\begin{array}{c}\text { Campo Grande } \\
\text { São Paulo }\end{array}$ & 133 & & & $x$ & 1945 \\
\hline C.R. da Mooca & IAPI & $\begin{array}{c}\text { Mooca } \\
\text { São Paulo }\end{array}$ & 576 & & $x$ & & 1946 \\
\hline Jardim Piratininga & IAPI & $\begin{array}{c}\text { R. Romildo Isaías } \\
\text { Neto, [Osasco] }\end{array}$ & $357(4000)$ & & & $x$ & 1946 \\
\hline$\frac{\text { Edifício Visconde }}{\text { de Ouro Preto }}$ & IAPC & $\begin{array}{c}\text { Consolação } \\
\text { São Paulo } \\
\end{array}$ & $0(48)$ & $x$ & & & 1946 \\
\hline$\frac{\text { Núcleo Residencial }}{\text { da Mooca }}$ & IAPETC & $\begin{array}{c}\text { Mooca } \\
\text { São Paulo }\end{array}$ & $242(302)$ & & $x$ & $x$ & 1947 \\
\hline C.R. Cidade Jardim & IAPC & $\begin{array}{l}\text { Cidade Jardim } \\
\text { São Paulo }\end{array}$ & $0(1118)$ & & $x$ & $x$ & 1947 \\
\hline$\frac{\text { Edifício de Santa }}{\text { Cecília }}$ & IAPC & $\begin{array}{c}\text { Santa Cecília } \\
\text { São Paulo }\end{array}$ & $0(367)$ & $x$ & & & 1947 \\
\hline C.R. Santa Cruz & IAPB & $\begin{array}{c}\text { Vila Mariana } \\
\text { São Paulo }\end{array}$ & 282 & & $x$ & & 1948 \\
\hline C.R. Nove de Julho & IAPB & $\begin{array}{l}\text { Jardim Paulista } \\
\text { São Paulo }\end{array}$ & 473 & $x$ & & & 1948 \\
\hline $\begin{array}{l}\text { Núcleo Residencial } \\
\text { do Caxingui }\end{array}$ & IPESP & $\begin{array}{c}\text { Butantã } \\
\text { São Paulo }\end{array}$ & 203 & & $x$ & & 1950 \\
\hline $\begin{array}{c}\text { C.R. da Pedreira } \\
\text { Guacuri }\end{array}$ & IAPI & $\begin{array}{l}\text { Pedreira } \\
\text { São Paulo }\end{array}$ & $38(93)$ & & & $x$ & $\begin{array}{c}\text { sd-a } \\
\sim 1950 \\
\end{array}$ \\
\hline $\begin{array}{l}\text { Núcleo Residencial } \\
\text { Francisco Morato }\end{array}$ & IPESP & $\begin{array}{c}\text { Tucuruvi } \\
\text { São Paulo }\end{array}$ & 840 & & $x$ & & 1951 \\
\hline C.R. Vila Isa & IAPC & $\begin{array}{l}\text { Campo Grande } \\
\text { São Paulo }\end{array}$ & 82 & & & $x$ & 1951 \\
\hline C.R. do Brás (NC) & IAPC & $\begin{array}{c}\text { Brás } \\
\text { São Paulo } \\
\end{array}$ & $0(92)$ & & $x$ & & 1952 \\
\hline $\begin{array}{c}\text { Vila dos } \\
\text { Eletricitários }\end{array}$ & $\begin{array}{c}\text { CAP } \\
\text { Eletricitários }\end{array}$ & $\begin{array}{c}\text { Mooca } \\
\text { São Paulo }\end{array}$ & 134 & & & $x$ & 1953 \\
\hline Edifício Ícaro & CAP SATC & $\begin{array}{l}\text { Bela Vista } \\
\text { São Paulo }\end{array}$ & 54 & $x$ & & & 1954 \\
\hline $\begin{array}{l}\text { Cidade Comerciária } \\
\text { Presidente Vargas }\end{array}$ & IAPC & $\begin{array}{l}\text { Jabaquara } \\
\text { São Paulo }\end{array}$ & 523 & & & $x$ & 1954 \\
\hline C.R. Vila Sabará & IAPETC & $\begin{array}{l}\text { Campo Grande } \\
\text { São Paulo }\end{array}$ & $100(242)$ & & & $x$ & 1955 \\
\hline
\end{tabular}

\footnotetext{
${ }^{1}$ Para o número total de unidades considerar: total construído (total proposto) quando houver discrepância.
} 


\begin{tabular}{|c|c|c|c|c|c|c|}
\hline $\begin{array}{l}\text { Núcleo Residencial } \\
\text { do Catumbi }\end{array}$ & IPESP & $\begin{array}{c}\text { Belém } \\
\text { São Paulo }\end{array}$ & 126 & $x$ & & 1956 \\
\hline C.R. de Perdizes & IAPC & $\begin{array}{l}\text { Perdizes } \\
\text { São Paulo }\end{array}$ & 37 & & $x$ & $\begin{array}{c}\text { sd-a } \\
\sim 1958\end{array}$ \\
\hline Comunidade & & Av. Presidente & & & & \\
\hline $\begin{array}{c}\text { Brasílio Machado } \\
\text { Neto }\end{array}$ & IAPC & $\begin{array}{c}\text { Kennedy } \\
\text { Suzano }\end{array}$ & 782 [749] & $x$ & $x$ & 1958 \\
\hline C.R. Santo Amaro & IAPB & $\begin{array}{l}\text { Santo Amaro } \\
\text { São Paulo }\end{array}$ & s/ info & & $x$ & 1957 \\
\hline Cidade Dutra & $\begin{array}{c}\text { CAP } \\
\text { Eletricitários }\end{array}$ & $\begin{array}{l}\text { Cidade Dutra } \\
\text { São Paulo }\end{array}$ & s/ info 1000 & & $x$ & 1959 \\
\hline C.R. Santo Antonio & IAPB & $\begin{array}{l}\text { Mandaqui } \\
\text { São Paulo } \\
\end{array}$ & 1272 [1302] & $x$ & & 1962 \\
\hline$\frac{\text { Chácara do Castelo }}{\text { e Vila Deodoro }}$ & CAP STLFG & $\begin{array}{c}\text { Vila Mariana } \\
\text { São Paulo } \\
\end{array}$ & $144(984)$ & $x$ & $x$ & sd \\
\hline$\underline{\text { Jardim Aeroporto }}$ & CAPFESP & $\begin{array}{c}\text { Campo Belo, São } \\
\text { Paulo }\end{array}$ & 48 & & $x$ & sd \\
\hline Vila Sorocabana & CAPFESP & $\begin{array}{c}\text { R. Dr. Elói Chaves, } \\
\text { Guarulhos }\end{array}$ & 160 & & $x$ & sd \\
\hline
\end{tabular}

Fontes: Elaboração da autora com base em: BONDUKI; KOURY (2014), BRUNA (1998), BOTAS (2011), PESSOLATO (2007), REGINO; PERRONE (2009), LIMA et. al (1942; 1943), MELLO (1947), Processos Administrativos 62.631/1944; 45.127/1944; 21.197/1942; 31.964/1948; 104.125/1951; 188.992/1965; 11.569/1946; 65.163/1948; 153.800/1959.

* Caixas de Aposentadoria e Pensões dos Serviços de Tração, Luz, Força e Gás de São Paulo.

Gráfico 03

Quantidade de projetos habitacionais por década em São Paulo e municípios vizinhos

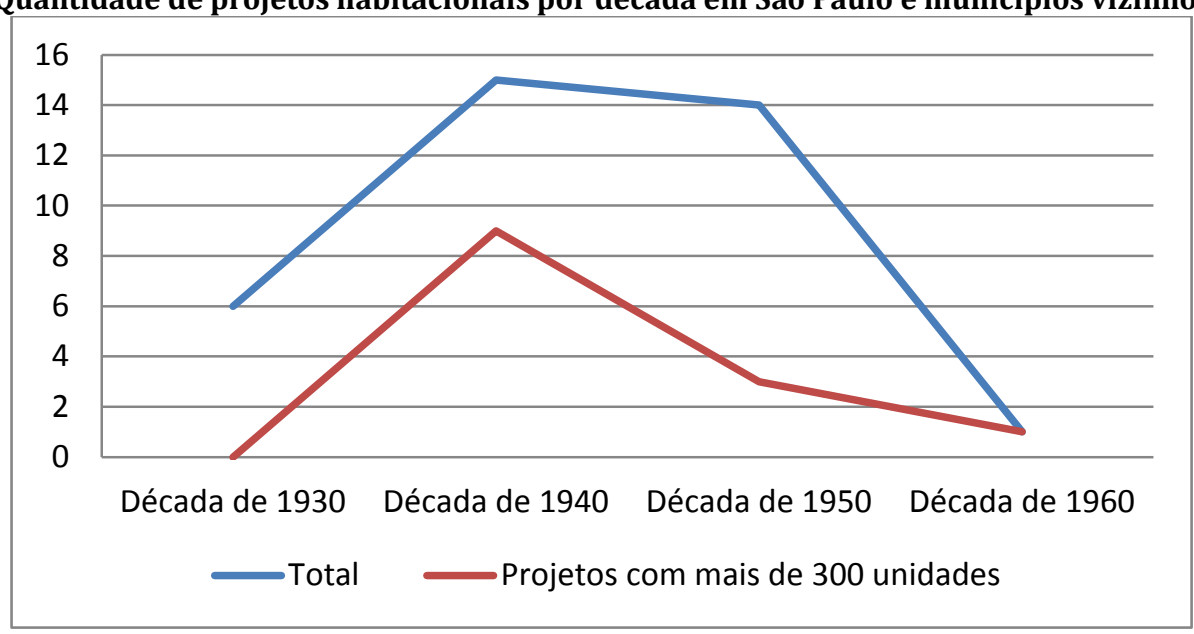

Elaboração da autora.

Gráfico 04

Quantidade de projetos habitacionais por década em relação à área central

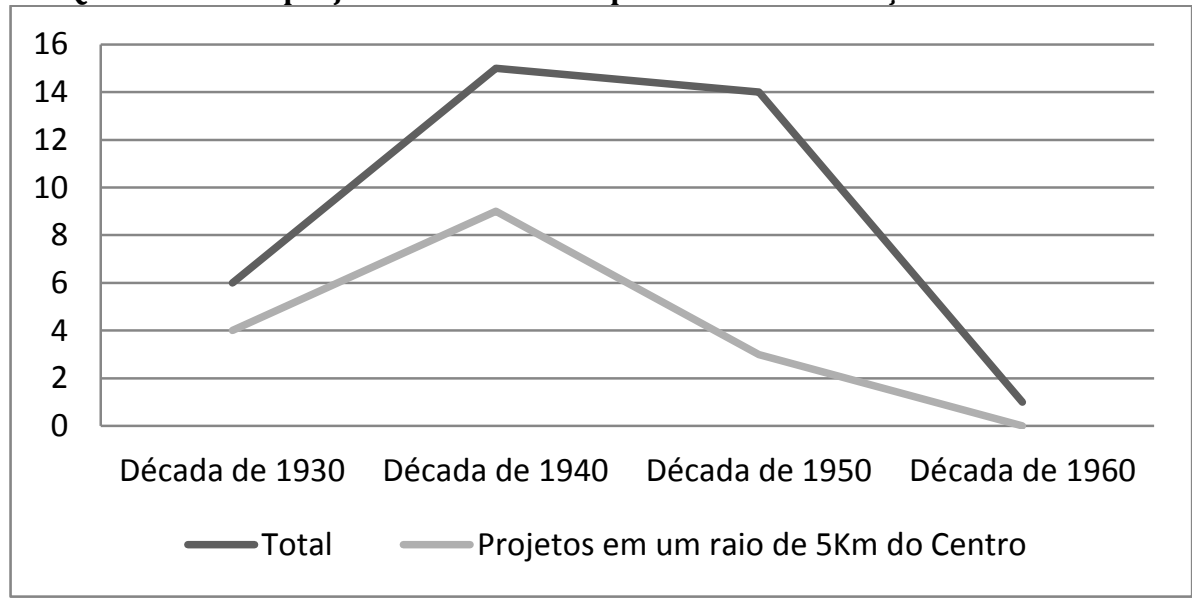

Elaboração da autora. 
Como se pode observar no Quadro e nos Gráficos 03 e 04, elaborados a partir deste, seis projetos habitacionais foram produzidos durante a década de 1930. Estes projetos praticamente se concentraram nas proximidades do Centro, estando quatro deles no raio de $5 \mathrm{Km}$ desde a Catedral da Sé e não apresentam mais de 150 unidades. Na década de 1940 foram produzidos quinze projetos habitacionais, nove dos quais se localizam no mesmo raio central de $5 \mathrm{Km}$. Nessa década, como se pode observar, é proposta a maior quantidade de projetos em grande escala, contando-se nove dos treze projetos com mais de 300 unidades destacados. Na década de 1950 são produzidos quatorze projetos habitacionais, dos quais apenas três estão nas proximidades do Centro. Três projetos dessa década possuem mais de 500 unidades, em que, apesar, destes três grandes conjuntos, predominam, portanto, projetos pouco massivos. Na década de 1950 os projetos se afastam da área central. Um único projeto foi proposto na década de 1960, estando distante do Centro e contando mais de 1000 unidades habitacionais.

Com relação às tipologias adotadas, todos os "edifícios verticais" (com mais de dez pavimentos) ou conjuntos com edifícios verticais estão no raio de $5 \mathrm{Km}$ desde o marco zero e foram projetados prioritariamente na década de 1940. Além dos edifícios, no raio de $5 \mathrm{Km}$ foram também propostos conjuntos de casas pouco massivos. Nos terrenos remanescentes, tanto no interior do raio central quanto fora dele, predominam conjuntos formados por blocos ou casas. Nas grandes glebas nas áreas de expansão urbana e municípios vizinhos estão os maiores núcleos, com mais de mil unidades e tipologias que variavam entre o conjunto de blocos e o conjunto de unidades unifamiliares, ou uma mescla de ambos.

Neste capítulo desenvolve-se a noção de que a localização dos projetos dos IAPs em São Paulo, considerando-se as particularidades de cada Instituto, reflete os dois escopos da política previdenciária de habitação, isto é, a função social e a capitalização dos recursos invertidos pelos Institutos de Previdência. Por um lado, foram previstos projetos para locais próximos a bairros industriais, ou seja, próximos a locais de trabalho da futura população moradora. Por outro lado, foram previstos projetos para locais potencialmente valorizados pela presença de infraestrutura e/ou pela demanda, como junto à área central e a importantes acessos viários. Em ambos os casos a provisão de valor de uso, como função social da habitação, e a acumulação de capital, a partir do retorno dos recursos aplicados em terras e construção, conviviam, como se demonstrará ao longo do capítulo. Em artigo de 2014, Botas e Koury tratam da atuação dos IAPs no processo de urbanização e ressaltam, por um lado, a relação entre a localização dos projetos habitacionais e os interesses fabris, conforme orientação de desenvolvimento industrial colocada pelo Estado, em que se aproximavam a moradia do local de trabalho do operariado e, por outro lado, contraditoriamente aos interesses econômicos e sociais previstos pelo governo, a ação dos IAPs de acordo com seus próprios interesses, incluindo-se na dinâmica do mercado imobiliário. 
Cada IAP, contando com seu próprio escritório técnico, apresentava políticas habitacionais e propostas de atuação bastante diferentes, conforme se explicou no Capítulo 02. Nos três grandes institutos que mais atuaram em São Paulo e sua região metropolitana (IAPI, IAPC e IAPB) as políticas eram claramente definidas, cabendo mencionar as indicações pela utilização de materiais nacionais e produção em série de tipos habitacionais e elementos construtivos e, ainda, pela questão econômica, pensada tanto em função dos futuros moradores quanto dos próprios Institutos, conforme se depreendeu da leitura de Bonduki (2014) e da análise dos Processos Administrativos de diversos projetos analisados. (PMSP, 1944a; 1944b; 1948a)

Estas políticas eram implementadas na prática conforme as possibilidades financeiras de cada Instituto e em função das características dos locais de implantação, que podiam implicar diretamente nos projetos. Attílio Corrêa Lima, ao apresentar o projeto para o Conjunto Residencial da Várzea do Carmo na Revista Municipal de Engenharia em 1942 explica:

A grande valorização que sofreram os terrenos naquela zona da cidade como consequência de fatores diversos e principalmente da proximidade da parte central e mais valorizada, pesa sobremaneira nas diretrizes básicas do plano a empreender. (LIMA, 1942, p.3)

Uma vez que a atuação dos IAPs no setor imobiliário se configura como forma de aplicação de fundos, conforme disposto nos respectivos decretos de criação e organização dos Institutos (BRASIL, 1934a; BRASIL, 1934b; BRASIL, 1936), a "capitalização do setor imobiliário proveniente das inversões realizadas" se torna fator importante no interior dos Institutos, conforme destacam Botas e Koury (2104). "O foco era a estabilidade econômico-financeira das instituições e havia a tendência em buscar a segurança oferecida pelos investimentos imobiliários" (BOTAS; KOURY, 2014, p.157). Deste modo, a localização dos terrenos - fator fundamental ao cálculo do preço da terra urbana ${ }^{2}$ - era importante de modo a se obter bons retornos financeiros.

A produção habitacional realizada a partir da política previdenciária de habitação implicava em uma "forma previdenciária de produção do espaço construído" ${ }^{3}$, de modo que a partir da década de 1940 os IAPs podem ser interpretados como agentes ${ }^{4}$ do processo de urbanização e expansão de São Paulo através da promoção de projetos habitacionais. Nesse sentido, revela-se uma segunda especificidade da política previdenciária de habitação referente à sua atuação em São Paulo. A localização dos projetos habitacionais no espaço urbano e o tipo de ocupação que realizam em cada local mostram que a ação dos IAPs no setor imobiliário através da aquisição de terrenos e produção de habitações

\footnotetext{
${ }^{2}$ O valor da terra urbana depende das construções e benfeitorias nela instaladas, porém o preço da terra urbana, que não é mais meio de produção, mas ela própria mercadoria, depende da sua localização. (SOUZA, 1994)

${ }^{3}$ Conforme se desenvolve no Capítulo 2.

${ }^{4}$ Conforme Souza $(1994$, p.185; 189) neste trabalho são entendidos como agentes "aqueles que interveem no processo de produção fundiária e imobiliária", entre os quais pode-se destacar pelo menos três categorias principais: incorporadores, construtores e vendedores, sendo possível que assumam concomitantemente duas ou três funções e ainda que variam sua atuação ao longo do tempo.
} 
procurava seguir lógica semelhante à de outros agentes do processo de urbanização paulistano, conforme se explicará na sequência.

Melo $\left(1992^{5}\right.$ apud BONDUKI, 1998, p.105) afirma que atuando no setor imobiliário e na produção habitacional os Institutos tornaram-se "os maiores detentores individuais de terra urbana no país". Bonduki (1998), Botas e Koury (2014) compreendem que os IAPs assumiram o papel de incorporadores na produção de conjuntos habitacionais e, como tais, foram agentes diretos do processo de especulação imobiliária (não apenas em São Paulo, como também em outras cidades). A figura do incorporador como agente promotor do espaço urbano se constitui a partir do processo de urbanização e desenvolvimento da indústria da construção, controlando diversas fases da produção habitacional, desde a compra dos terrenos até sua comercialização.

Conforme Souza (1994), em São Paulo as primeiras incorporações datam da década de 1940. Segundo a autora, desde finais do século XIX, quando São Paulo começa a expandir sua área urbanizada, se reconhecem as primeiras práticas relacionadas à especulação imobiliária. Desde então construtores, vendedores e incorporadores foram os grandes responsáveis por ditar os rumos da urbanização, comprando terrenos e os oferecendo à ocupação, onde e quando fosse mais conveniente.

\subsection{A lógica de mercado na produção habitacional dos IAPs}

O mapa a seguir (Figura 69) mostra a localização dos projetos habitacionais em São Paulo e nos municípios vizinhos com indicação dos Institutos promotores. Tomando-se a localização dos projetos dos IAPs que mais atuaram em São Paulo é possível estabelecer relações e fazer algumas considerações.

\footnotetext{
5 MELO, Marcus André. "O Estado, o boom do século e a crise da habitação: Rio de Janeiro e Recife (1937-1946)" In: FERNANDES, Ana; GOMES, Marco Aurélio (org.). Cidade \& história. Modernização das cidades brasileiras nos séculos XIX e XX. Salvador: UFBA, 1992.
} 


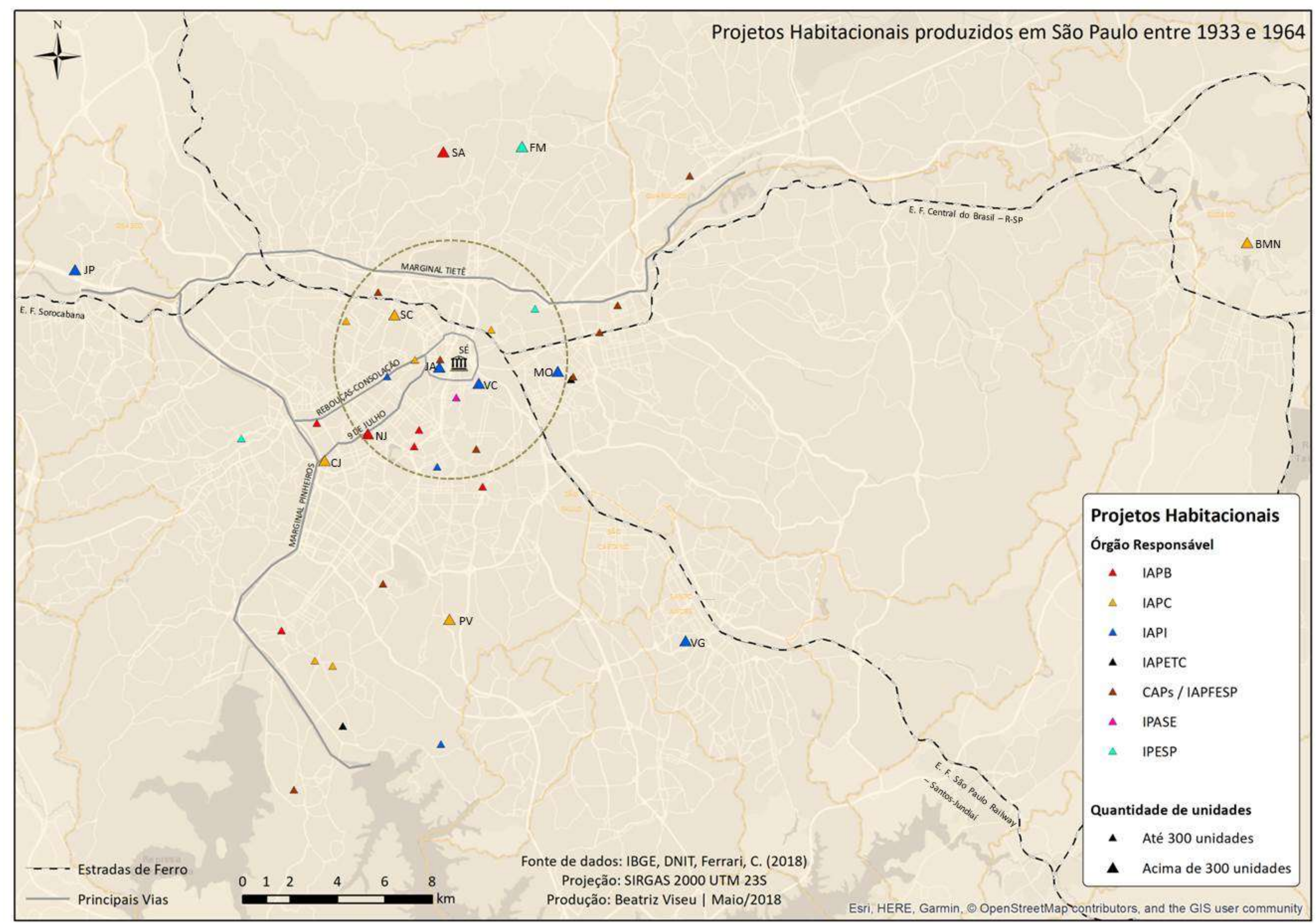

Figura 69. Localização dos conjuntos habitacionais projetados para a cidade de São Paulo e municípios vizinhos, com indicação do Instituto promotor. Elaboração de Camila Ferrari. Produção de Beatriz Viseu. 
Os conjuntos do IAPI (em azul no mapa) estão localizados fundamentalmente junto a regiões de concentração industrial (Mooca, Osasco, Santo André) e/ou muito próximos da área central. Percebese que as recomendações do setor de engenharia do IAPI - conforme descrevemos no Capítulo 02 são seguidas em São Paulo, com a construção de edifícios verticais e conjuntos de blocos na área urbana consolidada e conjuntos maiores e mistos na periferia.

Parte dos projetos do IAPC (em amarelo no mapa) estava próxima a importantes acessos viários (Norte da área central), enquanto outra parte se localizava em regiões de expansão urbana, especificamente no vetor Sul, com um único conjunto a Leste (no município de Suzano). Exceto pelo C.R. Santa Cecília, edifício vertical na área central, a perspectiva de grande escala aparece apenas nos conjuntos periféricos do IAPC, em conjuntos de casas, blocos e edifícios. Um único exemplar da "Cidade Jardim dos Comerciários", proposta por Ulisses Hellmeister para a política inicial da divisão de engenharia do IAPC, foi construído no bairro de Perdizes, em São Paulo. Os demais parecem seguir a especificações do escritório de engenharia do IAPC São Paulo, adotando a padronização das unidades e a associação das moradias a uma gama ampla de equipamentos, incorporando, inclusive o padrão urbanístico da unidade de vizinhança.

Os conjuntos habitacionais do IAPB (em vermelho no mapa) se localizam em terrenos remanescentes junto a loteamentos de alto padrão no vetor Sudoeste e em áreas de expansão urbana em locais estimados por condições de altitude e clima (zona Norte e Bosque da Saúde). Apesar da grande produção de projetos habitacionais em São Paulo (apenas no município), o IAPB tem poucos projetos massivos, um conjunto de blocos na área Norte da cidade e um conjunto de edifícios verticais em vazio remanescente entre os bairros jardins no vetor Sudoeste. Predominam conjuntos de casas, condizentes com a política inicial do Instituto, e de blocos, produzidos após 1940, também conforme a política da divisão de engenharia do IAPB.

Novamente nos referimos aos projetos promovidos em um raio central de $5 \mathrm{Km}$ (demarcado com linha tracejada no mapa). Nota-se que sua promoção se deu majoritariamente pelos três Institutos mais atuantes em São Paulo, IAPI, IAPC e IAPB. Os quatro projetos propostos em locais mais próximos do Centro são edifícios verticais. Três destes projetos são edifícios isolados e estão localizados em pontos muito próximos do anel viário central proposto pelo Plano de Avenidas de Prestes Maia. São eles o C.R. Japurá (IAPI) e o C.R. Ícaro (CAP Aéreos) na Bela Vista, respectivamente nas ruas Japurá e Nove de Julho, e o Edifício Visconde de Ouro Preto (IAPC), na Rua da Consolação. O quarto projeto na área central é um conjunto de edifícios multifamiliares, o C.R. da Várzea do Carmo (IAPI), que ocupa uma grande gleba até então desocupada na várzea do Tamanduateí, ao sul do Parque Dom Pedro II. O C.R. Japurá e o C.R. da Várzea do Carmo, ambos do IAPI, são concebidos sob uma perspectiva de produção em grande escala, expressa no projeto urbanístico racionalizado, na padronização de 
unidades e elementos construtivos, na utilização de novas técnicas e tecnologias e, nomeadamente, pela integração da moradia com equipamentos comunitários e serviços destinados ao público geral. Conforme esboçado anteriormente, é expressivo o número de conjuntos cuja localização se relaciona à atividade industrial que, em São Paulo, se vinculou sobretudo até a década de 1950, às ferrovias. Sete projetos habitacionais foram propostos nos bairros operários a Leste do Tamanduateí (Brás, Mooca, Tatuapé), nas adjacências da ferrovia Central do Brasil. Três deles estão localizados na Mooca e próximos também da E.F. Santos-Jundiaí, o C.R. da Mooca do IAPI, o C.R. da Mooca do IAPETC e a Vila dos Eletricitários (CAP Eletricitários). Destes projetos apenas o C.R. da Mooca do IAPI tem mais de 300 unidades (576) e alguma relação com o ideário moderno, expressa principalmente no plano urbanístico e na padronização e modulação dos tipos habitacionais.

Outro conjunto do IAPI, o C.R. Vila Guiomar, foi construído em proximidade com o eixo da ferrovia Santos-Jundiaí no município de Santo André, centro industrial já bastante desenvolvido na década de 1940. Conforme apresentado no Capítulo 01, o C.R. Vila Guiomar foi um dos maiores conjuntos habitacionais projetados pelo IAPI, ocupando uma gleba de grandes dimensões com 3.000 unidades em dois tipos padronizados de edifícios e casas. Os mapas de Meyer, Grostein e Biderman (Figura 70) mostram as áreas de concentração industrial de São Paulo em 1930 e 1950, auxiliando a compreensão da localização dos projetos com relação a estas áreas - em preto estão demarcadas as ferrovias e em branco os acessos viários.
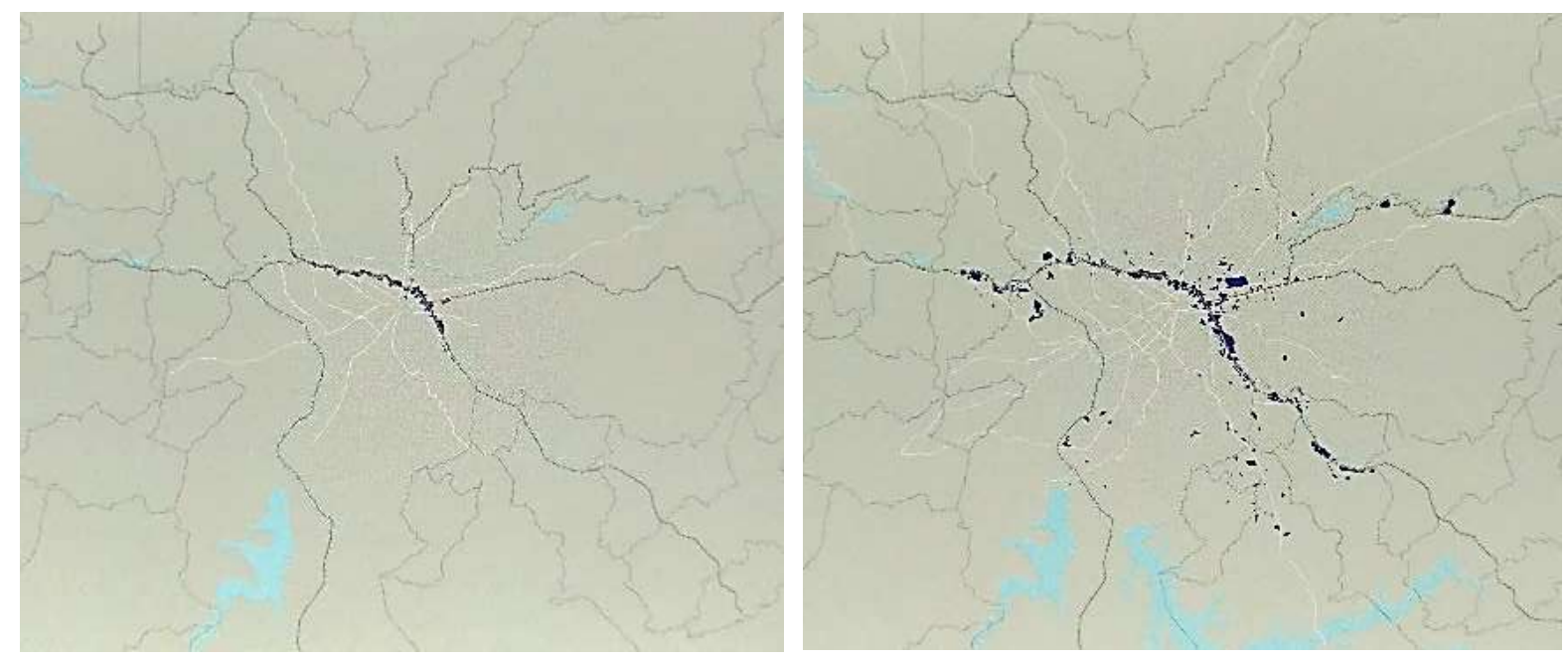

Figura 70. Áreas de concentração industrial em São Paulo e municípios vizinhos em 1930 e 1950. Fonte: MEYER, Regina M. Prospen; GROSTEIN, Marta Dora; BIDERMAN, Ciro. "São Paulo Metrópole". São Paulo: EDUSP: Imprensa Oficial do Estado de São Paulo, 2004. p. 166.

Em 1930 as áreas de concentração industrial estavam basicamente localizadas junto à E.F. São Paulo Railway (sentido Noroeste-Sudeste) e ainda no território do município de São Paulo. Em 1950 a concentração industrial junto a esta ferrovia se amplia no vetor Sudeste e ganha volume nas áreas já ocupadas anteriormente, ao mesmo tempo em que se associa também a outras ferrovias, com 
destaque para a E.F. Sorocabana a Oeste, expandindo-se para fora do município. Percebe-se também uma expansão desde o Centro no vetor Leste, próximo à E.F. Central do Brasil e uma ocupação já notável no vetor Sul-Sudeste junto à acessos viários, nomeadamente a via Anchieta. Além dos projetos mencionados nos bairros industriais a Leste e no vetor Sudeste, também na área de concentração industrial no extremo Oeste próxima à ferrovia Sorocabana e à Rodovia Castelo Branco, no futuro município de Osasco, foi proposto o Jardim Piratininga (IAPI), cujo projeto previa cerca de 4.000 unidades unifamiliares padronizadas.

A previsão de núcleos habitacionais nestes locais se justifica pela proximidade entre as residências e os locais de trabalho, as indústrias e outras atividades a elas relacionadas. Outra justificativa reside na proximidade com eixos estratégicos para a circulação, as ferrovias, fator de interesse para as próprias indústrias, para transporte de matérias primas e produtos, e para os conjuntos de habitação, garantindo a ligação destes, e seus moradores, com o restante da cidade.

Nota-se também, como já mencionado, um número importante de projetos no vetor Sul. Além dos conjuntos mais próximos do Centro, cinco projetos estão localizados em uma zona intermediária, isto é, nem periférica, nem central, que, como se viu no mapa anterior, achava-se já parcialmente urbanizada. São projetos de diferentes Institutos, destacando-se o IAPB, e nenhum deles apresenta grande número de unidades. Outros projetos no mesmo vetor estão bastante distantes do Centro, em áreas de expansão periférica, com destaque para o antigo núcleo de Santo Amaro, onde já havia certa concentração industrial, mais expressiva a partir da década de 1950, e para o bairro de Interlagos, mais ao Sul. Vale mencionar como fator de interesse nessa área, além da presença de indústrias, também a importância de acessos viários em construção que conectariam a cidade com cidades do interior e do litoral, como a Marginal do rio Pinheiros e a Rodovia Anchieta. Apesar do importante número de projetos no vetor Sul, apenas um deles, a Cidade Comerciária Presidente Vargas do IAPC tem grande escala, ocupando uma grande gleba com 523 unidades unifamiliares e equipamentos comunitários.

É relevante nesse sentido destacar a proximidade de alguns dos projetos habitacionais com outros acessos viários e rotas de transportes coletivos importantes. Destacam-se as vias radiais que garantiam a ligação do anel viário central com outras partes da cidade, tais como a Av. São João no vetor Oeste e as avenidas Consolação e Nove de Julho, no vetor Sudoeste, ligando-se à Marginal do rio Pinheiros. Junto a Av. São João o IAPC propõe o Edifício Santa Cecília. Passando no vetor Sudoeste por bairros ocupados por população de alto poder aquisitivo, foram propostos dois projetos junto a Av. Nove de Julho e a Av. Cidade Jardim, o C.R. Nove de Julho (IAPB) e o C.R. Cidade Jardim (IAPC). Estes três projetos se destacam nomeadamente pela verticalização, proposta inclusive na Cidade Jardim, na época ainda uma área de expansão. 


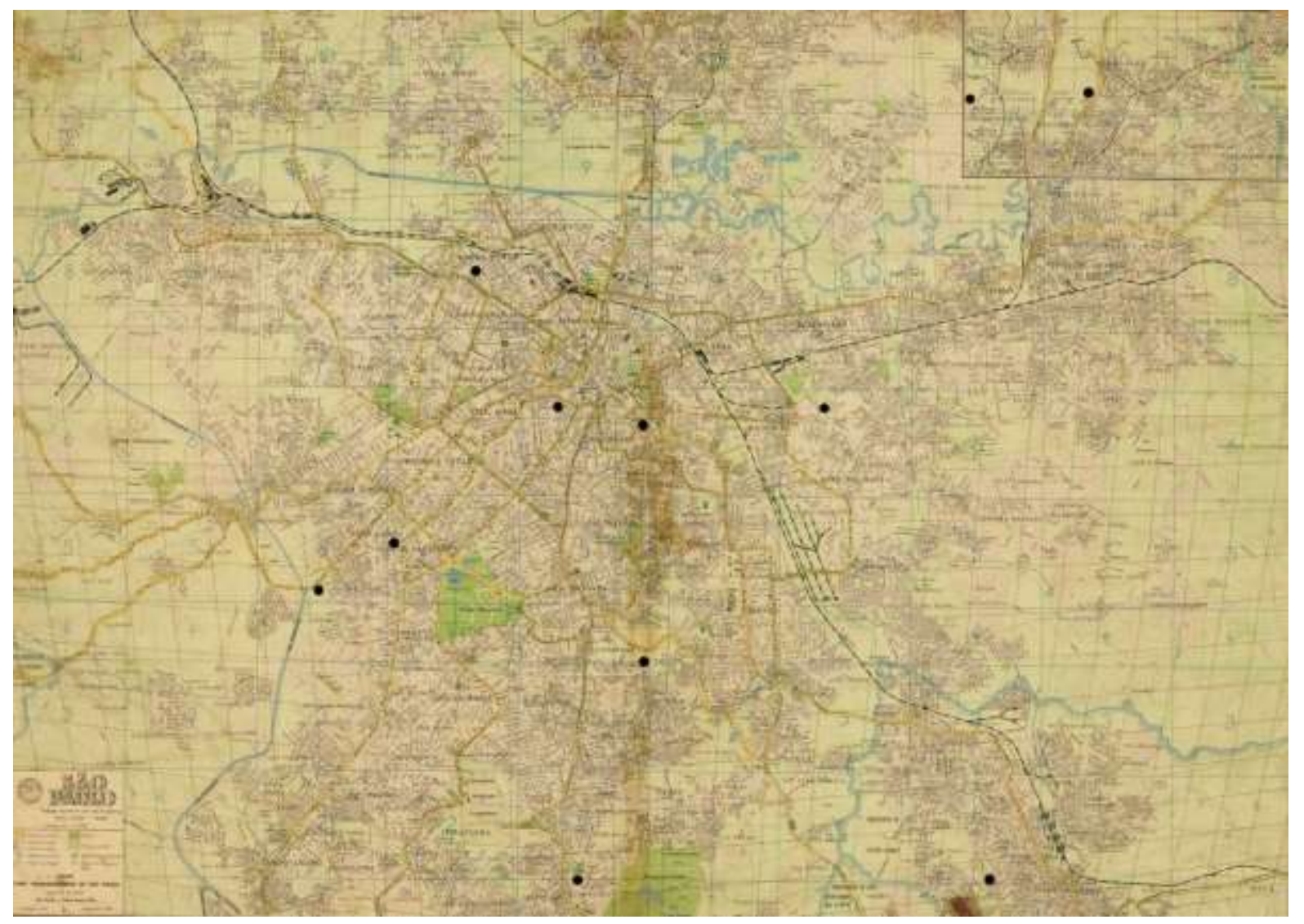

Figura 71: Localização de projetos em perspectiva de grande escala em São Paulo. Base Cartográfica: Projeção hiperboloid com rêde kilométrica em 1951. Fonte: Secretaria de Estado de Economia e Planejamento. Instituto Geográfico e Cartográfico - $\quad$ IGC. Acervo - $\quad$ Tombo: 1171 e $1152 . \quad$ Disponível em: <http://smdu.prefeitura.sp.gov.br/historico_demografico/1950.php> Acesso em 23 mar. 2016

É válido lembrar que na década de 1940 executam-se profundas alterações viárias em decorrência da implementação do Plano de Avenidas, executado efetivamente em 1938 com a prefeitura de Prestes Maia, apesar de iniciado ainda na administração de Fábio Prado em 1934. O mapa de São Paulo de 1951 (Figura71) mostra os novos acessos viários executados a partir do Plano, e ressalta (em amarelo escuro) as principais vias de circulação percorridas por linhas de transportes coletivos (nomeadamente de ônibus, mas também bondes) que se conectavam à área central. Localizamos os projetos selecionados (exceto os projetos de Osasco e Suzano, cuja área não está contemplada no mapa) e, como se pode observar, grande parte deles está próxima a importantes acessos viários, percorridos por linhas de bondes e/ou ônibus. A facilidade de locomoção era aspecto relevante para a proposição da moradia destinada ao trabalhador dada a necessidade de locomoção até o Centro ou aos locais de trabalho da população moradora.

Tendo destacado os projetos habitacionais produzidos em grande escala em São Paulo e em municípios vizinhos procurou-se determinar sua relação com o espaço urbano e o processo de urbanização. Destes projetos, os maiores conjuntos de blocos multifamiliares ou casas unifamiliares foram implantados majoritariamente em grandes glebas periféricas, a menor com 12 hectares, na área Norte de São Paulo e a maior com 87,5 hectares no município de Suzano. A exceção é o C.R. da 
Várzea do Carmo, previsto para uma gleba central com 28 hectares. Conjuntos menores formados por blocos foram propostos em glebas remanescentes, com áreas em torno de 5 hectares. Os edifícios isolados foram implantados em terrenos pequenos localizados em áreas já consolidadas.

Ao comparar o modus operandi dos promotores privados de habitação na década de 1940 em São Paulo, conforme analisado por Langenbuch (1971), com aquele dos IAPs iniciado nesta década é possível notar similaridades. Ambos propuseram edifícios verticais e adensamento construtivo nas áreas mais centralizadas e próximas a locais ou vias de interesse, bem como a ocupação de áreas remanescentes, beneficiadas pela presença prévia de alguma infraestrutura. Nas regiões periféricas se nota a maior diferença entre as duas atuações, que reside na proposta de verticalização, majoritariamente com blocos de quatro pavimentos executada pelos IAPs, enquanto de um modo geral, a expansão periférica baseada na promoção privada foi bastante horizontal. (LANGENBUCH, 1971; SOMECK, 1987; CAMPOS, 2002)

Pareceu assim relevante analisar características das áreas ou bairros em que se inseriram os projetos nas décadas de 1940 e 1950 (e 1960 para o C.R. Santo Antonio), de modo a compreender o interesse dos IAPs em promover habitação nestes locais. Por um lado interessa registrar as funções predominantes (residenciais, industriais, comerciais, etc.) e o próprio processo de urbanização e ocupação, dado que alguns desses projetos foram pioneiros tanto na ocupação, quanto no processo de verticalização de determinadas regiões. É importante frisar que neste trabalho consideramos a proposta de verticalização não apenas nos projetos formados por edifícios verticais (com mais de 10 pavimentos), mas também os projetos habitacionais compostos por blocos multifamiliares com pelo menos quatro pavimentos. Sempre que possível os projetos foram localizados com relação ao processo de verticalização da área ou bairro em que foram propostos, com base no trabalho realizado por Someck (1987).

Além de um panorama sobre o processo de urbanização de São Paulo, no intuito de registrar a atuação dos IAPs dentro da lógica de mercado na produção habitacional em São Paulo, analisamos as Plantas Genéricas de Valores (PGV) dos setores urbanos (do município de São Paulo) em que foram propostos os projetos com mais de 300 unidades no ano de 1953. Os preços dos terrenos em cada setor foram analisados relativamente ao preço da terra na área central, em torno do Triângulo, onde se registram os maiores preços naquele momento ${ }^{6}$.

\footnotetext{
6 "Os valores unitários nas faces das quadras constantes das referidas plantas correspondem em cruzeiro a metro quadrado de lotes padrões, com a profundidade de 25 e 50 metros, respectivamente, na 1a e nas demais sub-divisões da zona urbana". Fonte: Diário Oficial do Estado de São Paulo. Suplementos. Domingo, 1 de março de 1953. n. 48, ano 63, p. 1.
} 


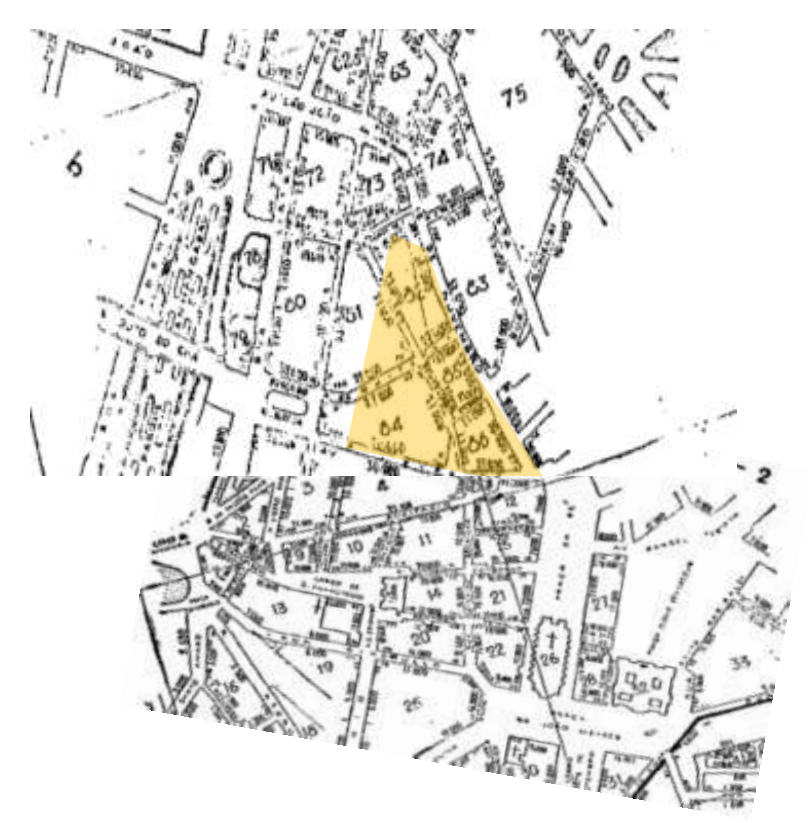

Figura 72. "Setores de Lançamento das zonas urbana e suburbana do Município de São Paulo". Triângulo Central. Setores 1 e 5 com intervenção da autora. Fonte: Diário Oficial do Estado de São Paulo. Suplementos. Domingo, 1 de março de 1953. n. 48, ano 63, p. 6.

Os valores dos terrenos nas principais ruas da região central em 1953 variavam entre $\operatorname{Cr} \$ 15.000$ e $\mathrm{Cr} \$ 30.000 / \mathrm{m}^{2}$. Nas ruas que conformavam o Triângulo Central, Direita, Quinze de novembro e São Bento, encontram-se os preços mais altos, em torno de $\mathrm{Cr} \$ 30.000 / \mathrm{m}^{2}$. Ao redor do Largo São Bento os preços são fixados entre $\operatorname{Cr} \$ 20.000 / \mathrm{m} 2$ e $\operatorname{Cr} \$ 25.000 / \mathrm{m}^{2}$ e ao redor da Praça da Sé entre $\mathrm{Cr} \$ 15.000 / \mathrm{m}^{2}$ e $\mathrm{Cr} \$ 25.000 / \mathrm{m}^{2}$ (FIGURA 72). Para cada área ou bairro em que foi proposto um projeto habitacional pelos IAPs em São Paulo ${ }^{7}$ levantou-se os preços dos terrenos, estabelecendo-se um paralelo entre as próprias áreas em função dos preços registrados e com relação aos preços da região central, buscando-se informações relevantes que indiquem o interesse por estes locais.

O mapeamento a seguir (Figura 73), com a demarcação dos terrenos dos projetos selecionados em São Paulo reforça a grande dimensão dos terrenos periféricos onde foram previstos os conjuntos Santo Antonio, Francisco Morato e Cidade Jardim. Dos terrenos localizados junto a áreas já ocupadas na década de 1940 - conjuntos da Várzea do Carmo, Mooca e Santa Cruz $^{8}$ - se destaca a grande dimensão do C.R. da Várzea do Carmo, muito próximo do Centro. Os terrenos onde foram construídos os edifícios verticais selecionados, Santa Cecília, Japurá e Nove de Julho, como se vê, aparecem praticamente como pontos no mapa. Além de localizar os terrenos dos conjuntos, demarcou-se no mapa as áreas com preços por metro quadrado semelhantes conforme a Planta Genérica de Valores de 1953.

\footnotetext{
${ }^{7}$ Nesta análise não foram contemplados o projeto da Cidade Comerciária Presidente Vargas e os projetos habitacionais localizados em Santo André, Suzano e Osasco, devido à não localização das respectivas Planta Genéricas de Valores.

${ }^{8}$ O C.R. Santa Cruz foi incluído na seleção, como já mencionado anteriormente, porque embora possua menos de 300 unidades foi o primeiro conjunto de blocos do IAPB, que até então só produzira conjuntos de casas unifamiliares.
} 


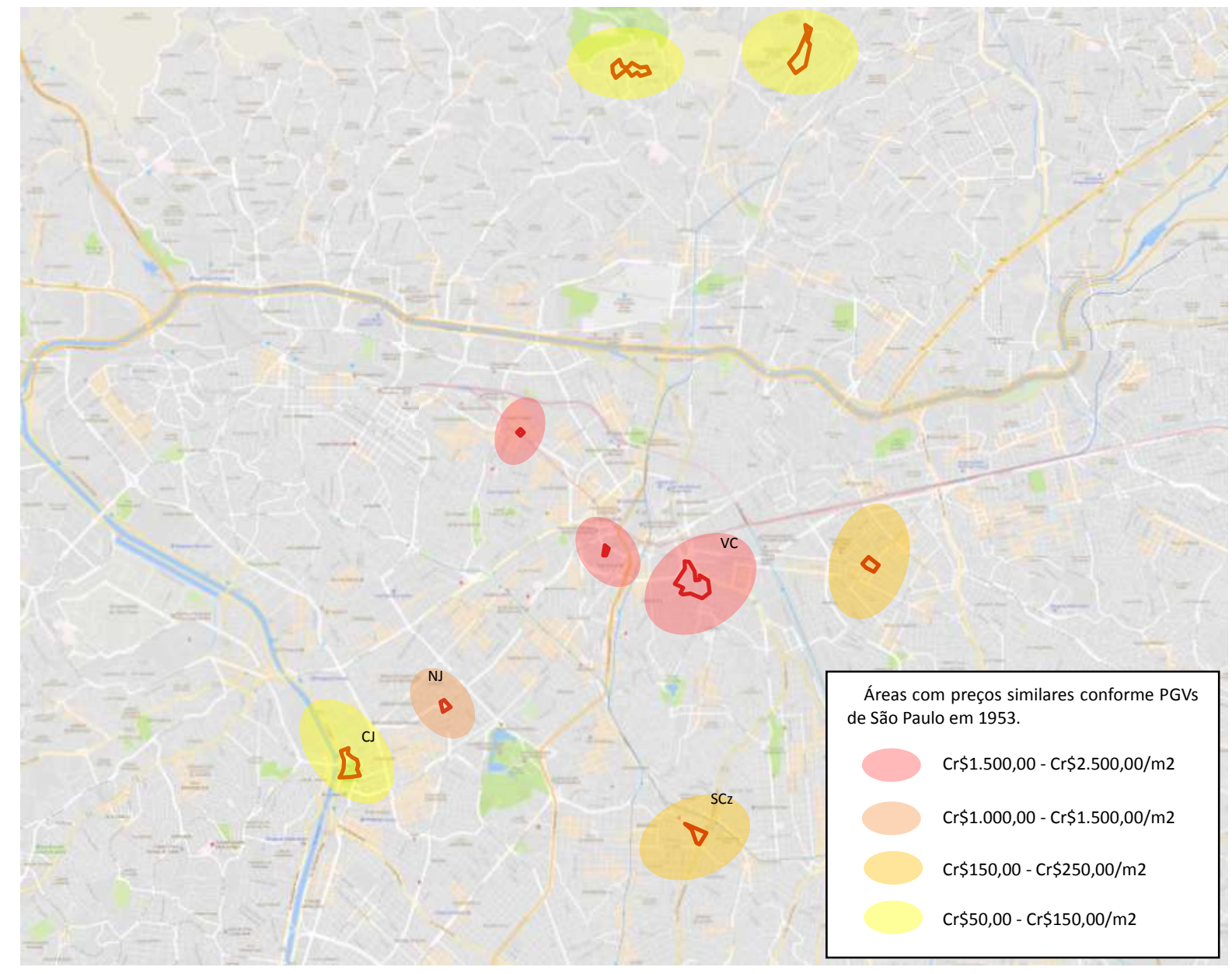

Figura 73. Mapeamento dos projetos habitacionais propostos sob uma perspectiva de grande escala na cidade de São Paulo com demarcação de áreas com preços similares conforme Planta Genérica de Valores da Cidade de São Paulo em 1953. Fonte: Diário Oficial do Estado de São Paulo. Suplementos. Domingo, 1 de março de 1953. Base Cartográfica: Mapa atual de São Paulo no Google Maps, com intervenção da autora. Sem escala.

É possível fazer algumas considerações relacionando os preços encontrados para cada área em questão e sua localização no espaço urbano. Os maiores preços registrados correspondem a cerca de 10\% dos preços junto ao Triângulo central. É possível afirmar que o alto custo dos terrenos nestes locais onde foram previstos os conjuntos Santa Cecília, Japurá e Várzea do Carmo indicou a solução pela verticalização das unidades em edifícios de pelo menos dez pavimentos. Além disso, nestes projetos foram propostos, em maior ou menor número, equipamentos coletivos e serviços que visavam não apenas suprir as necessidades cotidianas dos próprios moradores como também atender a comunidade do entorno, destacando-se restaurantes, salas comerciais e até mesmo um cinema, com o que se esperava rentabilizar os empreendimentos.

Um preço abaixo destes primeiros, porém bastante mais elevado que os demais projetos, é registrado no C.R. Nove de Julho, com preços entre $2 \%$ e $5 \%$ daqueles na área central. Neste caso acreditamos que os preços não se justifiquem pela proximidade/distância com relação ao Centro, mas pelo fato de o conjunto estar entre os bairros-jardim implantados pela Companhia City no vetor Sudoeste e por já contar com importante infraestrutura instalada na região. Também neste projeto o uso de edifícios 
verticais, associado ao grande número e variedade de unidades oferecidas pode ser considerado como forma de enfrentar o custo dos terrenos e garantir o retorno dos fundos investidos.

Em conjuntos como o da Mooca e o Santa Cruz, os preços bem menores que os primeiros, porém maiores que os de conjuntos periféricos, correspondendo a cerca de $1 \%$ dos preços no Centro, refletem sua localização também intermediária, entre bairros já edificados, entre o Centro e as regiões de expansão urbana. Embora os preços sejam baixos e as dimensões dos terrenos sejam relativamente pequenas, entre 5 e 6 hectares, a tipologia vertical e padronizada nestes casos (o bloco de 3-5 pavimentos em ambos formados por módulos-tipo) pode ser compreendida como uma forma de enfrentar o custo dos terrenos. O C.R. Santa Cruz, vale lembrar, foi o primeiro conjunto de blocos do IAPB, que a partir de então seguiria utilizando apenas tipologias verticais, o conjunto de blocos ou o edifício isolado.

Nos conjuntos então periféricos, Santo Antonio, Francisco Morato e Cidade Jardim, os preços correspondem a menos de $1 \%$ dos preços junto ao Triângulo, porém as dimensões dos terrenos são bastante grandes, respectivamente 12, 15,3 e 24 hectares, o que deve ter implicado em custos que justificavam a inversão de fundos, mas que direcionavam os projetos à produção em grande escala através do grande número de unidades de tipologias variadas, mas padronizadas e, nos dois últimos, de equipamentos e serviços diversos, alguns dos quais voltados não apenas aos moradores, como forma de recuperar os valores investidos.

Os preços mais altos são registrados nos conjuntos Santa Cecília (IAPC), Japurá (IAPI) e Várzea do Carmo (IAPI), encontrando-se aí valores de $\operatorname{Cr} \$ 1.500,00$ e $\operatorname{Cr} \$ 2.500,00 / \mathrm{m}^{2}$, que embora sejam bastante menores relativamente aos preços do Triângulo Central, correspondendo a cerca de $10 \%$ daqueles preços, podem ser considerados elevados para a finalidade de construção de habitações sociais. O Eng. Rogério Cesar Filho, que analisa o Processo de Expedição de Alvará de Construção do C.R. da Várzea do Carmo destaca "o fato de haver o Instituto adquirido a área de terreno em questão já tão valorizada" (PMSP, 1944b, grifo nosso). Os preços nestes locais se devem provavelmente à proximidade com o Centro e os serviços e infraestrutura aí presentes, bem como à escassez de terrenos nestas áreas na década em questão. O C.R. Santa Cecília se construído, ocuparia uma quadra entre os bairros Santa Cecília e Barra Funda, junto ao prolongamento da Avenida São João, o C.R. Japurá foi construído em terreno vizinho ao anel viário central e o C.R. da Várzea do Carmo, foi implantado em um grande terreno contiguo ao Parque D. Pedro II e ladeado pelo Rio Tamanduateí. 


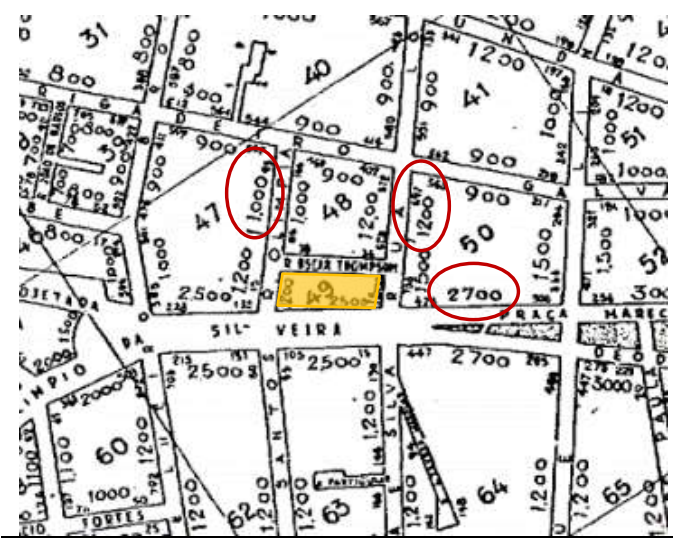

Figura 74. Conjunto Residencial Santa Cecília. Setores de Lançamento das zonas urbana e suburbana do Município de São Paulo. Setor 20. Fonte: Diário Oficial do Estado de São Paulo. Suplementos. Domingo, 1 março 1953. n. 48, ano 63, p. 22.

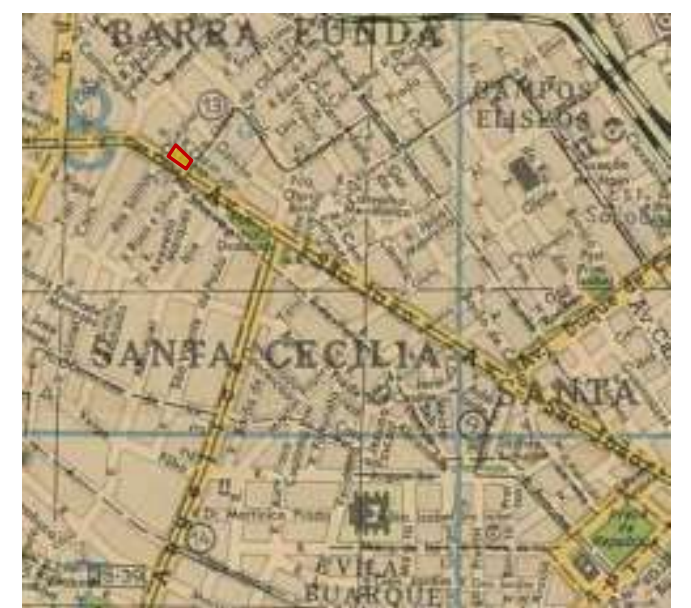

Figura 75. Localização do terreno do C.R Santa Cecília sobre Base Cartográfica: "Projeção hiperboloid com rêde kilométrica" de 1951, com intervenção da autora. Fonte: Histórico Demográfico do Município de São Paulo. Disponível em: <http://smdu.prefeitura.sp.gov.br/historico_demografico/1950.php> Acesso em 06 abril 2016.

O recorte da PGV em que se localiza o C.R. Santa Cecília (Figura 74) mostra que nas ruas que conformam o terreno do conjunto os preços indicados variam entre $\operatorname{Cr} \$ 1.200,00$ e $\operatorname{Cr} \$ 2.500,00 / \mathrm{m}^{2}$. 0 preço mais alto é indicado para a localização na Av. General Olímpio da Silveira-Av. São João, principal via do bairro. Nas duas ruas perpendiculares à avenida os preços são menores, $\operatorname{Cr} \$ 1.200,00$ e Cr\$1.500,00, embora relativamente elevados em comparação às demais ruas próximas. 0 bairro de Santa Cecília é considerado por Lecocq-Muller (1958) como zona de transição que apresenta tanto características de bairro como de Centro, sofrendo grande influencia da área central. Aberto no final do século XIX o bairro encontrava-se já bastante ocupado desde a década de 1930. O bairro é profundamente afetado pela implantação do Plano de Avenidas, quando a Av. São João se configura como uma das mais importantes vias de ligação entre o Centro e a região Oeste da cidade, conforme se observa no mapa de 1951 (Figura 75). O terreno onde seria construído o projeto é adquirido pelo IAPC em 1946, portanto, concomitantemente à implantação do Plano. (PMSP,1948c) 


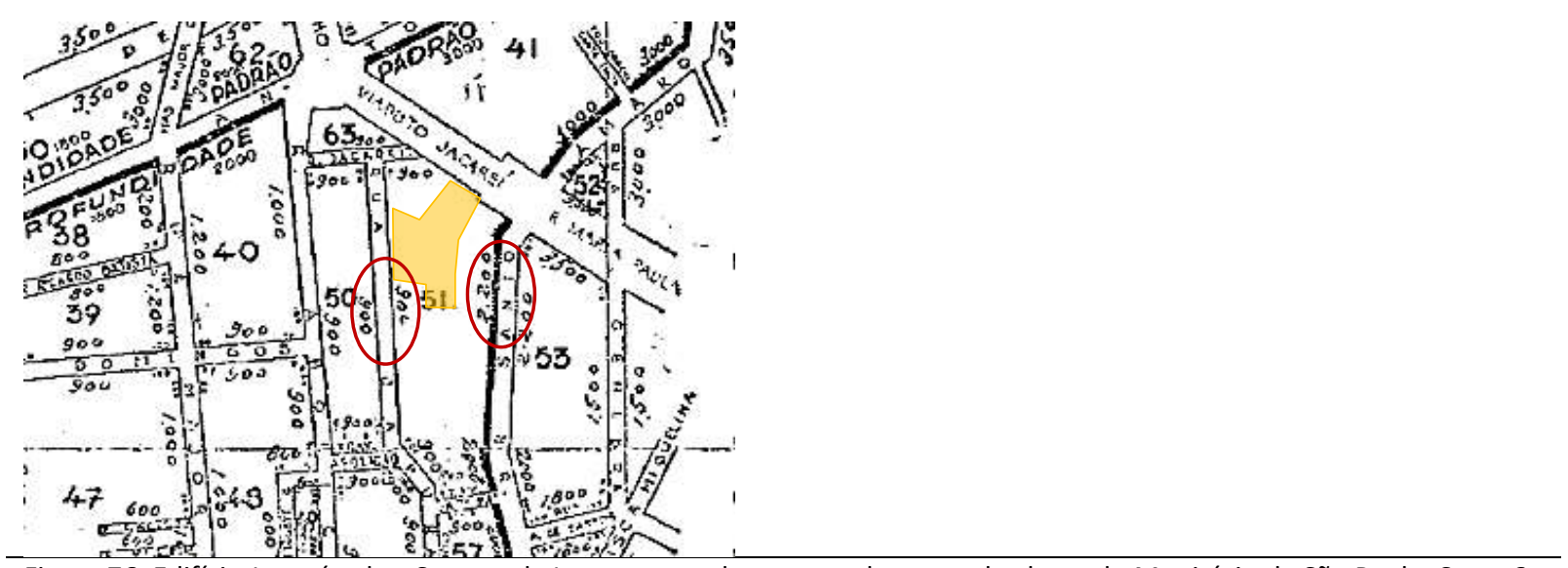

Figura 76. Edifício Japurá sobre Setores de Lançamento das zonas urbana e suburbana do Município de São Paulo. Setor 6. Fonte: Diário Oficial do Estado de São Paulo. Suplementos. Domingo, 1 março 1953. n. 48, ano 63, p. 8.

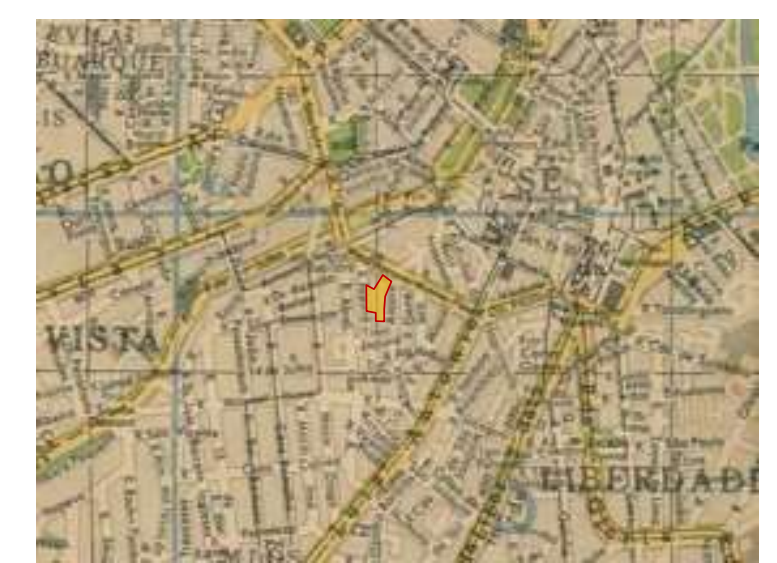

Figura 77: Localização do C.R. Japurá. Base Cartográfica: "Projeção hiperboloid com rêde kilométrica" de 1951, com intervenção da autora. Fonte: Histórico Demográfico do Município de São Paulo. Disponível em: <http://smdu.prefeitura.sp.gov.br/historico_demografico/1950.php> Acesso em 06 abril 2016.

A localização do conjunto Japurá sobre a Planta Genérica de Valores de 1953 (Figura 76) mostra que na Rua Japurá o preço indicado é de $\mathrm{Cr} \$ 900,00 / \mathrm{m}^{2}$, enquanto na Rua Santo Amaro o preço é de $\mathrm{Cr} \$ 2.200,00 / \mathrm{m}^{2}$. A Rua Japurá se restringe entre o Viaduto Jacareí e a Rua do Bixiga, enquanto a Rua Santo Amaro garantia o acesso do Centro (Praça das Bandeiras) até o Segundo anel Viário (Rua Jaceguai - Viaduto Júlio de Mesquita Filho), devendo-se possivelmente a isso o maior preço dos terrenos na segunda. Em 1953 o Viaduto Jacareí, parte do Perímetro de Irradiação do Plano de Avenidas, já constituía importante referência para a valorização da área, registrando-se nos terrenos voltados para ele o preço de $\mathrm{Cr} \$ 3.500,00 / \mathrm{m}^{2}$. O C.R. Japurá, portanto, ocupa local de prestígio em área consolidada junto do anel viário central (Figura 77), o que foi possível pela demolição de uma construção encortiçada que ocupava o terreno até então conhecida como Navio Parado (BONDUKI, 1998). A ocupação da área ocorre a partir da abertura da Estrada para Santo Amaro ainda no final do século XIX, que, inclusive, acarretou no tamponamento do Córrego Bexiga para maior aproveitamento dos terrenos (o Edifício Japurá foi construído sobre o leito do córrego). Bastante ocupado desde a década de 1920 o bairro apresentava não apenas pequenas casas operárias, mas grandes construções que na década de 1930 já se achavam encortiçadas. 


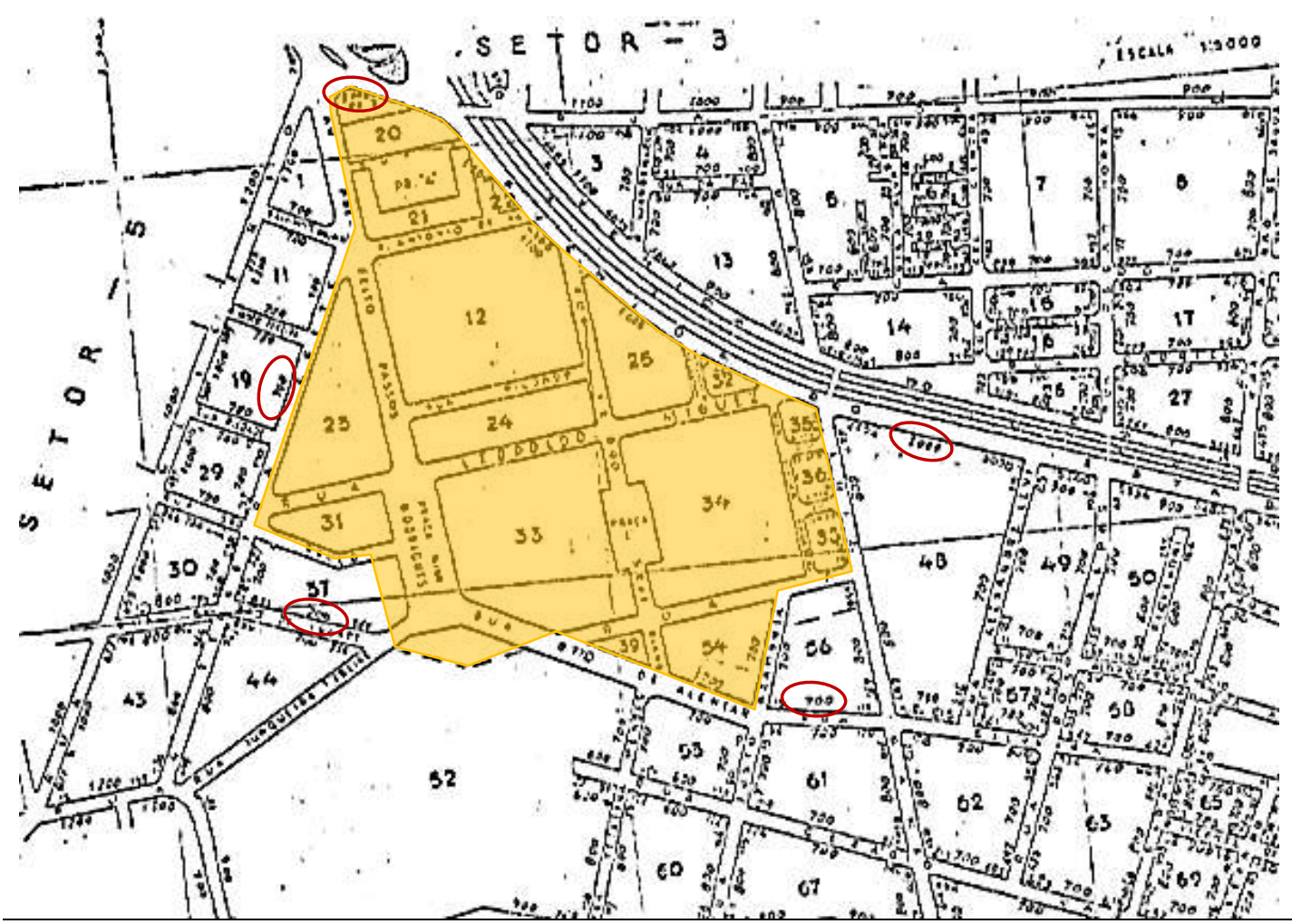

Figura 78. Conjunto Residencial da Várzea do Carmo sobre Setores de Lançamento das zonas urbana e suburbana do Município de São Paulo. Setor 4. Fonte: Diário Oficial do Estado de São Paulo. Suplementos. Domingo, 1 de março de 1953. n. 48, ano 63, p. 6.

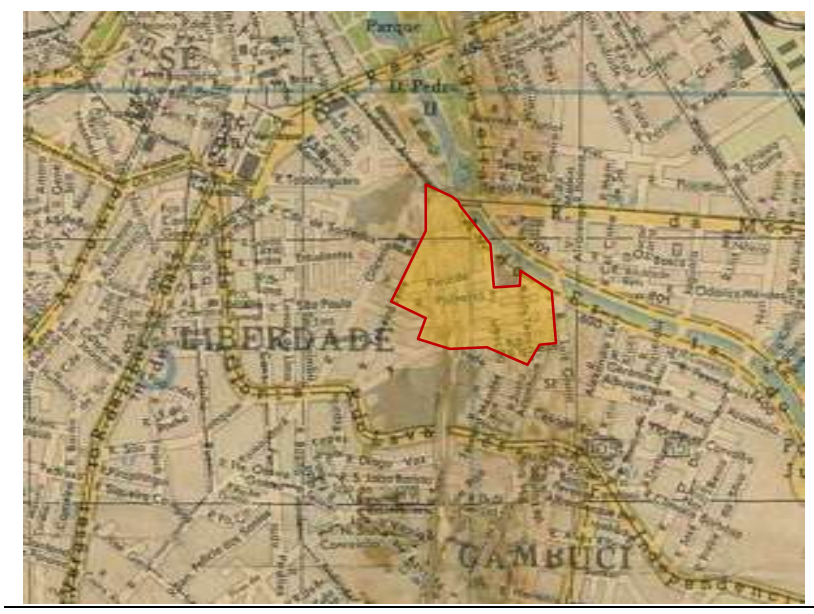

Figura 79: Localização do C.R. Várzea do Carmo. Base Cartográfica: "Projeção hiperboloid com rêde kilométrica" de 1951, com intervenção da autora. Fonte: Histórico Demográfico do Município de São Paulo. Disponível em: <http://smdu.prefeitura.sp.gov.br/historico_demografico/1950.php> Acesso em 06 abril 2016.

Uma parte dos terrenos que compunham a gleba de 28 hectares do C.R. Várzea do Carmo, aquela mais próxima ao Parque D. Pedro II, tinha preço de $\mathrm{Cr} \$ 2.000,00 / \mathrm{m}^{2}$ (Figura 78). Os preços, porém, diminuem conforme os terrenos se afastam do Parque, variando entre $\operatorname{cr} \$ 1.100,00 / \mathrm{m}^{2}$ e $\mathrm{Cr} \$ 1.000,00 / \mathrm{m}^{2}$ nos terrenos junto à Av. do Estado e entre $\mathrm{Cr} \$ 800,00 / \mathrm{m}^{2}$ e $\mathrm{Cr} \$ 700,00 / \mathrm{m}^{2}$ nos terrenos mais ao sul e no interior do bairro, preços que correspondem a $5 \%$ a $2 \%$ daqueles do Triângulo central. Segundo Mendes (1958) a ocupação inicial do bairro do Cambuci, ainda em finais do século XIX, se deu na sua porção norte, onde seria construído o conjunto do IAPI. Ali se percebia originalmente uma complexidade de funções, havendo residências, estabelecimentos comerciais e 
grande número de fábricas e indústrias, em nada diferente de outros bairros operários, com moradias "baixas e modestas" misturadas a galpões fabris e oficinas. A área do Parque, como se sabe, permaneceria desocupada até as primeiras décadas do século $X X$, quando este é implantado (CAMPOS, 2002). O alto custo dos terrenos junto ao Parque deve-se justamente ao fato de estarem contíguos a este espaço de sociabilidade e recreio da elite paulistana, sendo similar ao custo de outros terrenos tangentes ao parque conforme a pesquisa realizada. A Avenida do Estado já era então importante eixo viário de ligação entre o Centro e os bairros e Municípios a Sudeste de São Paulo, justificando-se o maior preço dos terrenos aí localizados com relação aos demais terrenos que compunham o conjunto. (CAMPOS, 2002)

Os preços dos terrenos destes conjuntos - considerando-se especialmente a porção mais cara do último - foram enfrentados através da verticalização: o C. R. Santa Cecília é composto por dois edifícios, um com 8 e um com 16 pavimentos, o C.R. Japurá é formado por um edifício com 14 pavimentos e o C.R. da Várzea do Carmo é constituído por blocos de 4 pavimentos e edifícios e 12 pavimentos.

A verticalização também foi a solução encontrada no C.R. Nove de Julho (IAPB), onde encontram-se preços consideravelmente menores em comparação a estes primeiros conjuntos analisados, porém mais elevados em comparação a outras áreas remanescentes em que foram propostos projetos, como por exemplo, o C.R. da Mooca, como mostraremos na sequência. O preço no caso do C.R. Nove de Julho está diretamente relacionado à sua localização, mas não com relação à área central, e sim aos bairros lindeiros a ele, os bairros-jardim da Companhia City e ao importante acesso viário constituído pela Av. Nove de Julho. O terreno é adquirido pelo IAPB em 1938 e, embora apenas na década de 1940 se iniciasse de fato a ocupação desta região, ela já contava com importante infraestrutura instalada. (PMSP, 1948b)

O processo de urbanização da região sudoeste da capital deve ser associado à Companhia City, que adquire as terras entre a região central e o rio Pinheiros, e inclusive aquelas além do rio no mesmo vetor. A City of São Paulo Improvements and Freehold Land Company Limited, é constituída em 1912 por investidores brasileiros e ingleses, tornando-se um dos mais importantes agentes do processo de urbanização paulistano, adquirindo e, portanto, controlando $12.380 .098 \mathrm{~m}^{2}$ de terras da cidade, aproximadamente $37 \%$ de toda a área urbanizada naquele início de século. (SAES, 2004; SIMÕES JÚNIOR, 1991). Souza (2004) afirma que graças a seus relacionamentos políticos a companhia se beneficiou de obras de infraestrutura e melhorias em seus loteamentos, que contavam com legislação urbanística própria e adquiriram o aspecto e o nome de "bairros-jardim". Com uso estritamente residencial e previsão de grandes avenidas que garantiriam a integração com o restante da cidade, os bairros se distinguiam ainda pelas ruas locais curvilíneas, os lotes de grandes dimensões com recuos frontais e laterais obrigatórios e as quadras com áreas verdes internas. 


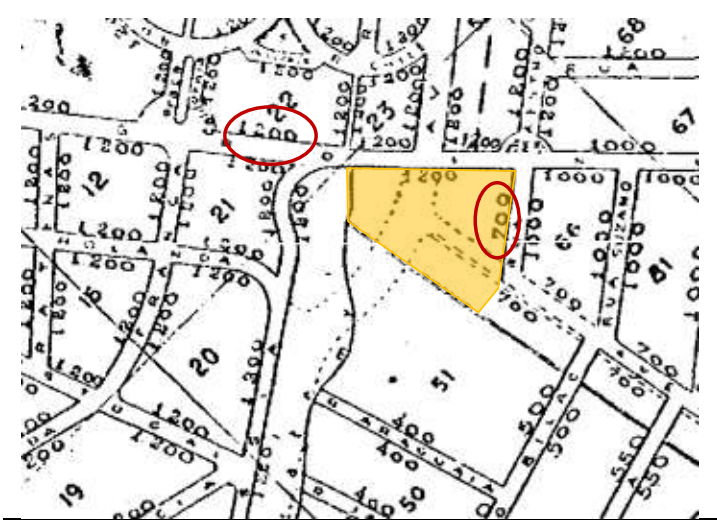

Figura 80. Conjunto Residencial Nove de Julho sobre Setores de Lançamento das zonas urbana e suburbana do Município de São Paulo. Setor 16. Fonte: Diário Oficial do Estado de São Paulo. Suplementos. Domingo, 1 de março de 1953. n. 48, ano 63, p. 18.

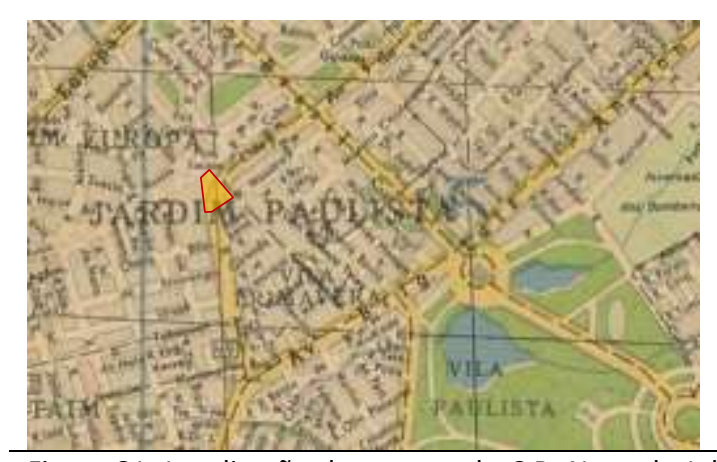

Figura 81: Localização do terreno do C.R. Nove de Julho. Base Cartográfica: "Projeção hiperboloid com rêde kilométrica" de 1951, com intervenção da autora. Fonte: Histórico Demográfico do Município de São Paulo. Disponível em: <http://smdu.prefeitura.sp.gov.br/historico_demografico/1950.php> Acesso em 06 abril 2016.

Na PGV de 1953 o terreno do C.R. Nove de Julho tem demarcados os preços de Cr\$700,00/m² na Avenida Flora (atual São Gabriel) e na Rua Maestro Elias Lobo e de $\mathrm{Cr} \$ 1200,00 / \mathrm{m}^{2}$ na Avenida Groenlândia, variando, portanto entre $2 \%$ e $5 \%$ dos preços na área central (Figura 80). É possível observar que conformavam então o terreno a Av. Groenlândia, uma parte da Rua Maestro Elias Lobo que terminava na Av. Flora e no lado oposto o córrego Iguatemi, unindo-se estas duas extremidades por um traçado que parece indicar uma linha de loteamento na Av. Flora. A Rua Nove de Julho, que dá nome ao conjunto, se inicia junto à área central e terminava justamente na Av. Groenlândia, havendo já indicação de seu prolongamento na direção Sul. A Av. Groenlândia fazia ligação entre as avenidas Rebouças e Brigadeiro Luis Antonio, sendo, portanto, a única rua a atravessar os bairros jardins além da Avenida Brasil (Figura 81), o que justifica o preço dos terrenos ser nela mais elevado que nas demais vias.

Assim como o C.R. Nove de Julho, outros projetos selecionados se localizam em terrenos remanescentes e, no entanto, apresentam faixas de preços muito díspares com relação a este e principalmente com relação à área central, variando entre $\mathrm{Cr} \$ 200,00$ e $\mathrm{Cr} \$ 250,00 / \mathrm{m}^{2}$, portanto $1 \%$ dos preços de terrenos no Triângulo. São eles o C.R. da Mooca (IAPI) e o C.R. Santa Cruz (IAPB), localizados, respectivamente, em terrenos remanescentes no bairro tipicamente operário da Mooca e junto ao córrego Ipiranga, no cruzamento da rua Santa Cruz com a atual Avenida Dr. Ricardo Jafet. 


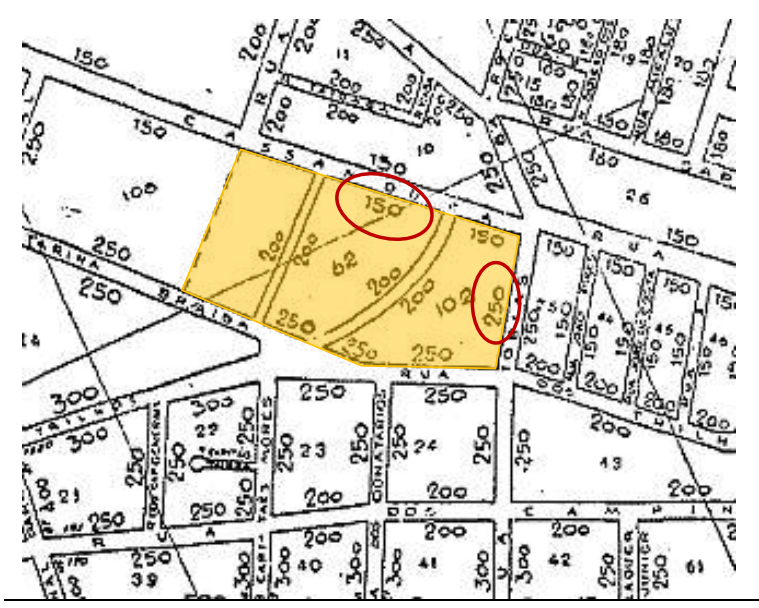

Figura 82. Conjunto Residencial da Mooca sobre Setores de Lançamento das zonas urbana e suburbana do Município de São Paulo. Setor 31. Fonte: Diário Oficial do Estado de São Paulo. Suplementos. Domingo, 1 de março de 1953. N. 48, ano 63, p. 33.

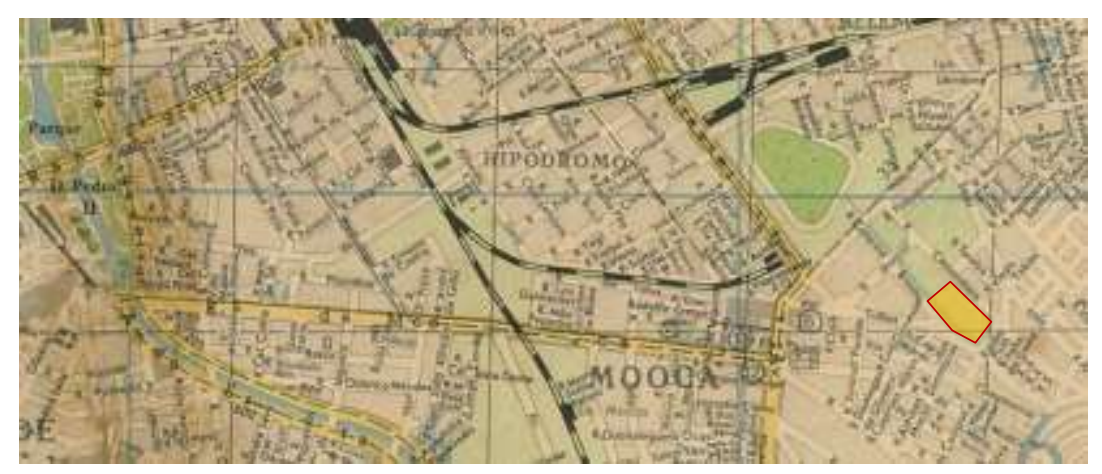

Figura 83. Localização do C.R. da Mooca. Base Cartográfica: "Projeção hiperboloid com rêde kilométrica" de 1951, com intervenção da autora. Fonte: Histórico Demográfico do Município de São Paulo. Disponível em: <http://smdu.prefeitura.sp.gov.br/historico_demografico/1950.php> Acesso em 06 abril 2016.

As ruas que conformam o terreno do C.R. da Mooca apresentam terrenos com preços que variam entre $\mathrm{Cr} \$ 150,00$ e $\mathrm{Cr} \$ 250,00 / \mathrm{m}^{2}$ conforme se vê no recorte da PGV (Figura 82). O preço mais alto é demarcado para os terrenos voltados para as ruas Tobias Barreto e dos Trilhos, sendo nesta última onde se localizavam os trilhos por onde circulavam trens de acesso ao Centro. É interessante notar que o preço demarcado para os terrenos nas ruas do conjunto, já então construído, é maior ou igual ao de outras ruas do entorno $\left(\mathrm{Cr} \$ 200,00 / \mathrm{m}^{2}\right)$ como a Rua da Cassandoca $\left(\mathrm{Cr} \$ 150,00 / \mathrm{m}^{2}\right)$, o que pode ser resultado de valorização em função da construção do próprio conjunto, entregue em 1949. Comparativamente ao terreno do C. R. Várzea do Carmo, também localizado em bairro industrial, estes preços são bastante inferiores, denotando o caráter industrial do bairro e a maior distância em relação ao Centro.

Merece referência na região o Hipódromo do Jockey Clube de São Paulo, construído em 1875, ocupando grande área próxima à E.F. Central do Brasil na Rua Bresser, ao sul do qual seria construído o C.R. da Mooca. O Hipódromo era facilmente acessado desde o Centro através de um ramal da São Paulo Railway, que, percorrendo a Rua dos Trilhos, ia até a estação Hipódromo, localizada a aproximadamente 400 metros do terreno do conjunto. Havia trens diários que faziam o percurso 
desde a Estação da Luz que, contudo, não realizavam apenas o transporte de pessoas, mas também de matérias primas e produtos, favorecendo a ocupação industrial. Indústrias como a Fiação e Tecelagem Aramina e o Cotonifício Rodolfo Crespi se estabeleceram junto ao ramal. (Figura 83) (Mendes, 1958)

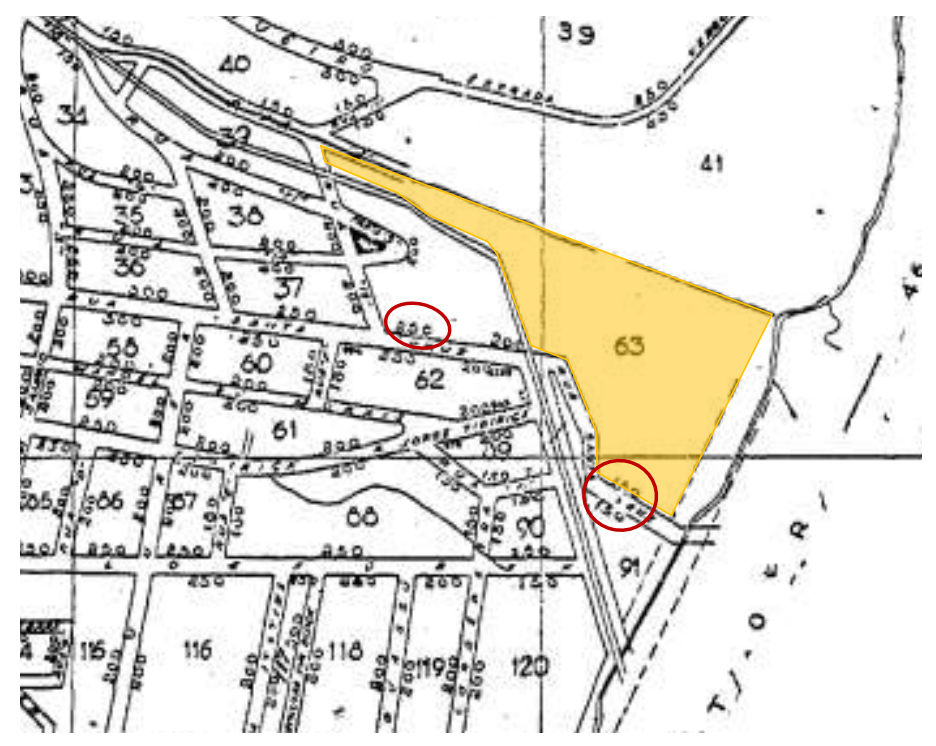

Figura 84. Conjunto Residencial Santa Cruz sobre Setores de Lançamento das zonas urbana e suburbana do Município de São Paulo. Setor 42. Fonte: Diário Oficial do Estado de São Paulo. Suplementos. Domingo, 1 de março de 1953. n. 48, ano 63, p. 45.

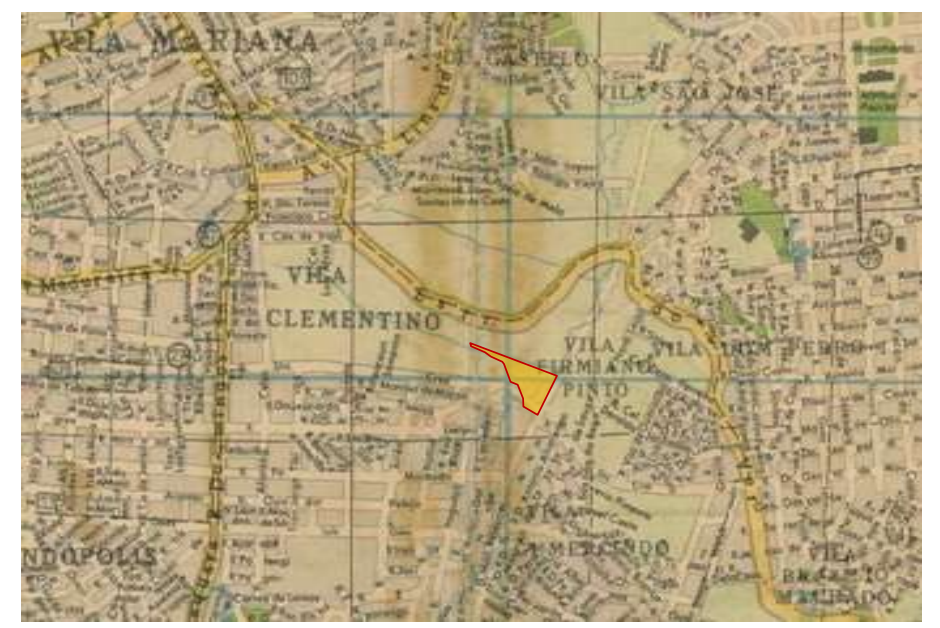

Figura 85. Localização do C.R. Santa Cruz. Base Cartográfica: "Projeção hiperboloid com rêde kilométrica" de 1951, com intervenção da autora. Fonte: Histórico Demográfico do Município de São Paulo. Disponível em: <http://smdu.prefeitura.sp.gov.br/historico_demografico/1950.php> Acesso em 06 abril 2016.

Os únicos preços indicados na Planta Genérica de Valores em que consta o terreno do C.R. Santa Cruz (Figura 84) estão na própria Rua Santa Cruz e variam entre Cr\$150,00 e Cr\$200,00/m². Esta é a única rua já aberta junto ao conjunto, que tem seus demais limites no próprio Córrego Ipiranga e em um afluente. O processo de urbanização da região é marcado pelo Córrego Ipiranga e seus afluentes, que determinaram a ocupação das regiões mais altas e planas e propiciaram a instalação de chácaras e casas para finais de semana, devido ao clima e altitude da região. (Figura 85) 
Relativamente à área central o preço da terra neste setor é bastante baixo (cerca de $1 \%$ daqueles), similar àqueles verificados para o C.R. da Mooca. Ambos os conjuntos se inserem entre loteamentos já urbanizados, porém com uma diferença importante: o C.R. Santa Cruz é proposto em um bairro residencial de classe média, enquanto o conjunto da Mooca é proposto em um bairro tipicamente industrial. Os preços similares possivelmente se devem ao fato de o conjunto do IAPB ocupar uma área que até a década de 1940 era desconsiderada para a ocupação devido aos alagamentos do Córrego Ipiranga, uma vez que em outras ruas de ocupação mais antiga na Vila Mariana os preços indicados na PGV chegam a $\mathrm{Cr} \$ 500,00, \operatorname{Cr} \$ 800,00$ e até $\mathrm{Cr} \$ 1.000,00 / \mathrm{m}^{2}$.

Outros três projetos selecionados apresentam junto a seus terrenos valores similares e muito menores em comparação aos demais e ao Centro, os conjuntos Santo Antonio (IAPB), Cidade Jardim (IAPC) e Francisco Morato (IPESP). Os três conjuntos se localizam em áreas de expansão urbana, na então periferia de São Paulo, dois na região Norte, ainda pouco ocupada, o C.R. Santo Antonio no bairro do Mandaqui e o Núcleo Francisco Morato no Tucuruvi, e um no vetor Sudoeste, junto à Marginal do rio Pinheiros, o C.R. Cidade Jardim.

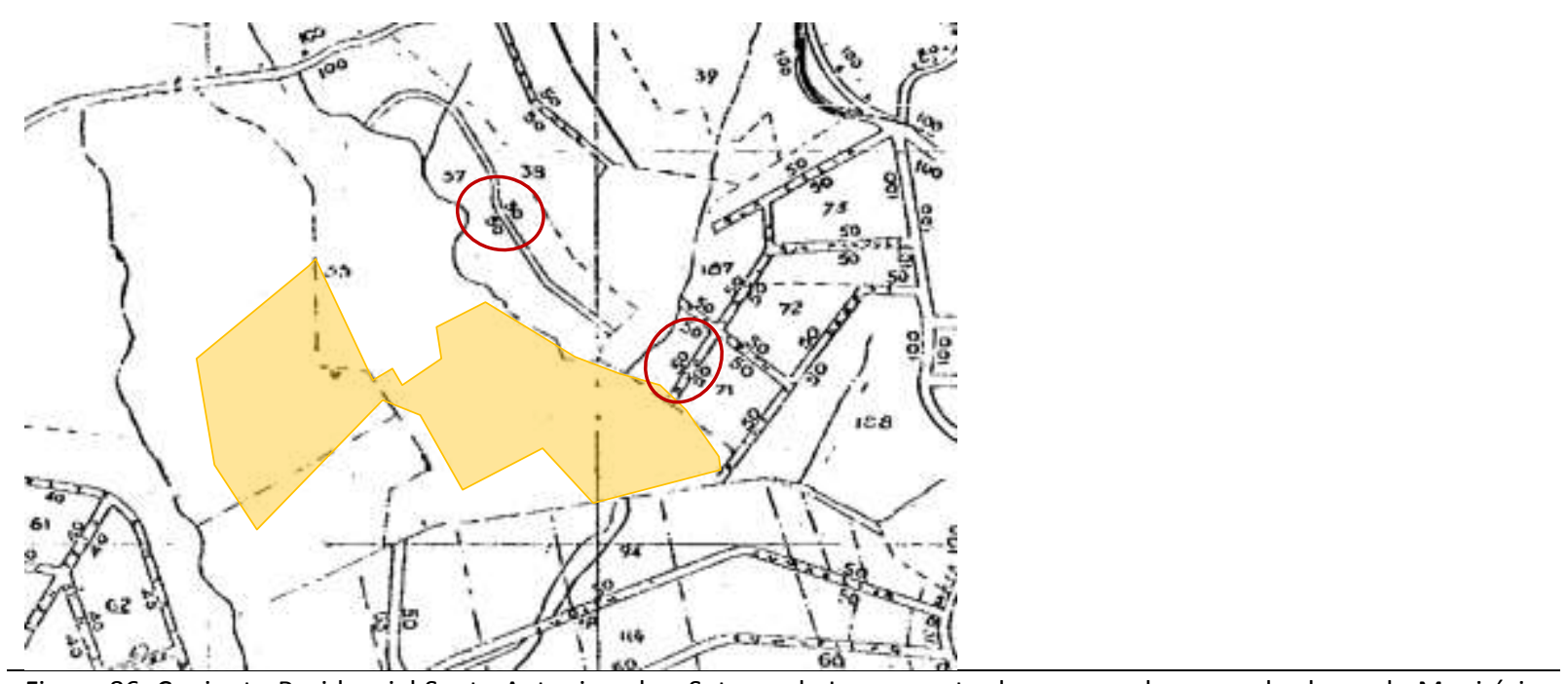

Figura 86. Conjunto Residencial Santo Antonio sobre Setores de Lançamento das zonas urbana e suburbana do Município de São Paulo. Setor 71. Fonte: Diário Oficial do Estado de São Paulo. Suplementos. Domingo, 1 de março de 1953. n. 48, ano 63, p. 91.

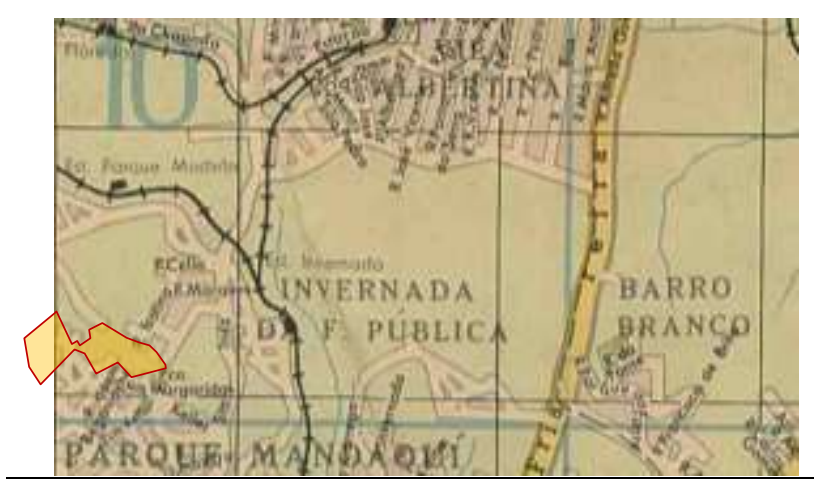

Figura 87. Localização do C.R. Santo Antonio. Base Cartográfica: "Projeção hiperboloid com rêde kilométrica" de 1951, com intervenção da autora. Fonte: Histórico Demográfico do Município de São Paulo. Disponível em: <http://smdu.prefeitura.sp.gov.br/historico_demografico/1950.php> Acesso em 06 abril 2016. 
Embora a PGV não registre nenhuma rua que conforme o terreno do conjunto Santo Antonio, todas as vias na região têm o preço de $\mathrm{Cr} \$ 50,00 / \mathrm{m} 2$, exceto pela Estrada da Parada, onde o preço é de $\mathrm{Cr} \$ 100,00 / \mathrm{m}^{2}$, portanto menos de $1 \%$ dos preços registrados na área central (Figura 86). São preços muito baixos que se explicam pela pouca infraestrutura presente e pela distância em relação ao Centro da cidade, apesar da possibilidade de conexão pelo Tramway da Cantareira. A região onde foi implantado o conjunto no Alto de Santana compreendia à época da construção, na década de 1960, uma área periférica na zona Norte de São Paulo, junto à reserva que constitui o Horto Florestal e ao local conhecido à época como Parada Parque Modelo ou Parada Pinto, que dava nome à principal via de acesso à região, a Estrada da Parada (Figura 87). A "Parada" ficava no ponto de confluência entre a via e o Tramway da Cantareira, onde as máquinas estacionavam na base da serra, local de relevo bastante acidentado em que muitas famílias possuíam chácaras para utilização aos finais de semana.

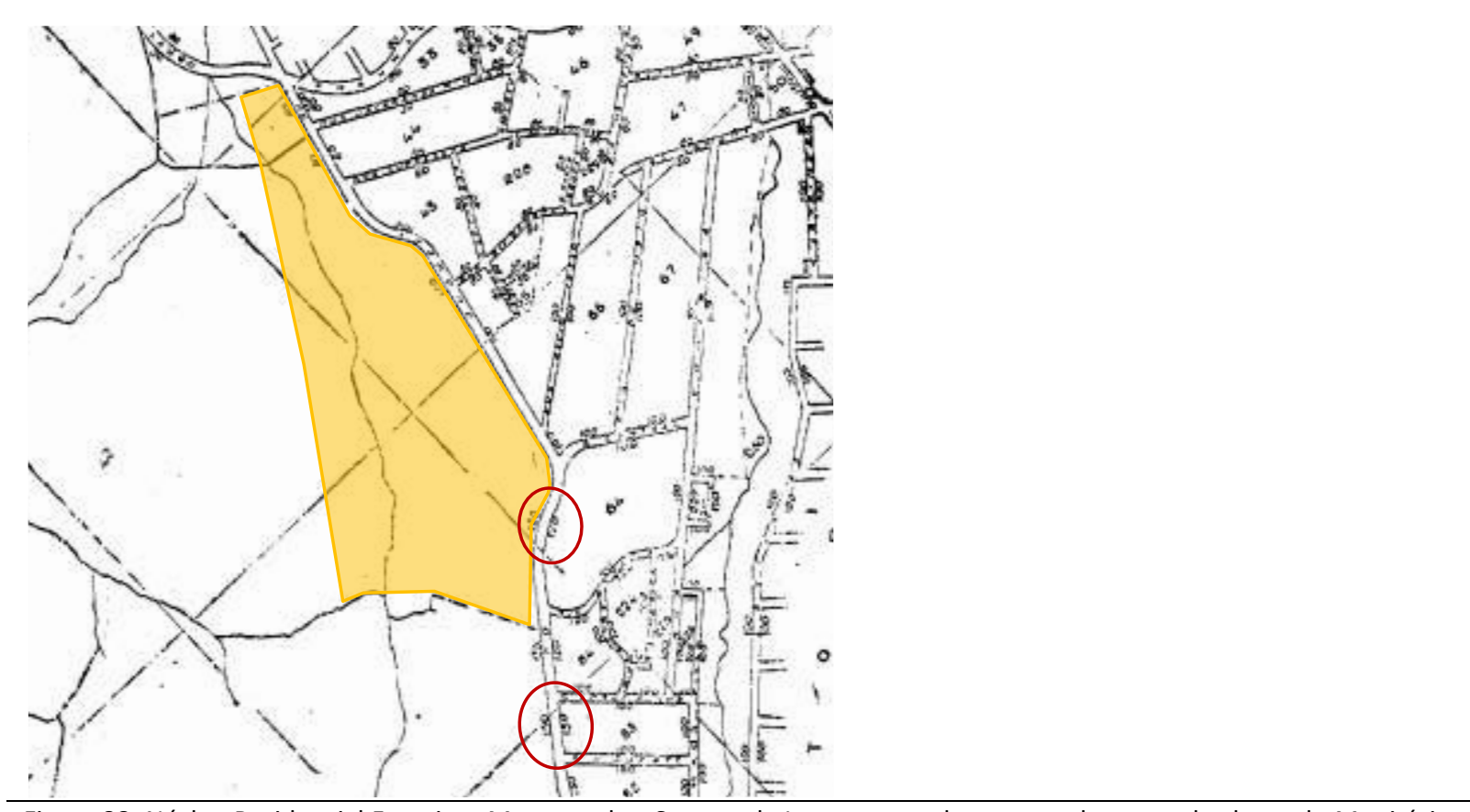

Figura 88. Núcleo Residencial Francisco Morato sobre Setores de Lançamento das zonas urbana e suburbana do Município de São Paulo. Setor 70. Fonte: Diário Oficial do Estado de São Paulo. Suplementos. Domingo, 1 de março de 1953. n. 48, ano 63, p. 89.

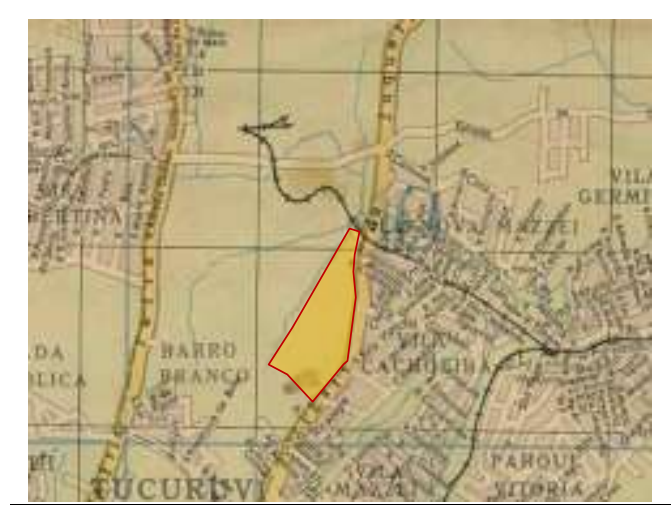

Figura 89. Localização do C.R. Núcleo Residencial Francisco Morato. Base Cartográfica: "Projeção hiperboloid com rêde kilométrica" de 1951, com intervenção da autora. Fonte: Histórico Demográfico do Município de São Paulo. Disponível em: <http://smdu.prefeitura.sp.gov.br/historico_demografico/1950.php> Acesso em 06 abril 2016. 
A rua de contorno do Núcleo Residencial Francisco Morato, a Estrada de Juqueri, ligava o núcleo principal da cidade ao Hospital São Luiz Gonzaga, centro de tratamento para tuberculosos localizado junto à Serra da Cantareira, ao norte do conjunto, registrando-se nela preços entre $\operatorname{Cr} \$ 100,00 / \mathrm{m}^{2}$ e Cr\$120,00/m², maiores com relação às demais ruas próximas, como se vê no recorte da PGV (Figura 88), mas equivalentes a menos de $1 \%$ dos preços nos terrenos da área central. Valem para esta área praticamente as mesmas considerações feitas para o C.R. Santo Antonio quanto ao baixo preço da terra, explicado pela pouca infraestrutura presente, mas principalmente pela distância até o Centro, embora também este bairro fosse acessado através do Tramway da Cantareira, havendo uma estação a Leste do terreno do IPESP (Estação Villa Mazzei). A área, no bairro do Tucuruvi, segundo Mendes (1958), como "subúrbio da capital" apresentava funções diversas, inclusive rural, e começa a apresentar crescimento populacional apenas nas décadas de 1940 e 1950. (Figura 89)

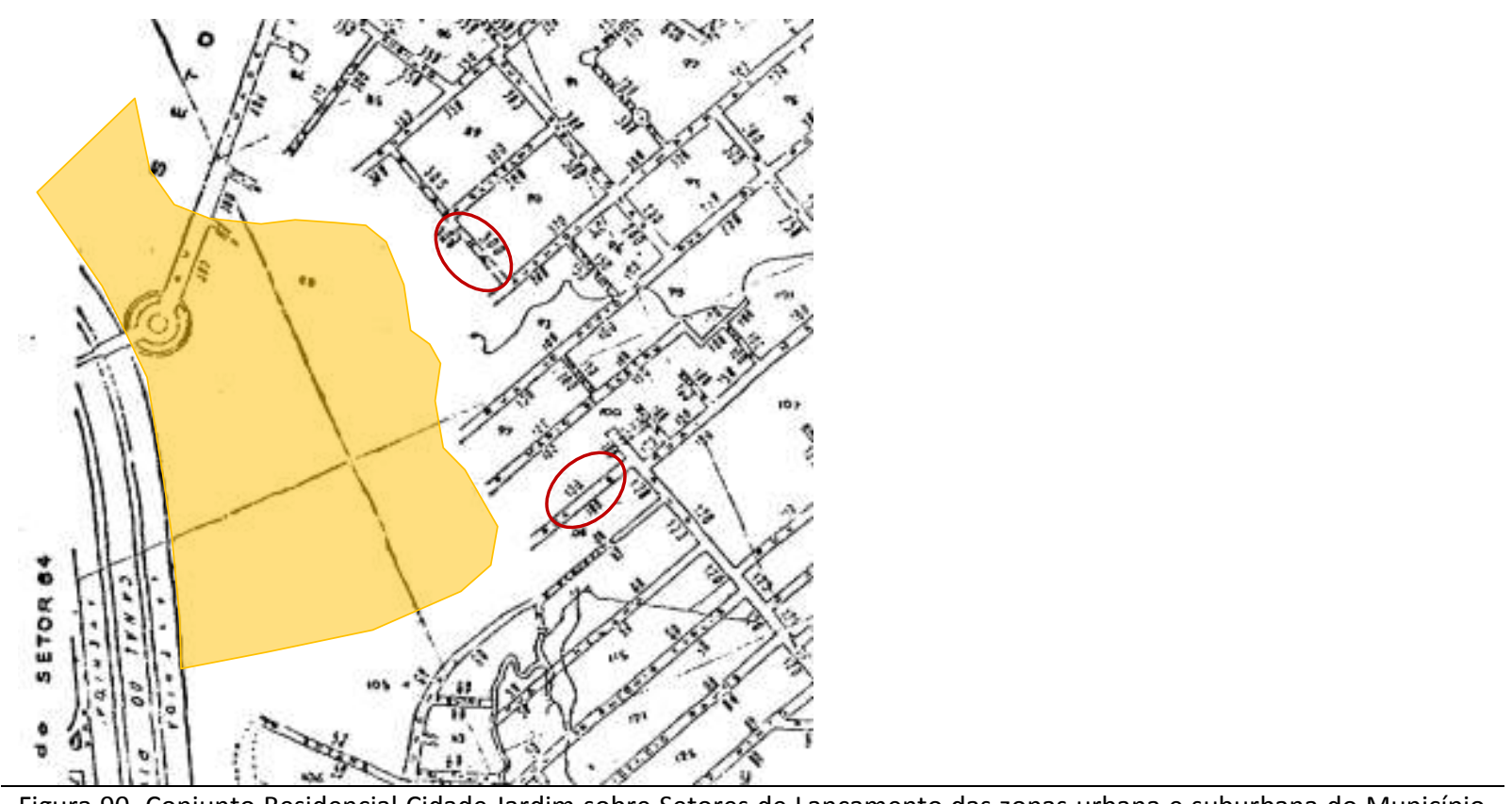

Figura 90. Conjunto Residencial Cidade Jardim sobre Setores de Lançamento das zonas urbana e suburbana do Município de São Paulo. Setor 84. Fonte: Diário Oficial do Estado de São Paulo. Suplementos. Domingo, 1 de março de 1953. n. 48, ano 63, p. 123.

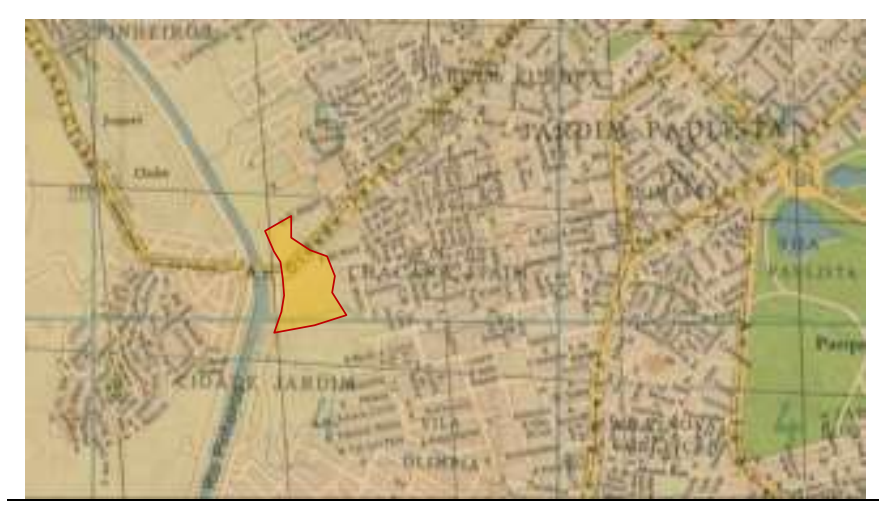

Figura 91. Localização do C.R. Cidade Jardim. Base Cartográfica: “Projeção hiperboloid com rêde kilométrica” de 1951, com intervenção da autora. Fonte: Histórico Demográfico do Município de São Paulo. Disponível em: <http://smdu.prefeitura.sp.gov.br/historico_demografico/1950.php> Acesso em 06 abril 2016. 
Da mesma forma que no mapa do C.R. Santo Antonio, a PGV da Cidade Jardim de 1953 também não apresenta as ruas que conformam o terreno do conjunto, porém nas vias próximas os preços variam entre $\operatorname{Cr} \$ 100,00$ e $\mathrm{Cr} \$ 50,00 / \mathrm{m}^{2}$ (Figura 90). Também neste caso os preços baixos (menos de $1 \%$ daqueles na área central) se explicam pela ausência de infraestrutura e distância com relação ao Centro, fatores agravados porque o terreno se tratava de uma área de várzea do rio Pinheiros, alagável até a construção da marginal. A acessibilidade da região seria garantida pela Marginal do rio Pinheiros, em projeto, e por sua ligação com vias radiais como as avenidas Nove de Julho e Rebouças, que facilitavam o acesso ao centro da cidade. Merece destaque para a análise da região a inauguração em 1941 da nova unidade do Jockey Clube Paulistano em terreno doado pela City na Cidade Jardim, a Oeste do rio Pinheiros, o que favoreceria a ocupação no vetor (Figura 91) (JOCKEY CLUB..., s/d). O terreno do C.R. Cidade Jardim ficava justamente no ponto de encontro da Marginal Pinheiros com a Avenida Cidade Jardim, que conectava os bairros da City dos dois lados do rio e é adquirido em 1941, ano da inauguração do novo Hipódromo. (PMSP, 1946)

Dado seu caráter de aplicação, é possível afirmar que a aquisição das terras dos Institutos estava sempre que possível relacionada à possibilidade de retorno financeiro em função da valorização imobiliária e, nesse sentido, ao promover habitação, seja no espaço urbano consolidado ou em áreas de expansão, os Institutos operavam de forma similar aos investidores privados. Quanto maior o custo do terreno, para que os futuros moradores não fossem severamente onerados, um maior número de unidades precisava ser construído, de modo que o custo da terra se diluísse em muitas frações ideais. Neste contexto foram produzidos projetos habitacionais através de verticalização e adensamento em terrenos na região central e em outros locais em que o preço da terra era maior, de adensamento em áreas menores remanescentes e da construção de grandes núcleos residenciais periféricos que incluíram a verticalização. Também a promoção de equipamentos e serviços comunitários propunha, como se viu, rentabilizar os projetos através de sua disponibilização ao público geral.

Pode-se considerar que em 1953, ano de publicação destas PGVs, todos os terrenos demarcados já pertenciam aos respectivos IAPs, uma vez que a maior parte já estava construída ou em construção. A compra de terras pelos Institutos deve ter-se realizado de forma efetiva em São Paulo entre o final da década de 1930 e o início da década de 1940, logo após a regulamentação de suas Carteiras Prediais que possibilitou a ampliação de sua atividade de inversão imobiliária em 1937. Das escrituras de Compra e Venda constantes dos Processos Administrativos analisados, as dos conjuntos Nove de Julho e Cidade Jardim datam de 1938 e 1941, respectivamente, enquanto a do C.R. Santa Cecília data de 1946. As datas dos processos de "Aprovação de Projeto" ou "Alvará de Construção" encontrados são de 1942, do C.R. Japurá, 1944, dos conjuntos da Várzea do Carmo e da Mooca, 1946 do C.R. 
Cidade Jardim e 1948, dos conjuntos Nove de Julho e Santa Cecília. (Processos n.21.197/ 1942, n.62.631/ 1944, n.62.631 / 1944, n.11.569/ 1946; n.31.964/ 1948; n.65.163/ 1948)

O início da década de 1940 é justamente marcado por um quadro que se mostra fundamental para as características da produção habitacional dos IAPs em São Paulo. Compunham esse quadro elementos como: a) o estágio do próprio processo de urbanização e expansão periférica de São Paulo marcado pelo Plano de Avenidas, que indicava a verticalização das áreas centrais e o crescimento horizontal das regiões periféricas; b) o desenvolvimento da indústria da construção civil, com incentivo à produção nacional de materiais e elementos construtivos antes importados; c) o aumento populacional da cidade de São Paulo, associado ao imperativo de se produzir em um curto espaço de tempo uma grande quantidade de edificações; e d) o início do processo de metropolização de São Paulo.

Somam-se ainda o cenário político nacional com preconização do atendimento das necessidades do trabalhador e a circulação de ideias que pressupunham uma postura ativa do Estado e dos profissionais no enfrentamento da questão habitacional. Cotejando a produção de habitações aos trabalhadores e o processo de urbanização e expansão periférica, bem como o início da metropolização de São Paulo na década de 1940, é possível dizer que ambos os movimentos estiveram fortemente relacionados entre si e ao desenvolvimento econômico e industrial do país e, em especial, da capital do estado.

\subsection{Expansão urbana, industrialização e a política previdenciária de habitação em São Paulo}

Entre as décadas 1940 de 1970 a expansão da indústria teve profundas implicações no espaço urbano de São Paulo, seja pela ampliação do número de estabelecimentos, que rapidamente ocuparam outros municípios, confirmando o processo de metropolização e expansão periférica, seja pelo aumento do pessoal empregado, com grande contingente migratório que necessitava estabelecer-se na cidade, seja, ainda, pela concomitante expansão do setor terciário. Segundo Saes (2004, p.257) “o rótulo de 'metrópole industrial', aplicado à cidade de São Paulo a partir de 1930 não é incorreto: sem dúvida a atividade industrial foi durante algumas décadas o motor da atividade econômica da cidade".

A partir da década de 1930 a migração interna supera as taxas de imigração. Brasileiros de outros estados e do interior do estado de São Paulo são atraídos "pela miragem da metrópole movimentada e dinâmica" (PETRONE, 1958, p.147). Os censos de 1940, 1950 e 1960 (que englobam nosso período de estudo), conforme se vê no quadro a seguir, contam no município de São Paulo, respectivamente 1.326.261, 2.198.096 e 3.781.446 habitantes. A população, portanto, era praticamente duplicada a cada dez anos. Concomitantemente, ocorria a expansão periférica registrando-se em 1940, 1.558.045 habitantes e em 1960 já 4.739 .406 habitantes nos municípios vizinhos de São Paulo. 
Quadro 7: População em São Paulo e municípios vizinhos (1872-1960)

\begin{tabular}{ccc}
\hline Ano & São Paulo & Municípios vizinhos \\
\hline 1872 & 31.385 & - \\
1890 & 64.934 & - \\
1900 & 239.820 & - \\
1920 & 579.033 & - \\
1940 & 1.326 .261 & 1.568 .045 \\
1950 & 2.198 .096 & 2.622 .786 \\
1960 & 3.781 .446 & 4.739 .406 \\
\hline
\end{tabular}

Fonte: IBGE, Censos Demográficos. Tabela modificada pela autora disponível em: <http://smdu.prefeitura.sp.gov.br/historico_demografico/tabelas/pop_brasil.php> Acesso em: 16 ago. 2016.

O desenvolvimento industrial implicava no fortalecimento de um mercado de capitais (produtivo, financeiro, imobiliário) para o qual era fundamental o sistema bancário, que se desenvolve praticamente no mesmo ritmo da indústria na década de 1940 (SOUZA, 2004). Nesse sentido, é possível compreender a existência de uma relação intrínseca entre as funções industrial e financeira e o processo de produção e apropriação do espaço urbano, ou, colocando de outro modo, entre o desenvolvimento do modo de produção capitalista e o processo de urbanização. Além do sistema bancário, o setor terciário como um todo é estimulado pelo desenvolvimento industrial e urbano como resultado de processos que se sustentam e se manifestam no espaço ocupado, implicando no que Feldman (2005) denomina "reestruturação da centralidade urbana", com definição de novas centralidades e zonas especializadas em determinados produtos e serviços para além do Centro.

O trecho do discurso do Presidente Getúlio Vargas transcrito a seguir, pronunciado por ocasião do Dia do Trabalho em 1944, revela importantes aspectos das políticas propostas pelo Estado Novo e da importância conferida a São Paulo em função destas:

Pela primeira vez, neste $1^{\circ}$ de maio, altero a praxe falar-vos da Capital da República. Vim a São Paulo e daqui vos dirijo a palavra, atendendo ao apelo de quase meio milhão de obreiros da riqueza e do progresso do país, [...]. Para alcançarmos resultados satisfatórios nestes dias difíceis e conturbados em que os obstáculos se multiplicam, a vossa colaboração foi decisiva e o Governo reconhece tão patriótico devotamento. $O$ vosso resoluto apoio de homens afeitos às duras labutas da indústria nunca faltou à administração e vale por um encorajamento constante no sentido de fazer triunfar a justiça social. (Vargas, 1944)

Em 1944 São Paulo se encontra na vanguarda das transformações do parque industrial brasileiro com a implantação de indústrias de bens de produção que já se instalavam nos municípios vizinhos da capital, aprofundando o processo de expansão periférica e metropolização (SINGER, 1968). Ao escrever sobre a industrialização em São Paulo e sua relação com o processo de metropolização na década de 1940 faz-se necessário um breve retorno ao final do século XIX, no sentido de compreender as condições que se organizam para o estabelecimento das primeiras indústrias na cidade e como estas se manifestam no momento em tela, no ápice do desenvolvimento industrial. 
Na década de 1890, São Paulo ascendia à condição de núcleo da região economicamente mais dinâmica do país devido à produção cafeeira. A mudança do centro produtor do café - principal produto da economia brasileira - do Rio de Janeiro para o eixo São Paulo-Santos iniciada na década de 1860, se confirma na década de 1880 e impõe novo ritmo à cidade. Para Souza (2004) é impossível compreender São Paulo como metrópole sem olhar para a implantação da estrada de ferro ${ }^{9}$ e a instituição do capital financeiro ${ }^{10}$, processos inteiramente vinculados à atividade cafeeira.

As consequências da expansão desta atividade no desenvolvimento paulista são enumeradas por Singer (1968), destacando-se (1) o aumento da população urbana, acompanhado da conformação de mercados de fatores: mercado de trabalho e mercado consumidor, (2) a aceleração do processo de urbanização, e (3) a formação de um mercado de capitais. Estes processos estavam fortemente entrelaçados e, por sua vez, seriam fundamentais à industrialização.

Contribuem para o aumento populacional da cidade na década de 1880 dois grupos principais: imigrantes e fazendeiros do café. Parte dos indivíduos que chegaram à Hospedaria dos Imigrantes em 1887 sequer saiu de São Paulo, enquanto outra parte abandonou as lavouras e retornou à cidade. 0 fazendeiro do café é sobretudo um empresário que acompanha o negócio desde o cultivo até a comercialização e apesar de o café ser comercializado principalmente em Santos, em São Paulo se localizavam as casas bancárias e os futuros trabalhadores das lavouras (os imigrantes), de modo que numerosos cafeicultores fixaram residência na cidade afirmando-se como classe dominante.

A contribuição dos imigrantes no processo de industrialização não reside apenas na conformação de um mercado de trabalho, mas também na ampliação do mercado de consumo até então exclusivo da elite, uma vez que estes, diferentemente dos escravos, eram também consumidores. Mattos (1958) destaca que a presença de imigrantes foi importante ainda para o estabelecimento da indústria artesanal em São Paulo, não apenas porque eram consumidores com hábitos já previamente estabelecidos, mas porque havia entre eles muitos artífices (sapateiros, funileiros, ferreiros).

A produção cafeeira imobilizava grande quantidade de capital e deste modo necessitava de "reforços monetários para poder realizar a epopeia de sua expansão" (SINGER, 1968, p.34). Assim muitos bancos, sobretudo ingleses, se estabeleceram na cidade: em 1887 havia seis bancos, além de sucursais de bancos ingleses (SAES, 2004). Os bancos dedicavam-se a atividades diversas como operações de importação e exportação, hipotecas, e aquelas pertinentes à atividade cafeeira, principalmente a de amparar os fazendeiros face o intermediário que o financiava (SINGER, 1968; SOUZA,2004; SAES, 2004). Estruturava-se assim um mercado de capitais.

\footnotetext{
${ }^{9}$ Em 1848 o Barão de Mauá consegue a concessão para construir uma linha férrea que ligasse a região produtora de café do planalto paulista até o porto de Santos, atravessando a Serra do Mar e, em 1867, ficaria pronta a São Paulo Railway, conhecida como Estrada de Ferro Santos-Jundiaí. Novas ferrovias seriam construídas a partir de 1868, substituindo alguns dos antigos caminhos de tropas, casos da E.F. Sorocabana implantada em 1875 e da E.F. São Paulo-Rio de Janeiro, a Central do Brasil, em 1877. Foram ainda construídas entre 1872 e 1886 a Cia. Paulista, ferrovia que partia na direção NorteNoroeste, a Cia. Ituana, rumo a Oeste e a Cia. Mogiana rumo ao Norte.

${ }^{10}$ Em 1856 é instalada em São Paulo uma filial do Banco do Brasil, até então presente apenas na capital Rio de Janeiro.
} 
A grande circulação de capital no período é circunstancial para o processo de industrialização que se delineia em São Paulo, dado que ao capital cafeeiro se somam, após a abolição, aquele não mais imobilizado na figura do escravo e aquele derivado da ampliação de crédito no período do chamado encilhamento $^{11}$, que levou à abertura de inúmeras empresas industriais. O encilhamento é considerado por Singer (1968) e Simonsen (1939) como o primeiro surto industrial brasileiro, dado que apesar de toda a especulação envolvida, houve grande mobilização de capital que de outro modo permaneceria guardado, sendo esta mobilização fundamental para a industrialização.

A industrialização, conforme expõe Singer (1968), é um dos efeitos indiretos da circulação do capital cafeeiro. Também Saes (2004) registra a importância do capital cafeeiro para o desenvolvimento econômico de São Paulo.

A noção de capital cafeeiro, bastante frequente na historiografia recente, procura dar conta de uma característica peculiar dos empresários paulistas do período. Com uma riqueza fundada na propriedade da terra, esses fazendeiros de café logo adquiriram a feição de empresários urbanos: são acionistas e dirigentes de estradas de ferro, comerciantes, banqueiros, acionistas e dirigentes de empresas de serviços urbanos, industriais e frequentemente políticos. Assim, seu capital, embora circule em torno de atividades ligadas à produção cafeeira, não se limita à esfera estritamente agrária dessa atividade: é um capital agrário, mas é também capital comercial, capital financeiro, capital industrial. (SAES, 2004, p.240)

A infraestrutura instalada foi também fator fundamental para que grandes indústrias se estabelecessem na capital. "O fato de terem as estradas de ferro aproveitado os vales, onde os terrenos podiam ser obtidos a baixos preços por não serem apreciados como locais de residência atraiu a instalação de estabelecimentos fabris" (Petrone, 1958, p.104). As primeiras fábricas se estabeleceram junto às estações e linhas ferroviárias, ocupando especialmente as terras baixas vizinhas ao Tamanduateí rumo ao porto de Santos.

A função industrial que se delineia em finais do século XIX se tratava ainda de um setor marginal na economia voltada à exportação agrária. Contudo, 32 estabelecimentos fabris já se situavam em São Paulo em 1889 (PETRONE, 1958), compreendendo manufaturas e fábricas de produtos de uso corriqueiro, as mais numerosas correspondendo à produção de vestuário e mobiliário, sendo, portanto, fundamental a proximidade com o mercado consumidor que se efetiva nas figuras do imigrante e dos fazendeiros do café. A ampliação da indústria paulista, que cresce em quantidade e qualidade, ocorreria definitivamente na década de 1920, quando o estado de São Paulo supera a capital Rio de Janeiro em número de indústrias, operários empregados e valor de produção como demonstra o Quadro 8. (MATTOS, 1958; FGV/CPDOC)

\footnotetext{
${ }^{11}$ O governo provisório no início da República proporciona maior facilidade, no plano legal, para a abertura sociedades anônimas e atribui a vários bancos a possibilidade de emitir moeda, induzindo a expansão de crédito. Como resultado, inúmeras empresas foram abertas - em maior número no Rio de Janeiro, mas também em São Paulo - e seus títulos eram negociados nos mercados financeiros dessas cidades. Esse "período de tumultuoso crescimento econômico" (SINGER, 1968, p.45) seria conhecido pelo nome de encilhamento. Entre os ramos que mais atraíram a atenção de investidores ressalta 0 industrial, com a constituição de 63 empresas.
} 
Quadro 8: Indústrias manufatureiras segundo Recenseamento em 1907 e 1920

\begin{tabular}{|c|c|c|c|c|c|c|}
\hline \multirow{2}{*}{$\begin{array}{l}\text { Unidades da Federação } \\
\text { e Distrito Federal }\end{array}$} & \multicolumn{2}{|c|}{$\begin{array}{c}\text { Número de } \\
\text { Estabelecimentos }\end{array}$} & \multicolumn{2}{|c|}{$\begin{array}{l}\text { Número de } \\
\text { Operários }\end{array}$} & \multicolumn{2}{|c|}{$\begin{array}{l}\text { Valor da Produção } \\
\text { (Contos de Réis) }\end{array}$} \\
\hline & 1907 & 1920 & 1907 & 1920 & 1907 & 1920 \\
\hline Distrito Federal & 652 & 1.541 & 35.104 & 56.229 & 221.619 & 666.275 \\
\hline Rio de Janeiro & 126 & 454 & 11.900 & 16.794 & 45.112 & 184.161 \\
\hline São Paulo & 314 & 4.145 & 24.355 & 83.998 & 110.754 & 986.110 \\
\hline $\begin{array}{l}\text { Fonte: Elaboração da au } \\
\text { “Recenseamento de 1920: } \\
\text { de Estatística. Recencesear }\end{array}$ & $\begin{array}{l}\text { a pa } \\
\text { Censo }\end{array}$ & $\begin{array}{l}\text { de: MIN } \\
\text { da popul } \\
\text { ealizado }\end{array}$ & $\begin{array}{l}\text { RIO DA } \\
\text { e 1o. da }\end{array}$ & AGRICULTU & INDÚSTRI & $\begin{array}{l}\text { COMERCIO. } \\
\text { retoria Geral } \\
\text { te) Indústria. }\end{array}$ \\
\hline $\begin{array}{l}\text { Rio de Janeiro: } \\
<\text { http://biblioteca.ibge.gov }\end{array}$ & $\begin{array}{l}\text { Typ } \\
\text { visualiz }\end{array}$ & $\begin{array}{r}\text { Est } \\
\text { livros/live }\end{array}$ & $\begin{array}{l}\text { tica, } \\
\text {.pdf> Ac }\end{array}$ & $\begin{array}{l}\text { 1927.p. } \\
\text { sso em: } 13\end{array}$ & $\begin{array}{ll}\text { VIII. } & \text { Di } \\
2016 . & \end{array}$ & vel em: \\
\hline
\end{tabular}

No momento pós-1930 a indústria passou a ser beneficiada pela política varguista, havendo transferência de capital e trabalho do setor agrário para o industrial.

\begin{abstract}
Para impedir a falência do setor exportador, ao assumir o governo, Getúlio Vargas desvalorizou a moeda, elevando o preço dos produtos importados, assim, diminuiu a concorrência estrangeira, manteve os estoques de café e assegurou o nível de emprego, sustentando a demanda e estimulando o mercado interno. Em outras palavras: as diretrizes monetárias, fiscais e cambiais da década de 30 propiciaram um efetivo estímulo ao desenvolvimento industrial. (QUEIROZ, 2004, p.40)
\end{abstract}

As primeiras empresas de bens de produção são implantadas em São Paulo durante a Segunda Guerra Mundial. O recenseamento geral realizado em 1940 evidenciou uma nova etapa do processo de industrialização do estado de São Paulo, demostrando com maior ênfase uma das principais características dessa produção: a diversificação industrial, registrando-se 22 grupos diferentes de indústrias e 14.225 estabelecimentos fabris, 272.865 operários e um valor de produção estimado em mais de 7.500 milhões de cruzeiros, confirmando a liderança do estado no país (MATTOS, 1958). O número de estabelecimentos fabris na cidade de São Paulo se eleva de cerca de 2.100 em 1932 para 12.000 em 1947. (PETRONE, 1958)

Em função deste processo se define o crescimento metropolitano a partir da década de 1940 . Os ramos mais expressivos implantados na cidade de São Paulo continuam sendo os tradicionais (têxtil e alimentos) enquanto os novos ramos, especialmente os de metalurgia e mecânica, tendem a buscar melhores condições para sua implantação: terrenos grandes planos e baratos e meios de transporte. $O$ chamado $A B C$ paulista é a primeira região privilegiada dessa nova fase de expansão industrial, beneficiado pela São Paulo Railway e depois pela Rodovia Anchieta, ambos ligando a cidade ao Porto de Santos.

O enorme espraiamento de São Paulo nas décadas de 1940 e 1950 é evidenciado na Figura 92. Segundo Azevedo (1958) a cidade de São Paulo teve sua população duplicada em 1890 e mesmo assim circunscrevia-se dentro de uma área com pouco mais de $2 \mathrm{~km}$ de raio. A partir de 1950, decorridos apenas 60 anos, a urbanização atingia pontos a $15 \mathrm{~km}$ do Centro. 


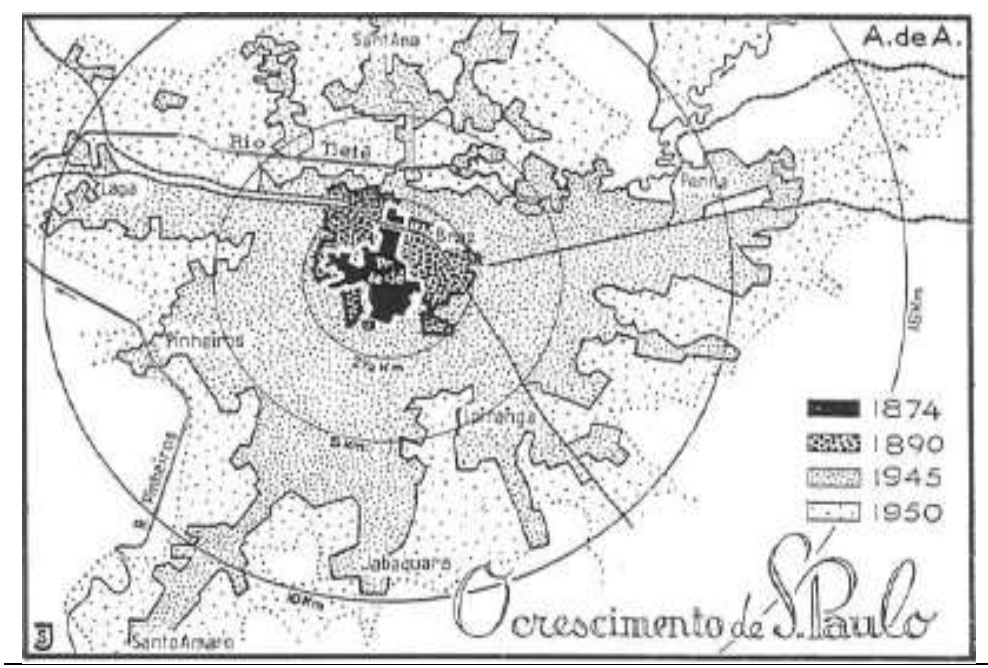

Figura 92: "O espetacular crescimento da cidade de São Paulo". Fonte: AZEVEDO, Aroldo (dir.). A Cidade de São Paulo: Estudos de geografia urbana. Volume 1: a região de São Paulo. São Paulo: Companhia Editora Nacional, 1958. p.11.

Na década de 1950 uma nova escala de produção acompanha o Plano de Metas de Juscelino Kubistchek e a relevância econômica do estado e da cidade de São Paulo se amplia devido ao desenvolvimento industrial, que se destaca não apenas pela criação de grande número de novos estabelecimentos industriais, mas principalmente pela transformação qualitativa do parque industrial (SINGER, 1968). O censo de 1950 contou 24.519 estabelecimentos fabris no estado, o que revela um crescimento de mais de mil fábricas por ano desde 1940. (MATTOS, 1958)

Os principais setores industriais continuam sendo o de alimentação e têxtil, seguidos pelas indústrias metalúrgicas e mecânicas, químicas e farmacêuticas, de cerâmica, vidros e cristais, de construção civil, vestuário, materiais de transporte, borracha e papel. Mattos $(1958$, p.42) afirma que "a maior parte dessas indústrias encontra-se concentrada na Região de São Paulo, no chamado 'Grande São Paulo', isto é, nos municípios da Capital, de São Caetano do Sul, de Santo André, de São Bernardo do Campo e de Guarulhos".

A localização das novas indústrias continua acompanhando o trajeto para o porto de Santos, mas extrapola o limite das linhas férreas e busca terrenos com as mesmas vantagens de transporte e comunicação, com áreas maiores e menores preços disponíveis ao longo das rodovias inauguradas na década de 1940, como a Via Anchieta, se concentrando nos municípios vizinhos de São Paulo neste vetor. "Esta formidável concentração de atividades industriais condicionou por sua vez uma extraordinária expansão de atividades terciárias na região" (SINGER, 2002, p. 127): a atividade comercial, a atividade financeira e bancária e os serviços de modo geral se ampliam e se especializam, enquanto a centralidade urbana se reestrutura. (FELDMAN, 2005)

De um modo geral três características marcam desde a década de 1940 até os anos 1970 um processo de mudança na composição espacial de São Paulo: (1) a compactação da área já edificada, especialmente através da intensificação da verticalização na área central e ocupação mais efetiva de loteamentos antes pouco adensados ou desocupados, (2) a expansão sobre porções dos arredores já 
ocupadas, absorvendo territorialmente núcleos periféricos e a expansão sobre os arredores ainda não urbanizados, (3) a reestruturação da centralidade urbana, dada especialmente em função da expansão do setor terciário. (SINGER, 1974; LANGENBUCH, 1971; FELDMAN, 2005)

Os mapas da Região Metropolitana de São Paulo, de 1949 e 1962 (Figura 93) permitem verificar a expressiva expansão periférica da área urbanizada, que ultrapassa em vários pontos o limite do município, especialmente a Leste e a Sudeste, vetores em que se desenvolve significativamente a atividade industrial no intervalo tomado.

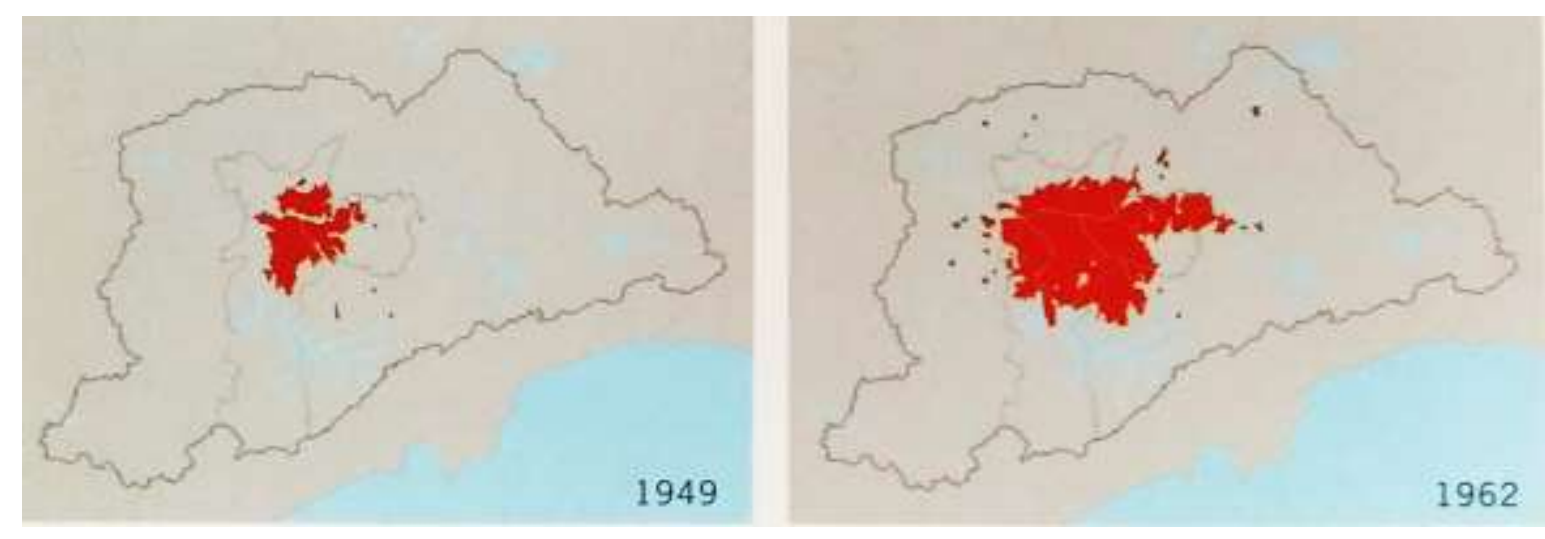

Figura 93. Evolução da área urbanizada. Região Metropolitana de São Paulo (1949-1962). Fonte: MEYER, Regina M. Prospen; GROSTEIN, Marta Dora; BIDERMAN, Ciro. "São Paulo Metrópole". São Paulo: EDUSP: Imprensa Oficial do Estado de São Paulo, 2004. p.43.

Fica evidente nesta breve exposição a relação entre o desenvolvimento da indústria, do sistema econômico-financeiro e do setor terciário e o processo de urbanização e expansão periférica de São Paulo, que se delineia desde finais do século XIX e se concretiza a partir da década de 1940. A relação entre esse esquema e a atuação dos IAPs se explicita na constatação de que a partir da década de 1940, estando concentrada em São Paulo grande parcela da atividade industrial e bancária do país e ampliando-se o setor terciário, suas categorias profissionais foram as mais fortemente beneficiadas pela construção de moradias através dos respectivos Institutos de Previdência.

Embora proporcionalmente em relação ao número de associados sua produção fosse pequena, o IAPI foi o órgão que construiu o maior número de moradias no período, chegando ao total de 36 mil unidades projetadas no país, sendo 24 mil construídas. Em São Paulo foram projetados oito conjuntos que se construídos integralmente totalizariam 12.218 unidades, cerca de quatro vezes mais do que foi realmente produzido (3.111 unidades).

Segundo Bonduki (2014) a categoria dos bancários teve a maior porcentagem de atendimento habitacional, alcançando 33\% do número de associados em 1950 e, ao contrário dos demais institutos, intensificou sua produção na década de 1950 e atuou até ter suas atividades encerradas pelo regime militar em 1966. O IAPB beneficiou no país 17,9 mil associados com a produção de 6.164 moradias, estando a maioria dos projetos, $43 \%$, no estado de São Paulo, sendo sete na capital e seis 
no interior e litoral. A maior produção habitacional previdenciária em São Paulo é do IAPB, com 55\% do total de unidades. Pelos dados levantados, seis projetos ${ }^{12}$ da cidade de São Paulo totalizam 2.206 unidades construídas.

Foram construídas no país cerca de 15.000 unidades em 85 conjuntos do IAPC, aproximadamente $60 \%$ das quais se localizam na cidade do Rio de Janeiro, enquanto $14 \%$ estão no estado de São Paulo (BONDUKI, 2014). Este número poderia ser maior se todos os nove projetos previstos pelo Instituto para São Paulo e seus municípios tivessem sido produzidos, totalizando 3.182 unidades, das quais apenas 1.557 foram construídas.

O IAPETC construiu 2.888 unidades habitacionais, das quais $20 \%$ estão no estado de São Paulo, divididas entre a cidade de Santos e a capital, $40 \%$ estão na cidade do Rio de Janeiro e os $40 \%$ restantes se distribuem em outros estados. Os dois conjuntos previstos para a capital somam 582 unidades, tendo sido construídas 342. As CAPs previram oito projetos habitacionais na capital paulista, com um total de pelo menos 1.549 unidades em sete conjuntos (não foram encontrados dados precisos sobre o oitavo projeto), das quais 709 foram construídas, beneficiando categorias como ferroviários e eletricitários. O IPASE produz em São Paulo um único conjunto com 28 unidades e o IAPM não atua na cidade ou nos municípios vizinhos.

Os Institutos que mais produziram moradias em São Paulo foram o IAPI, o IAPB e o IAPC, justamente as categorias cujos setores mais crescem no início do século XX, com destaque para a expansão na década de 1940, amplamente ligada ao processo de metropolização de São Paulo. Estes Institutos somam respectivamente 12.218, 2.206 e 3.182 unidades projetadas e $3.111,2.206$ e 1.557 construídas $^{13}$. Grande parte destas unidades está concentrada em poucos projetos, nos quais é possível distinguir uma perspectiva de produção em grande escala.

\footnotetext{
12 Não há informações sobre o número de unidades do C.R. Santo Amaro.

${ }^{13}$ É importante destacar que para os objetivos desta Tese trabalhou-se com o número de unidades previsto em cada projeto, independentemente do número construído. Não faz parte do escopo desta pesquisa evidenciar os motivos pelos quais os conjuntos não foram construídos integralmente.
} 
Capítulo 5

Produção habitacional como política de Estado em Buenos Aires nas décadas de 1940 e 1950 


\subsection{A Justiça Social através dos projetos de habitação}

Entre 1943 e 1955 atuam na Argentina como entidades comitentes estatais na promoção de projetos habitacionais a Administración Nacional de la Vivienda (ANV) e o Ministério de Obras Públicas (MOP) através da Dirección de la Vivienda. A ação destes órgãos é complementada por órgãos provinciais e municipais, destacando-se na capital a Dirección Municipal de la Vivienda de la Municipalidad de Buenos Aires (MCBA). O Banco Hipotecário Nacional (BHN) era a principal entidade creditícia na produção da moradia e a partir da vinculação da ANV em 1947 operou também por ação direta. Estes órgãos produziram no período em tela 28 projetos habitacionais para a Grande Buenos Aires. Deste total foram executados pelo menos 20 projetos ${ }^{1}$, totalizando aproximadamente 26.000 unidades (LA NACIÓN ARGENTINA..., 1950; BALLENT, 1993; DUNOWICZ, 2000; GUTIERREZ, 2011).

O mapa a seguir (Figura 94) traz a localização dos projetos habitacionais propostos entre 1943 e 1955 para a Grande Buenos Aires sobre a área urbanizada de 1948, portanto, logo após o início do governo peronista e da promulgação do Primeiro Plano Quinquenal (1946), que dá início à forte política de construção habitacional.

\footnotetext{
${ }^{1}$ Há discrepância de dados entre as diversas fontes consultadas.
} 
1948

Grande Buenos Aires

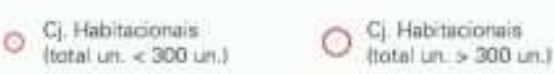

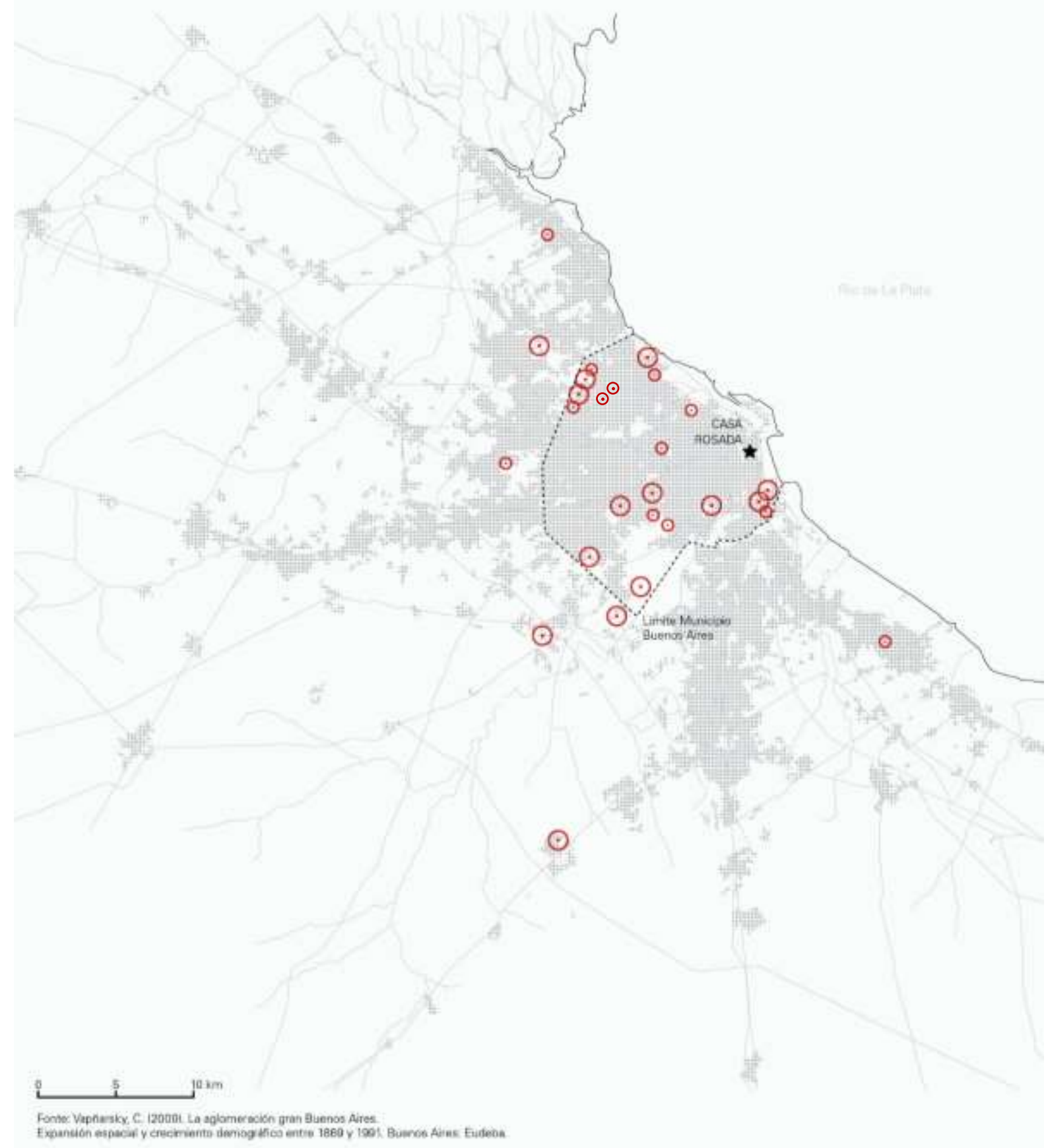

Figura 94. Área urbanizada da Grande Buenos Aires em 1948 com localização dos conjuntos habitacionais projetados entre 1943 e 1955. Elaboração da autora. Execução de Carolina Passos. 
É possível observar no mapa que a maior parte dos projetos foi proposta para o território da própria Buenos Aires que, como capital e maior cidade da Argentina, foi onde a questão da moradia adquiriu maior proporção e visibilidade, sendo aí propostos 12 projetos habitacionais. Conforme se expõe neste capítulo, o processo de urbanização desde o final do século XIX alcançava o limite administrativo de Buenos Aires e já na década de 1930 deixava poucas áreas disponíveis à ocupação, o que dificultou, ou impediu, por exemplo, a construção de projetos habitacionais junto ao Microcentro (área ao redor da Casa Rosada) e em outros bairros de ocupação mais antiga.

Algumas áreas do espaço urbano e suburbano ${ }^{2}$ foram privilegiados pela localização dos projetos, como se pode distinguir no mapa. O primeiro setor que se destaca é o vetor Sudoeste a partir do Centro, que se expande além dos limites municipais para municípios da Grande Buenos Aires. Como se nota no mapa e como se explicará ao longo do texto, este vetor era o menos urbanizado da capital em 1948 de modo que aí havia ainda grande quantidade de áreas disponíveis à ocupação.

A segunda área que se destaca é a região Norte da cidade e corresponde principalmente à ocupação de terrenos remanescentes, uma vez que o vetor, conforme apresentaremos, foi privilegiado pelo processo de urbanização, sendo um dos primeiros ocupados por famílias abastadas que deixavam o Centro de Buenos Aires. Destacam-se entre estes terrenos, áreas inundáveis próximas ao rio de La Plata localizadas no bairro de Belgrano, antigo município incorporado ao território da capital e de ocupação já bastante consolidada.

A terceira área privilegiada pela quantidade de projetos habitacionais propostos fica ao Sul do Centro e corresponde a bairros de ocupação antiga e vinculada à função industrial. Nesta área da cidade, os projetos ocuparam terrenos remanescentes ou áreas em que foi proposta remodelação de uso e ocupação, buscando-se também a renovação urbana. Os bairros mais antigos e de função industrial, especialmente La Boca, apresentavam também a função residencial associada à moradia operária que, no entanto, era extremamente precária e em muitos casos irregular. (LIERNUR; SILVESTRI, 1993) Por fim, uma quarta área privilegiada é o limite Noroeste de Buenos Aires, onde foram realizados projetos muito próximos à Avenida General Paz. Como se observa no mapa, que mostra a área urbanizada em 1948, os terrenos vazios a Noroeste eram praticamente apenas estes no limite do território, tendo sido este também um dos vetores privilegiados pelo processo de urbanização.

Essa setorização dos projetos se relaciona, por um lado, à consolidação do tecido urbano de Buenos Aires e, por outro, lado, conforme foi destacado por Ballent (2005), às políticas de ocupação e urbanização do território propostas a partir da produção habitacional, como se explicará na sequência.

\footnotetext{
2 Entenda-se, em municípios da Grande Buenos Aires adjacentes ao território da capital, onde ocorria a sua expansão periférica.
} 


\section{Quadro 9}

Projetos habitacionais promovidos na Grande Buenos Aires entre 1943 e 1955

\begin{tabular}{|c|c|c|c|c|c|c|c|c|c|}
\hline \multirow[b]{2}{*}{ Projeto } & \multirow[b]{2}{*}{$\begin{array}{l}\text { Órgão } \\
\text { Comitente }\end{array}$} & \multirow[b]{2}{*}{$\begin{array}{c}\text { Órgão } \\
\text { Creditício }\end{array}$} & \multirow[b]{2}{*}{ Localização } & \multirow[b]{2}{*}{$\begin{array}{l}\text { Número } \\
\text { de } \\
\text { unidades }\end{array}$} & \multicolumn{4}{|c|}{ Tipologia } & \multirow[b]{2}{*}{ Ano } \\
\hline & & & & & $\begin{array}{l}\text { Edifício } \\
\text { vertical } \\
\text { isolado }\end{array}$ & $\begin{array}{l}\text { Conjunto } \\
\text { de } \\
\text { edifícios }\end{array}$ & $\begin{array}{c}\text { Conjunto } \\
\text { de } \\
\text { blocos }\end{array}$ & $\begin{array}{l}\text { Conjunto } \\
\text { de casas }\end{array}$ & \\
\hline $\begin{array}{c}\text { Casa Colectiva } \\
\text { Martin Rodrigues }\end{array}$ & CNCB-ANV & & $\begin{array}{c}\text { Martín Rodriguez } \\
\text { Buenos Aires }\end{array}$ & 141 & $x$ & & & & 1943 \\
\hline $\begin{array}{l}\text { Barrio Villa } \\
\text { Concepción }\end{array}$ & CNCB-ANV & $\begin{array}{l}\text { BHN } \\
(1947)\end{array}$ & $\begin{array}{c}\text { Calle J.M. Campos, } \\
\text { Villa Zagala } \\
\text { San Martin }\end{array}$ & 530 & & & & $x$ & $\begin{array}{l}1944- \\
1949\end{array}$ \\
\hline $\begin{array}{c}\text { Obras Sanitarias de } \\
\text { la Nacion }\end{array}$ & MOP & - & San Isidro & 133 & & & & $x$ & $\begin{array}{l}1944- \\
1945\end{array}$ \\
\hline $\begin{array}{c}\text { Barrio 1o. De } \\
\text { Marzo - Roque } \\
\text { Saenz Peña }\end{array}$ & MCBA & $\begin{array}{c}\text { Plan } \\
\text { Munic. } \\
\text { Gremios }\end{array}$ & $\begin{array}{c}\text { Av. Ricardo Balbín, } \\
\text { Saavedra, } \\
\text { Buenos Aires }\end{array}$ & 177 & & & & $x$ & $\begin{array}{l}1945- \\
1948\end{array}$ \\
\hline $\begin{array}{l}\text { Barrio-Parque de } \\
\text { los trabajadores }\end{array}$ & o & & $\begin{array}{c}\text { Bajo Flores } \\
\text { Buenos Aires }\end{array}$ & 7690 & & $x$ & & & 1945 \\
\hline $\begin{array}{l}\text { Juan Perón - } \\
\text { Cornelio Saavedra }\end{array}$ & MOP & BHN & $\begin{array}{c}\text { Av. General Paz, } \\
\text { Saavedra } \\
\text { Buenos Aires } \\
\end{array}$ & 427 & & & & $x$ & $\begin{array}{l}1946- \\
1949\end{array}$ \\
\hline $\begin{array}{l}\text { Los Perales - Barrio } \\
\text { Manuel Dorrego }\end{array}$ & $\mathrm{MCBA}^{1}$ & BHN & $\begin{array}{l}\text { Av. Lizandro de la } \\
\text { Torre, Mataderos } \\
\text { Buenos Aires }\end{array}$ & 1068 & & & $x$ & & $\begin{array}{l}1946- \\
1952\end{array}$ \\
\hline $\begin{array}{l}\text { Barrio Alvear } \\
\text { (3a etapa) }\end{array}$ & $\begin{array}{l}\text { CNCB / BHN } \\
\text { (ação direta) }\end{array}$ & & $\begin{array}{c}\text { Av. Directorio, } \\
\text { Parque Avellaneda } \\
\text { Buenos Aires }\end{array}$ & 1692 & & $x$ & $x$ & & $\begin{array}{c}1943 / \\
47- \\
1954 \\
\end{array}$ \\
\hline $\begin{array}{c}17 \text { de Octubre - } \\
\text { Albarellos } \\
\end{array}$ & MOP & BHN & $\begin{array}{c}\text { Calle Albarellos } \\
\text { Buenos Aires }\end{array}$ & 40 & & & & $x$ & $\begin{array}{l}1947- \\
1952 \\
\end{array}$ \\
\hline Ciudad Evita & MOP & $\mathrm{BHN}$ & $\begin{array}{c}\text { Autopista Tte. Gral. } \\
\text { P. Ricchieri } \\
\text { La Matanza } \\
\end{array}$ & $\begin{array}{c}5000 \\
(10000)\end{array}$ & & $x$ & $x$ & $x$ & $\begin{array}{l}1947- \\
1953\end{array}$ \\
\hline Barrio Balbastro & MCBA & BHN & $\begin{array}{c}\text { Calle Balbastro, } \\
\text { Flores Sur } \\
\text { Buenos Aires } \\
\end{array}$ & 108 & & & $x$ & & 1948 \\
\hline $\begin{array}{c}17 \text { de Octubre - } \\
\text { Graffa }\end{array}$ & MCBA & BHN & $\begin{array}{c}\text { Av. General Paz } \\
\text { Buenos Aires }\end{array}$ & 960 & & & $x$ & & $\begin{array}{l}1948- \\
1950 \\
\end{array}$ \\
\hline Bajo Belgrano & MCBA & EPBA & $\begin{array}{c}\text { Belgrano } \\
\text { Buenos Aires }\end{array}$ & 9000 & & $x$ & & & 1948 \\
\hline $\begin{array}{c}\text { Curapaligüe -Simón } \\
\text { Bolívar } \\
\end{array}$ & $\begin{array}{c}\text { BHN } \\
\text { (ação direta) }\end{array}$ & & $\begin{array}{c}\text { Av. Curapaligüe } \\
\text { Buenos Aires }\end{array}$ & 676 & & $x$ & & & $\begin{array}{l}1948- \\
1953 \\
\end{array}$ \\
\hline $\begin{array}{c}\text { Monobloque } \\
\text { General Belgrano }\end{array}$ & MCBA & & $\begin{array}{c}\text { Calle Virrey del Pino } \\
\text { Buenos Aires }\end{array}$ & 133 & $x$ & & & & $\begin{array}{l}1948- \\
1952\end{array}$ \\
\hline $\begin{array}{c}\text { Pabellones Acoyte } \\
\text { y Ambrosetti }\end{array}$ & MCBA & IMPS $^{2}$ & $\begin{array}{l}\text { Calle Acoyte } \\
\text { Buenos Aires }\end{array}$ & 44 & $x$ & & & & $\begin{array}{l}1948- \\
1952 \\
\end{array}$ \\
\hline $\begin{array}{c}17 \text { de Octubre - } \\
\text { General Paz }\end{array}$ & $\begin{array}{c}\text { BHN } \\
\text { (ação direta) }\end{array}$ & & $\begin{array}{c}\text { Autopista Tte. Gral. } \\
\text { P. Ricchieri } \\
\text { La Matanza }\end{array}$ & 5536 & & $x$ & $x$ & $x$ & $\begin{array}{l}1948- \\
1954\end{array}$ \\
\hline $\begin{array}{l}\text { Barrio no. } 1 \text { - } \\
\text { Justicialista }\end{array}$ & MOP & BHN & $\begin{array}{l}\text { Autopista Tte. Gral. } \\
\text { P. Ricchieri } \\
\text { Esteban Echeverria }\end{array}$ & 382 & & & & $x$ & 1949 \\
\hline Casa Amarilla & MCBA & - & $\begin{array}{c}\text { La Boca } \\
\text { Buenos Aires } \\
\end{array}$ & 6200 & & $x$ & & & - \\
\hline Curapaligüe y Cobo & MCBA & - & $\begin{array}{c}\text { Flores Sur } \\
\text { Buenos Aires }\end{array}$ & - & & & - & & - \\
\hline Plaza Italia & MCBA & - & $\begin{array}{c}\text { Palermo } \\
\text { Buenos Aires }\end{array}$ & - & & & - & & - \\
\hline Parque Patrícios & MCBA & - & $\begin{array}{c}\text { Parque Patrícios } \\
\text { Buenos Aires }\end{array}$ & 700 & & & - & & - \\
\hline $\begin{array}{c}\text { Caseros }-3 \text { de } \\
\text { Febrero }\end{array}$ & MOP & - & San Martin & 200 & & & $*$ & & $*$ \\
\hline Catalinas Sur & $*$ & $*$ & $\begin{array}{c}\text { La Boca } \\
\text { Buenos Aires }\end{array}$ & 600 & & & $*$ & & $*$ \\
\hline $\begin{array}{c}\text { San Martin y } \\
\text { Moreno }\end{array}$ & $*$ & $*$ & Buenos Aires & 620 & & & $*$ & & $*$ \\
\hline Manuel Belgrano & $*$ & $*$ & Buenos Aires & 831 & & & * & & $*$ \\
\hline $\begin{array}{c}\text { Maria Eva Duarte } \\
\text { de Perón }\end{array}$ & $*$ & $*$ & La Matanza & 872 & & & $*$ & & $*$ \\
\hline Bernal & $*$ & $*$ & Quilmes & 200 & & & $*$ & & $*$ \\
\hline
\end{tabular}

Fontes: Elaboração da autora com base em: LA NACIÓN ARGENTINA..., 1950; BALLENT, 1993; DUNOWICZ, 2000; GUTIERREZ, 2011

1 A partir deste projeto a MCBA atua através da Dirección Municipal de la Vivienda; 2 IMPs - Instituto Municipal de Previsión Social.

* Projetos habitacionais contados entre a produção peronista no livro "Nación Argentina Justa Libre y Soberana" publicado em 1950.

${ }^{\circ}$ O Barrio Parque de los Trabalhadores en Bajo Flores obteve o Primeiro Prêmio no VI Salão Nacional de Arquitetura, sendo incluída entre as obras do período peronista por Ballent. O projeto não foi executado. 
O Quadro 9 apresenta o conjunto de projetos concebidos entre 1943 e 1955 para Buenos Aires e para os municípios da Grande Buenos Aires, destacando-se em cinza os projetos massivos. Considerou-se importante incluir projetos realizados desde 1943, ainda que iniciados por promoção da CNCB, pois estes foram finalizados por ação da ANV ou do BHN, e mesmo porque, como já mencionado, Perón já dava início a partir de então à política justicialista. Outro ponto a ressaltar no quadro é a inclusão de uma série de projetos contados entre a produção peronista na publicação oficial "La Nación Argentina Justa Libre y Soberana" de 1950, que, contudo, não se incluem nos levantamentos realizados por autores como Dunowicz (1998), Ballent (2005) e Gutierrez (2011) referentes ao período 1945-1955. É possível pensar que, assim como os projetos supracitados, estes tenham sido idealizados entre 1943 e 1945, não havendo, porém, indicação de seu órgão comitente ou creditício (exceto pelo Barrio Caseros, em San Martin, mencionado por Ballent) ou se foram ou não executados. Pode-se pensar ainda que estes projetos tenham sido propostos naquele momento e mencionados na propaganda oficial, sem que, contudo, tenham sido desenvolvidos posteriormente. Sendo a referida publicação estatal importante à divulgação da política justicialista considerou-se adequado, não obstante a falta de dados, incluí-los entre os projetos habitacionais propostos na Grande Buenos Aires pelo peronismo.

Gráfico 05

Quantidade de projetos habitacionais por ano na Grande Buenos Aires entre 1943 e 1950

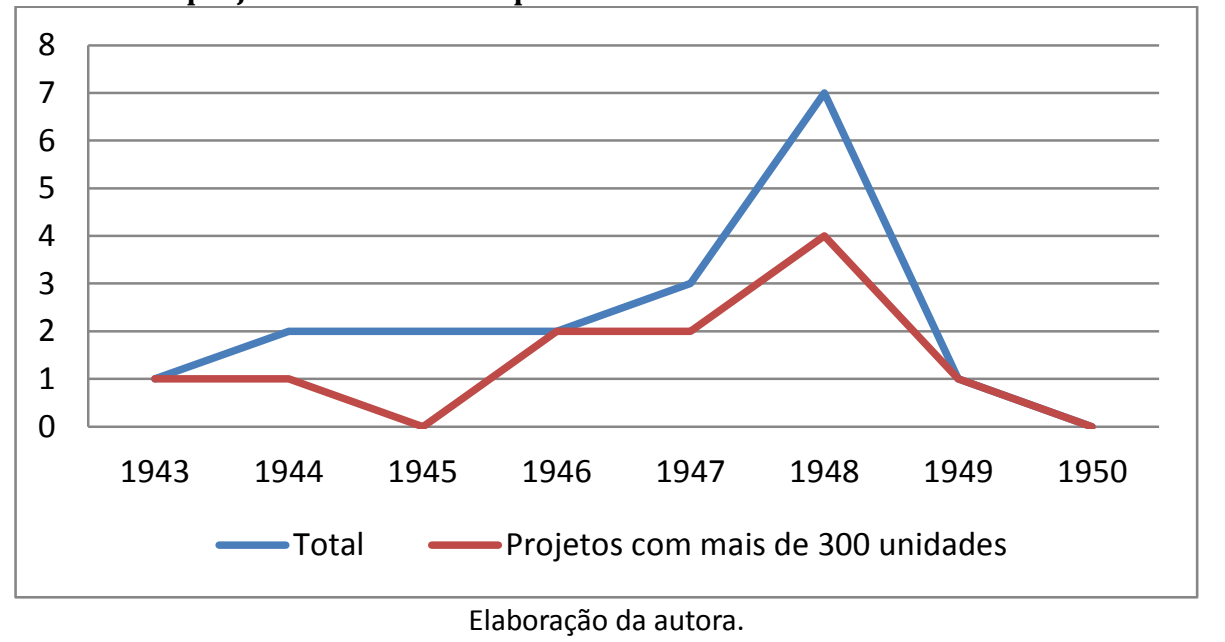

Nota-se no Quadro e no Gráfico 05, que registra a quantidade de projetos por ano na Grande Buenos Aires entre 1943 e 1955, que as datas iniciais dos projetos são unicamente da década de 1940, embora a construção de alguns tenha sido finalizada na década de 1950 (lembramos que o governo peronista sofre com a crise mundial em 1949, reduzindo desde então os investimentos diretos na obra pública). Dos dezoito projetos cujos dados incluem a data de realização, doze foram concebidos nos anos conseguintes à implementação do Primeiro Plano Quinquenal - treze, se considerarmos 
ainda o projeto de ampliação do Barrio Alvear ${ }^{3}$. Nove destes projetos são massivos, contando entre 382 e 10.000 unidades. Cinco projetos habitacionais são anteriores ao Plano, sendo dois deles massivos. É, portanto, logo após 1946, quando é lançado o Plano Quinquenal, que se concebe a maior parte dos projetos massivos da capital e Grande Buenos Aires ${ }^{4}$.

É possível constatar a existência de uma relação entre os locais em que foram implantados os projetos e as tipologias adotadas. Foi pouco utilizado o edifício vertical isolado, restrito a algumas poucas intervenções pontuais, três no total, em terrenos cujo tamanho compelia à verticalização como forma de garantir um número maior de unidades. Apesar disso, estes três projetos não são massivos, tendo entre 44 e 141 unidades.

Destaca-se, porém a construção do conjunto de edifícios (combinado ou não com outras tipologias). Os conjuntos de edifícios verticais foram sugeridos dentro de uma estratégia de concentração urbana que permitia elevar a densidade populacional mesmo em áreas de pequena dimensão em meio à ocupação consolidada. Essa tipologia foi também proposta no contexto de urbanização de áreas ainda pouco consolidadas como as áreas suburbanas e o vetor Sudoeste. Vale mencionar o fato de esta tipologia ser associada à superquadra, distinguindo-se por grandes espaços livres entre os edifícios, onde se dispunham áreas verdes, equipamentos e acessos peatonais.

O conjunto de casas foi proposto apenas na periferia e nos partidos vizinhos de Buenos Aires, vinculando-se a uma proposta de desconcentração urbana, isto é, de baixa densidade e ocupação extensiva. Um fato a destacar é que a tipologia da casa unifamiliar foi particularmente associada ao padrão urbanístico cidade-jardim, mais evidente nos projetos em que a tipologia era exclusiva e menos naqueles em que foi combinada a outras tipologias. No conjunto de casas distinguiam-se tipos variados de unidades, isoladas, geminadas ou enfileiradas, térreas ou assobradadas.

O conjunto de blocos, por fim, foi a tipologia mais adotada, destacando-se pela grande dimensão das glebas ocupadas com pabellones idênticos. Sua utilização, porém, não se restringiu a áreas específicas, havendo projetos menores nos poucos terrenos ainda remanescentes em meio à mancha urbanizada e grandes projetos na área suburbana. Assim como o conjunto de edifícios, essa tipologia foi associada à superquadra, ocorrendo a implantação dos blocos sobre grandes planos verdes e muitas vezes atravessados apenas por vias de pedestres.

Independentemente da tipologia adotada, estes projetos eram vinculados à política Justicialista e traziam em comum a proposta de elevação do padrão de vida, ou da "dignidade" como aparece no discurso oficial, da população trabalhadora (LA NACIÓN ARGENTINA..., 1950). Para alcançar este

\footnotetext{
${ }^{3}$ Apesar de o Barrio Alvear ter sido iniciado em 1943 pela CNCB, a proposta de ampliação de sua escala foi incorporada quando é assumido pelo BHN em 1947.

${ }^{4}$ De um dos projetos massivos, o Parque Patrícios, não foi localizada a data de elaboração. De outros quatro projetos massivos entre aqueles constantes na publicação "La Nación Argentina Justa Libre y Soberana" - Catalinas Sur, San Martin y Moreno, Manuel Belgrano e Maria Eva Duarte de Perón - não se encontraram mais informações além do número de unidades previsto.
} 
objetivo entendeu-se que não bastava apenas garantir a qualidade das moradias em si e, neste contexto, os projetos de conjuntos habitacionais foram propostos como planos de bairros, contando com grande variedade de equipamentos e serviços coletivos, em alguns casos propostos conforme o padrão da "unidade de vizinhança". Além disso, compreendeu-se que era fundamental a integração dos projetos como o espaço urbano, o que foi proporcionado pela proximidade com linhas de ônibus e trens. Em 1951 o Decreto n. 5945 regulamenta a Ley de Viviendas de 1948 e indica que a Dirección de la Vivienda:

Artículo 2.- Fomentará a instalação de serviços públicos nos bairros operários, a criação de bibliotecas públicas, a construção de parques, jardins e academias, com o objetivo de contribuir para a melhoria das condições de vida de seus habitantes.

Art. 3o Promoverá o funcionamento e a coordenação do serviço de transporte coletivo de passageiros dos bairros que constrói para os centros urbanos e locais de trabalho. (ARGENTINA, 1951, tradução nossa)

O novo decreto oficializava aquilo que na prática já era implementado, considerando o fato de que a maior parte dos conjuntos habitacionais produzidos pelo peronismo foi projetado e construído entre 1947 e 1950. Nesse sentido, é possível admitir que o projeto destes conjuntos como "barrios peronistas", conforme denomina Ballent (2005), não estava apenas relacionado à política estatal de Justiça Social, mas também à atuação de arquitetos no interior do aparato estatal ou junto dos órgãos comitentes, que buscaram colocar em prática as proposições e soluções debatidas pelo campo profissional a respeito da questão da habitação naqueles anos. Não é demais lembrar que os locais em que foram previstos os projetos eram em sua maioria terrenos fiscais, alguns inclusive destituídos de outros usos para a produção dos conjuntos, conforme disposto no Primeiro Plano Quinquenal. Este dado permite reconhecer a importância conferida e garantida à localização dos projetos no espaço urbano e suburbano.

A Doutrina Justicialista tinha um caráter de "reparação social histórica" perante os setores populares (ABOY, 2005; CIRVINI, 2012). De acordo com Ballent (2005) o bem-estar social é ao mesmo tempo base e produto da política de Justiça Social, buscando possibilitar à população de poucos recursos "vivir como la gente", isto é, viver dignamente. A dignidade e a felicidade da família operária eram associadas à vida privada, na moradia, porém se propunha construí-los em termos da obra pública, que ocupa lugar de destaque no Estado peronista, em particular através dos projetos de habitação. Os conjuntos habitacionais massivos são admitidos como "símbolos da aquisição de novos direitos e da extensão do bem-estar". No âmbito da política peronista, a moradia é ainda considerada um meio para a "construção de uma relação harmônica entre capital e trabalho", nesse sentido associando-se também ao plano de industrialização assumido pelo governo. (BALLENT, 2005, p. 66, tradução nossa) Conforme apontado por Aboy (2005, p.42, tradução nossa), mesmo que o número de moradias construídas por ação direta tenha sido menor que o total proposto e menor que o número de créditos outorgados para a autoprovisão da moradia, ou seja, a ação estatal indireta, o impacto das 
políticas habitacionais "reforçou o imaginário de um governo aliado às reivindicações proletárias". Segundo Ballent (2005, p.22, tradução nossa), "a implementação destas políticas [de habitação] implicou profundas alterações na relação Estado / Sociedade, por exemplo, ao instalar a ideia de 'direito à moradia'", que o Estado argentino não pôde deixar de reconhecer mesmo após o fim do governo de Perón.

Ainda conforme Ballent (2005), olhando especificamente para o caso de Buenos Aires, é possível afirmar que a partir da produção da habitação se desenvolveu outro direito associado ao da moradia, mesmo que este nunca fosse formalmente formulado: o direito à cidade. 0 Justicialismo propunha uma política compreensiva, destinada a enfrentar o "crescimento desorganizado e vertiginoso dos centros povoados" e redistribuir os benefícios da cidade à população (LA NACION ARGENTINA..., 1950, p.311, tradução nossa). O controle urbano e territorial, nesse sentido, fazia parte da proposta peronista, embora na prática muitas vezes tenham-se implementado estratégias contraditórias a essa premissa, como discutiremos neste capítulo.

Trabalhamos com a ideia de que a partir da política de Justiça Social colocada por Perón, a noção de que na produção habitacional se identificava a imagem dos novos direitos adquiridos e de um governo que atendia às necessidades da classe trabalhadora implicou na intenção de fazer de Buenos Aires uma vitrine da política peronista e da obra pública que ela realizava, no caso a obra habitacional. Acreditamos que essa intenção se aliou ainda a um segundo fator, a importante atuação da Dirección Municipal de la Vivienda da MCBA, culminando no fato de que em Buenos Aires foi produzida tão grande quantidade de projetos habitacionais - e projetos massivos - apesar da consolidação de seu espaço urbano.

No âmbito da Municipalidade da Cidade de Buenos Aires (MCBA) em 1946 é criada, a Dirección Municipal de la Vivienda, tendo por objetivo complementar a ação estatal na promoção habitacional na capital. À frente da Dirección foi designado o arquiteto Roberto Portal, que já fazia parte do corpo técnico da MCBA. No entanto, seriam admitidos no órgão "jovens figuras decididamente renovadoras no campo arquitetônico, como os arquitetos Elmer Willis e Carlos Coire, entre outros" (BALLENT, 1993, p. 191, tradução nossa). Como já discutimos, junto à MCBA atuaram também outros arquitetos ligados à difusão do ideário moderno na Argentina, pertencentes ao já referido Grupo Austral, como Jorge Ferrari Hardoy e Juan Kurchan.

O órgão promoveu uma série de projetos habitacionais de cunho modernizante, adotando a concepção de edifícios coletivos em forma de lâmina, os pabellones e monobloques, dispostos sobre grandes áreas verdes e relacionados ao conceito de unidade de vizinhança, com proposição de ampla gama de equipamentos. Entre 1946 e 1949, através da Dirección Municipal de la Vivienda, a MCBA inicia a construção de aproximadamente 2.700 unidades, destacando-se entre os projetos os conjuntos Los Perales (1946-1952) e 17 de Octubre - Barrio Grafa (1948-1950). 
Em 1947 a MCBA organiza o Estudio para El Plan de Buenos Aires (EPBA) a cargo do arquiteto Jorge Ferrari Hardoy e no âmbito deste estudo seria também proposta a produção habitacional. Destaca-se o projeto de urbanização de Bajo Belgrano, um conjunto de edifícios laminares que abrigaria 50.000 habitantes. Para realizar o estudo que em 1948 serviria de base para o Plano Diretor da cidade, Hardoy se apoia no Plano Diretor elaborado em 1937-38 por Le Corbusier, Juan Kurchan e ele próprio. (LIERNUR; ALIATA, 2004). Em 1949 membros importantes da MCBA renunciaram e a nova gestão dissolveu a Dirección Municipal de la Vivienda e paralisou a construção de Bajo Belgrano: de todo o projeto somente uma lâmina teve sua construção iniciada, sendo, porém, interrompida em 1950. A MCBA implantou naquela região um único edifício, não pertencente ao plano original, o Monobloque General Belgrano (1948-1952).

\subsection{Os projetos habitacionais em Buenos Aires: acesso à cidade e urbanização}

Embora existisse uma proposta oficial de redistribuição social dos benefícios das grandes cidades, especialmente através da produção habitacional, não encontramos no Primeiro Plano Quinquenal uma definição concreta de como era a cidade que se esperava redistribuir e quais instrumentos eram necessários para esta redistribuição (LA NACION ARGENTINA..., 1950; PRESIDÊNCIA DE LA NACION, 1946). Especificamente no caso da capital, dada sua ocupação consolidada física e simbolicamente, aí estava a maior quantidade de bens / benefícios já existentes a disponibilizar à população trabalhadora. No entanto, apesar do que Ballent (2005) denomina "vocação planificadora de Buenos Aires", isto é, sua capacidade de ao longo dos anos suportar inúmeras intervenções urbanísticas, o Estado peronista implementou em seu espaço urbano poucas alterações. Esta atuação, porém, não se deveu, segundo Ballent (2005), a uma falta de propostas ou de atividade oficial, mas, de um lado à própria consolidação da ocupação do território da capital e, de outro, a estratégias colocadas no interior do Estado.

Conforme descrito por Torres (2006) e Gutman e Hardoy (1992), desde a década de 1930 praticamente todo o território delimitado em 1887 já estava consolidado. Havendo poucas áreas onde atuar em termos da obra pública, em Buenos Aires esta atuação se deu pontualmente na área central e em outras áreas já consolidadas através da construção de edifícios, com grande destaque para aquele que seria grande símbolo do peronismo, o Edifício do Ministério de Obras Públicas, localizado na Avenida Nove de Julho. As intervenções urbanísticas em grandes espaços, conforme se constatou, ocorreram na capital sobretudo através dos projetos habitacionais.

Colocava-se ainda em Buenos Aires, uma dificuldade relacionada não à falta de espaços propriamente dita, mas ao seu alto valor material e simbólico (NEIBURG, 1992; BALLENT, 2005; GAMBINI; 2014). Consolidada historicamente do ponto de vista da ocupação urbana, conforme apresentaremos na sequência, com traçado urbano, edifícios e espaços públicos característicos, 
Buenos Aires era também historicamente marcada por uma carga simbólica de usos, lutas e representações.

De acordo com Ballent (2005), um conjunto de estratégias e circunstâncias conformadas no interior da política peronista chocava-se com a ideia de ampliar o acesso aos benefícios da cidade de Buenos Aires através de intervenções governamentais. Uma dessas estratégias justamente recomendava a manutenção da cidade conquistada pelo peronismo. Conforme apreendemos da leitura de Gambini (2014) e Neiburg (1992), a data de 17 de outubro de 1945, quando da ampla manifestação dos trabalhadores em favor de Perón, foi compreendida como momento em que a cidade fora conquistada por aquela população trabalhadora até o momento relegada à periferia urbana. $A$ Plaza de Mayo, onde ocorreu a manifestação foi cenário principal e se configurou como símbolo da luta, mas na verdade as ruas de Buenos Aires de modo geral foram objeto de disputa entre peronistas e antiperonistas. A partir daí se instala a noção de manutenção da cidade, especialmente dos espaços ocupados pela população. Entendemos que esta recomendação de certo modo se relaciona à questão de seu alto valor material e simbólico.

Compreendemos, com base nestas leituras, que Buenos Aires era um espaço a conquistar política e simbolicamente. Esta noção se constrói porque, como capital e maior cidade argentina, Buenos Aires era fundamental ao peronismo, em primeiro lugar, por sua representatividade política no próprio país e também fora dele e, em segundo lugar, porque estavam em Buenos Aires os espaços públicos, os edifícios, os usos historicamente consolidados e desde 1945 tomados pelo peronismo. Nesse sentido as futuras ações ou políticas aplicadas à cidade eram implicadas pela possibilidade de garantir o acesso da população à cidade consolidada e pela representação ou imagem que o Estado queria imprimir de si mesmo, no caso, fortemente relacionadas à política de Justiça Social.

A setorização dos projetos habitacionais em Buenos Aires e nos partidos da Grande Buenos Aires, portanto, se relaciona, por um lado, à insuficiência de grandes áreas livres na cidade e, por outro, à proposta peronista de garantir os benefícios dessa cidade à população. No mapeamento a seguir (Figura 95) demarcamos os setores privilegiados pela produção habitacional. 


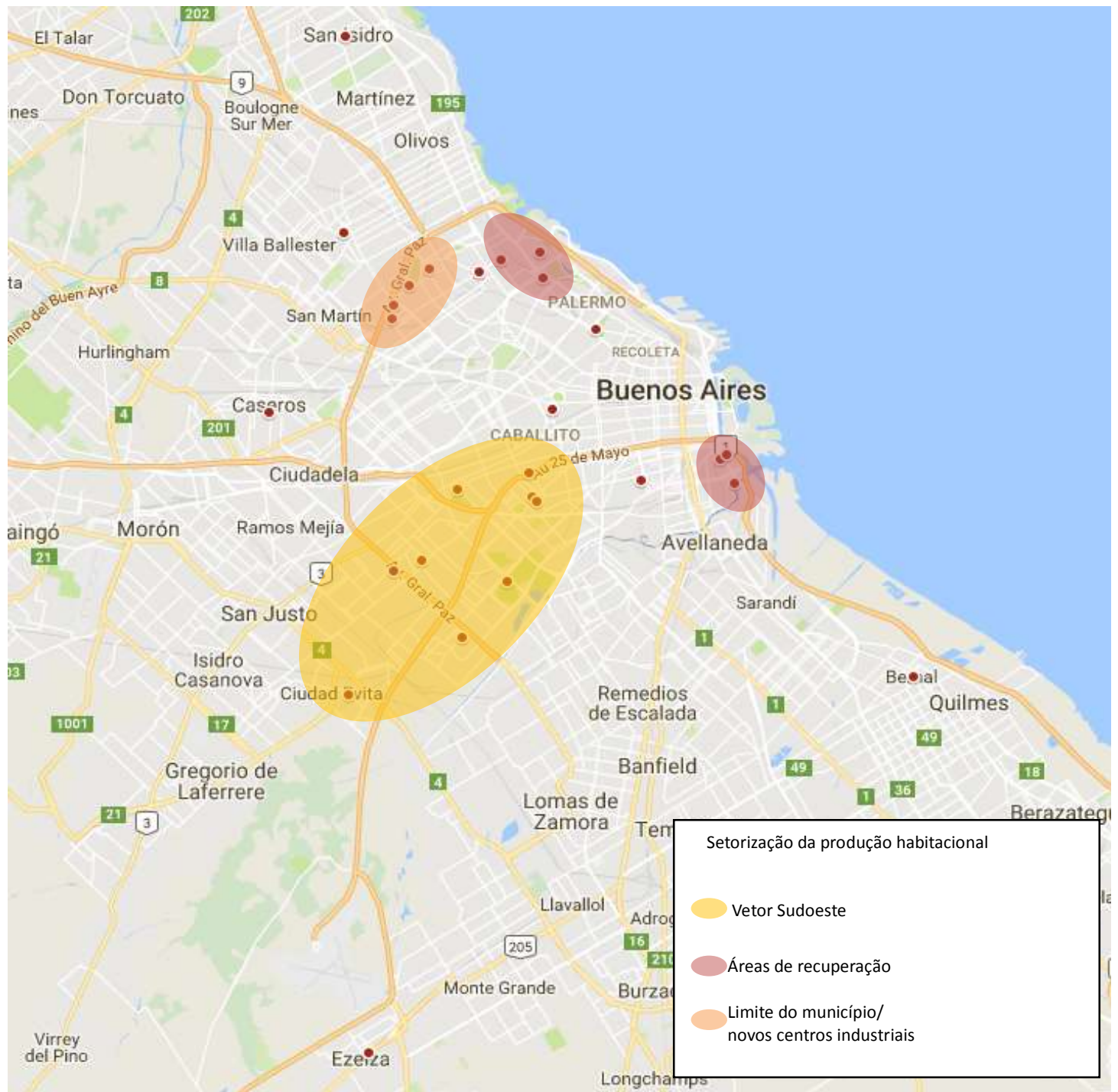

Figura 95. Setorização dos projetos habitacionais produzidos para a Grande Buenos Aires. Base cartográfica: Mapa de Buenos Aires no Google Maps. Elaboração da autora.

O primeiro setor privilegiado pela construção habitacional, como já mencionamos, é o vetor Sudoeste. Na capital este setor se identifica com Bajo Flores, área do antigo núcleo de Flores incorporado ao território da capital desde o final do século XIX, e os bairros Parque Avellaneda e Villa Lugano. A produção habitacional no vetor Sudoeste, porém, era ampliada ao espaço da Grande Buenos Aires, vinculando-se ao acesso ao novo aeroporto metropolitano em Ezeiza, passando pelos partidos de La Matanza e Esteban Echeverría. A implantação deste acesso incluiu junto à construção do autopista propriamente dita, uma vasta intervenção urbana com programas sociais e moradias, conhecida como "Operación Territorial de Ezeiza". (BALLENT, 1999)

No vetor Sudoeste foram previstos no território da capital, os conjuntos Curapaligue (MCBA), Balbastro (MCBA), Curapaligue y Cobo (MCBA), Alvear (BHN) e Los Perales (MCBA), enquanto no partido de La Matanza foram propostos os conjuntos 17 de Octubre (BHN) e Ciudad Evita (MOP). Exceto pelos conjuntos Balbastro e Curapaligue y Cobo, os demais projetos, como já apresentamos no Capítulo 1, se destacam por sua grande escala, expressa sobretudo na integração ao projeto 
urbanístico e na padronização e verticalização dos tipos construtivos, nomeadamente os dois projetos suburbanos.

A segunda setorização de projetos habitacionais divide-se, na verdade, em duas áreas, uma ao Norte e uma ao Sul do Centro de Buenos Aires. Em ambas é possível perceber uma intenção de recuperação ou renovação urbana, que Ballent (2005) denomina como "intenção de saneamento". Ao Norte do Centro destacamos a área conhecida como Bajo Belgrano, porção mais antiga do município de Belgrano, também incorporado ao território da capital no final do século XIX. Aí se sobressai o projeto de Urbanización de Bajo Belgrano realizado pela MCBA para abrigar 50.000 pessoas. O projeto se baseia no ideário moderno difundido pelo Grupo Austral e apresenta uma escala de bairro, compreendendo grande quantidade de unidades, equipamentos e projeto urbanístico calcado em zoneamento funcional das atividades.

Os bairros ao Sul do Centro se associam às primeiras atividades industriais implantadas na cidade, nomeadamente o bairro de La Boca. As intervenções no bairro remetem à atuação da CNCB, conforme pontuado anteriormente, e na década de 1940 demonstram uma ideia de intervenção em área fortemente ocupada, que propunha manter a alta densidade populacional diminuindo os índices de ocupação através da verticalização. Entre os projetos previstos para esta região, e não construídos, o conjunto para o local conhecido como Casa Amarilla, antiga área ferroviária em La Boca se destaca. Se não pela proposta da Dirección de la Vivivenda da MCBA, que se pode pressupor, dada a insuficiência de dados a seu respeito, que tivesse apenas um caráter propagandístico, pelo fato de esta área ter sido, em diversos momentos desde a década de 1940, considerada como espaço onde se deveria construir habitação social ${ }^{5}$. Nesse sentido, consideramos a importância de incluir esta área na análise sobre a setorização dos projetos.

O terceiro setor privilegiado para a construção de projetos habitacionais é o limite administrativo da capital no vetor Noroeste, onde concomitantemente se instalaram grandes centros de produção industrial. Conjuntos de moradias foram construídos em outros pontos do limite municipal, tanto em Buenos Aires quanto nos partidos adjacentes, mas o vetor Noroeste se destaca pelo agrupamento de quatro projetos, os conjuntos 17 de Octubre (MOP), Juan Perón (MOP), 1o de Marzo (MCBA) e 17 de Octubre-Grafa (MCBA). Destes, o Barrio Juan Perón e o Barria Grafa se destacam pelas grandes áreas ocupadas, no primeiro com unidades unifamiliares e no segundo com blocos multifamiliares.

A localização dos projetos habitacionais no espaço urbano e metropolitano de Buenos Aires, portanto, é marcada por três aspectos principais, a) a vinculação ao planejamento de expansão urbana e metropolitana no vetor Sudoeste, a "Operação Territorial de Ezeiza", b) a implantação em

\footnotetext{
${ }^{5}$ O primeiro projeto habitacional para Casa Amarilla foi elaborado por uma equipe formada por Antonio Bonet, Amancio Williams, Horacio Caminos, Eduardo Sacriste, Ricardo Rivas e Hilario Zalba em 1943, no âmbito da Organización de la Vivienda Integral en la República Argentina (OVRA). Atualmente o local ainda é subutilizado, mas conta com alguns edifícios residenciais. Em 2006 foi finalizada a construção de dois monobloques de apartamentos promovidos pelo Instituto de la Vivienda de la Ciudad de Buenos Aires, confirmando a vocação de Casa Amarilla para a construção de habitação social.
} 
áreas desfavorecidas da capital, promovendo a recuperação ou renovação urbana e c) a proximidade com importantes centros de produção junto ao limite Noroeste de Buenos Aires. Estes setores são referenciais não apenas porque neles está a maior parte dos conjuntos habitacionais propostos para a capital e a Grande Buenos Aires, mas porque neles estão os projetos que trazem a proposta de construção massiva da habitação. No mapa a seguir (Figura 96) é possível observar a localização de projetos que tinham entre 400 e 10.000 unidades, destacando-se a grande dimensão das áreas urbanizadas através da produção habitacional, especialmente em Bajo Belgrano, Ciudad Evita e no Barrio 17 de Octubre - General Paz.

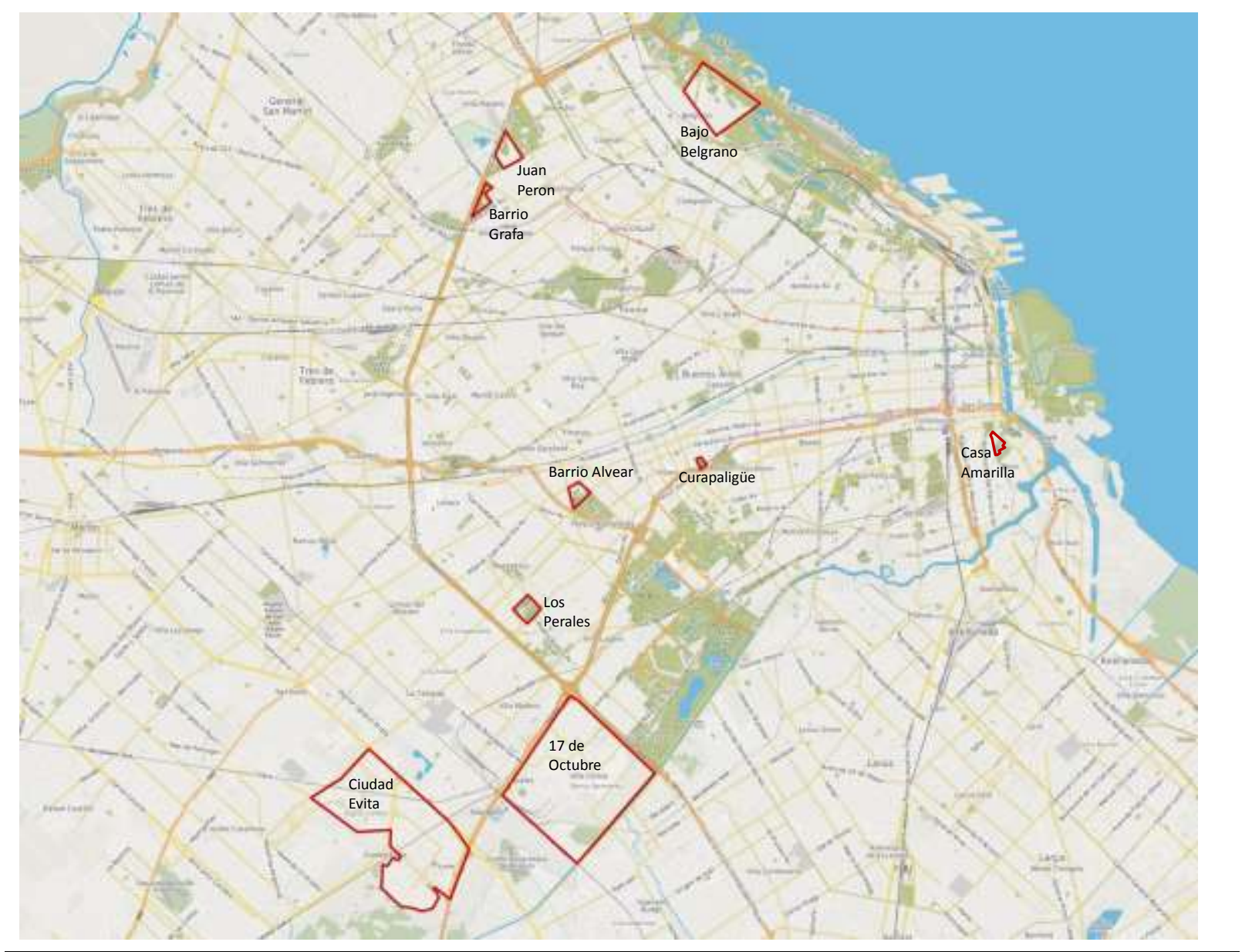

Figura 96. Mapeamento dos projetos habitacionais massivos em Buenos Aires e Grande Buenos Aires. Base cartográfica: "Mapa Interactivo de Buenos Aires", com intervenção da autora. Fonte: Mapa Interactivo. Gobierno de la Ciudad de Buenos Aires. Disponível em: <http://mapa.buenosaires.gov.ar>

* Não dispomos das áreas dos projetos de Villa Concepción, Barrio Justicialista e Parque Patrícios.

A operação territorial de Ezeiza conformou uma paisagem suburbana particular no vetor Sudoeste da Grande Buenos Aires, estabelecendo uma ampla gama de obras públicas e uma grande reserva de área verde (BALLENT, 1999). Partindo de um ponto relativamente próximo ao Centro da capital (distante $10 \mathrm{Km}$ ), no entorno do Parque Chacabuco, até o Aeroporto Internacional Ministro Pistarini em Ezeiza a operação percorria aproximadamente $24 \mathrm{Km}$, acompanhando a via que ligava estes dois 
pontos, a Autopista 25 de Mayo - Luis Dellepiane - Tte. Gral. Pablo Ricchieri, que no mapa acima é adjacente aos projetos Curapaligue, 17 de Octubre - General Paz e Ciudad Evita ${ }^{6}$.

Desde 1944, quando se inicia a construção do novo aeroporto ${ }^{7}$, o entorno da rota foi área de obras constantes executadas por diversas repartições do MOP. Tamanha foi a proporção da operação, que se promoveu a instalação de diversas olarias no vetor, garantindo o aproveitamento de material local. Entre as obras estão colônias de férias, hospitais, escolas, instalações esportivas e assistenciais, muitas delas vinculadas à Fundação Eva Perón, destacando-se conjuntos habitacionais de grande proporção. Na área urbana foram propostos conjuntos menores, ainda que dentro da proposta de construção massiva da habitação, enquanto fora do território da capital, foram propostos projetos em escala de bairros.

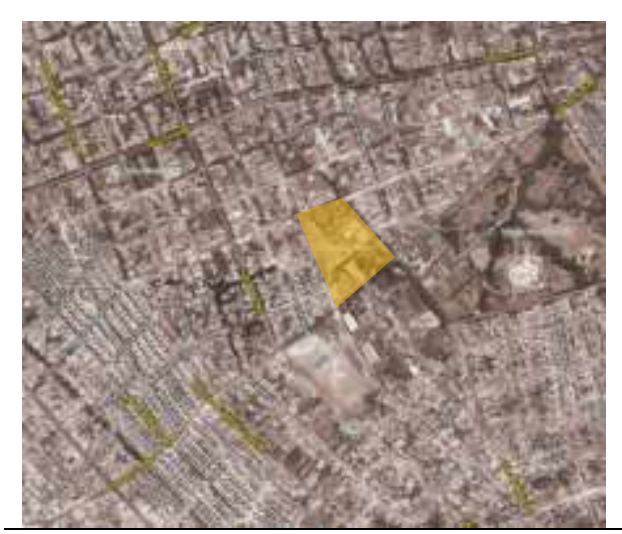

Figura 97. Vista aérea de 1940. Barrio Curapaligue. Fonte: Mapa Interactivo. Gobierno de la Ciudad de Buenos Aires. Disponível em: <http://mapa.buenosaires.gov.ar> Acesso em 06 maio 2017.

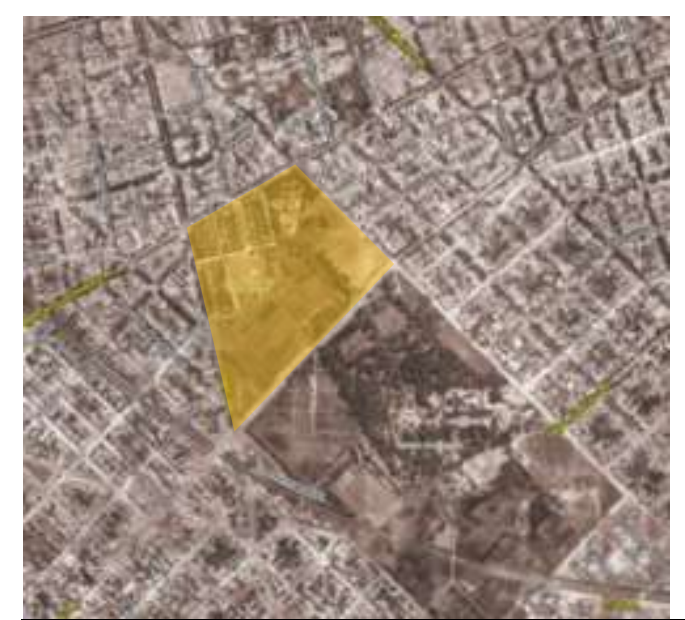

Figura 98. Vista aérea de 1940. Barrio Alvear. Fonte: Mapa Interactivo. Gobierno de la Ciudad de Buenos Aires. Disponível em: <http://mapa.buenosaires.gov.ar> Acesso em 06 maio 2017.

\footnotetext{
${ }^{6}$ Enfatizamos que embora o mapa seja atual, os principais acessos viários, que vemos em amarelo escuro, são os mesmos das décadas de 1940 e 1950.

${ }^{7}$ De acordo com Ballent (1999) as discussões sobre a construção do novo aeroporto remetem a 1935, mas é em 1943 que os ministros Juan Pistarini (Obras Públicas), Juan Peron (Guerra) e Alberto Tesaire (Marinha) escolhem o local definitivo (o lugar original era próximo ao rio Matanza, pois se pensavam em um aeroporto misto, que recebesse também hidroaviões), expropriando 6800 hectares no partido de Esteban Echeverria. A grande superfície desapropriada indicava que o aeroporto como questão técnica e urbanística era pensado já de forma diferente que na década anterior: não se previa somente o aeroporto, mas rodovias, moradias, equipamentos, parques e o plano de urbanização em si, ou seja, desde o inicio foi uma obra de grandes proporções.
} 
Os projetos Curapaligue e Alvear (III) foram propostos para as áreas já bastante ocupadas, como se pode observar nas fotos aéreas da década de 1940 (Figuras 97 e 98). Os terrenos remanescentes têm respectivamente áreas de 4,22 e 18 hectares, onde se propôs edifícios coletivos verticalizados ${ }^{8}$. Destaca-se também o fato de ambos os conjuntos estarem próximos a grandes parques da cidade, o Parque Avellaneda e o Parque Chacabuco, respectivamente. Os projetos do Barrio 17 de Octubre General Paz e Ciudad Evita, com áreas de 659 e 870 hectares, representam claramente o propósito de urbanização, correspondendo a verdadeiros bairros de moradias individuais e coletivas.

Os projetos no vetor Sudoeste, como já mencionado, estavam junto a vias importantes que faziam a ligação com o Centro de Buenos Aires. O Barrio Alvear é o único não margeado pelo acesso a Ezeiza, mas associa-se à Av. Perito Moreno, que se liga à Av. 25 de Mayo. Esta avenida parte da área ao Sul do Centro, junto a Puerto Madero, e na área próxima a estes conjuntos se torna a Rodovia Tenente Luis Dellepiane, que leva até o aeroporto em Ezeiza.

Estando muito próximo à Avenida General Paz, que perfaz o limite municipal, o Barrio Los Perales também se associa à ocupação do vetor Sudoeste. Ao mesmo tempo, sua construção se relaciona à atividade industrial localizada no bairro de Mataderos, onde o conjunto foi inserido. Tradicionalmente o bairro abrigava diversos matadouros, estando defronte o terreno onde foi proposto o conjunto Los Perales o Matadouro Lisandro De La Torre (Figura 99). Desde o Centro também se acessa o conjunto pela Av. 25 de Mayo, tomando a Av. Eva Perón antes que aquela se torne a Rodovia Dellepiane.

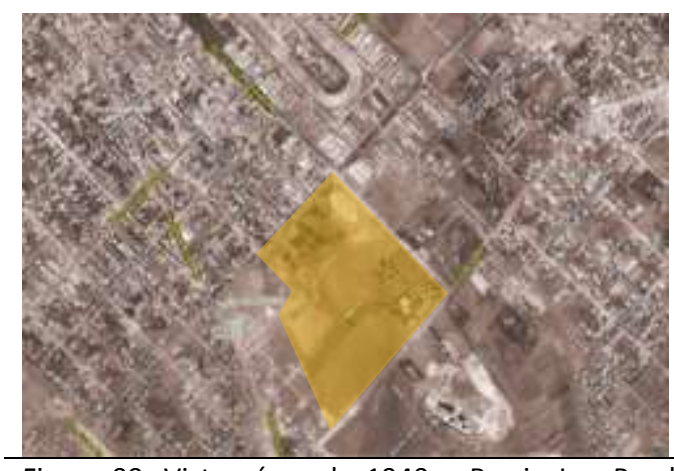

Figura 99. Vista aérea de 1940 - Barrio Los Perales e bairro operário parcialmente ocupado - a quadra adjacente ao conjunto, na direção Nordeste, é ocupada pelo Matadouro Lisandro De La Torre. Fonte: Mapa Interactivo. Gobierno de la Ciudad de Buenos Aires com intervenção da autora. Disponível em: <http://mapa.buenosaires.gov.ar> Acesso em 06 maio 2017.

Um ponto importante a destacar é que a operação Ezeiza criou uma nova entrada para a cidade, como uma nova fachada pensada em contraposição ao porto, por onde tradicionalmente se chegava a Buenos Aires. O rio deixava de ser o único acesso formal à cidade, valorizando-se o acesso através da pampa e, com isso, vinculando a capital a este território e, consequentemente, à sua população. "A pampa, símbolo do interior, era priorizada frente à abertura ao exterior, ao mundo, simbolizada pelo porto e o rio". (BALLENT, 2005, p.131, tradução nossa)

\footnotetext{
${ }^{8}$ Vale lembrar que o Barrio Alvear é iniciado ainda em 1927 pela CNCB, com a utilização de casas individuais e pabellones, sendo ampliado sob o governo peronista pelo BHN, através de pabellones e monoblocks.
} 
É possível considerar que a segunda setorização dos projetos na cidade, a implantação de projetos habitacionais em áreas que necessitavam de recuperação, por sua vez, representava uma ideia oposta àquela da valorização da pampa em detrimento do rio. Isto porque os projetos desse segundo setor se localizavam em áreas já consolidadas de Buenos Aires que de algum modo se vinculavam ao rio de la Plata, ao porto e à área industrial Sul (também diretamente ligada ao rio).

Exceto por um projeto habitacional (iniciado ainda pela CNCB e finalizado pela ANV), todos os demais previstos para as áreas em questão foram executados pela MCBA, o que nos diz muito a seu respeito. As tipologias de moradia coletiva eram priorizadas pela MCBA e estas se mostravam compatíveis com as condições de implantação nas áreas de recuperação, por se tratar de terrenos remanescentes ou alagáveis. Associando a verticalização ao uso do piloti, os projetos da MCBA garantiam a alta densidade populacional com baixa ocupação do solo, conformando ainda espaços de sociabilização. Além disso, uma parte dos projetos da MCBA aqui considerados se relaciona ao Estudio para el Plan de Buenos Aires iniciado em 1947, cujos principais aspectos são fundamentais à compreensão da proposta habitacional coletiva nestes locais desfavorecidos da capital. Entre os pontos principais do EPBA ressaltam a) a proposta de concentração urbana justamente através de áreas habitacionais de grande densidade, b) a redistribuição de atividades e densidades entre os vetores Norte e Sul, embora mantendo a área industrial próxima ao Riachuelo e c) abrir a cidade para o rio, remodelando a região portuária para criar espaços recreativos. É possível reconhecer estes pontos, por exemplo, nos projetos de Bajo Belgrano e Casa Amarilla ${ }^{9}$, respectivamente ao Norte e ao Sul da área central, o primeiro junto ao rio, o segundo em meio a uma antiga área industrial em La Boca, ambos propondo alta densidade habitacional através do conjunto de monobloques. Os três pontos levantados ajudam a entender a contraposição entre os projetos do Vetor Sudoeste, ligados a uma abertura para o interior, e os projetos de Belgrano e La Boca, associados ao rio.

$A$ área de Bajo Belgrano, embora tivesse grande porção de terrenos alagáveis devido à proximidade com o rio de la Plata, estava inserida em meio ao bairro ocupado historicamente por população de alto poder aquisitivo e além, disso, de fácil comunicação com a região central através de diversos ramais ferroviários, como se pode observar no mapa anterior e na foto aérea de 1940 (Figura 100). 0 projeto de Urbanización de Bajo Belgrano, concebido pela MCBA em 1948, buscava de fato urbanizar aquele espaço da "cidade frente ao rio", isto é, tornar possível a sua ocupação, conformando uma ampla área residencial. (URBANIZACIÓN DE BAJO BELGRANO, 1953)

O local conhecido como Casa Amarilla fica em La Boca, um dos bairros industriais de mais antiga ocupação na capital que, como tal, distinguia-se por grandes edificações fabris e casas operárias

\footnotetext{
${ }^{9}$ Apesar da insuficiência de dados a respeito do projeto elaborado para Casa Amarilla pela MCBA, temos a indicação de que seria constituído por 41 monobloques, conforme apresentado no Capítulo 1. É possível considerar também nesta análise o projeto pioneiro da equipe de Bonet, que se baseava na construção de monobloques, torres e um superbloco laminar que percorria toda a extensão do terreno, portanto, propondo também alta concentração para o local.
} 
bastante precárias, especialmente cortiços. A intenção deste projeto de urbanização era requalificar a área em questão, antiga zona ferroviária ocupada por linhas de ferro e construções abandonadas, junto ao estádio do Club Atletico Boca Juniors (Figura 101). O bairro conectava-se facilmente com o Centro através da Avenida Paseo Colón. (BAGNERA, 2008)

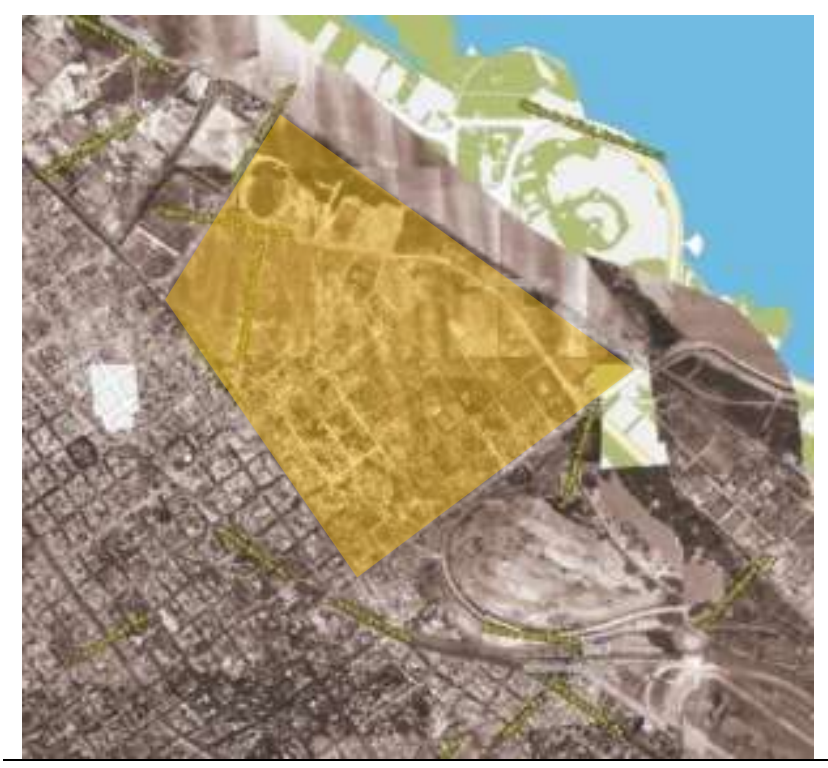

Figura 100. Vista aérea de 1940. Bajo Belgrano. Fonte: Mapa Interactivo. Gobierno de la Ciudad de Buenos Aires. Disponível em: <http://mapa.buenosaires.gov.ar> Acesso em 06 maio 2017.

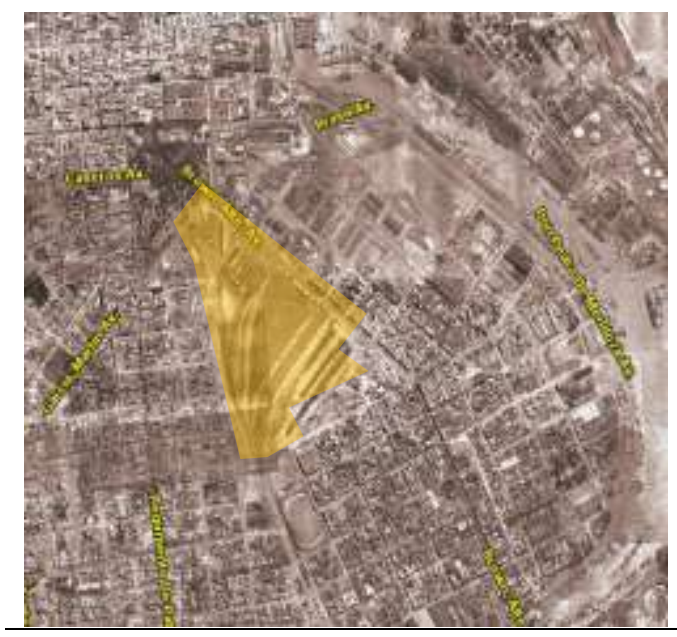

Figura 101. Vista aérea de 1940. Casa Amarilla. Fonte: Mapa Interactivo. Gobierno de la Ciudad de Buenos Aires. Disponível em: <http://mapa.buenosaires.gov.ar> Acesso em 06 maio 2017.

O terceiro aspecto que distingue a localização dos projetos habitacionais na Grande Buenos Aires, a proximidade com a atividade industrial instalada no limite Noroeste, se relaciona aos processos de industrialização, suburbanização e metropolização de Buenos Aires. Historicamente a atividade industrial se localizava no setor Sul da cidade, porém a partir da década de 1930 a abertura de novas vias de rodagem e o desenvolvimento de indústrias para as quais não era importante a proximidade com o rio implicou na conformação de uma espécie de anel industrial ao redor de Buenos Aires (GUTMAN; HARDOY, 1992). Essa nova localização industrial é favorecida ainda pelo aumento 
populacional a partir da mesma década de 1930, reforçado nos anos 1940 , que compõe amplo mercado de mão de obra, e pelas transformações promovidas pelo Estado peronista em termos da promoção de equipamentos e infraestrutura urbana que facilitariam o acesso à região periférica e às cidades da área metropolitana.

Junto à Avenida General Paz, que perfaz o limite urbano, localizam-se no setor Noroeste conjuntos habitacionais promovidos por diferentes entidades comitentes e, portanto, com características variadas. Aí estão os conjuntos Presidente Juan Perón (MOP) e Grafa (MCBA), massivos, e outros dois projetos menores, os bairros 1ㅇ de março (MCBA) e Albarellos (MOP).

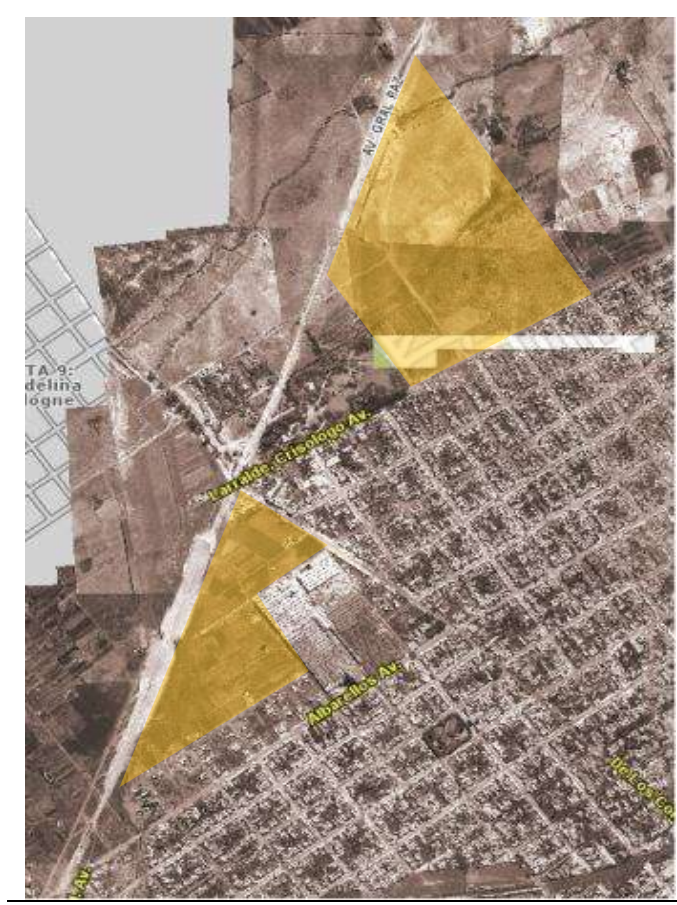

Figura 102. Vista aérea de 1940. Limite Noroeste e conjuntos Juan Perón e Grafa. Fonte: Mapa Interactivo. Gobierno de la Ciudad de Buenos Aires. Disponível em: <http://mapa.buenosaires.gov.ar> Acesso em 06 maio 2017.

Estando os quatro conjuntos muito próximos entre si é possível admitir que conformam um grupo a partir do qual se realizava a urbanização deste setor. Apesar de esta área encontrar-se já bastante ocupada, havia grandes terrenos vazios junto ao limite municipal e fora dele, como se vê na foto aérea (Figura 102) onde se instalaram diversas indústrias no período, de modo que é possível admitir que estes conjuntos se destinam também à produção da moradia para os operários. Não havia uma avenida importante de conexão direta entre estes conjuntos e o Centro, mas um ramal da ferrovia Mitre passava pelo bairro onde estavam inseridos, prevendo-se linhas de ônibus entre os conjuntos e os pontos de parada das ferrovias.

Conforme descrevemos, não é possível dizer que um único órgão tenha atuado em determinado setor, embora seja possível distinguir onde cada órgão mais atuou. Esta constatação fica evidente no mapeamento a seguir (Figura 103), que traz a localização dos projetos habitacionais no espaço da Grande Buenos Aires com identificação dos órgãos comitentes. 


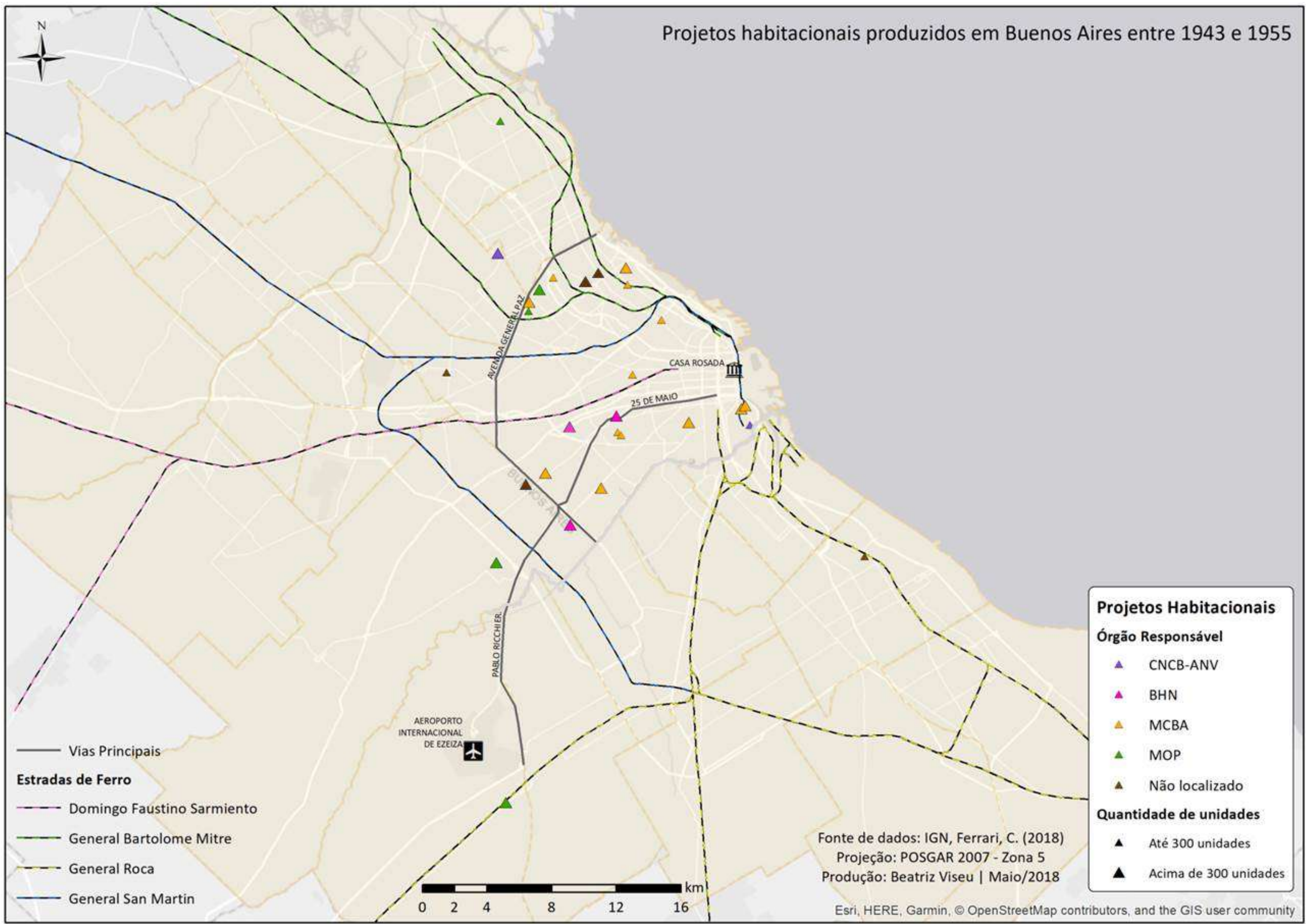

Figura 103. Localização dos conjuntos habitacionais projetados para a Grande Buenos Aires, com indicação do Instituto promotor. Elaboração de Camila Ferrari. Execução de Beatriz Viseu. 
O fato de diferentes órgãos atuarem na construção massiva da habitação social em Buenos Aires conferiu heterogeneidade aos projetos, conforme ressaltado por Aboy (2005) e Ballent (2005). Apesar de algumas linguagens se destacarem no conjunto da obra pública do período, não houve uma proposta única, uma "arquitetura peronista" associada a este ou aquele estilo. No entanto, existiram vínculos entre determinadas propostas estéticas e instituições promotoras, isto é, os programas arquitetônicos e urbanísticos assumiam determinada linguagem em função dos órgãos responsáveis por sua produção. Segundo Aboy (2005, p.45), a ação estatal direta na produção habitacional, revelava a "imagem com que o peronismo queria investir sua política social" e, ao ser realizada por vários órgãos, manifestava "conteúdos políticos, sociais e culturais mais plurais".

O órgão que produziu maior número de projetos habitacionais em Buenos Aires foi a MCBA, através da Dirección Municipal de la Vivienda (em amarelo no mapa). Apesar de restrita ao território da capital, ou seja, sem atuar na Grande Buenos Aires, a MCBA foi responsável por 13 dos 28 projetos habitacionais levantados, quase a metade, portanto. Sua ação ocorre em todos os setores em que é proposta a habitação, o vetor Sudoeste, as áreas de remodelação urbana em La Boca e Bajo Belgrano e a região Noroeste, junto ao limite administrativo e às novas áreas industriais.

Como já indicamos, os projetos da MCBA adotaram prioritariamente a proposta da moradia coletiva, utilizando tanto pabellones, com 4 pavimentos, quanto o monobloques de grande extensão. A obra de MCBA, portanto, se destaca pelo adensamento, a que se podem associar dois pontos importantes. O primeiro, o fato de que o escritório técnico da Dirección Municipal de la Vivienda contava com vários membros do Grupo Austral, cuja produção desde fora do aparato estatal era nomeadamente marcada por princípios modernistas, aos quais se associam o adensamento, a verticalização e a relação com o espaço da cidade, em detrimento de projetos desconcentrados, pouco densos e suburbanos (embora a MCBA tenha também atuado no limite urbano, mas promovendo conjuntos verticalizados). O segundo ponto, o fato de que a atuação no espaço da própria cidade podia estar vinculada a terrenos limitados em função da consolidação da ocupação, de modo que a produção massiva se concretizava através da verticalização.

A ação direta do BHN na produção habitacional (em rosa no mapa) se restringiu, conforme se observa, ao vetor Sudoeste, tanto na capital, quanto no município vizinho de La Matanza. Os projetos produzidos através de sua atuação não se distinguem por uma tipologia específica, verificando-se a construção de unidades em casas, blocos e edifícios. Apesar disso, é possível dizer que havia também certa tendência ao adensamento e à verticalização. Os três projetos do BHN vinculam-se ao projeto de construção massiva da habitação, dois deles ocupando terrenos remanescentes a partir da verticalização e o terceiro, proposto em ampla gleba periférica, mesclando as tipologias de edifícios, blocos e casas. 
O Ministério de Obras Públicas (MOP), através da Dirección de la Vivienda, ao contrário da MCBA, atuou mais fortemente nos partidos da Grande Buenos Aires, restringindo sua atuação na capital ao limite Noroeste, em terrenos fiscais aí disponíveis junto às novas indústrias instaladas na periferia (triângulos em verde). Também em oposição à atuação da MCBA, os projetos do MOP constituíramse prioritariamente de conjuntos de casas, que, apesar de massivos estavam associados a uma noção de baixo adensamento e dispersão da ocupação.

\subsection{Diferentes formas de morar em Buenos Aires no Peronismo}

$\mathrm{Na}$ busca por uma identidade nacional, a ação direta do Estado na provisão habitacional ao trabalhador a partir de 1946 implicou a conformação de um ampliado debate quanto à melhor forma de morar. As possibilidades ressaltadas por Aboy (2005) levaram à constituição e utilização de novos modelos urbano-arquitetônicos: o primeiro, o chamado "chalé argentino" construído no lote próprio associado ao padrão urbanístico cidade jardim e, o segundo, o monobloque ou o edifício em tira, associado à proposta da superquadra, respectivamente conformando os bairros de moradia individual e coletiva (LARRAÑAGA; PETRINA, 1987; BALLENT, 2005; ABOY, 2005). Cada modelo sugeria diferentes formas de morar, uma a partir de uma estética tradicionalmente utilizada no país, e por isso pensada como nacional, e outra a partir de uma estética modernista, pensada como a imagem desenvolvida que se queria para o país.

Larrañaga e Petrina (1987) destacam que ao eleger a unidade unifamiliar do tipo chalé, uma adaptação da casa popular no interior do país, de onde vinha grande parte da população moradora dos conjuntos produzidos nessa época, o Estado incorporava o modelo de vida do homem comum e este se identificava com esta arquitetura. Ao mesmo tempo o Estado não renunciava aos preceitos do Movimento Moderno, incorporando-os e sendo seu grande difusor em escala nacional através das obras produzidas pelos escritórios técnicos estatais, com destaque para os Edifícios dos Correios por todo o país e especialmente para o desenvolvimento da tipologia habitacional baseada no "monoblock racionalista", utilizada em diversos conjuntos habitacionais da época.

De acordo com Aboy (2005) esta heterogeneidade era expressão da tensão existente entre duas potentes imagens sociais mobilizadoras que atravessaram o peronismo: por um lado, a aspiração de ascensão social, cujo emblema era "o sonho da casa própria", e por outro, o ideário de igualdade social, materializado na produção seriada e massiva da habitação. A primeira ideia se concretizava no chalé individual, tanto na propriedade autoconstruída, quanto no âmbito da produção estatal direta nos bairros de casas unifamiliares. $\mathrm{O}$ chalé argentino, desde o princípio foi associado à propriedade $\mathrm{e}$ concebido sob uma estética que se associava a padrões de construção até então utilizados apenas pelas classes médias e altas. A segunda imagem se concretizava especialmente nas moradias coletivas, em que a imagem predominante era a dos edifícios padronizados, mesmo que houvesse 
apartamentos diferenciados. As unidades em moradia coletiva foram vinculadas apenas à locação até 1948, quando se aprova a lei de propriedade horizontal. Importa assinalar que em ambos os casos se propunha a definição de um novo entendimento da moradia, que

colocou a Argentina no topo de quase todas as políticas de habitação aplicadas por esses anos internacionalmente. Este conceito compreendia a habitação como uma função mais totalizadora que a tradicional concepção do tema, apenas limitado ao teto. As operações oficiais previam expressamente a incorporação de equipamentos comunitários [de educação, saúde, esporte, religião, recreação, cultura e comércio], o que veio a personificar fisicamente a doutrina progressista e socialmente integradora sustentada pelo governo. (LARRAÑAGA; PETRINA, 1987, p.110, tradução nossa)

Vale ainda mencionar que na década de 1930 o aumento do valor das terras urbanas em função da pouca disponibilidade de terrenos no território de Buenos Aires, associado ao desenvolvimento de novas tecnologias, apresentaram como consequência importante a compactação das unidades residenciais. De acordo com Aboy (2005), a redução e a racionalização das plantas se manifestaram tanto na moradia individual, quanto na coletiva e tanto na moradia operária quanto na casa burguesa, com algumas diferenças temporais e no padrão final adotado.

Nas unidades individuais essa redução foi em alguns casos associada a "um conjunto de recursos formais agrupados sob a denominação de 'linguagem' ou 'estilo californiano'" (ABOY, 2005, p.33, tradução nossa). A utilização do "estilo californiano" é, segundo Ballent (2005), um fenômeno de definição imprecisa, mas com imagem bastante característica: paredes brancas, cobertura inclinada com telha espanhola, utilização de materiais locais, efeitos pintorescos e recuperação de elementos da arquitetura colonial espanhola.

A linguagem era utilizada no país desde a década de 1920, quando conviviam estilos variados de origem europeia e formas recuperadas do passado colonial espanhol. A recuperação das formas coloniais se associava a uma corrente de revalorização da origem espanhola que se opunha aos referenciais da arquitetura acadêmica e ao Internacional Style difundido por experts e vanguardistas. A denominação "californiano", por sua vez, se deveu ao fato de essa recuperação da arquitetura colonial espanhola ter-se disseminado por intermédio de uma influência norte-americana na mesma década de 1920, através do chamado "Estilo Missões".

Quando o Estado dá início à construção social da habitação esta linguagem é associada a uma arquitetura rústica, à cidade-jardim e a desconcentração urbana, símbolos do que o peronismo considerava a felicidade popular (BALLENT, 2005). Sugeria-se que estes elementos garantiam a idiossincrasia das novas moradias perante a população moradora, considerando-se necessário a princípio, por "questões de responsabilidade e sensibilidade social, que se mantivessem características formais reconhecíveis aos usuários aos quais se destinava esta habitação", basicamente trabalhadores migrantes do interior do país, lançando-se mão de uma linguagem 
eclética que remetia às tipologias unifamiliares e ao espaço urbano do interior. (LARRAÑAGA; PETRINA, 1987, p.209, tradução nossa)

Nos anos 1940 se consolida a ideia de que a representação do país devia ser sinônima de interior, porém "o problema não consistia tanto na criação de uma arquitetura nacional, como certos setores nacionalistas pretendiam, mas de encontrar um tipo de obra adaptada à totalidade do país" (BALLENT, 2005, p.125, tradução nossa). Assim "o chalé californiano, miniaturizado e simplificado pelos requerimentos da construção massiva, se convertia pela ação da política em 'chalecito peronista"' (BALLENT, 2005, p.102, tradução nossa). Propondo a habitação em propriedade individual com uma mesma tipologia repetida em todo o país, a solução do "chalecito peronista" ou ainda "chalet argentino", em versões simplificadas do californiano, foi aplicada em todas as províncias. $\mathrm{Na}$ Figura 104 veem-se diferentes tipos de chalecitos construídos em Ciudad Evita.

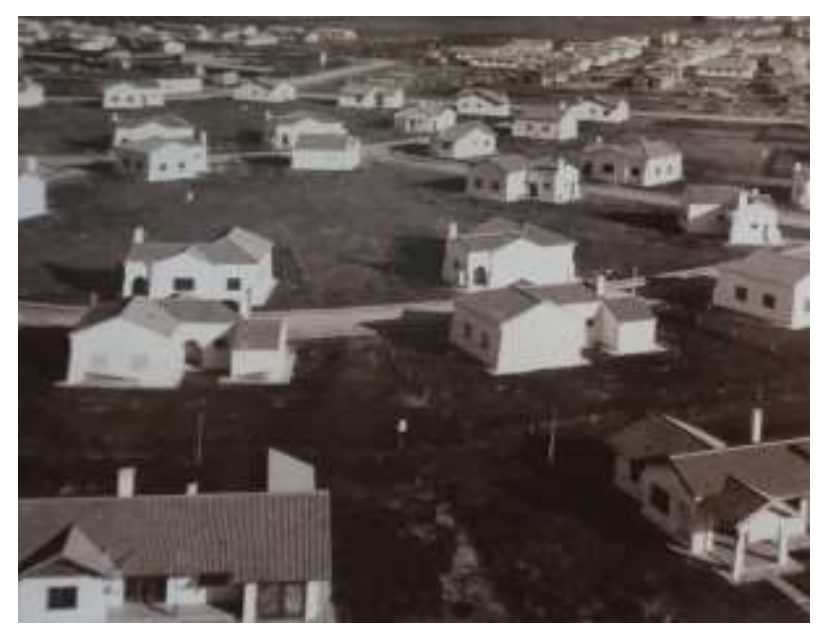

Figura 104. Tipos variados de "chalecitos peronistas" em Ciudad Evita. Fonte: Umbrales de un siglo: una historia de la vivienda social en la Argentina: de los Conventillos al Plan Federal. Buenos Aires: Ministerio de Planificación Federal, Inversión Pública y Servicios, 2010. s/p

As elites abandonam esta linguagem nos anos 1930 em favor de linguagens mais refinadas, porém ela ainda figurava na imprensa como um alto padrão construtivo e estético. Para vários autores a apropriação do estilo californiano trazia embutida a ideia de dignificação da moradia operária, tornando sua aparência similar às casas das elites: ao apropriar-se de um modelo prestigiado pelas classes médias e altas, o chalet figurava no imaginário coletivo como símbolo de prosperidade e modernidade. (LARRAÑAGA; PETRINA, 1987; ABOY, 2005; PASTOR, 1944)

A questão dos modelos urbano-arquitetônicos foi objeto de debates e disputas entre as décadas de 1930 e 1950. Os militantes do catolicismo social tinham grande participação nos debates e na definição de programas habitacionais, articulando-se a promotores privados desde as primeiras décadas do século XX e à produção estatal da moradia a partir da década de 1940, sendo partidários da casa individual. A principal crítica às tipologias coletivas era realizada em função do temor da propagação do Comunismo: estes tipos propiciavam o encontro e a sociabilidade e, portanto, a 
disseminação de ideias revolucionárias. Nesse sentido, a moradia era concebida como arena de disputa política e instrumento de reforma social, extrapolando o campo técnico. Contudo, desde a década de 1930 a partir da difusão do ideário moderno, a padronização, a simplicidade formal e a possibilidade de produção seriada das tipologias de moradia coletiva passam a ser valorizadas. Entre os setores altos e ilustrados já se superava a noção de que os espaços comuns associados a estas moradias possibilitavam o desenvolvimento do Comunismo, ao mesmo tempo em que se estimava o caráter vanguardista da arquitetura moderna. (ABOY, 2005)

Nas décadas de 1920 e 1930, com a incorporação do tema da moradia popular aos programas da Escola de Arquitetura da UBA novos critérios técnicos e estilísticos foram acionados para os projetos habitacionais, embora nem todas as propostas fossem passiveis de realização pela pouca disponibilidade de materiais construtivos modernos, em grande parte importados, e pela pouca capacidade técnica incorporada ao processo (CIRVINI, 2012). Contribuiu para a discussão sobre a moradia, além do próprio desenvolvimento tecnológico e da realização dos primeiros congressos profissionais em âmbito latino-americano, a convocação de concursos para a produção de conjuntos habitacionais.

Em 1925, por exemplo, a MCBA lançou um concurso para a construção de três conjuntos de moradias populares nos bairros de Chacarita, Flores e Palermo, sendo construído apenas o Conjunto de Chacarita, conhecido como Barrio Los Andes. Projetado pelo arquiteto Fermín Bereterbide (que obtivera também o primeiro prêmio para os outros dois conjuntos), o conjunto é composto por doze pabellones de 4 pavimentos com um total de 130 apartamentos com 3, 4 e 5 dormitórios. O conjunto conta ainda com salas comerciais, lavanderia, sala de espetáculos, um jardim de infância, uma biblioteca e espaços verdes de uso público (CONJUNTO LOS ANDES, 2017). Claramente se delineiam no projeto preceitos trabalhados pelos profissionais de arquitetura nos debates daquele momento, a começar pela própria proposta da moradia coletiva.

A partir de 1946, a necessidade de uma resposta à crescente demanda habitacional, não apenas por parte da população migrante, "mas também por diversos grupos que constituíam a classe média (empregados do Estado, indústria e comércio; bancários; oficiais das Forças Armadas) levou à percepção da moradia coletiva como forma mais efetiva para solucionar o problema", iniciando-se a produção dos monobloques, que elevavam a resolução da questão da moradia em grande escala a um novo patamar. (LARRAÑAGA; PETRINA, 1987, p.212, tradução nossa)

Em contraponto à imagem dos "chalecitos peronistas" em que se associavam a arquitetura rústica, o urbanismo do tipo cidade jardim e a proposta de desconcentração urbana, nas moradias coletivas destacam-se a arquitetura modernista, o padrão urbanístico da superquadra e a proposta de concentração urbana. A desconcentração, conforme mencionado, era questionada em função da pouca disponibilidade de terras livres na capital, colocando-se, portanto, a possibilidade de 
concentração, isto é, de alta densidade populacional sem que para isso se utilizassem grandes áreas urbanizadas. A concentração se relacionava diretamente à ideia do edifício vertical e "embora a moradia coletiva não se ligasse exclusivamente ao desenvolvimento da verticalização, em geral se associou a ela e a uma forma de morar urbana, metropolitana" (BALLENT, 2005, p.185, tradução nossa). Ao contrário, a imagem do chalé peronista era associada a uma forma de morar campesina.

O ideário moderno era incorporado aos edifícios verticais desde finais da década de 1920: fachadas brancas e sem adornos, plantas compactas e racionalizadas, novos dispositivos e elementos de conforto. Destaca-se na Buenos Aires dos anos 1930 o Edifício Kavanagh, construído em 1933 e que até hoje permanece como ícone da arquitetura modernista, diferenciando-se dos demais edifícios ao redor da Plaza General San Martin. Na produção habitacional estatal, vale mencionar o Monoblock General Belgrano (133 unidades, 1948-52) (Figura 105), edifício vertical isolado construído próximo à ferrovia Mitre em Belgrano.

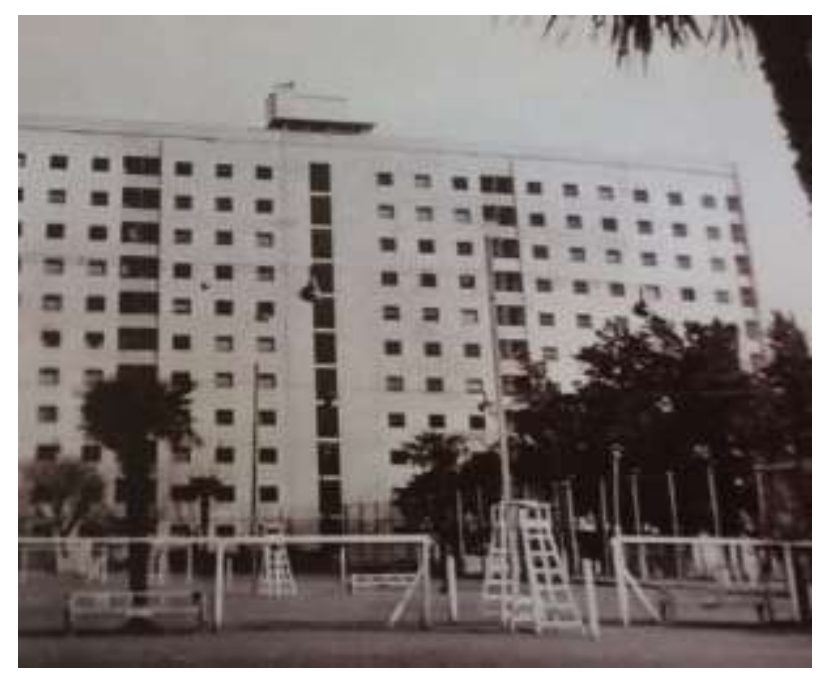

Figura 105. Monoblock General Belgrano. Fonte: Umbrales de un siglo: una historia de la vivienda social en la Argentina: de los Conventillos al Plan Federal. Buenos Aires: Ministerio de Planificación Federal, Inversión Pública y Servicios, 2010. s/p

Os modernos edifícios coletivos eram considerados máquinas de morar e, portanto, exigiam novas condições e posturas de seus moradores. Aos poucos a ideia do habitar coletivo se transfere do espaço perigoso, em que se disseminavam políticas socializantes, para um possível "fator de reforma social" em que se estabelecia a vigilância da conduta coletiva. Contribuiu certamente para este processo a evolução - não necessariamente linear - do edifício com pátio central para o pabellon, em que se garantia a abertura e visibilidade do espaço livre comum, alterando-se não apenas sua forma, mas também "seus usos e sua relação com a rua, reafirmando a necessidade de sua existência baseada em objetivos tanto higiênicos como moralizadores" (BALLENT, 2005, p.205, tradução nossa). Rapidamente os equipamentos e espaços de uso comum adquiriram importância não como um benefício extra aos conjuntos habitacionais, mas como suporte à própria definição do morar coletivo. 
Além do aspecto de uma nova postura social colocada (e esperada) ao morador dos conjuntos de edifícios coletivos, aí se materializava outra imagem importante para o peronismo, a ideia de igualdade social. No conjunto de moradias coletivas não se destacavam hierarquicamente unidades maiores ou mais luxuosas, ao contrário, predominava a padronização dos edifícios, mesmo que internamente às unidades houvesse diferenças.

A este propósito se associa fortemente a ideia da produção em série que, embora estivesse presente também na moradia individual pela utilização de alguns tipos pré-determinados de chalés, se evidencia na moradia coletiva. A produção em série pode ser notada pela repetição de tipos de edifícios em um mesmo conjunto, como no Barrio Los Perales, pela utilização de módulos, que associados compunham os edifícios laminares, como nos barrios Grafa e 17 de Octubre (em La Matanza) (Figura 106), onde inclusive foram utilizados os mesmos tipos de edifício do Barrio Curapaligue. Concomitantemente, eram oferecidos a todos os moradores os mesmos benefícios nos espaços coletivos do conjunto.

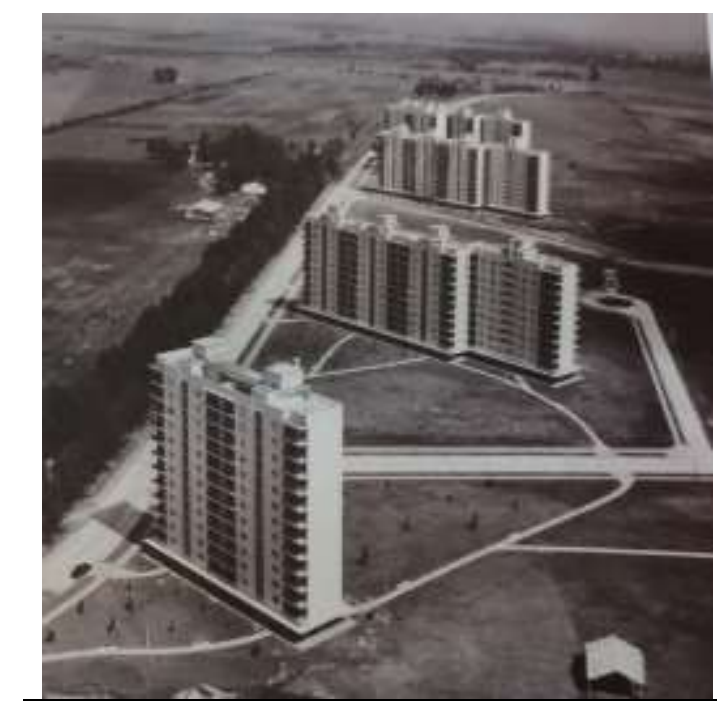

Figura 106. Edifícios do Barrio 17 de octubre - General Paz, La Matanza, Buenos Aires. Fonte: Umbrales de un siglo p.136

Conforme descrito por Ballent (2005) vários termos foram utilizados para descrever os edifícios multifamiliares na Argentina: casa colectiva, casa de renta, casa de departamentos, pabellon. Casa colectiva geralmente se referia a edifícios multifamiliares construídos pelo Estado ou outras instituições filantrópicas que incorporavam espaços de uso comum e exploravam os benefícios da concentração, tentando conformar uma comunidade. Os termos casa de renta e casa de departamentos se utilizavam para edificações particulares destinadas majoritariamente a classes mais abastadas, mas depois de 1948, em função da lei de propriedade horizontal, o último passou a distinguir os edifícios de unidades para venda. Já a expressão pabellon se referia a uma tipologia formal: o bloco isolado, linear e de altura variável, sinônimo também de monoblock, embora este último geralmente seja empregado em referência a edifícios mais verticalizados. O bloco isolado, 
como o próprio conceito compreendia, era vinculado à proposta de implantação em grandes glebas, sendo por isso mais utilizado em obras estatais que nas obras particulares. Logo, porém, se convencionou denominar edifícios pabellonales a blocos laminares mais compactos, edificados em lotes urbanos.

As construções públicas e privadas enfrentavam os mesmos problemas no que se referia ao custo da terra urbana, especialmente porque em grande parte dos casos se procurava garantir uma aproximação entre os locais de moradia e de trabalho, o que significava empreender em locais já urbanizados e consolidados e, portanto, mais caros. Em termos da localização no espaço urbano portenho, historicamente a CNCB concentrou suas edificações nos bairros ao sul do Centro como operação de recuperação urbana de um dos setores mais ocupados da cidade, enquanto a Cooperativa el Hogar Obrero, para apresentar um exemplo de atuação privada, optou por locais não necessariamente centrais, mas adensados, onde houvesse uma demanda potencial para as cooperativas de consumo instaladas nos níveis inferiores dos edifícios residenciais (HISTÓRIA ARGENTINA DE LA VIVIENDA..., s/d). A partir da década de 1940 o setor privado como um todo seguirá edificando em áreas densamente ocupadas, enquanto o Estado utilizará amplos terrenos "livres das limitações do traçado urbano tradicional", localizados majoritariamente na periferia urbana, dando lugar a massivos conjuntos habitacionais. (BALLENT, 2005, p.190)

Fora dos conjuntos a noção de igualdade social também era buscada no sentido da democratização do acesso aos benefícios da cidade, no que, a princípio, se pode objetar que as tipologias coletivas (e verticais) se sobressaíam em comparação às individuais, dada a possibilidade de edificá-las em locais já urbanizados em função da menor necessidade de espaço. Considerando aspecto importante para a compreensão da ação habitacional pelo Estado peronista o processo de ocupação urbana de Buenos Aires e dos municípios vizinhos à capital e o modo como a política peronista se relacionou com estes espaços, no âmbito do "direito à cidade" detectado por Ballent (2005), realizamos um breve estudo sobre o processo de suburbanização e metropolização de Buenos Aires.

\subsection{Suburbanização e Metropolização: Moradias e Indústrias na Grande Buenos Aires}

Os dados dos Censos Nacionais de 1914 e 1947 mostram um aumento de aproximadamente 1,5 milhão de pessoas na capital e de mais de 2,5 milhões na Grande Buenos Aires (Quadro 10). Na década de 1940 o principal fator de crescimento populacional não é a imigração europeia como no final do século $\mathrm{XIX}^{10}$, mas as migrações desde o interior do país. Entre 1936 e 1947 pessoas do interior se deslocam para as grandes cidades do país, nomeadamente para Buenos Aires, atraídas pela possibilidade de trabalho na indústria que crescia desde o início da década de 1930 e é

\footnotetext{
10 Devido aos efeitos da crise de 1929 a imigração europeia é praticamente interrompida e, apesar de retomada após a Segunda Guerra Mundial, não voltou a apresentar números importantes.
} 
justamente esta população a maior beneficiária da produção habitacional realizada pelo Peronismo (ABOY, 2005). Este período é considerado por Torres (2006) como o segundo momento de suburbanização de Buenos Aires, quando a ocupação urbana se estende sobre os municípios da Grande Buenos Aires. O primeiro momento de suburbanização, segundo o autor, corresponde aos anos entre a última década do século XIX e as duas primeiras décadas do século XX quando houve também grande adensamento populacional, mas a partir da imigração. Como se vê no Quadro 10 naquele momento a população de Buenos Aires aumentou em mais de 1 milhão de pessoas.

\section{Quadro 10}

População em Buenos Aires e na Grande Buenos Aires (1852-1960)

\begin{tabular}{ccc}
\hline Ano & Buenos Aires & Grande Buenos Aires $^{11}$ \\
\hline 1852 & $\sim 85.000$ & \\
1869 & 177.787 & \\
1887 & 433.375 & \\
1914 & 1.575 .814 & 2.034 .031 \\
1947 & 2.981 .043 & 4.722 .381 \\
1960 & 2.966 .634 & 6.739 .045 \\
\hline
\end{tabular}

Fontes: Tabela elaborada pela autora com base em dados de GUTMAN e HARDOY (1992) e INDEC - Censos Nacionales e Ministerio del Interior, Obras Publicas y Vivivenda.

Apesar de nos dois grandes momentos de aumento populacional registrar-se paralelamente um crescimento urbano expansivo, ou um processo de suburbanização, é necessário reforçar uma diferença fundamental quanto à localização destas novas populações no espaço urbano. Os primeiros novos habitantes, os imigrantes, se alojaram especialmente no Centro e nos bairros ao Sul da área central, enquanto a população anteriormente residente nestes locais se transladava para novos bairros mais distantes da área central, expandindo a área urbanizada. Os segundos novos habitantes, os migrantes, alojaram-se fundamentalmente na periferia, onde estavam as novas áreas industriais que conformavam um cinturão ao redor do território da capital, sendo, portanto, os responsáveis pela expansão da mancha urbana neste momento.

A diferença ocorre especialmente em função do próprio processo de ocupação urbana e da promoção da infraestrutura de serviços e transportes que se desenvolvem significativamente entre os dois momentos. Torres (2006, p.3, tradução nossa) afirma que "os períodos de mudança dos processos internos de estruturação espacial de Buenos Aires estão intimamente relacionados aos grandes períodos de mudança econômica, demográfica, social e política que afetam o desenvolvimento metropolitano como um todo."

O aumento das exportações de produtos relacionados à agropecuária, sobretudo grãos e couro, no final do século XIX, se relacionou a um rápido crescimento de certa atividade industrial em Buenos

11 A Grande Buenos Aires é oficializada em 1948, porém desde 1914 os Censos Nacionais realizavam a contagem populacional dos partidos da área metropolitana, compreendendo já a existência de uma relação estreita entre sua organização socioeconômica e a da capital. 
Aires. A atividade, por um lado, impulsionou a instalação de fábricas destinadas a suprir uma demanda crescente por produtos necessários à própria empresa e, por outro, possibilitou o aumento das importações, inicialmente de tecnologia para as próprias indústrias. A Argentina se industrializava ao mesmo tempo em que se integrava ao mercado mundial. (IRIGOIN, 1984)

O processo de industrialização desenvolvido em Buenos Aires, porém, esteve relacionado não apenas ao crescimento e às necessidades da atividade econômica principal, mas, assim como em São Paulo, à conformação de um mercado de fatores fundamentais à atividade industrial. A expansão da agroexportação se associava à formação de um mercado de capitais, que permitia certa acumulação necessária à empresa industrial. Ao mesmo tempo, o aumento populacional, vinculado ao fator de atração que Buenos Aires exercia em função da atividade econômica e política, como nova capital, possibilitava a constituição de um mercado de mão de obra e de consumo, que nesse sentido, impulsionava também a atividade comercial e de serviços.

Além da própria acumulação da atividade agroexportadora, foi fator importante para impulsionar a industrialização na década de 1880 a entrada de capitais externos, especialmente ingleses. A maior estabilidade política e a inserção no mercado mundial propiciaram a inversão de capitais estrangeiros em empresas do país e, especialmente, no desenvolvimento das comunicações, com destaque para a rede ferroviária que passa de $2.400 \mathrm{Km}$ em 1880 para mais de $30.000 \mathrm{Km}$ em 1914 (IRIGOIN, 1984). Interligando portos ao interior, as ferrovias promoveram não apenas o desenvolvimento industrial, transportando matérias primas e produtos, como também o desenvolvimento de núcleos urbanos no interior do território. Buenos Aires se conformava como ponto de encontro dos mercados interno e externo, onde estava o porto mais importante do país e para onde confluía a rede ferroviária.

A atividade de importação, além de atender às próprias indústrias, supria as necessidades do mercado de consumo interno que se conformava naquele período, nomeadamente um mercado de luxo, destinado às elites. Paralelamente, conformava-se também um mercado de consumo de produtos corriqueiros, destinados à população em geral. Este mercado foi em grande parte atendido por pequenas indústrias nacionais que se constituíam justamente para atender a esta demanda. Assim, além de indústrias relacionadas à pecuária e ao beneficiamento de grãos, instalavam-se também fábricas de alimentos, tecidos, carpintarias e serralherias.

O mercado de consumo dos produtos fabricados internamente se formava especialmente pelos imigrantes, cuja entrada no país se amplia na mesma década de 1880. Além de constituir mercado consumidor, a importância da corrente imigratória recai na conformação do mercado de mão de obra, o que, conforme explicam Gutman e Hardoy (1992) e Irigoin (1984), deve-se especialmente ao fato de que a grande maioria dos recém-chegados era de homens em idade ativa, muitos dos quais com experiência em atividades manufatureiras. 
Acentuavam-se neste momento as diferenças entre a estagnação econômica de grande parte do interior do país e o crescimento da região litorânea, de influência mais direta de Buenos Aires e seu porto. Segundo Irigoin (1984) os dados mostram que $83 \%$ da atividade industrial do país na década de 1890 se concentrava especialmente na Capital Federal e nas províncias de Buenos Aires, Santa Fe, Entre Ríos e Corrientes. O Quadro 11 mostra o número de estabelecimento fabris e o número de empregados no setor industrial no país, nas províncias de Santa Fé e Buenos Aires e na capital federal em 1895 e 1914, anos dos censos nacionais.

Quadro 11

Indústrias manufatureiras no país e na capital federal

\begin{tabular}{|c|c|c|c|c|}
\hline \multirow[t]{2}{*}{ Unidade } & \multicolumn{2}{|c|}{$\begin{array}{c}\text { Número de } \\
\text { Estabelecimentos }\end{array}$} & \multicolumn{2}{|c|}{ Pessoal empregado } \\
\hline & 1895 & 1914 & 1895 & 1914 \\
\hline País & 24.114 & 48.779 & 145.650 & 410.201 \\
\hline Santa Fé & 2.678 & 5.829 & - & - \\
\hline Buenos Aires & 5.576 & 14.848 & - & - \\
\hline Capital federal & 8.439 & 10.275 & 70.469 & 149.289 \\
\hline \multicolumn{5}{|c|}{$\begin{array}{l}\text { Fonte: Elaboração da autora com base em INDEC - Censos Nacionales de 1895, } \\
\text { 1914; Censos Municipales; Irigoin, Alfredo M. "LA EVOLUCIÓN INDUSTRIAL EN LA } \\
\text { ARGENTINA (1870-1940)" In: Libertas (ESEADE). Buenos aires, oct. } 1984 .\end{array}$} \\
\hline
\end{tabular}

Os dados mostram que em 1895 havia 24.114 estabelecimentos industriais no país e que um terço deles (35\%) aproximadamente ficava na capital enquanto outro terço se distribuía nas províncias de Buenos Aires e Santa Fé. Em 1914 o número de estabelecimentos é duplicado no país, mas na capital ocorre um aumento relativamente pequeno, de 1,2\% apenas, enquanto em Santa Fé o aumento é proporcional ao do país e na província de Buenos Aires o número de estabelecimentos é quase triplicado (2,66\%). Este dado condiz com o fato de que já em 1900 praticamente não havia espaços disponíveis no território da capital, implantando-se novas indústrias nos partidos ao Sul, como Avellaneda, Lanús e Quilmes. A evolução do número de empregados na indústria, porém, tem outra configuração: se em 1895 aproximadamente a metade (48\%) do pessoal empregado na indústria estava em Buenos Aires, em 1914 este número é duplicado e corresponde a pouco mais de um terço do total no país (36\%). Os dados revelam, portanto, que embora o número de indústrias na capital não tenha aumentado proporcionalmente ao aumento do país, o pessoal empregado continuava escolhendo morar em Buenos Aires, e, segundo Gutman e Hardoy (1992) e Irigoin (1984) com forte componente imigratório.

Os vetores Sul e Sudoeste da capital eram em 1910 as áreas menos urbanizadas de Buenos Aires, com predomínio de terrenos baixos e inundáveis, especialmente junto ao Riachuelo, que limitava o município a Sul. "Aí se localizaram as primeiras indústrias e demais atividades que exigiam espaço e produziam dejetos e odores, como matadouros e aterros sanitários" (GUTMAN; HARDOY, 1992, p.92, tradução nossa). 
A década de 1930, iniciada com a crise mundial, assiste na Argentina à queda do modelo agroexportador e ao desenvolvimento de um processo de industrialização para substituição de importações, direcionado especialmente à produção de bens de consumo. Neste novo contexto Buenos Aires não apenas continua a ser o principal núcleo da economia, como ganha importância em função da instalação de diversas indústrias na periferia da cidade e nos municípios vizinhos, conformando-se uma espécie de cinturão industrial ao redor da capital que permaneceria sendo a principal área de expansão industrial até a década de 1960.

Devido a uma série de fatores tais como seu desenvolvimento industrial anterior, a rede de transportes, comunicações e serviços existente, um grande contingente de mão-de-obra industrial, população e o tamanho do mercado interno, junto com a Grande Buenos Aires, a capital oferecia ainda as melhores vantagens comparativas do país para a indústria (GUTMAN, HARDOY, 1992). Embora várias indústrias (químicas e têxteis especialmente) tenham se estabelecido no vetor Sul entre 1930 e 1945, desde a década de 1930, essa tendência se alterava e numerosos estabelecimentos eram instalados nos partidos a Oeste e Norte da Capital, dando início à conformação do cinturão industrial da Grande Buenos Aires.

Nesses novos estabelecimentos a necessidade de proximidade com a ferrovia e o Riachuelo era menor, enquanto a proximidade com as rodovias foi decisiva. Entre 1936 e 1941 foi construída a Avenida General Paz em torno da capital e alguns anos depois o Acesso Norte, parte da Rota PanAmericana ao longo da qual se desenharia até a década de 1960 a nova área industrial da Grande Buenos Aires. Junto à Avenida General Paz, ainda dentro dos limites da capital se instalaram também grandes indústrias, tais como a Philips Eletrônicos e as têxteis Grafa e Sudamtex. No início da década de 1940 a Capital Federal ainda era a área industrial mais importante da Área Metropolitana, possuindo mais de trezentos mil trabalhadores industriais, cerca de três vezes mais o total de operários dos 25 partidos da Grande Buenos Aires.

O desenvolvimento da indústria baseado na substituição das importações aumentou a necessidade de mão de obra e a população portenha não era capaz de atender a esta demanda, o que acarretou, ainda na década de 1930, na elevação dos salários dos trabalhadores industriais. Homens do interior, especialmente jovens, acorreram à cidade e, tão logo resolvessem sua condição de trabalho e moradia, trouxeram também suas famílias. A grande maioria destes trabalhadores habitava os bairros mais periféricos e afastados do Centro. (GUTMAN; HARDOY, 1992)

Para entender as razões pelas quais a população de poucos recursos ocupou essencialmente a periferia da capital na década de 1930 é fundamental a compreensão de que neste momento o espaço urbano de Buenos Aires já se achava praticamente consolidado. Em função da consolidação da ocupação de seu território, o crescimento da própria cidade após 1930 ocorre praticamente 
apenas através do processo de verticalização das construções, enquanto a expansão horizontal ocorre como processo de suburbanização, ocupando os municípios adjacentes (TORRES, 2006).

Embora a cidade crescesse espacialmente, esse crescimento foi mais lento que o aumento da população, implicando um adensamento geral da capital e dos partidos mais próximos. Somente nas décadas de 1940 e 1950, coincidindo com o segundo período de crescimento acelerado da população da Área Metropolitana de Buenos Aires, houve uma grande expansão da área urbanizada acompanhada de uma diminuição geral das densidades. (GUTMAN; HARDOY, 1992, p.100, tradução nossa)

O Mapa de Evolução da Edificação de Buenos Aires (Figura 107) publicado em 1944 pela Dirección General de Obras Públicas y Urbanismo de la Municipalidad de la Ciudad de Buenos Aires auxilia a compreensão da ocupação urbana até aquele momento.

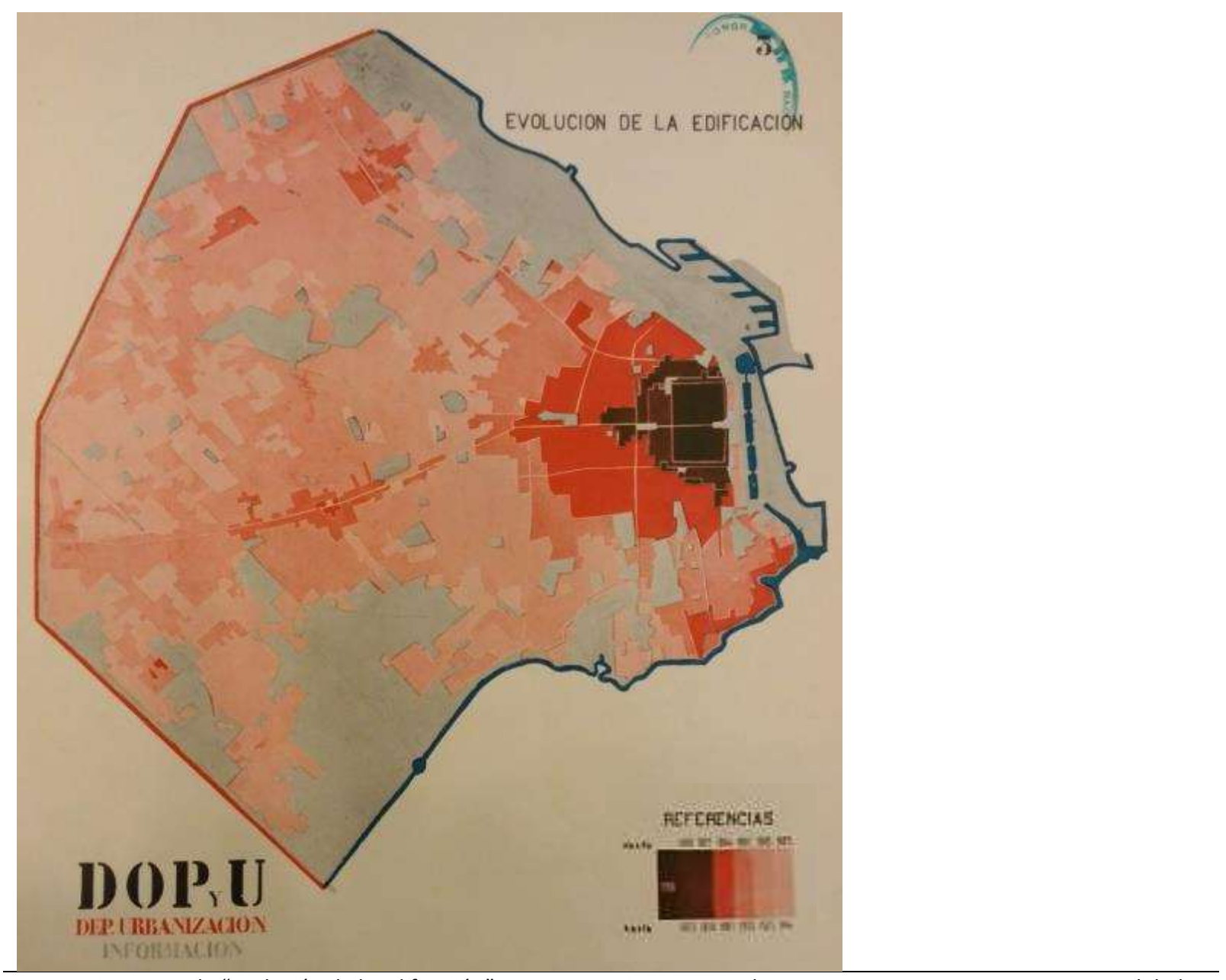

Figura 107. Mapa de "Evolución de la Edificación" em Buenos Aires. Fonte: Planeamiento en Buenos Aires. Municipalidad de la Ciudad de Buenos Aires. Dirección General de Obras Públicas y Urbanismo. Buenos Aires, 1944. s/p.

As cores escuras demarcam a área edificada até 1856 , que, nota-se, é pouco maior que o casco original de 1580 (área retangular em preto), com apenas um indicativo de expansão a Oeste. Em vermelho escuro e claro estão as áreas edificadas entre 1856 e 1887 e entre 1887 e 1905, respectivamente, notando-se aí grande ampliação do espaço urbano em praticamente todos os 
sentidos; destacam-se a ocupação ao Sul junto ao Riachuelo que saltou uma grande área (ocupada no período seguinte) para a implantação das primeiras fábricas e alguma ocupação junto às ferrovias Central Argentina ao Norte e Oeste de Buenos Aires a Oeste. Os dois tons mais claros demarcam a área edificada entre 1905 e 1925 e até 1944, registrando-se grande ocupação do espaço disponível do Município já no primeiro período, com notável expansão nos vetores Norte e Oeste acompanhando as ferrovias. No período 1925-1944 nota-se o preenchimento de espaços entre as ocupações anteriores e o avanço até o limite estabelecido em 1887 em todos os vetores, inclusive Sudoeste, que, contudo, aparece predominantemente desocupada. Grande parte desta região era alagável, havendo ainda zonas de descarte de resíduos.

O governo peronista procedeu em março de 1948 a nacionalização da rede ferroviária urbana e suburbana de Buenos Aires (já consolidada na década de 1940, porém de capitais ingleses), o que, em associação a uma política de subsídio estatal ao transporte público, impactou diretamente nos processos de expansão metropolitana no período. A Corporação de Transportes da Cidade de Buenos Aires, que incluía bondes, ônibus e metrôs também foi nacionalizada com o intuito de complementar o sistema, sendo dissolvida posteriormente. (GUTMAN; HARDOY, 1992; TORRES, 2006; ABOY; 2005). É interessante observar que a Ley General de la Vivienda é também de 1948, admitindo-se um pensamento que associava de fato os dois processos, a produção habitacional e o transporte público coletivo através dos trens metropolitanos.

Nas zonas circundantes à cidade de Buenos Aires onde a grande maioria das fábricas se assentou na década de 1940, havia grandes extensões de terra ainda desocupadas e baratas, que permitiram a instalação de moradias operárias. As políticas do Estado peronista contribuíram para a continuidade da expansão urbana horizontal nomeadamente através da outorga de créditos para a aquisição ou construção da moradia individual, mas também através da construção de conjuntos habitacionais massivos, sendo o limite municipal um dos setores privilegiados pela produção habitacional.

Desde então alguns urbanistas passam a referir-se à "Gran Buenos Aires" para aludir à aglomeração formada pela capital e os partidos vizinhos (GUTMAN; HARDOY, 1992). Ao final da década de 1940 a área administrativa de Buenos Aires estava totalmente ocupada e se consolidava a Área Metropolitana de Buenos Aires, praticamente com o traçado atual. A população da área Metropolitana é praticamente duplicada entre 1914 e 1947 e mais da metade destes habitantes se instala na própria capital. 0 crescente processo de metropolização e a complexificação das funções urbanas é registrado pelo Censo de 1947, que identifica já 17 partidos (municípios) integrando a Grande Buenos Aires. Em 1948 o Decreto n.70 da Província de Buenos Aires (vigente até 1957) adotou o termo "Gran Buenos Aires" para a "toda área urbana e rural compreendida nos partidos de Avellaneda, 4 de Junio, Lomas de Zamora, Matanza, San Martín, Vicente López, San Isidro, San Fernando, Las Conchas, Florencio Varela, Quilmes, Estevan Echeverría, Morón y General Sarmiento" 
(LA PLATA, 1948). Em 1948 foram criados órgãos destinados a executar um Plano Regulador para o conjunto da Grande Buenos Aires, com o objetivo de organizar o crescimento metropolitano.

Nos Mapas da Grande Buenos Aires de 1948 e 1965 (Figura 108), disponibilizados em Vapñarsky (2000), distinguem-se claramente que os eixos conformados pelas ferrovias já eram vetores de expansão metropolitana. De acordo com Vapñarsky (2000), até $1965^{12}$ os mesmo eixos de suburbanização foram privilegiados, com forte adensamento em todos os vetores, nomeadamente 0 vetor Oeste.
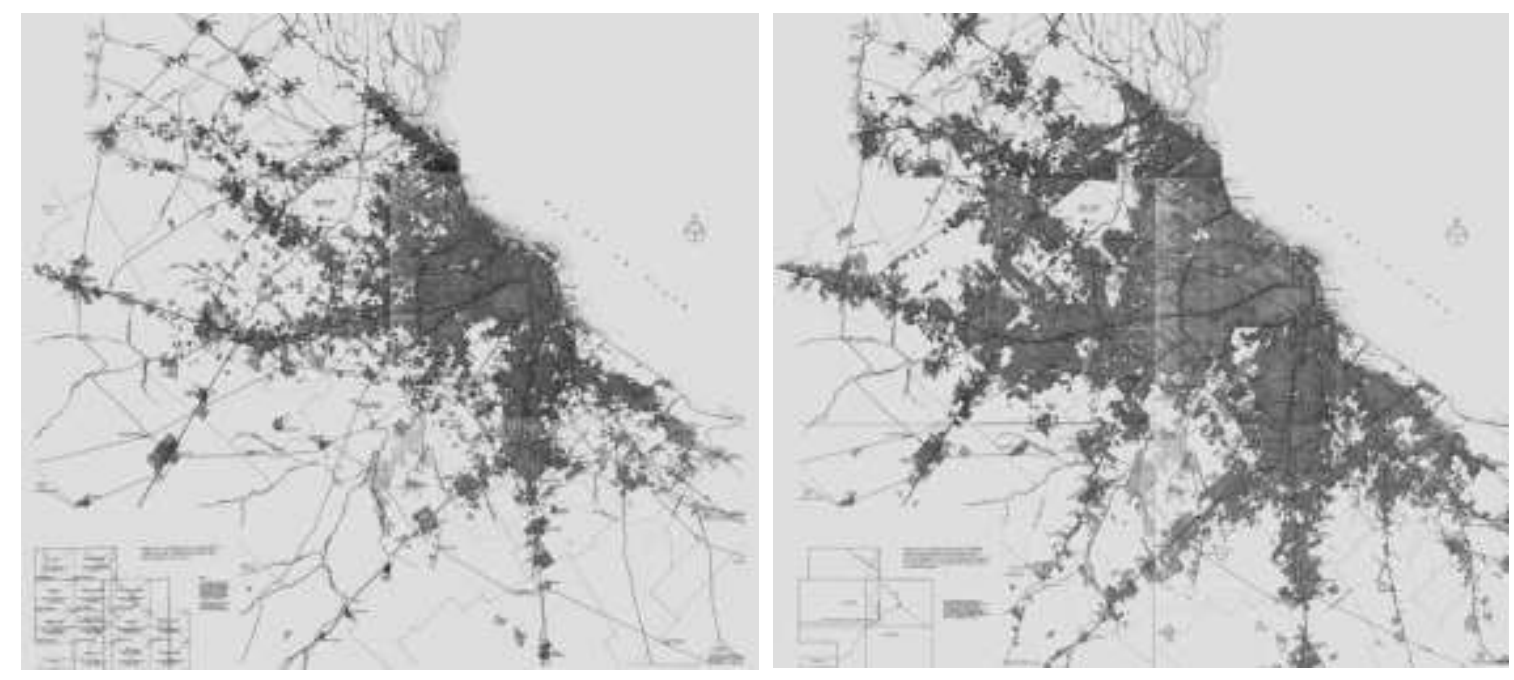

Figura 108. Grande Buenos Aires 1948 e 1965. Fonte: Vapñarsky, 2000.

A expansão metropolitana entre as décadas de 1940 e 1960 é reveladora do aumento da propriedade individual como forma de morar. Em 1947 contavam-se 26,8\% de casas próprias do total de moradias na área metropolitana, e em 1960 esse número chegaria a 58,1\% - na capital o aumento da proporção de proprietários é ainda maior, de 17,6\% para 45,6\% (TORRES, 2006). A suburbanização da moradia econômica vincula-se diretamente à outorga de crédito pelo BHN, ao mesmo tempo em que está também relacionada ao aumento dos salários e à redução das jornadas de trabalho, o que permitia a autoconstrução da moradia e a realização de longos trajetos entre a casa e o local da moradia. O lote de dimensões reduzidas na periferia era a forma de acesso à propriedade pelos setores populares.

\footnotetext{
12 Os eixos ferroviários continuam sendo eixos de suburbanização. (GÓMEZ PINTUS, 2015)
} 
Considerações Finais 
Apesar do quadro propício à produção da habitação social em grande escala observado no Brasil e na Argentina entre as décadas de 1930 e 1960, em função de Estados que se aproximaram das classes trabalhadoras e da ampliada articulação entre profissionais que compreendiam a função social da habitação, a perspectiva de produção em grande escala se concretizou de formas bastante diferentes em São Paulo e Buenos Aires. Três aspectos foram fundamentais para essa distinção. O primeiro, o diferente processo de institucionalização da produção habitacional pelo Estado brasileiro e pelo Estado argentino, com a conformação de diferentes políticas habitacionais e diferente aparato estatal relacionado à habitação, isto é, diferentes órgãos e instituições hegemônicas e profissionais nelas inseridos, atuando direta ou indiretamente na produção de habitações. O segundo, as diferenças na relação estabelecida entre vanguarda arquitetônica e Estado e na inclusão de profissionais de arquitetura em espaços estratégicos para a produção habitacional nos dois países. E o terceiro, as diferenças no processo de expansão da urbanização em São Paulo e Buenos Aires e no modo como o Estado e o aparato estatal se relacionaram com a ocupação urbana ao implementar a política habitacional nas duas cidades.

Em um primeiro momento são visíveis as semelhanças formais entre os projetos habitacionais produzidos em São Paulo e Buenos Aires entre as décadas de 1940 e 1950: lâminas baixas e altas de moradia multifamiliar idênticas implantadas sobre grandes quadras verdes, unidades isoladas de moradia unifamiliar também idênticas ou similares, associadas ao padrão urbanístico da cidadejardim, novos materiais e tecnologias, como o concreto armado e o elevador, elementos construtivos 
e tipos habitacionais padronizados. As aproximações teóricas com o ideário moderno, além daquelas que se refletem na linguagem formal, se reconhecem nos discursos e debates de profissionais dos dois países, especialmente no âmbito dos congressos continentais e locais, em que são expressas as preocupações para com a questão habitacional e são reconhecidas a sua relação com o urbanismo e a sua função social, implicando na proposição da produção habitacional em grande escala.

Em São Paulo foram três as tipologias de projetos habitacionais em que se propôs a produção em grande escala: o conjunto de unidades unifamiliares, o conjunto de blocos multifamiliares e o edifício vertical isolado, os primeiros ocupando grandes áreas e o último geralmente inserido em pequenos terrenos remanescentes em áreas consolidadas. Em Buenos Aires a perspectiva de produção em grande escala é percebida também em três tipologias: o conjunto de unidades unifamiliares, o conjunto de blocos multifamiliares, os pabellones, e o conjunto de edifícios verticais multifamiliares, os monobloques, o primeiro nomeadamente associado ao padrão urbanístico cidade-jardim e os dois últimos implantados sobre superquadras livres, como "barrios-parque".

A grande escala de produção habitacional se concretizou em São Paulo em projetos com número de unidades entre 300 e 4.000 - não necessariamente construídos, ou parcialmente construídos - que adotaram uma linguagem formal racional seguindo preceitos como a verticalização das unidades, a padronização de tipos habitacionais de blocos e casas e a produção seriada de elementos construtivos como tijolos, esquadrias e telhas. O reconhecimento do projeto habitacional como projeto de urbanismo também foi fator fundamental a esta produção, que se revela, na prática, na implantação racional dos edifícios e casas e na integração das moradias a equipamentos coletivos, mas também na integração dos conjuntos com o espaço urbano em que se inseriram, sobretudo no sentido de pensar os deslocamentos entre moradia e local de trabalho. Além disso, alguns conjuntos associaram ao grande número de unidades habitacionais e equipamentos, serviços destinados à população não moradora, voltados à rentabilização dos conjuntos.

A chamada "produção massiva" da habitação em Buenos Aires se distingue em projetos com 400 a 10.000 unidades - também não necessariamente construídos, ou parcialmente construídos. Tanto em projetos com linguagem formal mais racional, como naqueles com linguagem tradicional, a produção seriada de materiais construtivos como tijolos e peças de acabamento e a utilização de tipos padronizados de edifícios e casas pôde ser verificada. Os projetos dos conjuntos também chamam a atenção pela adoção clara de referenciais dos padrões urbanísticos da cidade-jardim e da unidade de vizinhança, com ampla gama de equipamentos coletivos e evidente integração com a cidade na proximidade com linhas de transporte coletivo. Os "barrios peronistas" chamam a atenção pela escala, destacando-se os projetos com 5.000 a 10.000 unidades, embora não construídos em sua totalidade, destinados a promover de fato a urbanização de bairros e distritos inteiros. A própria escala, portanto, é a diferença mais evidente entre os projetos das duas cidades. 
Getúlio Vargas no Brasil e Juan Perón na Argentina deram início a governos que compreenderam os trabalhadores entre as classes beneficiadas pelas políticas estatais. Entre estes benefícios foi incluída a habitação, cuja promoção a partir do Estado, no entanto, foi estruturada de formas bastante diferentes. No Brasil, a institucionalização da produção habitacional estabeleceu a partir da década de 1930 o que denominamos "política previdenciária de habitação", em que os principais órgãos responsáveis pela promoção da habitação social foram os Institutos de Aposentadoria e Pensões, a partir da aplicação dos fundos previdenciários no setor imobiliário. Destaca-se a conexão entre o objetivo financeiro e o objetivo social da produção habitacional realizada pelos IAPs e, particularmente em São Paulo, nosso caso de estudo, a atuação que seguiu a lógica de mercado na localização e realização dos projetos.

Na Argentina, embora o processo de institucionalização da promoção habitacional pelo Estado tenha se iniciado ainda em 1915, até a década de 1940 a produção resultante deste processo é tímida, estabelecendo-se a partir de 1943 uma política habitacional em sentido literal que a levaria para a produção massiva da habitação. No Primeiro Plano de Governo de Perón (Primer Plan Quinquenal, 1946) essa política é descrita e assentada a partir da organização de órgãos promotores técnicos e financeiros dedicados à produção da habitação social. Destaca-se a compreensão da habitação como elemento que cumpria a Justiça Social, conferindo dignidade à população através da propriedade. Para tanto, a ação indireta do Estado, garantindo através do Banco Hipotecário Nacional a outorga de empréstimos para aquisição da propriedade e o projeto de unidades-modelo para a população que desejasse construir, foi tão ou mais detalhada nos planos quinquenais (e privilegiada inclusive no segundo plano) quanto a ação direta na produção de conjuntos habitacionais.

Lembramos que os IAPs atuavam também indiretamente na produção habitacional garantindo empréstimos aos associados para aquisição da moradia (Plano B) e que em números, segundo Bonduki $(1998 ;$ 2014) essa ação foi maior que a produção direta através dos conjuntos, porém o estudo desta atuação não fazia parte do escopo desta tese. O estudo da ação indireta da política estatal peronista foi mais abordado devido à importância conferida pelo próprio projeto estatal a esta produção, vinculada inclusive à figura da primeira-dama, através do Plan Eva Perón.

Além da diferente organização também foram diferentes as estratégias de produção da habitação. No caso brasileiro, não foram encontradas no Decreto no 1.749 de 1937, que "aprova novo regulamento para a aquisição de prédios destinados à moradia dos associados", ou nos decretos que regulamentam a atuação de cada IAP indicações quanto à escala de produção de casas para os associados. Conforme afirma Bonduki (2014, p.42) "a questão habitacional foi tratada de maneira fragmentada por inúmeros órgãos promotores voltados para o atendimento de sua própria clientela, sem que existisse uma estratégia governamental estruturada". 
No caso argentino, no Primeiro Plano Quinquenal é colocado o objetivo de "construcción de barriadas de casas baratas" (PRESIDENCIA DE LA NACION..., 1946, p.316), ou seja, se determinava como premissa a escala de produção estruturada em bairros de habitação econômica. Em um dos principais veículos de propaganda do Peronismo, o livro "Nación Argentina Justa Libre y Soberana" (1950, p.312, tradução nossa) está escrito que no âmbito da política habitacional "o Governo constrói moradias, levanta bairros e faz surgir cidades inteiras".

Entretanto, encontramos indícios de que na produção de projetos através da política previdenciária em São Paulo a ideia da grande escala era colocada pelos profissionais inseridos no aparato estatal, tanto na estrutura técnica, isto é, na concepção dos projetos, quanto na estrutura mais relacionada à sua função administrativa. No primeiro caso, destacam-se como exemplos as falas de Attílio Corrêa Lima e Carlos Frederico Ferreira sobre a produção seriada e verticalizada da habitação econômica. No segundo caso, destacam-se as falas de Alim Pedro, presidente do IAPI, e Rubens Porto, assessor técnico no MTIC, sobre o imperativo da produção em série e da construção de conjuntos habitacionais como protótipos de cidades (FERRARI, 2013).

$\mathrm{Na}$ Argentina, é possível igualmente considerar que os projetos dos "barrios peronistas" não estavam apenas relacionados à política estatal de Justiça Social prevista no Primer Plan Quinquenal, mas também à atuação de arquitetos no interior do aparato estatal ou junto dos órgãos comitentes, especialmente porque os conjuntos traziam princípios do ideário moderno que não estavam colocadas oficialmente, sobretudo quanto à padronização de tipos construtivos (pedia-se a produção seriada de materiais construtivos) e a grande quantidade de equipamentos disponibilizados à população moradora (o que é oficializado em 1951, portanto, depois que os projetos foram concebidos e, em sua maioria, executados).

É relevante que também a participação dos profissionais na realização e execução dos projetos seja diferente nos dois países. No Brasil encontram-se arquitetos e engenheiros trabalhando no interior do aparato estatal vinculado direta ou indiretamente à produção habitacional, ao mesmo tempo em que também se encontram trabalhando através de escritórios de projeto contratados para a concepção de projetos. Na Argentina a pesquisa revelou uma participação exclusiva dos arquitetos no interior do aparato estatal peronista e nas contratações para realização de projetos. Nos dois países registramos a contratação de empresas construtoras ou construtores para a execução dos projetos habitacionais

A partir do estudo sobre a interlocução entre profissionais de arquitetura e urbanismo nas décadas de 1920 e 1960 através de congressos locais e continentais e da circulação de periódicos, é possível afirmar que os temas em discussão, salvo aqueles específicos a determinados países, eram comuns não só aos profissionais do Brasil ou da Argentina, mas da América Latina. Vale a pena recordar o próprio reconhecimento da habitação como questão social e de sua função social no campo da 
arquitetura, a integração do projeto habitacional ao campo do planejamento urbano e a necessidade de produção massiva de moradias. Contudo, a consolidação daqueles temas se realizava de formas diferentes em cada país, muito em função do papel atribuído aos profissionais na produção habitacional estatal, isto é, de como estes interagiam com o aparato estatal e com o próprio Estado, e de como suas proposições se colocavam na arena de interesses em relação àquelas do Estado, estivessem na sociedade civil ou na sociedade política.

Ao mesmo tempo, a materialização das políticas habitacionais e das proposições dos profissionais dependia também das condições de cada cidade em que eram implantados os projetos de habitação. São Paulo na década de 1940 estava em pleno processo de expansão urbana, tanto vertical, no Centro, quanto horizontal, nas periferias, e apenas indicava a expansão sobre os municípios vizinhos. A ocupação urbana em Buenos Aires, em contrapartida, achava-se, na década de 1940, praticamente consolidada e sua expansão se fazia através da verticalização, não apenas do Centro, mas também dos bairros centrais, e da suburbanização sobre municípios vizinhos, reconhecendo-se oficialmente a Grande Buenos Aires em 1948. Diante destes cenários, a inserção de projetos habitacionais em cada uma destas cidades e nas respectivas áreas metropolitanas ocorreu de formas bastante diferentes. Pode-se afirmar, no entanto, que as diferenças condiziam, por um lado, com os diferentes momentos ou estágios de ocupação urbana, e, por outro lado, com as diferentes estratégias adotadas pelas políticas de habitação e pelos órgãos comitentes, quanto à localização dos projetos em cada cidade e à relação que se estabelecia entre estes e o processo de urbanização.

Em São Paulo, a política previdenciária de habitação correspondeu à localização dos projetos no espaço urbano conforme a lógica de mercado. Em um primeiro momento (ainda na década de 1930) terrenos notadamente centrais receberam projetos de edifícios verticais com poucas unidades; na década de 1940 a localização dos projetos se expande a partir do Centro (metade da produção desta década está em um raio de $5 \mathrm{Km}$ desde o marco zero) já com projetos massivos, prevalecendo o conjunto de blocos multifamiliares. Já na década 1950, acompanhando o processo de expansão urbana, os projetos saem da área central e seu entorno, propondo-se prioritariamente a ocupação de áreas periféricas com grandes conjuntos habitacionais que mesclavam blocos e unidades unifamiliares. É possível reconhecer também relações entre a localização dos projetos e a proximidade com pontos de interesse conforme o Instituto promotor, como a previsão de projetos do IAPI na área central e em bairros industriais e de projetos do IAPC junto a acessos viários e/ou ferroviários, por exemplo. Nunca é demais lembrar que nem todos os projetos foram executados.

Em Buenos Aires, a política habitacional foi associada ao planejamento urbano e à relação com a cidade historicamente consolidada, tomando como condições o respeito pelos espaços históricos, físicos e simbólicos, e a representatividade da obra pública como símbolo do peronismo. Nesse sentido, a maior parte dos projetos foi prevista para áreas periféricas, ainda pouco urbanizadas, em 
parte associados também à inserção da atividade industrial, e em parte vinculados a um grande projeto de ocupação no vetor de expansão Sudoeste que criou uma nova entrada para a cidade desde o novo aeroporto em Ezeiza. Os grandes conjuntos inseridos no espaço urbano consolidado distinguem-se por associarem-se a uma proposta de requalificação de áreas precárias da capital. Os projetos habitacionais, portanto, eram compreendidos como projetos de urbanização e, em vários casos foram vinculados a outras obras do governo, como hospitais, escolas e espaços recreativos. Além disso, houve estreita relação entre a localização dos conjuntos habitacionais e o sistema viário e ferroviário metropolitano, com organização e nacionalização do sistema de transportes coletivos. Também em Buenos Aires, vale lembrar, nem todos os projetos foram executados.

Uma diferença fundamental também quanto à localização dos projetos na cidade diz respeito à propriedade das áreas em que foram propostos. Em São Paulo os terrenos pertenciam aos próprios IAPs, sendo adquiridos como aplicação dos fundos previdenciários. Em Buenos Aires os terrenos pertenciam ao Estado ou à Municipalidade e, conforme disposto no Primer Plan Quinquenal, foram destinados à implantação de moradias para os trabalhadores. Vale ainda lembrar que no caso dos projetos habitacionais de São Paulo as unidades foram prioritariamente alugadas, permanecendo como propriedade dos IAPs, enquanto nos projetos de Buenos Aires as unidades foram majoritariamente vendidas - associou-se à política habitacional a Ley de propriedad horizontal de 1948 (mesmo ano da Ley de Viviendas), que permitiu a venda de unidades em edifícios coletivos.

Uma última diferença importante a mencionar é a quem se destinava a produção habitacional realizada no período analisado. Se tanto no Brasil quanto na Argentina os discursos oficiais indicavam que as moradias eram construídas para os trabalhadores, na prática estes trabalhadores se constituíam de grupos bastante particulares. No caso brasileiro a demanda efetiva era constituída pelos trabalhadores associados aos IAPs, isto é, os trabalhadores formais. No caso argentino, mais abrangente, a demanda era conformada de modo geral pelos trabalhadores, mas especificamente em Buenos Aires, sobretudo pelos migrantes recém-chegados e excluídos física e socialmente na capital. Uma questão que fica em perspectiva para estudos futuros diz respeito às demandas por habitação colocadas pelos próprios trabalhadores. Compreendendo, no contexto de constituição das classes trabalhadoras, que os Estados varguista e peronista tomam do discurso operário as necessidades da classe e as retornam como benefício do líder previdente, considera-se que esta fosse uma das reivindicações mais contundentes, ao lado daquelas que buscavam direitos trabalhistas. A análise pormenorizada do discurso operário, porém não fez parte do escopo da pesquisa.

Uma questão que nos pareceu importante considerar e que, no entanto, não conseguimos explorar de forma ampliada, diz respeito ao desenvolvimento da indústria da construção civil como suporte material à produção habitacional nos dois países. Sabemos que foi importante para o próprio desenvolvimento de São Paulo o crescimento e diversificação da indústria da construção, que se 
relaciona diretamente à sua expansão horizontal e vertical-central a partir da década de 1940 . Na produção habitacional houve inclusão de empresas construtoras na execução de projetos promovidos pelos IAPs, sugerindo já o papel das próprias construtoras na produção habitacional pós-1964. Em Buenos Aires, é possível considerar, em função da grande escala de produção habitacional, que a indústria de materiais e a própria indústria da construção estivessem bastante desenvolvidas na década de 1940. Embora tenham sido encontrados poucos dados concretos relacionados a este momento da indústria da construção na Argentina, sabe-se que a proposta de desenvolvimento do setor estava colocada nos Planos Quinquenais. Nos projetos executados em Buenos Aires, como já registramos, foi ampla a participação de construtoras na execução da obra pública e, logo, dos projetos habitacionais, através de licitações. Entretanto, foram encontradas poucas informações a respeito das empresas responsáveis pela construção dos projetos habitacionais analisados.

Em síntese, é possível admitir que as semelhanças formais e mesmo teóricas percebidas em um primeiro momento entre a produção habitacional no Brasil e na Argentina e, especificamente, em São Paulo e Buenos Aires, na realidade contém grandes diferenças estruturais expressas notadamente na escala dos projetos e na sua localização no espaço urbano e metropolitano. É estrutural para as diferenças notadas a institucionalização da produção habitacional como política previdenciária no Brasil e como política estatal na Argentina, com implicações na conformação do aparato estatal e, logo, no papel atribuído aos arquitetos na produção habitacional e ainda, na lógica de inserção dos projetos nas duas cidades, além do público a que se destina esta produção. As diferentes escalas e a localização dos projetos dependiam não somente do modo como as políticas e órgãos se relacionavam com estas cidades, mas também do processo de ocupação e expansão urbana de São Paulo e Buenos Aries, que como vimos, encontravam-se em estágios muito diferentes.

Cabe por fim destacar, que a relação entre Estado e vanguarda arquitetônica na América Latina entre 1930 e 1970, possibilitou a produção de conjuntos habitacionais estatais em que estava em perspectiva a grande escala e a aproximação com o ideário moderno expressa na linguagem formal, na adoção da padronização, na produção seriada e na verticalização. Contudo, é possível admitir que as diferenças nesta relação no Brasil e na Argentina e na própria atuação da vanguarda em cada país implicaram de forma contundente na escala dos projetos e na sua integração com equipamentos coletivos e serviços e com o espaço urbano em que foram inseridos.

Nos anos 1970, como mostra Gorelik (2005a, p. 127) se verifica a impossibilidade de realização do "projeto desenvolvimentista como um projeto de encontro virtuoso entre o Estado, os técnicos e as necessidades sociais". Ficava claro que a cultura técnica não encontrava o apoio almejado no Estado, não apenas porque vários países naquele momento achavam-se sob governos ditatoriais, mas, essencialmente, porque as classes interessadas na modernização, não estavam igualmente preocupadas em impor as transformações estruturais necessárias para o pleno desenvolvimento. 
Referências Bibliográficas 


\section{Fontes Bibliográficas}

ABOY, Rosa. Viviendas para el pueblo: espacio urbano y sociabilidad en el barrio Los Perales, 19461955. Buenos Aires: Universidad de San Andrés: Fondo de cultura Econômica, 2005.

ALMANDOZ, Arturo. "Historiografia urbana en Latinoamerica: del positivismo al postmodernismo" In: Diálogos, DHI/UEM, v. 7. 2003. p. 117-156.

ALMANDOZ, Arturo. "Revisão da historiografia urbana na América Hispânica" In: PINHEIRO, E. P.; FILGUEIRAS GOMES, M. A. A cidade como história: os arquitetos e a historiografia da cidade e do urbanismo. Salvador: EDUFBA, 2004. p. 117-150.

ALMANDOZ, Arturo. "Urban planning and historiography in Latin America" In: Progress in Planning, 65, 2006. p. 81-123.

ALMANDOZ, Arturo. “Modernización urbanística en América Latina. Luminarias extranjeras y cambios disciplinares, 1900-1960" In: Iberoamericana, n. 27, 2007, p. 59-78. Disponível em: <http://www.redredial.net/referencia-bibliografica-39449.html> Acesso em: 19 fev. 2015.

ALMANDOZ, Arturo. Modernization urbanization and development in Latin America. Oxfordshire: Routledge, 2015.

AMEZTOY, María Virginia."Autoritarismo, sociedad y Estado en la Argentina" In: IZAGUIRRE, Inés (coord. y comp.). Violencia social y derechos humanos. Buenos Aires: Eudeba, 1998. pp.227-264.

ARAVECCHIA-BOTAS, Nilce. "Conexões Brasil-America Latina a partir do Centro Interamericano de Vivenda e Planejamento? CINVA"' In: II Encontro da Associação Nacional de Pesquisa e Pósgraduação em Arquitetura e Urbanismo, 2012, Natal. Anais do II ENANPARQ, 2012.

ARAVECCHIA-BOTAS, Nilce. Estado, Arquitetura e Desenvolvimento: a ação habitacional do IAPI. São Paulo: Editora Unifesp, 2016.

ARGENTINA: POBLACIÓN total por regiones y provincias. Censos Nacionales de 1914, 1947, 1960, 1970, 1980, 1991 y 2001. Elaborado con datos de INDEC: Censos nacionales. Disponível em: $<$ http://www.mininterior.gov.ar/poblacion/archivos_estadisticas/EvolucionPoblacionProvincias1914.p df> Acesso em: 23 maio 2017

ATIQUE, Fernando. "O Debate sobre Habitação nos Congressos Pan-Americanos de Arquitetos: 19201940" In: Anais do XI Encontro Nacional da Anpur. Salvador, 23-27 maio 2005.

ATIQUE, Fernando. arquitetando a "Boa-Vizinhança": a sociedade urbana do Brasil e a recepção do mundo norte-americano, 1876-1945. Tese (Doutorado) FAU-USP, São Paulo, 2007.

AZEVEDO, Aroldo de (Org.). A cidade de São Paulo: estudos de geografia urbana. São Paulo: Nacional, 1958. Vol. III.

AZEVEDo, Sérgio de; ANDRADE, Luis A.G. de. Habitação e Poder. Da Fundação da Casa Popular ao Banco Nacional de Habitação. Rio de Janeiro: Zahar Editores, 1982. 
AIZICZON, Fernando. "Anarquistas en Argentina" In: Revista Historia para todos [online]. Disponível em: $\quad$ <https://revistahistoriaparatodos.wordpress.com/2016/07/11/anarquistas-en-argentina-porfernando-aiziczon/> Acesso em: 24 abril 2018.

AYMONINO, Carlo. Orígenes y Desarrollo de la Ciudad Moderna. Barcelona:Gustavo Gili, 1972.

BALLENT, Anahí. Arquitectura y ciudad como esteticas de la politica. El peronismo en BuenosAires, 1946-1955 In: Anuário del IEHS - Instituto de Estudios histórico sociales, vol. 8, 1993. Disponível em: <http://anuarioiehs.unicen.edu.ar/1993.html> Acesso em: 05 jun. 2017.

BALLENT, Anahí. "La Operación Territorial Ezeiza (1944-1955)" In: ANALES del Instituto de arte americano e investigaciones esteticas 'Mario J. Buschiazzo'. n. 72, octubre de 1999. Disponível em: <http://www.iaa.fadu.uba.ar/publicaciones/critica/0072.pdf> Acesso em: 14 nov. 2017.

BALLENT, Anahí. Las Huellas de la politica: Vivienda, ciudad, peronismo en Buenos Aires, 1943-1955. Quilmes: Universidad Nacional de Quilmes, 2005.

BALLENT, Anahí; LIERNUR, Jorge Francisco. La casa y la multitud: vivienda, política y cultura en la Argentina moderna. Buenos Aires: Fondo de Cultura Económica de Argentina, 2014.

(O) BANQUEIRO (1851 - 1860) In: Barão de Mauá: o empreendedor, 2011. Disponível em: <http://www.brmaua.com.br/> Acesso em 24 set. 2017.

BARRIO 17 DE OCTUBRE a Buenos Aires. Disponível em: <http://www.archivioluigipiccinato.it/?s=17+de+octubre> Acesso em 28 abril 2017.

BELINI, Claudio. “Política industrial e industria siderúrgica en tiempos de Perón, 1946-1955” In: Ciclos, Año XIII, Vol. XIII, N²8, ler. semestre de 2005. pp. 89-113.

BENDER, Helena. Buenos Aires de Bonet: Antonio Bonet Castellana, habitação coletiva e o projeto da cidade moderna, 1943-1956. Dissertação (Mestrado). Universidade Federal do Rio Grande do Sul. Faculdade de Arquitetura. Porto Alegre, 2014.

BESSA, Antonio S. Beyond the Supersquare: Art and architecture in Latin America after Modernism. New York: Fordham University Press, 2014.

BLAY, Eva Alterman. Eu não tenho onde morar: Vilas Operárias na Cidade de São Paulo. São Paulo: Nobel, 1985.

BOBBIO, Norberto. O conceito de sociedade civil. Rio de Janeiro: Graal, 1982.

BONDUKI, Nabil G. Origens da Habitação Social no Brasil. Arquitetura Moderna, Lei do Inquilinato e Difusão da Casa Própria. São Paulo: Estação Liberdade/FAPESP, 1998.

BONDUKI, Nabil G.; KOURY, Ana Paula. "Das reformas de base ao BNH. As propostas do Seminário de Habitação e Reforma Urbana" In: Arquitextos, São Paulo, 10.120, Vitruvius, maio 2010. Disponível em: <http://www.vitruvius.com.br/revistas/read/arquitextos/10.120/3432>. Acesso em ago. 2011.

BONDUKI, Nabil G. Os pioneiros da habitação social no Brasil: cem anos de construção de política pública no Brasil. São Paulo: UNESP: SESC, 2014. Volume 1. 
BONDUKI, Nabil G.; KOURY, Ana Paula (orgs). Os pioneiros da habitação social no Brasil: inventário da produção pública no Brasil entre 1930 e 1964. São Paulo: UNESP: SESC, 2014. Volume 2.

BONDUKI, Nabil G.; KOURY, Ana Paula (orgs). Os pioneiros da habitação social no Brasil: onze propostas de morar para o Brasil moderno. São Paulo: UNESP: SESC, 2014. Volume 3.

BONDUKI, Nabil G.; KOURY, Ana Paula. “Das reformas de base ao BNH. As propostas do Seminário de Habitação e Reforma Urbana" In: Arquitextos, São Paulo, 10.120, Vitruvius, maio 2010. Disponível em: <http://www.vitruvius.com.br/revistas/read/arquitextos/10.120/3432>. Acesso em ago. 2011.

BONET, ANTONIO In: Moderna Buenos Aires [online]. Disponível em: <https://www.modernabuenosaires.org/arquitectos/antonio-bonet> Acesso em 28 março 2018.

BONICATTO, Virginia. "La inserción urbana del rascacielos en el Río de la Plata. (1900-1930). Debates, conflictos y diversificación de capitales en torno a una tipología" In: XII Jornadas Interescuelas/Departamentos de Historia. Universidad Nacional del Comahue, San Carlos de Bariloche. 2009. Disponível em: <http://www.aacademica.org/000-008/454> Acesso em 03 mar. 2016.

BOTAS, Nilce C. A. Entre o progresso técnico e a ordem política: arquitetura e urbanismo na ação habitacional do IAPI. Tese (Doutorado). FAU-USP, São Paulo, 2011.

BOTAS, Nilce Aravecchia; KOURY, Ana Paula. A cidade industrial brasileira e a política habitacional na era Vargas (1930-1954) In: URBANA V.6, no 8, jun. 2014 - Dossiê: Cidade e Habitação na América Latina (número especial). pp. 144-165. Disponível em:

<https://periodicos.sbu.unicamp.br/ojs/index.php/urbana/article/view/8635296/pdf> Acesso em: 13 ago. 2017.

BRUNA, Paulo. Os primeiros arquitetos modernos: Habitação social no Brasil 1930 - 1950. Tese de Livre-docência. FAU-USP, São Paulo, 1998.

BUENOS AIRES. Anuario Estadístico 2003 de la Ciudad de Buenos Aires [online]. Dirección General de Estadística y Censos. Disponível em: <http://www.estadisticaciudad.gob.ar/eyc/publicaciones/anuario_2003/Intro/Intro3.htm> Acesso em 23 maio 2017

CAMPOS, Candido Malta. Os Rumos da Cidade. Urbanismo e Modernização em São Paulo. São Paulo: SENAC, 2002.

CAMPOS, Pedro H. P. A ditadura dos empreiteiros: as empresas nacionais na construção pesada, suas formas associativas e o Estado ditatorial brasileiro, 1964-1985. Tese (Doutorado em História Social) Instituto de Ciencias Humanas e Filosofia - Universidade Federal Fluminense. 2012

CANTILO, José María. "El Primer Congreso Panamericano de la Vivienda Popular" In: La vivenda Popular: Conferências de los ciclos preparados pela Comisión Organizadora del Primer Congreso Panamericano de la Vivienda Popular. Buenos Aires: s/e., 1939. p.13-15. 
CARNOY, Martin. Estado e Teoria política. (equipe de trad. PUCCAMP) 2a ed. Campinas: Papirus, 1988. CARPINTÉRO, Marisa V.T. A construção de um sonho: os engenheiros-arquitetos e a formulação da política habitacional no Brasil 1917-1940. São Paulo: UNICAMP, 1998.

CASAS PARA OS INDUSTRIÁRIOS In: Industriários. Órgão oficial do IAPI. n. 17, out. 1950. p. 3-4.

CASTILLO, Ramón. "La vivienda y la ación del Estado" In: La vivenda Popular: Conferências de los ciclos preparados pela Comisión Organizadora del Primer Congreso Panamericano de la Vivienda Popular. Buenos Aires: s/e., 1939. p.9-12.

CASTRO-GÓMEZ, Santiago; GROSFOGUEL, Ramón (comp.). El giro decolonial: reflexiones para una diversidad epistémica más allá del capitalismo global. Bogotá: Siglo del Hombre/ Universidad Central, 2007.

CAVLAK, luri. A política externa brasileira e a Argentina peronista. São Paulo: AnnaBlume, 2008.

CIRVINI, Silvia Augusta. "Las revistas técnicas y de arquitectura (1880-1945): Periodismo especializado y modernización en Argentina" In: Argos. Caracas, v. 28, n. 54, p. 13-60, enero 2011. Disponível em: <http://www.scielo.org.ve/scielo.php?script=sci_arttext\&pid=S0254-16372011000100002\&lng=es\&nrm=iso>. Acesso em: 27 jun. 2017.

CIRVINI, Silvia Augusta. El ejercicio profesional de la arquitectura en el primer peronismo (19431955); Una relación comprometida entre el conflito y la negociación In: Estudios Interdisciplinarios de América Latina y el Caribe, Vol. 23, N. 1, 2012. pp. 113-136. Disponível em: <http://eial.tau.ac.il/index.php/eial/article/view/306> Acesso em: 27 jun. 2017.

CIUDAD EVITA a Buenos Aires. Disponível em: <http://www.archivioluigipiccinato.it/?s=ciudad+evita> Acesso em 28 abril 2017.

CODATO, Adriano. "Poulantzas, o Estado e a Revolução" In: Crítica Marxista [online], n.27, 2008. pp.65-85. Disponível em: <http://www.ifch.unicamp.br/criticamarxista/arquivos_biblioteca/ artigo156artigo4.pdf.> Acesso em: 23 jul. 2016

COIRE, CARLOS In: Moderna Buenos Aires [online]. Disponível em: <https://www.modernabuenosaires.org/arquitectos/carlos-coire> Acesso em 28 março 2018.

COLLADO, Adriana. "La vivenda popular: debates e teorias (1920-1940)" In: GUTIÉRREZ, Ramón. La habitación popular bonaerense 1943-1955: Aprendiendo en la historia. Buenos Aires: CEDODAL: Ministerio de Infraestructura y Vivienda, 2011. p. 29-34.

COMUNIDADE BRASÍLIO MACHADO Neto In: Acrópole. São Paulo, Ano 20, № 238, ago. 1958. p.466.

(II) CONGRESO PANAMERICANO de arquitectos: actas del comitê argentino In: Revista de arquitetura.

N. 32. Año VIII, Ago. 1923 (a). pp 33-34.

(II) CONGRESO PANAMERICANO de arquitectos: actas del comitê argentino In: Revista de arquitetura.

N. 33. Año VIII, Sept. 1923 (b). pp 60-62. 
(II) CONGRESSO PANAMERICANO de arquitectos In: Revista de arquitetura. N. 34. Año VIII, Oct. 1923 (c). pp. 76-82.

(II) CONGRESO PANAMERICANO de arquitectos: actas del comitê argentino In: Revista de arquitetura. N. 35. Año VIII, Nov. 1923 (d). pp. 104-106; 118

(III) CONGRESO PANAMERICANO de arquitectos In: Revista de arquitetura. Jul. 1927. N. 79. Año XIII.

(III) CONGRESO PANAMERICANO de arquitectos: conclusiones definitivas In: Revista de arquitetura. ago. 1927. N. 80. Año XIII. pp.312-343.

CONGRESO PANAMERICANO DE ARQUITECTOS: Conclusiones de las comisiones In Revista de Arquitectura. Dec. 1947. N. 324. Año XXXII. pp.434-445.

(VII) CONGRESO PANAMERICANO de arquitectos In: Revista de Arquitectura. Buenos Aires, n. 357, sept. 1950. p.256.

(VIII) CONGRESO PANAMERICANO de Arquitectos In: Revista de arquitetura. Sept. - Dec. 1952. N. 368. pp.49-52.

CORRÊA LIMA, Attílio. "Conjunto Residencial da Várzea do Carmo I.A.P.I. S. Paulo" In: Revista Municipal de Engenharia PDF. Vol. 10, n.4, nov. 1942.

CORRÊA LIMA, Attílio. "Conjunto Residencial da Vársea do Carmo I.A.P.I." In: Revista Municipal de Engenharia PDF. Vol. 9, n.6, out. 1943.

CORRÊA LIMA, Attilio "Parecer sobre o plano da Cidade Operária da F. N. M.", Rio de Janeiro, 24 ago. 1943 In: Arquitetura. Revista do Instituto de Arquitetos do Brasil, n.14. Rio de Janeiro, ago. 1963. p. 5-9. CORREIA, Telma de Barros. A construção do Habitat Moderno no Brasil - 1870 - 1950, São Carlos: RiMa/FAPESP, 2004.

CORREIA, Telma de Barros; ALMEIDA, Caliane Christie Oliveira de. "Habitação econômica no Brasil: o IDORT e sua revista (1932-1960)" In: Risco n.17, 1, 2013. pp. 35-49.

CORTÉS CONDE, Roberto. La cedula hipotecaria argentina. Buenos Aires: El autor, 2011.

COUTINHO, Carlos Nelson. Gramsci: um estudo sobre seu pensamento político. Rio de Janeiro: Campus, 1992.

CRAVINO, Ana. Una historia sobre la transformación de la habitación popular en Buenos Aires (I) In: Café de las Ciudades. AÑO 8, N. 76, Febrero 2009. Disponível em: <http://www.cafedelasciudades.com.ar/politica_76_p.htm> acesso em 12 abril 2017.

CRAVINO, Ana. Una historia sobre la transformación de la habitación popular en Buenos Aires (II) In: Café de las Ciudades. AÑO 8, N. 77, Marzo 2009. Disponível em: <http://www.cafedelasciudades.com.ar/politica_77_p.htm> acesso em 12 abril 2017.

DASSEN, Juan Justo. "Algunas consideraciones sobre la vivienda obrera en la Argentina" In: La Habitacion Popular - Boletin Oficial de la Comisión Nacional de Casas Baratas. Año VIII, n.36, 1942. p.30-43. 
D'ARAUJO, Maria Celina. Sindicatos, carisma e poder: o PTB de 1945-65. Rio de Janeiro: Editora da Fundação Getulio Vargas, 1996.

D’ARAÚJO, Maria Celina. (org.) Getúlio Vargas. Brasília: Câmara dos Deputados, Edições Câmara, 2011. DE ANDA ALANIS, Enrique X. de Vivienda Colectiva de la Modernidad en México. Los Multifamiliares Durante el Periodo Presidencial de Miguel Alemán (1946-1952). Mexico: Universidad Nacional Autonoma de Mexico, 2008.

DEL CAMPO, Hugo. Sindicalismo y peronismo: Los comienzos de un vínculo perdurable. Buenos aires: CLACSO, 1983.

DELLA PAOLERA, Carlos. "La Avenida 9 de Julio" In: Revista de Arquitectura, Año XXIII, n. 200, ago. 1937. pp.345-351.

DUNOWICZ, Renée. 90 años de vivienda social en la ciudad de Buenos Aires. Buenos Aires: Programa de Mantenimiento Habitacional, 2000.

ESCOBAR, Arturo. (2003). "Mundos y conocimientos de otro modo. El programa de investigación de modernidad/colonialidad latinoamericano" In: Tabula Rasa, n. 1, 51-86.

ESTUDIO PARA VIVIENDAS en Casa Amarilla In: Archivo Amancio Williams. Disponível em: <https://www.amanciowilliams.com/archivo/estudio-para-viviendas-en-casa-amarilla> acesso em: 5 maio 2017.

FAORO, Raymundo. Os donos do poder: formação do patronato político brasileiro. 3a ed. São Paulo: Globo, 2002.

FAUSTO, Boris. A Revolução de 1930. História e Historiografia. 11. ed. São Paulo: Brasiliense, 1987.

FAUSTO, Boris. "Estado, Classe Trabalhadora e Burguesia Industrial (1920-1945): uma revisão" In: Novos Estudos, n. 20, março 1988.

FAUSTO, Boris; DEVOTO, Fernando J. Brasil e Argentina: um ensaio de história comparada (18502002). São Paulo: Editora 34, 2005.

FELDMAN, Sarah. Planejamento e zoneamento: São Paulo 1947 a 1972. São Paulo: Fapesp: Edusp, 2005.

FELDMAN, Sarah. Instituições de urbanismo no Brasil na década de 1930: olhar técnico e dimensão urbano-industrial. 2007. Tese de livre-docência. Departamento de Arquitetura e Urbanismo, EESCUSP, São Carlos, 2008.

FELDMAN, Sarah. "Do Primer Congreso Panamericano de la Vivienda Popular (1939) ao Seminário de Habitação e Reforma Urbana (1963): Planejamento e habitação na Perspectiva da metrópole latinoamericana" In: URBANA, V.6, no 8, jun. 2014. p.129-143.

FELDMAN, Sarah. "Planejamento e habitação no Brasil: a perspectiva da metrópole latino-americana (1939-1963)" In: PEIXOTO, E. R.; DERNTL, M. F.; PALAZZO, P. P.; TREVISAN, R. (Orgs.) Anais do XIII 
Seminário de História da Cidade e do Urbanismo. Brasília, DF: Universidade Brasília- Faculdade de Arquitetura e Urbanismo, 2014. Disponível em: <http://www.shcu2014.com.br/content/ planejamento-e-habitacao-no-brasil-perspectiva-da-metropole-latino-americana-1939-1963> Acesso em 28 mar. 2015.

FERRARI, Camila. Projetos de habitação popular como projetos de cidade moderna: os conjuntos habitacionais dos IAP na Grande São Paulo de 1930 a 1964. Dissertação (Mestrado). IAU-USP, São Carlos, 2013.

FERRARI, Camila; NEGRELOS, Eulalia P. “Estado e planejamento na América Latina: origens do desenvolvimentismo no Brasil" In: URBANA. Rev. Eletrônica do Centro Interdisciplinar de Estudos sobre a Cidade. V. 8, n. 3 (2016) set./dez. [14] - Dossiê: Cidade latinoamericana. Disponível em: <https://periodicos.sbu.unicamp.br/ojs/index.php/urbana/article/view/8646414>

FERRARI, Camila; NEGRELOS, Eulalia P. “Alianças e rupturas entre aparato estatal, profissionais e indústria da construção na produção habitacional no brasil na década de 1960" In: Anales del Seminario Internacional Profesionales, Expertos y Vanguardistas: Cultura arquitectónica en el Cono Sur. Rosario. 7 - 8 jun. 2018.

FERRARI HARDOY, Jorge In: Moderna Buenos Aires [online]. Disponível em: <https://www.modernabuenosaires.org/arquitectos/jorge-ferrari-hardoy> Acesso em 28 março 2018. FGV-CPDOC. Dossiê o Governo de Juscelino Kubitschek: Biografias, Carlos Leão. Disponível em: <http://cpdoc.fgv.br/producao/dossies/JK/biografias/carlos_leao> acesso em 08 dez. 2017.

FGV/CPDOC. Verbete: Constituição de 1937. Disponível em: <http://www.fgv.br/cpdoc/acervo/dicionarios/verbete-tematico/constituicao-de-1937> Acesso em 23 jan. 2018.

FGV/CPDOC. Verbete: Aliança para o Progresso. Disponível em: <http://www.fgv.br/cpdoc/acervo/dicionarios/verbete-tematico/alianca-para-o-progresso-1> Acesso em 12 jul. 2016.

FGV/CPDOC. Aliança Liberal In: A Era Vargas: dos anos 20 a 1945. Disponível em: <https://cpdoc.fgv.br/producao/dossies/AEraVargas1/anos20/CrisePolitica/AliancaLiberal> Acesso em: 10 jul. 2016.

FGV/CPDOC. Anos de Incerteza (1930 - 1937) > Revolução Constitucionalista de 1932. Disponível em: <https://cpdoc.fgv.br/producao/dossies/AEraVargas1/anos30-37/RevConstitucionalista32> Acesso em: 10 jul. 2016.

FGV/CPDOC. Verbete. Jose de Segadas Viana. Disponível em:

$<$ http://www.fgv.br/cpdoc/acervo/dicionarios/verbete-biografico/jose-de-segadas-viana> Acesso em: 5 jun. 2018. 
FGV/CPDOC. Verbete. Confederação dos Trabalhadores do Brasil (CTB). Disponível em: $<$ http://www.fgv.br/CPDOC/BUSCA/dicionarios/verbete-tematico/confederacao-dos-trabalhadoresdo-brasil-ctb> Acesso em: 22 maio fev. 2018.

FICHER, Sylvia. Os arquitetos da Poli: Ensino e Profissão em São Paulo. São Paulo: FAPESP: EDUSP, 2005.

FIGUEIREDO, 2002 In: GITAHY, Maria Lucia C.; PEREIRA, Paulo C.X. (Org.). O complexo industrial da construção e a habitação econômica moderna 1930-1964. São Carlos: Rima: Fapesp, 2002. pp. 35-52 FOLZ, Rosana Rita. "INDUSTRIALIZAÇÃO DA HABITAÇÃO MÍNIMA: DISCUSSÃO DAS PRIMEIRAS EXPERIÊNCIAS DE ARQUITETOS MODERNOS - 1920-1930" In: CAdernos de Arquitetura e Urbanismo. Belo Horizonte. V. 12, N. 13 dez. 2005. pp. 95-112. Disponível em: $<$ http://periodicos.pucminas.br/index.php/Arquiteturaeurbanismo/article/view/777/740> Acesso em 12 abril 2018.

FREITAS, Maria Luiza de. Modernidade concreta: as grandes construtoras e o concreto armado no Brasil, 1920 a 1940. Tese de Doutorado. FAU-USP, São Paulo, 2011.

FREITAS, Maria Luiza. “Conexões sul-americanas: por uma cultura técnica do concreto armado na Argentina, no Brasil e no Uruguai" In: Anais do I Enanparq. Rio de Janeiro, 23 nov. - 03 dez., 2010. Disponível em: <www.anparq.org.br/dvd-enanparq/simposios/84/84-733-1-SP.pdf> Acesso em 30 set. 2015.

FURTADO, Celso. Formação Econômica do Brasil. 32ª ed. São Paulo: Companhia Editora Nacional, 2003.

GAMBINI, Hugo. Historia del Peronismo: El Poder Total (1946-1952). Buenos Aires: Ediciones B, 2016. GENEAU, Carlos. "Notas sobre el cogreso de la habitacion" In Revista de Arquitectura. Buenos Aires. n.27, ano VI, 1920. p.12-15.

GERMANI, Gino. "El surgimiento del peronismo. El rol de los obreros y de los migrantes internos" (1973) In: Mora y Araujo, Manuel; Llorente, Ignacio. El voto peronista. Buenos Aires:Sudamericana, 1982. pp. 435-488. Disponível em: <http://www.peronlibros.com.ar/content/germani-gino-elsurgimiento-del-peronismo-el-rol-de-los-obreros-y-los-migrantes-internos> Acesso em: 10 abril 2017. GIEDION, Sigfried. Espacio, Tiempo y Arquitectura (Edición definitiva). Barcelona: Reverté, 2009. GITAHY, Maria Lúcia Caira. São Paulo e a tecnologia, 1899-1948. Estudos de história do trabalho como fundamentos sociais da arquitetura e do urbanismo. (Tese de Livre-docência). São Paulo: Faculdade de Arquitetura e Urbanismo, Universidade de São Paulo, 2002.

GITAHY, Maria Lucia C.; PEREIRA, Paulo C.X. (Org.). O complexo industrial da construção e a habitação econômica moderna 1930-1964. São Carlos: Rima: Fapesp, 2002.

GOMES, Angela Maria de Castro. A invenção do trabalhismo. Rio de Janeiro: FGV, 2005.

GOMES, Angela Maria de Castro. Cidadania e Direitos do Trabalho. Rio de Janeiro: Zahar, 2002. 
GOMES, Marco Aurélio A. de Filgueiras; (org.) Urbanismo na América do Sul: circulação de ideias e constituição do campo, 1920-1960. (Online). Salvador: EDUFBA, 2009. Disponível em: <http://books.scielo.org/id/wvqr3>Acesso em: 10 fev. 2014.

GÓMEZ PINTUS, Ana Helena. "La configuración histórica del Gran Buenos Aires: transformaciones y debates en torno al objeto" In: Cuadernos de Geografía. Revista colombiana de geografía. Vol. 24, n.으 1, ene.-jun. 2015. Bogotá, Colombia. pp. 173-191.

GORELIK, Adrián. "O moderno em debate: cidade, modernidade e modernização" In: MIRANDA, W. M. (Org.). Narrativas da modernidade. Belo Horizonte: Autêntica, 1999, p.55-80.

GORELIK, Adrian (a). "A produção da 'cidade latino-americana'”. Tradução de Fernanda Arêas Peixoto. In: Tempo Social: Revista de sociologia da USP. (São Paulo), v. 17, n. 1, 2005, p. 111-133.

GORELIK, Adrian (b). Das vanguardas a Brasília: cultura urbana e arquitetura na América Latina. Trad. Maria Antonieta Pereira. Belo Horizonte: UFMG, 2005.

GUAIA, Esteban. La vivienda social en la Argentina. Evolución Hstorica. El déficit actual y sus consecuencias. Una propuesta de solución. BsAs: PROA AMERICAN Editors, 2012.

GUERRA, A. (Org.) Textos Fundamentais sobre a História da Arquitetura Moderna no Brasil. São Paulo:Romano Guerra, 2010.

GORELIK, Adrián. "Para una historia cultural de la 'ciudad latinoamericana'" In: Primer Congreso Latinoamericano de Estudios Urbanos - Pensar la ciudad, cambiar la ciudad. Los retos de la investigación en América Latina a comienzos de siglo XXI. Buenos Aires, Argentina, 24-26 ago. 2011.

GUTMAN, Margarita. HARDOY, Jorge E.; Buenos Aires: historia urbana del área metropolitana. Madrid Editorial: MAPFRE, c1992.

GUTIÉRREZ, Ramón. La habitación popular bonaerense 1943-1955: Aprendiendo en la historia. Buenos Aires: CEDODAL: Ministerio de Infraestructura y Vivienda, 2011. pp. 29-34

GUTIÉRREZ, Ramón; MÉNDEZ, Patricia; CACCIATORE, Julio. Jorge Sabaté. Arquitectura para la Justicia Social. Buenos Aires: CEDODAL-Instituto de Inv. Hist. Eva Perón, 2009.

GUTIÉRREZ, Ramón. Buenos Aires, evolución urbana. 1536-2000. Buenso Aires: CEDODAL: Libreria Concentra, 2014.

GUTIÉRREZ, Ramón; GUTMAN, Margarita (comp.). Vivienda: Ideas y contradicciones (1916 - 1956).

Buenos :Instituto argentino de investigaciones de historia de la arquitectura y del urbanismo, 1988.

HERNÁNDEZ, Manuel Martín. La Casa en la Arquitectura Moderna. Barcelona: Reverté, 2014.

HISTORIA ARGENTINA DE LA VIVIENDA de interés social - 1a parte: 1916-1943 In: Arquitectura y Comunidad Nacional. n.3, s/d. pp.17-40.

HISTORIA ARGENTINA DE LA VIVIENDA de interés social - 2a parte: 1943-1955 In: Arquitectura y Comunidad Nacional. n.4, s/d. pp.3-65. 
HISTORIA In: El Hogar Obrero: cooperativa de consumo, edificación e crédito Ltda. de la República Argentina. Disponível em: <http://www.eho.coop/historia> Acesso em 27 jun. 2017.

HISTORIA DEL MINISTERIO In: Argentina.gob.ar - Portal oficial del Estado argentino. Disponível em: <https://www.argentina.gob.ar/trabajo/historiadelministerio> Acesso em 7 out., 2017.

HISTÓRIA In: Instituto de Arquitetos do Brasil [online]. Disponível em: <http://www.iab.org.br/historia> Acesso em: 15 jan. 2016.

HISTÓRICO DEMOGRÁFICO do Município de São Paulo In: Prefeitura de São Paulo. Disponível em: <http://smul.prefeitura.sp.gov.br/historico_demografico/index.php> Acesso em: 3 set. 2015 HORA, Roy; LOSADA, Leandro. "Clases altas y medias en la Argentina, 1880-1930. Notas para una agenda de investigación" In: Desarrollo económico - Revista de Ciencias Sociales. Buenos Aires, vol. 50, № 200, enero-marzo, 2011. pp. 611-630.

IANNI, Octavio. A formação do Estado populista na América Latina. 2ạ edição. São Paulo: Ática, 1989. IAPI. A criação e a organização do Instituto de Aposentadoria e Pensões dos Industriários. Rio de Janeiro: Tipografia Mercantil, 1939.

INDA, HENRIQUE S. "La vivienda obrera en la formación del Gran Buenos Aires (1890-1940) In: Todo es historia. especial Imigracion. n. 296, feb. 1992. p.71-88.

INDUSTRIAS DE LA CONSTRUCCION: La producción nacional de cemento In: Revista de Arquitectura. Buenos Aires. AÑO VIII. número 32, 1922. pp.22-23.

INFORMACIONES DEL PRIMER Congreso nacional de urbanismo In: Revista de arquitectura. Buenos Aires. n. 173, año XXI, mayo 1935. p.217-218.

INSTITUTO DE APOSENTADORIA e Pensões dos Bancários e sua Carteira Imobiliária In: na Revista Acrópole. Ano 4, n.42, out. 1941.

INSTITUTO DE ARQUITETOS DO BRASIL. “Habitação popular" In: Revista Arquitetura, Rio de Janeiro: n.13, p.42-44, jul. 1963.

INSTITUTO DE ARQUITETOS DO BRASIL. "Ainda a tal da reforma urbana" In: Revista Arquitetura, Rio de Janeiro: n. 23, p.2, maio 1964.

IRIGOIN, Alfredo M. "La evolución industrial en la Argentina (1870-1940)" In: Libertas (ESEADE). Buenos Aires, oct. 1984.

JARAMILLO, Samuel. Hacia una teoria de la renta del suelo urbano. Bogota: Universidad de los Andes. Facultad de Economia, CEDE, Ed. Uniandes, 2010.

JOCKEY CLUB de São Paulo: uma rica história In: Jockey Club S. Paulo [online]. Disponível em: <http://www.jockeysp.com.br/historia.asp> Acesso em: 24 maio 2016.

KATZENSTEIN, Ernesto; NATANSON, Gustavo; SCHVARTZMAN, Hugo. Antonio Bonet: Arquitetura y Urbanismo en el Rio de la Plata y España. Barcelona: Espacio Editora, 1978. 
KNEESE DE MELLO, Eduardo. "Evolução da habitação no Brasil." Instituto Histórico e Geográfico Guarujá-Bertioga, 8 nov. 1964. In: KNEESE DE MELLO, Eduardo. Arquitetura Brasileira: Palestras e Conferências. São Paulo, FAU-USP, 1975, p. 119-129.

KOPP, Anatole. Quando o moderno não era um estilo e sim uma causa. São Paulo: Nobel, 1990.

KOURY, Ana Paula. Arquitetura construtiva: proposições para a produção material da arquitetura contemporânea no Brasil. Tese de Doutorado. FAU-USP, São Paulo, 2005.

LANGENBUCH, Juergen R. A estruturação da Grande São Paulo: estudo de geografia urbana. Rio de Janeiro: Instituto Brasileiro de Geografia, Departamento de Documentação e Divulgação Geográfica e Cartográfica, 1971

LA NACIÓN ARGENTINA Justa Libre Soberana. Control de Estado de la Presidencia de la Nación (Ed.). Buenos Aires: Peuser, 1950.

LARRAÑAGA, Maria Isabel de; PETRINA, Alberto. "Arquitetura de masas en laArgentina (1945-1955): hacia la busqueda de una expresión propria" In: ANALES del Instituto de arte americano e investigaciones esteticas 'Mario J. Buschiazzo' n. 25, año 1987. pp. 107-115.

LAS CONCLUSIONES del IV Congreso de Río de Janeiro In: Revista de Arquitectura, N. 117. Año XVI. Sept. 1930, pp.543-546.

LA VIVIENDA POPULAR y la tecnica In: Nuestra Arquitectura. Buenos Aires, n. 125, año 11, dec. 1939. pp. 402-403.

LECOCQ-MÜLLER, Nice. "A área central da cidade" In: AZEVEDO, Aroldo de (Org.). A cidade de São Paulo: estudos de geografia urbana. São Paulo: Nacional, 1958. Vol. III. pp.121-182.

LIERNUR, Jorge F. Arquitectura en la Argentina del Siglo XX: la construcción de la modernidad. Fondo Nacional de las Artes, 2001.

LIERNUR, Jorge F. Latin American architecture, 1929-1960: contemporary reflections. New York: Monacelli Press, 2004.

LIERNUR, Jorge Francisco. "The South American way: o milagre brasilero, os Estado Unidos e a Segunda Guerra Mundial - 1939-1943" In: GUERRA, Abílio (org.). Textos Fundamentais sobre historia da arquitetura moderna brasileira _ v. 2. São Paulo: Romano Guerra, 2010. pp. 169-218.

LIERNUR, Jorge F.; ALIATA, Fernando. Diccionario de arquitectura en la Argentina: estilos, obras, biografias, instituciones, ciudades, compiladores. Buenos Aires: AGEA 2004.

LIERNUR, Jorge F; PSCHEPIURCA, Pablo. La red austral: obras y proyectos de Le Corbusier y sus discípulos em Argentina, 1924-1965. Buenos Aires: Universidad Nacional de Quilmes: Prometeo 3010, 2008.

LIERNUR, Jorge F.; SILVESTRI, Graciela. El umbral de la metrópolis: transformaciones técnicas y cultura en la modernización de Buenos Aires (1870-1930). Buenos Aires: Editorial Sudamericana, c1993. 
LLOYD-SHERLOCK, Peter. "The Instituto Nacional de Prevision Social and Social Insurance Reform in Argentina, 1944 to 1953" In: London School of Economics \& Political Science Working Papers in Economic History. n. 8/92, Aug. 1992. Disponível em: <http://eprints.Ise.ac.uk/22454/1/08_92.pdf> Acesso em 06 fev. 2019.

LUNA, Felix. Peron y su tiempo 1946-1949. Buenos Aires: Sudamericana, 1984.

MALLOY, James. A política da previdência social no Brasil. Rio de Janeiro: Graal, 1986.

MAIS DE CEM CASAS para bancários serão construídas nesta capital In: Folha Bancaria. São Paulo, ano I, n.1, 02 set. 1939, p.6.

MALUENDA, Ana Esteban. La Arquitectura Moderna en Latinoamérica. Barcelona: Reverté, 2016.

MAPA DE LA CIUDAD In: Ciudad Evita. [online]. Disponível em: <http://www.cdadevita.com.ar/historia_Mapa.htm> Acesso em: 04 maio 2017.

MARTINS, Carlos A.F. Arquitetura e Estado no Brasil: elementos para uma investigação sobre a constituição do estado moderno no Brasil; a obra de Lucio Costa (1924-1952). Dissertação de Mestrado. São Paulo, FFLCH USP, dez. 1987;

MARTINS, Carlos A.F. Identidade nacional e Estado no projeto modernista. Modernidade, Estado e tradição. Óculum, n. 2, Campinas, set. 1992, p. 71-76;

MARTINS, Carlos A. F. Arquitetura Moderna Brasileira em Contexto - uma Proposta de Revisão Historiográfica. Tese de Livre-Docência EESC-USP, São Carlos, 1998;

MARTINS, Rafaela Cristina. "A concepção habitacional a partir dos discursos técnicos: o Primeiro Congresso de Habitação (1931) e a Jornada da Habitação Econômica (1941)" In: Revista Espacialidades [online]. 2011, v.4, n.3. pp.1-28. Disponível em:

<http://cchla.ufrn.br/espacialidades/v4n3/Rafaela.pdf> Acesso em: 11 out. 2016.

MATOS, Odilon N. de. "São Paulo no século XIX" In: AZEVEDO, Aroldo de (Org.). A cidade de São Paulo: estudos de geografia urbana. São Paulo: Nacional, 1958. Vol. II.

MELO, Marcus André B. C. "Política de habitação e populismo: o caso da Fundação da Casa Popular" In: Revista de Urbanismo e Arquitetura. Faculdade de Arquitetura da UFBA. V. 3, n. 1, 1990. pp.39-61. MELO, Marcus André. “O Estado, o boom do século e a crise da habitação: Rio de Janeiro e Recife (1937-1946)" In: FERNANDES, Ana; GOMES, Marco Aurélio (org.). Cidade e História. Salvador: UFBA, 1992.

MELLO, Eduardo Kneese de. "Nucleou residencial do Instituto de Aposentadoria e Pensões dos Comerciários em ‘Cidade Jardim' São Paulo" In: Revista Acrópole. Ano 9, n.107, mar. 1947.

MEMOLO NETO, Peregrino. "O salário do bancário e a Carteira Predial do Instituto" In Folha Bancária. São Paulo, Ano III, n. 10, jun. 1942, p.12. 
MEMORIAL DESCRITIVO PARA O ANTEPROJETO de Aproveitamento dos Terrenos do Instituto de Aposentadoria e Pensões dos Bancários, à Rua Santa Cruz. São Paulo, 25 de fevereiro de 1948. Processo Administrativo n. 29.326/1948.

MENDES, Renato S. "Os bairros da zona Norte e os Bairros Orientais" In: AZEVEDO, Aroldo de (Org.). A cidade de São Paulo: estudos de geografia urbana. São Paulo: Nacional, 1958. Vol. III. pp.183-256

MENDES, Renato S. "Os bairros da zona Sul e os Bairros Odidentais" In: AZEVEDO, Aroldo de (Org.). A cidade de São Paulo: estudos de geografia urbana. São Paulo: Nacional, 1958. Vol. III. pp. 257-364.

MENEGHELLO, Isabela Belém. Conjunto Habitacional da Várzea do Carmo: do projeto ideal ao conjunto real In: Anais do 8o Seminário DOCOMOMO Brasil. Rio de Janeiro, 01 a 04 set. 2009. Disponível em: <http://www.docomomo.org.br/seminario\%208\%20pdfs/082.pdf> Acesso em: 15 abril 2016.

MENDONÇA, Sonia Regina. "Estado e políticas públicas: considerações político-conceituais" In: Outros Tempos [online] 2007, Vol. 1 esp. pp. 1-12. Disponível em: <www.outrostempos.uema.br> Acesso em: 21 jun. 2017.

MEYER, R.M.P.; GROSTEIN, M.D.; BIDERMAN, C. São Paulo Metrópole. São Paulo: EDUSP: Imprensa Oficial do Estado de São Paulo, 2004.

MINISTÉRIO DE RELAÇÕES EXTERIORES. Moradia própria: Realidade argentina. Buenos Aires. [1953?]. MONASTA, Attilio. Antonio Gramsci. Tradução: Paolo Nosella. Recife: Fundação Joaquim Nabuco: Massangana, 2010.

MONTANER, Josep Maria. La arquitectura dela vivienda colectiva. Barcelona: Reverté, 2015.

MORAIS, Pedro Henrique Almeida de. Cidades verticais: habitação de grande escala na América Latina 1929-1979. Tese (Doutorado). UFMG, Belo Horizonte, 2016.

MORSE, Richard. Formação Histórica de São Paulo: de Comunidade à Metrópole. São Paulo: Difusão Europeia do Livro, 1970.

MUMFORD, Eric. Defining Urban Design: CIAM Architects and the Formation of a Discipline, 1937-69. New Haven and London: Yale University Press, 2009.

MUMFORD, Eric. Designing the Modern City: Urbanism Since 1850. New Haven and London: Yale University Press, 2018.

NEIBURG, Federico. 017 de outubro na Argentina. Espaço e produção social do carisma. In: Revista Brasileira de Ciências Sociais. 20 (7), pp. 70-89. Disponível em: <http://www.anpocs.org.br/portal/publicacoes/rbcs_00_20/rbcs20_07.htm> Acesso em 23 fev. 2018. NÚCLEO RESIDENCIAL DO INSTITUTO de Aposentadoria e Pensões dos Comerciários em "Cidade Jardim" São Paulo In: Acrópole. Ano 9, n. 107, março 1947. pp.73-84

ORTIZ, Federico; GUTIÉRREZ, Ramón. La Arquitectura en la Argentina 1930-1970. Buenos Aires: Unión Internacionale des Architetes. Separata del número 103 de la revista Hogar y Architectura, 1972. 
OSWALDO Correa Gonçalves. In: ENCICLOPÉDIA Itaú Cultural de Arte e Cultura Brasileiras. São Paulo: Itaú Cultural, 2018. Disponível em: <http://enciclopedia.itaucultural.org.br/pessoa345742/oswaldocorrea-goncalves>. Acesso em: 01 de Set. 2018. Verbete da Enciclopédia.

PALLERO, Sandro Olaza. "El Proyecto de Ley Nacional del Trabajo de Joaquín V. González (1904). Un intento de respuesta a la cuestión social" In: Aequitas: Publicación de la Facultd de Ciencias Jurídicas. [online]. Vol. 8, Núm. 22, 2014. Disponível em: <https://p3.usal.edu.ar/index.php/aequitasvirtual/article/view/3135/3814> Acesso em: 28 jan. 2018. PASTOR, Jose M.F. "La vivienda popular" In: Revista de Arquitectura. Buenos Aires, n. 279, marzo 1944. pp. 183-215.

PASTOR, Jose M. F. Areas residenciales In: Nuestra Arquitectura. N. 10, oct. 1946. pp. 360-366.

PEDRO, Alim. O Seguro Social, a Indústria Brasileira, o Instituto dos Industriários: Relatório do Presidente do IAPI, período 1946 a 1951. Rio de Janeiro: IAPI, 1950.

PEREIRA, Paulo Cesar X. Espaço, técnica e construção: o desenvolvimento das técnicas construtivas e a urbanização do morar em São Paulo. São Paulo: Nobel, 1988.

PERÓN, Eva Duarte. La razon de mi vida. Buenos Aires: Ediciones Peuser, 1951.

PERÓN, Juan Domingo. Obras Completas. Tomos VII, VIII e IX.

PESSOLATO, Cintia. Conjunto IAPI Vila Guiomar - Santo André - SP: projeto e história. Dissertação (Mestrado). FAU-USP, São Paulo, 2007.

PETRONE, Pasquale. "São Paulo no século XX" In: AZEVEDO, Aroldo de (Org.). A cidade de São Paulo: estudos de geografia urbana. São Paulo: Nacional, 1958. Vol. II

PINO, Patricia M. "La vivienda comunitaria, una opción del Estado" In: GUTIÉRREZ, Ramón. La habitación popular bonaerense 1943-1955: Aprendiendo en la historia. Buenos Aires: CEDODAL: Ministerio de Infraestructura y Vivienda, 2011. p. 113-122.

PLAN DIRECTOR para Buenos Aires 1937 - 1938 In: Moderna Buenos Aires [online]. Disponível em: <https://www.modernabuenosaires.org/proyectosurbanos/plan-director-para-buenos-aires> Acesso em: 14 ago. 2017.

PLANEAMIENTO EM BUENOS AIRES. Municipalidad de la Ciudad de Buenos Aires. Dirección General de Obras Públicas y Urbanismo. Buenos Aires, 1944.

PORTA, Paula. Historia da Cidade de Sao Paulo Vol. 3. São Paulo: Paz e Terra, 2004.

PORTELLI, Hugues. Gramsci e o Bloco Histórico. São Paulo: Paz e Terra, 1977.

PORTO, Rubens. O Problema das Casas Operárias e os Institutos de Aposentadoria e Pensões. Rio de Janeiro: [s.n.], 1938.

POULANTZAS, Nicos. "The Problem of the Capitalist State" In: New Left Review, n.58, Nov.-Dec. 1969.

pp.67-78. Disponível em: <https://www.ssc.wisc.edu/ wright/Soc924-2011/Poulantzas\%20-\%20the\%20problem\%20of\%20the\%20capitalist\%20state.pdf> Acesso em 15 ago. 2016. 
POULANTZAS, Nicos. Poder Político e Classes Sociais. Tradução de Francisco Silva. Revisão de Carlos Roberto F. Nogueira. São Paulo: Martins Fontes, 1977.

POULANTZAS, Nicos. O Estado. O Poder. O Socialismo. São Paulo: Paz e Terra, 2015.

(O) PROBLEMA DA AQUISIÇÃO da casa própria pelos bancários In: Folha Bancária. São Paulo, jun. 1940. p. 8.

(O) PROBLEMA DA HABITAÇÃO na política do General Eurico Dutra In: O Estado de São Paulo. São Paulo, 16 out. 1945. p.4.

(O) 1 o Congresso Brasileiro de Urbanismo In: A Noite, Rio de Janeiro, 17 jan. 1941. p.6.

Primeiro Congresso de Habitação. São Paulo, maio 1931 - Publicação official. São Paulo: Instituto de Engenharia, 1931.

PRIMER CONGRESSO PANAMERICANO de Arquitectos In: Revista de arquitetura. Nov-dec 1919, enefeb. 1920. N. 25. Año V, pp 3-6.

QUÉ HAY DEL PLAN de vivienda popular? In: Revista de Arquitectura. Buenos Aires, n.301, ene. 1946. pp. $44-46$

QUENTAL, Pedro de Araújo. "A latinidade do conceito de América Latina" In: GEOgraphia, Vol. 14, no 27, 2012, p.46-75. Disponível em:

<http://www.uff.br/geographia/ojs/index.php/geographia/article/viewArticle/520> Acesso em:19 ago. 2015. QUIROZ, ROBERTO In: Moderna Buenos Aires [online]. Disponível em: <https://www.modernabuenosaires.org/arquitectos/roberto-quiroz> Acesso em 28 março 2018.

REGINO, Aline Nassaralla. Eduardo Kneese de Mello / Arquiteto: análise de sua contribuição à habitação coletiva em São Paulo. Dissertação (Mestrado em Arquitetura e Urbanismo). Universidade Presbiteriana Mackenzie, São Paulo, 2006.

REGINO, Aline N.; PERRONE, Rafael Antonio C. "Eduardo Augusto Kneese de Mello: sua contribuição para habitação coletiva em São Paulo" In: Revista Risco. Revista de Pesquisa em Arquitetura e Urbanismo - PPGAU/EESC-USP, [São Carlos], n.9, 2009. p. 56-97. Disponível em: < http://www.iau.usp.br/revista_risco/Risco9-pdf/02_art04_risco9.pdf> Acesso em: 10 jul. 2011.

RELATÓRIO DA COMISSÃO MISTA BRASIL-ESTADOS UNIDOS. "Balanço de Pagamentos" In: Arte_memorias, n.02 (337_426), set. 2008, pp.337-195 - Originalmente publicado em: O Observador Econômico e Financeiro, Ano XX, № 231, maio de 1955. Disponível em: <http://www.centrocelsofurtado.org.br/arquivos/image/201109010925330.MD2_0_337.pdf> Acesso em: 22 maio 2018.

REPETTO, Raul T. (diretor técnico do Plan Eva Perón do BHN) "El Plan Quinquenal y la Vivienda" In: Construcciones. n 111, ago. 1954. pp. 74-83.

REZA, Silvia Mejía. "Mario Pani: precursor do adensamento" In: Arquitextos, São Paulo, 07.074, Vitruvius, 2006. Disponível em 
<http://www.vitruvius.com.br/revistas/read/arquitextos/07.074/337>. Acesso em 17 de janeiro de 2012.

RIGOTTI, Ana MAria. "El Reformismo Oligárquico y las Casas para Obreros" In: Estudios Sociales: Revista Universitaria Semestral. Universidade Nacional del Litoral, Santa Fé. Vol. 1, Núm. 1, 1991. p. 527. Disponível em: <http://bibliotecavirtual.unl.edu.ar/ojs/index.php/

RIGOTTI, Ana María. Las invenciones del urbanismo en Argentina 1900-1960: inestabilidad de sus representaciones científicas y dificultades para su profesionalización. Tesis de doctorado. 2005.

ROMERO, José Luis. Breve Historia de la Argentina. 6ạ edição. Buenos Aires: Fondo de Cultura Economica, 2016.

RUBIO, S. "El barrio 17 de Octubre. Obra del Banco Hipotecario Nacional" In: Construcciones. n 107, abril 1954. pp. 335-337.

SAES, Flavio. "São Paulo Republicana" In: PORTA, Paula. Historia da Cidade de Sao Paulo Vol. 3. São Paulo: Paz e Terra, 2004. pp. 226-234.

SAMBRICIO, Carlos (ed.). Ciudad y vivienda en America Latina 1930-1960. Madrid: Lampreave, 2012.

SAMPAIO, Maria Ruth Amaral de. (Org.). A promoção privada de habitação econômica e a arquitetura moderna, 1930-1964. São Paulo: Rima, 2002.

SANTOS, Lena C. Arquitetura Paulista em torno de 1930 - 1940. Dissertação (Mestrado). FAU-USP, São Paulo, 1985.

SANTOS, Wanderley Guilherme dos. Cidadania e Justiça. Rio de Janeiro: Editora Campus, 1979.

SETTIMI, Stella Maris; AUDINO, Patricia. "La nacionalización del Banco Central de la República Argentina, 1946: una interpretación" In: Revista Análisis Económico, vol. XXVII, núm. 64, 2012, pp. 233-253. Disponível em: <http://www.redalyc.org/articulo.oa?id=41324545011> Acesso em: 14 abril 2017.

SICILIANO, Heribaldo. "Habitação Econômica em sentido vertical”. In: Revista do Arquivo Municipal. São Paulo: ano VII, vol.LXXXI, mar.-abr. 1942, p.97-100.

SINGER, Paul. Desenvolvimento econômico e evolução urbana. São Paulo: Nacional: Edusp, 1968. pp. 19-79

SOLOW, Anatole S.; MASIS D., Rodrigo. "Cooperación Interamericana en el campo de la vivienda y del urbanismo" In: Revista de Arquitectura. Buenos Aires, n. 357, sept. 1950. p. 261.

SOMEKH, Nadia. (Des) verticalização de São Paulo. Dissertação (Mestrado). FAU-USP, São Paulo, 1987; SOMEKH, Nadia. A cidade vertical e o urbanismo modernizador. 2a edição revisada. São Paulo: Mackenzie: Romano Guerra, 2014.

SOMEKH, Nadia; CAMPOS, Cândido M. (Org.) A Cidade que não pode parar. Planos urbanísticos de São Paulo no século XX. São Paulo: Mack Pesquisa, 2002, p.13-32.

SOUZA, Maria Adélia Aparecida de. A Identidade da Metrópole. São Paulo: Hucitec:Edusp, 1994. 
TELLA, Guillermo. "La zonificación urbana en su primer escenario" In: WAM - Web Architecture Magazine, n. 03, nov.-dez. 1996. s/p. Disponível em:< http://www.arranz.net/web.archmag.com/3/cover.html> Acesso em 16 out. 2017.

TORRE, Juan Carlos. Ensayos sobre movimento obrero y peronismo. Buenos Aires: Siglo Veitiuno Editores, 2012.

TORRES, Horacio A. "El Mapa Social de Buenos Aires en 1943, 1947 y 1960. Buenos Aires y los Modelos Urbanos" In: Desarrollo Económico. Vol. XVIII № 701978.

URBANIZACIÓN DE BAJO BELGRANO In: Revista de Arquitectura. Buenos Aires, n. 369, ene./feb. 1953. p.17-75.

VARGAS, Getulio. A Nova Política do Brasil: no limiar de uma nova era. 20 de outubro de 1939 a 29 de junho de 1940. Volume VII. Rio de Janeiro: José Olympio, 1940.

VIVANCO, JORGE In: Moderna Buenos Aires [online]. Disponível em: <hhttps://www.modernabuenosaires.org/arquitectos/jorge-vivanco> Acesso em 28 março 2018 XAVIER, Alberto (Org.). Arquitetura Moderna Brasileira: depoimento de uma geração. São Paulo: Cosac\&Naify, 2a. edição, 2003.

WEFFORT, Francisco. O Populismo da Política Brasileira. Rio de Janeiro: Paz e Terra, 1980.

YUJNOVSKY, Oscar. "Revision histórica de la política de vivienda en la Argentina desde 1880" In: SUMMA. Buenos Aires, n.72, feb. 1974. pp.13-18.

YUJNOVSKY, Oscar. Claves políticas del problema habitacional argentino. 1955-1981. Buenos Aires: Grupo editor latinoamericano, 1984.

ZANZOTTERA, Maria Guillermina. "La vivienda y la ciudad en el $1^{\circ}$ Congreso Argentino de la Habitación Popular" In: XIV Jornadas Interescuelas/Departamentos de Historia. Departamento de Historia de la Facultad de Filosofía y Letras. Universidad Nacional de Cuyo, Mendoza, 2013. Disponível em: <http://cdsa.aacademica.org/000-010/417.pdf> Acesso em: 06 maio 2016.

\section{Fontes Documentais}

CADERNO DE ENCARgOS. Processo Administrativo 13964/1948 - "Alvará de Licença do Conjunto Residencial Nove de Julho".

GEGRAN - Grupo Executivo da Grande São Paulo. Levantamento aerofotogramétrico da Cidade de São Paulo. Acervo FAU-USP.

MINISTÉRIO DE FINANZAS DE LA NACIÓN. Carpeta técnica B1036 Plan "Eva Perón". Ministério de Finanzas de la Nación. Banco Hipotecario Nacional.

PRESIDENCIA DE LA NACION. Plan de Gobierno 1947-1951. Secretaria Técnica. Buenos Aires, 1946.

PMSP. Processo n.21.197, de 1942: “Aprovação de Projeto do C.R. Japurá”. São Paulo, 1942. 
PMSP. Processo n.45.127, de 23 de maio de 1944: "Aprovação de Projeto do C.R. da Mooca". São Paulo, 23 de maio de 1944 (a).

PMSP. Processo n.62.631, de 11 de agosto de 1944: "Expedição de Alvará de Construção do C.R. da Várzea do Carmo". São Paulo, 11 de agosto de 1944 (b).

PMSP. Processo n.11.569, de 1946: "Alvará de Construção, Loteamento e Arruamento do C.R. Cidade Jardim". São Paulo, 1946.

PMSP. Processo n. 29.326, de fevereiro de 1948: "Memorial descritivo para o anteprojeto de Aproveitamento dos Terrenos do Instituto de Aposentadoria e Pensões dos Bancários, à Rua Santa Cruz". São Paulo, fevereiro de 1948 (a).

PMSP. Processo n.31.964, de 9 de março de 1948: "Aprovação de Projeto do C.R. Nove de Julho". São Paulo, 9 de março de 1948 (b).

PMSP. Processo n.65.163, de 22 de julho de 1948: "Alvará de Construção do C.R. Santa Cecília". São Paulo, 22 de julho de 1948 (c).

PMSP. Processo n.104.125, de 12 de julho de 1951: "Expedição de Habite-se do C.R. Santa Cruz". São Paulo, 12 de julho de 1951 (a).

PMSP. Processo n.170.199, de 4 de dezembro de 1951: "Expedição de Habite-se do Clube do C.R. Santa Cruz". São Paulo, 4 de dezembro de 1951 (b).

PMSP. Processo n.161.263, 2 de outubro de 1954: "Habite-se Parcial do C.R. Nove de Julho". São Paulo, 2 de outubro de 1954.

PMSP. Processo n.257.656, de 1956: "Alteração de Projeto do C.R. Nove de Julho". São Paulo, 1956.

PMSP. Processo n.164.763, de 17 de novembro de 1958: "Expedição de Habite-se do C.R. Japurá". São Paulo, 17 de novembro de 1958 (a).

PMSP. Processo n.194.379, 28 de dezembro de 1958: "Habite-se Parcial do C.R. Nove de Julho". São Paulo, 28 de dezembro de 1958 (b).

PMSP. Processo n.153.800, de 13 de novembro de 1959: "Aprovação de Projeto parcial do C.R. Francisco Morato". São Paulo, 13 de novembro de 1959.

PMSP. Processo n.145.728, de 29 de setembro de 1960: "Expedição de Habite-se parcial do C.R. Francisco Morato". São Paulo, 29 de setembro de 1960 (a).

PMSP. Processo n.199.146, de 20 de dezembro de 1960: "Concessão de Habite-se Parcial do C.R. Várzea do Carmo". São Paulo, 20 de dezembro de 1960 (b).

PMSP. Processo n.188.992, de 10 de novembro de 1965: "Expedição de Habite-se parcial do C.R. Santo Antonio". São Paulo, 10 de novembro de 1965.

S.A.R.A. Brasil: restituindo o Mapa Topográfico do Município de São Paulo. In: Informativo Arquivo Histórico de São Paulo, Ano 10, n.37, dez. 2014. Disponível em: <http://www.arquivohistorico.sp.gov.br> Acesso em: 5 mar. 2016. 
SECRETARIA DE TRABAJO Y PREVISION (a). Informe Preliminar. Dirección de Viviendas. Comisión Asesora para la vivienda Popular. Buenos Aires. 1943.

SECRETARIA DE TRABAJO Y PREVISION (b). Plan orgânico para la construcción de viviendas destinadas al sector de población de renta reducida que, imprescindivelmente, requere o aporte do Estado. Dirección de Viviendas. Comisión Asesora para la vivienda Popular. Buenos Aires. 1943.

SECRETARIA DE TRABAJO Y PREVISION. Proyecto de creación del Banco Nacional de la Vivienda. Dirección de Viviendas. Comisión Asesora para la vivienda Popular. Buenos Aires. 1944.

SEGUNDO PLANO QUINQUENAL. Texto Completo del 2ㅇ Plan Quinquenal (Ley 14.184). Buenos Aires: Ediciones Hechos e Ideas, 1954.

\section{Legislação Consultada}

ARGENTINA. Ley 4.824, de 27 de septiembre de 1905. Nacional de Casas Baratas, también denominada Ley Irigoyen. Buenos Aires, 1905.

ARGENTINA. Ley no 8.871, de 26 de marzo de 1912. Ley Electoral (Sáenz Peña). Buenos Aires, 1912.

ARGENTINA. Ley Nacional no 9.677, de 5 de octubre de 1915. Da lugar a la creación de la Comisión Nacional de Casas Baratas (CNCB). Buenos Aires, 1915.

ARGENTINA. Decreto-Ley no 15.074, del 27 de Noviembre de 1943. Crea la Secretaría de Trabajo y Previsión. Buenos Aires, 1943.

ARGENTINA. Decreto 11.157, de 1945. Disuelta en 1944 la Comisión Nacional de Casas Baratas, el Decreto constituye la Administración Nacional de Vivienda. Buenos Aires, 1945.

ARGENTINA. Decreto no 14.961, de 24 de maio de 1946. Modifica a carta orgânica do Banco hipotecário nacional, com a finalidade de coordenar suas atividades com a política economica, financeira e social do Estado (tradução nossa). Buenos Aires, 1946 (a).

ARGENTINA. Decreto no 14962, de 24 de maio de 1946. Modifica o regime bancário vigente no país com a finalidade de alcançar um melhor controle do Estado (tradução nossa). Buenos Aires, 1946 (b). ARGENTINA. Lei 5.396, 22 de noviembre de 1.948. Ley de la Vivienda". Buenos Aires, 1948 (a). ARGENTINA. Lei n. 13.512, de 1948. Régimen de Propiedad Horizontal. Buenos Aires, 1948 (b). ARGENTINA. Constitucion de la Nación Argentina. Buenos Aires, 1949.

BRASIL. Decreto $n^{\circ} 4.682$ de 24 de janeiro de 1923. Cria em cada uma das empresas de estradas de ferro existentes no país, uma Caixa de Aposentadoria e Pensões para os respectivos empregados. Rio de Janeiro, DF, 24 jan. 1923.

BRASIL. Decreto no 19.667, de 4 de fevereiro de 1931. Organiza o Ministério do Trabalho, Indústria e Comércio. Rio de Janeiro, DF, 4 fev. 1931.

BRASIL. Decreto $n^{\circ} 19.433$, de 26 de novembro de 1930. Cria o Ministério do Trabalho, Indústria e Comércio. Rio de Janeiro, DF, 26 nov. 1930. 
BRASIL. Decreto ${ }^{\circ}$ 19.496, de 17 de dezembro de 1930. Altera os Arts. 10 e 12 da Lei [lê-se Decreto] $n^{\circ}$ 5.109, de 20 de dezembro de 1926, referentes à aplicação dos fundos das Caixas de Aposentadoria e Pensões, e dá outras providências. Rio de Janeiro, DF, 17 dez. 1930.

BRASIL. Decreto № 24.615, de 8 de julho de 1934. Institue a carteira profissional. Rio de Janeiro, DF, 21 março 1932.

BRASIL. Decreto no 22.872, de 29 de junho de 1933. Cria o Instituto de Aposentadoria e Pensões dos Marítimos, regula o seu funcionamento e dá outras providências. Rio de Janeiro, DF, 29 jun. 1933.

BRASIL. Constituição de 1934. Diário Oficial da União - Seção 1 - Suplemento - 16/7/1934, p.1.

BRASIL. Constituição da República dos Estados Unidos do Brasil, decretada pelo Presidente da República em 10.11.1937. Rio de Janeiro, 10 nov. 1937.

BRASIL. Decreto no 24.273, de 22 de maio de 1934. Cria o Instituto de Aposentadoria e Pensões dos Comerciários, dispõe sobre o seu, funcionamento e dá outras providências. Rio de Janeiro, DF, 22 maio 1934 (a)

BRASIL. Decreto $n^{\circ}$ 24.615, de 8 de julho de 1934. Cria o Instituto de Aposentadoria e Pensões dos Bancários. Rio de Janeiro, DF, 9 jul. 1934 (b)

BRASIL. Lei no 367, de 31 de dezembro de 1936. Crêa o Instituto de Aposentadoria e Pensões dos Industriarios Subordinados ao Ministerio do Trabalho, Industria e Comércio, e dá outras providências. Rio de Janeiro, DF, 31 dez. 1936.

BRASIL. Decreto no 1.749, de 28 de junho de 1937. Aprova novo regulamento para a aquisição de prédios destinados à moradia dos associados e à sede dos Institutos e Caixas de Aposentadoria e Pensões. Rio de Janeiro, DF, 28 jun. 1937.

BRASIL. Decreto-lei no 288, de 23 de fevereiro de 1938. Cria o Instituto de Previdência e Assistência dos Servidores do Estado. Rio de Janeiro, DF, 23 fev. 1938 (a).

BRASIL. Decreto-Lei № 651, de 26 de agosto de 1938. Altera a organização da Caixa de Aposentadoria e Pensões dos Trabalhadores em Trapiches e Armazéns e dá outras providências. Rio de Janeiro, DF, 26 ago. 1938 (b).

BRASIL. Decreto-Lei $n^{\circ} 5.452$, de $1^{\circ}$ de maio de 1943. Aprova a Consolidação das Leis do Trabalho. Rio de Janeiro, DF, 19 abril 1943.

BRASIL Decreto $n^{\circ}$ 7.526, de 7 de maio de 1945. Lei Orgânica dos Serviços Sociais do Brasil. Rio de Janeiro, DF, 7 maio 1945 (a).)

BRASIL. Decreto-Lei $n^{\circ}$ 7.720, de 9 de julho de 1945. Determina a incorporação do Instituto de Aposentadoria e Pensões da Estiva ao Instituto de Aposentadoria e Pensões dos Empregados em Transportes e Cargas e dá outras providências. Rio de Janeiro, DF, 9 jul. 1945 (b).

BRASIL. Decreto-Lei no 9.218, de 10 de maio de 1946. Autoriza a instituição da "Fundação da Casa Popular". Rio de Janeiro, DF, 1ㅇmaio 1946 (a). 
BRASIL. Decreto-Lei no 9.777, de 6 de setembro de 1946. Estabelece bases financeiras para a "Fundação da Casa Popular" e dá outras providências. Rio de Janeiro, DF, 6 set. 1946 (b).

BRASIL. Decreto $\mathrm{n}^{\circ}$ 34.586, de 12 de novembro de 1953. Determina a fusão de Caixas de Aposentadorias e Pensões e dá outras providências. Rio de Janeiro, DF, 12 nov. 1953 (a).

BRASIL. Decreto № 34.828, de 17 de dezembro de 1953. Dispõe sobre as operações imobiliárias das Instituições de Previdência Social. Rio de Janeiro, DF, 17 dez. 1953 (b).

BRASIL. Decreto $n^{\circ} 35.448$, de $1^{\circ}$ de maio de 1954. Expede o Regulamento Geral dos Institutos de Aposentadoria e Pensões. Rio de Janeiro, DF, 10 maio 1954.

BRASIL. Lei no 4.380, de 21 de agosto de 1964. Institui a correção monetária nos contratos imobiliários de interesse social, o sistema financeiro para aquisição da casa própria, cria o Banco Nacional da Habitação (BNH), e Sociedades de Crédito Imobiliário, as Letras Imobiliárias, o Serviço Federal de Habitação e Urbanismo e dá outras providências. Brasília, DF, 21 ago. 1964.

BRASIL. Decreto-Lei no 72, de 21 de novembro de 1966. Unifica os Institutos de Aposentadoria e Pensões e cria o Instituto Nacional de Previdência Social. Diário Oficial [da] União, Brasília. DF, 22 nov. 1966.

BRASIL. Lei no 5.455, de 19 de junho de 1968. Altera dispositivos da Lei no 4.380, de 21 de agosto de 1964, que institui a correção monetária nos contratos imobiliários, de interêsse social, o sistema financeiro para aquisição da casa própria, cria o Banco Nacional da Habitação (BNH), e sociedade de Crédito Imobiliário, as Letras Imobiliárias, o Serviço Federal, de Habitação e Urbanismo, e dá outras providências. Brasília, 19 jun. 1968.

LA PLATA. Decreto no 70, 8 de enero de 1948. Señalando con el nombre de "Gran Buenos Aires" el área urbana y rural que comprende a varios partidos que circundan a la Capital Federal. La Plata, 8 de enero de 1948.

SÃO PAULO. Decreto no 10.291, de 10 de junho de 1939. Organiza o Instituto de Previdência do Estado de São Paulo e dá outras providências. São Paulo, SP, 10 jun. 1939. 


\section{Bibliotecas e acervos consultados}

Archivo General de la Nación Argentina

Arquivo Público do Estado de São Paulo

Biblioteca Central da Escola de Engenharia de São Carlos - EESC-USP

Biblioteca da Faculdade de Arquitetura e Urbanismo - FAU-USP

Biblioteca da Pós-Graduação FAU-USP

Biblioteca de la Sociedad Central de Arquitectos (SCA)

Biblioteca del Banco Hipotecario

Biblioteca del Congresso de la Nación. Biblioteca Peronista de la Biblioteca del Congresso de la Nación Biblioteca del Consejo Profesional de Arquitectura y Urbanismo (CPAU)

Biblioteca Florestan Fernandes - Faculdade de Filosofia, Letras e Ciências Humanas - USP

Centro de Documentação do Sindicato dos Bancários de São Paulo

Centro de Documentación Latinoamericana (CEDODAL)

Centro de Documentación e Investigación de la Arquitectura Pública (CeDIAP)

Dirección de Servicios Legislativos de la Biblioteca del Congresso de la Nación.

Centro de Documentación e Información e Biblioteca do Ministerio de Hacienda

Centro Documental de Información y Biblioteca de la Legislatura de la Ciudad de Buenos Aires (CEDOM)

PMSP. Arquivo Geral de Processos / Divisão do Arquivo Municipal de Processos - DGDP-2 SMG PMSP Departamento de Gestão de Documentos Públicos da Secretaria Municipal de Gestão da Prefeitura Municipal de São Paulo.

Seção Técnica de Materiais Iconográficos FAU-USP 
Apêndice A ב- 
Sistematização de elementos das formas de produção do espaço urbano conforme Jaramillo (2010)

Com base em Jaramillo (2010) é possível elaborar um quadro sistematizado com os elementos característicos das diferentes formas de produção do espaço urbano.

Quadro - Elementos característicos das Formas de Produção do espaço urbano

\begin{tabular}{|c|c|c|c|c|c|c|c|}
\hline & $\begin{array}{l}\text { Controle } \\
\text { técnico }\end{array}$ & $\begin{array}{l}\text { Controle } \\
\text { econômico }\end{array}$ & $\begin{array}{l}\text { Motor da } \\
\text { produção }\end{array}$ & $\begin{array}{l}\text { Forma de } \\
\text { circulação }\end{array}$ & $\begin{array}{c}\text { Processo de } \\
\text { trabalho }\end{array}$ & $\begin{array}{c}\text { Propriedade } \\
\text { do espaço } \\
\text { construído }\end{array}$ & $\begin{array}{r}\text { Produção } \\
\text { de valor }\end{array}$ \\
\hline AUTOCONSTRUÇÃO & usuário final & usuário final & $\begin{array}{l}\text { autoprovisão de } \\
\text { valor de uso }\end{array}$ & autoprovisão & artesanal & usuário final & não \\
\hline ENCOMENDA & construtor & usuário final & $\begin{array}{c}\text { autoprovisão de } \\
\text { valor de uso }\end{array}$ & autoprovisão & manufatureiro & usuário final & potencial \\
\hline PROMOCIONAL & capitalista & capitalista & $\begin{array}{c}\text { acumulação de } \\
\text { capital }\end{array}$ & $\begin{array}{c}\text { mercado } \\
\text { geral }\end{array}$ & racional & $\begin{array}{l}\text { capitalista / } \\
\text { usuário final }\end{array}$ & $\operatorname{sim}$ \\
\hline $\begin{array}{l}\text { ESTATAL } \\
\text { (demanda efetiva) }\end{array}$ & $\begin{array}{l}\text { Estado / } \\
\text { construtor }\end{array}$ & Estado & $\begin{array}{c}\text { provisão de } \\
\text { valor de uso / } \\
\text { acumulação de } \\
\text { capital }\end{array}$ & $\begin{array}{l}\text { demanda } \\
\text { efetiva }\end{array}$ & racional & $\begin{array}{c}\text { Estado / } \\
\text { usuário final }\end{array}$ & $\operatorname{sim}$ \\
\hline ESTATAL (direta) & Estado & Estado & $\begin{array}{l}\text { provisão de } \\
\text { valor de uso }\end{array}$ & $\begin{array}{c}\text { demanda } \\
\text { não efetiva }\end{array}$ & racional & $\begin{array}{c}\text { Estado / } \\
\text { usuário final }\end{array}$ & não \\
\hline
\end{tabular}

Para analisar a cidade de Bogotá, Jaramillo (2010) parte do princípio que há distintas formas de produção do espaço urbano operando simultaneamente, com dinâmicas internas particulares e entrelaçadas entre si. A categoria mais importante de espaço construído conforme a análise do autor é a habitação. Partindo do pressuposto de que a produção de mercado ou capitalista, ou ainda, promocional da habitação exclui setores populares numericamente importantes, que não representam uma demanda efetiva Jaramillo (2010) explica como a produção capitalista então convive com outras formas de produção do espaço urbano que atendem estes setores da população: a forma doméstica (ou autoconstrução), a forma por encomenda e a forma estatal.

Para caracterizar e distinguir as diversas formas de produção, Jaramillo (2010, p.176, tradução nossa) analisa os seguintes aspectos: a) controle técnico da produção: regulação das atividades dos meios de produção, do ponto de vista do processo de trabalho, por exemplo, "coordenando os distintos indivíduos e elementos que interveem na produção, a disciplina interna, os ritmos e horários, a programação de tarefas, etc."; b) controle econômico direto da produção: "domínio sobre os meios de produção do ponto de vista econômico, o que implica poder iniciar o processo de produção e definir suas características"; c) motor de produção: "o elemento que comanda as decisões e práticas do agente que detém o controle econômico direto e, portanto, estrutura a dinâmica de produção" (na produção capitalista, por exemplo, o motor de produção é a acumulação de capital); d) forma de circulação: "o processo que encadeia os produtos e os distribui desde a produção até seu momento de consumo", ou seja, as condições de sua reprodução; e ainda e) processo de trabalho (artesanal, manufatureiro ou racional); f) propriedade do espaço construído; e g) produção de valor. 
Apêndice B 


\section{Fichas dos projetos habitacionais}

Estas fichas foram elaboradas a partir da pesquisa bibliográfica, documental e iconográfica sobre dos projetos habitacionais realizados em São Paulo e Buenos Aires entre 1940 e 1950. As fichas se constituem basicamente de mapas de localização, plantas, fotografias próprias e outras imagens que podem ou não ter sido apresentadas na Tese, compondo um pequeno banco.

\section{Conjunto Residencial da Várzea do Carmo}

Data do projeto: $1938-1942$

Órgão: Instituto de Aposentadoria e Pensões dos Industriários (IAPI)

Projeto: arq. Attilio Correa Lima, Hélio Lage Uchoa Cavalcanti, José Teodulo da Silva; eng. Alberto de Mello Flores

Construção: Serviço de Engenharia do IAPI

Engenheiro responsável: Vicente Campos Paes Barreto

Localização: Avenida do Estado - São Paulo

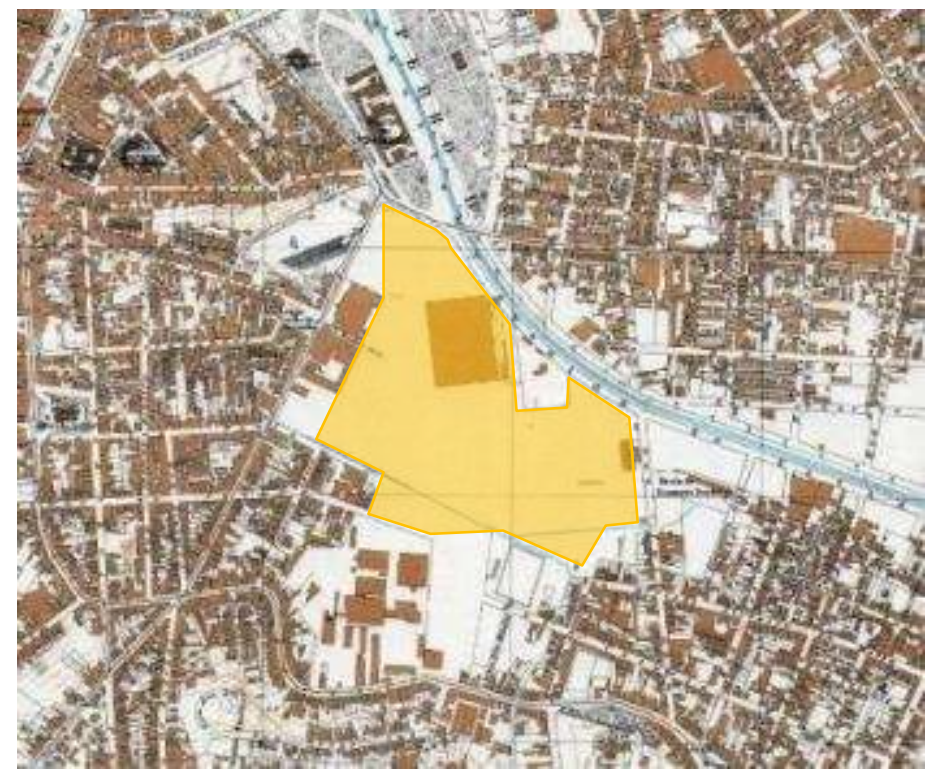

Figura 01: Localização do terreno do C.R. da Várzea do Carmo. Base Cartográfica: Mapa Topográfico do Município de São Paulo, 1930, Série 1:5000, Folhas 51-52. Fonte: MENDES, Ricardo. S.A.R.A. Brasil: restituindo o Mapa Topográfico do Município de São Paulo. In: Informativo Arquivo Histórico de São Paulo, Ano 10, n.37, dez. 2014. Disponível em: <http://www.arquivohistorico.sp.gov.br> Acesso em: 5 mar. 2016

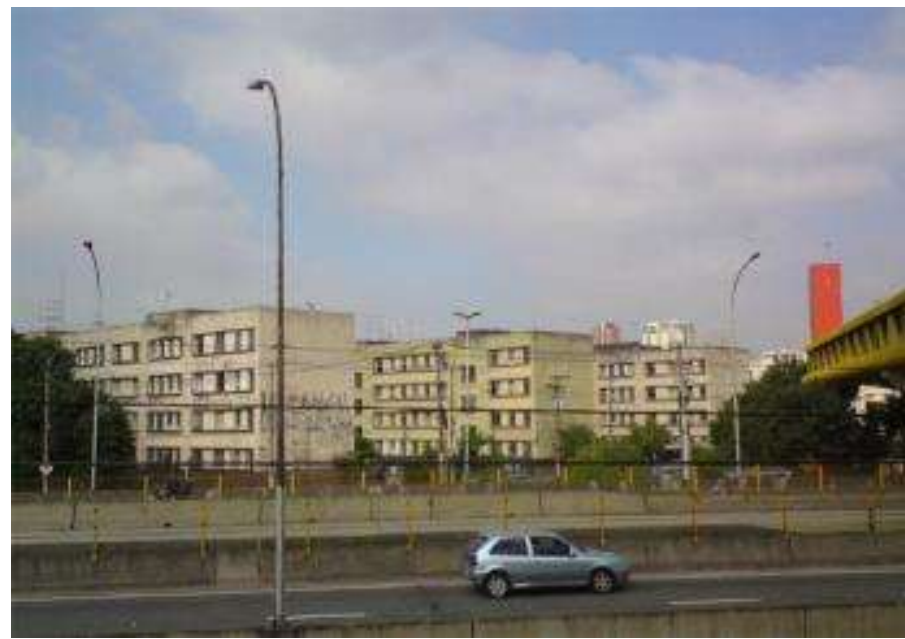

Figura 02: Perspectiva do conjunto a partir do viaduto sobre a Avenida do Estado. Fonte: Foto de Camila Ferrari. Abr. 2011. 


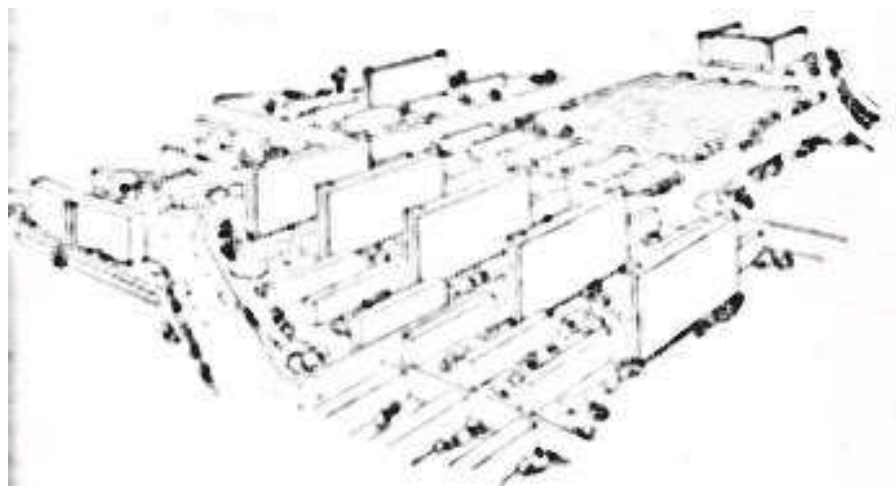

Figura 03: Perspectiva do conjunto. Fonte: CORREA LIMA. Conjunto Residencial da Várzea do Carmo IAPI S. Paulo In: Revista Municipal de Engenharia, n.6, vol. IX, Nov./1942, p. 09.

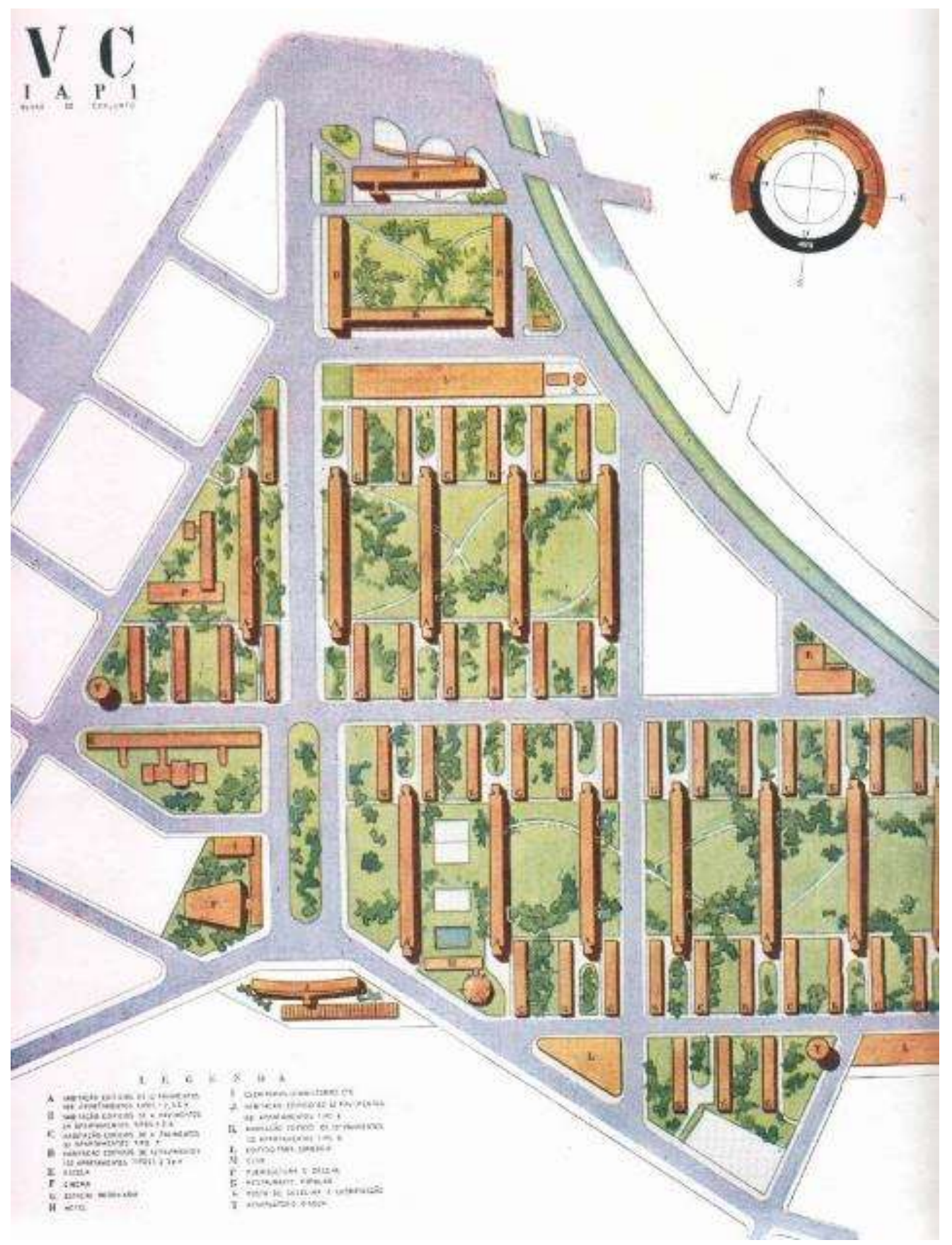

Figura 04: Planta do conjunto completo após as duas fases de implantação. Fonte: Revista Municipal de Engenharia, n.6, vol. IX, Nov./1942, p. 07. 


\section{Conjunto Residencial Japurá}
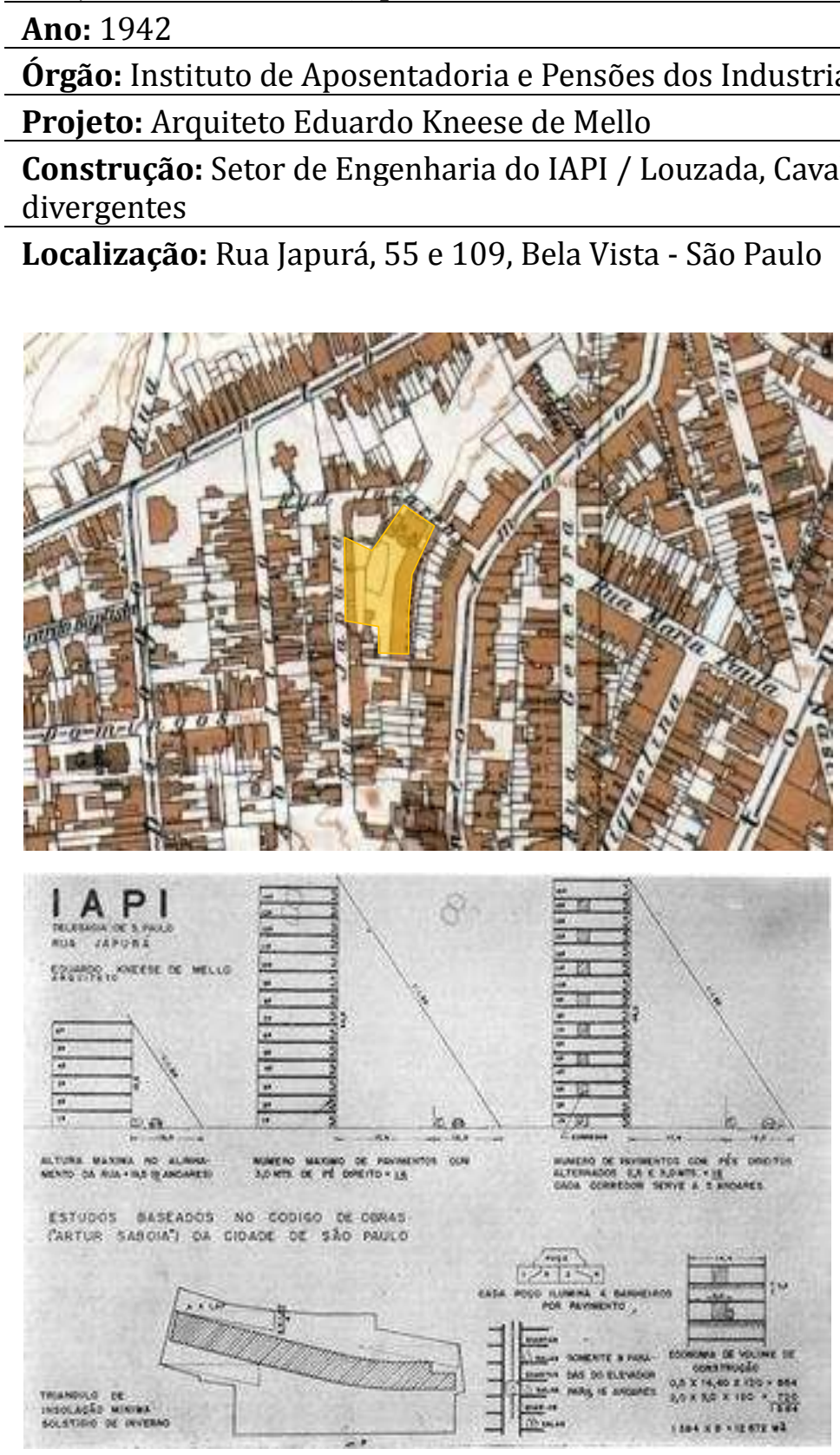

Figura 06: Estudos para o C.R. Japurá. Fonte:

Acrópole. Ano X, n.119, mar. 1948. p. 282.

Figura 05: Localização do terreno onde seria construído o C.R. Japurá, então ocupado por cortiços. Base cartográfica: Mapa Topográfico do Município de São Paulo, 1930, Série 1:5000, Folhas 51-52. Fonte: MENDES, Ricardo. S.A.R.A. Brasil: restituindo o Mapa Topográfico do Município de São Paulo. In: Informativo Arquivo Histórico de São Paulo, Ano 10, n.37, dez. 2014. Disponível em:

<http://www.arquivohistorico.sp.gov.br> Acesso em: 5 mar. 2016.

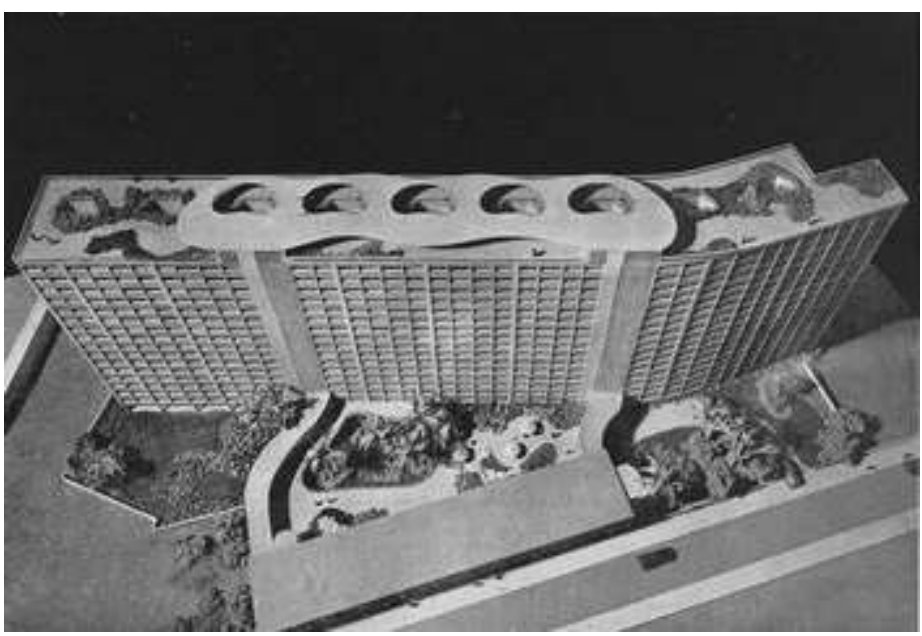

Figura 07: Maquete do C.R. Japurá. Fonte: MELLO, Eduardo K. "Apartamentos para industriários" In: Acrópole. Ano X, n.119, mar. 1948. p. 282. 

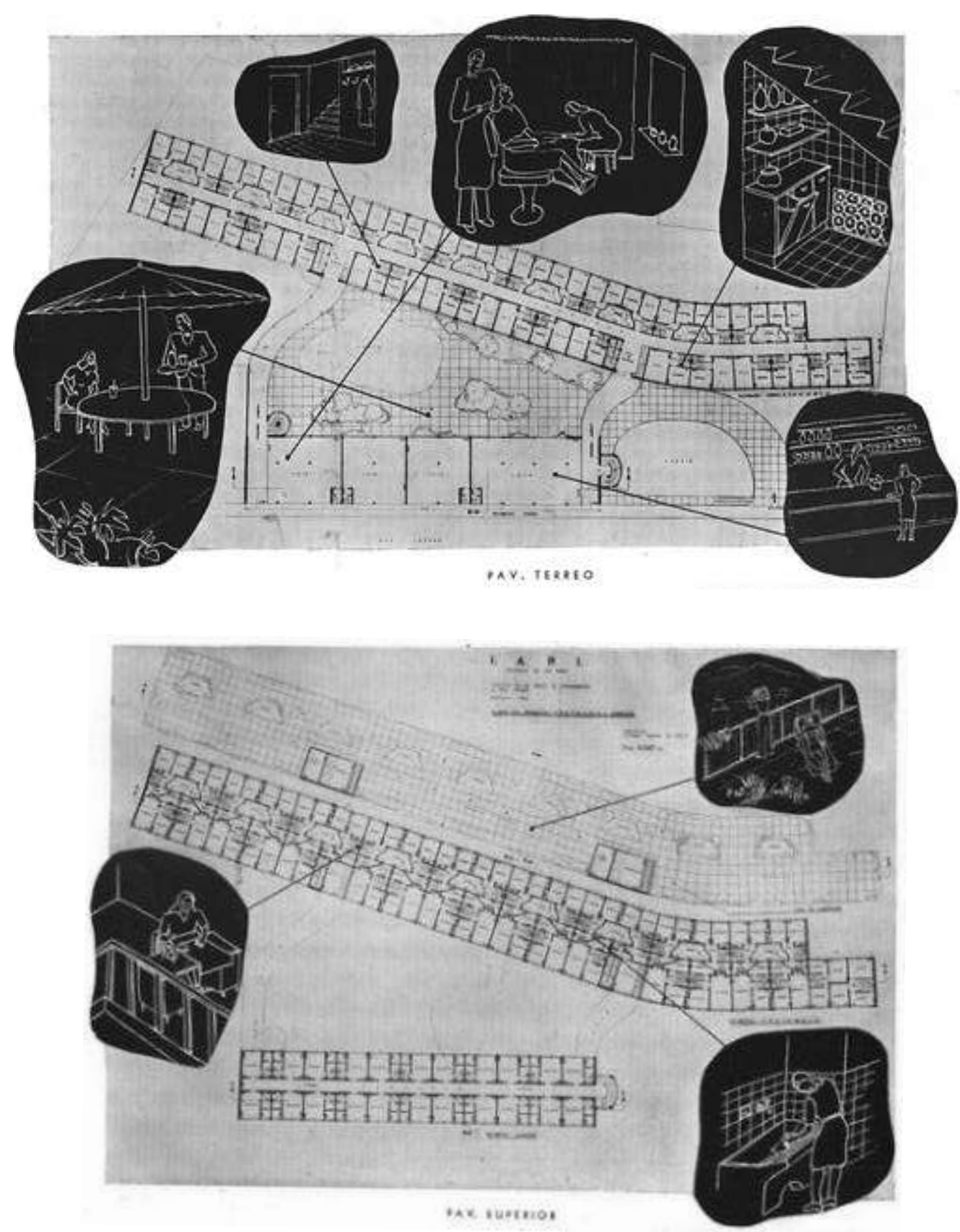

Figura 08: Plantas do C.R. Japurá. Fonte: Acrópole. Ano X, n.119, mar. 1948. p. 286,287. 


\section{Conjunto Residencial da Mooca}

Ano: 1946

Órgão: Instituto de Aposentadoria e Pensões dos Industriários (IAPI)

Projeto: Arquiteto Paulo Antunes Ribeiro

Construção: T. H. Marinho de Andrade Construtora S/A (Teagasa) / Serviço de Engenharia do IAPI - informações divergentes

Localização: Rua dos Trilhos x Rua Pe. Benedito Maria Cardoso

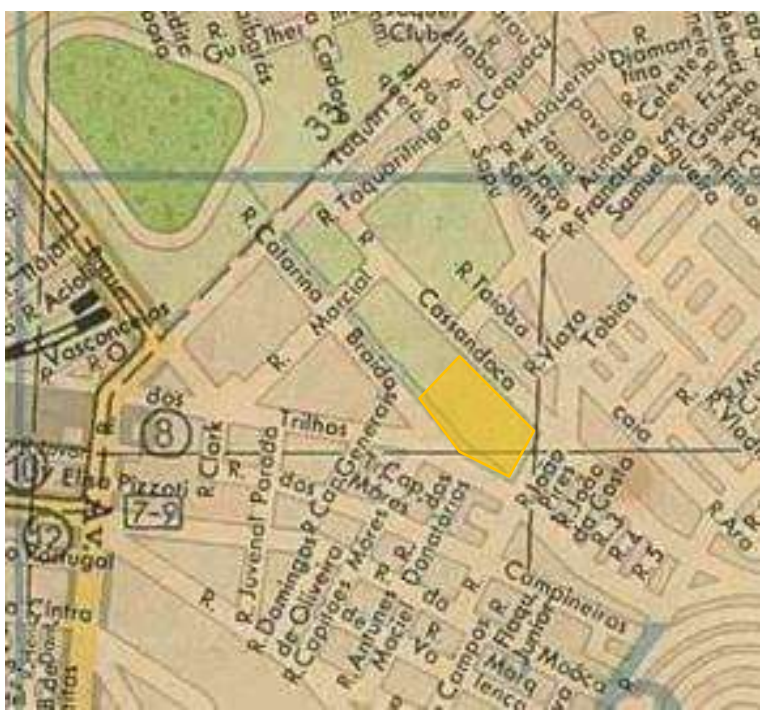

Figura 09: Localizaão do C.R. da Mooca, a Noroeste o Hipódromo do Jockey Clube Paulistano. Base cartográfica: São Paulo, Projeção hiperboloid com rede kilométrica, de 1951. Fonte: Histórico Demográfico do Município de São Paulo. Disponível em:

<http://smdu.prefeitura.sp.gov.br/historico_demogr afico/1950.php> Acesso em 06 abril 2016.

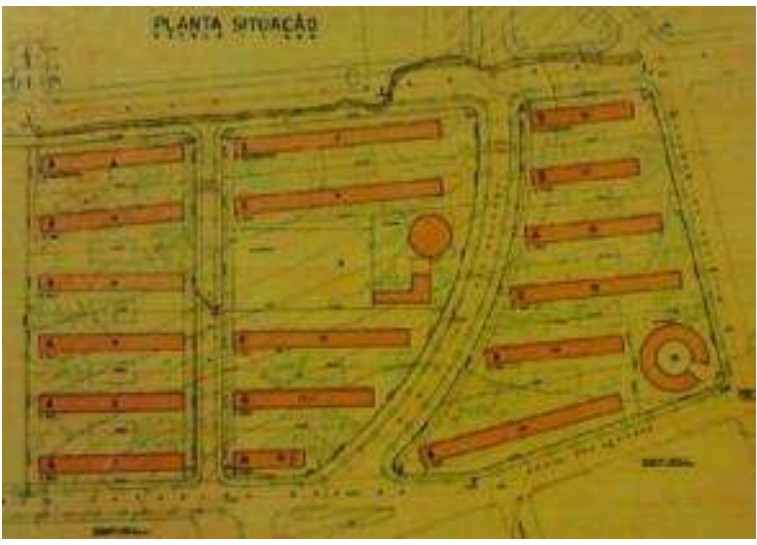

Figura 10: Planta original do C.R. da Mooca. Fonte: BONDUKI, Nabil. Pioneiros da habitação social no Brasil. Tese de Livre-Docência. FAU-USP, 2011, vol.2, p. 47.
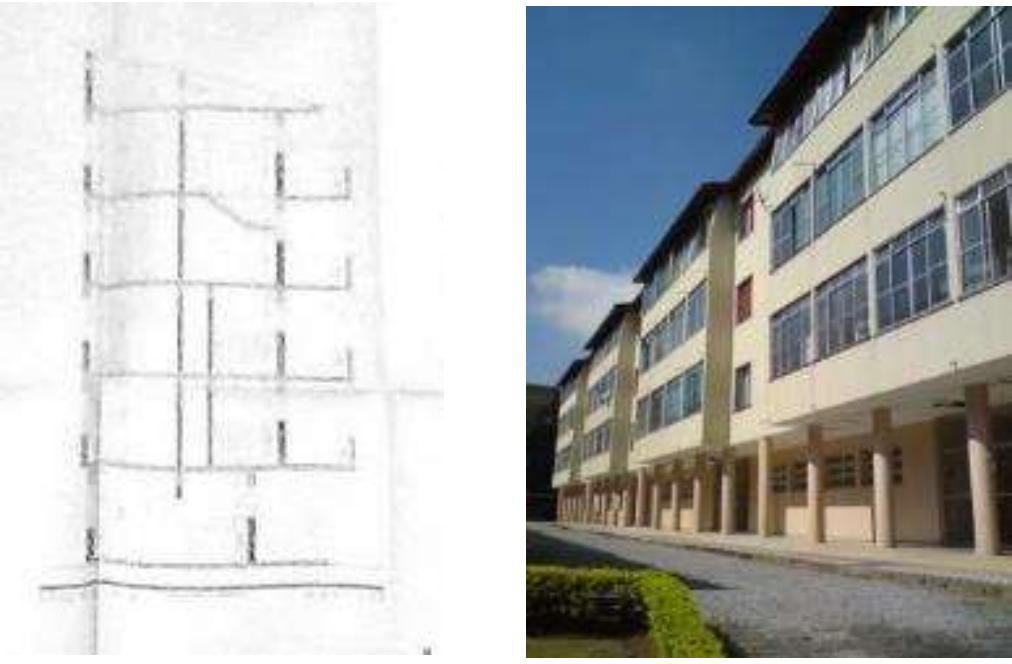

Figura 11. Corte transversal do bloco Tipo 2 (5 pavimentos) e foto do bloco Tipo 1 (4 pavimentos) do C.R. da Mooca. Fonte: Fonte: Processo Administrativo n.45.127/1944 e Acervo pessoal. Foto de Camila Ferrari, jun. 2010. 


\section{Conjunto Residencial Vila Guiomar}

Ano: $1942-1953$

Órgão: Instituto de Aposentadoria e Pensões dos Industriários (IAPI)

Projeto: Arquiteto Carlos Frederico Ferreira

Construção: Setor de Engenharia do IAPI

Localização: Rua da Catequese - Santo André, São Paulo

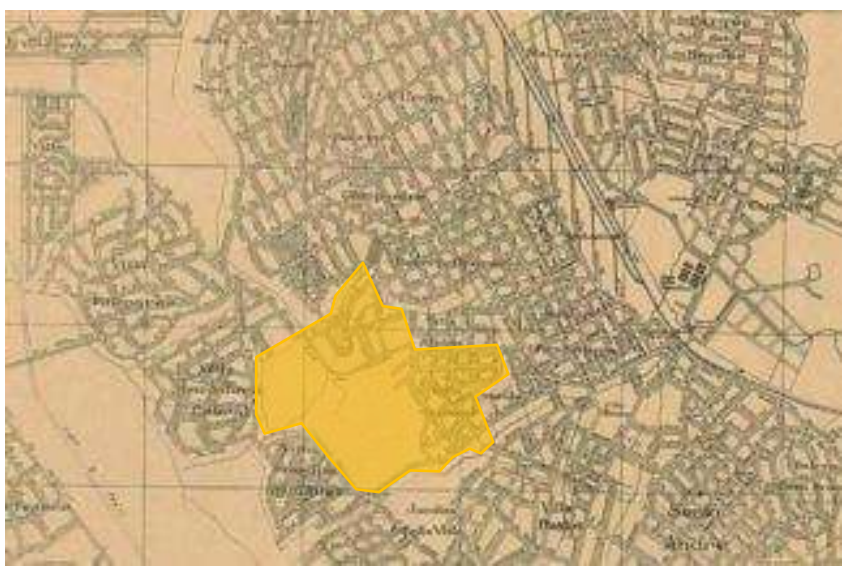

Figura 12: Município de Santo André e localização do terreno do C.R. Vila Guiomar. Base cartográfica: Planta da Cidade de São Paulo e Municípios Circunvizinhos, de 1943. Fonte: Histórico Demográfico do Município de São Paulo. Disponível em:

<http://smdu.prefeitura.sp.gov.br/historico_demogr afico/1940.php> Acesso em 23 mar. 2016.

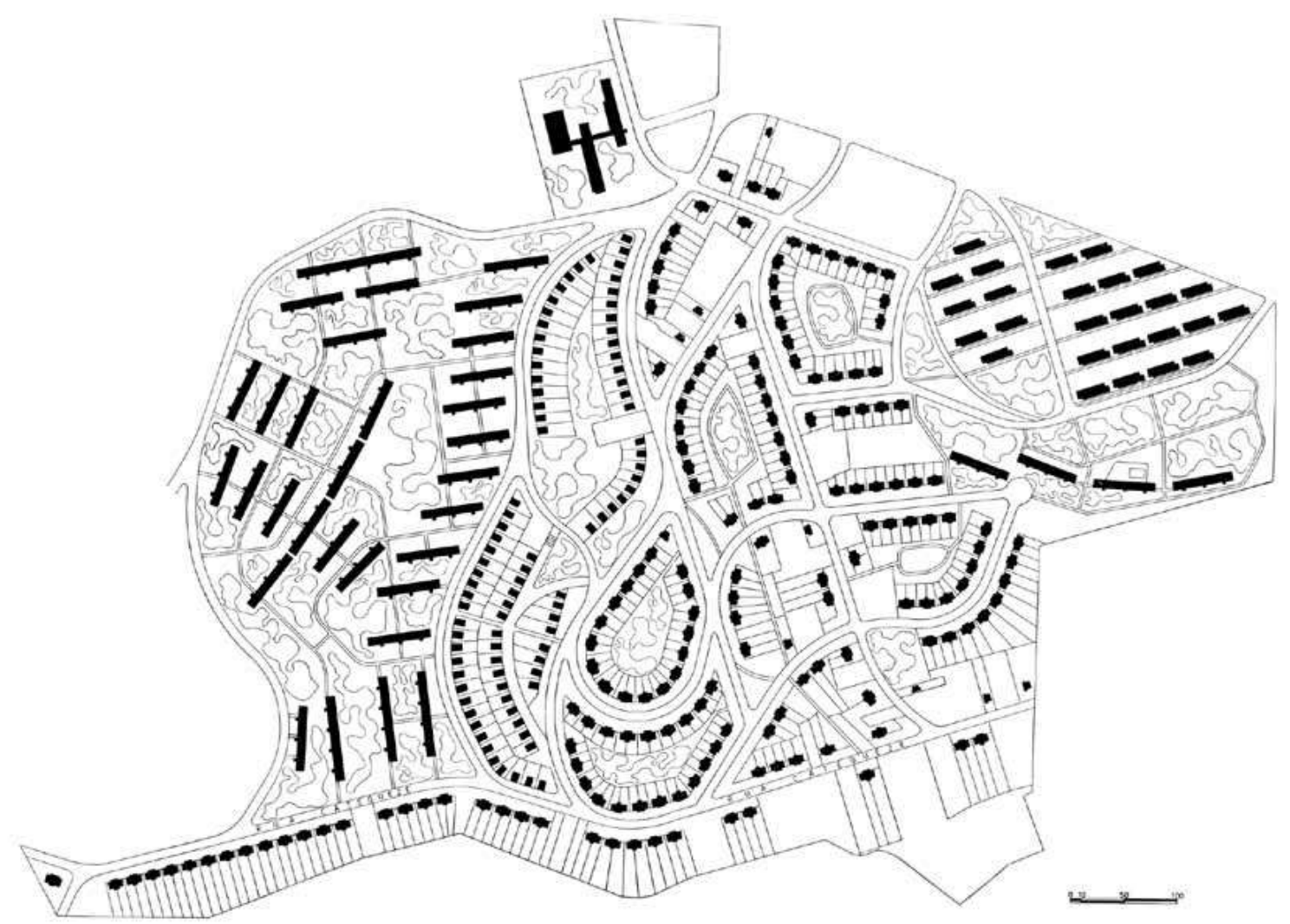

Figura 13: Implantação do conjunto. Fonte: BONDUKI, Nabil. Origens da Habitação Social no Brasil. Arquitetura Moderna, Lei do Inquilinato e Difusão da Casa Própria. São Paulo: Est. Liberdade/FAPESP, 1998, p.190. 


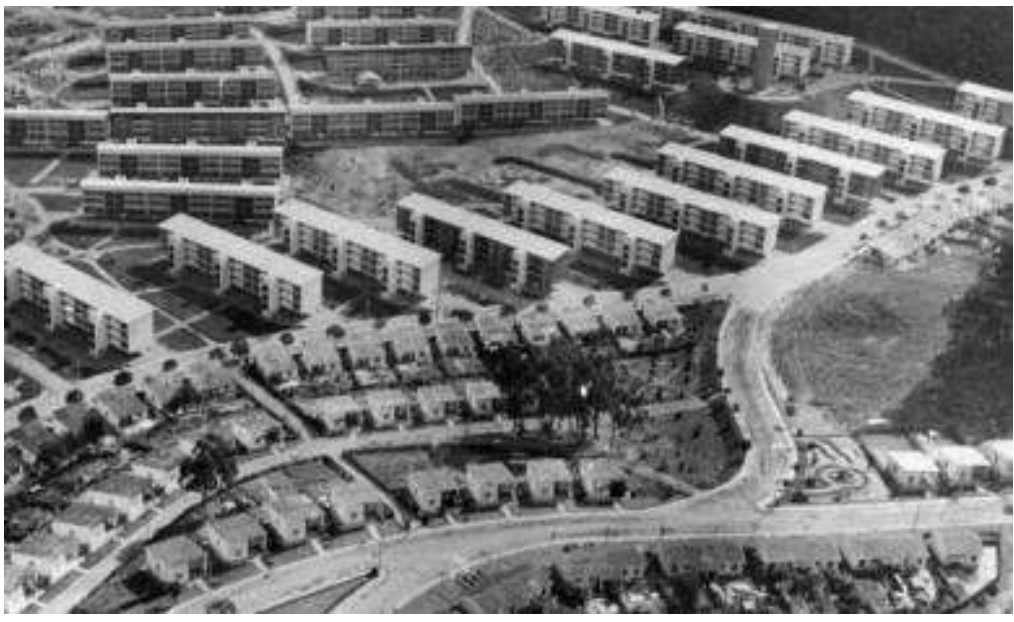

Figura 14: Vista Parcial do Conjunto Residencial Vila Guiomar (IAPI), 1940. Fonte: PESSOLATO, Cintia. Conjunto IAPI Vila Guiomar - Santo André-SP: Projeto e História. Dissertação (Mestrado), FAUUSP, 2007, p.126.

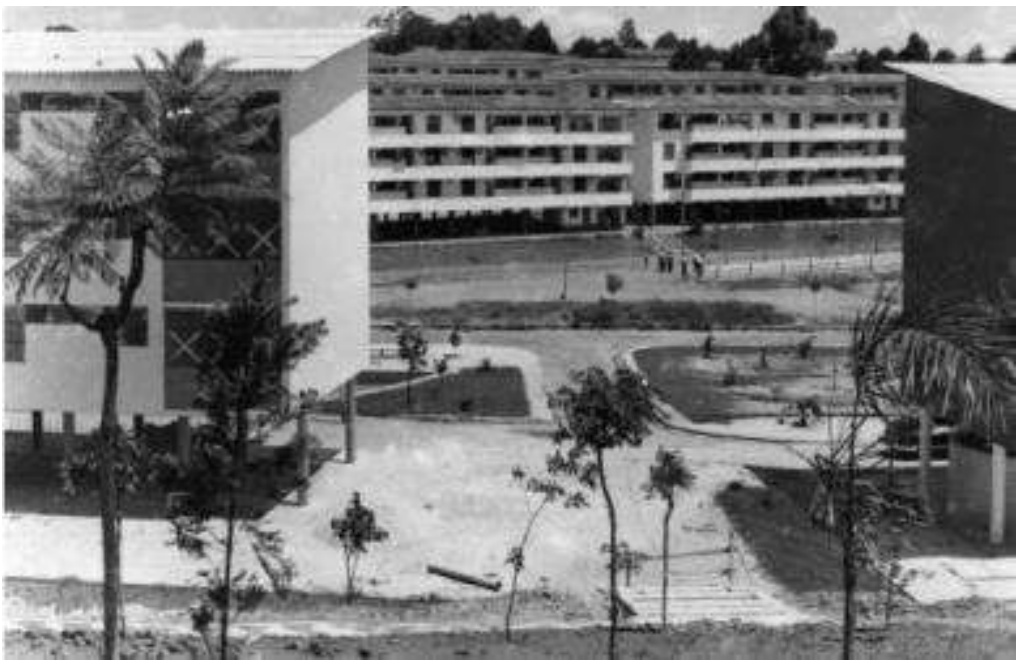

Figura 15: Grandes proporções de espaços livres e edifícios ainda com pilotis. Fonte: PESSOLATO, Cintia. Conjunto IAPI Vila Guiomar - Santo André - SP: Projeto e História. Dissertação (Mestrado), FAU-USP, 2007 p.117.
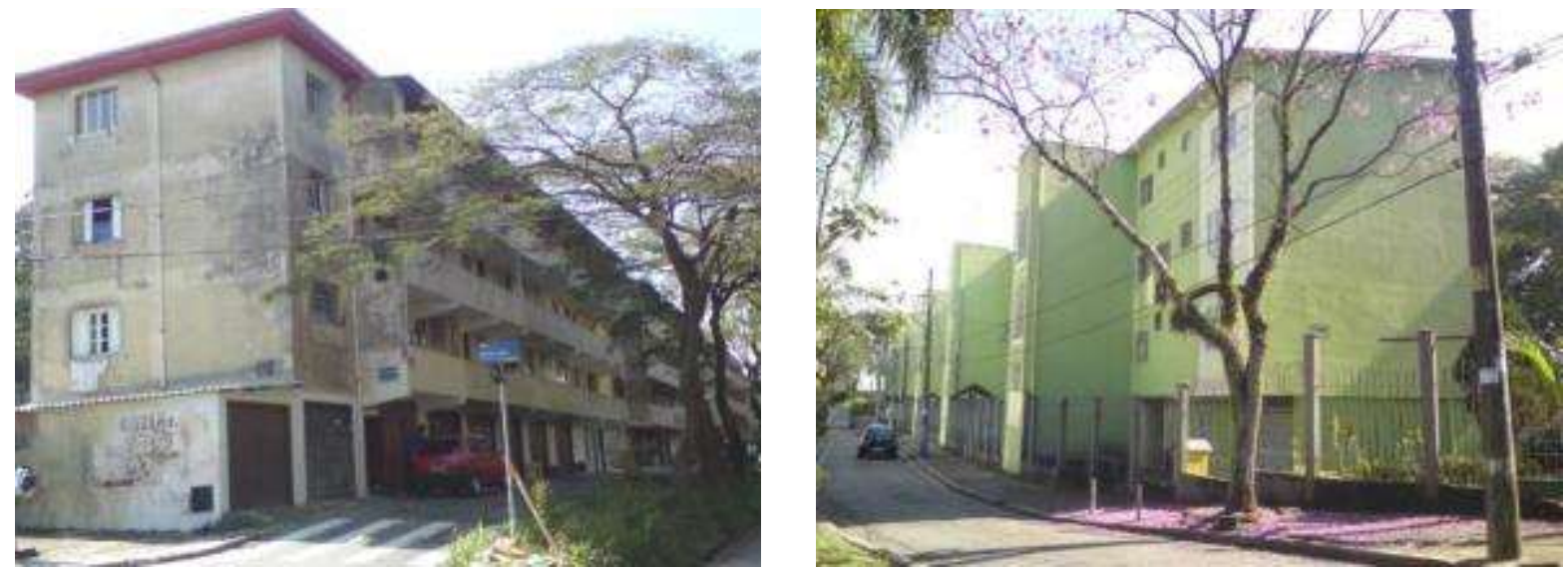

Figura 16: Blocos do primeiro e segundo tipos implantados. Fonte: Acervo pessoal. Fotos de Camila Ferrari. Jul. 2012. 
Conjunto Residencial Nove de Julho
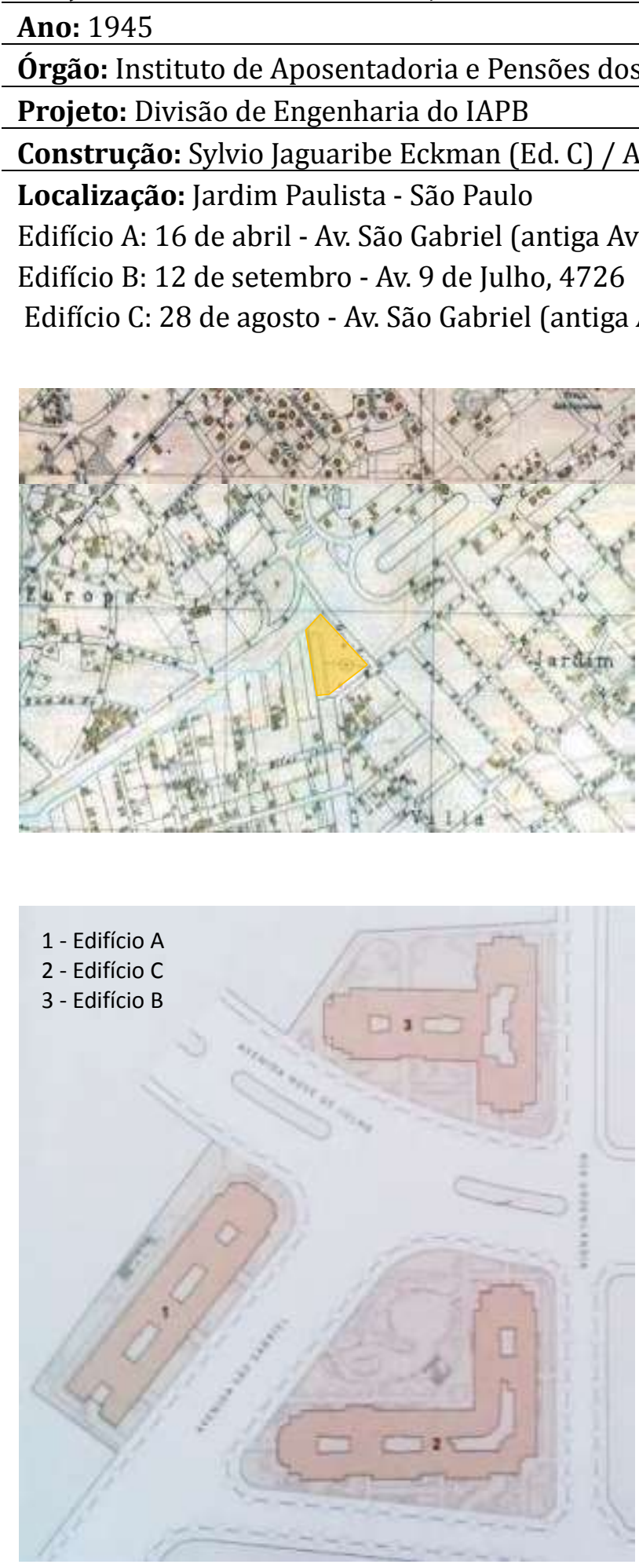

Figura 17: Região a Sudoeste do Centro e localização do C.R. Nove de Julho. Mapa Topográfico do Município de São Paulo, 1930, Série 1:5000, Folhas 51-52. Fonte: MENDES, Ricardo. S.A.R.A. Brasil: restituindo o Mapa Topográfico do Município de São Paulo. In: Informativo Arquivo Histórico de São Paulo, Ano 10, n.37, dez. 2014. Disponível em: <http://www.arquivohistorico.sp.gov.br> Acesso em: 5 mar. 2016

Figura 18. Implantação do C.R. Nove de Julho. Fonte: BONDUKI, N. G.; KOURY, A. P. Os pioneiros da habitação social no Brasil: inventário da produção pública no Brasil entre 1930 e 1964. São Paulo: UNESP: SESC, 2014. Vol. 2. p. 191. 

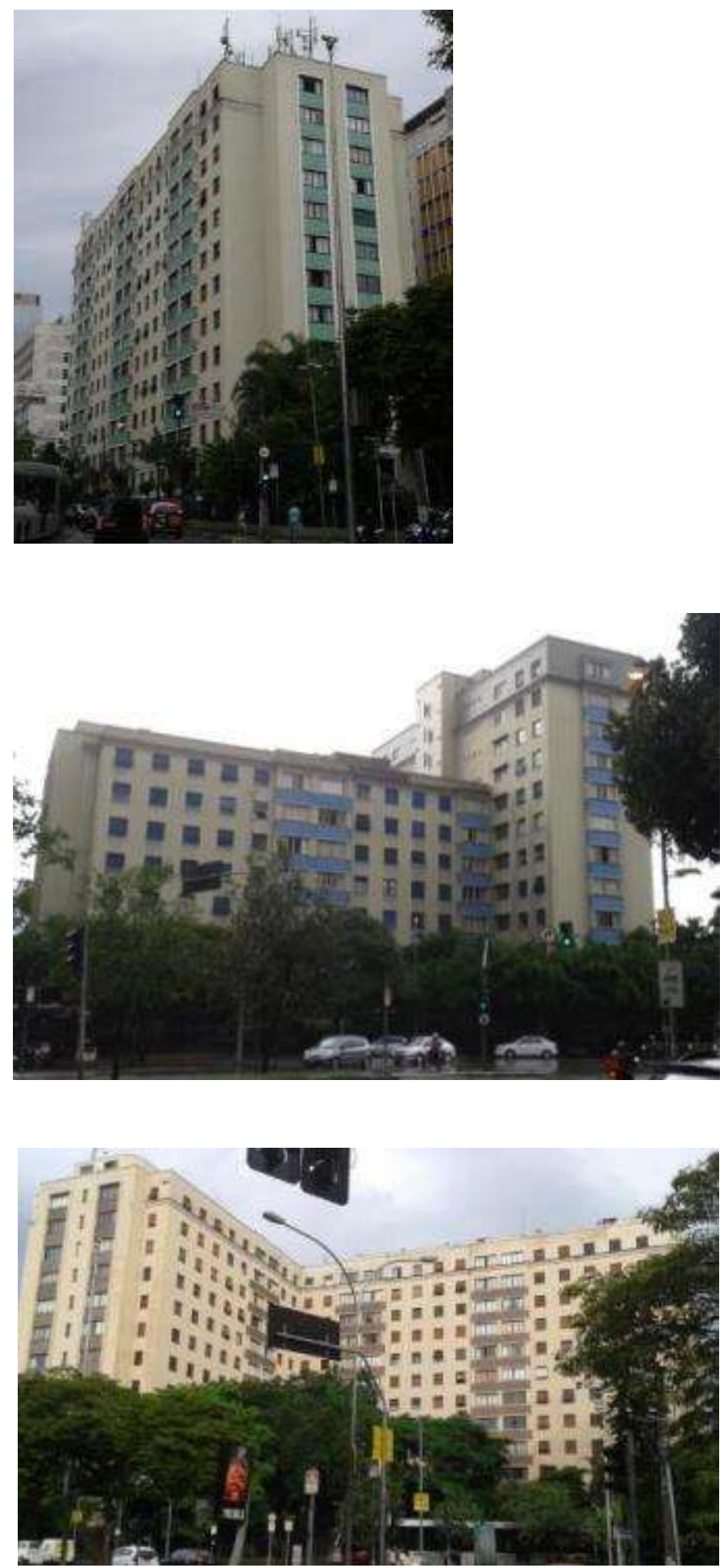

Figura 19: Edifício A. Fonte: Acervo pessoal. Foto de Camila Ferrari. Abril, 2016.

Figura 20: Edifício B. Fonte: Acervo pessoal. Foto de Camila Ferrari. Abril, 2016.

Figura 21: Edifício C. Fonte: Acervo pessoal. Foto de Camila Ferrari. Abril, 2016. 


\section{Conjunto Residencial Santa Cruz}

Ano: 1949

Órgão: Instituto de Aposentadoria e Pensões dos Industriários (IAPB)

Projeto: Engenheiro-Arquiteto Marcial Fleury de Oliveira

Construção: Predial de Lucca S/A / Construtor Marcial Fleury de Oliveira - informações divergentes

Localização: Rua Santa Cruz, 1191, Vila Mariana, São Paulo

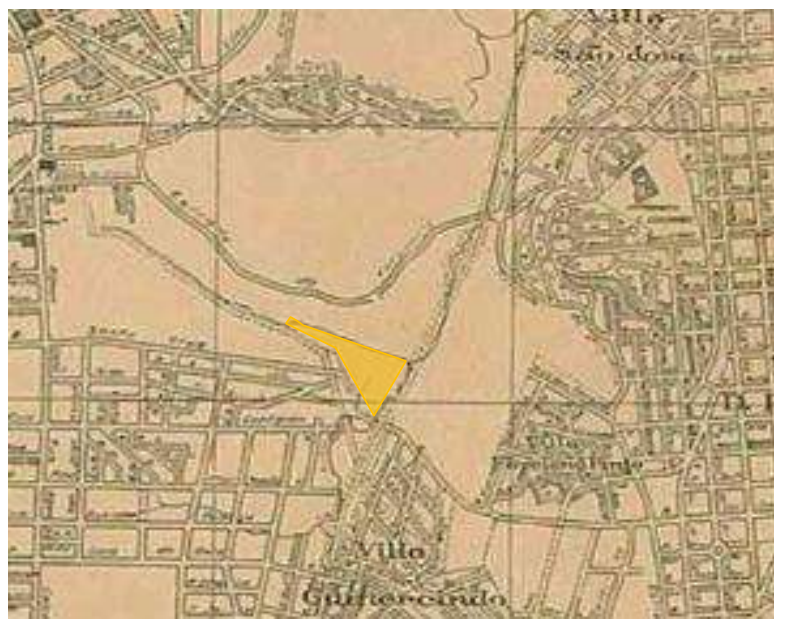

Figura 22: Região do Córrego Ipiranga e localização do C.R. Santa Cruz. Base cartográfica: Planta da Cidade de São Paulo e Municípios Circunvizinhos, de 1943. Fonte: Histórico Demográfico do Município de São Paulo. Disponível em: <http://smdu.prefeitura.sp.gov.br/historico_demografico/1940. php> Acesso em 23 mar. 2016.

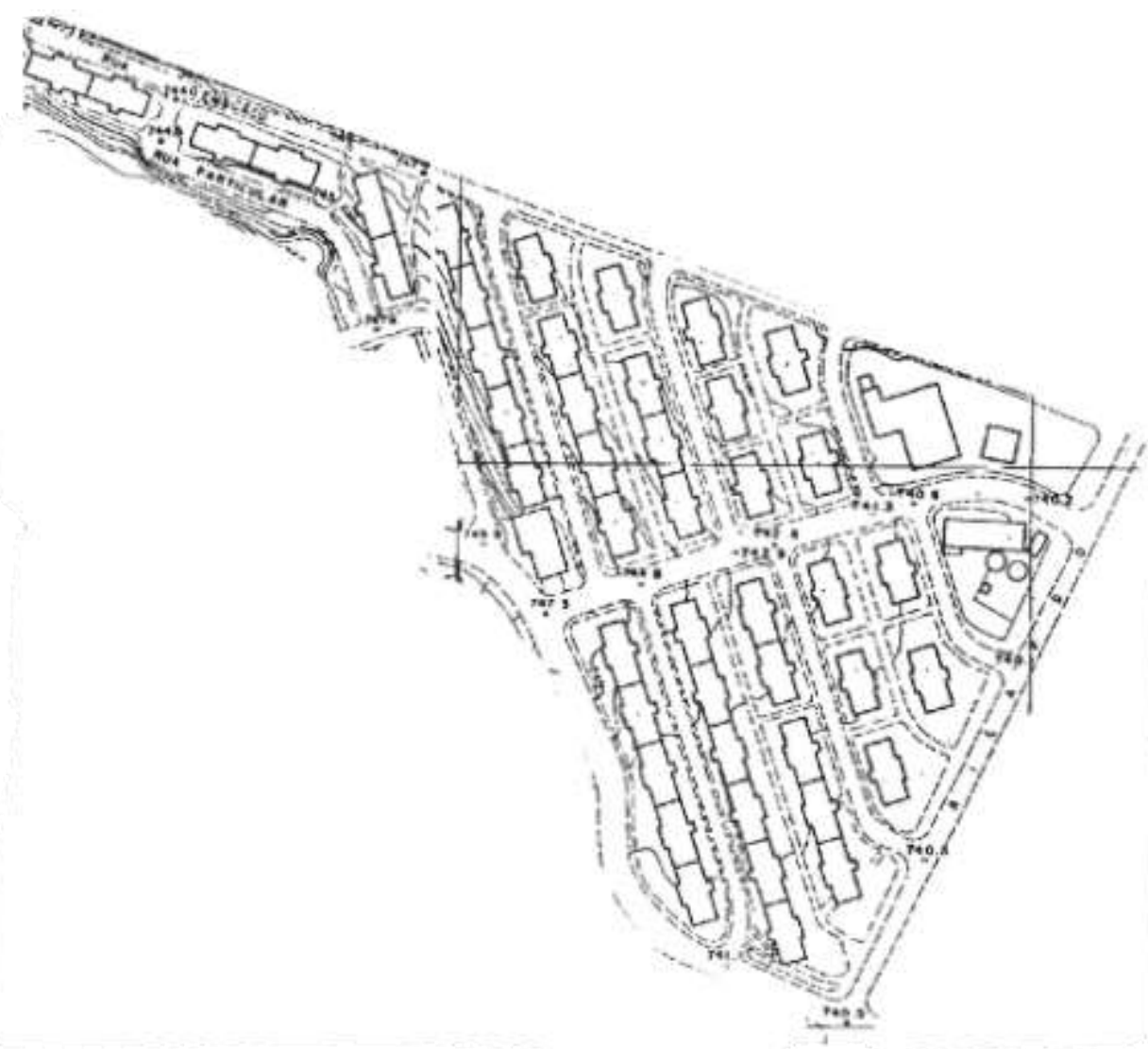

Figura 23: Implantação do conjunto Santa Cruz. Fonte: Levantamento GEGRAN, 1974. 


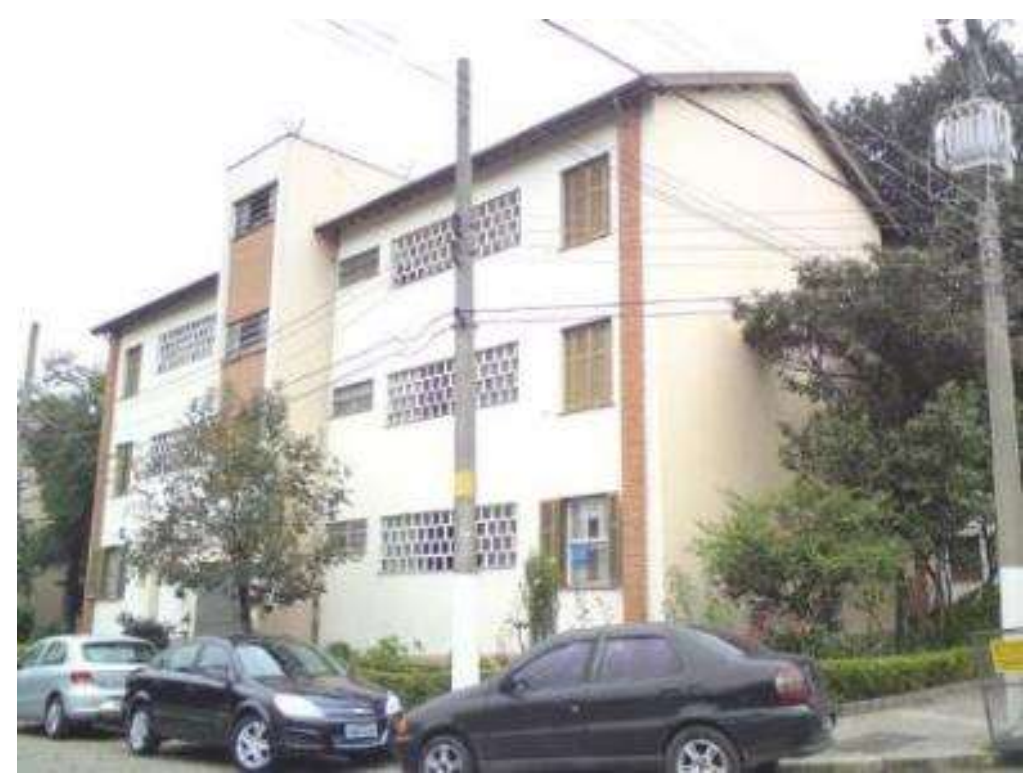

Figura 24: C.R. Santa Cruz. Bloco-tipo isolado. Fonte: Fotos de Camila Ferrari. Maio 2012.

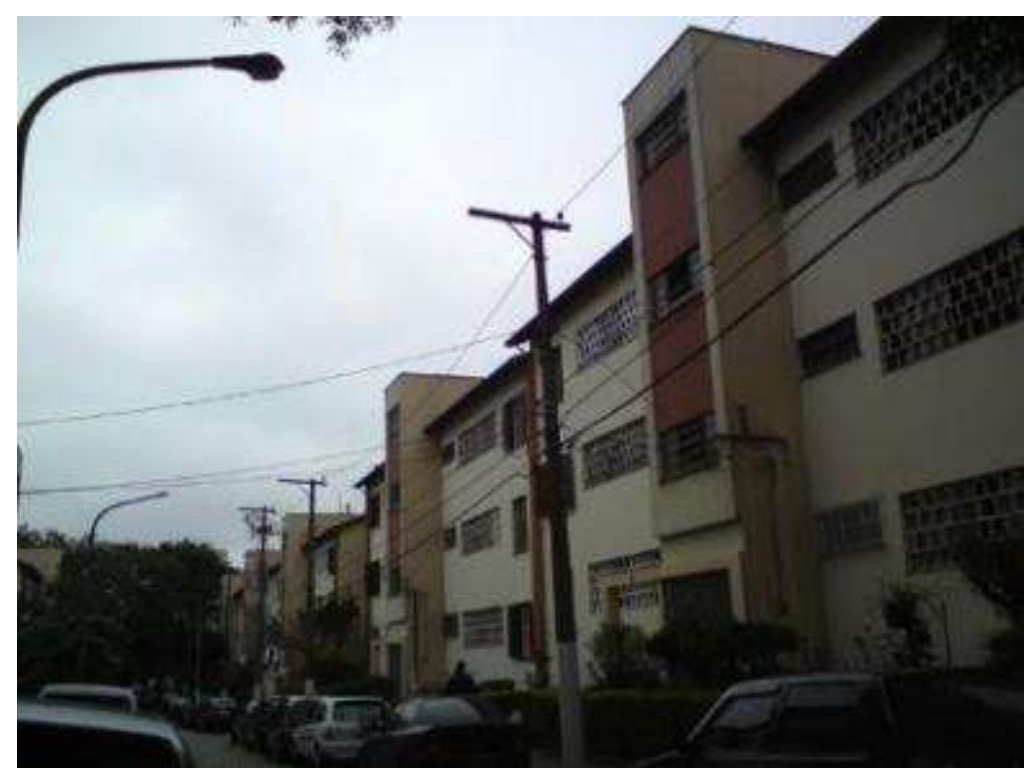

Figura 25: C.R. Santa Cruz. Bloco longilíneo conformado por cinco módulos. Fonte: Fotos de Camila Ferrari. Maio 2012. 


\section{Conjunto Residencial Santo Antonio}

Ano: $1962-1967$

Órgão: Instituto de Aposentadoria e Pensões dos Industriários (IAPB)

Projeto: Engenheiros Nicolau Barbieri e Rubens Betelman

Construção: Companhia Construtora Centenário (1 ${ }^{\text {a }}$ fase) e Carvalho Hosken Engenharia e Construção S/A (2a fase)

Localização: Rua Celina Guinle de Paula Machado, 130, Mandaqui - São Paulo

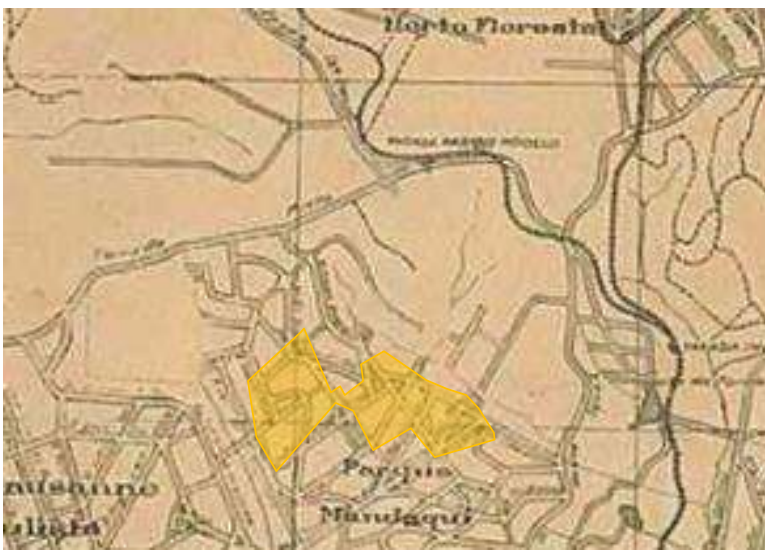

Figura 26: Região do Norte de Santana e localização aproximada do C.R. Santo Antonio. Base cartográfica: Planta da Cidade de São Paulo e Municípios Circunvizinhos, de 1943. Fonte: Histórico Demográfico do Município de São Paulo. Disponível em:

<http://smdu.prefeitura.sp.gov.br/historico_demografico/1940. php> Acesso em 23 mar. 2016.

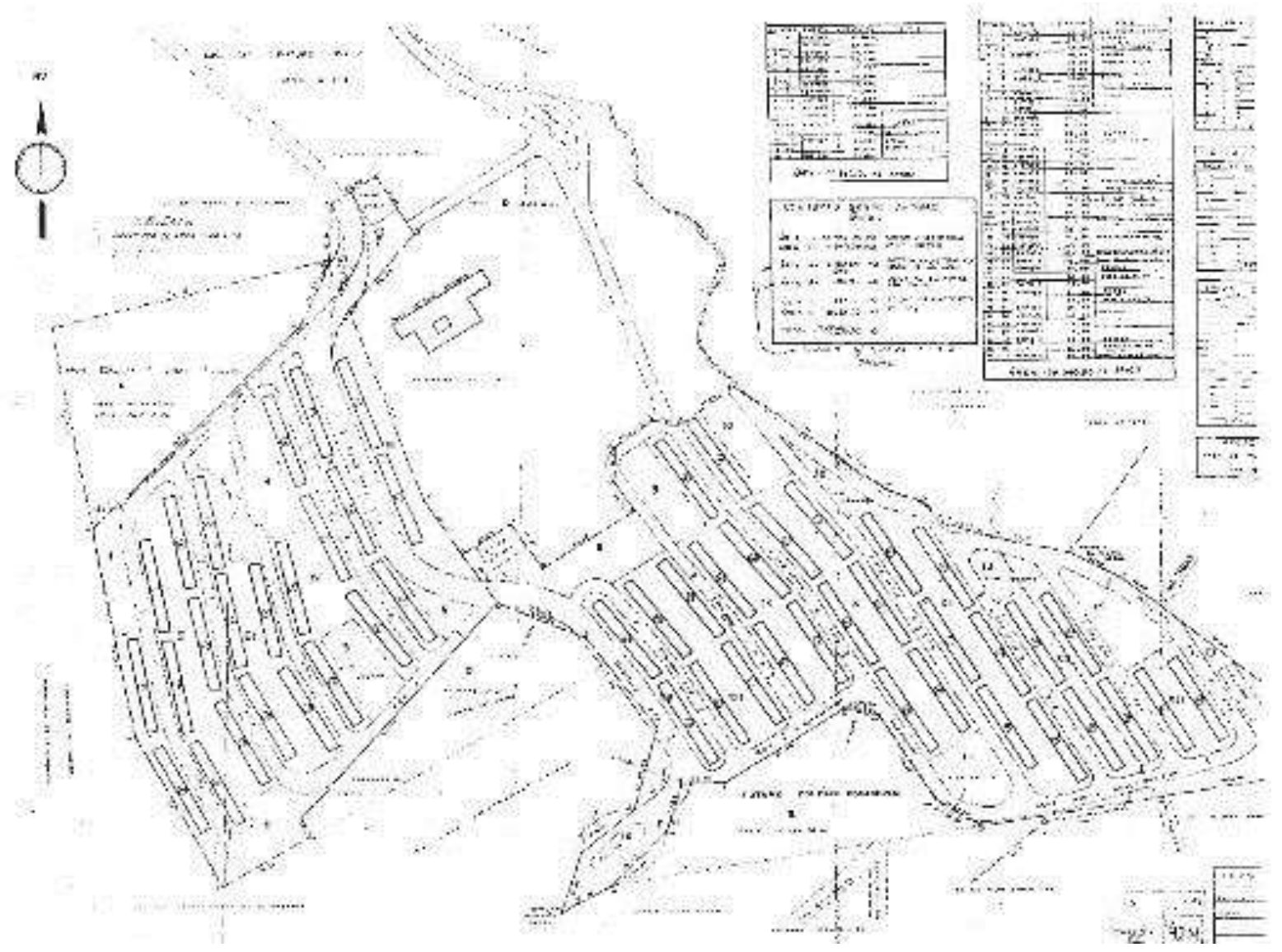

Figura 27: Planta do Conjunto Santo Antonio. Fonte: BRUNA, Paulo J. V. Os Primeiros Arquitetos Modernos: Habitação Social no Brasil 1930-1950. Tese de Livre-Docência, FAU-USP, São Paulo, 1998, p.179. 


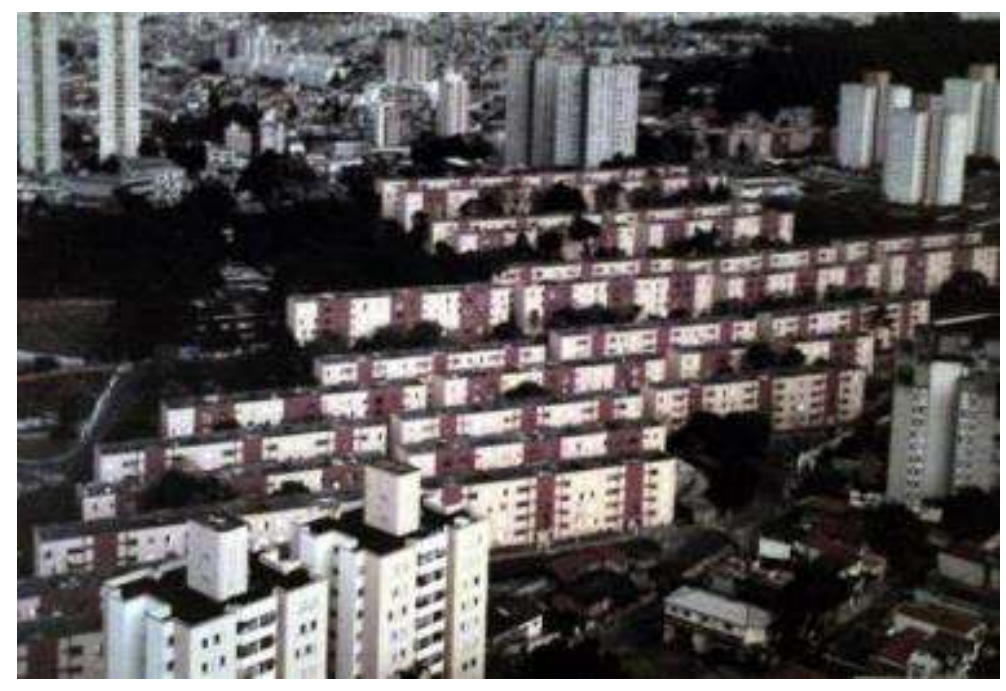

Figura 28: Foto aérea doada ao Condomínio Santo Antonio quando da reforma e pintura dos edifícios em julho de 2003 pela construtora Ankoflex, responsável pelas obras. Fonte: Acervo Condomínio Santo Antonio.
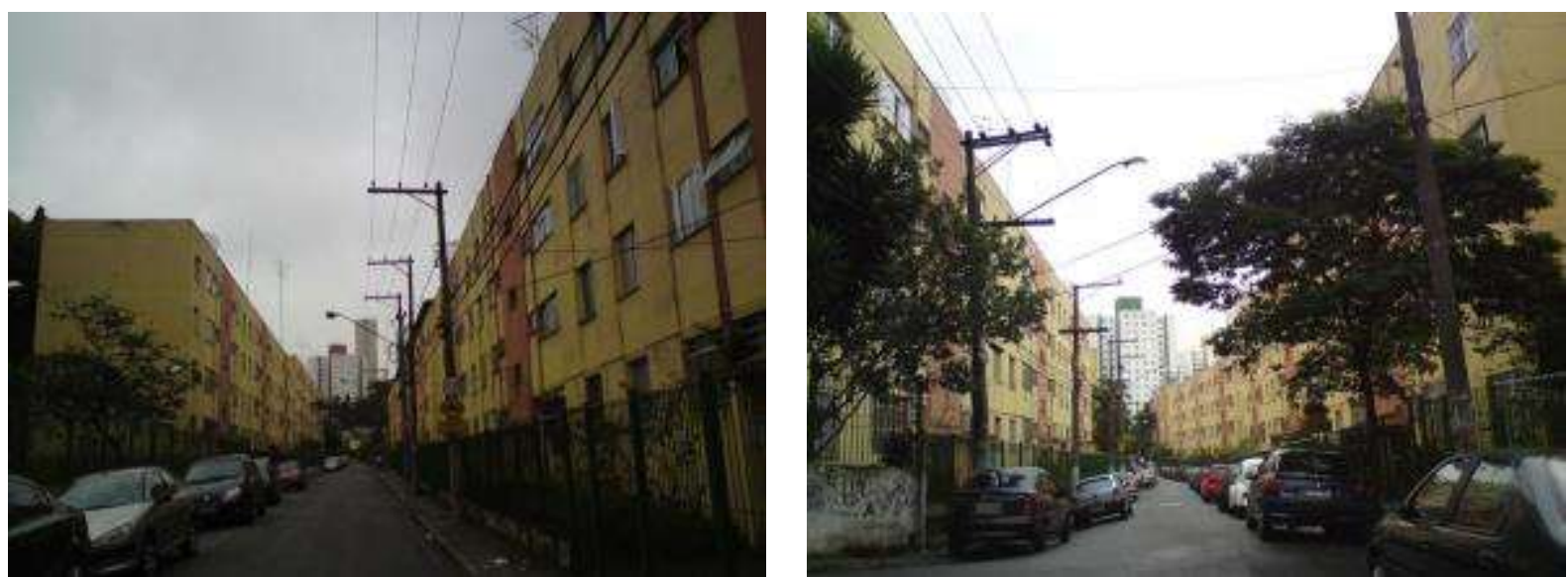

Figura 29: Associação de edifícios laminares. Fonte: Fotos de Camila Ferrari. Abr. 2012. 


\section{Núcleo Residencial Francisco Morato}

\begin{tabular}{l}
\hline Ano: 1951 \\
\hline Órgão: Instituto de Previdência do Estado de São Paulo (IPESP) \\
\hline Projeto: Escritório Técnico do IPESP \\
\hline Construção: Ribeiro Franco S/A
\end{tabular}

Localização: Avenida Professora Virgília Rodrigues Alves de Carvalho Pinto, 46, Jardim Leonor Mendes De Barros - São Paulo

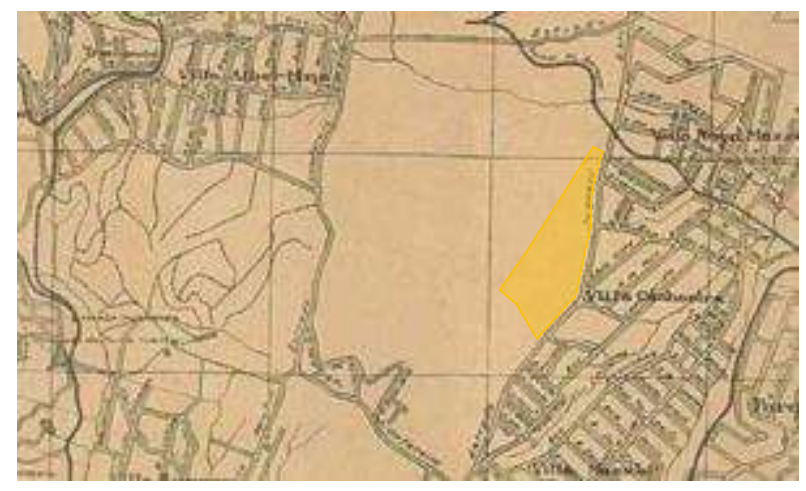

Figura 30: Região Norte de São Paulo e localização do terreno do Núcleo Residencial Francisco Morato. Base cartográfica: Planta da Cidade de São Paulo e Municípios Circunvizinhos, de 1943. Fonte: Histórico Demográfico do Município de São Paulo. Disponível em:

<http://smdu.prefeitura.sp.gov.br/historico_demografico/ 1940.php> Acesso em 23 mar. 2016.

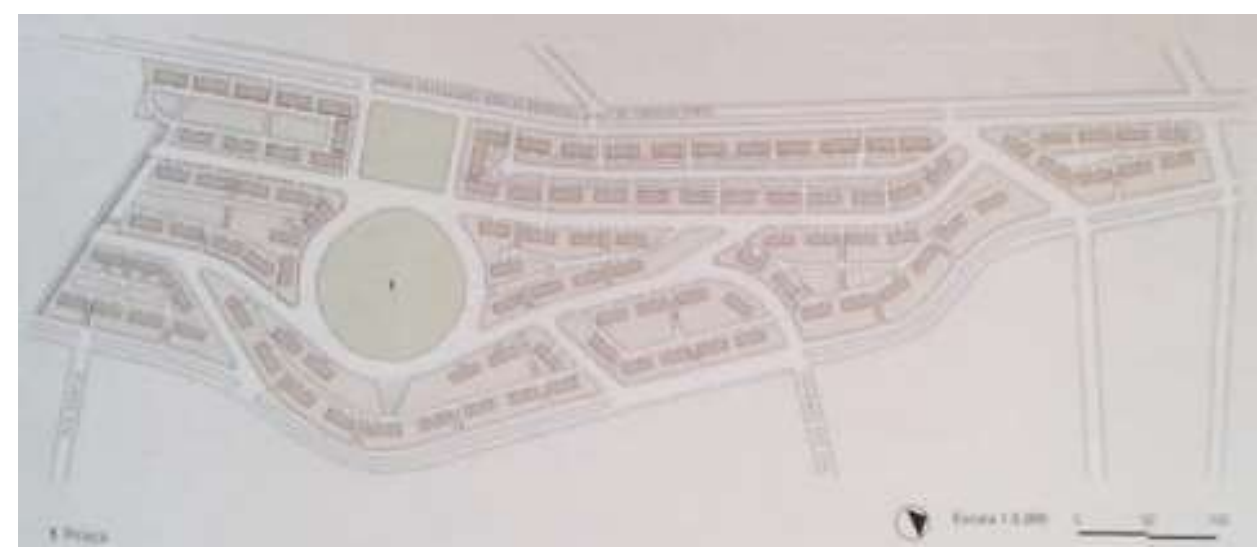

Figura 31. Implantação do Núcleo Francisco Morato. Fonte: BONDUKI, N.G.; KOURY, A.P. Os pioneiros da habitação social no Brasil: inventário da produção pública no Brasil entre 1930 e 1964. São Paulo:UNESP:SESC, 2014.Vol.2. p.407.

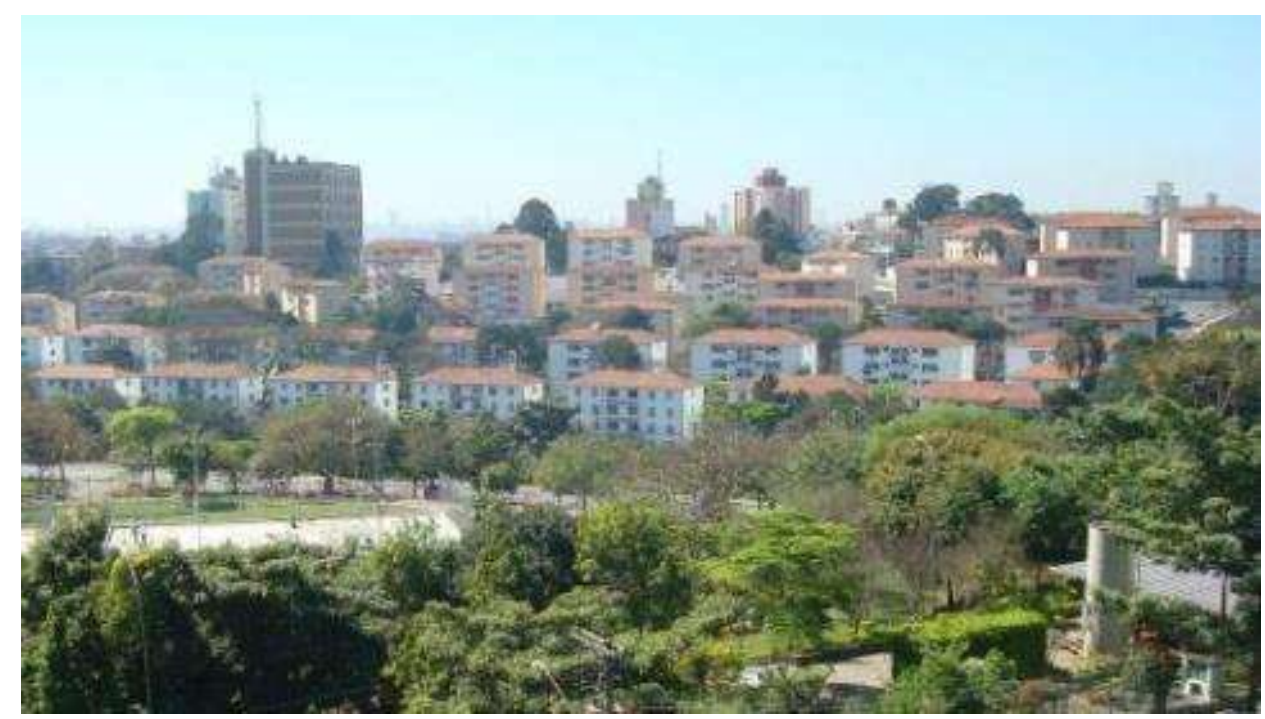

Figura 32. Vista do Núcleo Francisco Morato. Fonte: Panoramio - Google Maps. 


\section{Edifício Santa Cecília}

\begin{tabular}{l}
\hline Ano: 1947 \\
\hline Órgão: Instituto de Aposentadoria e Pensões dos Comerciários (IAPC) \\
\hline Projeto: Engenheiro-Arquiteto Armando Ciampolini
\end{tabular}

Localização: Av. Gen. Olímpio da Silveira, Santa Cecília - São Paulo

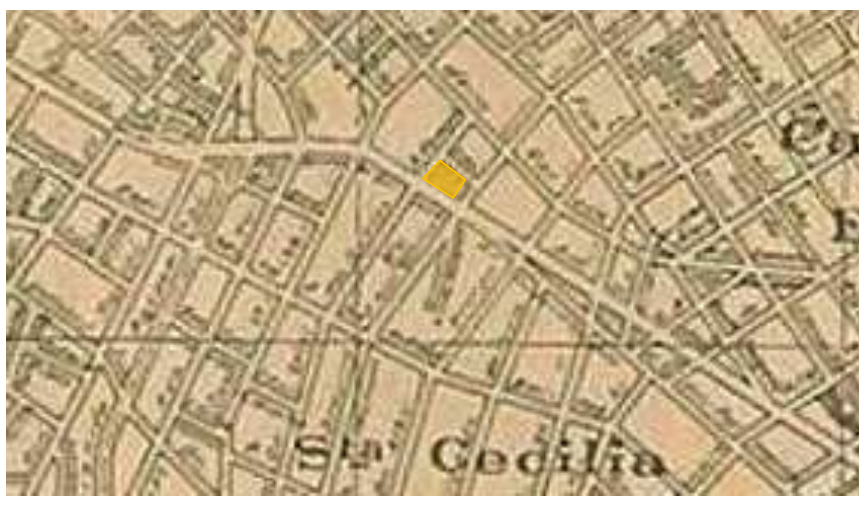

Figura 33: Região a Noroeste do Centro e localização do terreno do C.R. Santa Cecília. Base cartográfica: Planta da Cidade de São Paulo e Municípios Circunvizinhos, de 1943. Fonte: Histórico Demográfico do Município de São Paulo.

Disponível

em:

<http://smdu.prefeitura.sp.gov.br/historico_demografic o/1940.php> Acesso em 23 mar. 2016

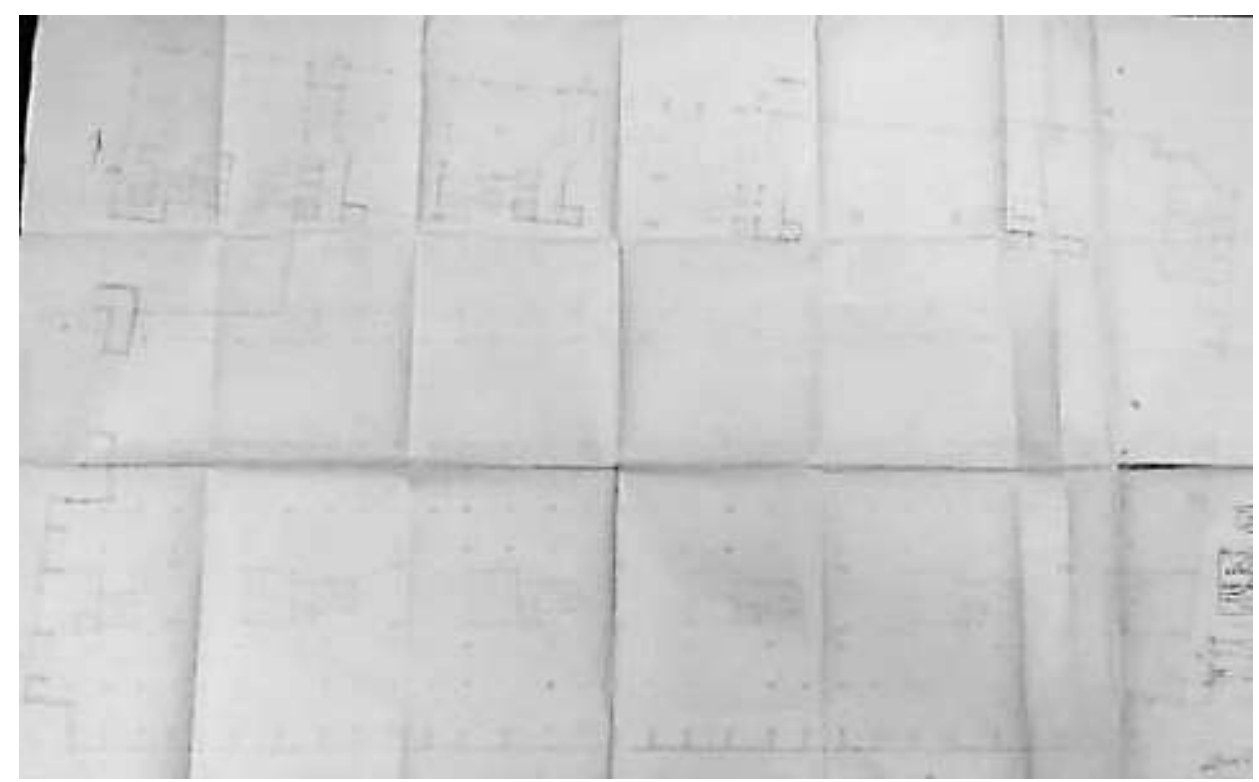

Figura 34: Pavimento térreo do Edifício Santa Cecília. Fonte: Processo n.65163, de 22 de julho de 1948. PMSP - Arquivo Geral de Processos. 


\section{Conjunto Residencial Cidade Jardim}

Ano: 1947

Órgão: Instituto de Aposentadoria e Pensões dos Comerciários (IAPC)

Projeto: Eduardo Kneese de Mello e equipe

Localização: Avenida Marginal Pinheiros x Avenida Cidade-Jardim, Cidade Jardim - São Paulo

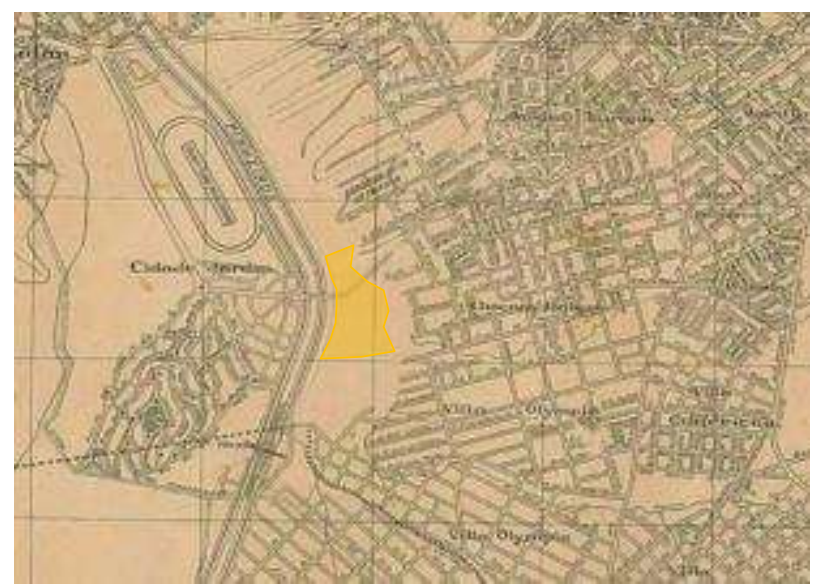

Figura 35: Região a Sudoeste do Centro e localização do terreno do C.R. Cidade Jardim. Base Cartográfica:

Planta da Cidade de São Paulo e Municípios

Circunvizinhos, de 1943. Fonte: Histórico Demográfico

do Município de São Paulo. Disponível em:

<http://smdu.prefeitura.sp.gov.br/historico_demografic

o/1940.php> Acesso em 23 mar. 2016.

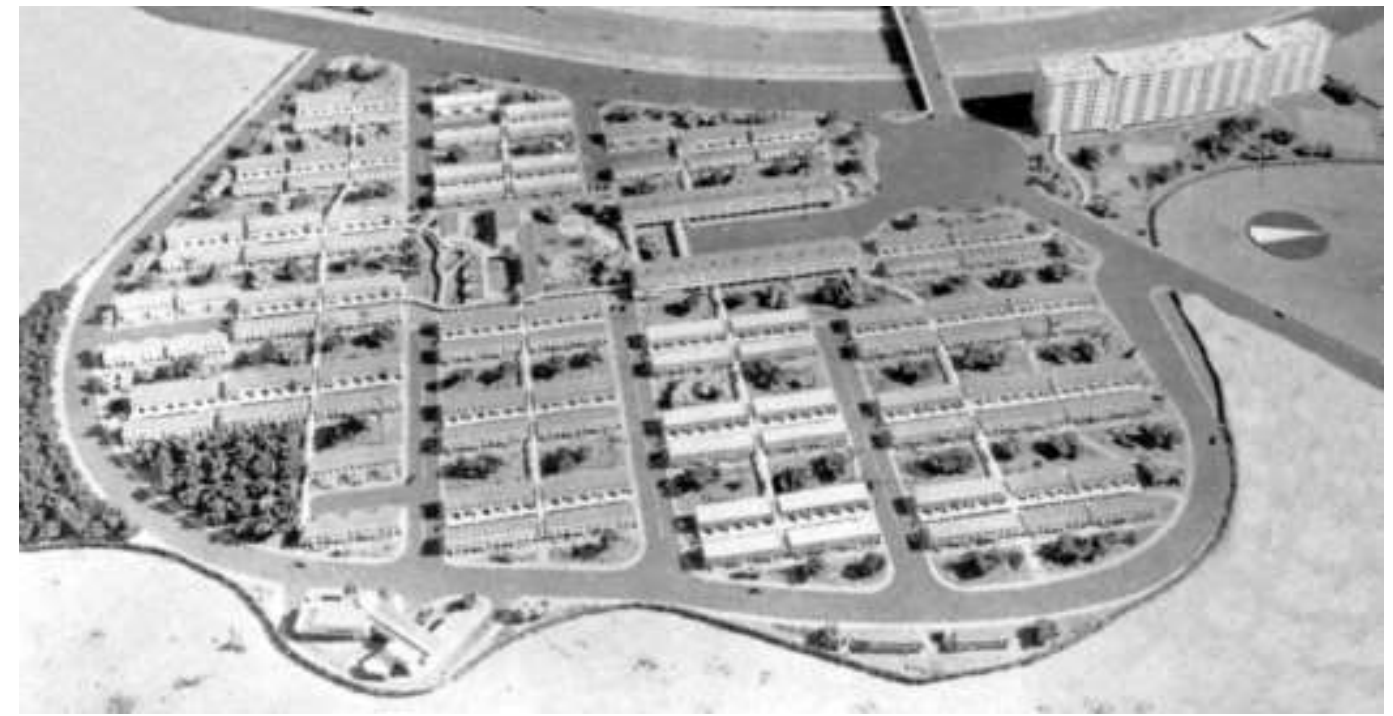

Figura 36: Vista geral do conjunto - maquete. Fonte: Acrópole, Ano 16, n. 184, 1953, p. 183. 

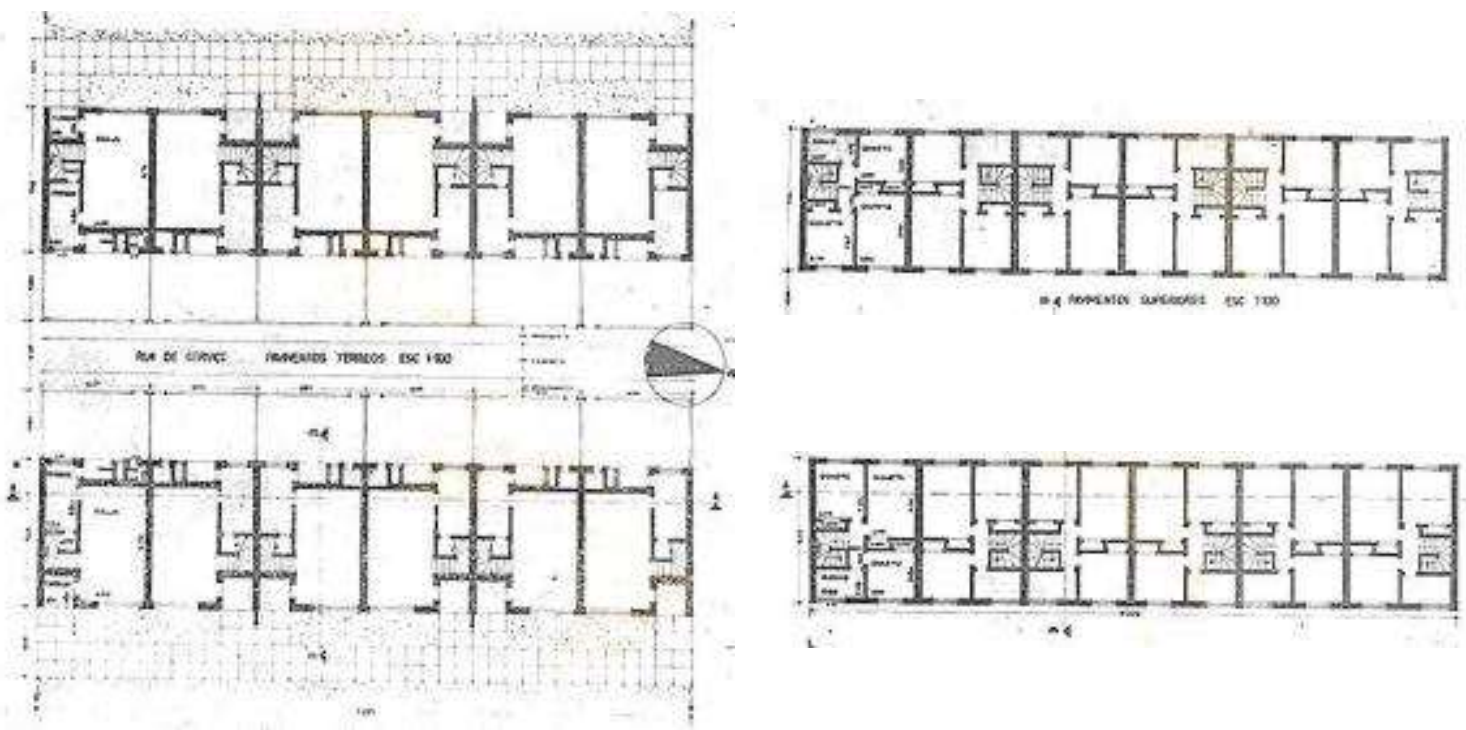

Figura 37. Plantas do Tipo A de fileira de casas assobradadas. Fonte: Acrópole, Ano 9, n. 107, março 1947, p. 277.

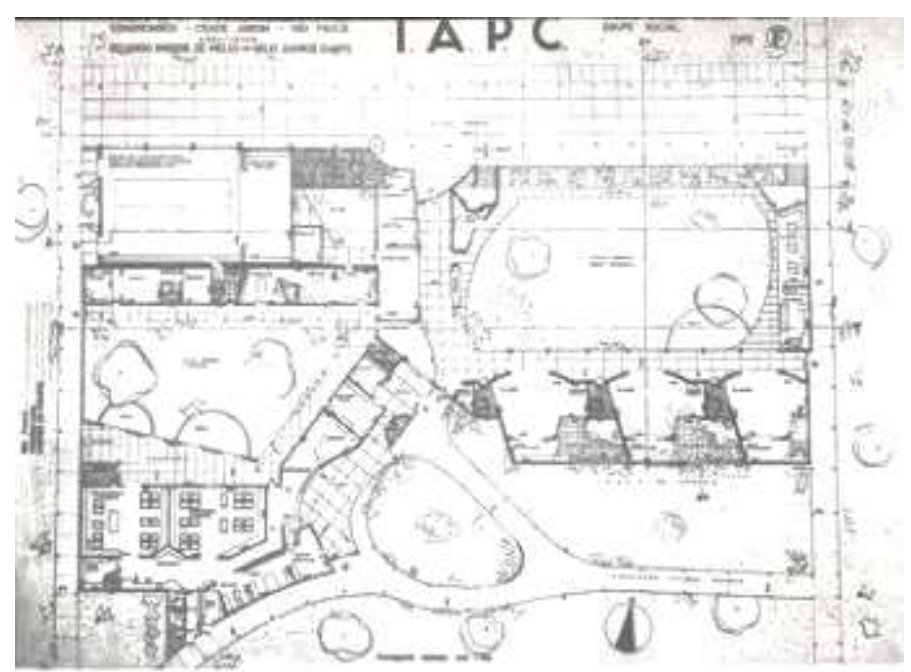

Figura38: Projetos dos equipamentos propostos. Fonte: Acrópole, Ano 09, n. 107, 1947, p. 282

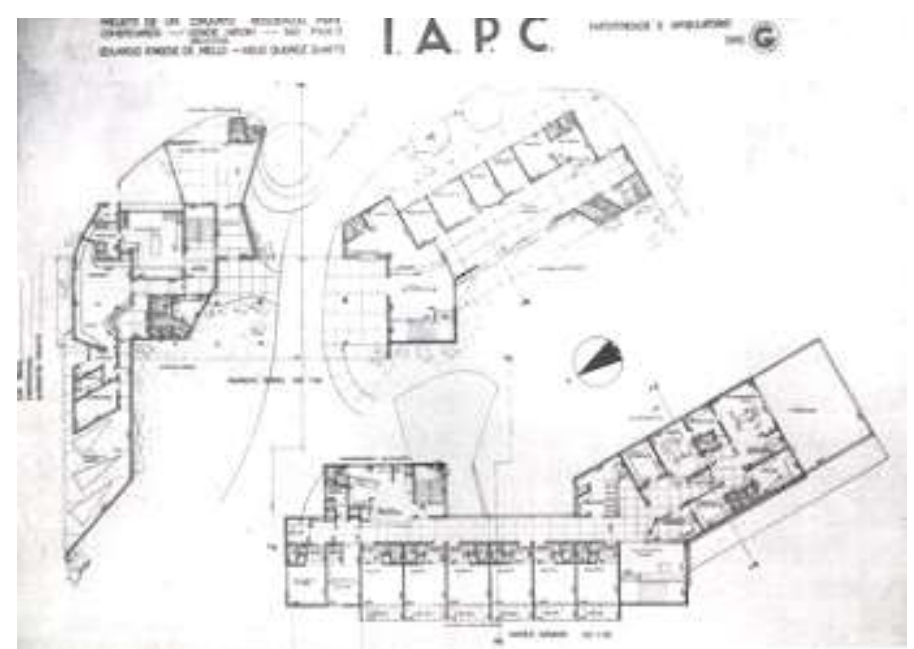

Figura 39: Projetos dos equipamentos propostos. Fonte: Acrópole, Ano 09, n. 107, 1947, p. 284. 
Data do projeto: 1958

Órgão: Instituto de Aposentadoria e Pensões dos comerciários (IAPC) e Serviço Social do Comércio (Sesc)

Projeto: arq. Osvaldo Correa Gonçalves; Heitor Ferreira de Souza; Araken de Martinho; Mário Reginato; Ubirajara Giglioti

Construção: Serviço de Engenharia do IAPC

Localização: Avenida Presidente Kennedy, Suzano

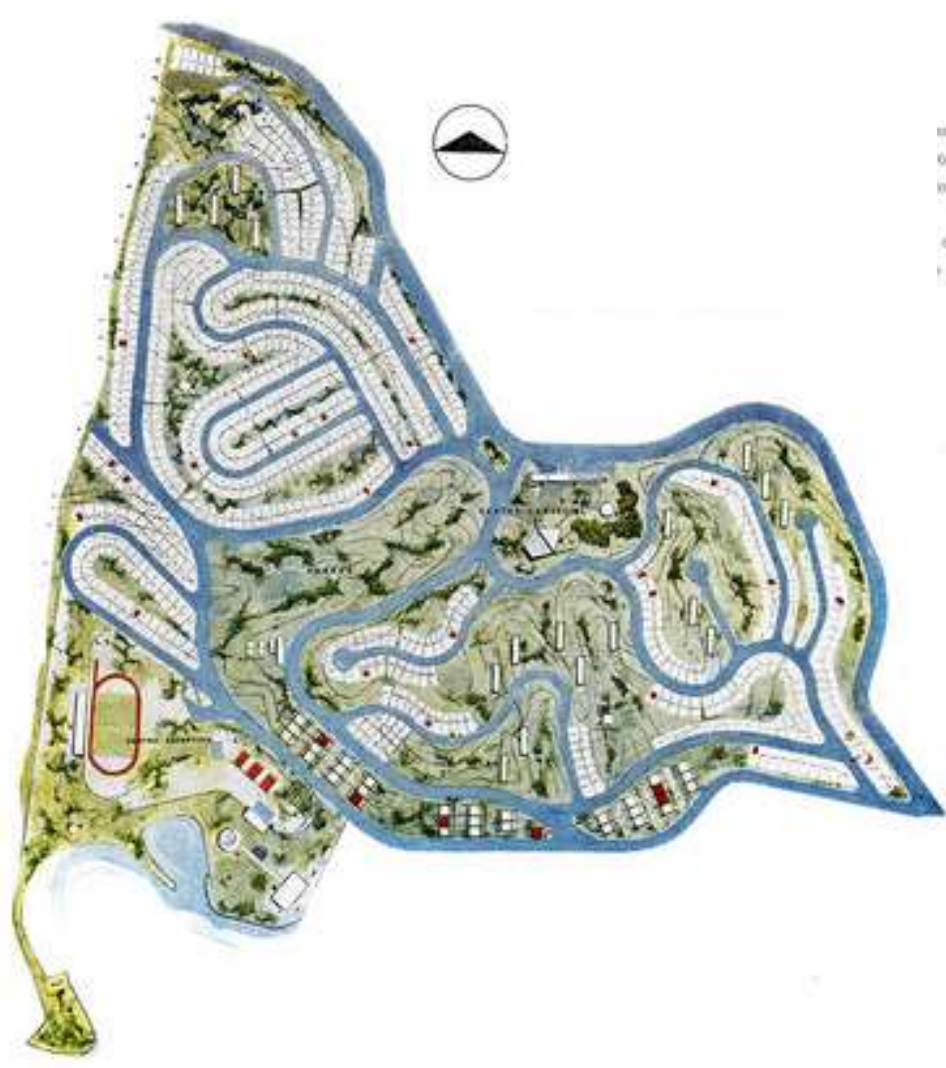

Figura 40: Implantação do conjunto. Fonte: Comunidade "Brasílio Machado Neto" In: Acrópole. São Paulo, Ano 20, N²38, ago. 1958. p.466.
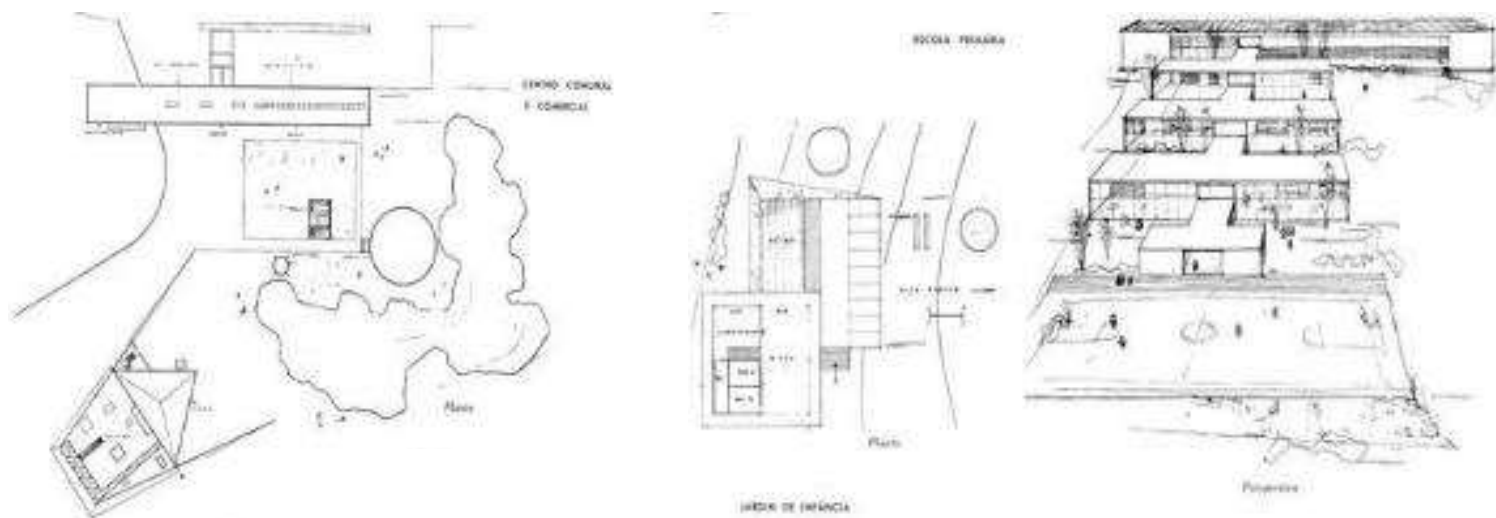

Figura 41: Projetos dos equipamentos propostos. Fonte: Comunidade "Brasílio Machado Neto" In: Acrópole. São Paulo, Ano 20, N²38, ago. 1958. p.468-469. 

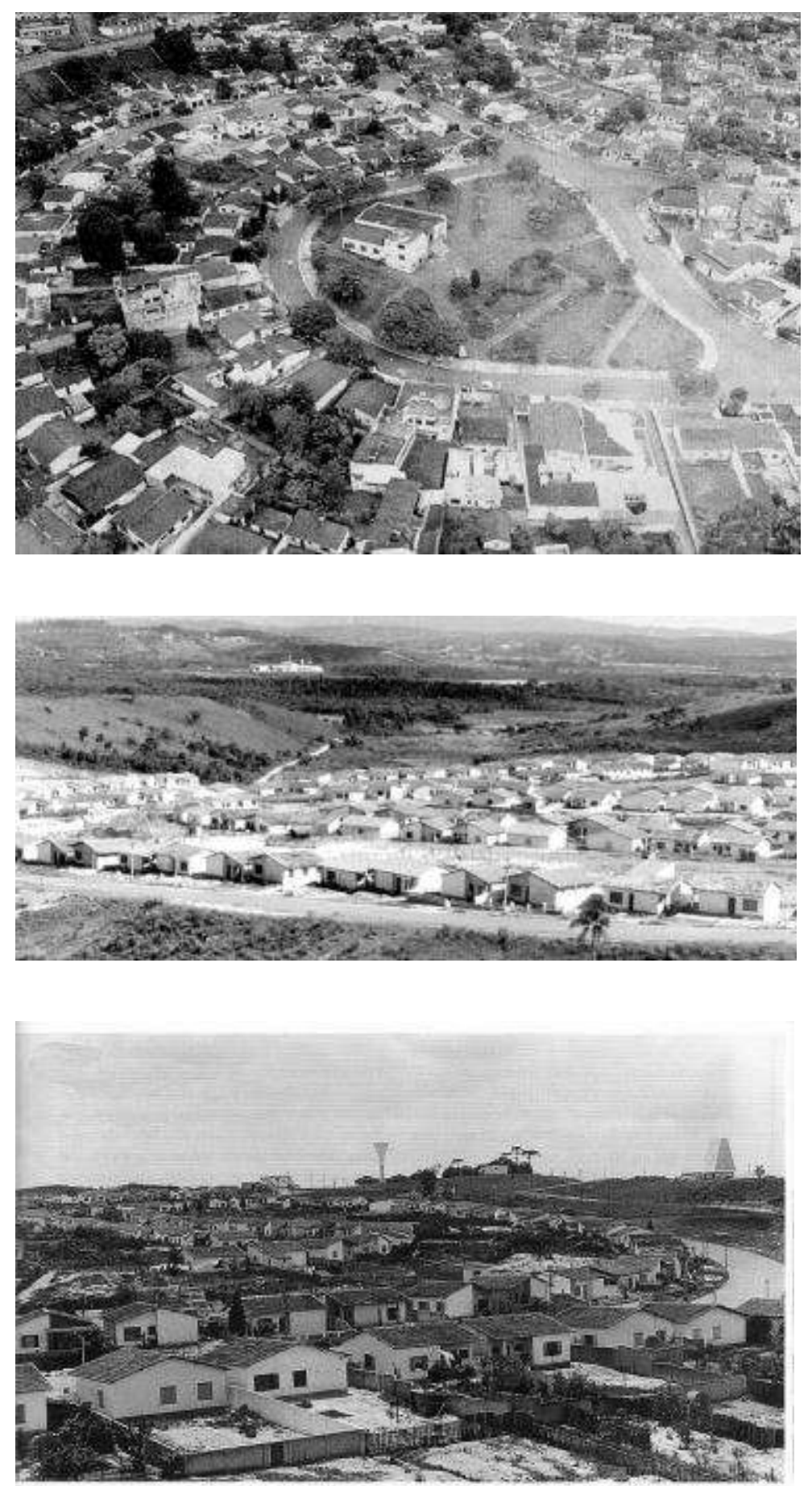

Figura 42. Fotografia do conjunto já construído. Fonte: Foto cedida pelo Portal SESC - Comunidade Brasílio Machado Neto - Suzano Recordações. Disponível em: <https://www.flickr.com/photos/ses csp/14067399434/in/photostream/> Acesso em 02 jul. 2017.

Figura 43. Fotografia do conjunto já construído. Fonte: Foto cedida pelo Portal SESC - Comunidade Brasílio Machado Neto - Suzano Recordações. Disponível em: <https://www.flickr.com/photos/ses csp/14067399434/in/photostream/> Acesso em 02 jul. 2017.

Figura 44. Fotografia do conjunto já construído. Fonte: Foto cedida pelo Portal SESC - Comunidade Brasílio Machado Neto - Suzano Recordações. Disponível em: <https://www.flickr.com/photos/ses csp/14067399434/in/photostream/> Acesso em 02 jul. 2017. 
Cidade Comerciária Presidente Vargas

Data do projeto: 1954

Órgão: Instituto de Aposentadoria e Pensões dos comerciários (IAPC)

Projeto: Divisão de Engenharia do IAPC

Construção: Divisão de Engenharia do IAPC

Localização: Jabaquara, São Paulo

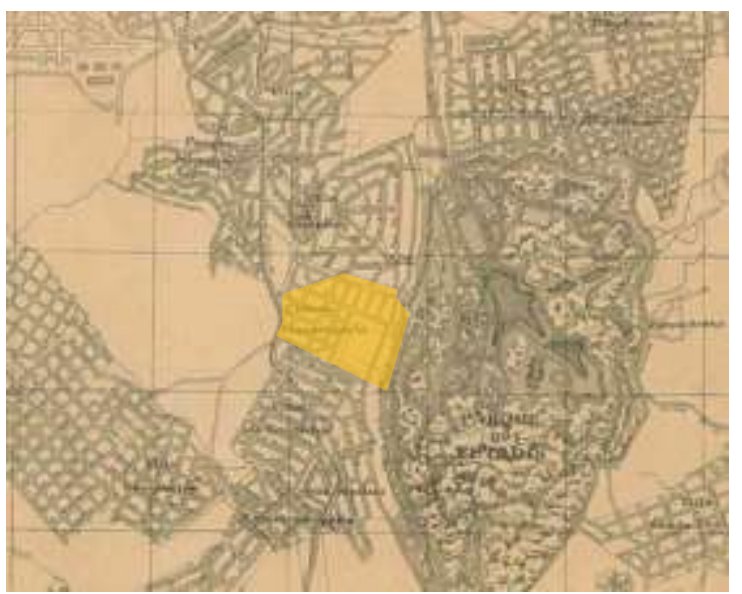

Figura 45. Localização da Cidade Comerciária Presidente Vargas. Base Cartográfica: "Projeção hiperboloid com rêde kilométrica" de 1951, com intervenção da autora. Fonte: Histórico Demográfico do Município de São Paulo. Disponível em:

<http://smdu.prefeitura.sp.gov.br/historico_demografico/19 50.php> Acesso em 06 abril 2016.

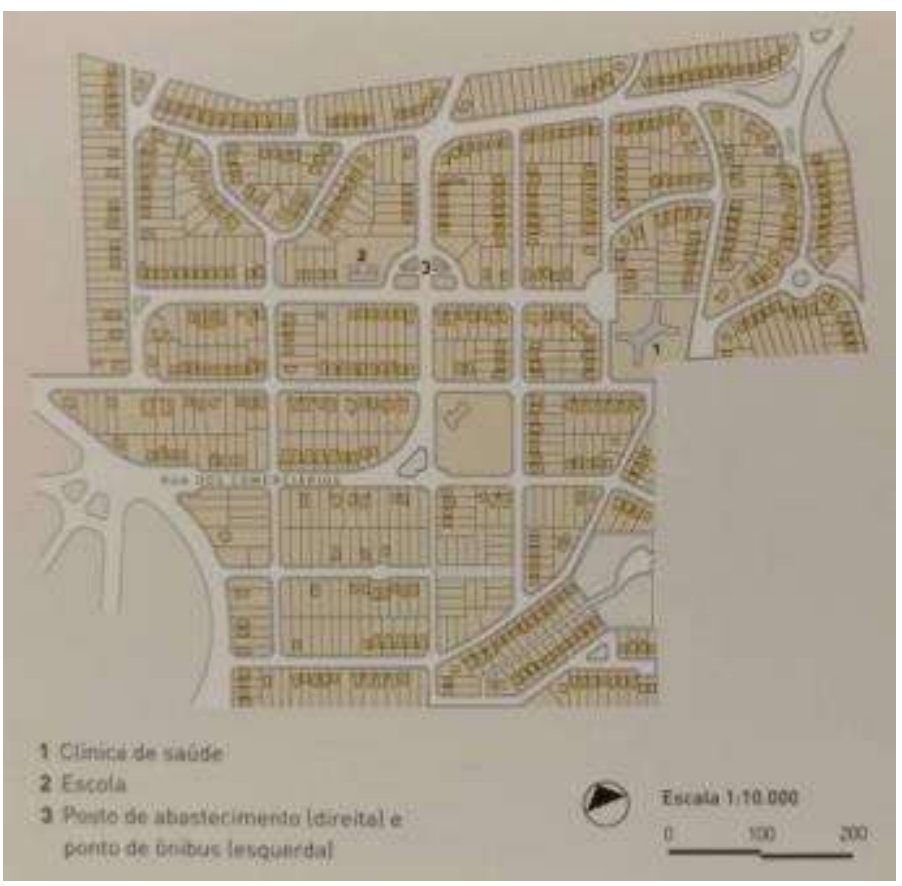

Figura 46. Implantação da Cidade Comerciária Presidente Vargas Fonte: BONDUKI, N.G.; KOURY, A.P. Os pioneiros da habitação social no Brasil: inventário da produção pública no Brasil entre 1930 e 1964. São Paulo:UNESP:SESC, 2014. Vol.2. p.166. 


\section{Jardim Piratininga}

Data do projeto: 1954

Órgão: Instituto de Aposentadoria e Pensões dos Industriários (IAPC)

Projeto: Carlos Frederico Ferreira - Serviço de Eng. do IAPI

Construção: Serviço de Eng. do IAPI

Localização: R. Romildo Isaías Neto, Osasco

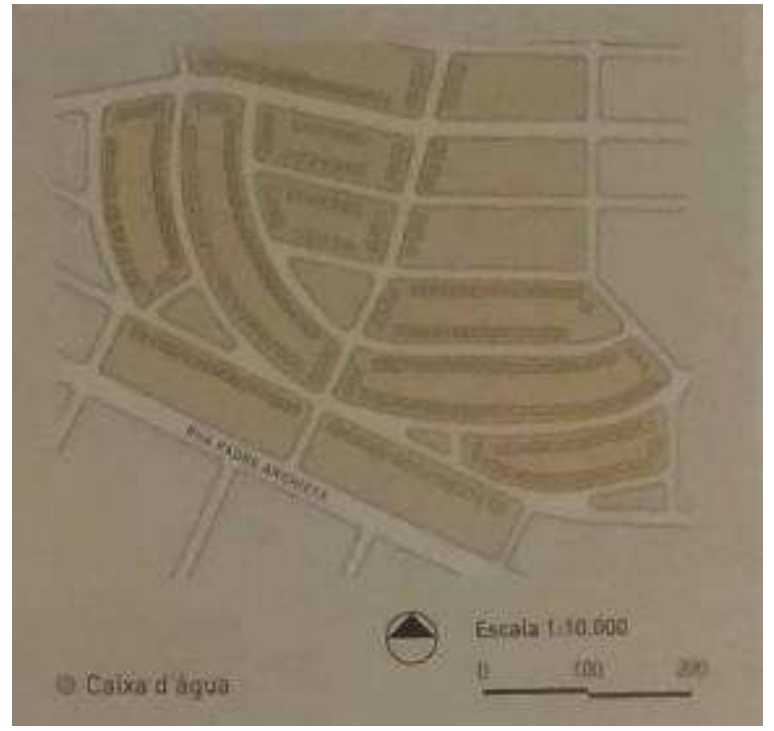

Figura 47. Implantação do Jardim Piratininga. Fonte: BONDUKI, N.G.; KOURY, A.P. Os pioneiros da habitação social no Brasil: inventário da produção pública no Brasil entre 1930 e 1964. São Paulo:UNESP:SESC, 2014. Vol.2. p.94

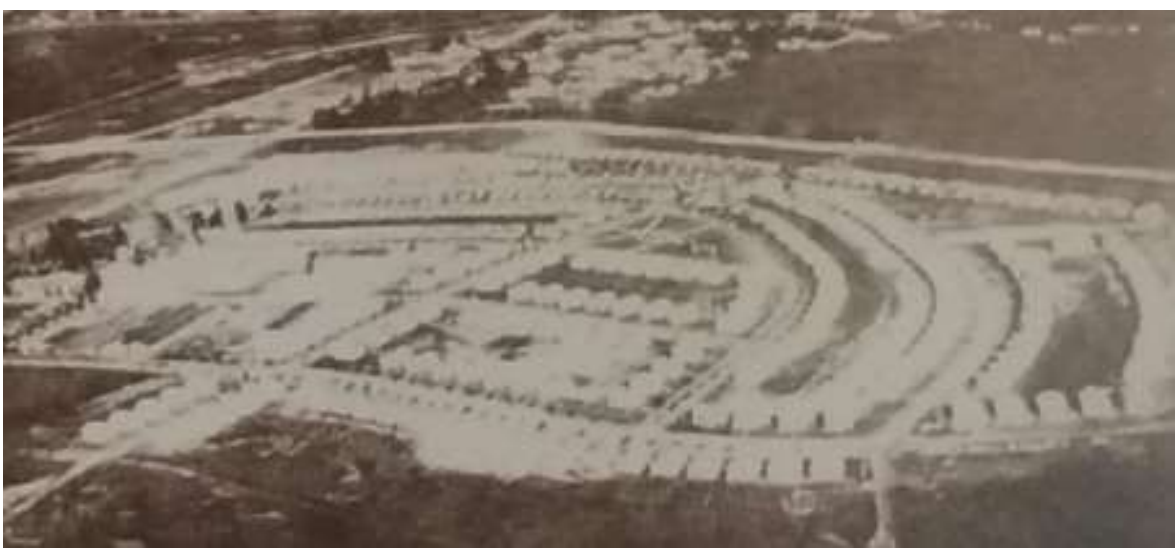

Figura 48. Vista aérea do Jardim Piratininga. Fonte: BONDUKI, N.G.; KOURY, A.P. Os pioneiros da habitação social no Brasil: inventário da produção pública no Brasil entre 1930 e 1964. São Paulo:UNESP:SESC, 2014. Vol.2. p.94

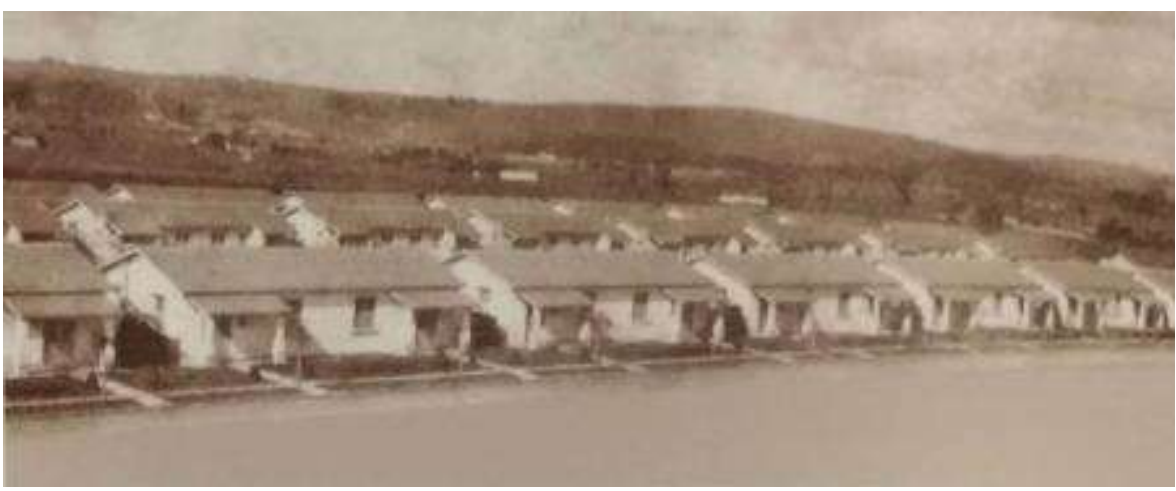

Figura 49. Casas geminadas com varanda do Jardim Piratininga. Fonte: BONDUKI, N.G.; KOURY, A.P. Os pioneiros da habitação social no Brasil: inventário da produção pública no Brasil entre 1930 e 1964. São Paulo:UNESP:SESC, 2014. Vol.2. p.94 
Los Perales - Barrio Manuel Dorrego

Data do projeto: $1946-1952$

Órgão Comitente: Direccion Municipal de la Vivienda - Municipalidad de la Ciudad de Buenos Aires (MCBA)

Órgão Promotor Financeiro: Banco Hipotecário Nacional (BHN)

Projeto: arq. Augusto Sergio Pieres; Dermot José Grehan; Bartolomé Repetto; Jorge Sabaté (igreja)

Construção: várias empresas

Localização: Av. Lizandro de la Torre, Mataderos · Buenos Aires
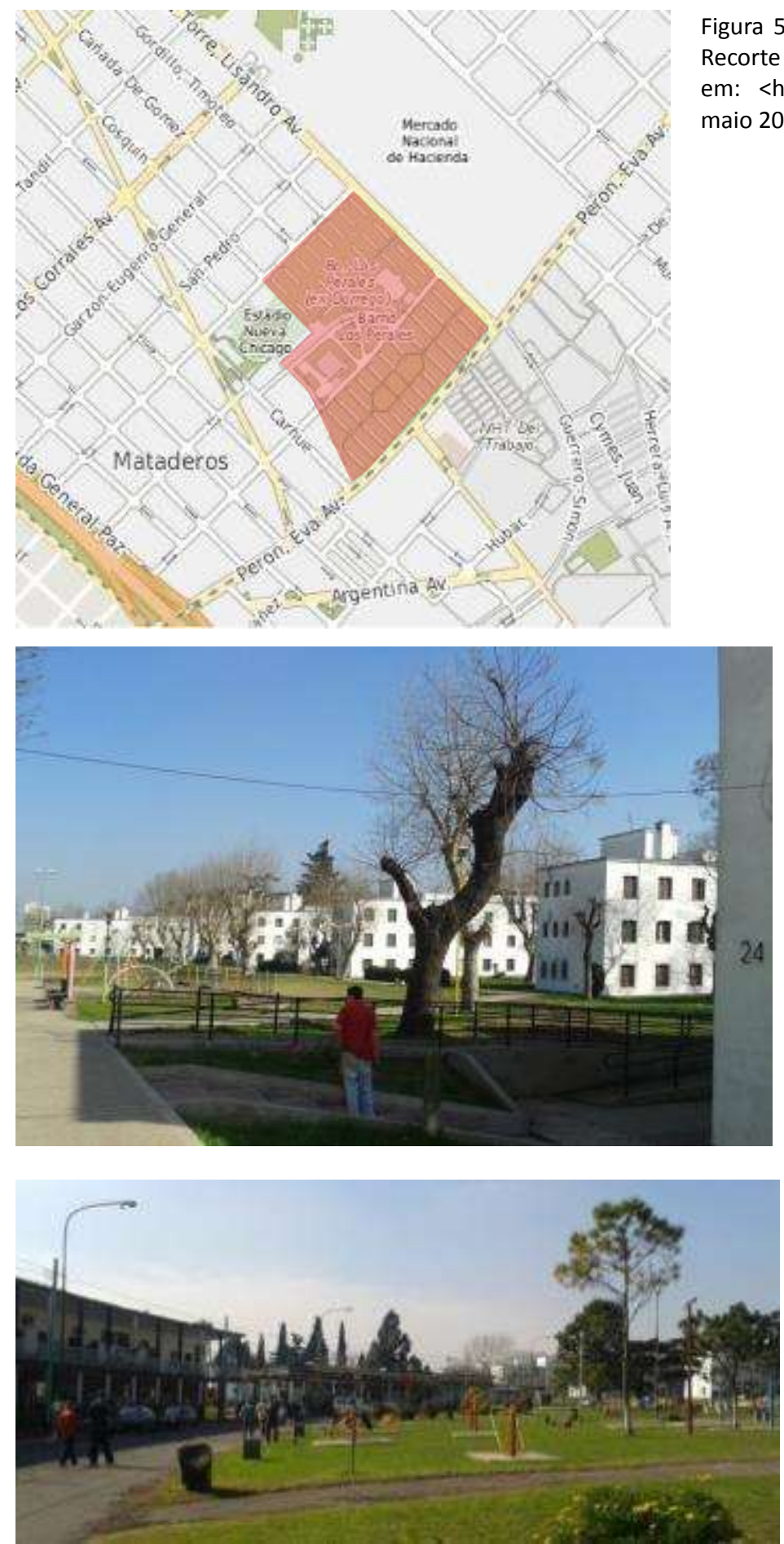

Figura 50. Localização do Los Perales. Base cartográfica: Recorte do Mapa Interactivo de Buenos Aires. Disponível em: <http://mapa.buenosaires.gov.ar> Acesso em 05 maio 2017.

Figura 51. Conjunto Los Perales. Fonte: Acervo pessoal. Foto de Camila Ferrari, jul. 2014.

Figura 52. Praça central, centro comercial (lateral) e centro cívico (fundo). Fonte: Acervo pessoal. Foto de Camila Ferrari, jul. 2014. 
17 de Octubre (Barrio Grafa) - Barrio General José de San Martín

Data do projeto: $1948-1950$

Órgão Comitente: Direccion de Viviendas - Municipalidad de la Ciudad de Buenos Aires (MCBA)

Órgão Promotor Financeiro: Banco Hipotecário Nacional (BHN)

Projeto: arq. Carlos Giannoni; Carlos Coire; M. C. Bianchi (sede cultural e de lazer)

Construção: Fernando Vanelli y hijos

Localização: Av. de los Constituintes, Villa Pueyrredón · Buenos Aires

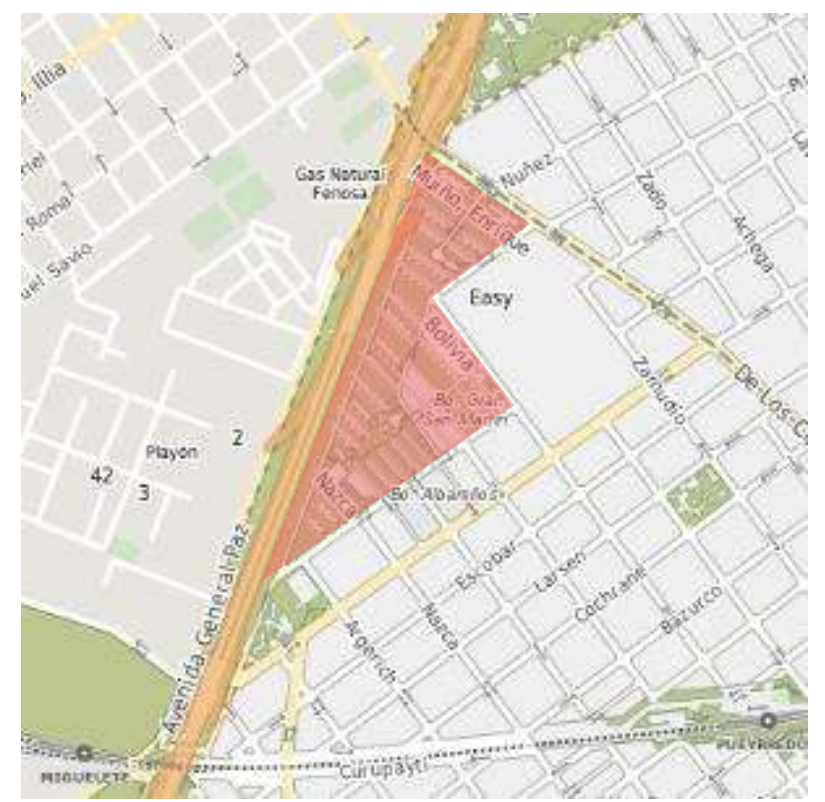

Figura 53. Localização do conjunto 17 de Octubre. Base cartográfica: Recorte do Mapa Interactivo de Buenos Aires. Disponível em: <http://mapa.buenosaires.gov.ar> Acesso em 05 maio 2017.

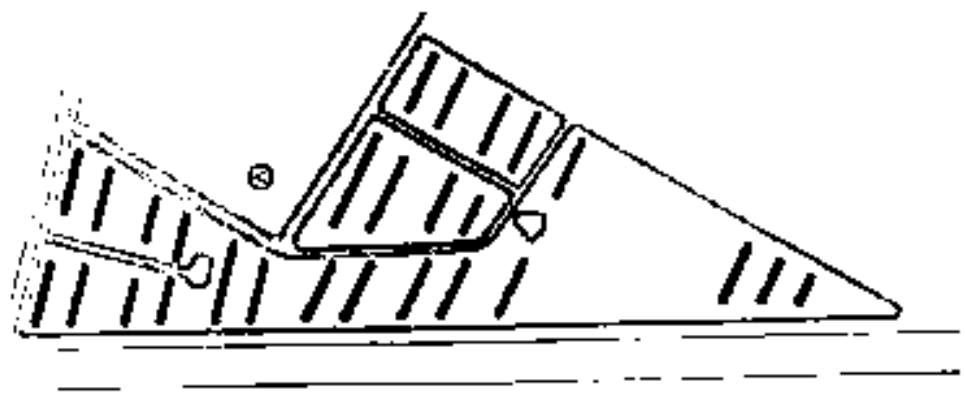

Figura 54. Planta do conjunto 17 de Octubre. Fonte: ORTIZ, Federico; GUTIÉRREZ, Ramón. La Arquitectura en la Argentina 1930-1970. Buenos Aires. Separata del número 103 de la revista Hogar y architectura, 1972. p. 5.

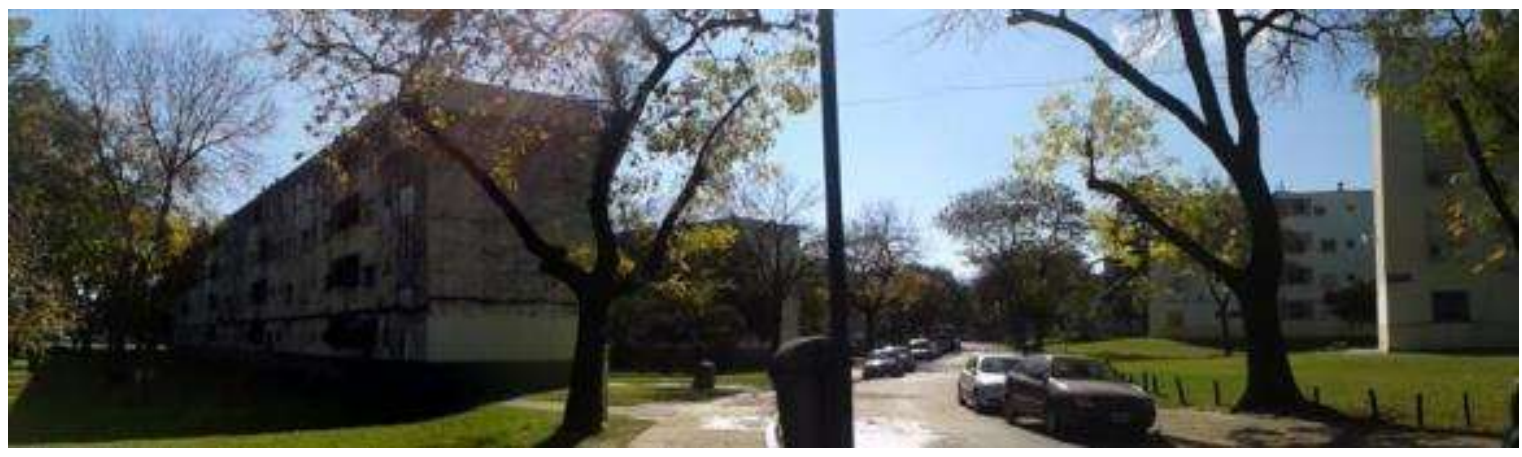

Figura 55. Conjunto 17 de Octubre. Fonte: Acervo pessoal. Foto de Camila Ferrari, maio 2017. 
Curapaligüe - 26 de Julio - Simón Bolívar

Data do projeto: $1948-1953$

Órgão Comitente: Administracion Nacional de la Vivienda (ANV) - Banco Hipotecário Nacional (BHN)

Órgão Promotor Financeiro: Banco Hipotecário Nacional (BHN)

Projeto: arq. Héctor Fariña Rice

Construção: -

Localização: Av. Eva Perón, Parque Chacabuco · Buenos Aires
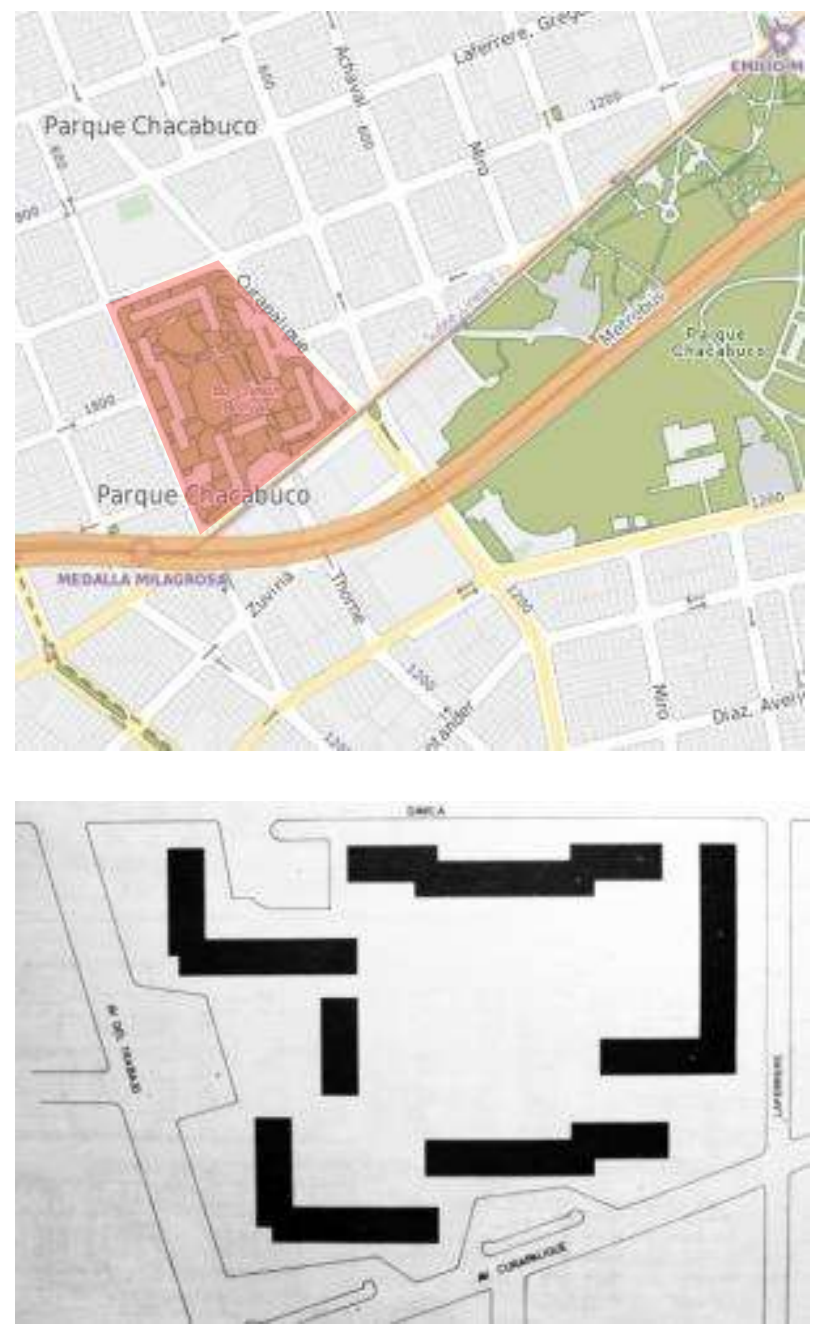

Figura 56. Localização do Conjunto Curapaligüe. Base cartográfica: Recorte do Mapa Interactivo de Buenos Aires. Disponível em: <http://mapa.buenosaires.gov.ar> Acesso em 05 maio 2017

Figura 57. Planta do Conjunto Curapaligüe. Fonte: SORIA, Jaime. "La vivienda argentina en la decada del 50"' In: TRAMA. n. 17, año 1987. p.22.

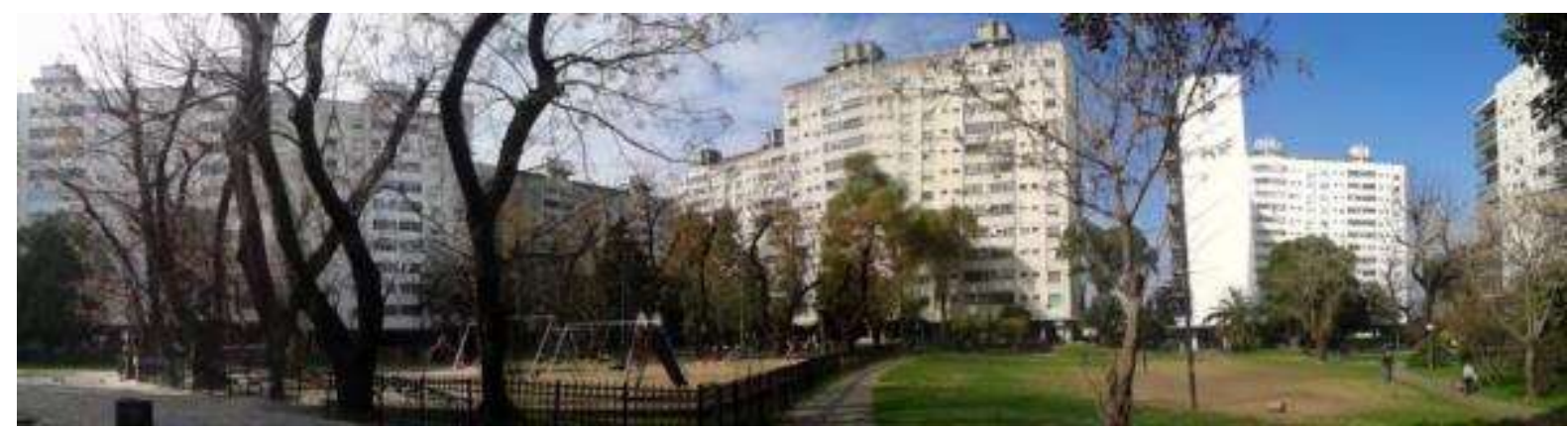

Figura 58. Conjunto Curapaligüe. Fonte: Acervo pessoal. Foto de Camila Ferrari, jul. 2014. 
17 de Octubre - Barrio General Paz

Data do projeto: $1948-1954$

Órgão Comitente: Banco Hipotecário Nacional (BHN)

Órgão Promotor Financeiro: Banco Hipotecário Nacional (BHN)

Projeto: arq. Luigi Piccinato; Adighero Gómez; Morelli; Stortini

Construção: Edifa, Sociedad Responsabilidad Limitada; Barraseta y Hartz Inmobiliaria;

Joaquín de Gamboa Construcciones, S.A.; Sebastián Maronese e Hijos, Sociedad de Responsabilidad Limitada

Localização: Av. Gral. Paz · La Matanza
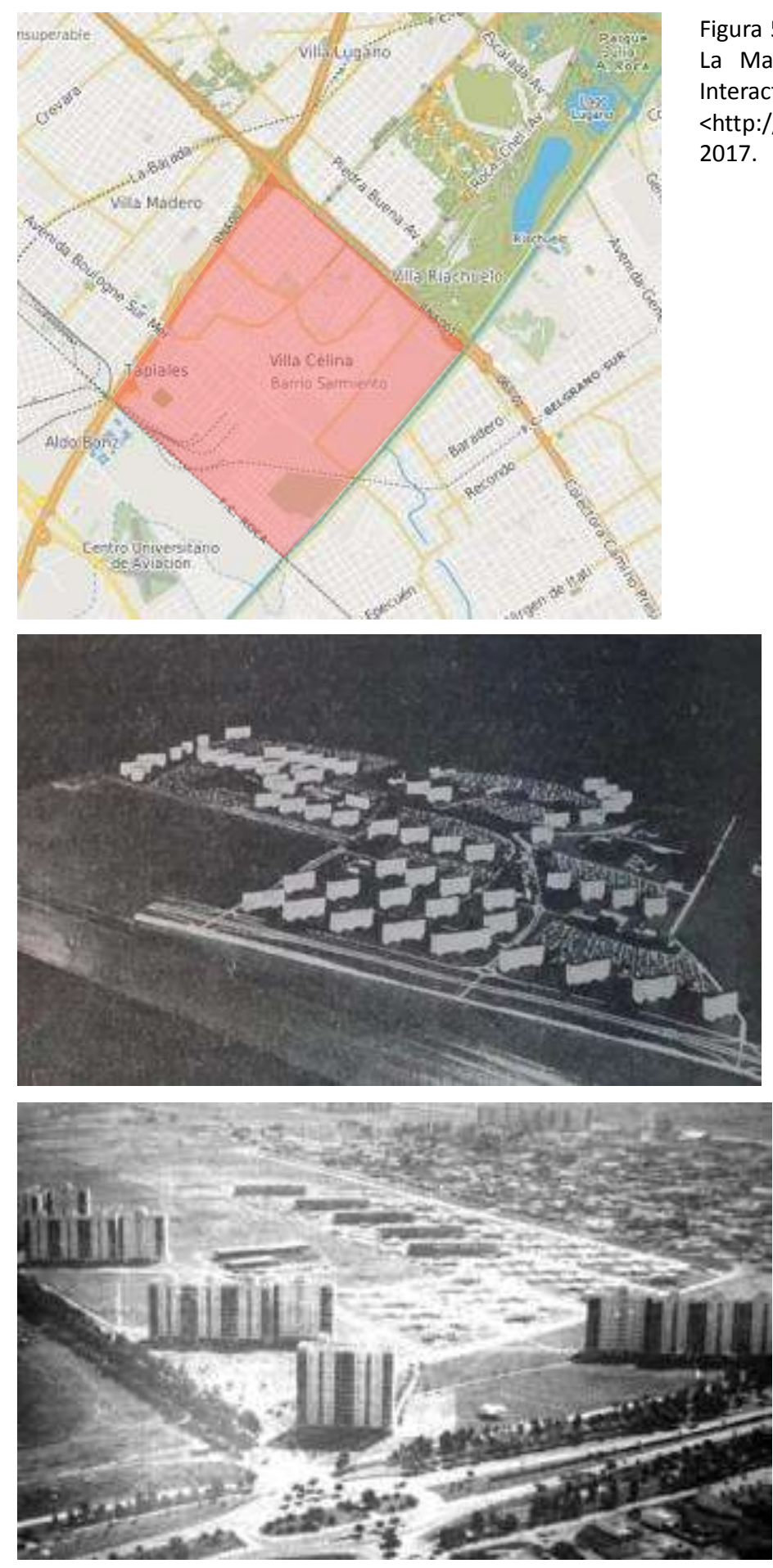

Figura 59. Localização do Conjunto 17 de Octubre em La Matanza. Base cartográfica: Recorte do Mapa Interactivo de Buenos Aires. Disponível em:

$<$ http://mapa.buenosaires.gov.ar> Acesso em 05 maio 2017.

Figura 60. Maquete do conjunto. Fonte: RUBIO, S. "El barrio 17 de Octubre. Obra del Banco Hipotecario Nacional" In: Construcciones. n 107, abril 1954. p.336

Figura 61. Vista do setor 1 do conjunto. Disponível em:

<https://lateja2.wordpress.com> Acesso em: 17 jul. 2017. 


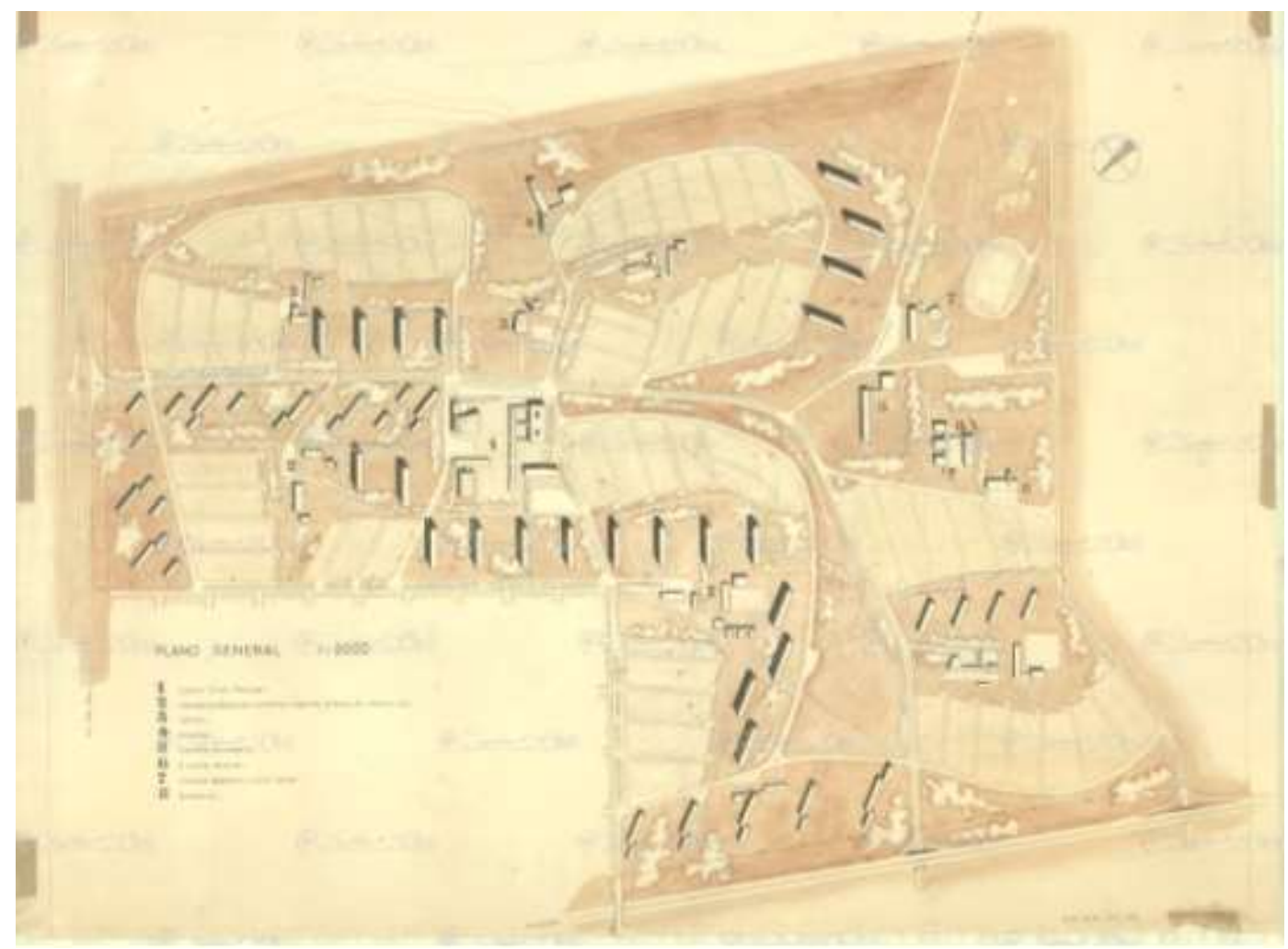

Figura 62. Barrio 17 de Octubre - Plano Geral. Esta é uma primeira versão do Plano, posteriormente todos os edifícios laminares seriam dispostos no eixo Norte-Sul. Fonte: Barrio 17 de Octubre a Buenos Aires. Disponível em: <http://www.archivioluigipiccinato.it/?s=17+de+octubre> Acesso em 28 abril 2017.

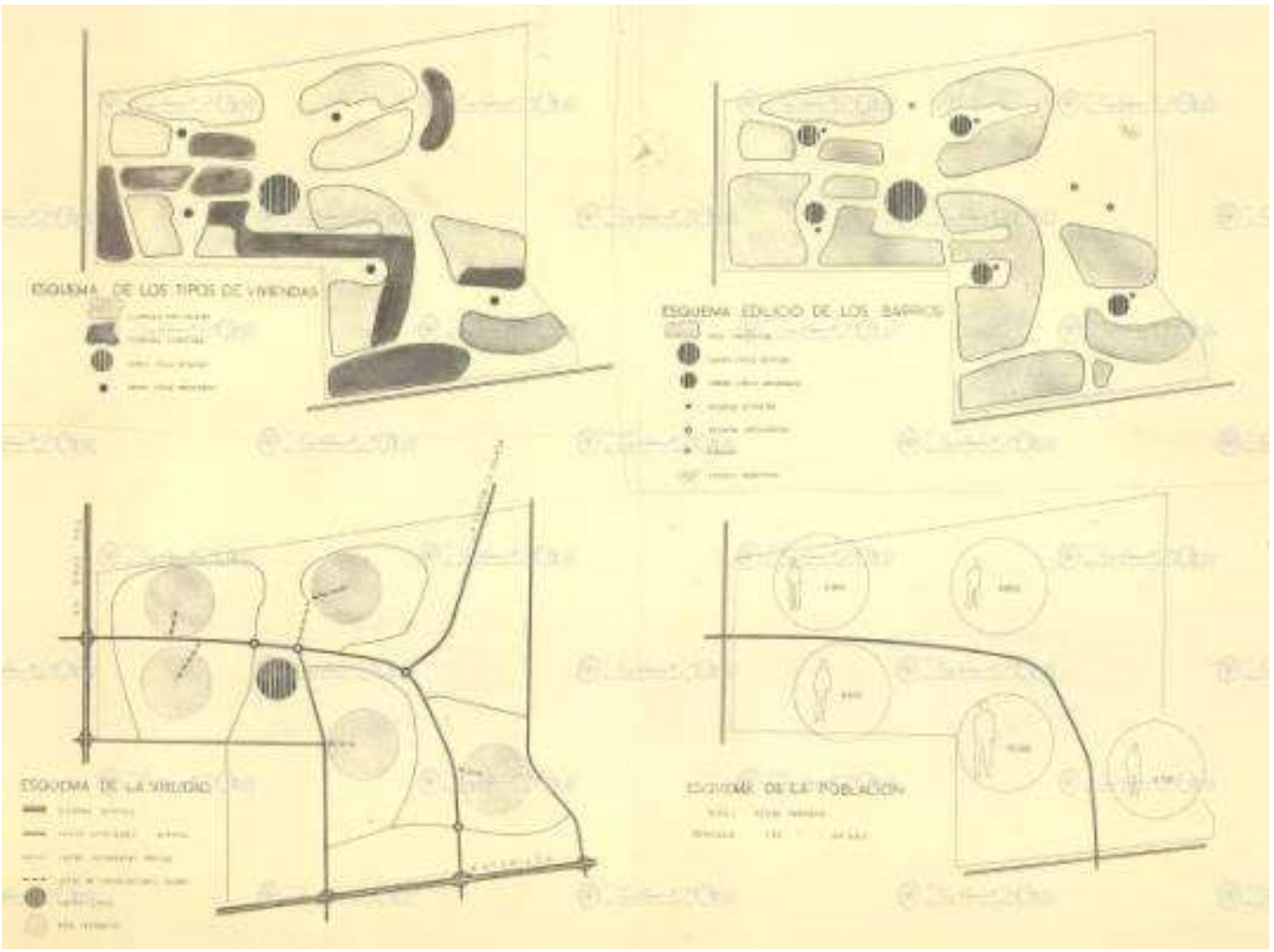

Figura 63. Barrio 17 de Octubre - Esquemas de tipologias, equipamentos, circulação e população. Fonte: Barrio 17 de Octubre a Buenos Aires. Disponível em: <http://www.archivioluigipiccinato.it/?s=17+de+octubre> Acesso em 28 abril 2017. 
Barrio Alvear III ( $3^{\mathfrak{a}}$ etapa)

Data do projeto: 1954

Órgão Comitente: CNCB - Banco Hipotecário Nacional (BHN)

Órgão Promotor Financeiro: Banco Hipotecário Nacional (BHN)

Projeto: Banco Hipotecário Nacional (BHN)

Construção: -

Localização: Av. Lacarra, Parque Avellaneda - BsAs · Buenos Aires
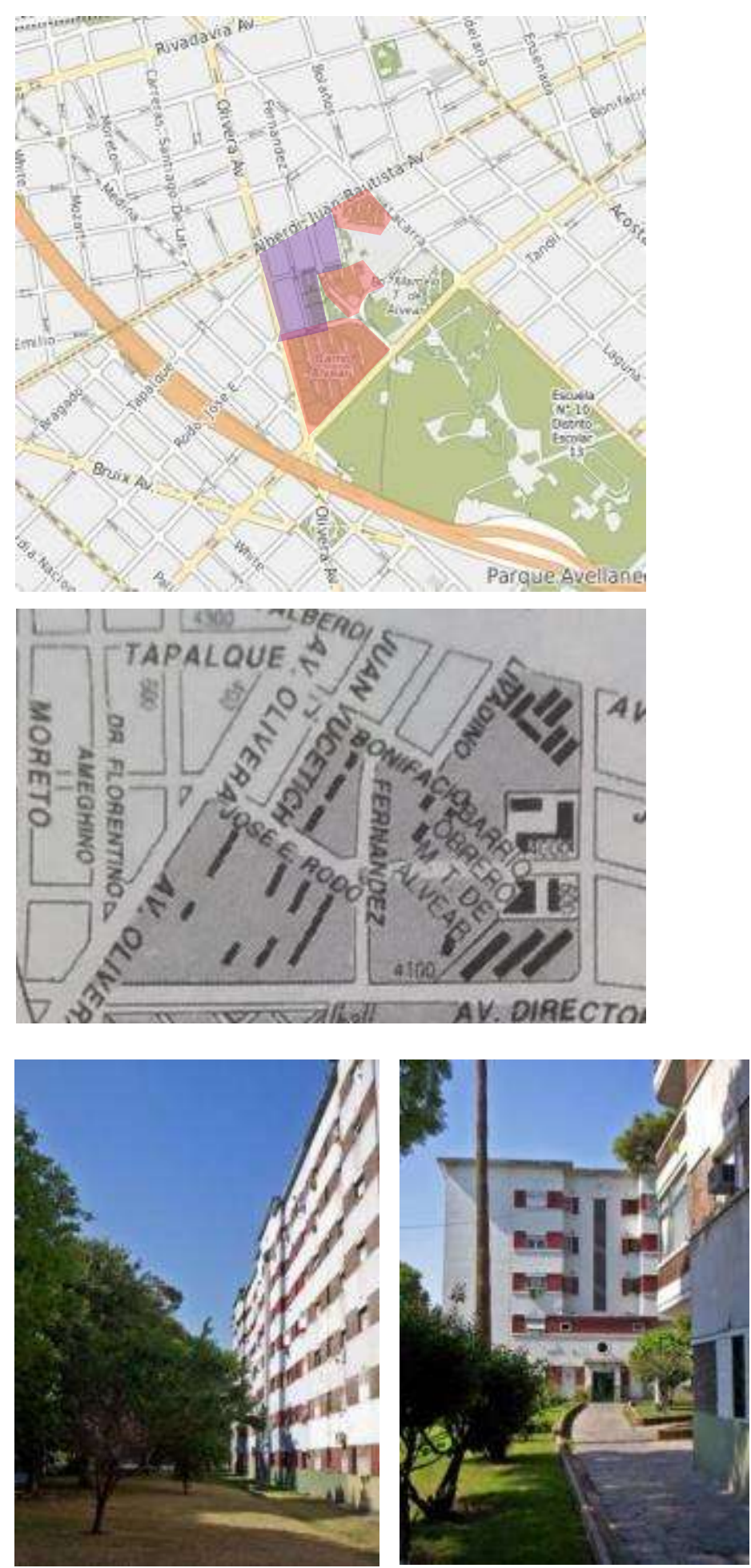

Figura 64. Localização e esquema de implantação do Barrio Alvear. Em roxo, casas unifamiliares e pabellones executados pela $\mathrm{CNCB}$ e em vermelho os monobloques construídos pelo BHN. Base cartográfica: Recorte do Mapa Interactivo de Buenos Aires. Disponível em: $<$ http://mapa.buenosaires.gov.ar> Acesso em 05 maio 2017.

Figura 65. Planta do Barrio Alvear. Fonte: NOGUÉS, Germinal. Buenos Aires Ciudad Secreta. Buenos Aires: Sudamericana, 1994. p. 32.

Figura 66. Edifícios do Barrio Alvear III. Fonte: La teja. Barrios Peronistas. Disponível em: <https://lateja2.wordpress.com/2009/05/01/195 4-barrio-alvear-III/> Acesso em: 23 jul. 2017. 


\section{Ciudad Evita}

Data do projeto: $1947-1953 / 57$

Órgão Comitente: Banco Hipotecário Nacional (BHN) / Ministério de Obras Públicas (MOP) ??? Órgão Promotor Financeiro: Banco Hipotecário Nacional (BHN)

Projeto: arq. Luigi Piccinato

Construção: Banco Hipotecário Nacional (BHN)

Localização: Autopista Tte. Gral. P. Ricchieri · La Matanza

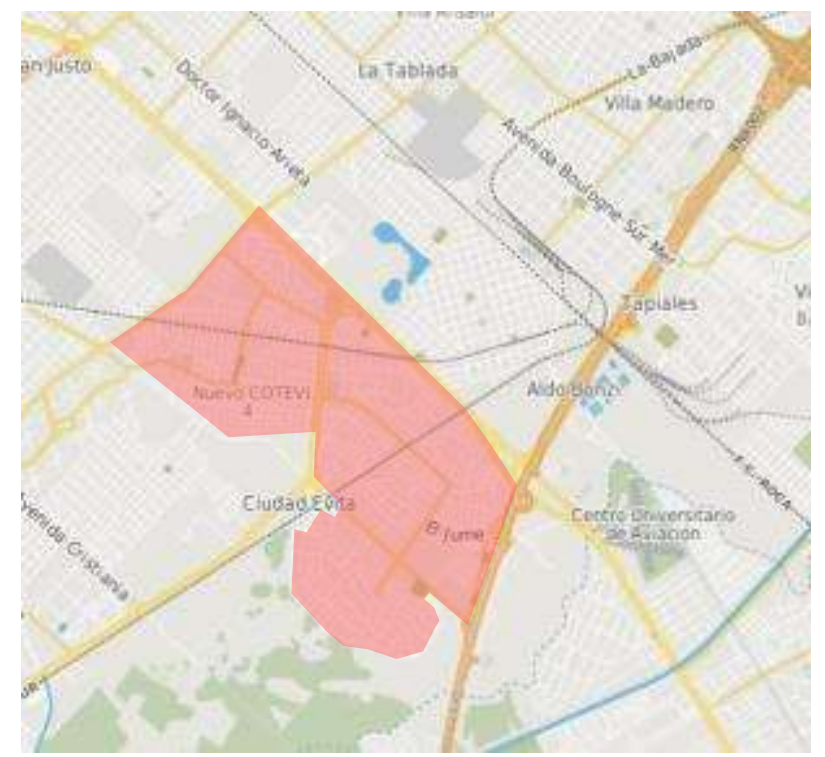

Figura 67. Localização da Ciudad Evita. Base cartográfica: Recorte do Mapa Interactivo de Buenos Aires. Disponível em: <http://mapa.buenosaires.gov.ar> Acesso em 05 maio 2017.

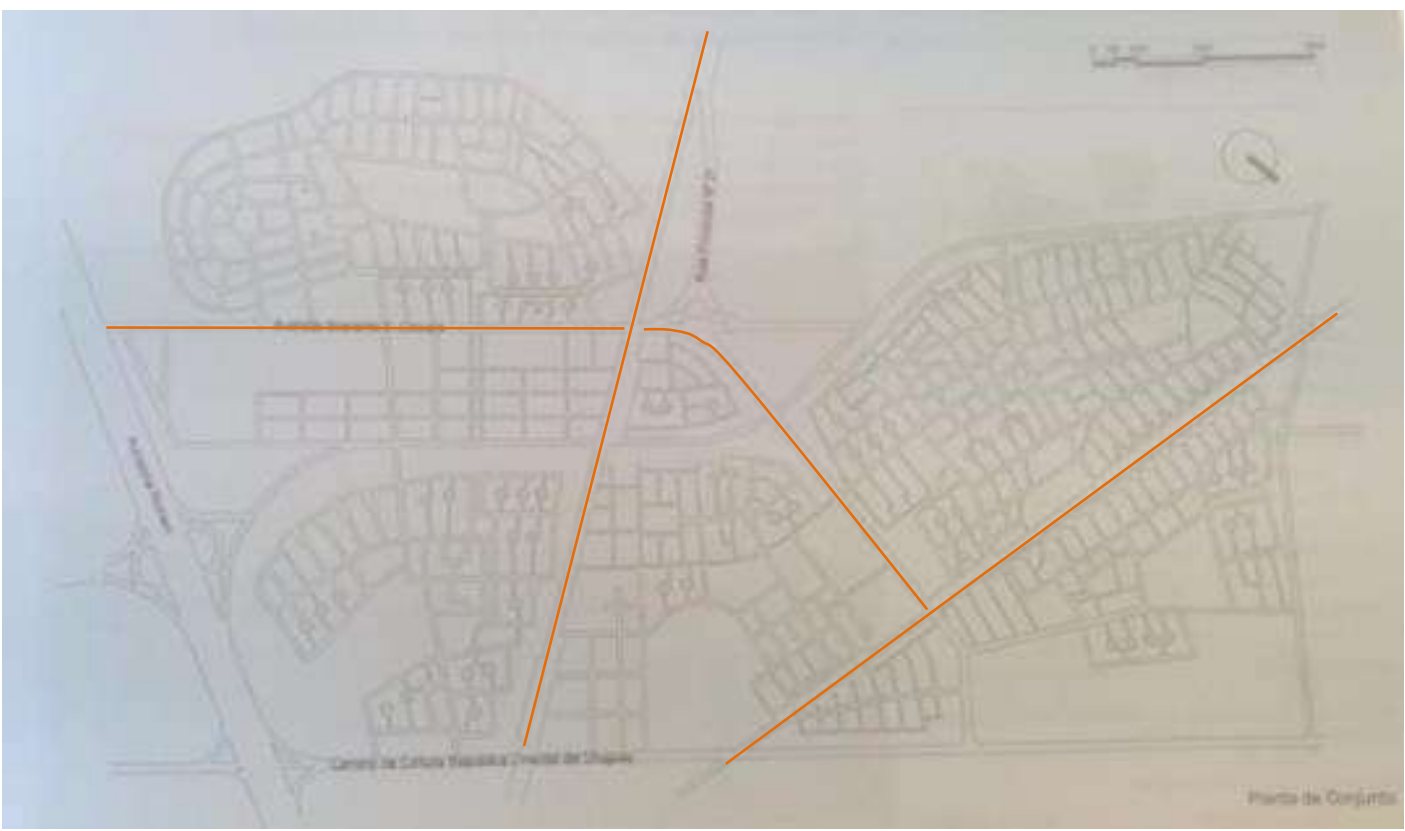

Figura 68. Planta do bairro Ciudad Evita. As linhas demarcam as cinco unidades de vizinhança. Fonte: BAGNERA, Paola. Vivienda Social y Arquitectura Moderna: Argentina y Cataluña (1930-1970). Rosário: Universidad Nacional del Litoral: Facultad de Arquitectura, Diseño y Urbanismo, 2008. p. 123. 


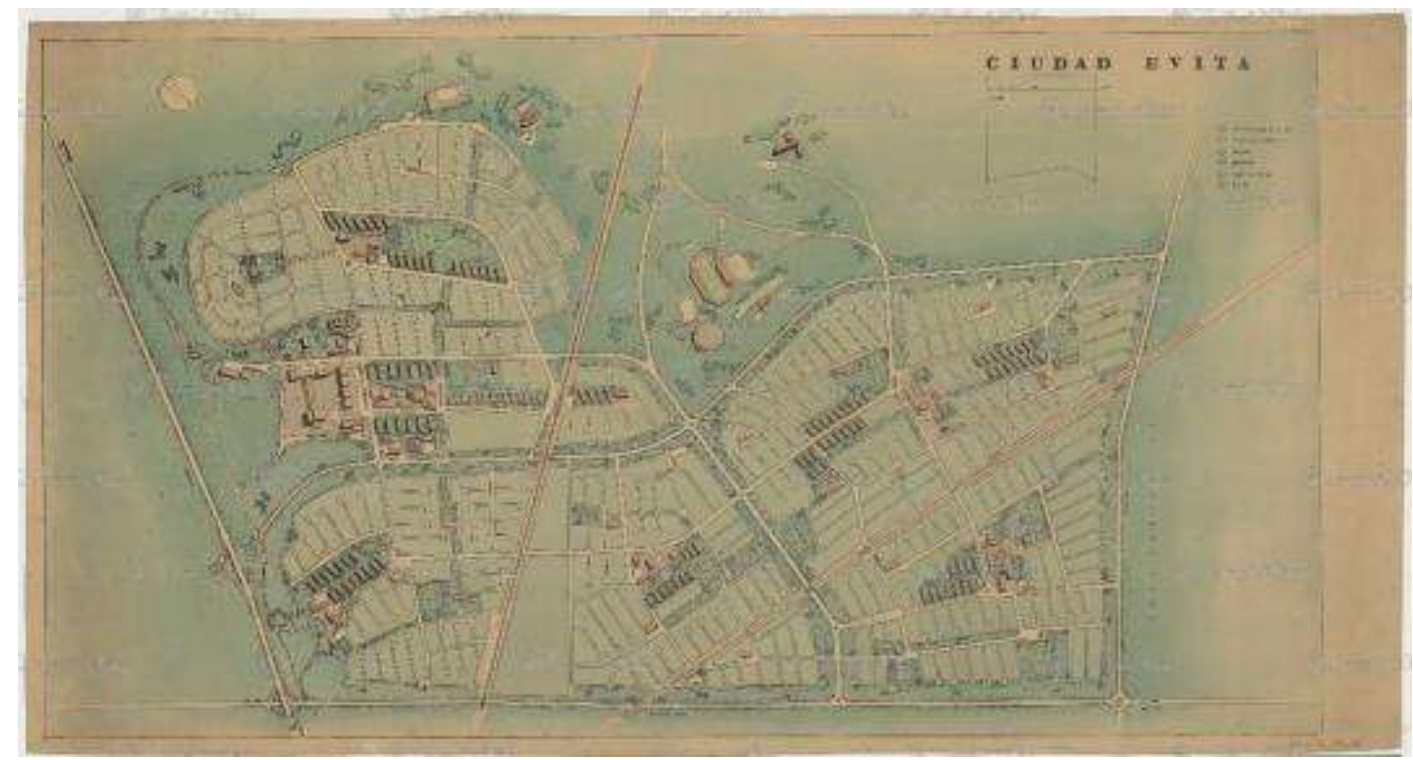

Figura 69. Planta de Ciudad Evita. Fonte: Ciudad Evita a Buenos Aires. Disponível em: <http://www.archivioluigipiccinato.it/?s=ciudad+evita> Acesso em 28 abril 2017.

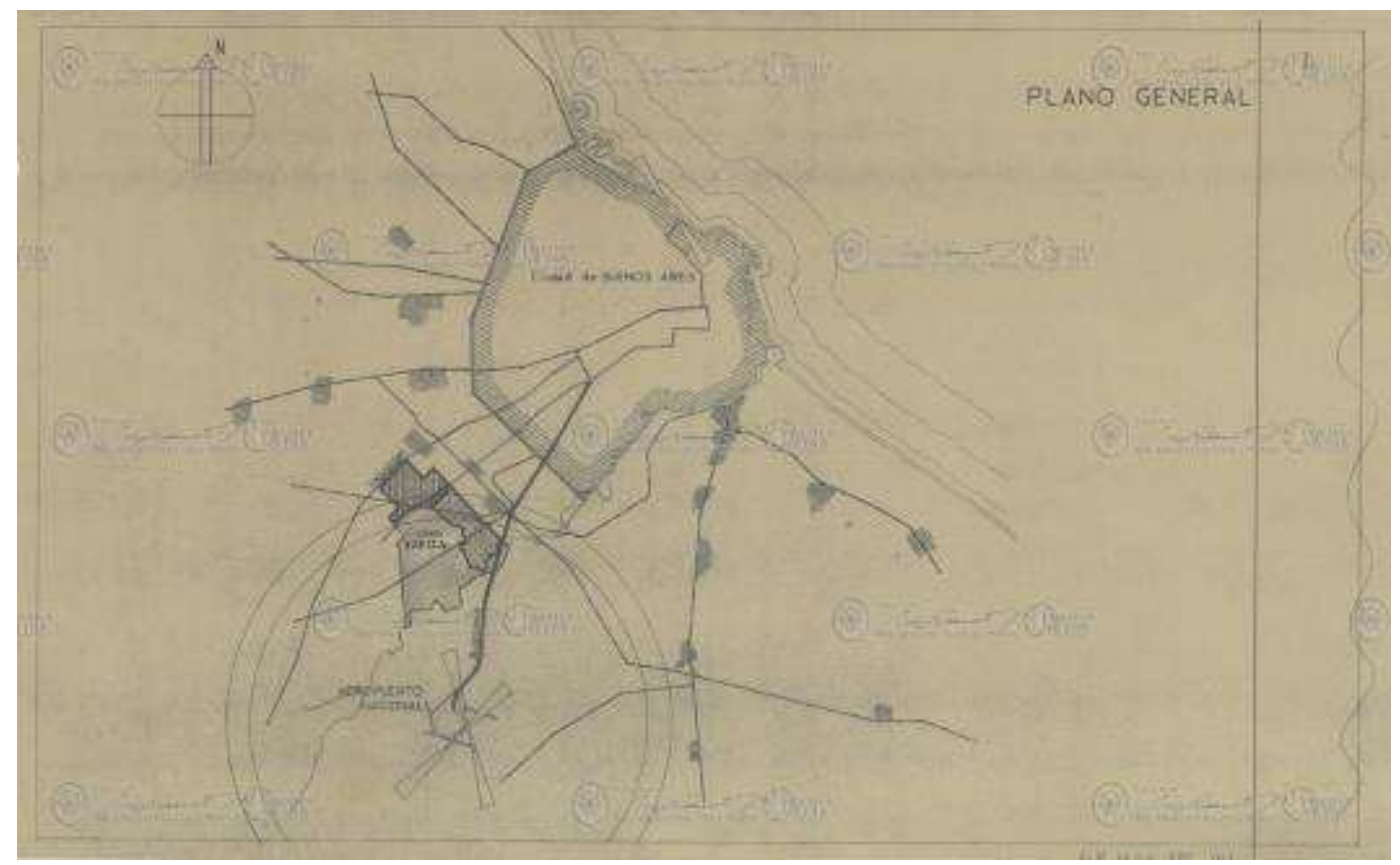

Figura 70. Plano geral de implantação de Ciudad Evita. Fonte: Ciudad Evita a Buenos Aires. Disponível em: <http://www.archivioluigipiccinato.it/?s=ciudad+evita> Acesso em 28 abril 2017.
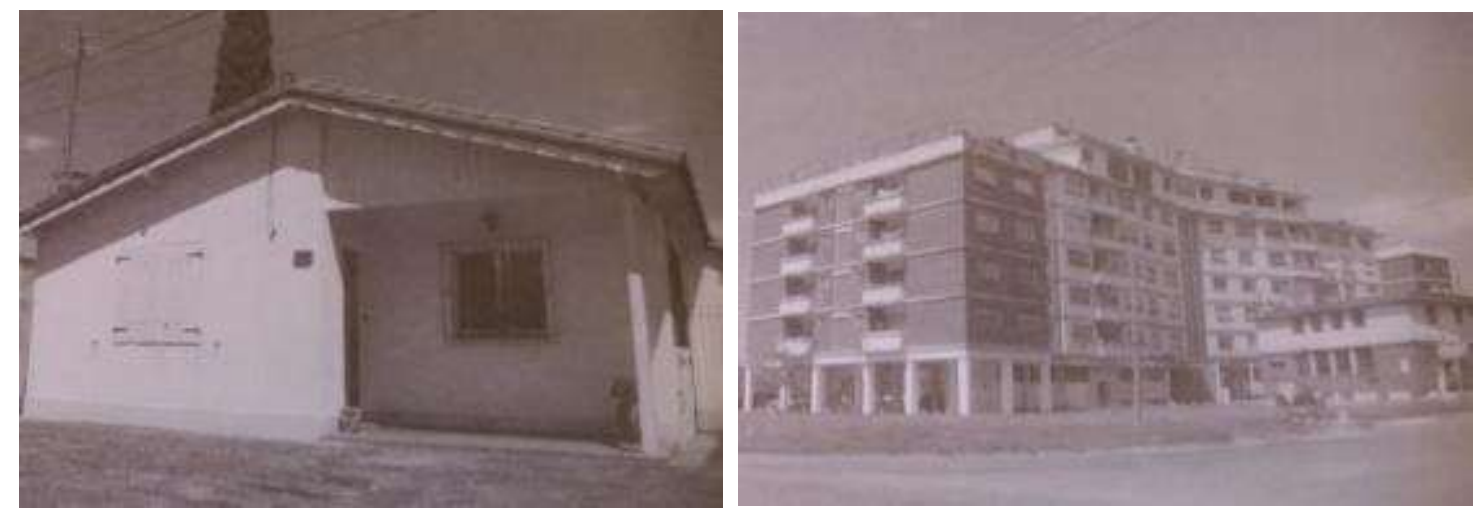

Figura 71. Um dos tipos unifamiliares isolados, com $76 \mathrm{~m}^{2}$ e bloco multifamiliar com 7 pavimentos. Fonte: BAGNERA, Paola. Vivienda Social y Arquitectura Moderna: Argentina y Cataluña (1930-1970). Rosário: Universidad Nacional del Litoral: Facultad de Arquitectura, Diseño y Urbanismo, 2008. p.126. 
Juan Perón - Cornelio Saavedra

Data do projeto: 1949

Órgão Comitente: Ministério de Obras Públicas (MOP)

Órgão Promotor Financeiro: Banco Hipotecário Nacional (BHN)

Projeto: arq. Francisco Capilla (diretor técnico do MOP); Roberto Quiroz

Construção: Banco Hipotecário Nacional (BHN)

Localização: Av. General Paz, Saavedra · Buenos Aires

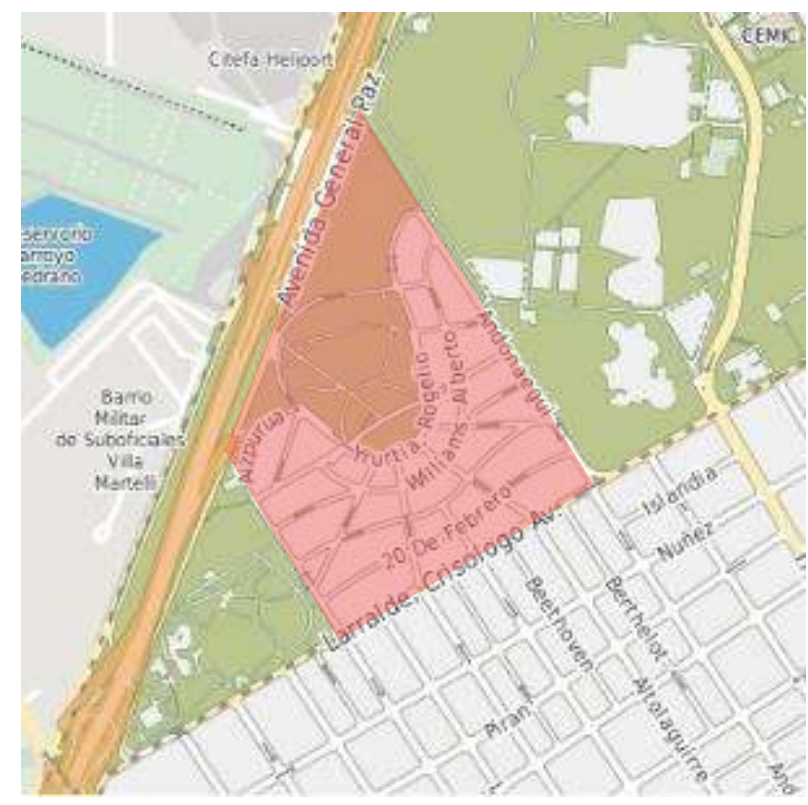

Figura 72. Localização do conjunto. Base cartográfica: Recorte do Mapa Interactivo de Buenos Aires. Disponível em: <http://mapa.buenosaires.gov.ar> Acesso em 05 maio 2017.

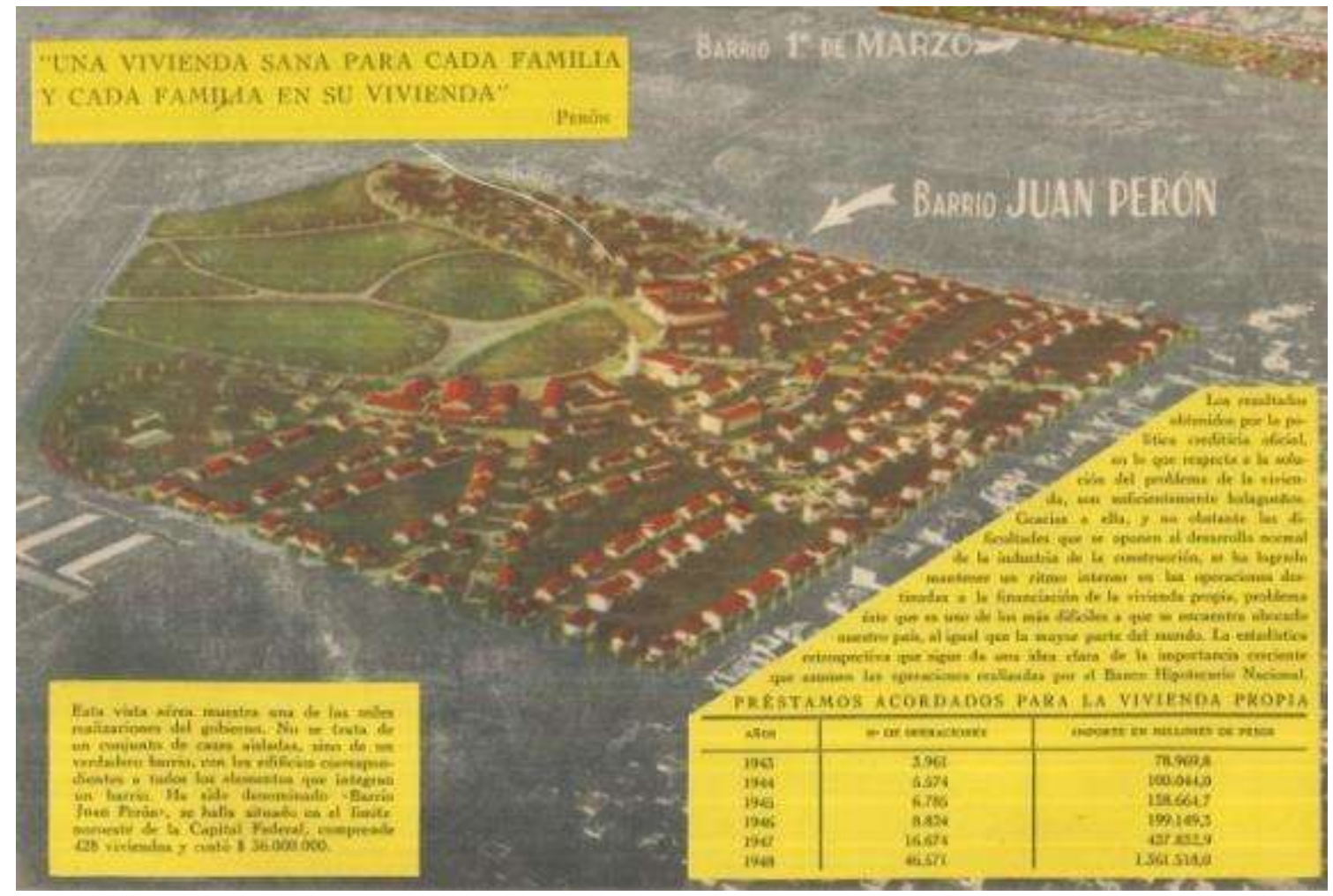

Figura 73. Foto aérea ilustrada do Barrio Juan Perón. LA NACIÓN ARGENTINA Justa Libre Soberana. Control de Estado de la Presidencia de la Nación (Ed.). Buenos Aires: Peuser, 1950. p. 317. 


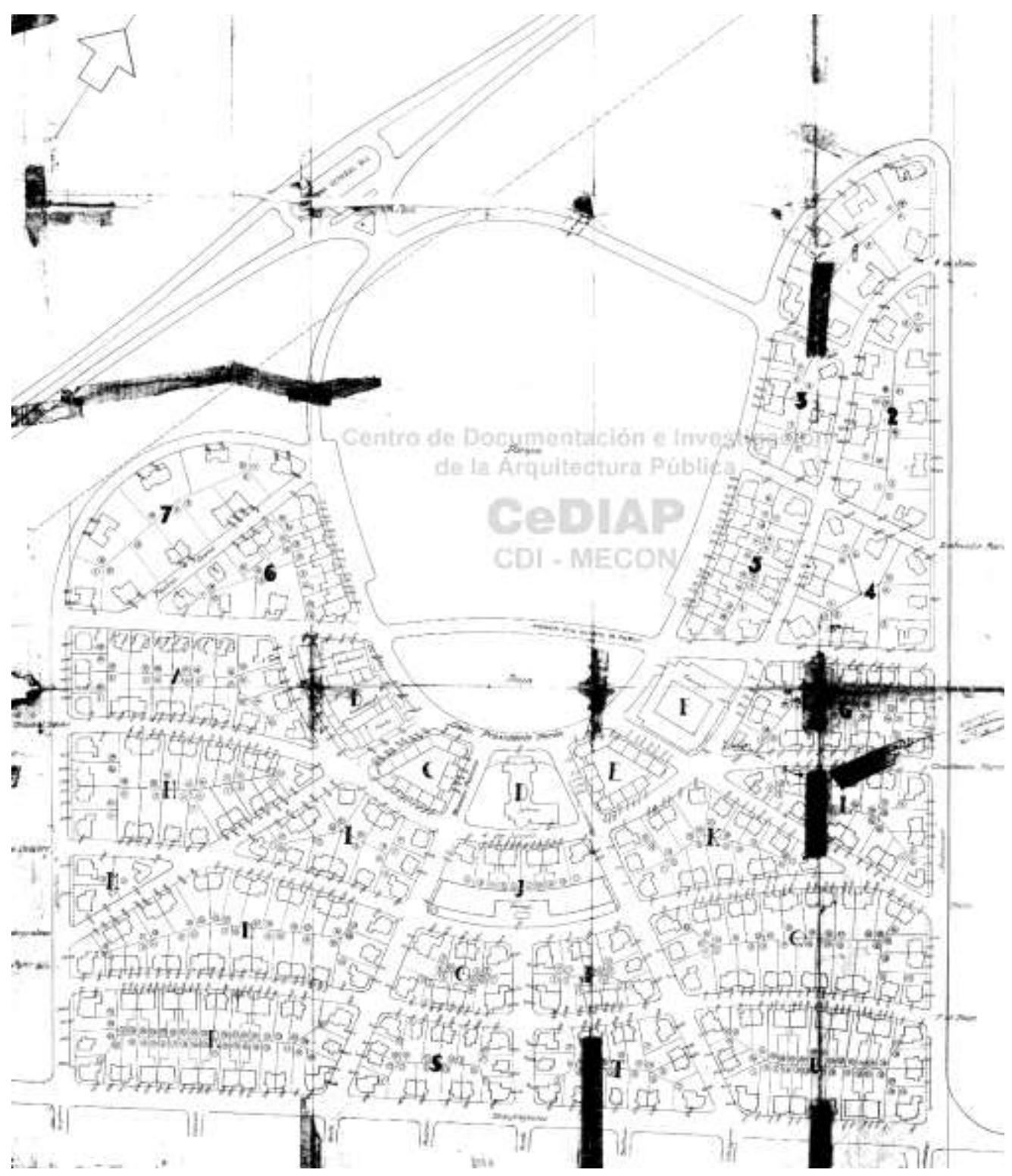

Figura 74. Planta do conjunto Juan Domingo Peron. Fonte: Processo Administrativo Barrio Cornelio Saavedra ex Presidente Peron. Nomenclatura Parcelaria.
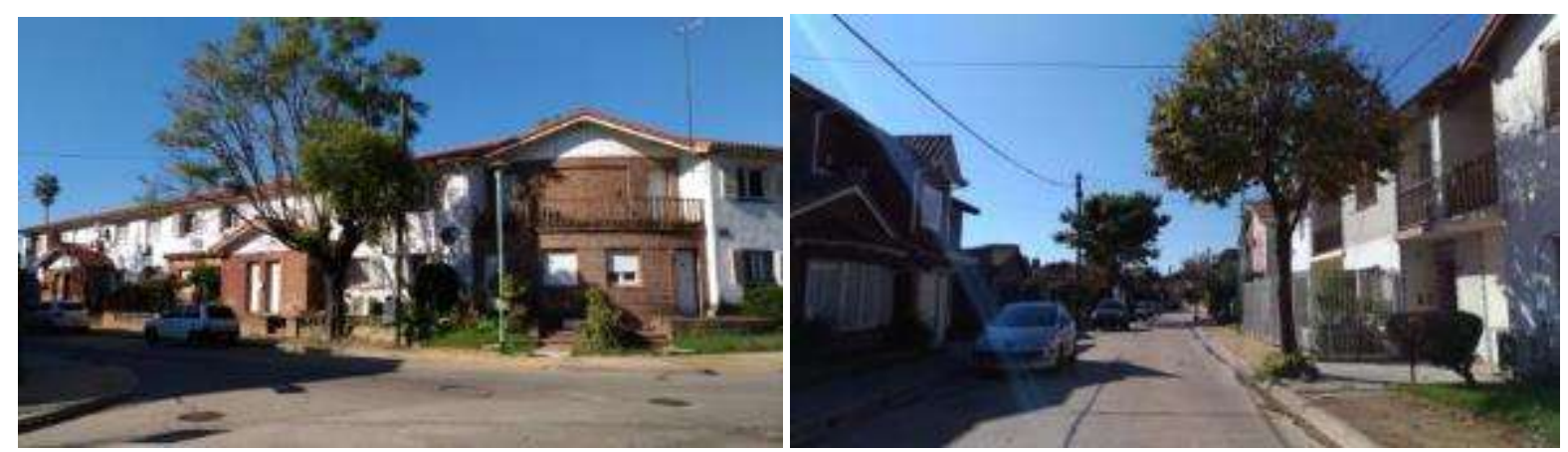

Figura 75. Diferentes tipos habitacionais. Fonte: Acervo pessoal. Foto de Camila Ferrari. Maio 2017. 
Urbanización de Bajo Belgrano

Data do projeto: 1948

Órgão Comitente: Municipalidad de la Ciudad de Buenos Aires (MCBA)

Órgão Promotor Financeiro: -

Projeto: arq. J. Ferrari Hardoy; A. Bonet; M. Roca; J. Vivanco

Construção: -

Localização: Belgrano · Buenos Aires

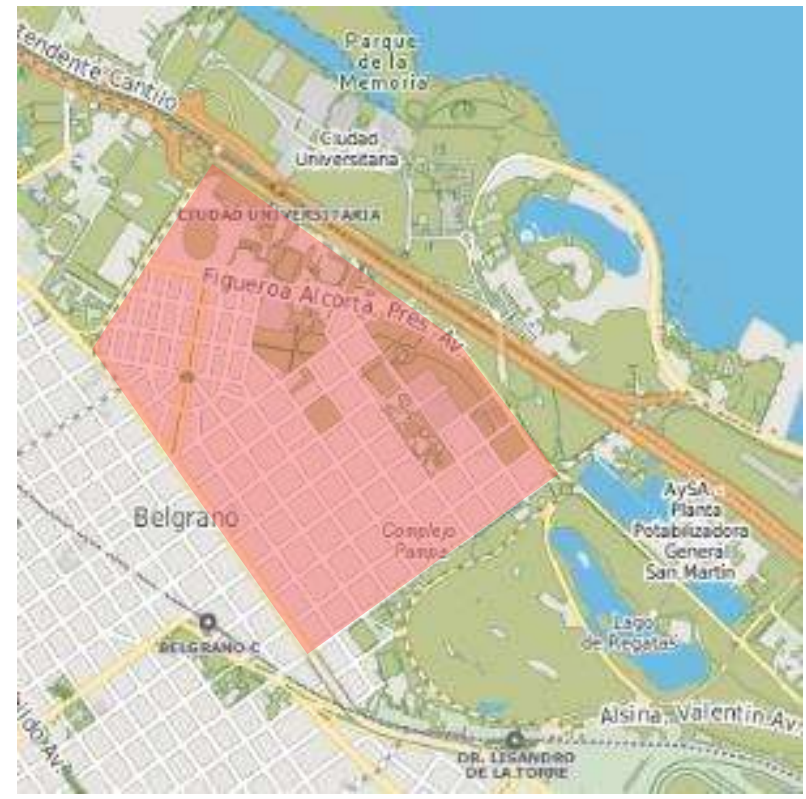

Figura 76. Localização do projeto de Urbanización de Bajo Belgrano. Base cartográfica: Recorte do Mapa Interactivo de Buenos Aires. Disponível em: $<$ http://mapa.buenosaires.gov.ar> Acesso em 05 maio 2017.

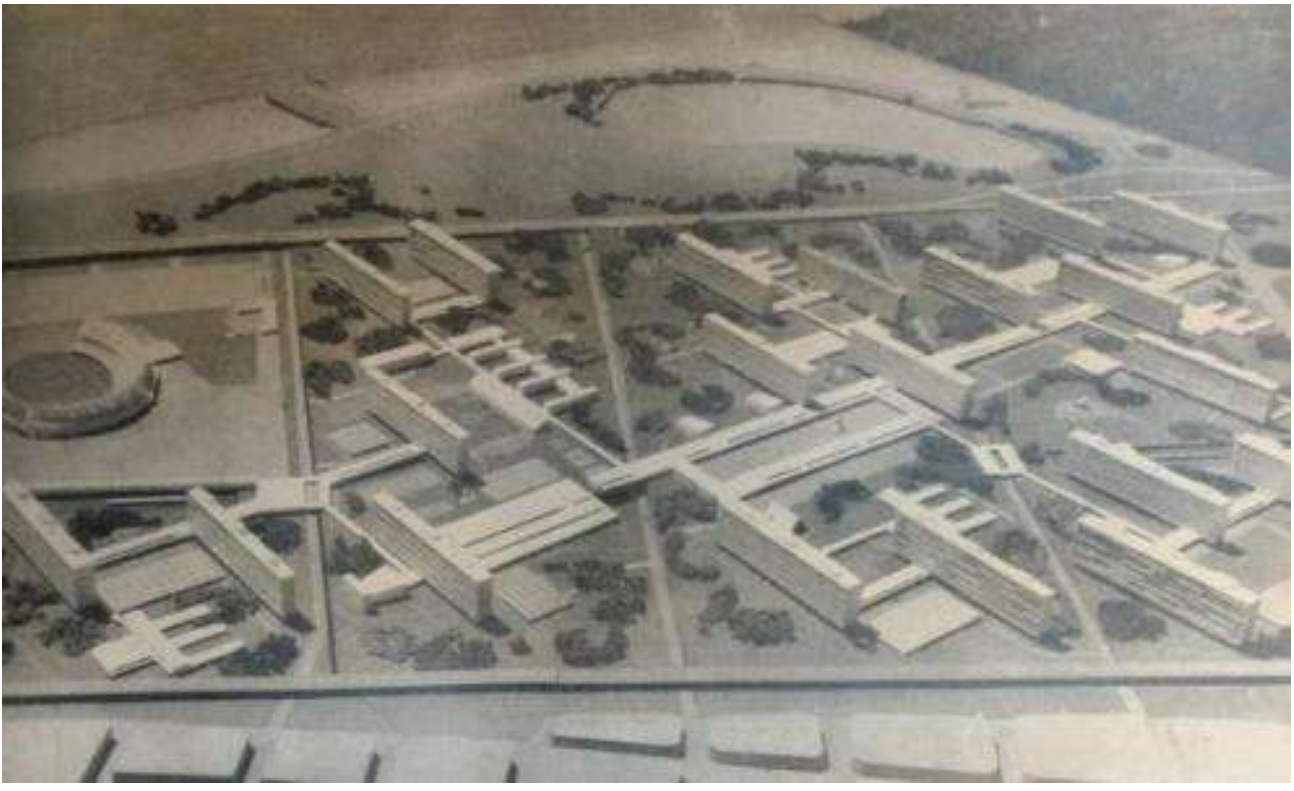

Figura 77. Maquete do conjunto. Fonte: “Urbanización de Bajo Belgrano" In: Revista de Arquitectura, n. 369, ene./feb. 1953. pp. 32. 
Casa Amarilla

Data do projeto: 1949-50

Órgão Comitente: Municipalidad de la Ciudad de Buenos Aires (MCBA)

Órgão Promotor Financeiro: -

Projeto: -

Construção: -

Localização: La Boca · Buenos Aires

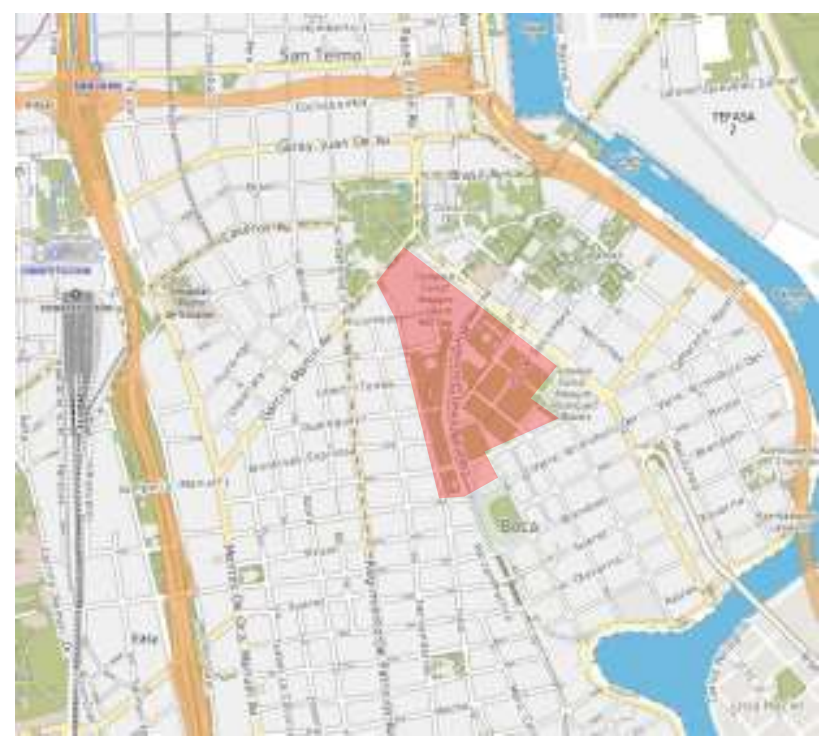

Figura 78. Localização do projeto de Casa Amarilla. Base cartográfica: Recorte do Mapa Interactivo de Buenos Aires. Disponível em: <http://mapa.buenosaires.gov.ar> Acesso em 05 maio 2017.

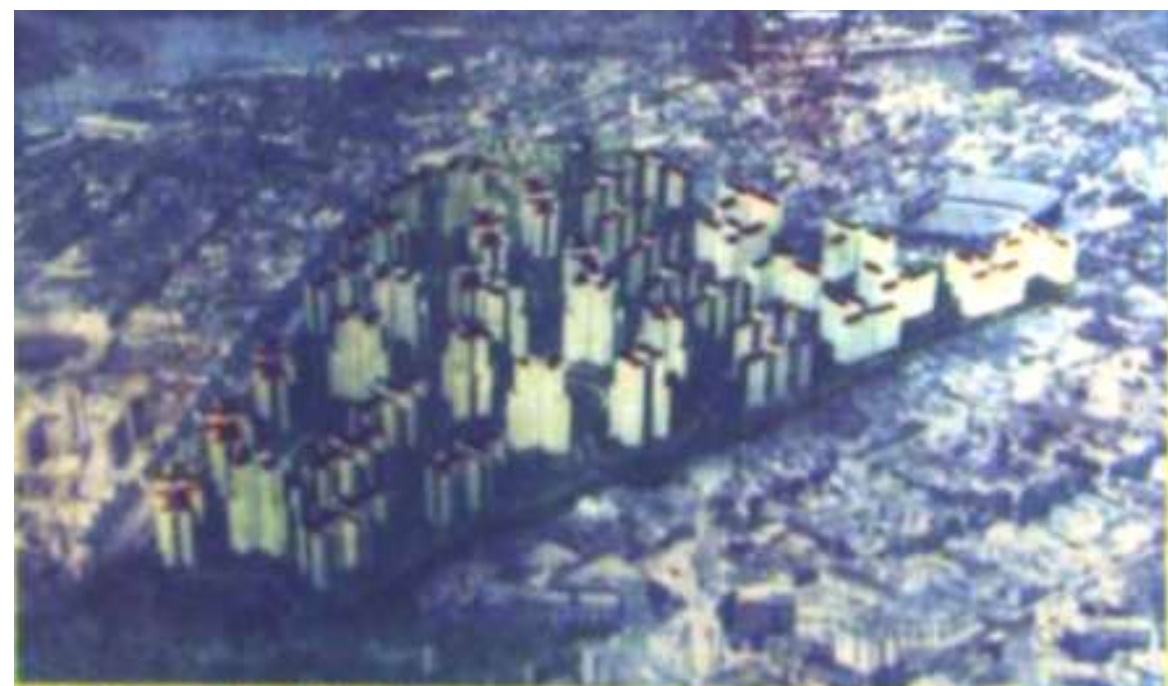

CIUDAD RVA PERON a censtruirse on la Fataciein Caka Amarilla.

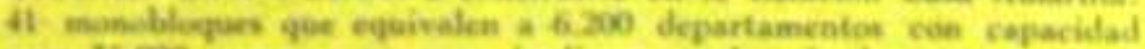
para 35.000 jeromess, paryoes, janlines, canchas de deportes y piletas

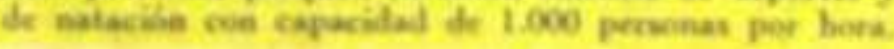

Figura 79. Foto aérea ilustrada do Barrio Casa Amarilla. LA NACIÓN ARGENTINA Justa Libre Soberana. Control de Estado de la Presidencia de la Nación (Ed.). Buenos Aires: Peuser, 1950. p. 315. 
Barrio n. 1 - Justicialista

Data do projeto: 1943

Órgão Comitente: Ministério de Obras Públicas (MOP)

Órgão Promotor Financeiro: Banco Hipotecário Nacional (BHN)

Projeto: arq. Fernando L. F. Capilla

Construção: Banco Hipotecário Nacional (BHN)

Localização: Ezeiza

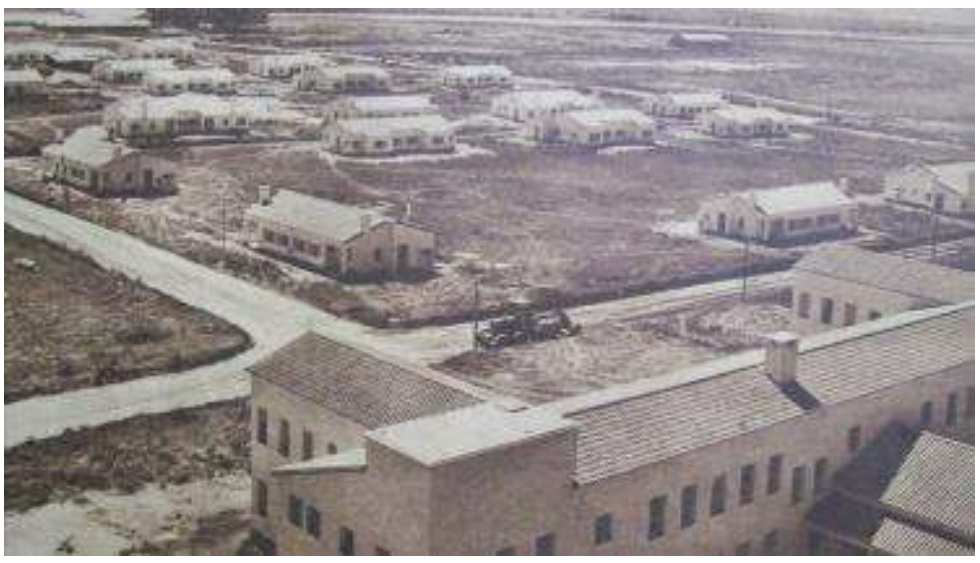

Figura 80. Vista do Barrio n. 1. Fonte: La Prensa, 13 de Marzo de 1949 - Suplemento 6. Disponível em: <La Prensa, 13 de Marzo de 1949 - suplemento 6> Acesso em 12 abril 2017. 


\section{Villa Concepción}

Data do projeto: $1944-49$

Órgão Comitente: CNCB / Administración Nacional de la Vivivenda - Banco Hipotecário Nacional (BHN)

Órgão Promotor Financeiro: Banco Hipotecário Nacional (BHN)

Projeto: arq. Carlos Alberto Chapeaurouge;Augusto Pieres;Carlos Juan Muzio;A. Fragueiro Olivera;J. Burone Risso;L. Nolasco Ferreira

Construção: Banco Hipotecário Nacional (BHN)

Localização: La Boca $\cdot$ Buenos Aires

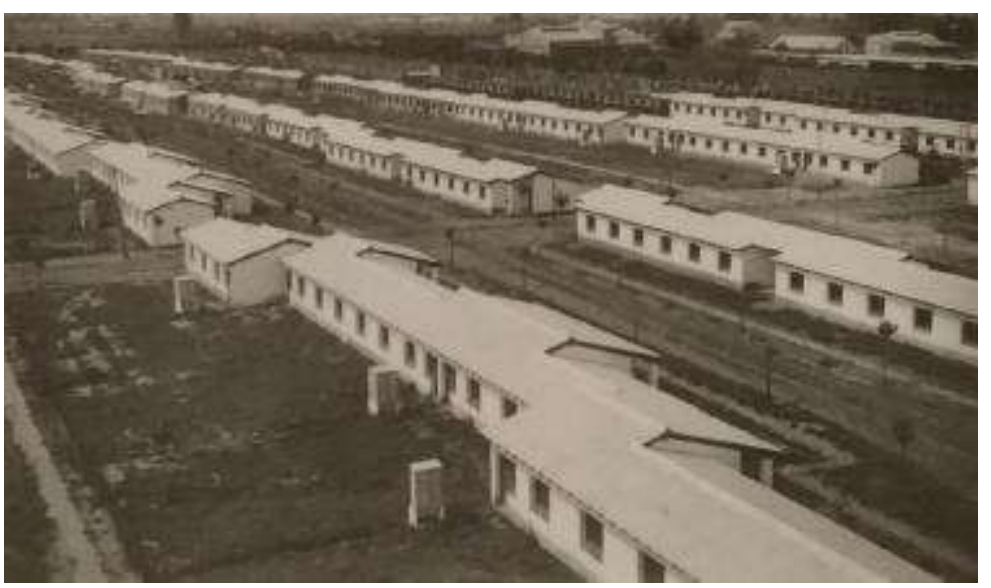

Figura 81. Barrio Villa Concepción. Fonte: GUTIÉRREZ, Ramón. La habitación popular bonaerense 1943-1955: Aprendiendo en la historia. Buenos Aires: CEDODAL: Ministerio de Infraestructura y Vivienda, 2011. p.146. 